\title{
Free movement of lawyers in the European Union
}

Citation for published version (APA):

Claessens, S. (2008). Free movement of lawyers in the European Union. [Doctoral Thesis, Maastricht University]. Wolf Legal Publishers. https://doi.org/10.26481/dis.20081218sc

Document status and date:

Published: 01/01/2008

DOI:

10.26481/dis.20081218sc

Document Version:

Publisher's PDF, also known as Version of record

\section{Please check the document version of this publication:}

- A submitted manuscript is the version of the article upon submission and before peer-review. There can be important differences between the submitted version and the official published version of record.

People interested in the research are advised to contact the author for the final version of the publication, or visit the DOI to the publisher's website.

- The final author version and the galley proof are versions of the publication after peer review.

- The final published version features the final layout of the paper including the volume, issue and page numbers.

Link to publication

\footnotetext{
General rights rights.

- You may freely distribute the URL identifying the publication in the public portal. please follow below link for the End User Agreement:

www.umlib.nl/taverne-license

Take down policy

If you believe that this document breaches copyright please contact us at:

repository@maastrichtuniversity.nl

providing details and we will investigate your claim.
}

Copyright and moral rights for the publications made accessible in the public portal are retained by the authors and/or other copyright owners and it is a condition of accessing publications that users recognise and abide by the legal requirements associated with these

- Users may download and print one copy of any publication from the public portal for the purpose of private study or research.

- You may not further distribute the material or use it for any profit-making activity or commercial gain

If the publication is distributed under the terms of Article $25 \mathrm{fa}$ of the Dutch Copyright Act, indicated by the "Taverne" license above, 


\section{Free Movement of Lawyers in the European Union}


Free Movement of Lawyers in the European Union

Sjoerd Claessens

ISBN 978-90-5850-397-8

Wolf Legal Publishers

POB 31051

6503 CB Nijmegen

The Netherlands

www.wolflegalpublishers

(C) Sjoerd Claessens 2008

Layout: Boekopmaak Nettie Litjens, Maastricht 


\section{Free Movement of Lawyers in the European Union}

\section{PROEFSCHRIFT}

ter verkrijging van de graad van doctor aan de Universiteit Maastricht,

op gezag van de Rector Magnificus, Prof. mr. G.P.M.F. Mols, volgens het besluit van het College van Decanen, in het openbaar te verdedigen

op donderdag 18 december 2008 om 12.00 uur

door

Sjoerd Joseph Franciscus Johannes Claessens 


\section{Promotor:}

Prof. dr. H.E.G.S. Schneider

\section{Beoordelingscommissie:}

Prof. dr. A.W. Heringa (voorzitter)

Dr. S. van den Bogaert

Prof. dr. H.J. Hellwig (Universität von Heidelberg)

Dr. J. Lonbay (University of Birmingham)

Prof. dr. B. de Witte (UM/European University Institute, Florence) 


\section{Acknowledgments}

Somehow, somewhere, it was logical that I would work at the Law Faculty Maastricht University. After the completion of my law degree in the first cohort of European Law School students in 1998, in the course of which I wrote my master thesis on the new Establishment Directive for lawyers, I broadened my horizon by means of an LL.M. in International Law at the University of Nottingham in the United Kingdom.

When I returned home from the U.K. in 1999, and just started to consider my future, I was asked by Hildegard Schneider to teach at the Law Faculty in Maastricht for a year. Being from a family where every single member was involved in teaching in some way I gladly accepted. Luckily I was able to prolong my time at the Faculty, but working at the Faculty also meant: writing a PhD. After trying to ward off the inevitable for some time, I started working on my $\mathrm{PhD}$ in 2001. Luckily, because I was still intrigued by the subject, it was possible to write a $\mathrm{PhD}$ on the subject of the free movement of lawyers.

Now, after seven years, that $\mathrm{PhD}$ is finished and lies before you in the form of this book. That book however could never have been written without the help of many people. A number of them I want to mention specifically.

First, and foremost, I want to thank Hildegard Schneider, my supervisor. Already during the preparation and writing of my master thesis I noticed that Hildegard and I have a way of cooperating where little, if any, words suffice to know what we expect from each other. Such cooperation must be treasured and luckily we have been able to continue on the same path during the writing of this $\mathrm{PhD}$. Hildegard was always there to comment or discuss anything that I had written, while on the other hand she has always given me the feeling that I was writing my own book. I seriously doubt whether I would have completed my $\mathrm{PhD}$ with any other supervisor. Hildegard, thank you for that!

Secondly, I want to thank all my colleagues at the Law Faculty and the Department of International and European Law in particular. You have provided the friendly and warm atmosphere in which it is a joy to work. Moreover, you have given me, in formal and more informal settings, the opportunity to present my ideas and your comments and critique have been of enormous value. A number of people deserve a special mentioning; Victoria Cherevach and Anja Wiesbrock, for their English language revision on earlier drafts, Sjaak Verstappen for his valuable comments on my Dutch summary and Nettie Litjens for taking care of the typography and layout of the book. Moreover, I want to thank the members of my reading committee: Aalt Willem Heringa, Stefaan van den Bogaert, Hans Jürgen Hellwig, Julian Lonbay and Bruno de Witte for their willingness to read my manuscript.

Thirdly, and most importantly, there is the support from outside the Faculty. Thanks first of all to my parents who have always supported me and gone through utmost lengths to provide me and my brother and sister with the best education possible. It is a terrible shame that my Dad is no longer among us to witness the fruit of his efforts. I can still feel his inspiration every day; therefore this book is dedicated to him. Secondly, there are my friends who actively and passively supported me over the years. Thank you for sticking with me. Moreover, thank you, Martijn and 
Martijn for agreeing to be my 'paranimfen'. There have been too few gigs of the band over the last few years, and that is mostly because of me. The gigs we did have provided me with the much needed opportunity to blow off steam. Thanks also to Annelies and Ron for listening and all the necessary relaxation.

Lastly and beyond everybody else, I want to thank Marthe, my one and only. Out of all these people, you have been the one that has supported me, come good times or bad, on a day to day basis. I could have never finished this book without your unconditional love and support.

The main research of this book was closed in June 2008. Sporadic adaptations have been made after that time up until 20 October 2008.

Maastricht, 20 October 2008 


\section{Table of Contents}

\section{Chapter 1 \\ Introduction}

S 1. Introduction ................................................................................. 1

\ 2. Need for a Free Movement of Lawyers? .................................................... 5

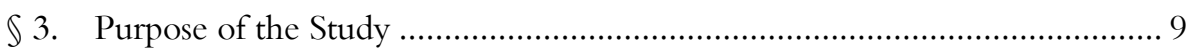

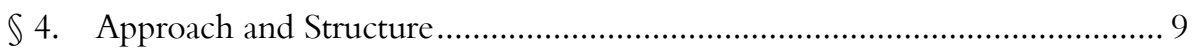

\section{Chapter 2}

\section{Development of the Free Movement of Lawyers 1958-2008}

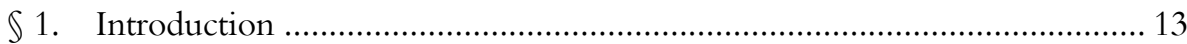

\2. First Generation Case Law: Creating a Free Movement of Lawyers ............ 14

\2.1 Opening the gates: Reyners and Van Binsbergen........................... 15

$\$ 2.2$ Towards Non-Discriminatory Restrictions: Thieffry ....................... 17

$\$ 2.3$ Towards Non-Discriminatory Restrictions: Klopp ........................ 18

$\$ 2.4$ Non-Discriminatory Restrictions: Vlassopoulou .............................. 19

$\$ 2.5$ Towards a Rule of Reason in the Freedom of

\2.6 Completing the System: Gebhard ............................................. 22

\3. Development of Secondary Legislation Affecting the Free

Movement of Lawyers............................................................................ 24

\3.1 Vertical Harmonisation and the Services Directive ......................... 24

S 3.2 The Horizontal Approach: The Diploma Directive 89/48/EEC and Directive 2005/36/EC ...................................................... 30

\3.3 The Lawyers Establishment Directive 98/5/EC............................ 39

\ 3.3.1 The CCBE Draft........................................................... 39

S 3.3.2 The Commission Proposal ................................................ 41

\ 3.3.3 The Opinion of the European Parliament ....................... 46

\ 3.3.4 The Amended Commission Proposal................................ 48

S 3.3.5 The Council's Common Position ....................................... 48

3 3.3.6 The Final Result: Directive 98/5/EC ............................. 50

$\int$ 3.3.7 Case Law Regarding the Lawyers Establishment

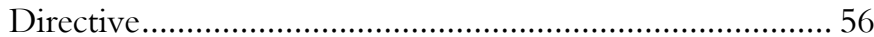

\ 3.3.8 Appreciation of the Directive .................................... 62

\ 4. New Generation Case Law: Beyond the Directives ................................... 63

$\int 5$. The Outside World: Third-Country Diplomas and Third-Country

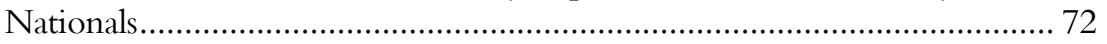

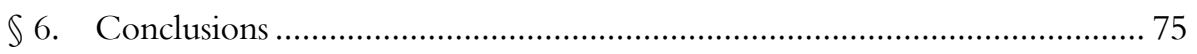




\section{Chapter 3}

\section{Applying the Model: Free Movement of Lawyers in Practice}

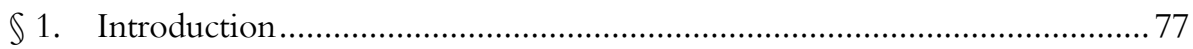

\2. The Legal Professions in the Member States..................................................78

$\$ 2.1$ The Legal Profession in Scandinavian and Nordic Countries ............78

$\$ 2.2$ The Legal Profession in the United Kingdom and Ireland ................ 85

$\$ 2.3$ The Legal Profession in the Benelux ................................................. 93

$\$ 2.4$ The Legal Professions in France, Italy, Spain and Portugal.............. 101

$\$ 2.5$ The Legal Professions in Germany, Austria and Greece ................... 115

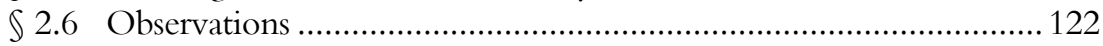

\3. The Free Provision of Services ……………………................................ 125

$\$ 3.1$ Freedom to Provide Services for Non Lawyers in Highly Regulated Member States............................................................ 126

$\$ 3.2$ The Free Provision of Services by Lawyers in the Member

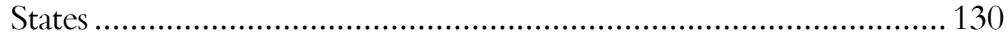

$\$ 3.3$ Observations with regard to Services ............................................ 138

\4. Establishment of Lawyers under their Home Country Professional

Title

\4.1 Establishment for Non-Lawyers in Highly Regulated

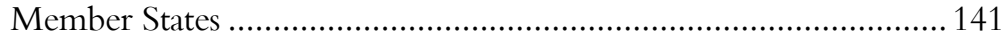

\ 4.2 Impact of the Establishment Directive ………................................ 143

$\$ 4.3$ Implementation of the Establishment Directive in the Member States

S 4.3.1 Implementation in the Scandinavian and Nordic

Member States

\4.3.2 Implementation in the United Kingdom and Ireland........160

\4.3.3 Implementation in the Benelux............................................ 173

\4.3.4 Implementation in France, Italy, Spain and Portugal........ 192

$\$$ 4.3.5 Implementation in Germany, Austria and Greece ............. 216

$\$ 4.4$ Observations and Conclusions in Connection with Establishment under Home Title.

$\int 5$. Integration into the Host Member State's Profession:

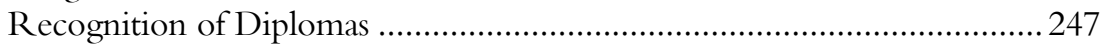

\5.1 Diploma Recognition for Non-Lawyers in Highly Regulated

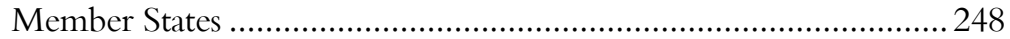

\5.2 Implementation of the (New) Diploma Directive in the

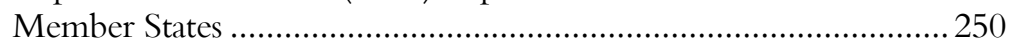

\5.3 Observations and Conclusions ............................................................ 264

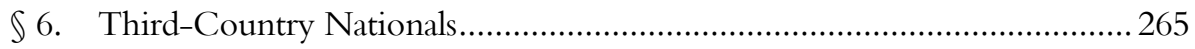

\$6.1 European Rules Applicable to Third-Country Nationals ................. 266

\6.2 The General Agreement on Trade in Services (GATS) .....................267

$\$ 6.3$ Applicability of GATS Rules for Third-Country Nationals ............278

\$6.4 Establishment Rights for Third-Country Nationals:

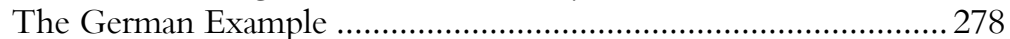

\6.5 Observations and Conclusions ......................................................2279 


\section{Chapter 4}

Free Movement of Persons Seeking to Qualify as a Lawyer

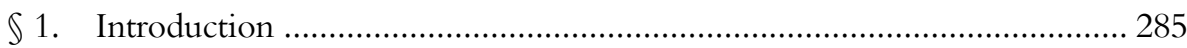

$\int$ 2. Qualifying as a Lawyer: Points of Entry and the Problem of

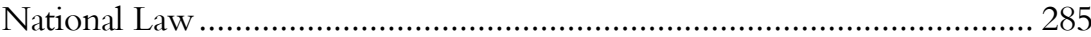

\ 3. European Union Rules Affecting the Qualification Track for Lawyers .... 287

\4. Creating an Area for Higher Education in Europe: The 'Bologna Process'....

\ 5 The Lisbon Recognition Convention and the Effect of Recent Case Law of the European Court of Justice.

\6. The Position of Those Seeking to Qualify for the Profession of Lawyer in the European Union.......................................................... 300

S 7. Furthering the Free Movement of Lawyers: the Content of Law Studies 302

\ 8. A Possible Result? The United States of America ................................... 309

\ 9. Realising New Law School Education: Who Should Take Charge? ........ 314

\ 10. Observations and Conclusions.............................................................. 317

\section{Chapter 5}

Observations, Conclusions and Recommendations

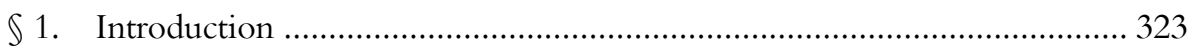

\2. Observations and Conclusions with regard to Chapter 2 ........................ 323

\3. Observations and Conclusions with regard to Chapter 3 ........................ 330

\ 4. Observations and Conclusions with regard to Chapter 4 ....................... 334

\ 5. Recommendations: The Future ........................................................ 335

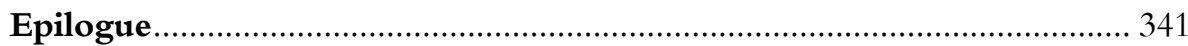

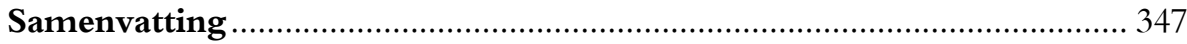

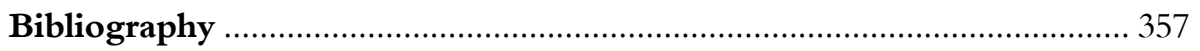

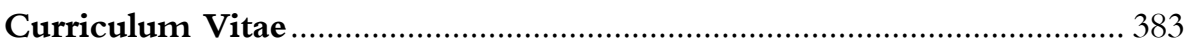





\section{Chapter 1}

\section{Introduction}

\section{\1. Introduction}

The year 2008 is in many ways a noteworthy one for the free movement of lawyers. Not only does it mark the fiftieth anniversary of the Treaty of Rome, but also the fifteenth anniversary of the Treaty of Maastricht and the introduction of European citizenship. Moreover, it is also the tenth anniversary of Directive $98 / 5 / \mathrm{EC},{ }^{1}$ the secondary legislation that marked the completion of the legal framework for the free movement of lawyers in the European Union, and will be the focal point of this book. In addition, Directive 77/249/EEC, governing the freedom of lawyers to provide services, has been in force for 30 years, ${ }^{2}$ while approximately 20 years ago lawyers were offered the opportunity of integrating into the legal profession of another Member State by means of Directive 89/48/EEC, the Diploma Directive, ${ }^{3}$ which was in turn replaced in October 2005 by Directive $2005 / 36 /$ EC. $^{4}$ It is also in 2008 that the European Commission must deliver its report on the functioning of Directive 98/5/EC.

On the basis of the EC Treaty, and more specifically Articles 14, 18, 39, 43 and 49 thereof, European Union citizens have the right to move freely in the territory of the European Union in order to take up a professional activity in any Member State of their own choosing. As stated in Article 14 of the EC Treaty, an internal market, or economic union, is characterised by the abolition of obstacles to the free movement of goods, persons, services and capital. ${ }^{5}$ Furthermore, the European Court of Justice has always given a broad definition of the term 'restriction'. In 1995, in the famous Gebhard case, ${ }^{6}$ the European Court of Justice ruled, based on earlier, more fragmented case law, ${ }^{7}$ that any national measure liable to hinder or make less attractive the exercise of one of the four freedoms mentioned in Articles 3 and 14 of the EC Treaty is, in principle, a restriction in the light of those articles. ${ }^{8}$ This very broad definition leads to the fact that nearly every national measure can be construed as a restriction ${ }^{9}$ to the exercise of one of the four freedoms.

Directive 98/5/EC, [1998] OJ L 77/36.

Directive 77/249/EEC, [1977] OJ L 78/17.

Directive 89/48/EEC, [1989] OJ L 19/16

Directive 2005/36/EC, [2005] OJ L 255/22.

See Belassa (1961), p. 181.

Case C-55/94, Reinhard Gebhard v. Consiglio dell'Ordine degli Avvocati e Procuratori di Milano, [1995] ECR 4165. For summaries of and comments on this case, see Arnull (2006), pp. 770771; Barnard (2007), p. 313; Chalmers (2006), pp. 703-704; Craig \& de Burca (2007), p. 793; Ewig (1996) pp. 13-15; Farthouat \& Puel (1996) pp. 18-22; Higgins \& Svenningsen (1995); Steiner (2006), p. 449; and Weatherill (2006), pp. 319-321.

7 See Chapter 2 below.

$8 \quad$ Case C-55/94, $\$ 37$.

9 See, for example, Chalmers (2006), pp. 697-742. 
One of the possible restrictions a Member State can impose is the regulation of entrance to a profession. According to Article 3 of Directive 2005/36/EC, a regulated profession is the exercise of a professional activity or group of professional activities, access to which, the pursuit of which, or one of the modes of pursuit of which, is subject, directly or indirectly, by virtue of legislative, regulatory or administrative provisions, to the possession of specific professional qualifications. ${ }^{10}$ Alternatively, stated in simpler terms, when a State governs the entrance to a certain profession, this profession is considered to be regulated. ${ }^{11}$ Clearly the restrictive effect of regulating a profession can be removed if rules regarding the regulation of that specific profession are harmonised throughout the European Union. In an ideal situation, this means that within the confines of the European Union a person can exercise any profession, providing he or she has the necessary qualifications to do so, anywhere in the European Union. The Member States and the Institutions of the European Community have been trying over the last few decades to achieve this goal. ${ }^{12}$ History has shown that for most regulated professions the realisation of such a removal of the restrictive effect of regulation is possible. ${ }^{13}$ That is mainly because of the nature of most professions. A doctor in Finland should have the same basic knowledge and skills as a doctor in Spain, and a dentist in France has received, in principle, the same education as a dentist in the United Kingdom. In other words, the exercise of most regulated professions has nothing to do with the country in which the person has trained and gained access to that profession. Professions that have a clear link to the Member State, in which they are exercised, however, such as notaries, are generally bound by much more stringent rules. ${ }^{14}$

That premise is not true for lawyers. Due to the way different States have adopted different legal systems throughout history, the profession of lawyer seems, at first sight, not suitable for border crossing. At present, the European Union consists

10 Article 1 (c) and (d) 89/48/EEC.

11 Throughout the European Union an abundance of professions are regulated by the respective Member States. An overview of regulated professions can be found at: <ec.europa.eu/internal _market/qualifications/regprof/index.cfm?lang=en>, last accessed 1 June 2007.

12 See Schneider (2002), p.17.

13 It proved very difficult to come to a harmonisation of the profession of architect, however, and it proved impossible to gain results with regard to harmonisation of the profession of engineer. See Schneider (1995), p. 161.

14 In these cases, Article 45 of the EC Treaty provides for the possibility that Member States might exclude free movement for professions that are connected with the exercise of state sovereignty. This provision extends the public service exception of Article 39(4) to the freedom of establishment. (Article 55 does the same for the freedom to provide services.) On the subject see, for example: Craig \& de Burca (2007), pp. 795-796. It will be shown that in the early days of the European Community (i.e. until 1974) this much more stringent regime applied to the profession in the majority of the member states. At this point, it must also be mentioned that the application of this stricter regime, i.e., excluding free movement by upholding nationality requirements, is not static. Recently the European Commission has initiated legal proceedings on the basis of Article 226 EC against 16 member states that apply the Article 45 EC exception to the profession of notary. See Press Release IP/06/1385, 12 October 2006, via <europa.eu> last accessed 1 June 2007. On the basis of press release IP/07/915, it is clear that the Commission is only pursuing seven of these cases. It has however (IP/07/1510) initiated new procedures in eight of the new member states, on the basis of the same issue. Both press releases via <europa.eu>, last accessed 11 December 2007. 
of 27 different Member States. Even simplified to the extreme, that means that there are 27 different legal systems (whereas actually there are many more) within the European Union. In addition, the nature of legal education in the present Member States leads to the effect that a lawyer who is educated in a certain Member State is an expert in the legal system of the State where he has received his education, but is a layman in the workings of the legal systems of the other Member States. ${ }^{15}$ This provides for an inherent obstacle to the free movement of lawyers that is independent of the will of Member States to create such a freedom.

This has not always been the case. The profession ${ }^{16}$ of those who followed the studies of law in the Middle Ages at the newly established universities started out as a true border-crossing profession, and the persons who had gained proficiency in this field were true masters of the Ius Commune Europaum. Around AD 1100 young men from all over Continental Europe came to the Italian city of Bologna to study, in the first instance, the rediscovered Roman law, and from 1140 onward also canon law, under the guidance of Irnerius. ${ }^{17}$ These two legal systems were in that age the basis for the majority of the legal systems in Continental Europe, and could, therefore, be regarded as a true Ius Commune Europcum. ${ }^{18}$ This being the case, it was irrelevant where a lawyer came from or where he was going to work, because the majority of Continental Europe fell under the same Ius Commune Europaum. ${ }^{19}$ This situation persisted throughout the Middle Ages until the eighteenth and in some cases the nineteenth century. As the concept of territorial sovereignty became more and more important, through the theories underlying the French Revolution and the ensuing tradition of legal positivism and codification, each State developed its own distinctive legal system and lawyers were educated in their own State. ${ }^{20}$ This development made it paramount that the lawyer was trained in the law of his State and therefore marked the end of the free movement of lawyers as it had existed until that time.

The modern profession of lawyer is no longer comparable to the legal professions as they were practised in the Middle Ages. ${ }^{21}$ The profession as we know it today originated in the nineteenth century and was characterised by its governance through strict rules of access. ${ }^{22}$ Combined with the fact that lawyers were only educated in the law of their respective State, this meant that the free movement of lawyers as it had existed in the Middle Ages did not survive.

In fact, this situation remained ${ }^{23}$ until the European Court of Justice ended the practices of the Member States of the European Community of applying nation-

\footnotetext{
15 See Schneider (2002), p. 15.

16 The activities that were in those times carried out by a lawyer can be traced back to classical times. See Forsyth (1875) and Pound (1943) C, pp. 203-228.

17 Lokin \& Zwalve (2001), pp. 110-120. See, for a very detailed overview of the reception of Roman Law in Europe: Mather (2001), pp. 323-362 and Wilson (1894), pp. 304-307.

Ibid.

19 For an English example, see Pound (1943) A, pp. 315-333.

20 For a detailed account of the changes in the Dutch legal education in that period, see Wachelder (1992), pp. 154-166.

21 Pound (1943) B, pp. 229-244.

22 Schneider (1995), p. 265.

23 Ibid.
} 
ality restrictions to their legal professions. ${ }^{24}$ The Reyners case marked the beginning of a renewed free movement of lawyers which was initially guaranteed by the European Court of Justice, ${ }^{25}$ but was later addressed by the law-making Institutions of the European Community. ${ }^{26}$ In the 1970s and 1980s, the European Community adopted two Directives which led to a considerable development in the free movement of lawyers. In Directive 77/249/EEC, the European Community laid down a strong base of mutual recognition in the field of the free provision of legal services. It will be shown that the Services Directive inspired a number of the core concepts of the Lawyers Establishment Directive (Directive 98/5/EC). At the end of the 1980s the European Community adopted the general Diploma Directive (Directive 89/48/EEC) which was the first legal instrument in the European Community to address the establishment of lawyers in other Member States. In spite of further development in the case law, a Directive that applied specifically to the establishment of lawyers was adopted in $1998 .^{27}$ This Directive will be the central element of this study.

The developments described above indicate that the evolution of the free movement of lawyers within the European Community took place in a distinctive manner. The evolution has been characterised by a combination of what is called 'positive integration' (i.e. secondary legislation) and negative integration (i.e. integration through judgments of the European Court of Justice). This two-tier development will be the central element in the efforts to create a model that grasps all the modalities of the free movement of lawyers in Europe. When looking at the legal profession one can distinguish three different types of lawyers that cross the border of the Member State in which they received their education. ${ }^{28}$ First, there are the lawyers who wish to become fully integrated in the legal profession of the Member States in which they plan to establish themselves. Second, there are lawyers who only occasionally want to work in another Member State. Lastly, there are those legal professionals who would like to establish themselves in another Member State permanently, but who do not want to become part of the legal profession of that Member State, but nevertheless still want to work as lawyers. It will be shown that the Directives in force at the time of writing cover all three modalities of bordercrossing lawyers. In addition, the European Court of Justice has also extended rights to people who are not (yet) fully qualified as legal professionals. These persons will also be included in the model.

\footnotetext{
24 Case 2/74, Reyners v. Belgium, [1974] ECR 631.

25 See, for example, Case 33/74, Van Binsbergen v. Bestuur van de Bedrifsvereniging voor de Metaalnijverheid, [1974] ECR 1299; Case 71/76, Thieffry v. Conseil de l'Ordre des Avocats à la Cour de Paris, [1977] ECR 756, [1977]; Case 222/86, UNECTEF v. Heylens, [1987] ECR 4097; and Case 340/89, Vlassopoulou v. Ministerium für Justiz, Bundes- und Europaangelegenheiten BadenWürttemberg, [1991] ECR 2357.

26 Directive 77/249/EEC, [1977] OJ L 78/17; Directive 89/48/EEC, [1989] OJ L 19/16 and Directive 98/5/EC, [1998] OJ L 77/36.

27 Directive 98/5/EC of the European Parliament and the Council of 16 February 1998 to facilitate the practice of the profession of lawyer on a permanent basis in a member state other than that in which the qualification was obtained [1998] OJ L 77/36.

28 House of Lords (1994), p. 25. See also: Clarcke (1996). Recently this view has also been recognised by the European Court of Justice: Case 168/98, Grand Duchy of Luxembourg v. European Parliament and the Council of the European Union, [2000] ECR I-09131.
} 
Apart from this inter-Community evolution, there have been (recent) developments outside the European Community which might influence the evolution of a free movement of lawyers in the European Community. More specifically, there has been an inter-governmental effort to streamline higher education in geographical Europe. This so-called 'Bologna Process' may also have an effect on the free movement of lawyers in the European Community. The reason why this development is situated outside the European Union is because of the restricted capacity of the European Union with regard to (higher) education, which is limited by the scope of Article 149 of the EC Treaty. This Article expressly excludes the possibility of harmonising the laws of the Member States with regard to education. ${ }^{29}$ Therefore any attempt to streamline higher education in Europe would have to take place outside of the European Union. This extra-Community development will therefore also receive much attention in this study. Before the structure of this study is set out however, a more fundamental question needs to be answered.

\section{\2. Need for a Free Movement of Lawyers?}

The developments that lead to an automatic link between the legal profession and the jurisdiction in which that profession is exercised, as described in the previous paragraph, still seem to reflect the status quo with regard to how people approach the free movement of lawyers. In undertaking this study, I was often confronted with the question: 'Why is a free movement of lawyers necessary? If you need a lawyer you hire a national lawyer.' At first sight, this is indeed a legitimate question. Why would a Dutch client hire a Rechtsanwalt in the Netherlands when he can also hire an advocaat?

This question can be answered in a number of different manners. First, it can be approached from a purely legal angle. The creation of an internal market is characterised by the abolition of State measures which hinder the free movement of persons. There is an abundance of restrictions to the free movement of lawyers in the European Community. In a situation where all these restrictions were removed, the actual free movement, of lawyers in this case, would be left to the invisible hand' of the free market, where supply and demand decide whether there will be a market for foreign lawyers. In short, from a legal perspective, a study into the abolition of restrictions to the free movement of lawyers is not concerned with the question of whether an actual demand for the free movement of lawyers exists. Although this becomes the technical answer to the question posed above, I realise

29 Article 149 EC was only introduced in the Treaty in 1992 with the Treaty of Maastricht, but it was always clear that education was not a part of the competences of the European Community. See Case 9/74, Donato Casagrande v. Landeshauptstadt München, [1974] ECR 773. It is typical that the Court states that such an exclusion does not mean that the competences the Community does have may not have any effect on the education policy of the Member States (ibid., \$6). That the ECJ is willing to keep to that premise can be seen in: Case C109/04, Karl Robert Kranemann v. Land Nordrhein-Westfalen, [2005] ECR I-02421; Case C313/01, Christine Morgenbesser v. Consiglio dell'Ordine degli avvocati di Genova, [2003] ECR I13467; Case C-147/03, Commission v. Austria [2005] ECR I 5969; and Case C65/03 Commission v. Belgium [2003] ECR I 6427. 
that this technical answer is unsatisfactory. Therefore, a more 'comprehensive' answer to this question is warranted.

While, on the one hand, it was established that free movement of lawyers is problematic, on the other hand, the call for lawyers to move freely from one country to another and to exercise their professional activity there becomes louder and louder, and it seems that, although solid empirical evidence is not available, an actual demand for the free movement of lawyers exists. The then-president of the Council of Bars and Law Societies in Europe (CCBE), Gout, even goes as far as to assume that such a demand exists. ${ }^{30}$ Although I am not sure whether I would go as far in my assumption, it is true that in the last 30 years, the world has become much smaller and the need for transnational legal activity is steadily increasing. ${ }^{31}$ At the time when the European Court of Justice gave its ruling in the Reyners case, for example, the internet was nothing more than a military experiment, while in 2008 it is very normal to conduct business transactions using the internet, and this might result in very complex transnational legal issues if something goes wrong. ${ }^{32}$ Because of the ongoing globalisation ${ }^{33}$ and internationalisation ${ }^{34}$ of society as a whole, including the globalisation and internationalisation of the economy, and legal services as a part of that, lawyers from different jurisdictions inevitably come in contact with each other. Such experiences often lead to the conclusion that, although at first sight the professions in different jurisdictions might seem very different, the principles underlying the legal profession are the same throughout the world. ${ }^{35}$

As said above, there is no clear evidence as to how large the demand for a free market of lawyers is, yet there is some more information on the supply-side of the market. The CCBE keeps track of the number of lawyers that actually move from one Member State to another under the regime of the Establishment Directive 98/5/ EC. Also under the regime of the Diploma Directive 89/48/EEC some numerical evidence was presented by the European Commission in its report to the European Parliament and the Council on the implementation of Directive 89/48/ EEC. ${ }^{36}$ In that piece, the European Commission states that in the period between 1991 and 1995 a total number of 620 lawyers obtained recognition under the system of Directive $89 / 48 / \mathrm{EEC}$, and more than 400 of them were granted immediate recognition

30 Gout (1998), where he states on page 3: 'Take first the citizens of Europe. They can travel freely and establish themselves and work in another Member State. In so many information campaigns it is explained to them that their rights as consumers or (self-employed) workers are protected in the same way everywhere. They elect in common their representatives in the European Parliament. Soon they will be sharing the same currency. For them, and as far as they are concerned, a united Europe is a fact. And they cannot imagine that a Europe of lawyers is not also a fact. Whether as ordinary tourists or company managers, they expect - and rightly so - that they will find everywhere the service providers whom they need: their French Rechtsanwalt, their Danish avvocato or their Luxembourg solicitor.'

31 Rivkin (1998), pp. 423-426.

32 See also: WTO (1998).

33 CCBE (s.d.) B.

34 On possible internationalisation of the legal profession, see also: Calkoen (2000), pp. 491-503, J. Drolshammer (2000), pp. 713-775, Korhonen (2000), pp. 545-555, Murray \& Drolshammer (2000), pp. 505-543 and Vagts (2000), pp. 403-413.

35 CCBE (s.d.) C.

36 Report to the European Parliament and the Council on the state of application of the general system for the recognition of higher education diplomas, 15-02-1996, COM(96) 46 Final. 
(the vast majority being Irish lawyers recognised in the United Kingdom and vice versa). Approximately 340 lawyers attempted an aptitude test (at least 180 in the United Kingdom) and 214 out of those actually passed the test.37 More recent numbers with regard to lawyers taking the aptitude test are not available. With regard to the cross-border provision of services on the basis of Directive 77/249/EEC, no statistics are yet available. Since 2004 the CCBE has started to collect statistical information on lawyers established under the regime of Directive 98/5/EC. ${ }^{38}$ The information is however outdated, the latest information dating back to 2006, and it is fragmented in the sense that not all Member States have responded to the CCBE's request to provide the information. A combination of the 2004, 2005 and 2006 statistics provides the following figures:

Table 1: Number of EU Lawyers in Member States

\begin{tabular}{|c|c|c|c|}
\hline Country & Numbers 2004 & Numbers 2005 & Numbers 2006 \\
\hline Austria & 47 & 28 & 60 \\
\hline Belgium & 490 & 509 & 406 \\
\hline Bulgaria & - & - & 0 \\
\hline Cyprus & - & 5 & 13 \\
\hline Czech Republic & - & 15 & 46 \\
\hline Denmark & 14 & 15 & 22 \\
\hline Estonia & - & 4 & 8 \\
\hline Finland & 3 & 4 & 3 \\
\hline France & 493 & 200 & 128 \\
\hline Germany & 185 & 206 & - \\
\hline Greece & 67 & 100 & 79 \\
\hline Hungary & - & 15 & 40 \\
\hline Ireland & - & 0 & 33 \\
\hline Italy & - & - & - \\
\hline Latvia & - & 1 & 5 \\
\hline
\end{tabular}

$37 \quad$ Ibid.

38 <www.ccbe.org/en/documents/stat_en.htm>, last accessed 5 June 2007. 


\begin{tabular}{|l|c|c|c|}
\hline Lithuania & - & 0 & 3 \\
\hline Luxembourg & 42 & 30 & 103 \\
\hline Malta & - & - & - \\
\hline The Netherlands & 32 & 44 & 47 \\
\hline Poland & - & - & 34 \\
\hline Portugal & 25 & 33 & 82 \\
\hline Romania & - & - & - \\
\hline Slovak Republic & - & 23 & 68 \\
\hline Slovenia & - & 4 & 5 \\
\hline Spain & 37 & 74 & 15 \\
\hline Sweden & 2 & 5 & 230 \\
\hline $\begin{array}{l}\text { The United } \\
\text { Kingdom }\end{array}$ & 150 & - & - \\
\hline
\end{tabular}

It may be assumed that the numbers from 2006 provide the most recent information, but I have decided also to include the 2004 and 2005 statistics since a number of Member States had failed to provide data in the 2006 overview, and because there was an inexplicable reduction in numbers in Belgium, Finland, France and Luxembourg (where the reduction of numbers in France by over 50 per cent is significant). ${ }^{39}$ In addition it must be mentioned that other comments can be made with regard to these statistics. First, and most importantly, the numbers do not say anything about what activities can be exercised by these lawyers. As will be established in this book, the activities that a lawyer exercises differ from one Member State to another. Legal advice, for example, is not a regulated activity in a number of States, and a lawyer who limits himself to giving legal advice in such a State most likely does not turn up in the above statistics. Moreover, it is not clear whether Member States treat the numbers from subsequent years as totals (i.e., whether an established lawyer is counted in 2004, 2005 and 2006) or as additions to earlier numbers, and whether lawyers who proceed to full integration in the legal profession of the host Member State are actually taken off the list. The numbers therefore provide nothing more than a very superficial glance at how many lawyers actually move from one Member State to another.

This inaccurate and incomplete overview of the numbers of lawyers who actually make use of the possibility to move freely throughout the European Union

39 The CCBE website offers no clue as to the relationship between the two sets of numbers, therefore they have been included as-is. 
at least proves that there is a supply of freely moving lawyers, which also indicates that there is a demand for these lawyers. There is no information on the geographical spread of lawyers throughout the territory of the Member States. The above table shows that the Member States that host the large economic centres in Europe, Brussels, Frankfurt and London, retain the largest numbers of lawyers established under their home country titles. The United Kingdom has also seen a large influx of lawyers as a result of the Diploma Directive 89/48/EEC. Luxembourg, as host of the European Court of Justice, also has an increasing number of lawyers established under their home country's professional title. In addition to working in the big cities of Europe it might be easily imaginable that the free movement of lawyers is attractive to those lawyers which are established in a border region of a Member State and who deal with these bordering countries in their daily practice.

\section{\3. Purpose of the Study}

Now it has been established that a free movement of lawyers actually exists, the relevant questions for this study can be identified. First, it was indicated that the rules governing the development of this free movement of lawyers developed along two different paths. This two-tier development has blurred the exact extent of the rules applicable to the free movement of lawyers. Therefore, the first question must be: What rules are applicable to the free movement of lawyers?

When these rules later become established, it is then possible to research the implementation of these rules in Member States in order to answer the second question: How is this free movement of lawyers realised in the Member States of the Community? The combined answers to the first and second questions should provide a view as to the extent of the free movement lawyers as it stands today.

That premise immediately leads to the third and final question: How can the free movement of lawyers as it stands today be further developed and refined?

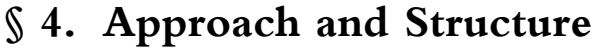

In order to answer these questions, a number of different steps must be taken. First, in order to answer the first question, a detailed account of the evolution of free movement must be given. This evolution will be described in Chapter 2 of this study. As was indicated above, advancement of the free movement of lawyers took place on two different planes. That poses a problem in the sense that a choice must be made between a thematic approach, i.e., dealing with the two different planes separately, and a more chronological approach where developments on both planes would be dealt with simultaneously. For an exercise that went no further than to give a mere description of this evolution, both approaches would suffice. The account of this development in this study has a more ambitious goal. Based on the evolution, a model will be presented that covers all modalities of the free movement of lawyers. Therefore a more intertwined approach must be followed. This approach will be largely based on chronology. The chapter will commence with a critical assessment of the case law of the European Court of Justice that has initiated the revival of the 
free movement of lawyers in Europe. This line of case law will be dubbed firstgeneration case law. After this, the chronological approach will be departed from, and a critical assessment of the three Directives that cover the free movement of lawyers will be given. This assessment will also include case law which deals with the implementation and application of the system of secondary legislation applicable to the free movement of lawyers. Lastly, a new generation of case law from the European Court of Justice is identified which then extends the results of the first generation case law beyond the scope of the application of the system of secondary legislation. In addition to this critical assessment of the last generation, attention will also be paid to the position of European Union citizens in the possession of third-country diplomas, and third-country nationals with either European Union or third-country diplomas. After this combined thematic/chronological assessment of the rules applicable to the free movement of lawyers it will be possible to draft a time-neutral model of rules that would apply to this freedom. The next chapter will also be based on that model.

The approach followed in Chapter 2 can be classified as a rule-based approach. Essentially, it will be a study of how the rules regarding the free movement ought to look on the basis of the developments that have led to the model presented at the end of that chapter. Such a rule-based approach is interesting, but it does not provide further insight as to how these rules are applied in the Member States and therefore it provides no answer to the second question posed above. In order to get such an insight, and the answer to that question, the implementation, or application, of the model in the Member States must be researched. This will be done in Chapter 3. This chapter will research how the model is implemented and applied in fifteen Member States. In the beginning of the doctoral research in 2001, I envisaged dealing with the implementation in all the Member States of the European Union in a detailed manner. When the European Union welcomed ten new Member States in 2004, and two more in 2007, it became clear that was a goal that could no longer be pursued. Twelve more Member States would add an enormous volume of research to the project with only limited added value. ${ }^{40}$ It can be questioned whether the conclusions that could be drawn from an implementation research in 27 countries would differ largely from the research in fifteen. It will be proven that this is not the case. Moreover, adding the twelve new Member States would also lead to large problems with regard to language and availability of documents. Clearly, however, these are no justifications in themselves. The exclusion of the twelve new Member States was merely for practical reasons. It is by no means a signal that the implementation in the new Member States is not interesting, but it is a subject that must be left for later research. As a prelude to such research I have added an epilogue that provides a quick glance at the implementation mechanisms of seven new Member States that have provided (unofficial) translations of their implementation mechanisms to the CCBE.

In order to provide a meaningful overview of the implementation of the model in the selected Member States, the third chapter will devote separate attention to all

40 Which is also corroborated by the rulings of the ECJ in: Case C-193/05, Commission of the European Communities v. Grand-Duchy of Luxembourg, [2006] ECR I-08673; and Case C-506/ 04, Graham J. Wilson v. Ordre des avocats du barreau de Luxembourg, [2006] ECR I-08613. 
three modalities in which a lawyer can exercise his or her professional activities abroad. These modalities will not be presented in a chronological fashion but rather along the degree of integration in the legal profession of the host Member States. Most attention will be paid to the implementation of Directive 98/5/EC which allows lawyers to establish themselves in other Member States under their home country professional title. This is not only because it is the newest addition to the model that was presented in Chapter 2 and a concise review of its implementation was still lacking, but also because it will be established that this modality has effects on areas that were previously covered by the other two modalities, i.e., the freedom to provide legal services and the right to establishment as a member of the host Member State legal profession.

In a prelude to this review, an assessment will be given of the legal professions in the fifteen Member States selected. Within this review particular attention will be given to the possibilities to qualify as a lawyer in that Member State and to the level of protection that is given to activities that are exercised by lawyers. It will be shown that in the fifteen Member States, on this latter criterion a threefold division can be made between States with a low level of protection with regard to the exercise of legal activities, Member States that grant an intermediate level and Member States that have a high level of regulation. In addition, Member States will also be grouped together in categories which have similar rules with regard to the legal profession. The review of the implementation of the different modalities will always follow the order of level of protection granted.

On the basis of this threefold division of protective attitude towards the legal profession, it will also be established that in Member States with low and intermediate levels of protection there is a 'hidden' category of professionals who are not fully qualified lawyers but who exercise activities which, in Member States offering a high level of protection, are reserved exclusively for lawyers. This category of professionals runs into problems if they seek to exercise their professional activity in a Member State with a high degree of regulation since they are not lawyers within the understanding of the latter. Their rights will be specifically addressed in the review of each modality.

Chapter 3 will also address the position of third-country nationals. The approach is somewhat different from the other modalities, since it also takes into account a set of international rules governing the exercise of legal services on a world level in the context of the World Trade Organisation (WTO) and the General Agreement on Trade in Services (GATS). After a short description of the general characteristics of GATS with regard to legal services, there will be a study of whether thirdcountry nationals can benefit from GATS rules in order to extend their very limited rights that can be awarded to them on the basis of the model. Since the review of GATS falls essentially outside the model, there will be no review of the national implementation mechanisms, however, the rules in one country will be presented as a 'best practice'.

With regard to the third question, it can be observed that one of the major shortcomings to the free movement of lawyers as it has developed over the last 30 years is the fact that it only applies to fully qualified lawyers. That does not only mean, as will be established in Chapter 3, that those professionals who are not lawyers cannot benefit from the system. However, the system does not affect the rules 
that Member States impose on the qualification track for the legal profession in their State. That problem is the subject of Chapter 4 of this study. In that chapter, research is extended to the rules which are applicable to the qualification track for the legal profession in the different Member States. ${ }^{41}$ In that sense it will be necessary to extent the scope of the research beyond the law of the European Union, since it will be established that the European Union has only very limited powers in this area. It will therefore prove necessary to assess the recent developments in the 'Bologna Process', the intergovernmental effort to create a European Area of Higher Education. In this sense specific attention will be paid to the Lisbon Recognition Convention, a Council of Europe Treaty that now forms an integral part of the 'Bologna Process'. Whether this process offers any added value in order to further the development of the free movement of lawyers in Europe will be assessed. In that sense, how the new generation case law that will be identified in Chapter 2 affects the qualification process as such and the application of the 'Bologna Process' to that process will also be reviewed. After that assessment the emphasis of Chapter 4 will shift from a critical assessment of the lex lata to the de lege ferenda. It will consider whether a possible solution to problems encountered in the qualification track can be solved by creating a new form of legal education that does not focus on the national law of the Member State but on the general principles of law (including European Law) to an extent that it can serve as a basis for the qualification track for the legal profession in more than one Member State, thus creating more flexibility for free movement in the qualification track. In this respect it will prove necessary to give an overview and an assessment of the qualification track for the legal profession in the United States of America. In addition how such new legal education should be realised and who would have to realise it will also be examined. In the epilogue some recent effects of the 'Bologna Process' will be addressed.

The fifth and final chapter of this book will draw conclusions with regard to the creation of the model for the free movement of lawyers, the implementation of that model in the Member States and the extension of that model into the qualification track to the legal profession in force in the different Member States. Based on those conclusions recommendations will be made in order to further complete and refine the free movement of lawyers in the future.

41 Duration of both university and professional education differs enormously throughout the European Union. See Schneider (2002), pp. 33-35. See also: Lonbay (1992), pp. 75-93. 


\section{Chapter 2}

\section{Development of the Free Movement of Lawyers 1958-2008}

\section{\1. Introduction}

It is apparent from the previous chapter that the free movement of lawyers in Europe was de facto non-existent from the nineteenth century. For the legal profession, the focus on national law after the period of codification meant that access to that profession was reserved only for those who were educated in, and had the nationality of, the State where they sought to become a lawyer.

This is how the situation remained after the EEC Treaty entered into force in 1958. The EEC Treaty provided for a framework of secondary legislation to be drawn up under Article 57 (now Article 47) that allowed for the mutual recognition of qualifications including (or at least not excluding) the profession of lawyers before the end of the transitional period that ended in 1969. Although some activities ${ }^{42}$ were undertaken based on that article in the field of craft and industry, no action was taken in the field of the legal profession. It was not until the European Court of Justice took the initiative that a renewed basis for the free movement of lawyers was created within the European Union. This observation also underlines a key characteristic of the development of free movement of lawyers, namely that it develops along a two-tier structure. On the one hand, the development takes place along the lines of secondary legislation, and on the other hand through case law of the European Court of Justice.

Because of this two-tiered structure, presenting the development of the free movement of lawyers is not a straightforward task. Two different approaches can be followed. On the one hand, there is a pure chronological approach, describing events as they happened. On the other hand, a more thematic approach can be followed, treating developments in case law separate from the developments in secondary legislation. The potential danger of the first approach is that a description can turn into an endless quagmire that, although chronological, at the same time is hard to understand. The downside of the thematic approach, however, is that the sense of time is lost and it is sometimes difficult, if not impossible, to explain certain developments out of their chronological context.

That being true, I chose to combine the two approaches. This chapter is devoted to a critical description of the past 50 years of the free movement of lawyers. The chapter starts by explaining the developments in the case law that led to the creation of a free movement of lawyers; this line of case law is dubbed first-generation case law. Next, the development of the three important pieces of secondary legislation

42 These 'transitional Directives' - Directive 64/427/EEC, 67/43/EEC and 68/653/EEC - were eventually consolidated by Directive 99/42/EC, [1999] OJ L 201/77, and later replaced by the new Diploma Directive, Directive 2005/36/EC [2005] OJ L 255/22. See also: Schneider \& Claessens (2005), p. 136. 
will be described, including the case law that was based on the Directives. Lastly, the case law that deals with applying established principles outside the scope of the Directives will be reviewed.

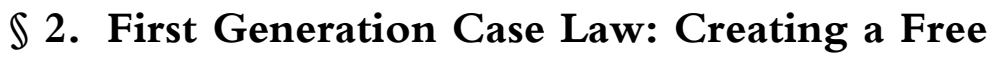 Movement of Lawyers}

Where it was next to impossible for lawyers to move freely between States in order to exercise their profession in another State before the EEC, their situation was equally bleak in the early days of the Community. As mentioned above, there was a provision in the Treaty that provided for a legal base to develop secondary legislation for the mutual recognition of qualifications in the area of the self-employed before the end of the transitional period in $1969 .{ }^{43}$ When that period expired no activity had been undertaken ${ }^{44}$ with regard to the legal profession. Therefore, lawyers remained in the same situation as before the EEC had been established, where all countries required, directly or indirectly, the State's nationality for the profession of lawyer ${ }^{45}$ (based on the so-called public-service exception, then laid down in Article 55 of the Treaty). The legal profession was at that time still almost exclusively focused at national law. It was not until 1974 that the European Court of Justice took the opportunity to kick-start the free movement of lawyers in Europe in two revolutionary cases.

43 Since the liberal profession of lawyer was, and to a certain extent still is, executed in a selfemployed manner, the applicable freedoms have always been the freedom of establishment and the freedom of services rather than the free movement of workers, even where this distinction is now regarded as 'anachronistic'. See Chalmers (2006), pp. 699-701. This anachronism is illustrated by the Kranemann case (C-109/04, Karl Robert Kranemann v. Land NordrheinWestfalen, [2005] ECR I-02421) where at least a trainee lawyer was considered to be a worker in the sense of Article 39 EC. The International Labour Organisation describes liberal professions as: 'Those services supplied by professional workers, often self-employed, such as doctors, lawyers, accountants, architects, etc.' See <www.ilo.org/public/libdoc/ILO-Thesaurus/english/ tr4621. htm>, last accessed 7 June 2007.

44 The reason that these Directives were not adopted in time is probably twofold. First, the legislative system as a whole became very slow after the Luxembourg Accords (see Craig \& de Burca (2007), p. 8), and second, it can be deduced from the complete silence on the subject of abolishing restrictions in the field of freedom of establishment, that both the Commission and the Member States were reluctant to open up regulated professions to non-nationals coming from other Member States.

45 Schneider (1995), p. 267. See also: Groeben (1991), pp. 986-990. 


\section{$\sqrt{ } 2.1$ Opening the gates: Reyners ${ }^{1}$ and Van Binsbergen ${ }^{2}$}

Jean Reyners was a Dutch national, who was born and resided in Belgium. He also chose to study law there. When he had completed all his studies, he applied to the Belgian Bar in order to become a practising lawyer, under the Belgian title of avocat or advocaat. The Belgian Bar denied his application solely on the basis that Mr Reyners had Dutch rather than Belgian nationality. Mr Reyners challenged the legislation on which the decision was based before the Conseil d'Etat. The Conseil referred several questions on the case under Article 234 of the Treaty (then Article 177) to the ECJ. The Conseil d'Etat asked whether Reyners could, in the absence of secondary legislation, rely on Article 43 directly and whether Belgium could rely on the public service exception to maintain a nationality requirement for lawyers. ${ }^{3}$

In an answer to these questions the Court actually created the free movement of lawyers. It stated that, after the expiry of the transitional period, Article 43 (then Article 52) could be relied upon directly. ${ }^{4}$ In answering this first question the Court already showed that it was willing to give a controversial ruling since it was more than obvious from the wording of the Treaty that Article 43 was never meant to be directly effective and that, according to the words of the Treaty, the Article needed the support of a system of secondary legislation. ${ }^{5}$

This revolutionary attitude of the Court was underlined by its answer to the second question. Here, the Court stated that the legal profession is not directly linked to the actual exercise of State sovereignty and can therefore not be caught under the public service exception of Article $45 .{ }^{6}$ Member States may therefore not uphold the nationality requirement for lawyers, and must facilitate the establishment of a lawyer who is fully qualified in that State (in this case Belgium), but who does not possess the nationality of that State.

The Van Binsbergen case, which was ruled upon the same year, was remarkably similar to Reyners since it dealt with almost the same questions, albeit that in this case a domicile requirement was at stake rather than a nationality requirement, ${ }^{7}$ and

1 Case 2/74, Reyners v. Belgium, [1974] ECR 631. For summaries of this case, see Arnull (2006), pp. 765-766; Bermann (1993), pp. 585-586 and 590-591; Craig \& de Burca (2007), pp. 795; Curtin (1994), pp. 458-462; Manschot (1975), pp. 136-147; Pollard \& Ross (1994), pp. 485486; Rasmussen (1989) pp. 126-127 and Steiner (2006), p. 447.

2 Case 33/74, Van Binsbergen v. Bestuur van de Bedriffsvereniging voor de Metaalnijverheid, [1974] ECR 1299. For summaries of this case, see Arnull (2006), pp. 784-786; Barnard (2007), p. 356; Chalmers (2006), pp. 744-745; Craig \& de Burca (2007), p. 792-793 and 815; Curtin (1994) p. 485, and Manschot (1975), pp. 136-147.

3 Direct effect as a matter of principle had already been established a good ten years earlier in the landmark Van Gend \& Loos case (Case 26/62, Van Gend \& Loos v. Nederlandse Administratie der Belastingen [1963] ECR 1).

4 Case 2/74 [1974] ECR 631 SS 30 and 32.

5 See further: Craig \& de Burca (2007), pp. 276-277.

6 Case 2/74 [1974] ECR 631, \$S 49-50 and 54-55. See, for a similar exception for workers in Article 39(4) EC Treaty, Case 149/79, Commission v. Belgium [1980] ECR 3881. For a further application of article 45 EC Treaty after Reyners see Case C-42/92, Thijssen v. Controledienst voor de Verzekeringen, [1993] ECR I-4047.

7 In that sense the case can be seen as a prelude to the cases dealing with indirect discrimination, which are dealt with below. 
that the case dealt with the freedom to provide services rather than the freedom of establishment.

Van Binsbergen had a legal dispute in the Netherlands. During the course of that dispute his legal advisor, Kortman, moved from the Netherlands to Belgium. When Van Binsbergen wanted to appeal against the original decision, the Centrale Raad van Beroep stated that Kortman could no longer be Van Binsbergen's lawyer since a provision under Dutch $\mathrm{Law}^{8}$ stated that in order to be a legal counsel in the Netherlands one had to be established in the Netherlands as well. Kortman and Van Binsbergen protested and indicated that this provision was contrary to Article 49 (then Article 59) of the Treaty. The Centrale Raad asked the ECJ, under the preliminary reference procedure of what is now Article 234 EC (then Article 177), whether or not Articles 49 and 50 were directly effective and could thus be relied upon by a national of a Member State before the national courts.

The European Court of Justice repeated its argument from the Reyners case stating that the Member States had foregone their chance to create Directives in the allotted time (the Treaty also required a system of directives governing the free provision of services to be set up before the end of the transitional period) and that direct application of the Treaty articles, in this case Article 49, would come in its place. ${ }^{9}$ With regard to the residence requirement, the Court stated that upholding such a requirement would deprive Article 49 of all its useful effect, and that such a requirement could also not be saved by the public service exception laid down in Article 55 of the Treaty. ${ }^{10}$

The ECJ further established in this case that the only way in which the freedom to provide services could be restricted by a Member State was if it was justified in the general interest of that State. ${ }^{11}$ General interest meant in this case, according to the ECJ, ${ }^{12}$ the rules governing organisation, ability, professional ethics, professional rules, control and liability. These rules can only be used if they are applied for all individuals who want to provide the service concerned in that specific Member State (so also the Member State's own nationals), and if these rules are necessary to avoid the provider of services from circumventing these rules by merely changing his place of establishment to another Member State. ${ }^{13}$

The Van Binsbergen case, which was determined five years before the landmark Cassis de Dijon case, ${ }^{14}$ marked only the beginning of the development of a rule of reason in the field of free movement of (legal) services in the European Community. The rule of reason concept in the free movement of services was further developed by the ECJ in Webb, ${ }^{15}$ where the ECJ elaborated on the 'objective justi-

Article 48 of the Beroepswet (wet van 2 februari 1955 houdende nieuwe regeling van de organisatie van de Centrale Raad van Beroep en raden van beroep).

9 Case 33/74 [1974] ECR 1299, \&S 20-22 and 24-26.

10 Case 33/74 [1974] ECR 1299, \$11.

11 From: Schneider (1995), page 47.

12 Case 33/74 [1974] ECR 1299, \$12.

13 Case 33/74 [1974] ECR 1299, \$\$ 12 and 13.

14 Case 120/78, Rewe-Zentrale AG v. Bundesmonopolverwaltung für Branntwein, [1979] ECR 649. For a summary of this case see Craig \& de Burca (2007), pp. 677-679.

15 Case 279/80, Criminal Proceedings against Webb [1981] ECR 3305. For similar (preceding) cases see Cases 110-111/78, Ministère public and 'Chambre syndicale des agents artistiques et impresarii de Belgique' ASBL v. Willy van Wesemael and others, [1979] ECR 32. 
fication' that was mentioned in Van Binsbergen. In 1990, the ECJ ruled in the Säger case, ${ }^{16}$ in no uncertain terms, that any restriction, even one which was non-discriminatory, that was liable to hinder the provision of services, should be abolished. For some time it remained unclear whether the ruling in Säger was confined to the freedom of services ${ }^{17}$ or whether it also applied to the freedom of establishment. It was not until the Kraus case and the Gebhard case (both described in more detail below) that this question was answered in the affirmative.

The line of case law that was initiated by Reyners and Van Binsbergen was further developed by the ECJ and gradually turned to include non-discriminatory restrictions, whereas in any event Reyners and to a lesser extent Van Binsbergen dealt with typical (in)directly discriminatory restrictions. ${ }^{18}$ The first indication that the European Court of Justice was willing to move to even lesser discriminatory restrictions imposed by Member States was illustrated by the question that was asked in the Thieffry case, ${ }^{19}$ namely whether a Member State may refuse access to its legal profession on the basis of the fact that the lawyer concerned did not possess a diploma that was required by that Member State.

\section{\2.2 Towards Non-Discriminatory Restrictions: Thieffry}

Mr Thieffry was a Belgian national who held a Belgian Law diploma (in fact he was a Doctor of Laws) and who had, sometime before this case was dealt with by the ECJ, practised as an advocate in Brussels. Subsequently his Belgian diploma was recognised by a French University and he obtained the Certificat d'Aptitude à la Profession d'Avocat ${ }^{20}$ in France. He applied for admission to the training stage at the Paris Bar, whereupon which he was refused admission solely on the basis that he held no degree in French Law. Although there was no secondary legislation on the mutual recognition of legal diplomas, the ECJ held that refusing to recognise a foreign legal diploma, where this diploma was recognised as equivalent to the national diploma by a university, could constitute a breach of Article 43. The ECJ stated that a Member State may not refuse the recognition of a diploma because of the fact that the Directives for recognition of diplomas in that profession had not yet been adopted.

16 Case C-76/90, Manfred Säger v. Dennemeyer \& Co. Ltd., [1991] ECR I-4421. See also: Case 275/ 92, Her Majesty's Customs and Excise v. Gerhart Schindler and Jörg Schindler, [1994] ECR I-1039.

17 See Schneider (1995), p. 43. See also: Schneider \& Claessens (2005), p. 125.

18 As the ECJ put it in $\int \mathbb{S} 25-26$ of Van Binsbergen: '25. The provisions of that article abolish all discrimination against the person providing the service by reason of his nationality or the fact that he is established in a Member State other than that in which the service is to be provided.

26. Therefore, at least as regards the specific requirement of nationality or residence, Articles 59 and 60 [now Articles 49 and 50 - S.C.] impose a well-defined obligation, the fulfilment of which by Member States cannot be delayed or jeopardised by the absence of provisions which were to be adopted in pursuance of powers conferred under Articles 63 and 66 [now Articles 52 and $55-$ S.C.].'

19 Case 71/76, Thieffry v. Conseil de l'Ordre des Avocats à la Cour de Paris [1977] ECR 756. For summaries of this case, see Arnull (2006), p. 811; Barnard (2007), p. 320; Bermann (1993) pp. 591-593; Craig \& de Burca (2007), p. 798; Curtin (1994), pp. 464-467; Pollard \& Ross (1994), pp. 486-487; Steiner (2006), p. 460 and Weatherill (2006), pp. 446-447.

20 This is a recognition of his qualifications as equivalent to a degree in French Law. From Craig \& de Burca (2007), page 798. 
Allowing such refusal would deny the lawyer concerned the practical benefit of the freedom of establishment. ${ }^{21}$

At first reading, this may seem just as revolutionary a ruling as the one given in the Reyners case, but from both the facts and from the ruling itself, it becomes clear that what the ECJ did was just complete a chain of events which was already very near to completion. From the facts of the case it is clear that Mr Thieffry was perfectly able to practise in France, since he was awarded a French certificate stating that his qualifications were equivalent to a French Law degree. So in this case the established equality between the qualifications had reduced the question of whether or not Mr Thieffry would need a French Law degree to an absolute technicality. The ruling itself clarified that Member States were allowed to ensure that prospective candidates have qualifications that are the equivalent of those required from national lawyers. So when it comes down to the technicality of having a particular diploma, the ECJ is willing to overlook that technicality and allow such a person to have his qualifications recognised in another Member State.

What is controversial in this case is the fact that the ECJ completely overlooked (perhaps on purpose) that Thieffry was denied access to the legal profession on the basis that he did not possess a French law degree, i.e., on the basis of academic qualifications. Recognition of academic qualifications fell (although Article 149 EC was not yet introduced in the Treaty) exclusively within the sovereignty of the Member States. The exact implication of this distinction (or the lack of distinction as is displayed by this case) will be discussed in Chapter 4 of this book. So even if the Thieffry case is not as revolutionary as it had first seemed, it again shows that the ECJ was not impressed by the lack of activity in the field of secondary legislation, and that it was not going to sit back and wait for secondary legislation to be enacted. The ECJ maintained this line of reasoning throughout the years, emphasising that Article 43 precluded national authorities from refusing applications for recognition in an arbitrary fashion. ${ }^{22}$ The ruling of the ECJ in Thieffry was confirmed in Heylens. ${ }^{23}$

\section{\2.3 Towards Non-Discriminatory Restrictions: Klopp ${ }^{24}$}

Where the restriction in Reyners was identified as discriminatory, this was more difficult to establish in the Thieffry case. The Klopp case, although still qualified as a case regarding indirect discrimination, moved even more towards non-discriminatory restrictions. Klopp was dually qualified in Germany and France and sought

21 Case 71/76 [1977] ECR 765, \$ 17: '17. Consequently, if the freedom of establishment provided for by Article 52 [now Article 43, S.C.] can be ensured in a Member State either under the provisions of the laws and regulations in force, or by the virtue of the practices of the public service or of professional bodies, a person subject to Community law cannot be denied the practical benefit of that freedom solely by virtue of the fact that, for a particular profession, the directives provided for by Article 57 of the Treaty [now Article 47, S.C.] have not yet been adopted.'

22 See Craig \& de Burca (2007), p. 799. For an application of the line of reasoning of the ECJ in the national sphere, see Platteau (1997), pp. 575-578.

23 Case 222/86, UNECTEF v. Heylens, [1987] ECR 4097. For summaries of this case, see Barnard (2007), p. 268; Craig \& de Burca (2007), p. 799; Pollard \& Ross (1994), pp. 487-495; Steiner (2006), pp. 133-134.

24 Case 107/83, Ordre des Avocats au Barreau de Paris v. Klopp [1984] ECR 2971. 
to establish himself in France while remaining established in Germany. The French authorities denied his request based on the French rule of unicité du cabinet, which meant that a lawyer established in France could only have one place where he conducted business. The ECJ ruled that double establishment lay at the core of the freedom of establishment and that therefore France was barred from applying the prohibition on double establishment as by maintaining this rule lawyers would be prevented from moving from one Member State to another. The ECJ was further of the opinion that allowing double establishment in different Member States did not impose a restriction on the application of the national professional rules in France. Theoretically, the ruling in Klopp leads to a situation of reverse discrimination. A foreign lawyer who is doubly qualified would be subject to a less strict regime than a French lawyer who was only qualified as a French lawyer. In order to counter this problem of reverse discrimination many Member States have removed their rules regarding unicité du cabinet. ${ }^{25}$

It was not until 1989 that the ECJ was confronted with the first case that could be really qualified as an indistinctly applicable restriction. The Vlassopoulou case ${ }^{26}$ would prove to be groundbreaking, and that assertion remains relevant even to this date, as it continues to serve as the standard in dealing with restrictions that flow from professional qualifications and the recognition thereof. The modern-day relevance of the case will be discussed later in this chapter.

\section{$\ 2.4$ Non-Discriminatory Restrictions: Vlassopoulou}

Mrs Vlassopoulou was a Greek national who obtained her law degree in Athens and was thereupon admitted to the Athens Bar. Subsequently, she acquired a doctorate in law from a University in Germany. She worked as a legal advisor (Rechtsberater) in a German law firm. Much of her professional practice was in the field of German law and was concentrated in the town of Mannheim in Germany. Therefore, she applied for admission to the Mannheim Bar and she sought an authorisation to practise in the Mannheim courts. Both applications were rejected by the German authorities on the ground that she lacked the necessary qualifications, which included the passing of the First and Second German State Examinations. This requirement was indistinctly applicable in nature, since German candidates also have to fulfil this requirement. Moreover, this restriction was also not indirectly discriminatory with regards to nationality and/or residence. This was therefore the first time that the ECJ would ${ }^{27}$ answer the question of the admissibility of non-discriminatory restrictions. The German Federal Supreme Court (Bundesgerichtshof) asked the ECJ whether

25 Schneider \& Claessens (2005), p. 127.

26 Case 340/89, Vassopoulou v. Ministerium für Justiz, Bundes- und Europaangelegenheiten BadenWürttemberg, [1991] ECR 2357. For summaries of this case see Arnull (2006), pp. 811-812; Barnard (2007), pp. 320-321; Chalmers (2006), pp. 716-718; Craig \& de Burca (2007), p. 800; Curtin (1994), pp. 471-475; Fierstra (1992), pp. 640-649; Lonbay (1991), pp. 507-520; Nachbaur (1991), pp. 470-472; Stein (1992), pp. 625-636; Steiner (2006), p. 462; and Weatherill (2006), pp. 455-456.

27 The ECJ had earlier carefully circumvented the problem of non-discriminatory restrictions. See for example: Case 182/83, Robert Fearon v. Irish Land Commission [1984] ECR 3677 and Case 221/85 Commission v. Belgium (Clinical Biology Services) [1987] ECR 719. 
or not it was possible to refuse Mrs Vlassopoulou access to the Mannheim Bar solely for this reason. The ECJ answered that even non-discriminatory restrictions could constitute a breach of Article 43 of the Treaty. The Court went on by stating that with regard to the specific facts of this case, such a breach could occur if the Member State in question failed to take into account experience and knowledge gained by the candidate through other means. According to the Court, a Member State that is confronted with a request from a person to access a profession that is protected by a diploma, is obliged to carry out a comparison between the knowledge and abilities required for the diploma and the knowledge and the abilities that the candidate has obtained. A Member State may not bluntly refuse access by stating that the person does not have the required diploma. ${ }^{28}$ The case shows that even in a system where there are no provisions for the recognition of equality of diplomas (in contrast to all the described cases before), as was the case in Germany, where access to the legal profession depended on the successful completion of the two German State Exams, the competent authorities of the Member States are nonetheless obliged to carry out such a comparison when they are asked to do so. According to the ECJ it is not enough to compare the different diplomas (or other qualifications involved) but Member States are also, when it is established that qualifications are not equivalent, obliged to take into account any professional experience or practical training acquired in the host Member State. They must see if that experience or training is enough to eliminate the discrepancies between the professional qualifications of the host and home Member State. If that is the case, the Member State will have to recognise the equivalence of the professional qualifications and allow the candidate into the profession concerned.

After this case, the ECJ had created a self-supporting system of the establishment of lawyers, or at least a system that has created a possibility for lawyers to ascertain whether or not their qualifications are the equivalent of those in another Member State. The ECJ went from stating that Article 43 did not need secondary legislation to be effective and that Article 45 did not apply to lawyers, to declaring that lawyers from other Member States have a right to have the equivalence of their professional qualifications scrutinised, even where such a system does not exist in the particular Member State. This line of case law shows that the ECJ was able to create a system for the free movement of lawyers in spite of the complete absence of secondary legislation for the legal profession. By the time the ECJ determined the Vlassopoulou case a

28 Case 340/89 [1991] ECR 2357, \S 15 and 16: '15. It must be stated in this regard that, even if applied without any discrimination on the basis of nationality, national requirements concerning qualifications may have the effect of hindering nationals of the other Member States in the exercise of their right of establishments guaranteed to them by Article 52 [now Article 43, S.C.] of the EEC Treaty. That could be the case if the national rules in question took no account of the knowledge and qualifications already acquired by the person concerned in another Member State. 16. Consequently, a Member State which receives a request to admit a person to a profession to which access, under national law, depends upon the possession of a diploma or professional qualification must take into consideration the diplomas, certificates and other evidence of qualifications which the person concerned has acquired in order to exercise the same profession in another Member State by making a comparison between the specialised knowledge and abilities certified by those diplomas and the knowledge and qualifications required by the national rules.' 
system of secondary legislation for the lawyer had entered into force. ${ }^{29}$ That system provided for a similar approach towards the recognition of diplomas. Undoubtedly, the ECJ was influenced by this secondary legislation when deciding the case. The development of secondary legislation will be described later on in this chapter.

After Vlassopoulou a specific corpus of case law existed for a specific non-discriminatory restriction of the freedom of establishment, namely the lack of correct qualifications. In its case law the ECJ developed a more general rule for the freedom of establishment, one that closely mimicked the rules developed in the free movement of goods and the freedom to provide services, which was discussed earlier in this chapter.

\section{$\$ 2.5$ Towards a Rule of Reason in the Freedom of Establishment: Kraus $^{30}$}

Dieter Kraus was a German national who had studied law in Germany, and who was a fully qualified German lawyer. He had obtained a Master of Laws (LL.M.) degree after he followed a postgraduate course in Scotland. At that time, Germany required official authorisation of academic qualifications. This meant that Kraus had to apply to the German authorities to have his title officially recognised in order to use it. The use of titles without prior official authorisation was regarded as a criminal offence. Kraus was of the opinion that this rule was overly restrictive and therefore he notified the authorities of the fact that he had obtained the LL.M. title, but refused to ask for an official authorisation of that title. The authority declared that official recognition was still absolutely necessary and that penalties would be imposed if Kraus were to use his title without prior official authorisation. Kraus appealed against this decision and in the subsequent proceedings, prejudicial questions were asked.

The ruling of the ECJ in this case resembled one of its earlier, celebrated rulings, namely that of the Cassis de Dijon case. ${ }^{31}$ The ECJ proclaimed that national measures which are liable to hinder or make less attractive the exercise of the freedom of establishment are only allowed when they can be objectively justified. The ECJ also stated that this objective justification includes a proportionality test. In this case the latter meant that the authorisation procedure may only be employed in order to verify whether the title was properly awarded. In addition, the ECJ ruled that the verification process needed to be readily accessible and that verification should not come at excessive administrative costs. ${ }^{32}$

This case provided for a genuine breakthrough. As a result of the very generalised language adopted by the ECJ, Kraus can be used in a variety of situations. The ECJ stated that every national measure that is liable to hinder or make less attractive the freedom of establishment must be objectively justified. This was the first time in

29 The implementation period for Directive 89/48/EEC ended in January 1991, while the ECJ ruled on Vlassopoulou in May 1991.

30 Case C-19/92, Kraus v. Land Baden-Wïrttemberg [1993] ECR I-1663. See, for summaries: Arnull (2006), pp. 761-762; Barnard (2007), pp. 273-274; Chalmers (2006), pp. 217-218; Roth (1993), pp. 1251-1258; and Smith (1994), pp. 643-662.

31 Case 120/78, Rewe-Zentrale AG v. Bundesmonopolverwaltung für Branntwein, [1979] ECR 649.

32 See also: Schneider \& Claessens (2005), p. 129. 
the context of the freedom of establishment that the ECJ laid down a rule in such broad terms. In previous cases the ECJ had dealt with specific restrictions (such as recognition of diplomas in Vlassopoulou) but never with restrictions in general. The ruling in Kraus therefore went far beyond the facts of the case, and the interests of the parties. Kraus did not stand on its own. As was described above, the ruling mirrors that of Cassis de Dijon in the field of free movement of goods. The free movement of services saw an early development of a rule of reason in the Van Binsbergen case (determined five years before Cassis de Dijon) which was later developed in cases like Säger and Webb. It was not until 1995 that the ECJ gave a ruling that would bring about the creation of one general rule for restrictions regarding all four freedoms. This ruling was given in the Gebhard case. ${ }^{33}$

\section{\2.6 Completing the System: Gebhard}

Reinhard Gebhard was a German lawyer who was working in Italy. He was prosecuted by the Milan Bar Association because he had used the title avvocato on the letterheads sent from his Milan-based office without any authorisation from the Milan Bar Association, and also because he had opened that office in Milan. Italian law authorised lawyers from other Member States to work on a temporary basis in Italy but it prohibited their permanent establishment for those purposes. Mr Gebhard argued that the Italian law was contrary to the Lawyer's Services Directive ${ }^{34}$ (Directive 77/249/EEC, which will be dealt with in the next paragraph) because the prohibitions of the Milan Bar Association constituted, in his view an obstacle to his freedom to provide services. The Italian Court asked for an ECJ ruling on two separate points; first, it wanted to know whether the opening of an office was compatible with the Lawyer's Services Directive, and secondly which criteria had to be used in order to determine whether a certain activity was deemed as temporary or permanent. Advocate-General Léger agreed with Mr Gebhard. In his conclusion he stated that the prohibitions of the Milan Bar Association, i.e., the prohibition to open an office in another Member State and the prohibition to use the professional title of the host Member State, were contrary to Directive 77/249/EEC. He further stated that the difference between establishment and the provision of services should be derived from the lawyer's principal centre of activity and from the length of time spent in the host Member State.

The ECJ ruled that it was inherent in the provision of services that they are to be performed on a temporary basis. ${ }^{35}$ However, this does not preclude the lawyer from providing these services within a certain infrastructure, i.e., an office, at his

33 Case C-55/94, Reinhard Gebhard v. Consiglio dell'Ordine degli Avvocati e Procuratori di Milano, [1995] ECR 4165. For summaries of this case, see Arnull (2006), p. 762; Barnard (2007), p. 274; Chalmers (2006), p. 703-704; Craig \& de Burca, pp. 801-802; Denys (1996), pp. 3437; Ewig, (1996), pp. 13-15; Farthouat \& Puel (1996); Huglo (1996), pp. 741-746; Jarvis M (1996), pp. 247-255; Lonbay (1996) A, pp. 1073-1087; Steiner (2006), p. 455 and Ysewyn (1997), pp. 24-29.

34 It is remarkable to see that no mention was made of Directive 89/48/EEC which was not implemented at that time in Italy, but which could have served in providing a solution in this case.

35 Case 55/94, $\$ 26$. 
disposal. ${ }^{36}$ The ECJ ruled that the activities Mr Gebhard exercised fell under the freedom of establishment and not under the freedom to provide services, because they were professional activities exercised on a stable and continuing basis. ${ }^{37}$

With regard to the second question, the ECJ determined the criteria which national laws must fulfil in order to constitute an objective justification to a limitation to the freedom of establishment. The ECJ set out four criteria. National rules which are liable to hinder or make less attractive the exercise of the fundamental freedoms guaranteed by the Treaty (whereby the ECJ does not distinguish between the different freedoms) must fulfil four criteria: they must be applied in a non-discriminatory manner; they must be justified by imperative requirements in the general interest; they must be suitable for securing the attainment of the objective which they pursue; and they must not go beyond what is necessary. ${ }^{38}$

Gebhard therefore extrapolated the rule of reason that was developed in the realm of the free movement of goods and services through the Cassis de Dijon and the Van Binsbergen cases, and which was later, through Kraus, also adopted for the freedom of establishment, to the rule of reason that is independent of the individual freedoms, stating that any restriction on any of the four freedoms should be objectively justified. Gebhard can therefore be seen as the capstone of the line of case law dealing with the free movement of lawyers.

When a person who seeks to exercise his right of free movement encounters a national measure in another Member State that is liable to hinder, or make less attractive, his exercise of those free movement rights, the first step is to research whether secondary legislation (which will be described in the next paragraph) applies to his situation. When his situation is covered by secondary legislation, this legislation (or its implementation) prevails over the system laid down in case law. What is problematic in this context, is establishing the exact leeway that a Member State has in imposing rules prescribed in that legislation. In almost every instance, case law of the ECJ will be required in order to clearly define the margin of leeway awarded to the Member State in question.

Secondly, if it has been established that the case falls, either completely or partly, ${ }^{39}$ outside the scope of application of secondary legislation applicable in that sector, the solution must be sought in the case law of the ECJ. The ECJ first developed specific rules for specific restrictions with the result that different systems in case law apply for different restrictions. ${ }^{40}$ Restrictions with regard to the recognition of diplomas may, for instance, be solved under the Vlassopoulou doctrine.

Only in the third instance, and indeed as a capstone, the general system laid down in Gebhard is applied. Where no secondary legislation applies, and where no specific system is laid down in the case law, a national measure that is liable to hindering, or make less attractive, the exercise of one of the freedoms may be objectively justified by applying the four-stage test that was laid down in Gebhard.

\footnotetext{
36 Case 55/94, \27.

37 Case $55 / 94, \S 28$.

38 Case $55 / 94, \$ 37$.

39 See cases C-164/94, Aranitis v. Land Berlin, [1996] ECR I-135 and C-234/97, Teresa Fernández de Bobadilla v. Museo Nacional del Prado, Comité de Empresa del Museo Nacional del Prado, Ministerio Fiscal, [1999] ECR I-4773. For the latter case, see Wasmeier (1999), pp. 746-750.

$40 \quad$ See Chalmers (2006), pp. 707-722.
} 
Gebhard was decided under similar conditions as Vlassoupoulou, namely with preparations for a new piece of secondary legislation affecting the free movement of lawyers well underway. At this point in the chapter it is therefore necessary to switch to an assessment of the developments that occurred in secondary legislation, including applicable case law, and the changes occurring in the next generation case law.

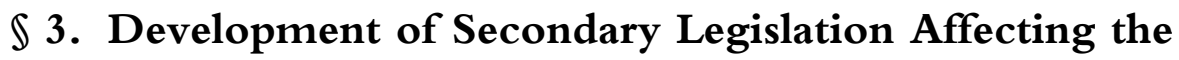 Free Movement of Lawyers}

The original EEC Treaty provided for a system of secondary legislation to be drawn up in order to implement the freedom of establishment and the freedom to provide services. This procedure of adopting secondary legislation should have been completed before the end of the transitional period in 1969. Only very limited activity was undertaken during this transitional period, however. The adoption of the Council General Programmes in order to abolish restrictions on the freedom of establishment occurred in $1961 .^{41}$ Although no activity had been deployed in the field of lawyers (as was concluded in the Reyners case) or for any liberal profession for that matter, the European Community did deploy some activities in the 1960s. In this period some 'transitional directives' were adopted which governed the recognition of professional experience in a number of sectors such as commerce, industry and small crafts industries. In the late 1990s, these 'transitional' directives were consolidated in Directive 99/42/EC, ${ }^{42}$ which in itself is now replaced by Directive 2005/36/EC. ${ }^{43}$ With regard to the free movement of lawyers, no activity was undertaken during the transitional period (apart from one attempt, described below) and therefore it was the ECJ that had to create a free movement of lawyers by means of its rulings.

There are three pieces of secondary legislation that are of importance for the development of the free movement of lawyers. These will be dealt with in chronological order in this paragraph.

\section{\3.1 Vertical Harmonisation and the Services Directive}

It is not difficult to imagine what kind of restrictions can be imposed on people who seek to establish themselves in another Member State. As was described above, the Reyners case has already dealt with nationality requirements. Other restrictions can be easily imagined, for example, language requirements. ${ }^{44}$ By far the most restrictive rules that can be maintained by Member States are those concerned with professional qualifications. If a Member State has the right to decide that certain professions may only be exercised when the migrant possesses a diploma that was awarded in that Member State, it can be virtually impossible for people from other Member States to enter that profession. It was precisely in this area that the legislative institutions employed their first efforts to create secondary legislation. After the previous non-

41 OJ Spec. Ed., Second Series, IX.

42 See Schneider \& Claessens (2005), p. 136.

43 Directive 2005/36/EC [2005] OJ L 255/22.

44 On language requirements as a restriction, see Schneider \& Claessens (2005), pp. 132-136. 
activity in opening up regulated 'liberal' professions, the Institutions of the European Community issued, between 1975 and 1985, a number of Directives which were meant to lay down minimum harmonisation of education and the mutual recognition of diplomas for certain regulated professions. These professions were: doctors, ${ }^{45}$ nurses ${ }^{46}$ dentists, ${ }^{47}$ veterinarians,${ }^{48}$ midwifes ${ }^{49}$ and pharmacists. ${ }^{50}$ For architects, a Directive was issued on the recognition of diplomas yet no minimum harmonisation of education was laid down. ${ }^{51}$ It was completely impossible to create harmonisation measures for professional engineers or for lawyers. Through this vertical approach the Institutions tried to liberalise the free movement in these regulated professions. In principle the approach had to be successful since adopting common standards for education would take the sting out of mutual recognition and open the professions to those who had not enjoyed the national qualification process previously. However, problems remained in that negotiating minimum educational standards (and mutual recognition) proved to be a cumbersome and an enormously time-consuming task that eventually proved impossible for certain professions, like the profession of lawyer. ${ }^{52}$

When reviewing this development, a number of observations can be made with regard to the freedom of establishment for lawyers. Firstly, no directives were issued exclusively for this profession. Thus, the only evidence of the existence of the freedom of lawyers to establish in another Member State remained linked to the ruling of the ECJ in the Reyners case. ${ }^{53}$ Secondly, because directives had been issued for some other professions, it could have been deduced that the Member States were perhaps willing to open all regulated professions in principle, but that they deemed it impossible to achieve in practice. Although the institutions failed to issue directives for the co-ordination of legal education and the recognition of legal diplomas, some action was taken in the area of trans-border activities for professional lawyers. In 1977 a directive was issued which regulated the trans-border provision of services by lawyers within the European Community. ${ }^{54}$ This directive would prove to be the fertile soil on which the later establishment directive could be built.

The idea of issuing a directive that would regulate the freedom to provide services was not new. On the contrary, the original proposal for Directive 77/249/EEC, facilitating the effective exercise by lawyers of their freedom to provide services (legal

45 Directive 75/362/EEC of 16 June 1975 (recognition) and Directive 75/363/EEC of 16 June 1975 (minimum standards), [1975] OJ L 167.

46 Directive 77/452/EEC of 27 June 1977 (recognition) and Directive 77/453/EEC of 27 June 1977 (minimum standards), [1977] OJ L 176.

47 Directive 78/686/EEC of 25 July 1978 (recognition) and Directive 78/687/EEC of 25 July 1978 (minimum standards), [1978] OJ L 233.

48 Directive 78/1026/EEC of 18 December 1978 (recognition) and Directive 78/1027/EEC of 18 December 1978 (minimum standards), [1978] OJ L 362.

49 Directive 80/154/EEC of 21 January 1980 (recognition) and Directive 80/155/EEC of 21 January 1980 (minimum standards), [1980] OJ L 33.

50 Directive 85/432/EEC of 16 September 1985 (recognition) and Directive 85/433/EEC of 16 September 1985 (minimum standards), [1985] OJ L 253.

51 Directive 85/384/EEC of 10 June 1985 (recognition), [1985] OJ L 223.

52 See further Schneider \& Claessens (2005), pp. 136-139.

53 Case 2/74, Reyners v. Belgium, [1974] ECR 631.

54 Directive 77/249/EEC of 20 March 1977, [1977] OJ L 78. 
bases are Articles 47 and 55), was already issued in 1969. At the time it was rejected because Germany and Luxembourg were of the opinion that the legal profession was subject to the exception laid down in Article 45 of the Treaty. It was only after Reyners and Van Binsbergen that the possibility arose to adopt a Directive in order to facilitate the effective exercise by lawyers of the freedom to provide services. ${ }^{55}$

Although the Services Directive was adopted in the era of vertical harmonisation, it differs from the vertical approach on some essential points. The essence of the vertical approach was the mutual recognition of the qualifications of the individuals exercising that profession and was made 'harmless' by laying down minimum criteria for education. It showed that this was impossible for for the profession of a lawyer. Even if all parties involved, Institutions, Member States and professional organisations, had been willing to create such a system for lawyers, it would have been next to impossible, since lawyers are educated in their national legal systems and in consequence know little of the legal systems of their neighbouring Member States.

The Services Directive therefore seems to be fairly similar to the Architects Directive, which was also adopted without an accompanying Directive laying down minimum educational standards. However, they differ in that the Architects Directive allows establishment, whereas the Lawyer's Services Directive is limited to services. The first article of the Directive states that it shall apply to all lawyers in the Member States. A lawyer in the sense of the Directive is a person who is allowed, on the basis of national law, to bear one of the professional titles listed in that article. The article also gives the right to Member States to exclude certain activities which are, in that particular Member State, not exercised by lawyers. For example, activities which are exercised in the Netherlands by a notaris (notary) may be exercised in the United Kingdom by a solicitor. That same solicitor may, however, not exercise such activities when providing services in the Netherlands, since a Dutch advocaat (lawyer) may not exercise such activities either.

According to Article 2, Member States have to recognise a lawyer as any person who is entitled to bear the professional titles listed in the second paragraph of Article 1. The question of which professional title should be used by a lawyer providing services in another Member State is solved by Article 3 of the Directive. That article states that lawyers who provide services in another Member State are obliged to use their own professional title, also known as the 'home title'. That means that if a German lawyer provides services in the Netherlands he must indicate that he is a Rechtsanwalt.

Moreover, a lawyer providing services in another Member State is obliged to indicate either the professional organisation through which he or she is authorised to practise, or the court of law before which he or she is entitled to practise according to the laws of that Member State. Therefore, if the above-mentioned German lawyer is a member of the Mannheim Bar and is providing services in the Nertherlands, he will have to indicate that he is a Rechtsanwalt authorised to practise by the Mannheim Bar.

The core of the Directive can be found in Article 4. That Article lays down the conditions under which services may be provided in another Member State. The first paragraph of Article 4 states that where the services provided by the lawyer consist of representing a client in legal proceedings or before public authorities, that 
lawyer must abide by all the conditions laid down in the host Member State for lawyers established in that State, except of course, all the conditions which require residence and/or registration with a professional organisation in the host State.

The second paragraph of the Article states that a lawyer who provides services of the kind laid down in the first paragraph of the Article must observe the rules of professional conduct of the host Member State without prejudice to his obligations in the Member State in which he is established, i.e., his home Member State. Hence it becomes clear that a lawyer who provides services in another Member State will have to abide by two sets of rules; the rules of professional conduct of the host Member State and the rules of professional conduct set by his home Member State. This phenomenon is often referred to as the Kumulationsprinzip. ${ }^{56}$ Clearly this principle leads to quite some difficulties when the host Member State's rules of conduct do not coincide with rules of the home Member State. Although the Directive offers no direct solution for this problem, it is now generally believed that when there is a conflict, the rules of the host Member State prevail. ${ }^{57}$

Article 5 of the Directive provides for a further elaboration of the rules for representing a client in legal proceedings if a Member State so desires. According to Article 5, the elaboration can consist of an introduction, in accordance with local rules or customs, to the presiding judge, and, where appropriate, to the President of the relevant Bar in the host Member State. A host Member State may also require the lawyer who provides the services to work in conjunction with a lawyer who is a member of the legal profession in the host Member State and who practises before the judicial authority in question and would therefore, if necessary, be answerable to that authority.

Where activities exercised by the lawyer do not constitute representation of a client in court, paragraph 4 of Article 4 states that a lawyer exercising those activities shall be subject to the rules of professional conduct in the home Member State, without prejudice to respecting the rules, whatever their source, governing such subjects in the host Member State. The paragraph states further that visiting lawyers must be especially respectful toward the rules of the host Member State on incompatibility of the exercise of the activities of a lawyer with the exercise of other activities in the host Member State, professional secrecy, relations with other lawyers, the prohibition on the same lawyer acting for parties with mutually conflicting interests, and publicity.

The Article states that these latter rules only apply to those lawyers not established in the host Member State who are capable of observing them, and to which extent their observance is objectively justified to ensure the proper exercise of a lawyer's activities, the standing of the profession and respect for the rules concerning incompatibility, in the host Member State. From this rather cryptic sentence, one could deduce that the rules of professional conduct in the host Member State only have to be observed, at least in so far as activities outside trials are concerned, when they do not lead to an unjustified restriction to the freedom to provide services. ${ }^{58}$

Article 7 of the Directive lays down the rules applying to disciplinary measures. The first paragraph of this Article states that the competent authority in a host Member State may require the lawyer who seeks to provide the services to prove his legal

Van Camp (1989), p. 38.

Ibid., p. 40.

58 Schneider (1995), p. 272. 
qualifications which were obtained in the home Member State. The second paragraph states that a lawyer who provides services is, in the event of non-compliance with the obligations laid down in Article 4 of the Directive, subject to the rules laid down in the host Member State. The competent authority in the host Member State has the right to obtain information about the person providing the services, without violating the confidential nature of that information. Moreover it shall notify the competent authority of the home Member State of any decision taken.

What is most striking about the Services Directive is that there seems to be complete mutual recognition of lawyers who provide services in other Member States. Apart from some specific peculiarities of the British legal system, there are no limitations on professional activity, and a lawyer providing services in another Member State may apparently exercise all the professional activies of a home lawyer, albeit under a rather complicated regime of applicable professional rules. The Services Directive is remarkably liberal for its time, and it questions the necessity of the blood, sweat and tears which went into the creation of the minimum educational standards Directives in the vertical approach. Partly, this is explained by the fact that the Services Directive would only apply to lawyers providing occasional services in another Member State. However, as has already been mentioned above, it also did good service to those who wanted to be established as a lawyer in another Member State at a time when there was no (European) legal framework for them to do so.

The Services Directive attracted some criticism as well. Legal scholars argued that the field of trans-national consultation, which was not regulated and therefore very liberal, was now subject to the rules laid down in the Directive, and that the Directive was actually more of a step back than a step forward to the freedom of lawyers to provide services. ${ }^{59}$ I find it hard to understand this particular critique, since Member States that employed less stringent regimes for activities that in other countries were part of the lawyer's legal monopoly, like legal advice, would still allow persons not being lawyers to exercise this activity. Aside from this, it could also be argued that the Directive is not complete in that, for example, there is a total lack of regulation in the field of fees.

In the 30 years of its existence, the Lawyer's Services Directive has generated surprisingly little case law. The most important case in this respect is Commission $v$. Germany. ${ }^{60}$ This case dealt with the German implementation of Article 5 of Directive 77/249/EEC.

The German authorities had implemented this Article in a manner by which a foreign lawyer was at all times required to work together with a German lawyer, who would also act as the primary lawyer dealing with the case. Foreign lawyers were even obliged to follow this requirement/structure in cases where representation by a lawyer was not mandatory. In addition, the German authorities required extensive proof of this compulsory cooperation and required that the German lawyer assigned to the lawyer providing services would be the lead counsel in the case. The European Commission thought that this implementation went beyond the scope of Article 5 of the Directive and brought the case, by means of the procedure laid down in Article 226 of the EC Treaty, to the European Court of Justice, which agreed with

$59 \quad$ Van Camp (1989), p. 55.

60 Case 427/85, Commission v. Germany, [1988] ECR 1123. See, for a summary of this case, Bermann (1993), pp. 598-601. 
the Commission. The European Court of Justice ruled that a foreign lawyer should be allowed to work alone if representation by a lawyer was not mandatory in the particular circumstances in the host Member State. In cases where such representation was mandatory, the foreign and the national lawyer working together should themselves determine their relationship, and that it could not be laid down in a law that the national lawyer should always have the primary role in the case. The ruling of the European Court of Justice was confirmed in the case of Commission v. France. ${ }^{61}$

The European Court of Justice clearly did some important work here in order to safeguard the free provision of services for lawyers. Had the Court not intervened, then the Member States would have had the opportunity to reduce the freedom of services for lawyers almost completely. The role of a lawyer in providing representation for a client abroad would be marginal if he was forced to work with a national lawyer even in situations where the national law did not prescribe compulsory legal representation. The importance of this case clearly stretches beyond Directive 77/249/EEC. The Lawyers Establishment Directive contains a similar provision on working in conjunction with a national lawyer. Although there are no limitations on this provision included in the text of the Directive, it is self-evident that the limits imposed by the Court on the cooperation provision in the Services Directive also apply to the similar cooperation provision in the Lawyers Establishment Directive.

Other cases under the Lawyers Services Directive have been scarce. It is worth mentioning the Gebhard case, which had been classed as a first-generation case, where the Court also ruled that setting up of an office or other infrastructure can fall within the freedom to provide services, and the demarcation between services (which is governed by Directive 77/249/EEC) and establishment (governed by Directives 89/48/EEC and 98/5/EC) is made on time difference alone. ${ }^{62}$ The last case which requires some attention is the $A M O K$ case $^{63}$ which dealt with a subject that was not as such regulated by the Directive, namely the restitution of fees. The Court stated that the Directive warrants that a calculation of restitution of fees is made on the rules in force in the host Member State, and that the restitution of fee for a lawyer is limited to what a home State lawyer would have received. According to the Court, it is a violation of the Directive if the Member State does not allow restitution of legal fees for a lawyer who is, according the rules of the Member State, cooperating with the lawyer who provides services in that Member State. The ratio behind this dictum is clear, because if a person soliciting for a lawyer is not able to claim restitution of the fees of the cooperating lawyer, it is unlikely that such a person would opt for the services of a foreign lawyer over a domestic lawyer. This German rule therefore directly infringed the full enjoyment of the provision of services as safeguarded by the Directive. Therefore the Court held this rule to be in violation of the Directive.

The next Directive that needs to be reviewed is the so-called Diploma Directive, which was the result of a dramatic change in the approach towards the recognition of diplomas.

61 Case C-294/89, Commission v. France, [1991] ECR I-03591.

62 Italy needed some more encouragement to abolish the rules that made it illegal for lawyers providing services to have an infrastructure, see Case C-145/99, Commission of the European Community v. Italian Republic, [2002] ECR I-02235.

63 Case C-289/02, AMOK Verlags GmbHv. AER Gastronomie GmbH, [2003] ECR I-15059. 


\section{\3.2 The Horizontal Approach: The Diploma Directive 89/48/ EEC $^{64}$ and Directive 2005/36/ CC $^{65}$}

Directive 89/48/EEC did not emerge completely without warning. As early as 1974 the Council expressed the will, in a non-binding resolution, ${ }^{66}$ to abolish the scheme of very detailed directives for all the different professions. According to the Council, the future system should be based on more lenient criteria and the future directives should abstain, as much as possible, from detailed requirements. ${ }^{67}$ In the early 1980 s this opinion was so well established within the Council that the adoption of the last two directives in the vertical harmonisation scheme, the aforementioned directives on pharmacists and architects, was a very long and difficult process. ${ }^{68}$

This line of reasoning was prolonged in 1984 when the European Council decided in Fontainebleu that a new, more general approach towards the recognition of higher-education diplomas was necessary, also because the admission of new Member States would inevitably lead to the alternation of existing and possible future directives in the vertical harmonisation scheme, which would be a time-consuming process. ${ }^{69}$ This view led to the adoption, on 21 December 1988, of Directive 89/48/ EEC, created on the basis of what were then Articles 49, 57(1) and 66 (now Articles 40, 47(1) and 55), providing for a general system for the recognition of highereducation diplomas awarded on completion of professional education and training of at least three years duration.

The Diploma Directive completely departed from the old system. The Directive started from the premise that qualifications giving access to a certain regulated profession, dubbed 'diploma' in the terminology of the Directive, would be mutually recognised. This meant that if a person was allowed to exercise a regulated profession in one Member State, he would consequently also be allowed to exercise the corresponding profession in any other Member State in the European Community. Only in circumstances where it was established that there was a considerable difference between the regulated profession of the Member State where a person obtained his qualifications and the profession in the Member State he sought to go to, could the latter State require compensatory measures in order to cover for this difference.

Article 1 of the Directive gives detailed definitions of education considered to correspond to a diploma in the sense of the Directive. The most important requirement is that the diploma be awarded after the completion of a post-secondary course of at least three years' duration, or of an equivalent duration part-time, at a university or a higher education establishment. In addition, there is a requirement that the bearer of the diploma must have completed the professional training required in addition to the post-secondary course. A limitation of the scope of the Directive can be found in Article 2, which states that the Directive only applies to those nationals of the European Community who seek access to a regulated profession. Moreover,

64 [1989] OJ L 19/16. For a very elaborate article on Directive 89/48/EEC, see Pertek (1992), pp. 293-324. See also: Schneider (1989), pp. 368-374.

65 Directive 2005/36/EC, [2005] OJ L 255/22.

66 [1974] OJ C 98/1.

67 From: Craig \& de Burca (1996), p. 726.

68 Pertek (1994), p. 61.

69 See Pertek (1994), pp. 61-62 and Schneider (1995), p. 162. 
the Article states that regulated professions subject to a directive from the vertical harmonisation scheme will remain governed by that directive and not by Directive 89/48/EEC. Since the adoption of the new Diploma Directive, the sectoral Directives have been revoked and their acquis is now governed by Directive 2005/36/EC.

Article 3 of the Directive states that the mere lack of a diploma of the Member State in which the pursuit of a regulated profession is sought is not enough to reject an application for pursuit of that profession by a national from another Member State. This is the case where the applicant holds the diploma required by another Member State for the taking up of the profession in question. However, if the applicant has pursued the profession in question full-time for two years during the past ten years in another Member State that does not regulate the profession, and if the applicant possesses evidence that he had been awarded a formal qualification, ${ }^{70}$ recognition cannot be refused.

While Article 3 is beneficial to individuals seeking entrance to a regulated profession in another Member State, Article 4 ensures that Member States can take appropriate compensatory measures in order to make sure that the quality of the regulated profession does not deteriorate with the application of the Directive. In order to ensure quality, the Article allows Member States to require either additional professional experience (where the education in the home Member State is shorter than in the host Member State), or require applicants to take an aptitude test or to complete an adaptation period (with a maximum duration of three years). These latter options are open to the Member States where the substance which is dealt with in the education and the professional training differs substantially in the two Member States concerned, or where the regulated profession covers more fields in the host Member State than in the home Member State.

In principle the applicant is free to choose between the aptitude test and the adaptation period, where so required. Only when precise knowledge of the law of the Member State concerned is required the host Member State may prescribe either the aptitude test or the adaptation period. ${ }^{71}$ Having said this, it must be kept in mind that the application of a compensatory measure is secondary to an individual review of the applicant's knowledge and experience, as was also laid down by the ECJ in the Vlassopoulou case. Only when it has been decided on the basis of that comparison that the candidate has too little knowledge of the legal system of the Member State in question, a compensatory measure may be imposed. With regard to the lawyer, as it is dealt with in this book, all Member States have opted for an

70 I.e., which have been awarded by the competent authority in that Member State and which show that the applicant has completed a post-secondary course of at least three years' duration, or of an equivalent duration part-time, at a university or an establishment of higher education, and which shows, where applicable, that the applicant has completed the professional training required in addition to the post-secondary course which has prepared the applicant for the pursuit of the profession in question.

71 That this can also occur in a profession other than that of lawyer is illustrated by Case C149/05, Harald Price v. Conseil des ventes volontaires de meubles aux enchères publiques [2006] ECR I-07691. That it is, however, not completely up to the Member State's discretion is illustrated by Case C-197/06, Confederatie van Immobiliën-Beroepen van België VZW, Beroepsinstituut van Vastgoedmakelaars v. Willem Van Leuken, [2008] ECR I-nyr. 
aptitude test. Denmark had originally chosen the adaptation period but it changed its view under the influence of the choices taken by the other Member States. ${ }^{72}$

Article 10 of Directive 89/48/EEC allows Member States to extend the limitation of choice beyond the professions requiring precise knowledge of the law of the host Member State. In order to impose such a limitation, prior approval of the Commission must be sought. No such permission has been given since the coming into force of the Directive.

Article 5 of the Directive gives applicants the possibility to undergo professional education and training that had not been followed in the home Member State, with the assistance of a qualified member of the profession in the host State. Although the article does not say so, it seems that this additional professional education would be aimed at circumventing compensatory measures provided for in Article 4 of the Directive.

Article 6 of the Directive gives Member States the right to require proof of good character. Member States must accept as sufficient proof official documents provided by the competent authorities in the home Member State. Where a Member State does not produce these documents, they can be replaced by a declaration on oath or a solemn declaration. Where the national oath or declaration is unsuitable for use by foreigners the competent authorities of the host Member State shall provide a suitable equivalent.

Article 7 clarifies the question of which professional title a national of another Member State should use when he is allowed into the regulated profession of his choice in the host Member State. The Article makes clear that where a national is allowed into such a profession, he or she is also allowed to use the professional title that is reserved for that profession in the host Member State. In Member States where the right to use a certain professional title is dependent on the membership of a professional organisation, the national who is allowed entrance to the regulated professions shall also have a right to become a member of that professional organisation.

Even at first glance it is clear that the Diploma Directive is significantly different when compared with the other Directives, both the Vertical Directives and the Lawyer's Services Directive adopted previously. It contains no detailed rules on minimum educational standards, but still ensures mutual recognition (albeit under certain conditions). When compared with the Services Directive, the Diploma Directive offers something new for lawyers, namely complete and full integration into the host Member State's legal profession, including the use of the professional title of the host Member State. This was not possible under the Services Directive since it requires the use of the host country professional title. However, this possibility came at a price. From the nature of the legal profession, and legal education, and with different legal systems in place in each Member State, it is likely that there are substantial differences between the professions in the home Member State and the host State, so that the requirement of compensatory measures by the host State is more often than not warranted. Where the competent authority of a Member State decides that an aptitude test is necessary, the actual, substantive, recognition of diplomas is left to the discretion of the Member State. In the case of lawyers each Member State can decide for itself how much knowledge a candidate must have in order to 
obtain access to the regulated profession. It must be mentioned that this discretion is limited by the principle of proportionality. Nevertheless, an aptitude test can be a difficult hurdle to pass. ${ }^{73}$ The ECJ had the opportunity to rule on the extent of the aptitude test in Commission v. Italy. ${ }^{74}$ The Italian legislation governing the implementation of the Diploma Directive ${ }^{75}$ contained two problems that were to be addressed in this case. First of all, the legislation required that the lawyers established in Italy on passing an aptitude test had to be permanently resident there. Such a residence requirement was contrary to the very principle of the freedom of establishment and had already been provided for in Klopp (discussed above). Therefore, the Court had little difficulty in ruling that this part of the Italian implementation was contrary to the Directive. The second complaint of the Commission was more difficult. The rules with regard to the aptitude test laid down in the Italian implementation mechanism were very general. The Commission stated that in practice these general rules were abused and lawyers seeking integration in the Italian legal profession by way of an aptitude test were discriminated against since they were obliged to take a test which was more demanding than the exam Italian lawyers had to sit in order to become a member of the Italian legal profession. The Court was not convinced by the evidence put forward by the Commission so it stopped short of ruling that the Italian aptitude test was discriminatory. The Court did, however, rule that the Italian implementation of the Diploma Directive was too vague and created a situation of legal uncertainty. Subsequently, the implementation mechanism has been changed. ${ }^{76}$ Whereas the Court did not rule on the actual extent of the aptitude test as a result of insufficient evidence, it can be deduced from the case that the outermost border of an aptitude test lies with the test national lawyers must take. In individual cases even a less intensive aptitude test can be in violation of the Directive. To this date, the corpus of the ECJ's case law lacks rulings on this specific issue. There are, however, three other cases which illustrate well the opinion of the ECJ with regard to the possibility of Member States applying compensatory measures.

The first case worth mentioning in this respect is the Beutenmüller case, ${ }^{77}$ which was concerned with the demarcation between Directive 89/48/EEC and 92/51/EEC

73 Podell (1999), pp. 57-70. See also: Report to the European Parliament and the Council on the state of application of the general system for the recognition of higher education diplomas, 15-02-1996, COM(96) 46 Final. In this document, the European Commission states that in the period between 1991 and 1995 a total number of 620 lawyers obtained recognition under the system of Directive 89/48/EEC, more than 400 of which were granted immediate recognition (the vast majority being Irish lawyers recognised in the United Kingdom and vice versa). Approximately 340 lawyers attempted an aptitude test (at least 180 in the United Kingdom) and 214 out of those actually passed the test. It must also be mentioned that this study does not into account the people who were deterred from taking an aptitude test in the first place. No studies have taken place in order to find out if there were people who were deterred from taking an aptitude test, and, if yes, how many people did not take the test.

74 Case C-145/99, Commission of the European Community v. Italian Republic, [2002] ECR I-02235.

75 Decreto Legislativo 27 gennaio 1992, n. 115, Attuazione della direttiva n. 89/48/CEE relative ad un sistema generale di riconoscimento dei diplomi di instruzione superiore che sanzionano formazioni professionali di durata minima di tre anni, Gazzetta Ufficiale n. 40 del 18 febbraio 1992.

76 Decreto 28 maggio 2003, Regolamento di cui all'articolo 9 del decreto legislativo 27 gennaio 1992, n. 115, in materia di prova attitudinale per l'esercizio della professione di avvocato, Gazzetta Ufficiale 25 luglio 2003, n. 171

77 Case C-102/02, Ingeborg Beuttenmüller v. Land Baden-Württemberg, [2004] ECR I-5405. 
(the second General-System Directive, see below). Ms Beutenmüller was an Austrian national who worked as a teacher in Germany. She had gained her professional qualifications in Austria and was seeking entrance to the teaching profession in Germany because she would thus receive a higher salary. She was denied entrance because of the fact that her Austrian Diploma, which was awarded after two years of higher education, did not fulfil the definition of a diploma under Directive 89/48/EEC. Directive 92/51/EEC was not implemented in Baden-Württemberg at that time. The Court made use of an exception in Directive 89/48/EEC that provided for a situation where the time required for a diploma changed in the Member State of origin. This is exactly what had happened. Austria now required three years of higher education before awarding a diploma for a teacher. The Court therefore allowed Ms Beutenmüller to rely on Directive 89/48/EEC (and Directive 92/51/EEC for that matter) directly. It showed that the Court was willing to allow persons to rely on the rights contained in the Directive if it was established that the Member State in question had not implemented the Directive correctly. Moreover, the Court reiterated that when it was established that a Member State had incorrectly implemented a Directive, it could not rely on possible derogations laid down in the Directive. BadenWürttemberg argued that Ms Beutenmüller's diploma fell under Directive 92/51/EEC because of a derogation contained in Article 3 of the Directive.

The ruling of the ECJ in Beutenmüller immediately raises the question of whether this sanction by the Court placed upon a Member State for not correctly implementing a Directive also applied to the compensatory measures laid down in the Diploma Directive, i.e. in the case of lawyers, the aptitude test. The Court strongly reaffirmed this view in two cases concerning Greece. In the Peros case ${ }^{78}$ the Court ruled, with remarkable clarity, that a person seeking entry to the engineering profession could rely on Article 3 of the Diploma Directive (guaranteeing mutual recognition) where a Member State had not implemented the Directive in its national law (with regard to that profession). The Court added that the right to rely on the Directive directly cannot be made dependent on the recognition of qualifications by the competent authority of the host Member State. In the Aslanidou case ${ }^{79}$ (concerning an occupational therapist) the Court repeated this ruling, including also the Second General System Directive, underlining that only those compensatory measures may be applied that were in force in national law, i.e. correctly implemented, at the date of application for mutual recognition.

It is clear that this string of case law has some potential for lawyers. If a lawyer can establish that Directive 89/48/EEC is not correctly implemented for lawyers (or the new Directive 2005/36/EC for that matter) such a lawyer may be integrated in the legal profession of the host Member State by relying on the Directive directly, without the Member State in question being able to apply compensatory measures, such as an aptitude test.

Although the adoption of Directive 89/48/EEC was heralded as a great achievement at the time, developments in the recognition of diplomas did not stop with the Directive. A number of years after the adoption of Directive 89/48/EEC it

78 Case C-141/04, Michail Peros v. Techniko Epielitrio Ellados, [2005] ECR I-07163.

79 Case C-142/04, Maria Aslanidou v. Ipourgos Igeias \& Pronias, [2005] ECR I-07181. 
became clear that it was the first of three Directives which would cover the recognition of professional qualifications. This system has been named 'the General System'.

A second General System Directive, 92/51/EEC was adopted in $1992 .{ }^{80}$ This Directive was aimed at creating a system for the recognition of qualifications for regulated professions that had qualification tracks of less then three years' duration. It also covers vocational training certificates. The system of Directive 92/51/EEC is identical to the system of Directive 89/48/EEC, described above. People who seek integration in a profession that is caught under Directive 92/51/EEC benefit from the general rule of mutual recognition laid down in that Directive. Where substantial differences exist between the qualifications concerned, the host Member States may impose compensatory measures. A third General System Directive was adopted in $1999 .{ }^{81}$ Directive $99 / 42 /$ EC did not create new rules, but merely consolidated the transitional directives that had been issued in the 1960s. It was already established that these directives dealt with the recognition of professional experience in a variety of sectors such as commerce and industry.

A second consolidation operation was undertaken in 2001. Directive 2001/19/ $\mathrm{EC}^{82}$ was adopted in the light of the SLIM (Simpler Legislation for the Internal Market) strategy. It affected the three General Systems Directives to a small extent (the Vassopoulou ruling was incorporated in Directive 89/48/EEC among other smaller adaptations) but had a major impact on the systems of the vertical directives.

A major adaptation to the diploma recognition system was achieved in 2005 when a completely new directive was adopted which replaced all the vertical directives and the three General System directives. Ever since the famous Lisbon summit, the European Commission had been preparing a new directive for the recognition of professional qualifications, ${ }^{83}$ an effort that was confirmed by the European Council in Stockholm: 'The Commission intends to present for the 2002 Spring Council [...] specific proposals for a more uniform, transparent, and flexible regime of recognition of qualifications and periods of study. ${ }^{84}$ Together with a number of policy documents on the issue ${ }^{85}$ the European Commission came forth with a proposal for a new Directive in 2002. ${ }^{86}$ The main objective was to "create a clear, secure and quick system for the recognition of professional qualifications in the field of regulated professions ${ }^{87}$ In its proposal, the Commission seeks to achieve this simplification procedure by consolidating all the fifteen existing Directives (the three General System Directives and the twelve sectoral Directives) into one single directive covering all

80 [1992] OJ L 209/25

81 Directive 99/42/EC [1999] OJ L 201/77.

82 Directive 2001/19/EC [2001] OJ L 206/1.

83 Directive 89/48/EEC had already undergone a considerable overhaul in the context of the SLIM (Simpler Legislation in the Internal Market) initiative by Directive 2001/19/EC, which among other amendments, saw the codification of the Vlassopoulou doctrine in Article 4 of Directive 89/48/EEC.

84 Conclusions of the Stockholm European Council, 23 and 24 March 2001, point 15.

85 High Level Task Force on Skills and Mobility, Final Report, 14 December 2001, p. 20; Commission's Action Plan for Skills and Mobility, point 15; Commission Communication on An Internal Market Strategy for Services, COM (2000) 888 and the Commission's White Paper on European Governance, COM(2001) 428.

86 COM (2002) 119 final.

87 Explanatory Memorandum COM (2002)119, p. 3. 
aspects of recognition of professional qualifications. Much of this consolidation and simplification will take place in the field of the twelve sectoral Directives. Additionally, there are some very important changes that take place in the scope of the application of the General Systems Directives.

The new Directive makes a number of changes to the system as it was laid down in Directive 89/48/EEC and the two other General System Directives. Firstly, the scope of the application of the new Directive is considerably broader than Directive 89/48/EEC and 92/51/EEC. Every regulated profession or regulated professional activity that is not caught by Parts II and III of the new Directive (professions traditionally governed by the third General System Directive and the Sectoral Directives respectively) is now caught by Article 10 of the new Directive. Problems encountered in the Beutenmüller case, i.e., cases that fell in between the Directives, will not occur anymore under the new system. The new system recognises the differences in levels of professional qualifications by introducing five levels to different qualifications in Article 11 of the new Directive. Recognition of professional qualifications in a host Member State is dependent on the level of qualification that is required in the home Member State. According to Article 13 of the new Directive, recognition of professional qualifications is required when the level of qualification in the home Member State is equal to the level immediately prior to the level required in the host Member State. Articles 13 and 14 further clarify the requirements for recognition of professional qualifications. In general it must be said that the outlines of the system in Article 3 and 4 of Directive 89/48/EEC (and 92/51/EEC for that matter) are still visible in the new system but there are some developments that make it actually more difficult to have one's professional qualification recognised. Similar to the system under Article 3 and 4 of Directive 89/48/EEC, Article 13 begins with the general rule that professional qualifications from another Member State will be recognised only if certain criteria are fulfilled. These criteria are that the person concerned is authorised to exercise the corresponding regulated profession in his home Member State and he must be able to prove this authorisation with evidence of professional qualification (or an attestation of competence) issued by the competent authority of the home Member State. In addition, the proof must also show that the qualification process in the home Member State is at least equivalent to the level (as identified in Article 11 of the Directive) directly prior to the level required in the host Member State. ${ }^{88}$

Just as under the system of Directive 89/48/EEC, the new Directive also has the possibility for the host Member State to require compensatory measures from candidates who seek to be integrated in the regulated profession. In comparison with the old system deviations become immediately apparent. The system of compensatory measures is laid down in Article 14 of the Directive. The new system begins by stating that Article 13 of the Directive (the general rule laying down the principal rule of recognition of professional qualifications) does not preclude a Member State from requiring compensatory measures in the form of an adaptation period or an aptitude test. The first obvious difference from the old system is that the possibility

88 The second paragraph of Article 13 also provides for a recognition procedure for those people who have pursued a profession that is regulated in the host Member State but not in the home Member State. This exception will not be explored further since the profession of lawyer is regulated in all the Member States of the European Union. 
to compensate time differences by means of proof of professional qualification is no longer part of the system of compensatory measures. Article 14 continues to state that the compensatory measures may be required in three separate events. First of all, such compensatory measures may be required in the event where the training of the candidate is at least one year shorter than the training required in the host Member State. It must be noted that this was the original reason for requiring professional experience as a compensatory measure. In this sense, the Directive is stricter than the old system, since now a Member State may ask for more invasive compensatory measures such as an aptitude test or an adaptation period.

The other two instances in which the host Member State may ask for compensatory measures are similar to the old system, i.e., where the training enjoyed covers matters that are substantially different from the requirements in the host Member State or where the profession in the host State contains one or more professional activities which do not exist in the corresponding profession of the home Member State, and that the difference consists in specific training which is required in the host State and which covers substantially different matters than those covered in the training in the home Member State. Similar to the old system, the host Member State must let the candidate choose between an aptitude test and an adaptation period. The rule in the old system which states that the host Member State can enforce a choice in professions that require a precise knowledge of the national law and where the professional activity concerns advice or assistance relating to national law is maintained. ${ }^{89}$ Furthermore, the exception for other professions as to the choice of compensatory measures has been given a prominent position in Article 14 (whereas it used to be placed in Article 10 of the old Directive, separately from the general procedure which was laid down in Article 4). Article 14 further mentions the exact definition of substantial differences, a definition that was lacking from the old Directive 89/48/EEC. According to paragraph 4 of Article 14 'substantially different matter' means the matter of which knowledge is essential for pursuing the profession and with regard to which the training received by the candidate shows important differences in terms of duration or content from the training required by the host Member State.

Lastly, the new Article 14 states that compensatory measures shall be applied with due regard to the principle of proportionality. More particularly, it must first be ascertained whether substantial differences that were encountered can be recovered instead by knowledge acquired during the candidate's professional experience. This paragraph is intriguing as it seeks to implement the Vlassopoulou doctrine, which was also implemented in the old Directive (at least after adaptation by the SLIM Directive) but this was the first time it was formulated as part of the proportionality principle. It would be interesting to know whether the proportionality principle applies in full to the application of compensatory measures, or only as far as the Vlassopoulou principle. The explanatory memorandum does not offer any clarity in this matter. ${ }^{90}$ Moreover, and perhaps more seriously, there seems to be an inadvertent mistake with regard to the application of the Massopoulou principle to compensate for time differences between the professional qualifications in the host and home Member States. In the old system this used to fall under the regime of Article 4(1)

89 Although the Commission sought to abolish it.
90 COM (2002) 119 def. 
(a) which provided for professional experience to compensate for time differences in the professional education. This was abolished in the new system, and the reference to the Vlassopoulou principle was taken over literally from the old system (where it only referred to the system of aptitude tests and adaptation periods) and it only refers to taking into account professional experience in order to cover for substantial differences (and not differences in time). Compensation for time differences must therefore be applied with the principle of proportionality in mind, yet without the specific reference to the Massopoulou principle. This seems to be an inadvertent mistake which can be easily countered, but taken to the letter it is not definitive that Member States have to apply the Vlassoupoulou principle in order to avoid application of compensatory measures.

The Directive also has a new feature. Article 15 provides for a method whereby compensatory measures can be avoided. The Article provides for a form of selfregulation. If a certain regulated profession can come to a common platform (i.e., a set of criteria in order to counter substantial differences) for at least two-thirds of the Member States (including all Member States that regulate the profession) such a common platform can be notified to the Commission. If a candidate then fulfils the criteria laid down in the common platform the Member State concerned shall not implement compensatory measures. It will be interesting to keep track of any efforts to create such a common platform for the legal professions reviewed in this book, but as of yet no move has been made to start such a process.

There is a last noteworthy element to the new system of mutual recognition of professional qualifications. Unlike Directive 89/48/EEC, Directive 2005/36/EC has a specific reference to language requirements. Article 53 states: 'Persons benefiting from the recognition of professional qualifications shall have a knowledge of languages necessary for practising the profession in the host Member State. ${ }^{91}$ This is a very strict reference to language restrictions that leaves, potentially, enormous leeway for Member States to impose language requirements. The Commission, in its explanatory memorandum to the original proposal, made a specific reference to the principle of proportionality. ${ }^{92}$ Time will tell how stringently Member States will adhere to this requirement, which could ultimately be a considerable hindrance to the free movement of professionals. It will not affect the situation of lawyers, however - language proficiency was already implicitly part of their integration since the aptitude tests are conducted, both in written form and orally, in the language of the host Member State.

Focussing on the lawyer's profession, it is safe to say that little or nothing has changed from the regime of Directive 89/48/EEC. Under the new Directive 2005/ $36 / \mathrm{EC}$, it is neither easier nor is it considerably more difficult for a lawyer to integrate into the legal profession of the host Member State. More often than not, such a lawyer will be obliged by the Member State to take an aptitude test. In my opinion the explicit reference to knowledge of languages will have little or no impact on lawyers since the language requirement was already implicitly imposed under the old system by the fact that aptitude tests, which for lawyers generally have both an oral and a written part, take place in the language of the host Member State.

91 Article 53 Directive 2005/36/EC.

92 COM (2002) 119 def. 


\section{\3.3 The Lawyers Establishment Directive 98/5/EC ${ }^{93}$}

As was indicated in Chapter 1, there are three types of lawyers who seek to pursue activities outside their home Member State. It was observed that the two Directives covered in the previous paragraphs catered for the two extremes, i.e., lawyers who want to provide services and lawyers who want to fully integrate in the legal profession of the host Member State. The third type of migration, i.e., establishment without integration, was left without a clear foundation in secondary legislation. Lawyers who sought this form of establishment, perhaps best illustrated by Mr Gebhard whose situation was described above, were for a long time forced to use the figure of installation limitée, using the Services Directive and profiting from the ambiguity that was maintained (perhaps on purpose) by the European Court of Justice until it ruled in the Gebhard case. At the time the ECJ determined the Gebhard case work was ongoing on a Directive that would cover this situation. This Directive, which would become Directive 98/5/EC, will be discussed below.

\section{$\$$ 3.3.1 The CCBE Draft}

Already in 1975 the Commission invited the Council of the Bars and Law Societies of the European Communities (hereinafter the CCBE) to consider a means by which the freedom of establishment of lawyers could be realised. The CCBE took seventeen years to come up with a draft that was finally presented at a CCBE meeting in 1992. The fact that the draft was after all that time presented at all has been called the Miracle of Lisbon. The reason it took the CCBE seventeen years to come up with a draft was because the delegations of the Member States to the CCBE were divided over how to realise such a right of establishment for lawyers. In a very interesting piece in the Irish Student Law Review, Hagan unearths the political machinations that lay behind the years and years of negotiation in the CCBE. ${ }^{94}$ Based on interviews of $\mathrm{CCBE}$ and Commission officials, Hagan tells a tale of a CCBE that is deeply divided over this issue, where on the one hand the Luxembourg delegation wanted no part in developing any form of establishment other than full integration in the host profession, and on the other hand the Spanish delegation proposed automatic recognition and full right of establishment for any lawyer. Both views were too extreme for the majority of the delegation. The central positions in the discussion were voiced by a British-led faction which proposed a right of establishment under home country professional title without an obligation to register with the professional authority of the host Member State, and a French-led faction which proposed immediate integration in the host country profession, with an obligation to register with the competent authority in the host Member State.

93 Directive 98/5/EC of the European Parliament and the Council of 16 February 1998 to facilitate the practice of the profession of lawyer on a permanent basis in a Member State other than that in which the qualification was obtained [1998] OJ L 77/36.

94 Hagan (2003), pp. 149-172. Hagan's story is backed up by and elaborated upon in the official history of the CCBE. See CCBE(2005), pp. 25-33. 
The eventual draft ${ }^{95}$ proposed a compromise, stating that lawyers would be allowed to establish themselves under their home country title on the precondition that they would register with the competent authority of the host Member State. There would be no obligation for a lawyer established under his home country professional title to integrate fully in the legal profession of the host Member State, unless he should choose to do so. If he should choose to do so, the regime of the Diploma Directive, 89/48/EEC, including the possible application of the aptitude test would apply to him. ${ }^{96}$ Obviously experience and knowledge gathered while working under the home country professional title would be taken into account when deciding whether the application of compensatory measures under Directive 89/48/EEC was necessary. ${ }^{97}$ Establishment under home title would take place after registration, and a lawyer would be registered if he could prove that he was registered as a lawyer in his home Member State. ${ }^{98}$ When established under his home title, a lawyer would be allowed to exercise all professional activities which a host country lawyer would be able to do, except for preparing certain deeds and representing clients in court, where a duty to cooperate with a host Member State lawyer was upheld. ${ }^{99}$ This requirement is akin to the duty to cooperate as it was observed in the Services Directive. ${ }^{100}$

When established under his home country professional title, a lawyer is subject to the professional rules of the host Member State as long as they do not interfere with the CCBE code of conduct. ${ }^{101}$ With regard to disciplinary proceedings the draft provides

95 CCBE Draft Directive on the Right of Establishment for Lawyers, adopted by the CCBE on 23 October 1993. For the text of the CCBE Draft see House of Lords (1994), pp. 34-40.

96 Article 4 of the CCBE Draft. Article 7 regulates the use of professional titles. The first section states that where a lawyer is qualified to practise under the legal systems of both the host and the home Member State, he is obliged to carry on his professional activities under both professional titles. Section 2 states that a lawyer who is established in the host Member State under his home title must use that title in the language of his home Member State. In addition, he must give an indication of his registration with the competent authority in the host Member State. A lawyer who is established under his home title is further obliged to avoid any confusion about his title. In the final Directive the obligation to use both title was changed into the right to use either title, since an obligation to use both would have been discriminatory.

97 The French delegation was very much against the aptitude test, or any alternative to it. It even withdrew its support to the Lisbon draft after the other delegations failed to accept a reservation stating that the aptitude test would be removed after a period of five years. In giving evidence to the House of Lords, the leader of the French CCBE delegation, with regard to an assessment by the host state competent authority that was to replace the aptitude test, stated that it was unacceptable and susceptible to manipulation by the professional bodies of the Member States for their own protectionist ends. See Hagan (2003), p. 164. With this statement, the leader of the French delegation underlines the danger of large discretion for the Member States in deciding who may enter their legal profession, something that was already noted when dealing with the Diploma Directive above.

98 Article 5 of the CCBE Draft.

99 Article 6 of the CCBE Draft.

100 It may be clear that such obligatory cooperation must abide by the rules laid down by the European Court of Justice in relation to the cooperation requirement in Directive 77/249/EEC, most notably the restriction of that cooperation requirement in Case 427/85, Commission v. Germany, [1988] ECR 1123, which was dealt with earlier in this chapter.

101 Article 8 of the CCBE Draft. For the text of the Code of Conduct, see Advocatenblad [1989] 15 pp. 435-441. For a description of the code and its application in different national systems 
for a complex system involving close cooperation between the competent authority of the home Member State and the competent authority of the host Member State, whereby both authorities may initiate proceedings, share all information pertaining to proceedings, and the home Member State may request the formation of a mixed panel. ${ }^{102}$

The Draft also deals with practice in association, proposing that a lawyer who is a member of an association may establish himself in another Member State alone, or as member of the association even where the host Member State does not allow practice in association. Membership of an association, however, cannot be used to circumvent the professional rules of the host Member State. ${ }^{103}$ The competent authority of the host Member State must facilitate the creation of an association composed of lawyers established under their respective home country title and lawyers established under their host country professional title. On the other hand, the host Member State may refuse practice in association by a lawyer if the decisions within the association are taken by persons who are not lawyers.

It is clear that the Draft of the CCBE deals with the third type of lawyer identified earlier. The Draft creates a system that is perfectly complemented by the two legal instruments that have been described above. Establishment under home title is made quite simple by the Draft. A mere proof of registration with the Bar of the home Member State suffices for one to become established in the host Member State. In light of previous developments in the field of freedom of movement of lawyers this seems revolutionary. The establishment of foreign lawyers as such is not the only controversial point the CCBE addresses in its Draft. Another difficult subject is the establishment of lawyers who are members of an association. The CCBE proposal is quite progressive in the sense that it allows lawyers established under their home title to establish themselves in an association, regardless of the rules on practice in an association in the host Member State. The only limitation on practice in association is put by the CCBE on practice in association with lawyers from the host Member State (national or integrated), or practice in an association with professionals who are not lawyers, but have decision making power in the association. In that case, the competent authorities of the host Member State can impose rules on, or completely prohibit the practice in association. The CCBE Draft provided the basis for a Commission proposal for a new Lawyers Establishment Directive.

\section{$\$$ 3.3.2 The Commission Proposal ${ }^{104}$}

On 30 March 1995 the Commission submitted a 'proposal for a European Parliament and Council Directive to facilitate practice of the profession of lawyer on a permanent basis in a Member State other than that in which the qualification was obtained'. The legal bases for this envisaged Directive were Articles 40, 47(1) and 47(2) of the EC Treaty. In general, it can be said that the proposal breathed the

see Ambtliche Bekendmachungen, in: BRAK-Mitteilungen, [1996] 6 pp. 240-252; Bermann (1993), pp. 603-605 and Reinmüller (1995).

102 Articles 9 and 10 of the CCBE Draft.

103 Article 11 of the CCBE Draft.

104 [1995] OJ C 128/6. 
same atmosphere as the CCBE Draft, i.e., it allowed persons who are established as lawyers to establish themselves under their home title in another Member State based on nothing more than written proof that they are entitled to practise as a lawyer in their home Member State. ${ }^{105}$

There were, however, two major issues in the proposal that were radically different from the CCBE Draft. First, there is the length of the period of establishment under home title. Whereas the Draft gave a permanent right to a lawyer for establishment under home title, Article 2 of the Commission's proposal stated that a lawyer will only be allowed to practise for a period of five years under his home country professional title. After that, if the lawyer wished to stay longer, he had to integrate in the legal profession of the host Member State by means of Article 10 of the proposal. It is in that Article that the second novelty lies. Whereas the CCBE draft merely referred to the mechanism of Directive $89 / 48 /$ EEC for integration, the Commission's proposal includes a way to avoid the aptitude test of the Diploma Directive. ${ }^{106}$ Article 10 of the proposal stated that if a lawyer established under his home title in the host Member State has effectively pursued for an unbroken period of at least three years an activity involving the law of the host Member State, he or she shall be exempted from any aptitude test required under Directive 89/48/EEC. The lawyer himself would be responsible for proving that he has effectively pursued these activities for at least three years. If the lawyer has had professional experience in the host Member State for at least three years, but was not involved with the law of the host Member State then, according to Article 10, the aptitude test needed under the system of Directive 89/48/EEC will be limited to the law of procedure and the rules of professional conduct of the host Member State. The Article stated further that, while examining the application of a lawyer's who is established under his home country title, the host Member State shall take into account any attendance of lectures or seminars on the law of the host Member State. Furthermore, the Article states that if a lawyer formerly established under his home title becomes fully integrated in the legal profession of the host Member State he may use the professional title of both his home and his host Member State. ${ }^{107}$

Aside from these major changes to the CCBE Draft, the proposal also contained more moderate adaptations. Unlike the CCBE Draft, the Commission's proposal made a positive reference to the scope of activities by stating that the lawyer may exercise the same professional activities (including advice on host State law) as a host State lawyer. The proposal included the same limitations, the most important being the requirement to cooperate with a host State lawyer while representing clients in court. The proposal formulates this however, as a facultative restriction to be imposed by the host State. ${ }^{108}$ With regard to practice in association, the Commission's

105 Articles 1-4 of the proposal.

106 It must be mentioned that the CCBE did not envisage every candidate who had been established under his home country professional title in another Member State for a certain period of time would be forced to take the aptitude test. Lawyers who were established under their home country title would be in the position to acquire enough knowledge of the law of the host Member State to be exempted from an aptitude test. The Draft did, however, stop short of a more or less automatic integration, that was provided for in the proposal.

107 Therewith doing away with the obvious discrimination that was observed in the CCBE Draft which required integrated lawyers to use both professional titles.

108 Article 5 of the proposal. 
proposal states that if the host Member State has no practice in association for its own lawyers, it may refuse practice in association altogether. If, however, practice in association is allowed, then the rules of the home Member State of the lawyer prevail, unless the application of host Member State rules is objectively justified in cases where home and host Member State rules are incompatible. ${ }^{109}$ With regard to disciplinary proceedings the possibility of a mixed panel is dropped and there is a provision stating that if a lawyer, due to disciplinary proceedings, loses his right to practise in the home Member State, this will be automatically extended to the host Member State.

The major changes to the temporal limit on the establishment under home title make the result of the proposal fundamentally different from the original CCBE Draft. Where the Draft recognised the third type of lawyer as an independent type with a permanent right of residence under home title, the Commission's proposal treated establishment under home title as a preparatory stage for full integration in the host Member State's profession. The reason for this change was explained by the Commission. The then Director-General of the Directorate-General in question ${ }^{110}$ explained in a letter to the Select Committee of the House of Lords ${ }^{111}$ that the Commission had opted for a strict interpretation of Article 43 (then Article 52) in particular of the phrase: 'under the same conditions as nationals of the host Member State', because a more liberal interpretation of the Article seemed inappropriate to the Commission. In the next sentence of the letter, the Director-General declared that the right laid down in Article 2 of the Commission's proposal is at least a step towards full establishment. This comes close to the opinion of the Luxembourg delegation to the CCBE, which stated that establishment could only be achieved under the same conditions as nationals of the host Member State, i.e., as a member of the host Member State's professional title. ${ }^{112}$ In other words, together with the Luxembourg delegation to the CCBE, the Commission was of the opinion that Article 43 (then 52) of the EC Treaty did not sanction a possibility for lawyers to establish themselves under their home country professional title, at least not as an independent category. By imposing a time limit on the establishment under home title, and offering an alternative route into integration in the host Member State's legal profession, the Commission sought to circumvent this potential problem. The only thing that remains unclear is why the Commission chose a period of five years. ${ }^{113}$ That seems to have been a spontaneous decision, since the Commission did not justify the length of the period at all. Moreover, although the proposal offered an alternative to the aptitude test after three years, it did not specify what was to happen after the termination of the five-year period. Clearly the Commission must have been of the opinion that every lawyer who was established under his home country title would, at the end of the five years, take the short route into establishment under host country professional title.

\footnotetext{
109 Article 11 of the proposal.

110 J.F. Mogg, Director-General of Directorate-General XV, at that time the competent DG of the Commission, now called DG Internal Market.

111 House of Lords (1994), p. 60.

112 See Hagan (2003), pp. 149-172.

113 That remains unclear even for those directly involved. See Hagan (2003), pp. 149-172.
} 
It may be obvious that the Commission's proposal met with fierce criticism from commentators. Lonbay, for example, writes in his article in the European Law Review ${ }^{114}$ that: "The proposal as it stands arguably does not "facilitate" mobility but hinders it, because of the restrictive five year rule found in Article 2'. ${ }^{115}$ Vaughan argues in his memorandum, which he submitted to the House of Lords Select Committee on the European Communities that the Commission's proposal infringes Community law because it does not make it easier for persons to take up and pursue cross-border activities. ${ }^{116}$ Both writers doubt the legal basis of the Directive. They argue that, in order for this Directive to be implemented, the national laws of some of the Member States need adaptation and therefore the second sentence of Article 47(2) (then 57(2)) must be invoked. ${ }^{117}$ This provision, at the time, provided for a consultation procedure and unanimous voting in the Council. Lonbay states that it can easily be imagined why the Commission wanted to avoid this procedure. ${ }^{118}$

Schneider stated that, aside from the five-year limitation on the establishment under home title in Article 2 of the proposal, the rules governing the integration of the lawyer in the legal system of the Member State laid down in Article 10 of the proposal also infringe Community law. She states it as follows: 'Es ist jedoch nicht nur die Fünfjahresfrist, die unverständlich und nach meiner Meinung vertragswidrig ist, auch die unterschiedlichen Verfahren gemäß Art. 10 des Richtlinienentwurfs lassen erhebliche Zweifel an ihrer Zulässigkeit und Praktibilität entstehen. ${ }^{, 19}$ Schneider's main point of criticism with Article 10 of the proposal comes down to the fact that in order to become integrated in the legal profession of the host Member State the lawyer, who is established under his home title, must have effectively pursued, for an unbroken period of at least three years an activity involving the law of the host Member State, including Community law. The Article defines 'effective pursuit for an unbroken period' as the actual exercise of the activity without any interruption other than that resulting from everyday life. It is strange that the Commission requests the lawyers to work in the legal system of the host Member State for an unbroken period of three years as the European Court of Justice explicitly rejected the requirement of permanent presence of the lawyer in the host Member State in Klopp ${ }^{120}$ which dealt with double establishment of lawyers. Moreover, Schneider states that Article 10 as a whole creates confusion. The wording of Article 10(3) in particular implies that the aptitude test of Directive 89/48/EEC can only be taken during the five-year period of establishment under home title. This cannot be the case, of course, because the system of Directive 89/48/EEC implies that anyone can take an aptitude test (if the Member State has chosen for this option) at any time without being obliged to establish themselves for a certain period of time prior to taking the aptitude test. Schneider states further that a too strict of an adherence to the five-year limit on

\footnotetext{
114 Lonbay (1996) B, pp. 50-58.

115 Ibid., p. 58.

116 House of Lords (1994), p. 80.

117 See also: Case C-168/98, Grand-Duchy of Luxembourg v. European Parliament and Council of the European Union, [2000] ECR I-09131.

118 Lonbay (1996) B, p. 58.

119 Schneider (1995), p. 285.

120 Case 107/83, Ordre des avocats au barreau de Paris v. Onno Klopp, [1984] ECR 2971. It must be mentioned here that the proposal did not require permanent residence as such but merely to qualify for the exemption of the aptitude test.
} 
establishment under home title may constitute a breach of Article 43 (then Article 52) of the Treaty. ${ }^{121}$

The House of Lords Select Committee on the European Communities states that it does not agree with the Commission on that the establishment under home title should be seen as a phase which must lead to the full integration of the lawyer in the legal profession of the host Member State. Moreover, the Select Committee is of the opinion that the five-year limitation on the establishment under home title is not at all justified. It states that it believes that the requirement of full integration in the legal profession of the host Member State is not in conformity with Article 43 (then Article 52) of the EC Treaty, because the passage: '[...] under the conditions laid down for its own nationals by the law of the country where such establishment is effected [...]' does not justify an obligatory integration of the lawyer who is established under his home title, in the legal profession of the host Member State after that lawyer has practised for five years under his home title.

The Select Committee also states that the present proposal cannot fall under the legal basis of Article 47 (then Article 57) because the Directive does not make it easier for lawyers to take up and pursue activities as self-employed persons. With all these observations in mind, the House of Lords Select Committee on the European Communities recommended that the Commission's proposal should be amended on the two principal points which differed from the CCBE Draft, namely the fiveyear limit on the establishment under home title and the full integration of the lawyer in the legal profession of the host Member State. ${ }^{122}$ Not all comments of the writers cited above were negative. All applauded the Commission's efforts at regulating the position of employed lawyers ${ }^{123}$ and the problem of joint practices. ${ }^{124}$

In addition to this critique from the outside world, there were two developments from inside the European Community that would determine the fate of the Commission's proposal. First of all the Council requested the opinion of the Economic and Social Committee. In its opinion ${ }^{125}$ the Committee stated that although it agrees with the underlying principle of Article 2, namely the establishment under home title as a preparatory stage for the complete integration of the lawyer in the legal system of the host Member State, is sees no justification for a five-year time limit. With this statement the Committee makes matters even more complicated. The Commission had at least tried to quantify its opinion that the establishment under home country professional title should only serve as a preparatory stage for full integration by imposing a time limit. The opinion of the Committee would render it useless to maintain that underlying view since without any limitation establishment under home title became de facto permanent. In addition to this rather unhelpful comment, the Committee also proposed that lawyers established under their home country title should not be able to give advice on host country law (therewith making it virtually

121 Schneider (1995), p. 288.

122 House of Lords (1994), pp. 17-19.

123 Which were allowed to establish themselves under Article 8 of the proposal, provided that the host Member State allowed salaried practice.

124 For further articles on the Commission proposal, see Denys (1995), pp. 143-151; Gout (1995), pp. 1285-1294; de Waard (1995), p. 59; Wackie Eysten (1995) A, pp. 631-632 and Wackie Eysten (1995) B, pp. 743-758.

125 [1995] OJ C 256/05 
impossible to fulfil the requirements for integration in the host Member State's profession without an aptitude test) and to include in the competent authority's assessment of lawyers who sought integration in the host profession without an aptitude test that their language capabilities in the language of the host Member State were sufficient. Apart from the critique on the five-year limitation, the Committee clearly called for a more restrictive right of residence.

A second development that proved detrimental for the Commission's proposal was the ruling of the ECJ in the Gebhard case. After that ruling, in which the ECJ finally gave a clear distinction between establishment and services, it became clear that a right of establishment that was limited in time would not constitute establishment but would instead be considered as services. That being so, the legal base of the proposed Directive would be wrong since it referred to the Treaty articles relating to establishment. Moreover, it could be argued that although the objective justification test for restricting free movement laid down by the Court in Gebhard would not be directly applied to rules laid down in a piece of secondary legislation. The rules laid down in the proposal would not survive the application of the objective justification test.

All this taken together, it was evident that the Commission's proposal could not be upheld as it stood and it was therefore for the European Parliament to propose extensive amendments.

\section{$\mathbb{5}$ 3.3.3 The Opinion of the European Parliament ${ }^{126}$}

On 19 June 1996, the European Parliament issued an opinion in the Official Journal of the European Communities in which it approved the Commission's proposal on the condition that the amendments given by the European Parliament were taken into account by the Commission. The opinion of the European Parliament is characterised by three rather substantial amendments of the original Commission's proposal. First, and most importantly, the European Parliament removed every reference to the five-year temporal limit on the establishment under home country professional title. ${ }^{127}$ If the amendment proposed by the European Parliament would have been accepted it would have meant that the major point of critique on the Commission's proposal would have been taken away, while on the other hand it was again much

126 [1996] OJ C198/85. For another description of the Opinion of the European Parliament see Ricour \& Vatier (1996), pp. 1235-1238.

127 It is interesting to note that the European Parliament has left the underlying ideas of the Commission intact. The recitals still utter the view of the Commission that the establishment under home title is still meant as a preparatory stage to the full integration of the lawyer into the legal profession of the host Member State.

From the third amendment of the European Parliament it becomes clear that the Parliament does recognise the right of lawyers to become permanently established in a host Member State, while they remain able to make use of their home title. What the European Parliament construes with these amendments is quite similar to the opinion of the Economic and Social Committee. Without reference to a time limit, but leaving the underlying views of the Commission intact, the European Parliament creates an establishment of lawyers under home title that should eventually lead to a full integration of the lawyer in the legal profession of the host Member State. Since there is no time limit placed on this establishment under home title it actually becomes, albeit de facto, a permanent right of establishment under home title. 
more in conformity with the original CCBE Draft. By leaving the reference that indicated establishment under home title was a preparatory stage to full integration in the host Member State's profession in the recitals, the European Parliament had the potential violation of Article 43 also covered, which was also incidentally Luxembourg's concern with the CCBE Draft.

The second major amendment to the Commission's proposal was concerned with the full integration of the lawyer established under his home country title in the legal profession of the host Member State. With regard to the Commission's proposal it was observed that the requirement of working for a constant unbroken period of three years in the host Member State might be contrary to the explanation of the freedom of establishment given by the ECJ in Klopp. The European Parliament tried to eliminate this potential violation by altering the requirement to "having pursued the profession in the host Member State, involving host state law, regularly for a period of at least three years'. The European Parliament quantified the term by stating that 'effective and regular pursuit' meant the actual exercise of the activity without any interruption other than that resulting from the events of everyday life. It is at least doubtful that, if the original wording of the Commission was contrary to the Court's ruling in Klopp, the illegality is taken away by the wording of the European Parliament. The European Parliament also changed the approach towards lawyers who seek integration after less than three years activity in the law of the host Member State. Where the Commission required these lawyers to take a limited aptitude test under the system of Directive 89/48/EEC the European Parliament proposed that such a lawyer should be subject to an interview by the competent authority taking into account all the knowledge and experience the applicant had with the law of the host Member State and based on all the cases and documents provided by the applicant. ${ }^{128}$ Furthermore, a lawyer established under his home Member State title may at any point ask to take an aptitude test under the regime of Directive 89/48/EEC. ${ }^{129}$

In addition to these major adaptations, less extensive amendments were proposed. The European Parliament suggested a specific reference to the public service exception, by way of including a certificate of honour in the documents which were necessary for registration under home country professional title, a possibility to be exempted under the host country social security scheme, and an elaborate equal treatment provision for salaried lawyers. With regard to joint practice the European Parliament reinforced the possibility of the host Member State blocking lawyers from practising jointly or opening a branch or agency where the capital is held, the name of the group is used or the decisions in the group are taken (wholly or in part) by professionals who are not lawyers in the sense of the Directive. Mainly the requirement concerning the use of the name considerably diminishes the effect of the proposed Directive on the rules governing Multi-Disciplinary Partnerships (MDPs) in the Member States, where the rule in the Commission's proposal only affected those MDPs where the decisions where actually taken by non-lawyers.

\footnotetext{
128 Which is an application of the Vlassopoulou ruling.

129 Which, under that system, becomes more and more limited as the candidate gains knowledge and experience in the law of the host Member State because of including the Vlassopoulou principle in the Directive.
} 
It was evident that, after the extensive nature of the proposed amendments by the European Parliament, the Court's ruling in Gebhard and the reception of the Commission's proposal in the literature, the Commission had to generate/fashion a new proposal.

\section{$\mathbb{~ 3 . 3 . 4 ~ T h e ~ A m e n d e d ~ C o m m i s s i o n ~ P r o p o s a l ~}$}

On 24 September 1996 the European Commission submitted an amended proposal to both the Council and the European Parliament. ${ }^{130}$ Concerning the major amendments proposed by the European Parliament the Commission had changed its proposal to be in conformity with them. The reference to a time limit placed on the establishment under home title was removed, albeit in the recitals there is a reference to a temporary right of establishment, but this seems to be a slip of the pen. ${ }^{131}$ The Commission has essentially accepted the amendments of the European Parliament in connection with integration in the host Member State where the candidate has been active for less then three years in the law of the host Member State and regarding to the additional possibilities for Member States to limit the activity of MDPs in their territory. Minor adaptations, such as the reference to the public service exception and the certificate of honour, along with the possible exemption of host Member State social security schemes, were not approved by the Commission, the first two because of superfluity, the latter because of an alleged conflict with the provisions of Regulation 1408/71/EEC.

The amended Commission proposal was welcomed in the Member States. The Select Committee on European Legislation of the House of Commons stated in its third report of the 1996-1997 session that it welcomed the amendments and that the government was content that the new text was a significant improvement over the original draft, and that it was much closer to the intentions that the CCBE wanted to lay down in this Directive. ${ }^{132}$ After the Commission had brought its proposal in conformity with the view of the European Parliament and with the pertaining view that came forth from literature, the time was ripe for the Council to formulate its common position on the Commission proposal.

\subsubsection{The Council's Common Position}

On 24 July 1997 the Council gave its common position with a view to the proposal for a European Parliament and Council Directive to facilitate the practice of the lawyer's profession on a permanent basis in a Member State other than that in which

\footnotetext{
130 [1996] OJ C 355/19.

131 With regard to the recitals, the Commission has followed the proposed amendments of the European Parliament almost everywhere. Only in recital 14 the Commission has omitted to leave out the word 'temporarily', which the European Parliament proposed. The text of the amended Commission proposal reads as follows: 'Whereas the purpose pursued by the Directive in enabling lawyers to practice temporarily (my emphasis, S.C.) in another Member State under their home-country professional title is in particular to make it easier [...].'

132 House of Commons (1996).
} 
the lawyer's qualifications were obtained. ${ }^{133}$ In connection with the major subjects the Council follows the text as proposed in the Commission's new proposal. The text of the Common Position therefore includes a right to establishment under home title that is not limited in time. What is different is that, unlike the Commission, the Council makes a full and explicit choice for a right of establishment under home title without any forced link between the establishment and the integration in the host Member State profession. ${ }^{134}$ Apparently, the Council is of the opinion that Article 43 of the Treaty also sanctions this kind of establishment. ${ }^{135}$ As for integration in the host Member State's profession and the rules governing joint practice, the Council followed the Commission's proposal.

Moreover, the Council made some new additions to the proposed Directive. With reference to the pursued professional activities the Council made two additions. Firstly, it stated that the lawyer who exercises his or her professional activity is obliged to take into account the host Member State's rules of procedure. It is not clear why the Council added this obligation which, in the light of Article 6 of the proposal (applicable professional rules) seems to be superfluous. The Council stated in its statement of reasons that this provision is meant to ensure the 'smooth operation of justice'. ${ }^{136}$ In the eleventh recital it is also stated that these specific rules may not frustrate the integration of lawyers from other Member States if they fulfil the criteria laid down by the specific rules laid down in Article 5(3). That meant that a Member State may not reserve access to its Supreme Court excusively for its own national lawyers, but that it may lay down specific rules and that it has to allow access to any lawyer, national or non-national, who fulfils these criteria. When addressing disciplinary proceedings the Council also added the requirement that the competent authorities of the host and home Member States shall cooperate at times when disciplinary proceedings are initiated against a lawyer in his home Member State. The Council introduced this new subparagraph because it wanted to ensure, according to its statement of reasons, ${ }^{137}$ that the supply of information between the competent authorities of the host and home Member States on the initiation of disciplinary proceedings was two-way, whereas the Commission's proposal only required cooperation if the proceedings were started in the host Member State.

133 Common Position (EC) No. 35/97, [1997] OJ C 297/6.

134 Although similar to the opinion of the European Parliament, the recitals of the Council's Common Position also state that establishment under home title must eventually lead to full integration in the host Member State's profession.

135 In its statement of reasons the Council states that the objective of the Directive is to allow lawyers from Member States to enter and practice their profession in a Member State other than that in which they are already authorised to practice. The Council goes on by stating that because of the fact that there were already Directives that governed the freedom of lawyers to provide services and that governed the full integration of lawyers in the legal profession of the host Member State (respectively Directive 77/249/EEC and Directive 89/48/EEC). Therefore, the establishment of lawyers under their home professional title should be governed by a separate Directive in order to improve a lawyers' freedom of movement. See Statement of the Council's Reasons, [1997] OJ C 297/14.

136 Statement of the Council's Reasons, [1997] OJ C 297/14.

137 Statement of the Council's Reasons, [1997] OJ C 297/14. 


\section{\$ 3.3.6 The Final Result: Directive 98/5/EC}

As was to be expected the European Parliament was satisfied with the common position of the Council and it saw no need to initiate the conciliation procedure that is provided for in Article 251 of the Treaty. The European Parliament adopted the text of the common position of the Council in its decision of 19 November 1997. On 15 December 1997 the Council officially adopted the final text of the Directive. The Directive was signed by the President of the European Parliament at that time, J.M. Gil-Robles, and the then President of the Council, J. Cunningham, on 16 February 1998. Directive 98/5/EC was published in Official Journal no. 77 of 1998 on 14 March 1998. ${ }^{138}$

As observed above, the recitals of the Directive still reflect the underlying view of the Commission that the establishment of the lawyer under his home title must eventually lead to the full integration of the lawyer in the legal profession of the host Member State. ${ }^{139}$ On the other hand, the recitals have lost every reference to the fact that the establishment under home title should be of a temporary nature. This is because the Council was of the opinion that there is a need for establishment under home title that has no connection with the full integration of the lawyer in the legal profession of the host Member State, and that, therefore, the establishment under home title should be seen as an independent form of establishment. ${ }^{140}$

Article 1 lays down the purpose of the Directive, namely to facilitate the practice of the profession of the lawyer on a permanent basis in a self-employed or salaried capacity in a Member State other than that in which the professional qualification was obtained. The Article states further that the Directive is applicable to anyone allowed to practise in his home Member State under one of the professional titles listed in Section 2a of Article 1. Section 4 of the Article states that the Directive only applies to the establishment of lawyers, and not to the provision of services, which is governed by Directive 77/249/EEC.

Article 2 of the Directive concerns the general right for lawyers to establish themselves on a permanent basis in any of the Member States under their home title in order to pursue the professional activities that are further specified under Article 5 of the Directive. Integration of the lawyer into the legal profession of the host Member State shall be subject to the rules laid down in Article 10 of the Directive.

Articles 3 and 4 lay down the requirements which have to be fulfilled by the lawyer in order to become established in another Member State other than the one in which he obtained his qualification. Article 3 states that, in order to become established, the lawyer must register with the competent authority of the host Member State. That competent authority shall register that lawyer if he can produce a certificate

138 Directive 98/5/EC of the European Parliament and the Council of 16 February 1998 to facilitate the practice of the profession of lawyer on a permanent basis in a Member State other than that in which the qualification was obtained; [1998] OJ L 77/36. See Ewig (1999), pp. 248253; Henssler (1999), pp. 689-712; Pertek (2000) B; Pertek (2001), pp. 106-111; Sobotta \& Kleinschnittger (1998), pp. 645-650; Viciconte (1999), pp. 194-204; Van der Vlies (2000), pp. 1-11 and Weil (1997), pp. 530-533.

139 See, for example, recital 3, [1998] OJ L 77/36.

140 See Statement of Council's Reasons, [1997] OJ C 297/14. 
from the home competent authority certifying that he is registered with the them. ${ }^{141}$ The competent authority of the host Member State may require that no more than three months have elapsed since the certificate was issued, and shall further inform the competent authority of the home Member State of the lawyer concerned that it has registered that lawyer. Article 3 further states some specific rules relating to the special nature of the profession of the lawyer in the common law countries within the European Union, namely the United Kingdom and Ireland.

Article 4 states that the lawyer who wants to practise in another Member State other than the one in which he obtained his professional qualifications must do so under his home country professional title. The lawyer is obliged to avoid any confusion with the professional title used in the host Member State. The competent authority in the host Member State may require that the lawyer, who is established under his home title, gives an indication of the professional body of which he is a member in his home Member State or the judicial authority before which he is allowed to practise according to the laws of the home Member State. The competent authority of the host Member State may further require the lawyer to include a reference to his registration with the competent authority in that State.

Article 5 of the Directive lays down the areas of activities in which a lawyer, established under his home title, may practise. Section 1 of the Article states that a lawyer established under his home title is allowed to carry out the same professional activities as a lawyer who is practising under the professional title of the host Member State. That lawyer may give advice on the law of his home Member State, on Community law, on international law and on the law of the host Member State. The lawyer, established under his home title, shall comply in any event with the procedural rules applicable in the national courts of the host Member State. Section 2 of the Article states that a Member State may exclude a lawyer, established under his home title, from exercising certain specialist activities (such as preparing deeds) if these activities are reserved for a profession other than that of the lawyer in the lawyer's home Member State. This provision clearly did not have to be formulated in a twoway manner. Where such activities are reserved in the host Member State for professions other than that of lawyer, the lawyer established under his home country professional title is also not allowed to pursue these activities based on Section 1 of the Article. Section 3 of the Article states that, where activities pursued include the defence or representation of a client in legal proceedings, the host Member State may require the lawyer, established under his home title, to cooperate with a lawyer who is established under the professional title of the host Member State if the host Member State reserves such activities for lawyers established under the professional title of the host Member State. This requirement may be subject to the limits laid

141 This means that there is at least a requirement to be registered as a lawyer in one's home Member State. Persons who fulfil the criteria to be a lawyer in their home Member State, but who are not registered as such can therefore not register under their home country professional title in another Member State. At first sight this requirement might also cause problems with regard to obligations of life-long learining. This potential problem has been solved by the CCBE by stating that a lawyer established under his home country professional title in another Member State may fulfil his or her life-long learning obligations in that state. See 'CCBE Guidelines on the Implementation of the Establishment Directive' and 'CCBE recommendation on continuing training', both via <www.ccbe.org>, last accessed 23 October 2006. 
down by the European Court of Justice in Commission v. Germany, which dealt with the fact that Germany required cooperation between a German lawyer and a visiting lawyer even in cases where representation by a lawyer was not compulsory. ${ }^{142}$ The second subparagraph of Section 3 states further that the host Member State may, in order to secure the smooth operation of justice, lay down specific rules for access to its Supreme Court, such as the use of specialist lawyers. The eleventh recital of the Directive makes it clear that the specialist nature of such a lawyer may not be connected to his nationality, because the recital implicitly says that a foreign lawyer may also gain access to the Supreme Court if he fulfils the criteria.

Article 6 of the Directive lays down with which rules of professional conduct the lawyer, who is established under his home title, must observe. Section 1 states that lawyers who are established under their home title are subject to the host Member State's rules of professional conduct, notwithstanding those rules to which they are subject in their home Member State. ${ }^{143}$ Section 2 of the Article states that the lawyers established under their home title shall be adequately represented in the professional associations of the host Member State. The section provides that such representation shall involve at least the right to vote in elections of those associations' governing bodies. The third section states that a lawyer must have professional indemnity insurance, whether it be in the host Member State or in his home Member State.

Article 7 states the manner in which disciplinary proceedings against a lawyer established under his home title in another Member State should be carried out. The first section of the Article states that if the lawyer who is established under his home title fails to fulfil his obligations under the law of the host Member State, the rules of procedure, penalties and remedies provided for in the host Member State shall apply. The remaining sections of the Article provide for an elaborate cooperation between the competent authority of the home Member State and the competent authority of the host Member State. Cooperation is also required if the competent authorities of the home Member State decide to open disciplinary proceedings. Section 4 states that a decision of the competent authority of the host Member State may also have repercussions for the lawyer concerned in his home Member State. Section 5 states that if the competent authority of the home Member State revokes, permanently or temporarily, the authorisation of the lawyer to practise in his home Member State, this shall automatically lead to a prohibition against the lawyer practising under his home title in the host Member State.

Article 8 of the Directive states that a lawyer established under his home title may practise as a salaried lawyer to the same extent that the host Member State permits for lawyers established under the professional title of the host Member State.

Article 9 states that a decision not to effect registration as meant in Article 3 of the Directive, a decision to cancel such a registration and decisions imposing disciplinary measures shall be accompanied with a statement of reasons. Moreover, a remedy before

142 Case 427/85, Commission v. Germany, [1988] ECR 1123.

143 There is a difference in the application of professional rules compared with Directive 77/249/EEC, where in the case of Directive 98/5/EC the emphasis lies much more on the professional rules of the host Member State. This is logical since an established lawyer is much more 'embedded' in the legal system of the host Member State than a lawyer who provides services in another Member State. 
a court or tribunal against such a decision shall be available in accordance with the national law of the host Member State.

Article 10 provides for three different ways in which a lawyer can become fully integrated in the legal profession of the host Member State. The first method is the simplest one. Section 2 of the Article states that a lawyer may, at any point in time, take an aptitude test under the system of Directive 89/48/EEC if the competent authority of the host Member State deems it necessary in order to become fully integrated in the legal profession of the host Member State. Subsequently that lawyer may practise under the professional title of the host Member State. Section 1 states the second method in which a lawyer established under his home title can become fully integrated in the legal profession of the host Member State. That section states that if a lawyer has effectively and regularly (meaning: the actual exercise of the activity without interruption other than that resulting from everyday life) pursued professional activities involving the law of the host Member State, including Community law, for a period of at least three years, he or she shall be granted access to the legal profession of the host Member State. Subsequently that lawyer has the right to practise under the professional title of the host Member State without being required to take an aptitude test under the system of Directive 89/48/EEC. In order to gain such access the lawyer concerned shall provide the host Member State's competent authority with all the relevant information, notably on the number and nature of the matters he or she has dealt with. The competent authority of the host Member State has the right to verify the information and may to that end require the lawyer to provide, orally or in writing, clarification of, or details on, the information provided. If the competent authority decides to deny the lawyer access to the legal profession of the host Member State, that decision must be reasoned and subject to appeal in the national courts or tribunals of the host Member State.

The third method through with one can gain access to the legal profession of the host Member State is laid down in Section 3 of Article 10. The section concerns lawyers who have effectively and regularly pursued professional activities in the host Member State for at least three years, but for a lesser period than three years with regard to the law of the host Member State, including Community law. Such a lawyer may obtain admission to the legal profession of the host Member State from the competent authority of that Member State, without having to take the aptitude test under the system of Directive 89/48/EEC. In deciding whether or not to give the lawyer concerned access to the legal profession of the host Member State, the competent authority of that State shall take into account the effective and regular professional activities pursued by the lawyer concerned. In addition, it shall also take into account all the knowledge and professional experience gained with respect to the law of the host Member State and any attendance made at lectures or seminars on the law of the host Member State, including the rules regulating professional practice and conduct. This is clearly a codification of the principle laid down by the European Court of Justice in the Vlassopoulou case. ${ }^{144}$ It may also be noted that this principle is also codified in Directive 89/48/EEC, and that the third method of integration to a certain extent overlaps with the first method, since under the system

144 Case 340/89, Massopoulou v. Ministerium für Justiz, Bundes- und Europaangelegenheiten BadenWürttemberg, [1991] ECR 2357. 
of Directive 89/48/EEC the competent authority is also obliged to determine whether or not the taking of an aptitude test is deemed necessary. The lawyer concerned shall provide the competent authority of the host Member State with all the relevant information and documentation, notably on the cases he or she has dealt with. Assessment of the lawyer's effective and regular activity in the host Member State and assessment of his capacity to continue the activity he has pursued there shall take place by means of an interview with the competent authority of the host Member State in order to verify the regular and effective nature of the activity. If the competent authority of the host Member State decides not to grant access to the legal profession of the host Member State, such a decision shall be reasoned and it shall be subject to appeal in the national courts of the host Member State. Section 4 of the Article states that the competent authority of the host Member State may also deny lawyers the benefits of the provision of the Article if it considers that this would be against public policy, in particular because of disciplinary proceedings, complaints or incidents of any kind. Again, such a decision shall be reasoned and it shall be subject to appeal in the national courts of the host Member State. Section 6 states that a lawyer who gains access to the legal profession of the host Member State shall be entitled to use his home title alongside the professional title of the host Member State.

Article 11 governs the rules concerning the joint practice of lawyers. The introduction states that lawyers who are established under home title may practise jointly if the lawyers practising under the professional title of the host Member State are allowed to do so, albeit subject to the rules laid down in this Article. Section 1 of the Article states that joint practice of lawyers established under their home title is allowed. In the case where the fundamental rules of the home Member State governing groupings are incompatible with the rules governing the same subject in the host Member State, the rules of the host Member State shall prevail, as long as their application is justified by the public interest in protecting clients and third parties. ${ }^{145}$ Section 2 states that the host Member State shall make it possible for two or more lawyers who are established under their home title, to practise in a form of joint practice. If the host Member State provides more forms of joint practice for the lawyers established under the professional title of the host Member State, that the host Member State must also provide these forms to lawyers who are established under their home title. The manner in which lawyers practise jointly shall be subject to the laws of the host Member State. Section 3 states that Member States must also take measures to permit different mixed forms of joint practice: lawyers who are established under their home title but who come from different Member States, and lawyers established under their home country title practising jointly with lawyers established under the professional title of the host Member State. Section 4 states that a lawyer established under his home title and who wants to work in a grouping, must provide the competent authority of the host Member State with all the relevant information concerning that grouping. Section 5 gives the right to Member States to refuse lawyers who are established under their home title, to practise in a grouping in which some of the members are not lawyers, insofar as it prohibits lawyers who are established

145 It must be noted at this point that the Directive does not allow for a straightforward application of the rules of the host Member State. In contrast, an objective justification is required in order to apply the rules concerning joint practice of the host Member State. 
under the professional title of that Member State from practising in groupings in which some members are not lawyers. The section states further that a grouping is deemed to include persons who are not lawyers if; the capital of the grouping is held entirely or partly by non-lawyers, the name under which it practises is used by nonlawyers, or if the decision-making power in that grouping is exercised, de iure or de facto, by persons who are not lawyers in the sense of Article 1(2) of the Directive. Furthermore, the section states that if the fundamental rules governing a grouping in the home Member State are incompatible with the rules in force in the host Member State or with the rules of Section 5, the host Member State may refuse to permit the lawyer concerned to open a branch or agency of the grouping in the host Member State. This prohibition may be imposed without the restrictions laid down in Section 1 of the Article.

Article 12 states that a lawyer may, while established under their home title in another Member State, employ the name of any grouping to which he belongs in his home Member State. The host Member State may require that, besides the name of the grouping, also its legal form and/or the names of the members practising in the host Member State is/are mentioned.

Article 13 provides for close cooperation between the competent authorities of the host and home Member State in order to facilitate the application of the Directive. The Article states further that the competent authorities must preserve the confidentiality of the information exchanged.

Article 14 states that Member States shall designate, by 14 March 2000 at the latest, the authority which shall be competent to receive the applications and take the decisions referred to in this Directive. The Member State shall inform the Commission and the other Member States of such a designation. Article 15 states that the Commission shall, at the latest ten years after the entry into force of this Directive, i.e., 14 March 2008, report to the European Parliament and the Council on the progress of the implementation of the Directive. The Commission may, in such a report, propose changes to the system as it exists up to that point. Article 16 states that the Directive must be implemented in the legal systems of the Member States by 14 March 2000 at the latest. The second section of the Article states that the Member States shall inform the Commission of any changes in their domestic law through which they adopt the matters covered by this Directive. Article 17 states that the Directive enters into force on 14 March 1998, the date of its publication in the Official Journal of the European Communities. Finally, Article 18 states that the Directive is addressed to the Member States.

Even after the Directive had come into force, the freedom of movement of lawyers under their home title was still not guaranteed because Luxembourg had filed a complaint of nullity regarding the Directive. So before it is possible to draw any conclusions from the new Directive, it is necessary to deal with the nullity claim of Luxembourg. 


\section{\3.3.7 Case Law Regarding the Lawyers Establishment Directive}

With regard to the Lawyers Establishment Directive, five cases are worth mentioning. First of all, on 4 May 1998, not even two months ${ }^{146}$ after the entry into force of Directive 98/5/EC, the Grand-Duchy of Luxembourg filed an appeal for nullity on the basis of Article 230 of the EC Treaty. The European Court of Justice dealt with this question in Luxembourg $v$. Parliament and Council. ${ }^{147}$ Luxembourg based its appeal against the Directive on three different arguments.

The first argument was concerned with the violation of Article 43 of the Treaty (at the time of the appeal still Article 52). Luxembourg argued that the right of lawyers to establish themselves under their home title could lead to reverse discrimination, i.e., that Luxembourg lawyers would be left in a less beneficial position than lawyers who exercised their right under the Directive. According to Luxembourg, this is the case because persons who want to become lawyers in Luxembourg have to follow professional education, whereas lawyers who establish themselves under the regime of Directive 98/5/EC do not have to do anything additional in the sense of professional education, to comply with Luxembourg law. In addition to that, Luxembourg argued that because Directive 98/5/EC takes away all rules with regard to professional education in the host Member State, the distinction between the freedom of movement of services and the freedom of establishment is blurred. According to Luxembourg this is the case because the exercise of the legal profession in another Member State without regulations regarding professional education (as is the case under the regime of Directive 89/48/EEC, ${ }^{148}$ where the host Member State controls the content of the aptitude test to be taken by the lawyer concerned) falls under the exercise of the freedom of movement of services. This argument seems to voice, albeit not expressly, the concern also voiced by the Luxembourg delegation to the CCBE and the Commission in its original proposal, namely that Article 43 does not support this form of establishment since it is carried out under different conditions than those applicable to nationals of the host Member State.

The European Court of Justice did not agree with these arguments. In paragraph 24 of the judgment, the Court states that there is no reverse discrimination because it has to be assumed that the professional situation of a foreign lawyer who is established under his home title cannot be compared with the situation of a national lawyer. According to the Court, this difference is ensured/created because a national lawyer may exercise, ipso facto, all activities that a lawyer is allowed to exercise in that Member State. This is in contrast with Article 5 of Directive 98/5/ EC, which allows the competent authority of the host Member State to limit the activities of the lawyer established under his home country title. Additionally, the Court argued that lawyers who are established under their home title are obliged to avoid any confusion between themselves and national lawyers. Due to these differences, the Court stated that there was no place for an appeal based on equal treatment. Basically, the Court went further with this ruling than the Parliament and the Council.

\footnotetext{
146 Necessary under the requirements of Article $230 \mathrm{EC}$, which imposes a time limit of three months.

147 Case C-168/98, Grand-Duchy of Luxembourg v. European Parliament and Council of the European Union, [2000] ECR I-09131. On this case see Bettin (2001), pp. 196-205; Cabral (2002), pp. 129-150 and Ferraro (2001), pp. 205-217. 
These were, in their respective opinion and common position, of the opinion that eventually establishment under home title would lead to full integration in the legal profession of the host Member State, albeit only to cover the eventuality that Article 43 would not cover establishment under other conditions than those applicable to nationals of the host Member State. The Court's ruling implies that establishment under home title is sanctioned by Article 43 of the Treaty.

The second part of Luxembourg's first argument was concerned with the fact that, due to the application of Directive $98 / 5 / \mathrm{EC}$, every possibility for quality control is lost. According to Luxembourg, this loss of quality control leads to an infringement of consumer protection principles that Member States try to achieve by means of rules for qualification and education. The lack of quality control therefore also leads to an infringement of the general interest.

The Court reacted to these accusations in a way that was fully in accordance with the views of the defendants and the intervening parties in this case. The Court reviewed a number of articles in the Directive that are concerned with quality control. The Court again stated that Articles 4 and 5 lay down the rules obliging lawyers to avoid confusion when being established under their home title. Moreover, the host Member State may limit the activities that a lawyer, established under his home title, may concern himself with while being established in the host Member State if this is justified under the applicable articles of the Directive. In addition the European Court of Justice underlined Article 6 of the Directive, that lawyers who are established under their home title are not only subject to the rules of conduct of their home Member State but also to the rules of conduct of the host Member State. Moreover, lawyers who are established under their home title are obliged to hold professional indemnity insurance. The Court also made reference to Article 7 of the Directive, which provides for an extensive cooperation procedure between the competent authorities of the host and home Member State in the case of disciplinary proceedings. The Court was of the opinion that the aforementioned guarantees are sufficient in order to conclude that there is no infringement of principles of consumer protection.

The second argument that Luxembourg brought forward was of a more technical nature. Luxembourg argued that Article 47(2) of the EC Treaty prescribes that in this case the voting in Council should have been based on unanimity instead of applied qualified majority. Article 47(2) prescribes that this alternative voting method must be used when dealing with Directives whose application leads, in at least one of the Member States, to a change in the principles for education and the access of natural persons to certain professions in the laws of the Member State. According to Luxembourg, this situation is applicable because Articles 2, 5 and 11 of the Directive change the existing principles in the laws of different Member States. Luxembourg argued that there is a change in principles for education since the Directive allows persons to establish themselves as lawyers without previous education in the host Member State, or without previous recognition of equality of diplomas. Luxembourg also argued that the principles for access are violated because it is possible, under the regime of the Directive, for every lawyer to establish himself under his home country professional title in any Member State without being obliged to educate himself in the law of the host State. Lastly, Luxembourg stated that the Directive violates the principle that every lawyer in Luxembourg is tested on his knowledge of Luxembourg law. This situation leads to a violation of consumer protection. 
The European Court of Justice did not agree with this line of reasoning. According to the Court, Directive 98/5/EC creates a mechanism of mutual recognition of professional titles for migrating lawyers that is a supplement to the system under Directive 89/48/EEC, according to which lawyers may exercise their profession without limitations in the host Member State. The Court therefore concluded that Directive 98/5/EC did not deal with new matters, and that therefore there is no violation of national law principles, since national laws should be completely adapted to the rules and contents of Directive 89/48/EEC. With regard to Luxembourg's complaint concerning Article 11 of Directive 98/5/EC, the Court held that rules pertaining to group practise of lawyers did not lead to a requirement of access but to a modality of the exercise of the profession. The Court therefore dismissed the argument. It must be observed that what the Court implied with the first argument, that establishment under home title was an independent form of establishment, is weakened by the ruling on the second argument, which stated that establishment under home title is complementary to full integration in the host Member State's profession. It seems that the Court did not want to give a clear ruling on this matter.

The third, and last, argument that Luxembourg brought forward to support its appeal of nullity was an alleged violation of Article 253 of the EC Treaty. This article requires that all legislative acts of the Institutions must be duly motivated. According to Luxembourg, this Article was violated because the Council and the European Parliament have not explicitly indicated why lawyers are not required to have their credentials recognised by the competent authority of the host Member State, and why lawyers are entitled to deal with the law of the host Member State, as of the first day of their establishment in that host State. Luxembourg also argued that the right of a lawyer to integrate in the legal profession of the host Member State after a certain period of time is contrary to the possibility of unlimited establishment under home title. With this last argument it seems that Luxembourg wanted to lure the Court into dealing with the problems regarding a possible violation of Article 43 of the EC Treaty. The Court merely reviewed the recitals of the Directive and concluded on the basis of established case law ${ }^{149}$ that the Directive is duly motivated and therefore argument given by Luxembourg was also dismissed. That meant that the Luxembourg's appeal was unfounded in arguments of law, and therefore its appeal for nullity was dismissed.

In itself, this case is not very spectacular. The European Court of Justice quickly, and rather simply, dismissed Luxembourg's arguments. Maybe it was a bit too quick. On some points, it seems that the European Court of Justice contradicted itself. In reaction to Luxembourg's first argument the Court stated that lawyers who were established under their home country professional title were not in the same situation as lawyers who worked under the professional title of the host Member State (whether national or integrated lawyers). With this statement the Court recognised that the tripartite system of the freedom of movement of lawyers (Directive 77/249/EEC, Directive 89/48/EEC and Directive 98/5/EC) also led to a tripartite division of the profession of lawyers, namely lawyers who occasionally provide services in another Member State, lawyers who establish themselves in another Member State and who become fully integrated in the legal profession of the host Member State, and lawyers 
who establish themselves under their home country title, and who, therefore become not fully integrated in the legal profession of the host State. This is an important factor since this was the first time that the European Court of Justice was so clear about the exact relation between the different forms of the legal professions in the Member States. It is, therefore, a pity that the European Court of Justice blurred a great deal of this clarity when delivering its judgment for Luxembourg's second argument. In reaction to that argument, the Court stated that Directive 98/5/EC is supplementary to the system laid down in Directive 89/48/EEC. With that statement, the Court suggested that both forms of establishment are very closely linked.

In my opinion, the Court has manoeuvred itself into in a precarious position. If the Court had maintained the line of argument it gave when answering Luxembourg's first argument in respect of the second argument, then the Court would have had to state that there was a new system for the establishment of lawyers. Such a new system would have made it highly likely that existing principles of national laws were to be changed and therefore the exception of 47(2) would have been applicable, i.e., unanimity would have been required in the Council (and subsequently Luxembourg would have voted against). It appears, from the arguments given above, that establishment under home title is very closely linked to full integration in the legal profession of the host Member State. The reasoning of the Court as to why Article 47(2) is not applicable is not a good example of convincing reasoning. The Court found it sufficient to note that Directive 98/5/EC is supplementary to Directive 89/48/EEC, and that therefore the exception of Article 47(2) did not apply. Similarly, it is a pity that the Court did not take the opportunity to clarify the distinction between establishment and services.

All this taken together means that if the Court had given a less evasive ruling, Luxembourg would have won on at least one argument and the Lawyers Establishment Directive would have been nullified. The Court apparently did not want to do so and therewith rescued the Directive and in turn the development of the free movement of lawyers.

After the implementation period of the Directive had expired in 2000, the Court had the opportunity in two instances to rule on failure of implementation. As will be shown more elaborately in the next chapter, many countries failed to implement the Directive on time, but only in the case of France ${ }^{150}$ and Ireland ${ }^{151}$ did it come to legal proceedings. France did not contradict the Commission's view that it had violated the Treaty by not implementing the Directive, nor did France offer any explanation or justification as to why it was late with its implementation. In Ireland implementation was late due to technicalities relating to the Irish legislative process. The Court was, however, not impressed and convicted both countries of violating the Treaty due to late implementation of the Directive. In themselves the cases are uneventful, marginal even, since they do not add anything to the development or offer any better understanding for the application of the Directive.

The last two cases are much more interesting in their connection to the Directive since they deal with its application by Member States. Unsurprisingly, both cases

150 Case C-351/01, Commission v. France [2002] ECR I-08101.

151 Case C-362/01, Commission v. Ireland [2002] ECR-I 11433. 
stem from Luxembourg, one being a Treaty violation procedure ${ }^{152}$ and the other being a prejudicial procedure. ${ }^{153}$ As will be shown in the next chapter, Luxembourg's resistance to the Lawyers Establishment Directive was not limited to its adoption. It will be shown that the implementation of the Directive in Luxembourg was not only late, but also rather difficult. At this point it suffices to say that Luxembourg, among other countries, required lawyers established under their home title to produce proof of their registration in their home Member State annually, required a language proficiency test for lawyers seeking establishment under home title, and refused lawyers established under their home country professional title to act as professional domicile in Luxembourg. None of these requirements and limitations are expressly sanctioned in the Directive. Therefore the Court had to rule on the legality of these requirements.

In the case of Commission v. Luxembourg, all these issues were addressed. The ruling of the ECJ largely followed the opinion of Advocate-General Stix-Hackl in this case. In her conclusion, the Advocate-General stated, based on a review of the recitals of the Directive, that Article 3 of the Directive fully harmonises the rules on registration of lawyers under their home country professional title. She also argued that the case-law concerning language requirements was not applicable to the situation of lawyers establishing themselves under home country professional title. The ECJ duplicated the opinion of the Advocate-General and stated that Article 3 leads to full harmonisation of the rules regarding registration under home country title. This meant that no further conditions may be imposed on the registration under home country professional title, even where such additional conditions were objectively justified on the basis of the conditions laid down in Gebhard. ${ }^{154}$ Consequently, as the ECJ indicated, language requirements and the annual proof of registration in the home Member State, were not in conformity with the Directive and therefore illegal. The approach towards the alleged violation of Article 5 of the Directive (professional activities) is marginally different from the approach that was used for Article 3. Both the Advocate-General and the ECJ stated that the exceptions to the exercise of a professional activity (laid down in paragraphs 2 and 3 of Article 5 of the Directive) are exhaustive and that other limitations on professionals are not allowed. There is no mention however of the extent of the harmonisation of Article 5, at least not in any explicit sense. Based on the formulation by the ECJ, it may be readily assumed that the ruling has a similar effect to the statement that Article 5 leads to full harmonisation, since the ECJ stated that no other exceptions to professional activities may be imposed other than those laid down in paragraphs 2 and 3 of Article 5 of the Directive. That statement leads me to the conclusion that Article 5 of the Directive leads to full harmonisation of the rules on professional activity of lawyers established under their home country professional title. This means that all limitations encountered in the review of implementations that cannot be covered by the exceptions of Article $5(2)$ and (3) of the Directive are illegal on the basis of this ruling.

152 Case C-193/05, Commission of the European Communities v. Grand-Duchy of Luxembourg, [2006] ECR I-08673.

153 Case C-506/04, Graham J. Wilson v. Ordre des avocats du barreau de Luxembourg, [2006] ECR I08613.

154 Case C-55/94, Reinhard Gebhard v. Consiglio dell'Ordine degli Avvocati e Procuratori di Milano, [1995] ECR I-04165. 
The Wilson case largely overlaps with Commission v. Luxembourg. Graham Wilson was a United Kingdom national who belonged to the profession of barristers. He sought registration under his home country professional title in Luxembourg. As was laid down in the Luxembourg implementation, Mr Wilson was requested to take a language proficiency test. When he arrived for this test accompanied with a Luxembourg avocat the latter was not permitted to attend the test. Mr Wilson therefore refused to take the test altogether. His request regarding his registration under his home title was subsequently denied. Mr. Wilson was informed that he could challenge the decision before the Conseil Disciplinaire et Administratif (the disciplinary council of the Luxembourg Bar Association). Mr Wilson challenged the decision but the Conseil denied jurisdiction. Mr Wilson brought his case before the Cour Administrative, which subsequently referred prejudicial questions to the ECJ.

The prejudicial questions touched upon two different subjects. On the one hand, the Cour Administrative asked whether a language proficiency test was allowed under the system of Article 3 of Directive 98/5/EC. In this sense, the Wilson case coincides with Commission v. Luxembourg. It is not surprising that the ECJ follows exactly the same line of reasoning as it did in Commission v. Luxembourg. The ECJ repeated that Article 3 of Directive 98/5/EC leads to full harmonisation in the field of registration under home country professional title. An additional language proficiency test is not allowed. Commission v. Luxembourg did not cover the second line of questioning of the Cour Administrative. Therefore, the ECJ devoted more attention to those questions. The Cour Administrative asked whether an appeal procedure such as the one before the Conseil Disciplinaire et Administratif was sanctioned by the rules laid down in Article 9 of the Directive. The Directive provides for a judicial remedy against decisions taken by the competent authority of the host Member State. The court began by stating that the terms 'court or tribunal', as per Article 9 of the Directive are terms defined by Community law. The ECJ then proceeded to state that the Conseil does not fulfil the criteria laid down by Community law, more importantly the criteria of independence and impartiality, since the Conseil is composed of Luxembourg avocats. The ECJ reasoned that a negative decision regarding registration under home country professional title can only be challenged before a council that is made up of other avocats who would also be potential competitors to the lawyer who seeks establishment under home country professional title. The ECJ therefore concluded that the judicial remedy offered by the Luxembourg authorities is not in conformity with Article 9 of the Directive.

To this date these are the only cases concerned with the application of Directive 98/5/EC. The ECJ also provided some clarity on the extent of the harmonisation of Articles 3 and 5 of the Directive. It must be made clear that, with regard to Article 9, the Court has said nothing about the extent of the harmonisation, and rather mentioned that the application of that Article in Luxembourg did not live up to the standards laid down in the Directive and in Community law in general. Questions remain whether the cases can shed some light on the extent of harmonisation of the rest of the Directive. Because of the limitations on subject matter in both cases the ECJ did not have the opportunity to assess the level of harmonisation of the Directive as a whole. As for Articles 3 and 5, the ECJ reached the conclusion that the Directive fully harmonises the rules on registration under home country professional 
title and the rules on professional activities that may be exercised by a lawyer which are exercised under his home country professional title.

In connection with the Directive, it may be assumed that Articles 3 and 5, together with Article 2, form the central core of the Directive. These articles actually implement the right for lawyers to establish themselves in other Member States and to exercise professional activities in the host Member State. It may be assumed that all the other articles, which support the key articles in the Directive (such as professional rules, disciplinary proceedings etc.) will not lead to a lesser extent of harmonisation than the articles which form the 'core'. This is corroborated by the fact that the wording, or rather the drafting technique, of the other articles in the Directive do not differ from Articles 3 and 5. If the ECJ reached the conclusion that Articles 3 and 5 of the Directive lead to full harmonisation, it must be assumed that the Directive as a whole was intended to fully harmonise the subject matter.

\section{3.3.8 Appreciation of the Directive}

It is clear that the Lawyers Establishment Directive (98/5/EC) is a capstone to the secondary legislation governing the free movement of lawyers. As was established, three different types of lawyer can be distinguished, but with earlier secondary legislation only the two extremes of the spectrum are covered. On the one hand, there is the short term provision of services by lawyers in another Member State in Directive $77 / 249 / \mathrm{EEC}$, and on the other hand, the full integration in the legal profession of the host Member State on the basis of Directive 89/48/EEC. Lawyers who wanted a lesser form of integration were therefore pressed between an aptitude test that extends beyond its purpose and the (ab)use of the Services Directive in the context of installation limitée. Despite early hesitations by the Commission, the Directive recognises the third type of lawyer as a separate category that deserves its own set of rules.

The rules laid down in the Lawyers Establishment Directive excel in simplicity. No technical and endless enumerations of educational requirements that were observed in the Directives adopted in the Vertical Approach are found. Like the Services Directive and the Diploma Directive, the Lawyers Establishment Directive is firmly rooted in the principle of mutual recognition. But where the mutual recognition was deemed harmless in the Services Directive because of the short duration of the activities, and was rendered useless ${ }^{155}$ in the Diploma Directive, because of the forced aptitude test that was fully in the competence of the Member States, the Lawyers Establishment Directive lets lawyers benefit fully from this principle. Brought back to its bare essentials, the Lawyers Establishment Directive allows lawyers from other Member States to exercise the profession of the host Member State, subject to the professional rules of the host Member State and under the professional title of the home Member State. In addition to that, the Directive also provides an interesting alternative to those lawyers who seek to integrate in the legal profession of the host Member State, since the Directive allows for integration without having to take an aptitude test. The only area where the Directive failed to live up to the expectations of the CCBE Draft is in the case of joint practice. Where the CCBE proposed joint practice under home country professional rules even in Member States where this 
was prohibited with only a small exception for certain MDPs, the joint practice rules in the Lawyers Establishment Directive are reduced to a mere equal treatment provision with the possibility of applying home Member State rules and with an almost complete equal treatment provision for MDPs.

In conclusion, one can say that Directive $98 / 5 / \mathrm{EC}$ is an important new piece of legislation in various capacities. First, it acknowledges and regulates the legal position of a new category of lawyers that did not formally exist until the adoption of this Directive, namely lawyers who want to establish themselves permanently in another Member State without becoming fully integrated in the legal profession of the host Member State. Secondly, the Directive opens possibilities for another category of lawyers, namely those who want to become established in another Member State, and who want to integrate fully in the legal profession of that Member State. Those lawyers might circumvent the more stringent rules of the secondary legislation that govern their legal position. Thirdly, and lastly, the Directive regulates, and introduces, a number of subjects which had not been specifically regulated before, namely the right of establishment for salaried lawyers and rules governing lawyers who practice jointly.

\section{$\int 4$. New Generation Case Law: Beyond the Directives}

After having described the development of the free movement of lawyers in the case law and the developments in secondary legislation which have affected this freedom, the question arises as to how these two mechanisms interact. It became clear from the Gebhard ruling that the system of objective justification only applies where the subject matter is not covered by secondary legislation, and rather specific case law, as the one described in the previous paragraph is required in order to ascertain the scope of the provisions laid down in the Directive concerned. ${ }^{156}$ Over the years the European Court of Justice has ruled on a number of cases that have explored the interaction between the two systems and the exact demarcation between them. These cases will be described in this paragraph and have all dealt with the demarcation between the Diploma Directive and the system of case law described earlier in this chapter. What was to happen if the candidate concerned did not have a diploma? What if the activity exercised could not be regarded as a regulated professional activity? These problems were addressed in a line of case law which could have enormous potential for furthering the free movement of lawyers in Europe.

With regard to the choice of system to be applied to a situation where there is no diploma in the sense of the Diploma Directive, the Burbaud case $\mathrm{e}^{157}$ provides clarity. This case concerned Ms Burbaud, a French national who wanted to become a hospital administrator in France. Ms Burbaud was a former Portuguese national. She studied

156 Sometimes the Court even avoids the subject. See Case C-153/02, Valentina Neri v. European School of Economics (ESE Insight World Education System Ltd), [2003] ECR I-13555. This case revolved around the question whether Italy could refuse to recognise a diploma of an English University when the person in question had followed courses in an Italian seat of that University, where the diploma would be recognised if she had studied in England. The Court avoided the question of diploma recognition by ruling that such a practice was an unjustified hindrance to the freedom of establishment of the school concerned.

157 Case C-285/01, Isabel Burbaud v. Ministère de l'Emploi et de la Solidarité, [2003] ECR I-08219. 
law in Portugal and was a fully qualified hospital administrator in Portugal (which involved passing a comparative entrance exam). As is the case with many professions in the public sector in France, the profession of the hospital administrator in France is only accessible for those who have completed training in a state-run school, in this case the École Nationale de la Santé Publique (ENSP). Completion at the ENSP is an automatic guarantee for a job as a hospital administrator. Access to the ENSP is subject to a comparative exam, a so-called concours. Ms Burbaud was denied access to the profession on the basis that she did not complete the ENSP. Ms Burbaud challenged this decision and the French administrative judge referred questions to the European Court of Justice. The questions posed by the French court dealt with two situations. First, the court asked whether or not the completion of a state-run school in order to obtain a position in the public sector, in this case the ENSP could be regarded as a diploma in the sense of Directive 89/48/EEC. Secondly, the court asked whether a Member State could require a person to fulfil certain criteria, in this case the comparative entry exam for the ENSP, in order to gain access to a certain profession, which in this case was the profession of hospital administrator.

In connection to the first question, the Court decided that the completion of the ENSP did lead to the awarding of a diploma in the sense of the Diploma Directive. Recognition of equivalence of foreign diplomas should, according to the Court, be based on the Diploma Directive. It is noteworthy that France argued that the Diploma Directive was not applicable to professions in the public sector, although it recognised that the public service exception did not apply. ${ }^{158}$ This argument was dismissed by the Court on the basis of previous case law, stating that the notion of a 'regulated profession' was a Community concept, and that the profession concerned was regarded as a regulated profession since it was regulated by French law. ${ }^{159}$

The second question referred to the Court was more complicated. Ms Burbaud argued that by maintaining the requirement for a compulsory entrance exam there would be a violation of Article 3 of the Diploma Directive. Consequently, in her view prescribing an entrance exam should not be allowed. The French government argued that the compulsory entrance exam fell outside the scope of the Diploma Directive altogether and that, in any case, it was a requirement that was indistinctly applied to both French nationals and nationals of other Member States. The Court agreed with the French reasoning in the sense that it ruled that the entrance exam to the ENSP did not fall within the scope of the Diploma Directive. But the Court further stated that the requirement for a compulsory entrance exam where there is no possibility to gain credit for previous experience and knowledge (compare Vlassopoulou) constitutes a hindrance to the free movement of workers as guaranteed by Article 39 EC. The Court continued to state that the hindrance concerned could not be objectively justified (compare Gebhard) because the system allows for French nationals to circumvent the entrance exam when they gained prior experience. The compulsory entrance exam for the ENSP therefore constitutes a violation of the free movement of persons. Although the Burbaud case cannot be regarded as being 'revolutionary' as such, it at least makes clear that the Court is willing to fall back on principles laid

\footnotetext{
158 Case C-285/01, \ 40.
}

159 Case C-285/01, \43. 
down in case law for situations which are not covered by the Diploma Directive, and that these situations are not for the discretion of the Member State.

Another ruling of the Court that is of importance for the demarcation of the material scope of application of the Diploma Directive is the case of Aranitis. ${ }^{160} \mathrm{Mr}$ Aranitis was a Greek national who was trained as a geologist in Greece. For over ten years he exercised his profession there, and then he moved to Germany. In Germany he sought employment as a geologist. He was allowed by the German authorities to use his Greek title with an accompanying German translation. Aranitis found out that employers were exclusively looking for people with the German diploma, Diplom Geologe, without there being a provision in German law protecting the access to this profession or requiring the possession of this diploma. Aranitis requested the German authorities to recognise his qualifications on the basis of the Diploma Directive, which the authorities refused. The reasoning behind this denial lay in the fact that the profession of the geologist was not a regulated profession in Germany and therefore the Diploma Directive did not apply. The Court agreed with this line of reasoning and stated that where access to a profession is not governed by any domestic legislation the Diploma Directive is not applicable and there was no opportunity for Aranitis to obtain the German diploma. The Court also mentioned that in this situation the general non-discrimination provisions in the Treaty and the case law of the Court, notably the Court's ruling in Vlassopoulou, apply. Although helpful, this reminder was of little use for Aranitis, who was still a victim of the laws of supply and demand on the market for geologists in Germany.

A similar problem arose in Fernandez de Bobadilla. ${ }^{161}$ Ms Fernandez de Bobadilla was trained as an art restorer and held diplomas from US and United Kingdom universities. She had worked at the Prado museum in Madrid on the basis of a temporary contract. The Prado is an autonomous State agency attached to the Spanish Ministry of Culture. In a collective labour contract that was imposed by the Prado on its employees, it was stipulated that for an indefinite contract for the position of restorer it was required that the candidate had a degree as art restorer from a Spanish educational institution or had a degree from another country that was recognised by the Spanish authorities. Ms Fernandez de Bobadilla's request for a tenured position was denied on the basis that she did not fulfil the requirements laid down in the collective labour agreement. The profession of the art restorer was not regulated under Spanish law. The Court did not give a clear ruling on the question of whether laying down entry requirements in a collective labour contract of a government institution led to the regulation of that profession. If the national court decided that this is the case, the Diploma Directive should be applied. If, however, the national judge ruled that the profession was not regulated it should apply the general conditions for diploma recognition laid down in Vlassopoulou.

By far the most interesting ruling in this respect came from the Court in the Morgenbesser case. ${ }^{162}$ Doctrinally, this case can be seen as belonging to cases like Aranitis and Fernandez de Bobadilla, which in hindsight, can be seen as Morgenbesser's

160 C-164/94 Aranitis v. Land Berlin, [1996] ECR I-135.

161 C-234/97, Teresa Fernández de Bobadilla v. Museo Nacional del Prado, Comité de Empresa del Museo Nacional del Prado, Ministerio Fiscal, [1999] ECR I-4773.

162 Case C-313/01, Christine Morgenbesser v. Consiglio dell'Ordine degli avvocati di Genova, [2003] ECR I-13467. See also: Baas (2003), p. 973 and Timm \& Kempter (2005), pp. 2826-2828. 
predecessors. Ms Morgenbesser, a French national, had studied law in France and obtained her degree there. After obtaining her degree, a maittrise en droit, she started working at a Parisian law firm without qualifying as an avocat. After eight months, she moved to Italy and found a similar job with a law firm in Genoa. One and a half year later, she filed a request with the Genoa Bar Association to be registered on the register of practicanti, the register for lawyers who are in the process of qualifying to become an avvocato.

The Genoan Bar association refused, and so did the National Bar Association, on the ground of the fourth criterion of Article 17 of the law on the profession of avvocato, which requires candidates to have a law degree conferred by an Italian university. ${ }^{163}$ In reaction to these decisions, Ms Morgenbesser tried to have her French university diploma recognised in Italy. ${ }^{164}$ The University of Genoa was willing to recognise her Maitrise on the condition that Ms Morgenbesser was to follow a twoyear course in Italian law, pass thirteen exams and write a dissertation. Ms Morgenbesser politely declined and appealed to the Tribunale amministrativo regionale della Liguria. The case eventually arrived at the Consiglio di Stato. Ms Morgenbesser had in the meantime applied for cassation of the National Bar Association's decision. It was the Corta suprema di cassazione which, in the end, filed the preliminary questions to the European Court of Justice. ${ }^{165}$

The Italian Supreme Court of Cassation asked the European Court of Justice whether a diploma conferred by a university in another Member State must be automatically valid for registration in a register of persons who follow a period of practical training in order to enter into the legal profession of another Member State on the basis of the rules regarding free movement of services and freedom of establishment. ${ }^{166}$ The European Court of Justice reformulated the question and stated that the Supreme Court on the whole wanted to know whether a person who had a law degree from another Member State could be refused entry into a register of persons who follow practical training in order to enter in the legal profession of the Member State concerned on the sole ground that the individual did not have a law degree that was conferred, ratified or regarded as equal by a university from the Member State concerned. ${ }^{167}$

The European Court of Justice ruled that the status of practicanti could not be seen as a separate profession since being a practicanti is a necessary step in order to qualify as an avvocato. Morgenbesser's situation therefore did not fall under the regime of Directive 89/48/EEC. The Court could have stopped there, since that was the extent of the question posed by the Italian court. However, it continued and ruled that even in the event where an activity was not caught by Directive 89/48/EEC (or any of the other Directives) the general rules covering the recognition of diplomas, as laid down in established case law of the European Court of Justice, should apply. The Court then went on to refer to the Vlassopoulou judgment in which it was stated that a Member State impairs the free movement of persons in an unjustified

\footnotetext{
163 Case C-313/01, JS 25-27.

164 This is a situation that generally falls outside European law. See, however, Chapter 4 below.

165 Case C-313/01, SS 28-31.

166 The Supreme Court bases its question on Articles 10, 12, 14, 39, 43, 49 and 149EC, since Ms Morgenbesser appealed on the basis of these articles. See case C-313/01, \31-32.

167 Case C-313/01, §33.
} 
manner if it fails to take in account knowledge gained in another Member State (irrespective of whether the situation concerned the free movement of workers or the freedom of establishment). ${ }^{168}$ The Court came to the conclusion that the Genoan Bar Association could not refuse to enter Ms Morgenbesser into the register of practicanti for the sole reason that she had no diploma conferred, ratified or recognised by an Italian university, and that her knowledge gained in France (proven by her maitrise) should be taken into account. The Court furthermore reiterated that when deciding upon the equivalence of diplomas the national authority could only look at the level of the qualification, except for diplomas concerning national law, whilst the national authority is allowed to compare taking into account established differences between the legal systems concerned.

It might be questioned why the Court did not rule that the activities of a practicanti constitute a regulated professional activity in the light of Directive 89/48/EEC. It seems obvious that Italy as a Member State applies rules that control the entry to the level of practicanti while training for the profession of avvocato. It should therefore not have been very difficult to rule that the professional activities exercised by a practicanti could be seen as a regulated professional activity. The Court could then have determined the case by referring to Articles 3 and 4 of the Directive, ${ }^{169}$ and avoided the question of whether the system for the recognition of diplomas also applied to persons who were not considered as a produit fini as the Court had done in Neri. ${ }^{170}$ The reason the Court could not deal with the question in the light of a regulated profession, or a regulated professional activity, was not so much because of the fact that the level of practicanti could not be seen as a regulated professional activity, ${ }^{171}$ but more as a result of Morgenbesser's status in France. Ms Morgenbesser did not have credentials that could be regarded as a diploma in the light of Article 1 of Directive 89/48/EEC. Morgenbesser only obtained her maitrise en droit, which did not give her access to the training for an avocat, since she did not pass the entrance exam for this CRFPA. So even when the level of practicanti was seen as a 'semi produit fini' then Directive 89/48/EEC could still not be applied since she did not qualify to participate in that similar level of training (stagiaire) in her home Member

168 Doctrinally, the basis of the system lies in Gebhard (Case C-55/94). In that case the Court ruled that any hindrance to the free movement of person should be objectively justified. In this niche, objective justification could be obtained by adhering to the Vlassopoulou doctrine.

169 It could even be argued that in that case the situation of Peros and Aslanidou would have applied, since Italy had not implemented an aptitude test for practicanti. Morgenbesser could then have integrated without Italy being allowed to impose compensatory measures.

170 Case C-153/02, Valentina Neri v. European School of Economics (ESE Insight World Education System Ltd.), [2003] ECR I-13555. This case revolved around the question whether Italy could refuse to recognise a diploma of an English University when the person in question had followed courses in an Italian establishment of that University, where the diploma would be recognised if she had studied in England. The Court avoided the question of diploma recognition by ruling that such a practice was an unjustified hindrance to the freedom of establishment of the school concerned.

171 The Court even implicitly acknowledged that a regulated professional activity was at stake (Morgenbesser, $\int \mathbb{S} 50-51$ ) and only denied explicitly that the level of practicanti was a regulated profession. 
State, France. ${ }^{172}$ The Court was therefore forced to deal with the question of recognition of diplomas outside the scope of Directive 89/48/EEC.

As stated above the Court referred to, and applied, the Vlassopoulou ruling to the problem posed by Ms Morgenbesser. The application of the Vlassopoulou doctrine to situations that did not fall, or did not fall completely, under the system of diploma recognition laid down in secondary legislation is not new. In the cases of Aranitis, Fernandez de Bobadilla and Burbaud, the Court reached the same conclusion. Having said that, the case of Morgenbesser does have revolutionary potential. That potential does not lie in the application of the Vlassopoulou doctrine as such, but more in the situation of the facts to which the doctrine was applied. In Morgenbesser, the Court first applied the Vlassopoulou doctrine to a situation that was concerned with a person who was not fully qualified to exercise a regulated profession in any of the Member States, including her home Member State, where she was not even qualified to enter the vocational training for the profession of the avocat. ${ }^{173}$ Ms Morgenbesser could therefore not be regarded as a produit fini in the context of Directive 89/48/EEC. This is different from the cases described above which had all dealt with persons qualified to exercise a certain profession. Moreover the Court applied the ruling to a situation where the applicant wanted to enter a higher level in another Member State than the level which she had achieved in her home Member State.

In its judgment the Court never referred to the special circumstances of this specific case (i.e., the system of registers for practicanti) which ultimately brought the Court to this decision. It must therefore be assumed that the principle decision in Morgenbesser, i.e., the application of the Vlassopoulou doctrine to non-produits fini, is a rule that can be generally applied. It can furthermore be assumed that a person who is in the process of qualifying for a legal profession in one Member State can move to another Member State and continue the process of qualification in that Member State. The host Member State may not impose its criteria for entering that qualification process ipso facto but must take into account any knowledge and experience that the candidate already gained in the qualification process in the other Member State, even where the candidate seeks entry in a level of the qualification process that he has not reached in his home Member State. If the ruling in Morgenbesser is applied to this extent, the Court encroaches upon academic recognition on the basis of Article $149 \mathrm{EC}$, an area where the European Union has no legislative power. ${ }^{174}$

Apart from a circumstance in Germany which will be considered below, there is little information on the application of the Morgenbesser ruling in the Member

172 Morgenbesser $\$ 54$. In this respect Morgenbesser can be distinguished from Lubina, discussed below, since Ms Lubina did qualify for a position of advocaat-stagiaire in the Netherlands with her 'meester' title.

173 In that sense the ruling of Morgenbesser even stretches beyond Massopoulou, since Ms Morgenbesser was able to use the Vlassopoulou comparison in a situation where she sought access to a stage of the qualification for a regulated profession that she was not entitled to enter in her home Member State because of the fact that she did not fulfil the criteria for entering that stage.

174 On the difference between recognition of academic and professional qualifications, see Van der Mei (2001), pp. 453-454. Traditionally the European Community has no competence with regard to harmonisation of purely academic qualifications. Problems do however occur when academic qualifications coincide with professional qualifications, as is the case, for example, in Spain, where access to the legal profession can be obtained with an academic degree alone. 
States. ${ }^{175}$ The CCBE issued a position paper concerning this case in 2004 which offers no more than the judgment itself. ${ }^{176}$ Recently, the Verwaltungsgericht Düsseldorf was awarded the opportunity to rule on a similar case to Morgenbesser, which is known as the Lubina case. ${ }^{177}$ Ms Lubina had German nationality. She completed two university courses in the Netherlands (Law and Cultural Sciences) and she obtained a 'Master in European Studies' from the Humboldt University in Berlin. Her Dutch law degree, 'meester in de rechten', has the so-called civil effect, which means that she is allowed to start working as an advocaat-stagiaire. In that sense an immediate distinction with Morgenbesser can be made, since Ms Morgenbesser did not have adequate qualifications to start as a stagiaire in France. Lubina sought admittance to the Referendardienst (comparable to the practicanti in Italy, the stagiaire in France and the advocaatstagiaire in the Netherlands). Her application was denied on two grounds. Firstly the Oberlandesgericht (which decides on applications) in Düsseldorf stated that she did not have the necessary qualifications to enter the Referendardienst (a similar position the Italian authorities had taken in the Morgenbesser case), more specifically she did not pass the First German State Examination, which is a necessary requirement for entering the Referendardienst. Secondly, the Oberlandesgericht stated that the 'profession' of Referendar did not fall under the free movement of persons (more specifically the free movement of workers) since it was regarded as a part of the education of a prospective lawyer, rather than a professional activity. ${ }^{178}$ The latter reason was rendered useless already during the Lubina proceedings because the European Court of Justice ruled in the Kranemann case, ${ }^{179}$ without any reservation, that people who were a Referendar fell under the free movement of workers. ${ }^{180}$ So the only reason which remained was that Ms Lubina lacked the necessary requirements to enter the Referendardienst.

Eventually the case was settled without there being an official judgment. The Verwaltungsgericht ordered that the Oberlandesgericht take a new decision on Ms Lubina's accession to the Referendardienst. It is noteworthy, however, that the Verwaltungsgericht supported this decision with a combination of reasons which did not come together completely. The Verwaltungsgericht stated firstly that, based on the Kranemann judgment, the profession of the Referendar fell under the free movement of workers and is therefore regarded as a regulated profession. It must be noted that the latter statement (with regard to the status of regulated profession) is a statement of the Verwaltungsgericht which is in no way corroborated by the Kranemann ruling which did not even address the question of regulated professions. Oddly enough the Verwaltungsgericht then proceeded by 'solving' the case, using the Morgenbesser judgment where the Court ruled that 'practicanti' was not a regulated profession. ${ }^{181}$ If the profession of Referendar was a regulated profession according to the Verwaltungsgericht it should

175 See also: Hodgson (2005).

176 CCBE (s.d.) E.

177 Katja Lubina/Präsidentin des Oberlandsegericht Düsseldorf, Aktenzeichen 10 K 7279/04.

178 Here once more the controversy between academic and professional qualifications surfaces.

179 Case C-109/04, Karl Robert Kranemann v. Land Nordrhein-Westfalen, [2005] ECR I-02421. See for summaries of this case: Barnard (2007), pp. 278-279; Chalmers (2006), pp. 711-712; Comijs (2005), pp. 150-153 and Pina (2006), pp. 394-402.

180 Provided, of course, that there is border crossing element in the case, which was the case in the Kranemann case.

181 Although they hinted in the direction of the level of 'practicanti' being a regulated professional activity. 
have solved the problem according to Directive 89/48/EEC and not according to the Morgenbesser judgment.

Now the Oberlandesgericht Düsseldorf must make a decision on the additional requirements (if any) which Ms Lubina must fulfil before she can be allowed entrance into the Referendardienst. In other words, the Oberlandesgericht must now exercise a Vlassopoulou comparison in order to ascertain what requirements need to be fulfilled. Further litigation following this decision is not unthinkable. ${ }^{182}$

Apparently the Oberlandesgericht was inspired by a forthcoming legal change in Germany. In January 2007 a new provision (paragraph 112a) of the Deutschen Richtergesetzes (German Judges Law) entered into force. ${ }^{183}$ The Deutschen Richtergesetzes mainly covers the profession of the judge in Germany, but it also contains the requirements necessary for entering the Refendariat since there is only one German professional education for all the legal professions. The new paragraph 112a of the Deutschen Richtergesetzes seems a straightforward implementation of the Vlassopoulou comparison as mentioned in the Morgenbesser ruling. The paragraph states that any national of other Member States of the European Union who has a university diploma that gives him access to the professional training of the legal professions under Article 1 of Directive 98/5/EC may have his diploma checked by the German authorities in order to obtain a decision on equivalence. This description makes it immediately clear that whilst Ms Lubina could have profited from paragraph 112a of the Deutschen Richtergesetzes, Ms Morgenbesser could not have done so were she to seek entrance as a Referendar in Germany, because she did not qualify for professional training in France. So even in Germany the Morgenbesser ruling is still relevant to protect those who fall outside the scope of application of paragraph 112a of the Deutschen Richtergesetzes. ${ }^{184}$ Paragraph 112a further states that, where it is decided that the university diploma is not equivalent to the entrance requirements in Germany, the candidate concerned may take an aptitude test in order to obtain entry in the profession of the Referendar. This aptitude test will cover civil law, penal law, administrative law and procedural law. Clearly, in the majority of cases equivalence will not be achieved as such and an aptitude test may be necessary. On the other hand, the adaptation of the Deutschen Richtergesetzes is a favourable action from the German authorities (even where it falls short of the Morgenbesser ruling) as it provides Ms Lubina and her peers with much needed legal certainty regarding entrance in the qualification stages of the legal profession. Similar legislation has not been observed in other jurisdictions, but in those circumstances prospective lawyers may fall back on the Morgenbesser ruling.

From my perspective, even in the wake of the German legal reform, it would be a good development if further proceedings were started, and ideally, a referral to the European Court of Justice could be obtained. The Lubina case may provide the Court with a set of facts that could lead to the decision that 'vertical differentiation' within regulated professions is possible, i.e., by ruling that separate parts of the quali-

182 The OLG Düsseldorf responded in 2006 with a list of compensatory requirements that Ms Lubina had to fulfil. These requirements were deemed excessive and further litigation is to be expected.

183 Deutsches Richtergesetz in der Fassung der Bekanntmachung vom 19. April 1972 (BGBl. I S. 713), zuletzt geändert durch Artikel 4 des Gesetzes vom 22. Dezember 2006 (BGBl. IS. 3416).

184 And the paragraph would not have served as sufficient implementation had the Court ruled that Morgenbesser's situation was a regulated professional activity, because of the difference of levels. 
fication process for a regulated profession could be construed as a regulated professional activity to which the system of Directive 89/48/EEC applies. This would be a valuable addition to the Morgenbesser case, where the Court could not reach this decision because of the fact that Ms Morgenbesser did not qualify for the position of stagiaire in France.

Recent case law has shown that the Court is willing to accept differentiation within regulated professions. ${ }^{185}$ This form of differentiation could be classified as 'horizontal differentiation' since it allows differentiation in different regulated professions and to allow persons (at their own request) only into a part of a certain profession. Vertical differentiation, i.e., differentiation in the different stages of the qualification process and application of the system of recognition of diplomas to these different stages would greatly benefit the development of the free movement of lawyers. With the application of the system of the Directive, people in the process of qualifying for a legal profession would then enjoy even more protection than under the situation in Morgenbesser.

In addition to the encroachment on academic recognition in Morgenbesser, the Court gave another ruling that is important in this field, namely the Commission $v$. Austria case. ${ }^{186}$ This case was concerned with Austrian laws which allowed students who had finished Austrian secondary education to enter studies in medicine without any further requirements. Students from outside Austria, on the other hand, were required to fulfil the criteria laid down in their home Member State to enter the study of medicine there. The Commission stated that this was an unjustified discrimination between Austrian students and students from other Member States. Austria argued that this practice, which was in conformity with the Lisbon Recognition Convention, ${ }^{187}$ concerned academic recognition and fell out of the scope of the Community Treaty. The European Court of Justice disagreed with this approach and treated the alleged violation under the regime of Article $12 \mathrm{EC}$, as discrimination on grounds of nationality. ${ }^{188}$ The Court concluded that the Austrian practice is a discrimination based on nationality. In a strict sense, the ruling should end there since Article 12 EC does not provide for any grounds of justification. Nevertheless, the ECJ (and surprisingly also Advocate-General Jacobs) applied an objective justification test that is of uncertain origin, to say the least. ${ }^{189}$ In that test the justifications

185 Case 330/03 Colegio de Ingenieros de Caminos, Canales y Puertos, [2006] ECR I-00801. See Barnard (2007), pp. 325-326. In this case the Court accepted that instead of applying compensatory measures laid down in Article 4 of the Diploma Directive, the competent authority can also allow a candidate, on the latter's own request, partial access to the profession in question, in order to provide access to at least a portion of the profession. The ratio behind this ruling lies in the intimidating character and often far reaching consequences of applying compensatory measures.

186 Case C-147/03, Commission v. Austria, [2005] ECR I 5969. For summaries of this case see Barnard (2007), pp. 302-303; Hilpold (2005), pp. 647-652; Hilpold (2006), pp. 333-336 and Rieder (2006), pp. 1711-1726.

187 See below.

188 The ECJ does so with reference to another (almost simultaneous) case, Case C-65/03, Commission v. Belgium [2003] ECR I 6427, where the ECJ decided that the subject matter concerned (which was the same in the Belgium case) fell within the scope of Community law since it dealt with the access to higher education, rather then academic recognition. See also below on Gravier.

189 Jacobs refers to 'the free movement of persons' in general, and specifically refers to Articles 39 and 46 in particular. It must be noted at this point that the students concerned cannot and do not 
brought forward by the Austrian government (homogeneity of the Austrian education system, abuse of Community law and the Lisbon Recognition Convention) were set aside by the European Court of Justice. The ECJ subsequently found that the Austrian rules were in violation of Articles 12, 149 and 150 of the EC Treaty.

Although the implications of the Commission v. Belgium and Commission v. Austria cannot be announced with certainty, the potential for another revolution is certainly lingering. The Court has in essence brought academic recognition (or more specifically the recognition of secondary education qualifications) under the scope of Community law. Moreover, the Court failed to give information on how Member States should deal with this recognition (whereas that information was given in the Morgenbesser case). At this point in time, every discriminatory measure affecting the equality of secondary education qualifications must be seen as a violation of Article 149. It is clear that the Court overstepped the boundaries of Article $149 \mathrm{EC}$ even more bluntly than it had in Morgenbesser. To that extent it may also be observed that the new paragraph 112a of the Deutschen Richtergesetzes provides a sample of academic recognition that is 'Europeanised'.

\section{5. The Outside World: Third-Country Diplomas and Third-Country Nationals}

The final aspect of the free movement of lawyers that needs to be addressed in this chapter is the interaction of the rules governing the free movement of lawyers in Europe with the world outside the European Union. In this respect two main categories can be identified. First, a situation can arise where a Union citizen has obtained his or her professional qualifications in a third State. Secondly, situations can be found which concern third-country nationals in possession of either European Union qualifications or third-country qualifications and who seek to benefit from the rules governing the free movement of lawyers. These eventualities will be described in this paragraph.

The first eventuality, where a Union citizen has obtained his professional qualifications in a third Member State, is relatively easily solved by the system of secondary legislation. This situation is covered in both Directive 89/48/EEC (Article 1) and in the new Diploma Directive 2005/36/EC (Article 3(3)). Article 3(3) of Directive 2005/36/EEC states that qualifications obtained by a Union national are covered by the Directive if a Member State has recognised these qualifications as being the equivalent to qualifications in that Member State on the basis of their own rules, and if the candidate has three years' professional experience in the profession of that Member State. When these criteria are fulfilled the Union national in question enjoys the full application of Directive 2005/36/EC.

Both Directives 77/249/EEC and 98/5/EC do not contain any provisions specific to those Union nationals who have obtained their professional qualifications in a

classify as workers, nor can they be seen as persons who are 'established' (which would make Article 46 applicable). The foundations of the objective justification test that was applied in Commission v. Austria (and which was absent in the Commission v. Belgium case) remain uncertain. One might even argue that students remain in a closed system, i.e., Article 7(1) of Directive 2004/38. 
third country. At first sight this could mean that these lawyers may not benefit from the provisions of the Directives. If, however, they obtain a recognition of their professional qualifications in a Member State (based on the rules in force in that State) they may benefit from the Directives since they fulfil both criteria necessary for application of the Directives (i.e., they are Union nationals and they are allowed to practise under one of the professional titles mentioned in the Directives). It is noteworthy that in this circumstance the lawyer concerned can circumvent the additional requirement of the Diploma Directive 2005/36/EC that requires an additional professional experience of three years.

Case law in this field is scarce and is mainly concerned with the sectoral Directives (which are now also covered by Directive 2005/36/EC). An example is the Haim case. ${ }^{190}$ Haim was an Italian national who obtained a Turkish dentistry diploma. This diploma was subsequently recognised in Germany and Belgium. Haim worked in Belgium as a dentist in a social security scheme, whereas in Germany he had a private practice. When Haim sought to work in a social security scheme in Germany his application was denied on the grounds that he did not fulfil the requirement of completing a two-year preparatory training period. According to Haim, this was in violation of the Dentist Directive (one of the vertical harmonisation Directives). The Court ruled that the Directive did not apply, since Haim had a Turkish diploma, and that the German authorities were therefore entitled to enforce the training period. However, the Court continued by stating that Germany was not entitled to enforce the training period before examining whether the experience already gained by Haim corresponded to that which is required by the training period. This is an application of the Court's ruling in Vlassopoulou.

Another relevant ruling can be found in the Hocsman case. ${ }^{191}$ Hocsman was an Argentine national who acquired Spanish nationality, and subsequently French nationality. Hocsman had a university degree in medicine and trained in Spain to become a urologist. After he obtained Spanish nationality he was allowed to practise urology in Spain. When Hocsman moved to France he worked as an assistant or associate specialising in urology in various hospitals there, but his request to be registered was refused by the relevant minister, stating that he was not allowed to practise medicine in France because his Argentinean diploma was not recognised there. The Doctors Directive did not provide for recognition of third-country qualifications. The Court ruled, this time explicitly referring to Vlassopoulou (and Haim), that in a situation not regulated by a directive on mutual recognition of diplomas, a Community national applies for authorisation to practise a profession, the access to which depends, under national law, on the possession of a diploma or professional qualification, or on periods of practical experience, the competent authorities of the Member State concerned must take into consideration all the diplomas, certificates and other evidence of formal qualifications of the person concerned and his relevant experience, by comparing the specialised knowledge and abilities certified by those diplomas

190 Case C-319/92, Haim v. Kassenärtzliche Vereinigung Nordrhein, [1994] ECR I-425. See also: Barnard (2007), p. 330

191 Case C-238/98, Hocsman v. Minister de l'Emploi de la Solidarité, [2000] ECR I-6663. See on Hocsman: Barnard (2007), p. 330; Chalmers (2006), p. 718 and Prinssen (2001), pp. 184-186. 
and that experience with the knowledge and qualifications required by the national rules. ${ }^{192}$

The position of third-country nationals, whether with Community or thirdcountry qualifications, is more problematic. All the Directives refer specifically to nationals of Member States, thus excluding third-country nationals from the scope of the Directives. Moreover, regimes imposed on third-country nationals can be restrictive and are, to a great extent, left to the discretion of the Member States. An important case in this respect is that of Gül. ${ }^{193}$ Gül was a Cypriot national ${ }^{194}$ who was married to a British national and was living in Germany. He derived his right to stay in Germany from being the spouse of a worker. He requested his Turkish diploma to be recognised in Germany. The German authorities refused the recognition, stating that third-country nationals cannot hold a licence to practise and can only obtain a temporary permit. The Court ruled in clear terms that Article 11 of Regulation 1612/68 (now repealed by Directive 2004/38/EC) ${ }^{195}$ requires that spouses of workers should have the same access to work as nationals of the Member State. This implies that Gül would have to be placed in a similar position as a German who held Turkish qualifications. Whether this leads to the conclusion that third-country family members of Community nationals have a right to the Diploma Directives ${ }^{196}$ must be doubted. ${ }^{197}$ In the light of Haim and Hocsman, Gül could not have relied on the Doctors Directive but only on the Vlassopoulou case, since his original qualifications were obtained in a third country, a situation where Community nationals also cannot rely on the sectoral Directives. Had Gül been active in a profession that would be covered by Directive 2005/36/EC he would have been subject to the German rules on the recognition of Turkish diplomas.

A new development in the secondary legislation is also very important in this respect. This is the Long Term Residence Directive, 2003/109/EC. ${ }^{198}$ This Directive creates the possibility for third-country nationals to gain the status of 'Long Term Resident', which provides them with certain benefits within the European Union. In Article 11 of this Directive, it is stated that a third-country national who has obtained Long Term Resident status has a right to equal treatment with regard to the recognition of diplomas according to the rules in force in that Member State. This means that if a third-country national with Long Term Resident status has a third-country diploma, the national rules will apply to him; if he has a thirdcountry diploma that is recognised in another Member State the Diploma Directive will apply (or the Haim and Hocsman rulings in the case of a sectoral profession) and, if he has a diploma from a Member State, the Diploma Directive will apply. With regard to Directives 77/249/EEC and 98/5/EC, the Long Term Residents Directive does not offer any solutions. Keeping in mind that both Directives require beneficiaries to be Union nationals, it seems that these Directives will not apply to third-country nationals.

\footnotetext{
192 Case C-238/98, \40.

193 Case 131/85, Emir Gül v.Regierungspräsident Düsseldorf, [1986] ECR 1573

194 At the time Cyprus was not a Member State.

195 But application of Article 24 (23 out) of that Directive leads to the same conclusion.

196 As is concluded by Wapenaar in: Wapenaar (1997), p. 116.

197 Schneider \& Claessens (2005), p. 148.

198 Directive 2003/109/EC OJ L16/44.
} 


\section{Conclusions}

This chapter has shown that in the past 50 years enormous changes have taken place in the developments relating to the free of movement of lawyers. Before the development began in 1974, free movement of lawyers was non-existent, since Member States required lawyers to have the nationality of the Member State in which they practised. It was the European Court of Justice that encouraged and fostered at least the possibility of freedom of movement for lawyers when it ruled in the Reyners case that Member States could no longer enforce the nationality requirement for lawyers. In subsequent case law, extensively described above, the European Court of Justice created a self-supporting system that facilitated lawyers' movement from one Member State to another by assigning certain rights regarding the mutual recognition of their professional qualifications and their free movement rights in general. In a parallel development which started in 1977, secondary legislation was adopted facilitating various modalities of this freedom. It has been established that the applicable Directives cover all the modalities of the free movement of lawyers that have been observed, i.e., provision of services and establishment of lawyers with or without integration in the legal profession of the host Member State. More recent case law of the European Court of Justice has dealt with the application and extent of the harmonisation of the Directives and with the application of the system laid down in the case law to categories of persons who were originally not caught by the Directives, such as third-country nationals and people who are not fully qualified to exercise a regulated profession in the home Member State.

This chapter has presented these developments largely in chronological order. When approached from a different angle it should be possible to devise a model that represents the current state of affairs with regard to the different possibilities for the different modalities of the free movement of lawyers. When presented in a graphical format that same model would look like the flowchart on the next page. In the next chapter the application and the implications of this model in fifteen Member States will be researched. Since it is the most recent addition to the model in the sense of secondary legislation, major attention will be paid to the implementation and application of Directive 98/5/EC. Research is also applied to the level of effectiveness in practice of the different routes presented in the model. On the basis of that, propositions for improvement and refinement of the model will be made. 
Figure 1: Free movement of lawyers in the European Union

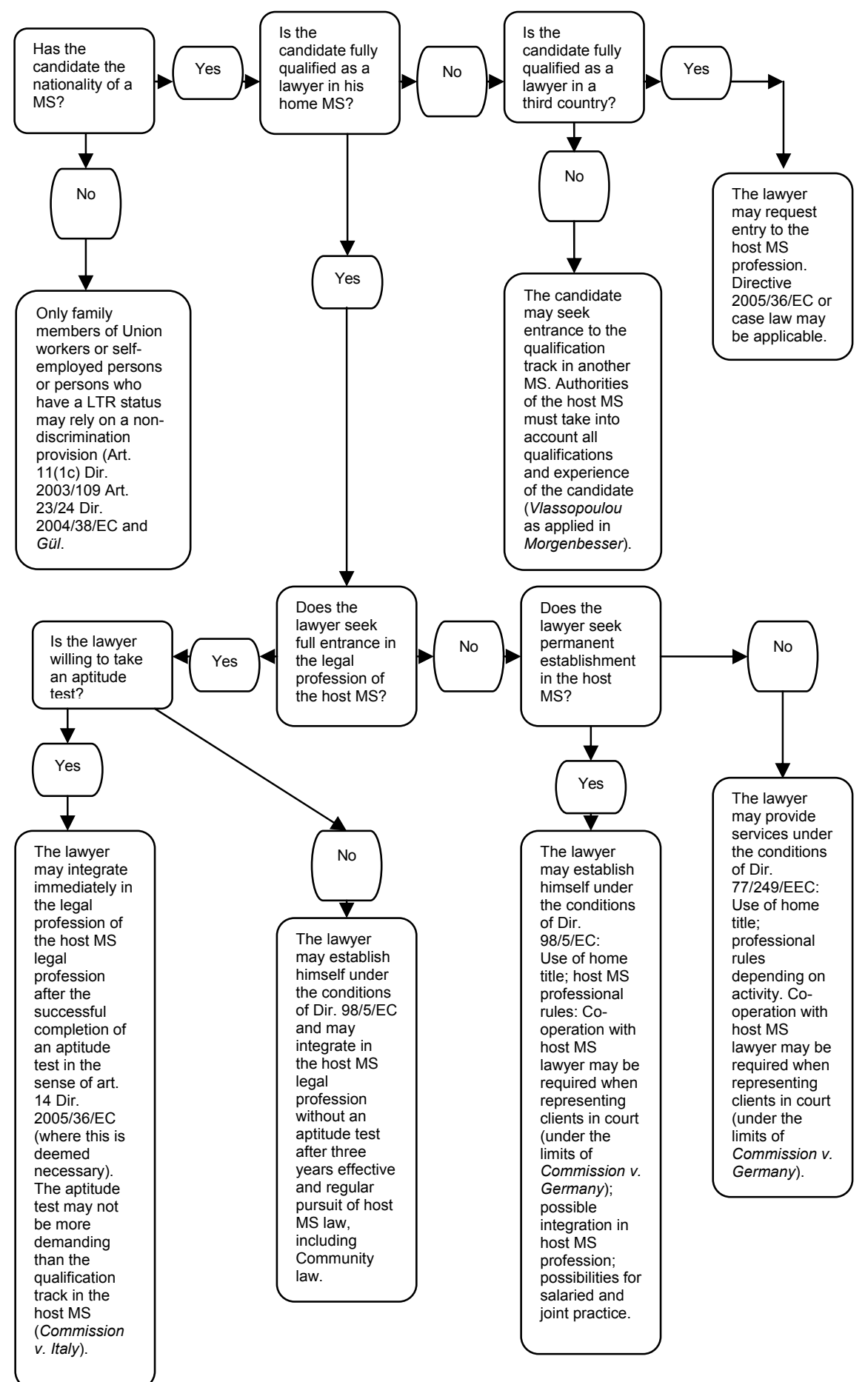




\section{Chapter 3}

\section{Applying the Model: Free Movement of Lawyers in Practice}

\section{\1. Introduction}

In the previous chapter a model for the free movement of lawyers was created based on the different rules laid down in the applicable secondary legislation and the case law of the European Court of Justice. Inevitably, this model is created based on a top-down approach, i.e., a model based on how the rules should be, according to the Institutions of the European Union. Stopping at this stage would mean, however, that one cannot give an overview of the reality of the free movement of lawyers in Europe, but merely give an overview of how the free movement of lawyers ought to look. It is therefore necessary to descend to the level of the Member States and look at the actual application and implementation of the rules on the free movement of lawyers.

This review of the application and implementation will take shape in this chapter. In order to properly review the application and implementation of the model described above, it is necessary to create a reliable image of the legal profession in the different Member States. In the first chapter it was already described that due to the differences in the historical backgrounds, the level of regulation, and indeed the characteristics of the different legal professions, there are differences in these professions from Member State to Member State. This makes it not only difficult to compare the application of the different rules in the different Member States, but it will be shown that it can have a detrimental effect on the application of the model to certain categories of persons that exercise professional activities which are generally associated with the legal professions. In order to paint a reliable picture of the application and the implementation of the model described above, this study will review fifteen out of the 27 Member States of the European Union, namely the fifteen pre2004 Member States. Firstly, these States have been chosen on account of their involvement in the adoption of Directive 98/5/EC, which will play a large role in this chapter. Secondly, the information necessary for this exercise was more readily available, and the language barrier was surmountable. Moreover, I believe that, based on the results presented in this chapter, an analysis that included the remaining Member States would not generate a different result.

In order to provide a clear picture on the application and implementation of the rules on the free movement of lawyers, the chapter will start with a description of the legal professions in the selected Member States, classifying them into different clusters of States that have similar rules. Following this, the author will provide an overview of the problems concerning the free movement of services, that will also take into account the new Directive on the provision of services. The next part will give an overview of the implementation of Directive 98/5/EC in the selected Member States, after which the implications of the new Diploma Directive will be 
reviewed. The chapter also includes a general review of the application and implementation of the rules applicable to third-country nationals, including the influence of WTO rules, or more specifically GATS rules on these persons.

\section{$\int 2$. The Legal Professions in the Member States}

As will be shown in the remainder of this chapter, one of the most important factors in assessing the application and implementation of the rules of free movement of lawyers is the level of regulation that is imposed on the profession of the lawyer in the different Member States. Therefore, this paragraph will give an overview of the legal professions in the different Member States. In this paragraph it will be researched how one can qualify domestically for the legal profession concerned. In addition, a general characterisation of the legal profession will be given that will focus on the degree of regulation. The order in which the countries are presented in this paragraph is based on the level of regulation that the Member States impose on the exercise of legal professional activities, or put differently, the size of the legal monopoly that lawyers in the Member State concerned enjoy. In addition to this, Member States will be presented in clusters of countries having similar characteristics. The overview starts with the countries that have a low degree of regulation, namely Sweden and Finland. For reasons of proximity Denmark is also included in this overview, although Denmark has a higher degree of regulation than Sweden and Finland. Subsequently, the Member States with a higher, or intermediate, degree of regulation will be analysed. These countries are presented in two clusters, namely the two Member States with a common law background, the United Kingdom and Ireland in one cluster, and the Netherlands, Belgium and Luxembourg in a second cluster. Luxembourg is included in this cluster since all three Benelux countries have, albeit for other reasons, an atypical approach to the legal profession. Therefore, they are dealt with together, although based purely on the degree of regulation Luxembourg would belong to the next group. After that, the Member States with a high degree of regulation will be reviewed. These countries are once again dealt with in two separate clusters. Firstly, the Member States that follow the French model of regulation; France, Italy, Spain and Portugal, and secondly the States that follow the German model of regulation; Germany, Austria and Greece. At the end of the paragraph some observations will be made.

\section{\2.1 The Legal Profession in Scandinavian and Nordic Countries}

Due to their closely intertwined history, the Scandinavian and Nordic countries included in this review are dealt with in one paragraph. Based on their approach towards the regulation of the legal profession this is only partly justified. It will be shown that Sweden and Finland have a very relaxed attitude towards the legal profession and the exercise of legal activity, whereas Denmark has a much more strict approach. However, since it was problematic to put Denmark in any of the other clusters the Danish legal profession will be dealt with in this cluster. 


\section{Qualification as an Advokat/Asianajaja}

\section{Sweden}

In Sweden there is one legal profession which is called advokat. The profession is regulated in the Rättegångsbalken, which is the Swedish Code of Judicial Procedure. The requirements for becoming an advokat are laid down in Chapter 8 of the Rättegangsbalken and are further elaborated in $\$ 3$ and $\$ 4$ of the Charter of the Sveriges Advokatsmfundet. ${ }^{1}$ Section 2 of Chapter 8 lists the criteria required for becoming an advokat in Sweden. First of all, a prospective advokat must be a citizen of Sweden, a Member State of the European Union or a Member State of the European Economic Area. ${ }^{2}$ The same section states that where there is a lack of European Union citizenship, legal residence in one of these territories will be deemed sufficient to enter into the Swedish legal profession. ${ }^{3}$ In addition to the citizenship and residence requirements, Section 2 of Chapter 8 of the Rättegångsbalken requires prospective advokats to pass the proficiency tests prescribed for judicial service. ${ }^{4}$ A prospective Swedish advokat must qualify to work as a judge or as another member of the judicial services before he or she is eligible to work as an advokat in Sweden. The Swedish proficiency tests prescribed for the judicial service are deemed to be fulfilled when the prospective advokat has obtained his jur. Kand. (equivalent to an LL.B.) from a Swedish university. The university education should be followed by a period of practical and theoretical training that is required for working as an advocate. ${ }^{5}$

This requirement is detailed further in paragraph 3(4) of the Stadgar för Sveriges Advokatsamfundet. ${ }^{6}$ The paragraph states that the training mentioned in the Rättegangsbalken shall consist of at least five years of training in the practice of law, three years of which must be performed as an assistant to an advokat or as an employee of a legal aid office. In addition to that experience the prospective advokat must also take preparatory courses in the ethics and professional techniques of an advokat. ${ }^{7}$ Further requirements are that the prospective advokat needs to gain a reputation for integrity and that he is otherwise considered suitable to practise as an advokat. ${ }^{8}$ According to the Charter of the Advokatsamfundet, this last requirement has specifically to do with the financial situation of the prospective advokat and shall not be fulfilled if the prospective advokat is declared bankrupt or is under trusteeship. ${ }^{9}$ Other incompatibilities include being a legally qualified judge, a court official, a public prosecutor or an enforcement officer. In addition, people employed by the State or a municipality or who are employed by another individual who is not a lawyer may not be admitted to the Bar. ${ }^{10}$ The last incompatibility can be waived by the Advokatsamfundet and does not apply for people who work in a public advocates office. ${ }^{11} 12$

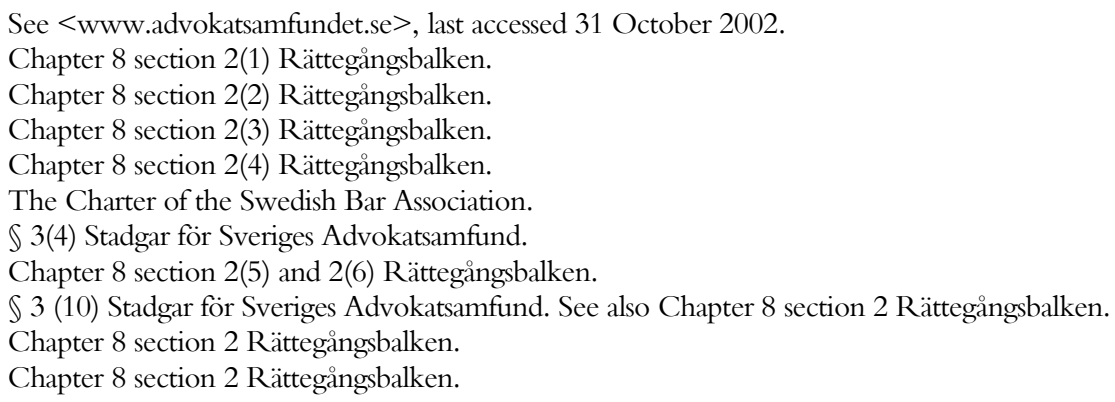


In addition to these requirements prospective advokats will have to take an examination. In May 2001, the Advokatsamfundet decided to introduce a Bar examination. ${ }^{13}$ The Advokatsamfundet laid down the rules of this examination, which has been enforced since 1 January $2004 .{ }^{14}$ As of 2006, there were 4415 lawyers in Sweden. ${ }^{15}$

\section{Finland}

The single legal profession in Finland, that of advokat or asianajaja, ${ }^{16}$ is very similar to the legal profession of its neighbour Sweden. ${ }^{17}$ The profession of advokat or asianajaja is regulated in the Lag om advokater or the Laki Asianajajista, ${ }^{18}$ which also states that there shall be an advokatforbundet or asianajajaliito. ${ }^{19}$ The Advocates Act, together with the by-laws of the Finnish Bar Association lay down the rules regarding entry into the legal profession in Finland. Section 3(1) of the Advocates Act regulates the access of a prospective advokat or asianajaja into the regulated profession in Finland. The section states that anyone who is a national of either Finland or a Member State of the European Economic Area ${ }^{20}$ and who has reached the age of 25 years may be accepted as an advokat or asianajaja when he fulfils the additional criteria. ${ }^{21}$ These additional criteria are threefold. First of all a prospective advokat or asianajaja must be known to be honest and to have characteristics and a way of life that is suitable for an advokat or asianajaja. Second, a candidate must have passed the academic requirements - a masters degree (LL.M.) in $1 \mathrm{law}^{22}$ - that entitles him to hold a judicial office in Finland. He must also have acquired the skills required for practice as an advokat or asianajaja, ${ }^{23}$ and to have acquired the practical experience stipulated in the by-laws of the Finnish Bar Association. ${ }^{24}$ Lastly, the prospective advokat or asianajaja may not be bankrupt, or his legal capacity may not be compromised in any other way. ${ }^{25}$ In addition to these requirements, the Advocates Act

12 These public advocates offices are active in legal aid schemes, see $\$ 3(12)$ Stadgar för Sveriges Advokatsamfund.

13 Sveriges Advokatsamfund inför Advokatexamen in: <www.advokatsamfundet.se>, last accessed 31 October 2002.

14 Regler om obligatorisk advokatexamen för inträde I Sveriges advokatsamfund, see <www. advokatsamfundet.se >, last accessed 20 November 2006.

15 <www.ccbe.org>, last accessed 11 June 2007.

16 There are two official languages in Finland, both Swedish and Finnish.

17 Adamson (1998), p. 14.

18 Advocates Act.

19 Bar Association.

20 This part of the Advocates Act was created in 1993, at a time when Finland was not yet a Member State of the EU.

21 Section 3(1) Advocates Act.

22 See Advocates, <www.advonet.fi>, last accessed 10 December 2002.

23 According to the website of the Finnish Bar Association, this also includes a Bar examination. See Advocates, <www.advonet.fi>, last accessed 10 December 2002. See also section 4 a of the by-laws of the Finnish Bar Association (Helsinki 24 April 1959/191, last amended 2000/671).

24 According to Section 4 of the by-laws of the Finnish Bar Association (Helsinki 24 April 1959/ 191, last amended 2000/671) states that this professional experience consist of practice for at least four years in the field of judicial administration or comparable duties requiring legal education, but in any case for at least two years as an advocate's assistant or public legal counsellor or independent legal practitioner or in other tasks handling a comparable amount of matters of advocacy. 
lays down some additional criteria with respect to the access to the regulated legal profession in Finland. A person who holds a State or municipal office or who is in other services based on an employment relation in the public sector cannot be an advokat or asianajaja. ${ }^{26}$ Additionally, anybody who is engaged in a gainful employment in a manner that is presumed to be detrimental to his independence as an advokat or asianajaja is not allowed to access the legal profession. ${ }^{27}$

\section{Denmark}

In Denmark there is a single legal profession of advokat that has been regulated since $1638 .{ }^{28}$ Since $1919,{ }^{29}$ the profession of advokat is regulated in the Lov om rettens pleje (Retsplejenloven). ${ }^{30}$ This law also lays down that the profession of advokat shall be governed by an association called the Advokatsamfundet. ${ }^{31} 32$ The entry into the profession of advokat is regulated in Chapter 12 of the Retsplejenloven. Paragraph 119 section 1 states that the Minister of Justice grants candidates a licence that gives them the status of advokat. The second section of the paragraph lists the criteria required for this licence. ${ }^{33}$ First of all, the section states that the candidate must be of full age and that he must not have been placed under legal guardianship. ${ }^{34}$ Second, a candidate may not be under a bankruptcy regime and he may not have filed a notice suspending payments. ${ }^{35}$ Third, the candidate must have obtained a law degree ${ }^{36}$ from either the University of Copenhagen or the University of Aarhus. ${ }^{37}$ The last requirement that needs to be fulfilled is that the candidate must have worked in the legal profession for at least three years. ${ }^{38}$ The rules pertaining to this training period of three years are laid down further in sections 3 to 5 of Paragraph 119. In general, it can be said that the training period must involve the normal activities of a lawyer, and it can be exercised as a clerk of an advokat, as an employee of the courts, the prosecution, or the police. ${ }^{39}$ Two out of the three years may be completed with other professions, subject to individual scrutiny of the Minister of Justice. ${ }^{40}$ Lastly the Minister of Justice can grant a licence to anyone who has a comparable level of training to those lawyers who have fulfilled the three-years training (for example, academic staff of a university).$^{41}$ Denmark was one of the few countries where one could become a lawyer after training alone, i.e. without having to sit a Bar examination after the vocational training. This situation, however, has changed. In section 6 of

\footnotetext{
26 Unless the Finnish Bar Association grants a waiver. Section 3(3) Advocate Act.

27 Section 3(3) Advocate Act.

28 Torbøl \& Worsøe (1993), p. 101.

29 Torbøl \& Worsøe (1993), p. 102. See also: Henssler \& Prütting (s.d.) A and M. Kilian (1999) A, pp. 29-30.

Administration of Justice Act.

Society of Advocates.

SS 143-145a Retsplejenloven.

$\int 119$ (1) and (2) Retsplejenloven.

\} 1 1 9 \text { (2) Retsplejenloven: 'er myndig og ikke er under vaergemål...'. }

$\int 119$ (2) Retsplejenloven: 'ikke har anmeldt betalingsstandning og ikke er under konkurs'.

\} 1 1 9 \text { (2) Retsplejenloven: 'har bestået juridisk kandidateksamen...'. }

Torbøl \& Worsøe (1993), p. 105.

$\int 119$ (2) Retsplejenloven: 'I mindst 3 år har vaeret I praktisk juridisk virksomhed jf. Stk. 3-5'.

$\int 119$ (3) Retsplejenloven. See also: Torbøl \& Worsøe (1993), p. 105.

$\int 119$ (4) Retsplejenloven. See also: Torbøl \& Worsøe (1993), p. 105.

S 119 (5) Retsplejenloven. See also: Torbøl \& Worsøe (1993), p. 105.
} 
Paragraph 119 it is now laid down that candidates must also pass a Bar examination. The details of this examination are presented in a ministerial directive. ${ }^{42}$

In addition to these requirements, there are some additional requirements laid down in Paragraph 121 of the Retsplejenloven. ${ }^{43}$ First of all, the Minister of Justice can refuse to issue a licence to a person who fulfils the criteria of Paragraph 119 when this person has been convicted of a criminal offence and where there is a direct risk of abuse of access to the profession of the lawyer. The Minister may also refuse the licence where the nature of the offence committed denies the person concerned the respect and trust that is necessary for the exercise of the profession of the lawyer. ${ }^{44}$ A licence to practise can also be denied to a person who has shown conduct in the past that would lead the Minister to believe that he or she would practise law in an irresponsible manner. ${ }^{45}$ Lastly, the Minister of Justice can deny a practice licence to those persons who have a debt to the State of more than 50,000 krone. ${ }^{46,47}$ Decisions of the Minister of Justice to deny a practice licence can be challenged before the landsretten. ${ }^{48}$ An advokat is allowed to start his own practice only when he has worked for another lawyer for at least a year. ${ }^{49}$

\section{Professional Profile of an Advokat/Asanajaja}

\section{Sweden}

In Sweden the only protection that the Rättegangsbalken offers for advokats is the regulation of the professional title use. Aside from that, Sweden does not recognise any monopoly with regard to activities for advokats. ${ }^{50}$ Anybody who is not found unfit by a court to do so may give legal advice or represent a client in court. ${ }^{51}$ This means that fulfilling the formal requirements to become a lawyer is more a choice than a necessity. In other Member States the qualification as a lawyer is a necessary requirement in order to be active in the field of legal advice and to represent clients in court. In Sweden, this necessity does not exist. Therefore, the choice to become a lawyer in Sweden is much more to do with an assurance of quality. With the decision to become part of a regulated profession, one chooses to be bound by a set of rules that one has to follow. What is peculiar in this sense is that the profession is regulated by law, whereas professions which do not exercise a legal monopoly are more often regulated by the members of the profession themselves. ${ }^{52}$ With regard to the exercise of the activities it may be said that, apart from the incompatibilities

\footnotetext{
42 Bekendtgørelse om obligatorisk efteruddansele som betingelse for at få beskikkelse som advokat. Bekendtgørelse nr. 1129 af 13 december 1996.

$43 \int 121$ Retsplejenloven.

$44 \int 121$ (1) Retsplejenloven. See also: Torbøl \& Worsøe (1993), p. 106.

$45 \int 121$ (2) Retsplejenloven. See also: Torbøl \& Worsøe (1993), p. 106.

46 To the equivalent of a little over $€ 6500$.

$47 \int 121$ (3) Retsplejenloven.

$48 \int 121$ (4) Retsplejenloven.

$49 \int 123$ Retsplejenloven.

50 Killian (s.d.) A.

51 Letter of the Sveriges Advokatsamfund to the author, dated 23 May 2000.

52 With regard to the application of Directive $98 / 5 / \mathrm{EC}$ it must be mentioned that only lawyers from Sweden who are allowed to use the title advokat are entitled to the benefits of the Directive. For an example with regard to Finland (which has similar rules), see Hickman (2004).
} 
mentioned in the previous paragraph, the only limitation lies in the fact that Swedish rules on advertising, joint practice and multi-disciplinary partnerships are very strict. The Swedish Code of Conduct for lawyers states that they may in no way advertise to procure clients or hire someone to do so on their behalf. ${ }^{53}$ With regard to joint practice and multidisciplinary partnerships, the Rättegangsbalken states that a lawyer may only collaborate or be employed with another lawyer, but other forms of joint practice and multidisciplinary partnerships are not open for a Swedish advokat. ${ }^{54}$ In Sweden there are approximately 4400 lawyers in a population of 9 million. ${ }^{55}$

\section{Finland}

Similar to Sweden there is no legal monopoly on the activities of lawyers in Finland. Therefore, there are very few rules concerned with professional activity included in the Advocates Act. Comparably to Sweden, the choice to become an advokat or asianajaja in Finland has nothing to do with gaining access to a certain type of professional activity. ${ }^{56}$ This activity can also be exercised without becoming a member of the regulated profession. The choice of regulated profession is more largely concerned with guaranteeing a certain quality to prospective clients. ${ }^{57}$ In connection with professional activities, Section 5 of the Advocates Act states that an advokat or asianajaja shall honestly and conscientiously fulfil the tasks entrusted to him and adhere to the proper practice of an advocate in all his activities. ${ }^{58}$ This rather cryptic sentence is accompanied by an elaborate Code of Conduct, which was drawn up by the Finnish Bar Association. ${ }^{59}$ In addition to this very general rule on professional activities, Section 5 of the Advocates Act lays down a number of more specified rules connected to professional activities. It designates a prohibition for advokats or asianajajas to work together with any person who is not a lawyer, unless the Finnish Bar Association grants a waiver. ${ }^{60}$ An advocate is also obliged to keep his funds separated from any funds or assets of his clients. ${ }^{61}$ There are separate rules pertaining to the obligation of advokats or asianajajas to serve as counsel or advocates in a court of law. ${ }^{62}$ At this point there are 1750 advokats $^{63}$ in a population of approximately 5.2

53 S 5 5-8 of the Swedish Code of Conduct.

54 Sections 2 and 4 of Chapter 8 Rättegångsbalken.

55 Via <www.ccbe.org>, last accessed 20 November 2006 (see also <www.advokatsamfundet. se>) and <www.cia.gov>, last accessed 20 November 2006. Kilian (s.d.) A mentions a number of 3600 in 2002. That means that a significant growth has taken place in the profession in Sweden.

56 Which leads to the same problems as in Sweden with regard to the application of Directive 98/5/EC. See Hickman (2004).

57 Which could also explain the emphasis that is put on the requirement of general eligibility (e.g., honour and character) for prospective lawyers in the Swedish and Finnish systems.

58 Section 5(1) Advocates Act.

59 Rules of proper professional conduct for advocates (9.6.1972), <www.advonet.fi >, last accessed 10 December 2002.

60 Section 5(2) Advocates Act. The section also contains detailed rules on the legal form of a cooperation between two or more lawyers, which is of little interest to this book.

61 Section 5(4) Advocates Act.

62 Section 5(5) Advocates Act. No further reference is found in the relevant legislation with regard to this rule. The exact meaning of this rule remains uncertain.

63 <www.advonet.fi>, last accessed 20 November 2006; the CCBE mentions a number of 1761. See <www.ccbe.org>, last accessed 11 November 2007. 
million. ${ }^{64}$ Similar to Sweden, this low rate probably provides a distorted view of the exact provision of legal services since any person can provide legal services as a result of the absence of a legal monopoly on the exercise of legal activities.

\section{Denmark}

Of the three professions reviewed in this paragraph, only the legal profession in Denmark has a legal monopoly. The Retsplejenloven mentions nothing about the actual activities that an advokat can pursue and merely states some of the activities that cannot be exercised by an advokat. These activities include being employed at one of the courts, for the prosecution or at the police. ${ }^{65}$ Aside from these incompatibilities, an advokat performs all the tasks that a lawyer normally performs. These tasks include advising clients, providing representation in court and preparing formal documents. ${ }^{66}$ With regard to the provision of advice to clients it can be said that advokats have some type of a monopoly. The 'Pettifogger Act' states that only certain categories of people are allowed to give legal advice. Among these categories are advokats, lawyers from other Member States, accountants, and architects. ${ }^{67}$ Lawyers are not allowed to solicit clients. ${ }^{68}$ Any advokat has the right to represent clients in court. In fact, advokats hold a monopoly on the representation of clients in court. This monopoly is not absolute, since in Denmark a party may, in principle, conduct his own case or let his case be conducted by a close relative or an employee. A court can always impose representation by an advokat in these cases. ${ }^{69}$ The Retsplejenloven lays down extra criteria to represent a client in a higher court. It states that a right to represent a client before a higher court may only be obtained after the advokat concerned has completed two test cases before that court. ${ }^{70}$ For the preparation of formal documents, it must be said that the same rules which were applied to supplying advice, apply here. This means that anyone who may give legal advice can also prepare formal documents. ${ }^{71}$ With regard to practise in associations, it can be said that lawyers may associate amongst themselves, even in the form of a limited liability company, ${ }^{72}$ but it is not allowed for lawyers to take part in any multidisciplinary associations. ${ }^{73}$ At this moment the total number of advokats is approximately $4635^{74}$ in a population of almost 5.5 million, ${ }^{75}$ or one lawyer for every 1186 people.

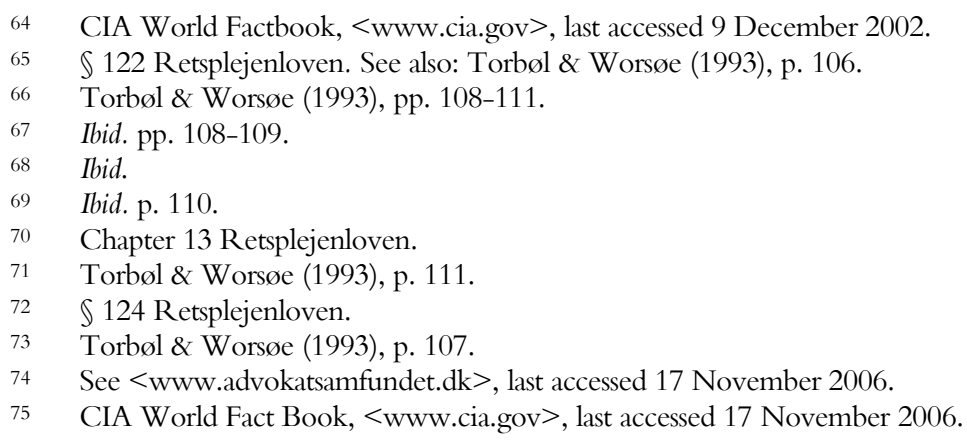




\section{$\mathbb{1}$ 2.2 The Legal Profession in the United Kingdom and Ireland}

There is no such thing as 'the' legal profession of the United Kingdom. First of all the United Kingdom is divided into three different legal systems; England and Wales, Scotland and Northern Ireland. Secondly, the legal profession is shared by two very different professions, namely solicitors and barristers, the latter called advocates in Scotland. ${ }^{76}$ In total there are six different legal professions within the jurisdiction of the United Kingdom. The legal professions in Ireland are also typical common law legal professions that closely resemble the legal professions in the different jurisdictions in the United Kingdom. This resemblance is due to the fact that Ireland was a part of the United Kingdom until 1921. The legal professions in both countries developed along the same lines. The legal profession in Ireland is also divided between solicitors and barristers.

\section{Qualification as a solicitor}

\section{England and Wales}

In order to qualify as a solicitor in England and Wales one does not necessarily need a law degree from a university, although it remains the most common way to enter the qualification process. If the candidate concerned does not have a law degree he must complete a Common Professional Examination. ${ }^{77}$ After that, the prospective solicitor needs vocational training and a period of commonly two years ${ }^{78}$ as a trainee to a fully qualified solicitor. ${ }^{79}$ The first part of the vocational training, the Legal Practice Course, can take either one year of full-time studies, or two years of parttime studies. ${ }^{80}$ The LPC is centralised, i.e., the same for everyone, for law graduates and non-lawyers. ${ }^{81}$ There do not seem to be any hard and fast rules for the traineeship, apart from the fact that any trainee solicitor is obliged to take the Professional Skills Course. ${ }^{82}$ The Law Society is putting effort into regulating the training period, ${ }^{83}$ but as of yet there a no binding standards to which a trainee solicitor is assessed. ${ }^{84}$ After this process, the prospective solicitor can apply to the Law Society for a practice certificate after which he becomes a fully-fledged solicitor.

\footnotetext{
76 Adamson (1998), p. 27

77 Cownie \& Bradney (1996), p. 140. If one does not have a University degree in law one needs to take a Common Professional Examination. See <www.lawsociety.org.uk. $>$, last accessed 30 October 2006.

78 See Law Society (2001) A, p. 3.

79 Cownie \& Bradney (1996), p. 141.

$80<$ www.lawsociety.org.uk>, last accessed 30 October 2006.

81 See Law Society (2001) A, p. 3.

82 Law Society (2001) A, p. 34

83 See Law Society (2001) B; Law Society (2003); Law Society (2005) C; See also: Law Society (2004) and Law Society (2005) B. Moreover a number of consultant's reports have also been written on this subject. These reports are available on <www.lawsociety.org.uk>, last accessed 30 October 2006.

84 Law Society (2005) C.
} 


\section{Scotland}

The profession of the solicitor in Scotland differs from that in England and Wales. In contrast to England and Wales, Scottish solicitors are required to have a university degree, more specifically a degree in Law (LL.B.) from one of the five Scottish universities. ${ }^{85}$ The only way to avoid this requirement is to sit the Law Society Examinations. Before taking this examination as a pre-Diploma trainee prospective students must find employment with a qualified solicitor for a duration of at least three years in which the areas of conveyance, court work and either trusts and executries or the work of a local authority, must be covered ${ }^{86}$ After the academic qualification is completed, all prospective solicitors need to obtain a Diploma in Legal Practice which is awarded after a vocational training of a 26 -week duration. ${ }^{87}$ Following the degree and the diploma, students are required to serve a two-year post-Diploma training contract with a practising solicitor in Scotland ${ }^{88}$ The Scottish Law Society has already adapted its rules for the traineeship. As of 2001, trainees are required to complete logbooks which are monitored by the Law Society. In addition, from 2002, trainees are obliged to follow a two-week Professional Competence Course, and from 2003 the first cohort of prospective Scottish solicitors took the Test of Professional Competence before they were admitted as solicitors to the Law Society of Scotland. ${ }^{89}$

\section{Northern Ireland}

In Northern Ireland the solicitor's profession is open for graduates and non-graduates. It must be noted that those who do not have a law degree must give proof to the Law Society that they have attained a satisfactory level in a number of subjects. ${ }^{90}$ Queen's University Belfast offers a course that covers these subjects. Mature, nongraduate students may provide proof to satisfy the Law Society that they are suitable for the profession. ${ }^{91}$ All prospective students must gain a place at the Institute of Professional Legal Studies, by means of an entrance examination. After that, the student begins his period as an apprentice. Part of that period will be spent in office under a Master, which the student must find himself, while another part will be spent at the Institute for Professional Legal Studies. ${ }^{92}$ Normally the apprenticeship takes two years, but it may exceed four years for those who wish to qualify without a degree. ${ }^{93}$ If the student passes all examinations and has convinced the society that he has received proper training, he can enrol as a solicitor of the Supreme Court of Judicature in Northern Ireland. Once enrolled, the solicitor may apply for a practice certificate. In the first three years of their qualification, solicitors are obliged to

\footnotetext{
$85 \quad$ Law Society of Scotland (s.d.) C.

86 Ibid.

87 Ibid. In October 2000 the Diploma in Legal Practice was revised in order to match the new training regime. See Law Society of Scotland (s.d.) B.

$88 \quad$ Ibid.

89 See Law Society of Scotland (s.d.) B.

90 These subjects are: Constitutional Law, Criminal Law, Land Law, Law of Tort, Equity, Law of Evidence, Law of Contract and European Law. A Law degree must also cover these subjects. See Law Society of Northern Ireland (s.d.), Notes 1 and 2(a).

$91 \quad$ Ibid. Note 3.

$92 \quad$ Ibid. Note on Apprenticeship.

93 Ibid.
} 
work in employment. If they attend the Law Society's Continuing Legal Education programme, the required period of employment is shortened to two years. ${ }^{94}$

\section{Republic of Ireland}

Similar to the solicitor's profession in the United Kingdom there is not one single way to qualify as a solicitor in the Republic of Ireland, and a law degree from a university is not essential. The Solicitors Act governs the entrance to the profession of the solicitor. In good common law tradition, previous versions of laws remain in force, in so far as they had not been changed by later versions. In Ireland, there are four different versions of the Solicitors Act, the basic Act from 1954 and amendments of 1960, 1994 and 2002. ${ }^{95}$ Qualification was laid down in Articles 24 to 45 of the Solicitors Act 1954 but the Solicitors (Amendment) Act 1994 changed the rules considerably. The provisions of the latter law will be dealt with in this paragraph. In order to qualify as a solicitor one needs to fulfil the criteria laid down by Article 40 of the Solicitors (Amendment) Act 1994. Article 40 of that Act states that a person may become a solicitor in Ireland if the following requirements are fulfilled. He must be at least 21 years of age ${ }^{96}$ and be bound by the indentures of apprenticeship for the appropriate term. ${ }^{97}$ Moreover, he must have followed the courses and passed the examinations prescribed, ${ }^{98}$ complied with the prescribed requirements in order to serve under indentures of apprenticeship, ${ }^{99}$ and have satisfied the Society that he is a fit and proper person to be admitted as a solicitor. ${ }^{100}$ If the Society refuses to admit him as a solicitor, the person concerned shall have a legal remedy. ${ }^{101}$

These requirements are elaborated upon in the following articles of the Solicitors (Amendment) Act 1994. Article 41 lays down several requirements for the access to apprenticeship. According to the article, a person can be admitted to the apprenticeship if he has attained the age of seventeen years, ${ }^{102}$ followed the prescribed courses ${ }^{103}$ and passed the necessary examinations. ${ }^{104}$ Furthermore, he must have obtained the written consent of the Society ${ }^{105}$ and fulfilled any other requirement prescribed by the Society for admission to the apprenticeship. ${ }^{106}$ Further requirements with regard to the terms of indentures are laid down in Article 42 of the Solicitors (Amendment) Act 1994. Article 42 states that the term of indentures shall be no longer than two years. ${ }^{107}$ It must be noted that the article implies that law clerks can also be eligible for apprenticeship. A law clerk in the sense of this article is a person who can prove

\footnotetext{
94 Ibid.

95 Solicitors Act 1954; Solicitors (Amendment) Act 1960; Solicitors (Amendment) Act 1994 and Solicitors (Amendment) Act 2002, via <www.irishstatutebook.ie>, last accessed 11 July 2005.

96 Article 40 Section 24(1)(a) Solicitors (Amendment) Act 1994.

97 Article 40 Section 24(1)(b) Solicitors (Amendment) Act 1994.

98 Article 40 Section 24 (1)(c) Solicitors (Amendment) Act 1994.

99 Article 40 Section 24(1)(d) Solicitors (Amendment) Act 1994.

100 Article 40 Section 24(1)(e) Solicitors (Amendment) Act 1994.

101 Article 40 Section 24(2) Solicitors (Amendment) Act 1994.

102 Article 41 Section 25(a) Solicitors (Amendment) Act 1994.

103 Article 41 Section 25(b) Solicitors (Amendment) Act 1994.

104 Article 41 Section 25(c) Solicitors (Amendment) Act 1994.

105 Article 41 Section 25(d) Solicitors (Amendment) Act 1994.

106 Article 41 Section 25(e) Solicitors (Amendment) Act 1994.

107 Article 42 Section 26(1) Solicitors (Amendment) Act 1994.
} 
that he has been a bona fide clerk to a practising solicitor for at least a continuous period of five years, ${ }^{108}$ that he has busied himself with activities that satisfy the Society to be of a sufficiently responsible nature, ${ }^{109}$ and that he has diligently served as such a clerk. ${ }^{110}$ Article 43 concerns the proof that must be given in order to benefit from the rules laid down in the previous articles. ${ }^{111}$

A further important provision in the Solicitors (Amendment) Act is Article 49 which amends the original Section 40. The Article governs the education that a prospective solicitor must have followed in order to qualify for an apprenticeship, and ultimately for the solicitor's profession. Similar to the position in the United Kingdom, a law degree from a university is not a strict requirement for becoming a solicitor in Ireland. Those who are not exempted by means of Articles 50 and 51 (university graduates and barristers, respectively) must pass the Law Society's preliminary examination. ${ }^{112}$ Law clerks can also be exempted from the preliminary examination. ${ }^{113}$ In order to enter into apprenticeship every prospective solicitor must take, and pass, the Final Examination-First Part. ${ }^{114}$ After having passed this examination, the prospective solicitor may enter in apprenticeship but not before he has passed the first Professional Practice Course (PPC I). ${ }^{115}$ During his apprenticeship the prospective solicitor must attend, and pass, the second Professional Practice Course (PPC II). ${ }^{116}$ At the end of the apprenticeship, the prospective solicitor must take and pass the Final Examination-Second Part, after which he can be registered as a solicitor. All these courses and examinations are supervised by the Law Society, based on Article 49 of the Solicitors (Amendment) Act 1994. ${ }^{117}$ Before a person who has obtained all the necessary qualifications may practise as a solicitor, he needs to obtain a practising certificate. ${ }^{118}$

\section{Professional Profile of a Solicitor}

\section{England and Wales}

In England and Wales solicitors can work in private practice (either as a partner or as a salaried solicitor) or as a salaried lawyer in a business or government institution. ${ }^{119}$ As of 31 July 2005 there were 126,145 solicitors on the Roll, of which 100,938 held a practice certificate. ${ }^{120}$ Of practising lawyers, 61.9 per cent are involved in private practice, 18.1 per cent work in areas other than private practice. ${ }^{121}$ According to the CCBE, this number had risen to 135,514 in $2006 .{ }^{122}$ Solicitors are not allowed

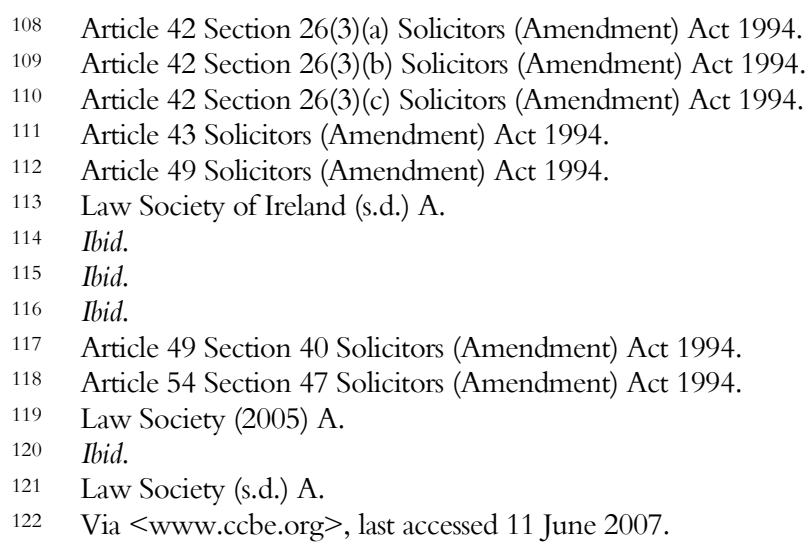


to practise in multi-disciplinary practices. That means that they are not allowed to form a partnership with a member of another profession, ${ }^{123}$ but the rules have been somewhat relaxed over recent years. ${ }^{124}$ There is no statutory monopoly for a solicitor and apart from the preparation of certain documents none of his activities are legally protected, ${ }^{125}$ although a solicitor is the only one who can instruct a barrister. Traditionally, solicitors were barred from representing clients in court, since that activity was reserved for barristers. Historically, the dichotomy between solicitors and barristers, although only on a superficial level, has been rather simple: solicitors deal with clients and provide legal advice, while barristers are instructed by solicitors to present a case in court. This dichotomy was always oversimplified, ${ }^{126}$ but under the Access to Justice Act 1999 it is simply incorrect. Section 36 of the Access to Justice Act 1999, which reformed the Courts and Legal Services Act 1990, gave solicitors the right to appear in all courts, albeit after additional training. According to the Lord Chancellor: 'All barristers and solicitors, including those in employment, should obtain full statutory rights on admission or call to the Bar or on admission to the Roll of Solicitors. ${ }^{127}$ This means that in effect the distinction between the two professions is merely one of form, and no longer one of substance, at least not where the solicitor is concerned.

\section{Scotland}

For Scotland it can be said that Scottish solicitors perform the same tasks as English and Welsh solicitors. It is possible for solicitors to appear in Court when they are qualified as solicitor-advocates. ${ }^{128}$ Similar to England and Wales there is no statutory monopoly for Scottish solicitors, although there is some protection for the preparation of documents. ${ }^{129}$ As of 2007 there were around 10,000 solicitors in Scotland. ${ }^{130}$

\section{Northern Ireland}

The work that solicitors do in Northern Ireland is similar to the work performed by their English counterparts, although in Northern Ireland materials there is no reference to the Access to Justice Act of 1999. This does not mean, however, that solicitors do not have audience rights. Solicitors in Northern Ireland have audience rights in certain lower courts, comparable to those in England and Wales. ${ }^{131}$ As of 2007, there were 1850 solicitors with a licence in Northern Ireland. ${ }^{132}$

\footnotetext{
123 Bailey \& Gunn (1996), p. 138.

124 Ibid., p. 139.

125 Lawrenson (1993), p. 325.

126 See Bailey \& Gunn (1996), p. 133

127 Law Society (s.d.) B. See also: Lord High Chancellor (1998), paragraph 2.27, page 19.

128 The existence of 'solicitor-advocates' is hinted at in: Law Society of Scotland (s.d.) A, pp. 20-22. Solicitors can become solicitor-advocates by means of Section 25A of the Solicitors (Scotland) Act 1980, and not, as in England and Wales, by means of the Access to Justice Act 1999.

129 Secretariat of the Law Society of Scotland (1993), p. 350.

$130<$ www.lawscot.org.uk/about/scots_law/>, last accessed 18 October 2007.

131 Doherty (1993), p. 358.

132 See <www.lawsoc-ni.org/council.htm>, last accessed 25 October 2007.
} 


\section{Republic of Ireland}

In the Republic of Ireland, comparable to the situation in England and Wales, the traditional division between the two professions has been blurred by the fact that solicitors in Ireland have gained a general right of audience, ${ }^{133}$ without barristers gaining any territory on the traditional turf of the solicitor. As in the United Kingdom, this imposes pressure on the barrister's profession. With complete audience rights for solicitors, both solicitors and barristers share the same legal monopoly, namely the representation of clients in court. ${ }^{134}$ Although both solicitors and barristers (via solicitors) have an important role with regard to giving legal advice, this advisory function does not seem to be part of the legal monopoly of solicitors and barristers. In addition to the audience rights in court, solicitors (and barristers) ${ }^{135}$ also enjoy monopoly rights for the preparation of documents in relation to real property. ${ }^{136}$ As of 2007, there were about 10,000 practising solicitors in Ireland. ${ }^{137}$

\section{Qualification as a Barrister}

\section{England and Wales}

In England and Wales barristers are obliged to have a degree, although it is not essential to have a degree in law. Graduates who do not have a law degree have to take the one-year 'Common Professional Examination' in order to cover the required legal subjects. ${ }^{138}$ After the academic stage, but before the prospective barrister starts his vocational training, he or she must join one of the four Inns of Court. ${ }^{139}$ The objective of the vocational training is to complete the 'Bar Vocational Course', a highly competitive course that is only available to a limited number of people. ${ }^{140}$ After the vocational training, the prospective barrister proceeds to a one-year pupillage, a training period that can be compared with the traineeship for solicitors. ${ }^{141}$ During the pupillage, a prospective barrister is required to learn how to practise on his own, and more importantly, to establish contacts with solicitors who have to instruct him. In addition, he must follow mandatory courses on advocacy and management. The barrister can then gain a place in chambers, set up a practice of his own or be employed by institutions like the armed forces or the Government. It must be made clear that working in chambers is not the same as practising in partnership, since that is forbidden for barristers. The chamber must be seen as a facilitating entity that supports a number of individually practising barristers. ${ }^{142}$

\footnotetext{
133 Hartnett (1993), p. 187.

134 Ibid., p. 186. It must be noted that nothing precludes a person to defend his or her own case before a court.

135 Ibid., p. 187

136 Section 53 Solicitors Act 1954.

137 See <www.lawsociety.ie/Annual\%20Reports/ar06.pdf>, last accessed 25 October 2007.

138 Slapper \& Kelly (1997), p. 333; Lonbay (s.d.) B and Bar Council (1998), p. 5.

139 Bar Council (1998), p. 5.

$140 \quad$ Ibid., p. 7.

141 Ibid., p. 9.

142 Bailey \& Gunn (1996), pp. 153-154.
} 


\section{Scotland}

In Scotland, there is no barrister's profession, but rather a profession of the advocate. In order to become an advocate the prospective student needs to follow a rather complicated route comprised of four stages. ${ }^{143}$ The first stage involves the student's admittance as an Intrant to the Faculty of Advocates, this is called the Matriculation process. Only those who have a degree in Scottish law shall be admitted as Intrants, when they have the correct references and present a petition to the Court. ${ }^{144} \mathrm{~A}$ fee must also be paid. It seems that this process resembles, at least in function, the 'call to the Bar' in England, Wales and Northern Ireland, which involves joining one of the Inns of Court. The second stage is the completion of the educational demands of the Faculty. This involves passing the Law examinations of the Faculty and completing the Diploma in Legal Practice at a Scottish university. ${ }^{145}$ The third stage involves professional training. The training consists, first, of a period of training in a solicitor's office for 21 months, second, a period of nine and a half months serving as a pupil to a member of the Bar, approved by the Dean of the Bar (called devilling, pupils are called devils), and third, passing the Faculty examinations in evidence, practice and procedure. During the training in the solicitor's office the trainee is paid an appropriate salary, while during devilling the Intrant is paid nothing and must abstain from activities that are deemed 'inappropriate' by the Dean. ${ }^{146}$ The fourth stage involves being accepted as an advocate after completion of the first three requirements. ${ }^{147}$

\section{Northern Ireland}

In Northern Ireland, similar to England and Wales, the starting years as a practising barrister are full of financial insecurity and hardship. ${ }^{148}$ In order to qualify as a barrister, students must hold a recognised law degree and must be admitted to the Institute of Professional Legal Studies in Northern Ireland in order to gain their Certificate in Professional Legal Studies, which is awarded after a one-year postgraduate vocational training. ${ }^{149}$ Before prospective barristers commence their vocational training they have to spend four weeks working in a Citizens Advice Bureau or Law Centre and a week work-shadowing a practising solicitor. After the vocational training they have to undergo a twelve-month pupillage, in which they can only accept work on their own account in the second six months of their pupillage. ${ }^{150} \mathrm{~A}$ prospective barrister must be a member of the Inns of Court as well. ${ }^{151}$ After all the requirements are met, the student will be awarded the title of Barrister-at-Law.

\footnotetext{
143 Faculty of Advocates (s.d.), p. 7.

144 An advocate must carry the seven lamps of advocacy; honesty, courage, industry, wit, eloquence, judgement and fellowship. See Faculty of Advocates (s.d.), p. 4.

145 Faculty of Advocates (s.d.), p. 7.

146 Ibid., pp. 7-8.

147 Ibid., p. 8.

148 Institute of Professional Legal Studies (s.d).

149 Ibid.; See also: Bar Council (s.d.) B.

150 Institute of Professional Legal Studies (s.d.).

151 Bar Council \& Bar Library of Northern Ireland (s.d.) B.
} 


\section{Republic of Ireland}

In the Republic of Ireland, the barrister's profession is governed by common law, unlike the profession of the solicitor which is governed by statute. ${ }^{152}$ Similar to the profession of the solicitor, however, it is not strictly necessary for a barrister to have a university degree in law. Qualifying as a barrister is comprised of three different stages. ${ }^{153}$ The first stage is the academic stage, which is fulfilled by either completing a law degree, accepted by the King's Inn or by the King's Inn Diploma in Legal Studies obtained after a two-year part-time course. ${ }^{154}$ After completing the academic stage, the prospective barrister can enter the vocational stage of the qualification process after passing an entry examination. The vocational stage consists of a year-long degree course that ultimately leads to the degree of Barrister-at-Law at the King's Inn. After the prospective barrister has passed the exams that lead to the degree, he or she is then called to the Bar. ${ }^{155}$ The call to the Bar is where the barrister registers with the Law Library and it certainly does not mean that the qualification process has ended. Before a barrister is allowed to practise on his own, he is obliged to spend a year as a pupil under a practising barrister, the so-called 'divelling'. The divelling period also involves following a course, and following guidance of the Master (who must be Dublin-based). The divelling is unpaid. ${ }^{156}$ After the year of divelling is complete, the barrister may start a practice of his own, albeit within the Law Library where all barristers of the Republic of Ireland are seated.

\section{Professional Profile of a Barrister/Advocate}

\section{England and Wales}

In England and Wales the barrister was originally the lawyer who appeared as advocate in court, although as we have seen above this does not hold true anymore after the introduction of the Access to Justice Act 1999. The number of barristers in practice is considerably lower than the number of solicitors. In 2006, there were 12,034 practising barristers. ${ }^{157}$ Other than these shared audience rights, the barrister has no legal monopoly on other legal activities.

\section{Scotland}

With regard to the activities of an advocate in Scotland, it can be stated that these do not differ from those of the barristers in England, Wales and Northern Ireland. The primary duty of an advocate is to present cases in court. Similar to England and Wales, this traditional monopoly must be shared with other professions, such as the profession of the solicitor. In addition to that, advocates can also be employed in different branches of government. ${ }^{158}$ Similarly to England, Wales and Northern Ireland, the harsh qualification process, which seems even harder than the qualification of barristers in England and Wales, does not automatically lead to the certainty of a

152 Hartnett (1993), p. 175.

153 The Bar Council (s.d.) A. See also the helpful scheme on <www.kingsinn.ie>, under 'education' and 'prospective students', last accessed 22 August 2005.

154 Ibid.

155 Ibid.

156 Ibid.

157 Via <www.barcouncil.org.uk>, last accessed 11 June 2007.

158 Faculty of Advocates (s.d.), p. 4. 
considerable income. Akin to England and Wales, advocates work in so-called 'stables' where they share the office infrastructure and resources but they are still self-employed and therefore completely dependent on their own income. ${ }^{159}$ In 2006, there were 758 advocates in Scotland. ${ }^{160}$

\section{Northern Ireland}

The barrister's profession in Northern Ireland is similar to the profession of the barrister in England and Wales. The primary task of the 580 barristers ${ }^{161}$ is similar to their English counterparts. Their main task is to give legal advice (although there is no legal monopoly on legal advice) and to litigate. In principle, this occurs through instructions via the solicitors, but in recent years it has been possible for a number of professional bodies to gain direct access to a barrister. ${ }^{162}$

\section{Republic of Ireland}

In the Republic of Ireland the situation is quite similar. Traditionally, barristers had a legal monopoly of representing clients in court but now this right must be shared with the solicitors in Ireland. ${ }^{163}$ There are no further monopolies for barristers in Ireland. In 2005 (the most recent figure available) there were 1539 barristers. ${ }^{164}$

\section{\2.3 The Legal Profession in the Benelux}

The next three countries in this review have less in common with each other than the countries described in the previous subparagraphs. In fact the only resemblance between the three countries is that they are more or less exceptions to the other categories. The Netherlands is an exception since the organisation of the legal profession leans towards the common law and Scandinavian/Nordic traditions that were observed above, although it remains based in the civil law tradition. Belgium and Luxembourg are both solidly founded in the civil law tradition but have different attitudes towards the legal profession due to the activity of the European Institutions in those jurisdictions.

\section{Qualification as an Advocaat/Avocat}

\section{The Netherlands}

In the Netherlands, just as in any other legal system that is founded in civil law, there are a number of protected legal and quasi-legal professions. ${ }^{165}$ The most important of those, and the subject of this paragraph, is the profession of the advocaat, which is in essence the profession of the lawyer. In addition to the profession of the advocaat

\footnotetext{
159 See <www.advocates.org.uk>, last accessed 19 November 2001.

160 Via <www.ccbe.org>, last accessed 11 June 2007.

161 As of October 2006, see The Bar Council \& Bar Library of Northern Ireland (s.d.) D. 586, according to the CCBE see <www.ccbe.org>, last accessed 11 June 2007.

162 The Bar Council \& Bar Library of Northern Ireland (s.d.) A.

163 Hartnett (1993), p. 186. It must be noted that nothing precludes a person from defending his or her own case before a court.

164 See <www.barcouncil.ie>, last accessed 25 October 2007.

165 See Hoegen Dijkhoef (1993), pp. 225-229.
} 
there are also the professions of procureur, ${ }^{166}$ who assist advocaten from other constituencies, notarissen (notaries) who deal with the preparation and validation of official documents and deurwaarders (bailiffs) who function as process-servers. In addition to these regulated professions, there are a number of legal and quasi-legal professions that are not legally protected. These are the professions of the belastingadviseur (tax adviser), rechtskundig adviseur (legal advisor), and octrooigemachtigde (patent lawyer). Different from other legal professions that have their origin in civil law, the Dutch legal profession is highly centralised. ${ }^{167}$ Since 1952 there has been a centralised body called the Nederlandse Orde van Advocaten (hereinafter the Orde) that is placed above the nineteen Bar Associations that govern the legal profession in each of the nineteen legal constituencies in the Netherlands. ${ }^{168}$ The rules that govern the legal profession are laid down in a separate law, namely the Advocatenwet. ${ }^{169}$

The requirements for becoming an advocaat are laid down in the Advocatenwet and are elaborated upon in several regulations of the Orde. Article 2 of the Advocatenwet lays down the basic requirements for becoming an advocaat. The Article states that the profession of the advocaat is accessible for those who have acquired a degree of Doctor or Master in Law. A university education can lead to this degree if the education consists of, among other things, examinations in private law (including procedural law), criminal law (including procedural law), and one of the following courses; constitutional law, administrative law (including procedural law) or tax law. ${ }^{170}$ Of all the countries reviewed, the Netherlands is the only country that lays down the minimal contents of a degree leading to the title of doctor or master in law (Germany has a similar system). ${ }^{171}$ If a candidate fulfils this criterion and can produce a certificate of correct behaviour, ${ }^{172}$ he will be sworn in by a judge of the district court of the legal constituency where he holds office. ${ }^{173}$ When a lawyer is sworn in as an advocaat he is still not a fully-fledged advocaat in the sense of being able to start his own practice. Therefore, membership to the Bar could be seen as probationary at this stage. In order to be able to start his own practice, an advocaat has to complete three years of vocational training under the guidance of an experienced advocaat, called his patroon. ${ }^{174}$ During this training period, an advocaat, then referred to as a

166 Because every advocaat in the Netherlands is, in principle, automatically sworn in as a procureur, this profession is no longer viewed as a separate profession. See Adamson (1998), pp. 22-23. In the light of the implementation of Directive 98/5/EC, however, the distinction between the two professions has led to some serious doubts as to whether the Dutch implementation is in accordance with European Law. Adamson (1998), pp. 22-23.

168 Ibid.

169 Law of 23 June 1952, houdende instelling van de Nederlandse Orde van Advocaten alsmede regelen betreffende orde en discipline voor de advocaten en procureurs (Advocatenwet), last adaptation Stb. 2002, 441.

170 Article 2(1) Advocatenwet.

171 This is the so-called civiel effect. When universities create a new curriculum they have to convince the Orde that it fulfils the requirements of Article 2 of the Advocatenwet before they can grant the title of Master of Law or Doctor of Law to persons who have completed such a curriculum. The discussion about the civiel effect is very relevant at this point in time since Dutch universities are reforming their curricula to fit in the Bachelor-Master system of the Bologna Declaration.

172 Article 2(2) Advocatenwet.

173 Article 3 Advocatenwet.

174 Article 9b Advocatenwet. 
stagiaire, is obliged to work in the office of his patroon. The stagiare assists his patroon in dealing with cases but in the later stages of the three-year period the stagiaire will enjoy an increasing amount of independence from his patroon. Moreover, a stagiaire is obliged to take part in an education programme that is managed by the Orde. ${ }^{175}$ In the course of his education, the stagiaire will be obliged to take nine examinations. ${ }^{176}$ These will mount up to an equivalent of the Bar exam in some of the other Member States. If a stagiaire has passed all these examinations, he will receive a certificate stating that he has passed these examinations and that therefore his probationary membership of the Bar will be transformed into a definitive membership. ${ }^{177}$

\section{Belgium}

The legal professions in Belgium are firmly rooted in the civil law system. In Belgium there are a number of legal professions. Aside from the most important profession of the avocat there are also the professions of notaires (notaries) and hussier (bailiff). ${ }^{178}$ In the past times there was also the avoué but this profession was abolished in 1970 with the implementation of the 1967 Gerechtelijk Wetboek (Judicial Code). ${ }^{179}$ All the monopolies that the avoués had with regard to pleading were transferred to the profession of the avocat. Other than the profession in the Netherlands, which evolved considerably in the last years and now forms some intermediate position between the civil law tradition and the common law/Scandinavian/Nordic tradition, the Belgian profession remains firmly rooted in the civil law tradition. This tradition is reflected in the fact that the profession of the avocat remains a true 'free' profession characterised by a high degree of decentralisation. Nowadays, the Bars for the different legal constituencies in Belgium still have a degree of autonomy and only very recently initiatives were deployed to achieve a degree of centralisation in the profession, which further resulted in the foundation of a central Flemish Bar and a central Walloon bar. The latter also represents the German-speaking Bar of Eupen. In addition there is also a Bar representing the selected number of avocats who appear exclusively before the Cour de Cassation. This leads to 31 Bar Associations; fourteen Walloon Bars (one of them in Brussels), fourteen Flemish Bars (one of them in Brussels); one Walloon Bar Association; one Flemish Bar Association and one more Association in Brussels representing the avocats who have access rights to the Cour de Cassation. ${ }^{180}$ In the past there was also a national order of avocats. ${ }^{181}$ The major part of the autonomy lies with the 28 regional Bars, and not with the central authorities as is the case in the Netherlands.

The road to qualification as an avocat is laid down in Book III of the Gerechtelijk Wetboek (Judicial Code). Article 428 of the Gerechtelijk Wetboek lists the basic requirements for becoming an avocat. First, one must be a Belgian national, or a

\footnotetext{
175 Article 9c Advocatenwet. See also: Stageverordening 1988 via <www.advocatenorde.nl>, last accessed 23 February 2003.

176 See Article 14 of the Stageverordening 1988 and the Examenreglement Beroepsopleiding via <www. advocatenorde.nl>, last accessed 15 February 2003.

177 Article 8(3) Advocatenwet.

178 See Philippe \& Roberts (1993), pp. 69-70. See also: Adamson (1998), p. 12.

179 See Philippe \& Roberts (1993), p. 69.

180 See <www.barreauxdebruxelles.be>, last accessed 27 April 2004.

181 Some of whose regulations are still in force. See <www.advocaat.be >, last accessed 28 April 2004.
} 
national from one of the Member States of the European Union. Furthermore, one must have a licenciaat ${ }^{182}$ or a doctorate in Belgian law, to have taken the oath and be listed on the tableau ${ }^{183}$ or on the list of stagiaires ${ }^{184}$. The licenciaat is a diploma in law that is autonomously awarded by the Belgian universities, and there is no State control to the extent found in the Netherlands. ${ }^{185}$ Persons who have not studied law in Belgium can acquire a licenciaat by equivalence. In this case, a Belgian university will examine the equivalence between a university diploma from another country and the licenciaat. The oath that is mentioned in Article 428 is specified further in Article 429 of the Gerechtelijk Wetboek. That article states that the oath shall be taken in a public session of the Hof van Beroep (Court of Appeal) in the capital of the jurisdiction of the specific bar where the prospective avocat seeks entrance, on recommendation of an avocat who has been on the tableau for more than ten years. The oath must be taken in the presence of the Battônnier (the chair of that respective Bar) and on request of the Openbaar Ministerie (Ministry of Justice). ${ }^{186}$ After the prospective avocat has taken the oath, he is not yet eligible to become an avocat. Before a prospective avocat can be listed on the tableau, he first must take a stage that takes three years. Besides working under a patron for three years, the prospective avocat or stagiaire must also follow courses and take examinations in order to acquire his Certificate d'Aptitude à Exercer la Profession d'Avocat, his professional certificate, or CAPA. ${ }^{187}$ For this purpose, the prospective avocats are listed on a list of stagiaires. Only after successful completion of their stage, which also involves charity or pro deo work ${ }^{188}$ can they be listed as avocats on the tableau of the respective bar where they are registered.

\section{Luxembourg}

Similar to Belgium, the legal profession of the avocat in Luxembourg is strongly rooted in the civil law tradition, characterised by a high degree of protection and decentralisation. The legal profession in Luxembourg is very small, consisting only of two Bars; the main bar in Luxembourg City and a much smaller one in the city of Diekirch. ${ }^{189}$ Although the two Bars are completely independent, they share a single administrative and the disciplinary council. ${ }^{190}$ In addition to the profession of the avocat Luxembourg also knows the legal professions of notaire and hussier. Similar to Belgium, the profession of avoué no longer exists and is merged with the

\footnotetext{
182 'Licence' is the diploma that is awarded after five years of law studies.

183 'Tableau' is the list of all the lawyers in that legal jurisdiction.

184 Stagiaires are trainee lawyers.

185 See Philippe \& Roberts (1993), p. 71.

186 The oath is as follows: 'Ik zweer getrouwheid aan de Koning, gehoorzaamheid aan de Grondwet en aan de wetten van het Belgische volk, dat ik niet zal afwijken van de eerbied aan het gerecht en de openbare overheid verschuldigd, en geen zaak zal aanraden of verdedigen die ik naar eer en geweten niet geloof rechtvaardig te zijn.' This oath roughly translates as: 'I swear loyalty to the King, obedience to the Constitution and to the laws of the Belgian people, not to fail in the respect due to the courts and public authorities and not to counsel or defend any cause save that which I sincerely and conscientiously believe to be just.' Translation from: Philippe, \& Roberts (1993), p. 72. Philippe \& Roberts (1993), p.74

Ibid., p. 75

Brucher (1993), p. 212.

190 See <www.barreau.lu>, last accessed 27 November 2006.
} 
profession of the avocat. ${ }^{191}$ The avocat in Luxembourg is governed by a separate law, which in this paragraph is referred to as the Avocat law. ${ }^{192}$

The requirements for becoming an avocat in Luxembourg are laid down in the Avocat law, more specifically in Articles 5 and 6 of that law. Article 5 firstly states that the profession of the avocat may only be exercised if the person concerned is listed on the tableau of one of the Bar Associations of the Grand-Duchy of Luxembourg. Article 6 of the Avocat law lays down the criteria necessary for becoming enlisted on one of the tableaux in Luxembourg. First of all, it states that the conditions for being accepted for a stage need to be fulfilled. ${ }^{193}$ The fact that the stage does not need to be completed yet stems from the fact that the tableaux are divided into three separate lists. ${ }^{194}$ The conditions for being accepted to the stage are more elaborate than appears from Article 6 of the Avocat law. First of all, an applicant needs to have a law degree. ${ }^{195}$ Since the University of Luxembourg did not offer law degrees until recently, that requirement posed a small problem. Those who sought entrance into the Luxembourg legal profession and who could be of foreign or of Luxembourg origin needed to obtain a law degree in another country. Additionally, they then needed to have their law degree recognised by the Luxembourg authorities. The preconditions for recognition are laid down by Luxembourg law. ${ }^{196}$ The main precondition is that the law degree conferred must be in accordance with the general characteristics of the Luxembourg legal system. In essence this means that the law degree needs to be obtained in a civil law jurisdiction. In general, Belgian and French law degrees offer no problems with regard to homologation. ${ }^{197}$ After it is established that the prospective avocat has an eligible law degree, he will then be allowed to commence the stage. Prior to this, the candidate lawyer will be

191 See <www.barreau.lu>, last accessed 27 November 2006.

192 Loi du 10 août 1991 sur la profession d'avocat, Memorial Journal Officiel du Grand-Duché de Luxembourg, Recueil de Legislation, A-No 58, 27 août 1991, p. 1110.

193 Article 6(1b) Avocat law.

194 'Liste I' comprising lawyers who have completed their stage and professional examination (avocat-inscrit); 'Liste II' comprising lawyers who are still in the process of completing their stage (avocat-stagiaire) and 'Liste III' comprising those lawyers who have been accepted as honorary members. See Brucher (1993), pp. 212-213. This is also reflected in Article 8(3) Avocat law.

195 Brucher (1993), p. 215.

196 Loi du 18 juin 1969 sur l'enseignement supérieur et homologation des titres et grades étrangers d'enseignement supérieur. Memorial Journal Officiel du Grand-Duché de Luxembourg, Recueil de Legislation A-No 27, 21 juin 1969, page 796. This law is executed specifically for the legal profession in: Règlement grand-ducal du 18 décembre 1970 fixant les critères d'homologation des titres et grades étranges en droit, Memorial Journal Officiel du Grand-Duché de Luxembourg, Recueil de Legislation A-No 70, 23 décembre 1970, page 1441. Articles 3 and 4 of that Règlement lay down the criteria for the foreign law degree as follows:

Article 3 Le diplôme final étranger présenté à l'homologation doit conférer un grade d'enseignement juridique supérieur reconnu par le pays d'origine pour ses propres nationaux ou donner, dans ce pays d'origine, accès à la profession d'avocat ou au stage préparatoire à celle-ci.

Article 4 Le diplôme présenté à l'homologation doit sanctionner un cycle complet d'études de droit d'au moins quatre années ou huit semestres ou douze trimestres. L'enseignements doit avoir porté au moins sur les matières suivantes: le droit civil, le droit commercial, le droit pénal, le droit judicaire, le droit international privé ou le droit international public, le droit administratif. L'enseignement du droit civil doit avoir été au moins de deux ans, soit quatre semestres, ou six trimestres. Le droit enseigné doit correspondre dans ses conceptions fondamentales aux principes généraux du système juridique luxembourgois.

197 Brucher (1993), p. 215. 
presented to the Cour de Cassation by the Bâtonnier in order to take the oath. ${ }^{198}$ Once the candidate lawyer has taken the oath he will be listed on 'Liste II' of the tableau.

The organisation of the stage is also laid down by law. ${ }^{199}$ The Luxembourg stage encompasses a characteristic that is unique and is a consequence of the fact that Luxembourg had no university conferring law degrees. Graduates entering the legal profession in Luxembourg will have no specific knowledge of Luxembourg law. In order to counter that problem, every candidate lawyer is obliged to follow a cours complémentaires (complementary course) in Luxembourg law at the University of Luxembourg. ${ }^{200}$ In that course specific Luxembourg topics and rules are followed. ${ }^{201}$ All the subjects must be passed. ${ }^{202}$ The complementary course lasts for three months. After the candidate lawyer has passed the complementary course he is then eligible to commence his stage. ${ }^{203}$ The stage lasts three years and consists of a theoretical and a practical part under the supervision of an older avocat, where the practical part is divided between a stage as a lawyer and a stage as a magistrate. ${ }^{204}$ The stage is completed by an overall exam which consists of a written and an oral part. ${ }^{205}$ After the avocat-stagiaire has successfully completed this exam, he will be included in 'Liste I' of the tableau, and is then an avocat-inscrit. ${ }^{206}$

In addition to the stage the Avocat law names two further criteria that need to be fulfilled in order to become an avocat. First, one must be a Luxembourg national or

198 The oath is mentioned in Article 6(2) of the Avocat law: 'Je jure fidélité au Grand-Duc, obeisance à la Constitution et aux lois de l'Etat; de ne pas m'encarter du respect dû aux tribuneaux; de ne conseiller ou defender aucune cause que je ne croirais pas juste en mon âme et conscience.'

199 Règlement grand-ducal du 21 janvier 1978 portant organisation du stage judiciaire et règlement l'accès au notariat, Memorial, Journal Officiel du Grand-Duché de Luxembourg, Recueil de Législation, A-No 3, 27 janvier 1978, page 40.

200 Article 3 Règlement grand-ducal du 21 janvier 1978 portant organisation du stage judiciaire et règlement l'accès au notariat, Memorial, Journal Officiel du Grand-Duché de Luxembourg, Recueil de Législation, A-No 3, 27 janvier 1978, page 40.

201 Constitutional law, civil law, commercial law, procedural law (civil/commercial), penal law, procedural law (penal) and law of the organisation of justice.

202 Article 5 Règlement grand-ducal du 21 janvier 1978 portant organisation du stage judiciaire et règlement l'accès au notariat, Memorial, Journal Officiel du Grand-Duché de Luxembourg, Recueil de Législation, A-No 3, 27 janvier 1978, page 40.

203 Article 10 of the Règlement grand-ducal du 21 janvier 1978 portant organisation du stage judiciaire et règlement l'accès au notariat, Memorial, Journal Officiel du Grand-Duché de Luxembourg, Recueil de Législation, A-No 3, 27 janvier 1978, page 40, states that: 'Pour être admis au stage, il faut: soit présenter le certificat de formation complémentaire prévu par les articles 5 et 8 , soit presenter le diplôme de docteur en droit delivré par un jury luxembourgeois conformément à la loi du 5 août 1939 sur la collation des grades.' That law of 1939 is replaced by the 1969 law mentioned above.

204 Articles 12 and 13 Règlement grand-ducal du 21 janvier 1978 portant organisation du stage judiciaire et règlement l'accès au notariat, Memorial, Journal Officiel du Grand-Duché de Luxembourg, Recueil de Législation, A-No 3, 27 janvier 1978, page 40.

205 Articles 18 and 19 Règlement grand-ducal du 21 janvier 1978 portant organisation du stage judiciaire et règlement l'accès au notariat, Memorial, Journal Officiel du Grand-Duché de Luxembourg, Recueil de Législation, A-No 3, 27 janvier 1978, page 40.

206 Article 6(1b) provides for an exemption to the stage. Lawyers who have finished their stage in their home country can become a member of the Luxembourg bar if they have at least five years of practical experience. 
hold the nationality of one of the Member States of the European Union. ${ }^{207}$ Also, a candidate lawyer must present a guarantee of honour. ${ }^{208}$

\section{Professional Profile of an Advocaat/Avocat}

\section{The Netherlands}

In the Netherlands there is a rather limited professional monopoly for lawyers. There is no monopoly for giving legal advice ${ }^{209}$ and just a limited monopoly for representing clients in court. ${ }^{210}$ As in other civil law countries, the preparation of deeds and other formal documents is the territory of the notaris, or the notary. ${ }^{211}$ The Netherlands does not have a prohibition with regard to lawyers working together, quite to the contrary. The Netherlands has always been, as is the case with the United Kingdom, a Member State in which large law firms thrive. ${ }^{212}$ It is only in recent years that some other Member States, such as Germany, have developed large law firms. Also with respect to associations with lawyers from other Member States and other professions, the so-called multi-disciplinary partnerships, the rules are quite relaxed. ${ }^{213}$ The Nederlandse Orde van Advocaten has issued a Verordening in which the professions that are allowed to practise in association with lawyers are listed..$^{214}$ In 2006 there were 14,251 advocaten in the Netherlands. ${ }^{215}$ In a population of about 16.5 million people, ${ }^{216}$ there is a ratio of one lawyer for every 1158 people. Similar to the Scandinavian countries, the low proportion of lawyers is probably explained by the fact that there is no legal monopoly for giving legal advice and only a moderate monopoly with regard to representing clients in court. ${ }^{217}$

\section{Belgium}

The monopoly rights of an avocat in Belgium are similar to those of other civil law jurisdictions in Europe. There is, however, no legal monopoly for giving legal advice and the preparation and validation of documents is the domain of the notary and not that of the avocat. The legal monopolies of the Belgian avocat are laid down in more detail than, for example, in the Netherlands. Chapter II of Book III of the Gerechtelijk Wetboek lays down the rights and duties of lawyers. Article 439 states that lawyers have the right to plead before the Courts (excluding the Hof van Cassatie

Article 6(1c) Avocat law.

Article 6(1a) Avocat law.

See Hoegen Dijkhoef (1993), p. 245.

210 This trial monopoly mainly extends over civil and criminal cases and the Tax Chamber of the Supreme Court, in all other cases advocaten do not have a trial monopoly. See See Hoegen Dijkhoef (1993), p. 246.

211 See Hoegen Dijkhoef (1993), p. 247.

212 Adamson (1998), pp. 23-24.

213 Adamson (1998), p. 23.

214 Samenwerkingsverordening 1993. The interpretation of this Verordening has led to serious questions with regard to European competition law in the famous Wouters case (Case C-309/99, J.C.J. Wouters, J.W. Savelbergh, Price Waterhouse Belastingadviseurs BV v. Algemene Raad van de Nederlandse Orde van Advocaten, [2002] ECR I-01577) On Wouters, see also: Duncan (2001), pp. 537-559 and Vossestein (2002), pp. 841-863.

215 See <www.ccbe.org>, last accessed 20 November 2006.

216 See CIA World Fact Book, <www.cia.gov>, last accessed 20 November 2006.

217 See Hoegen Dijkhoef (1993), p. 245. 
(Supreme Court)). ${ }^{218}$ Article 440 of the Gerechtelijk Wetboek makes this right to plead before the Courts exclusive for avocats. ${ }^{219}$ The remainder of the articles are devoted to the duties of an avocat. Article 441 Gerechtelijk Wetboek, for example, states that avocats must wear the clothing prescribed by the King. ${ }^{220}$ Other duties include the duty to replace judges and public prosecutors when called upon, ${ }^{221}$ the duty to pay fees to the Bar, ${ }^{222}$ the duty to defend the truth and the law, ${ }^{223}$ the duty to refrain from attacking the monarchy, the Constitution or laws of the Belgian people $^{224}$ and to perform pro deo duties. ${ }^{225}$

In keeping with the civil law tradition, it is not commonplace for Belgian lawyers to work in association. Lawyers are prohibited from working in a salaried practice. ${ }^{226}$ Working in association is allowed, although it must be stressed that lawyers may only function as associates in a law firm and not as employees. ${ }^{27}$ Although MDPs were always prohibited, ${ }^{228}$ the Orde van de Vlaamse Balies (Flemish Bar Association) has established a regulation that at least opens the door for avocats to participate in MDPs. ${ }^{229}$

There are 14,592 avocats in Belgium. ${ }^{230}$ In the total population of 10.3 million $^{231}$ this represents a ratio of one lawyer for every 705 persons. This is a high rate when compared with the other Member States reviewed. The higher rate is perhaps explained by the fact that the legal monopolies for avocats are more extensive for representation of clients in court, than, for example, in the Netherlands and the Scandinavian and Nordic countries, which have more limited statutory monopolies for lawyers.

\section{Luxembourg}

Similar to Belgium, and in accordance with its civil law tradition, the legal monopolies for an avocat in Luxembourg are laid down in the Avocat law. Avocats are not allowed to exercise other regulated legal professions, nor are they allowed to work in salaried practice. ${ }^{232}$ Article 2 of the Avocat law regulates the activities especially reserved for

218 Article 439 Gerechtelijk Wetboek.

219 Article 440 Gerechtelijk Wetboek.

220 Article 441 Gerechtelijk Wetboek.

221 Article 442 Gerechtelijk Wetboek.

222 Article 443 Gerechtelijk Wetboek.

223 In which they need to refrain from attacking the honour of any person unless it is absolutely necessary, Article 444 Gerechtelijk Wetboek.

224 Article 445 Gerechtelijk Wetboek.

225 Articles 446 and 446bis Gerechtelijk Wetboek.

226 See Philippe \& Roberts (1993), p. 86.

227 Ibid.

228 Ibid.

229 Reglement inzake beroepsmatige samenwerking met niet-advocaten, 22 January 2003. Via <www. advocaat.be>, last accessed 24 May 2004. The reglement did not prohibit MDPs as such, but the articles explicitly prohibiting certain MDPs were quashed by the Hof van Cassatie (Supreme Court) in its judgment of 25-09-2003, NJW nr. 43, 8 October 2003. This judgment was based on the infamous Wouters case which dealt with the regulation on cooperation with non-lawyers from the Nederlandse Orde van Advocaten.

$230 \quad$ See <www.ccbe.org $>$, last accessed 21 November 2006.

231 See $<$ www.cia.gov>, last accessed 21 November 2006.

232 Article 1 Avocat law. 
avocats. First of all, Article 2 states that avocats have the sole right to represent clients before a court and the sole right to exercise all the activities that are linked to such representation. ${ }^{233}$ Unprecedented in the Member States reviewed until now is the fact that Article 2 of the Avocat law also regulates the provision of legal advice. Paragraph 2 of Article 2 of the Avocat law states that no-one but a lawyer can give legal advice. This creates an enormous legal monopoly for lawyers, and furthermore proceeds to explain the high lawyer to person ratio that exists in Luxembourg. ${ }^{234}$ Paragraph 3 of Article 2 clarifies that the prohibition on giving legal advice for non-lawyers is not absolute. The paragraph names a few situations where the provision of legal advice by non-lawyers is acceptable. These exceptions focus mainly on advice for educational reasons; advice given on a non-profit basis and advice by in-house lawyers, and so forth. ${ }^{235}$ Article 3 of the Avocat law reconfirms that point of view by stating that the Avocat law does not hinder dealing with legal matters on an educational basis or for the benefit of documentation. ${ }^{236}$ The protection of the title, the right to wear a robe, and the liberal characteristics of the profession and the conditions of honour required for the profession can be found further on in the Avocat law. ${ }^{237}$ Article 34 of the Avocat law regulates practice in association. Avocats are allowed to practise in association among themselves. Nothing is mentioned with regard to MDPs, which could lead to the conclusion that avocats are not allowed to function in MDPs. ${ }^{238}$

In a population of 450,000 people, there are about 800 lawyers in Luxembourg, a quarter of whom are lawyers of foreign origin. ${ }^{239}$ This makes a lawyer-to-person ratio of one lawyer for every 562 people, which needless to say, is extremely high. This can be explained by the fact that the European Court of Justice is established in Luxembourg's capital, and by reference to the strict civil law basis on which the legal profession is based.

\section{$\mathbb{5}$ 2.4 The Legal Professions in France, Italy, Spain and Portugal}

The review of the professions in Belgium and Luxembourg provides for an almost seamless transition to the review of the other legal professions from jurisdictions that have their origin in the civil law tradition. These jurisdictions represent one of the two remaining clusters of countries that are both characterised by a higher degree of regulation for the legal profession. The other cluster is the legal professions in Germany, Austria and Greece which will be dealt with in the next paragraph.

\footnotetext{
233 Article 2(1) Avocat law.

234 Article 2(2) Avocat law.

235 Article 2(3) Avocat law.

236 Article 3 Avocat law.

237 Articles 31-40 Avocat law.

238 Article 34 Avocat law. This thesis is also underlined by the fact that avocats may not work in salaried practice.

239 See <www.barreau.lu>, last accessed 27 November 2006. The CCBE mentions a number of 1261 avocats. According to the same statistic, 103 lawyers are established under their home country professional title in Luxembourg. Via <www.ccbe.org>, last accessed 11 June 2007.
} 


\section{Qualifications as an Avocat/Avvocato/Abogado/Advogado}

\section{France}

The current profession of the avocat in France is an assembly of a number of older professions, both traditional and non-traditional legal professions. In 1971, a number of legal professions were created. The professions of the avocat and avoué had existed since the Middle Ages, while the profession of conseil juridique was newly created. In 1991, these three professions were brought together into one, the profession of avocat. A remnant of the profession of the avoue still exists before the highest courts in France, namely the Cour de Cassation and the Conseil d'État. Aside from these professions, the classical civil-law profession of the notaire also remains independent in France. The focus of this chapter will be on the profession of the avocat as it has been since 1991. ${ }^{240}$ The legal profession in France is governed by an abundance of laws, decrees and lower governmental rules. ${ }^{241}$ The requirements for becoming an avocat in France are scattered throughout the numerous legal provisions. This paragraph will describe the road to qualification in chronological order and will therefore meander through the different legal provisions. ${ }^{242}$ The first condition for becoming an avocat in France is one traditional in civil law jurisdictions, namely the condition of nationality. Under the influence of particular developments in France ${ }^{243}$ this condition of nationality is very broad. One needs to have either French nationality, the nationality of one of the Member States of the European Union, the nationality of one of the Member States of the European Economic Area or the nationality of one of the territorial units that have an agreement with France on this matter. ${ }^{24}$ After it has been established that the prospective avocat has the adequate nationality it must then be examined whether he or she has the correct education in order to become an avocat. In order to become an avocat one must have a university diploma in law, a maitrise de droit or a diploma that is deemed to be the equivalent with such a maitrise. ${ }^{245}$ The diplomas that are deemed equivalent are laid down in subordinate legislation. $^{246}$

After a prospective avocat has finished his university education or an education that is deemed equivalent, he must then start his professional education. In other Member States this professional education normally consists of a combination of education which is sometimes followed by a concluding examination, and a stage. This is also the case in France, but here the approach is more 'scholastic' than in

240 For the development of the profession of avocat, see Adamson (1998).

241 The most important of these rules are: Loi no. 71-1130 du 31 décembre 1971 portant réforme de certaines professions judiciaires et juridiques, JO de la République Française, 5 janvier 1972, 131; Loi no 90-1259 du 31 décembre 1990 rélative à l'exercice sous forme de sociétés des professions libérales soumises à un statut législatif ou règlementaire ou dont le titre est protégé, JO de la République Française, 5 janvier 1991, 220; Décret no 91-1197 du 27 novembre 1991 modifié organisant la profession d'avocat, JO de la République Française, 28 novembre 1991, 15502. There is an abundance of further rules but they will be dealt with where appropriate. On the basis of an overview published by the Conseil National de Barreaux. See <www.cnb. avocat.fr.>, last accessed 16 August 2004. The order has somewhat changed in 2005.

243 Membership of the European Community and the independence of France's former colonies.

244 Article 11 \&1(1) of the Loi du 31 décembre 1971.

245 Article $11 \int 1(2)$ of the Loi du 31 décembre 1971.

246 Article 1 of the Arrêté du 25 novembre 1998 fixant la liste des titres ou diplômes reconnus comme équivalents à la maitrise en droit pour l'exercice de la profession d'avocat. 
other Member States. After the completion of university education, a prospective avocat must sit an exam in order to be accepted to what is called a Centre régional de formation professionelle d'avocats (CRFPA). ${ }^{247}$ The criteria for the exam are laid down in lower regulation. ${ }^{248}$ In some circumstances, prospective avocats can be exempted from sitting the entry exam. ${ }^{249}$ Courses at the CRFPA last for one year. The courses will focus mainly on the practical side of the avocat's profession. Students are taught, among other things, how to write legal documents, how to plead and so forth. ${ }^{250}$ Following a year of study in the CRFPA, the prospective avocat will have to pass an examination in order to obtain the certificat d'aptitude à la profession d'avocat or CAPA. ${ }^{251}$ As soon as the prospective avocat has obtained the CAPA he may apply to the Council of the Bar of his choice in order to commence his 'in-house' professional training. The Bars in France enjoy a large amount of autonomy, and the unicité $d u$ cabinet prevents a lawyer from being established at more than one Bar at the same time. ${ }^{252}$ The Council of the Bar shall allow the prospective avocat admission to the Bar after having checked that the candidate fulfils all the necessary requirements in order to be sworn in as an avocat. ${ }^{253}$ If the Council is convinced that the requirements are fulfilled, the candidate is enlisted on the stage list after he has taken the oath. ${ }^{254}$

After the candidate is sworn in as avocat, he will commence his stage which is of two years' duration. ${ }^{255}$ During that stage the avocat will work using his title but under the supervision of a patron. ${ }^{256}$ After the avocat has successfully completed his stage, he will be inscribed on the Tableau. ${ }^{257} \mathrm{He}$ is then a fully-fledged avocat.

\section{Italy}

The legal profession in Italy used to consist of two separate professions, namely avvocato and procuratore. ${ }^{258}$ Access to the profession of the avvocato was only possible after having worked as a procuratore for six years. ${ }^{259}$ This system was recently abolished $^{260}$ leaving only the profession of the avvocato. ${ }^{261}$ This abolition was achieved

247 Articles 51 to 54 of the décret du 27 novembre 1991.

248 Arrêté du 29 janvier 1998 fixant le programme et les modalités de l'examen d'accès au centre régional de formation profesionelle d'avocats.

249 Arrêté du 17 février 1993 modifié fixant la liste des diplômes universitaires à finalité professionelle permettant d'être dispensé de tout ou partie de l'examen d'accès au centre régional de formation professionelle d'avocats. See also: Arrêté du 22 juin 1998 fixant la liste des diplômes universitaires en sciences juridiques ou politiques permettant d'être dispensé de tout ou partie de l'examen d'accès au centre régional de formation professionelle d'avocats. Articles 56 to 61 of the décret du 27 novembre 1991.

251 Articles 68 to 71 of the décret du 27 novembre 1991.

252 Article 101 of the décret du 27 novembre 1991.

253 Article 72 of the décret du 27 novembre 1991.

254 Article 3(2) of the loi du 31 décembre 1971: 'Je jure, comme avocat, d'exercer mes fonctions avec dignité, conscience, indépendance, probité et humanité. The rules with regard to inscription on the stage-list are laid down in Articles 72 to 76 of the décret du 27 novembre 1991.

255 Articles 77 to 83 of the décret du 27 novembre 1991.

256 Ibid.

257 Articles 93 to 96 of the décret du 27 novembre 1991.

258 See Davoni (1993), p. 198.

259 Ibid., p. 199.

260 Legge 24 febbraio 1997, n. 27 'Soppressione dell'albo dei procuratori legali e norme in materia di esercizio della professione forense', Gazzetta Ufficiale, n. 48 del 27 febbraio 1997. 
quite easily as there were no additional entry requirements for the profession of avvocato when one had qualified as a procuratore. This is due to the fact that entry into the profession of avvocato was achieved after six years by virtue of seniority alone. ${ }^{262}$ Similar to the situation found in France, the legal profession in Italy is highly decentralised. There is a national Bar Association, the Consiglio Nazionale Forense, that has certain powers in connection with the legal professions, but it is nonetheless mainly responsible for the supervision of the 160 regional Bar associations, the Consiglio dell'ordine. ${ }^{263}$ Another similarity with France is that the law governing the legal profession has been amended quite a few times, with the original text of the law remaining intact. This has at times led to confusing situations. A law dating from 1933 governs the legal profession in Italy. ${ }^{264}$ This law has been modified a number of times, most notably in 1997 when the distinctions between the professions of procuratore and avvocato were abolished. ${ }^{265}$ The 1933 legislation, which will be referred to as the Avvocato law from here on, still lists the criteria required for becoming a procuratore. ${ }^{266}$ The law abolishing the dichotomy between the professions of procuratore and avvocato states that anywhere where the Avvocato law mentions the term procuratore it should be read as avvocato ${ }^{267}$ It can therefore be concluded safely that Article 17 of the Avvocato law lists the criteria for becoming an avvocato. First, Article 17 states that a person who seeks to become an avvocato must have Italian nationality. ${ }^{268,269}$ In addition, a person who seeks entry to the legal profession must have legal capacity ${ }^{270}$ and must be of 'honourable and spotless' conduct. ${ }^{271}$ The fourth requirement for becoming an avvocato in Italy is the possesion of a law degree. ${ }^{272}$

261 Besides the profession of notario, which will not be dealt with in this study.

262 See Davoni (1993), p. 199.

263 Ibid., p. 195.

264 Regio Decreto Legge 27 novembre 1933, n. 1578, 'Ordinamento delle professioni di avvocato e di procuratore', Gazzetta Ufficiale, n. 281, 5 dicembre 1933, Serie Generale; Convertito in legge, con modificazioni, dalla Legge 22 gennaio 1934, n. 36.

265 Legge 24 febbraio 1997, n. 27 'Soppressione dell'albo dei procuratori legali e norme in materia di esercizio della professione forense', Gazzetta Ufficiale, n. 48 del 27 febbraio 1997.

266 Article 17 Avvocato law.

267 Legge 24 febbraio 1997, n. 27 'Soppressione dell'albo dei procuratori legali e norme in materia di esercizio della professione forense', Gazzetta Ufficiale, n. 48 del 27 febbraio 1997.

268 Article 17(1) Avvocato law.

269 It may be obvious that, after the Reyners case (Case 2/74, Reyners v. Belgium, [1974] ECR 631) a nationality requirement for the profession of avvocato can no longer be upheld. It must therefore be concluded that the requirement 'having Italian nationality' must be read as 'having the nationality of one of the Member States of the European Union'. See also: Davoni (1993), p. 196. This premise was confirmed in Italian legislation: Legge n. 146, 'Disposizioni per l'adempimento di obblighi derivati dall'appartenenza dell'Italia alla Comunità europea, legge comunitaria 1993'. See $\int 15$ of A-G Stix-Hackl's opinion in Case C-313/01, Christine Valia Morgenbesser v. Consiglio dell'Ordine degli avvocati di Genova. In 1998 a law was adopted that also suppresses the requirement of nationality for non-EU nationals. See Article 35 of the Legge 6 marzo 1998, n. 40, 'Disciplina dell'immigrazione e norme sulla condizione dello straniero', Gazzetta Ufficiale n. 59 del 12 marzo 1998 Supplemento Ordinario-n. 40. See also: <elixir. bham. ac.uk/Country\%20information/Italy/lawyers_frameset.htm>, last accessed 9 November 2004.

270 'Godere il pieno esercizio dei diritti civile', Article 17(2) Avvocato law.

271 'Essere di condotta specchiatissima ed illibata', Article 17(3) Avvocato law.

272 'Essere in possesso della laurea in giurisprudenza conferita o conformata in una università del regno', Article 17(4) Avvocato law. Traditionally this law degree took four years to complete. See 
According to the Avvocato law, these four criteria must be fulfilled for entry to the second phase of the professional education, namely the practical training that will eventually lead to the successful completion of the Bar Exam. To this end, the prospective lawyers will be registered in a separate list as practicanti. ${ }^{273}$

In recent years, however, an additional criterion has been added to these four criteria to enter into the second phase of professional training as a practicanto. In 1997, the Italian legislature introduced a new possible stage of theoretical training for prospective lawyers. ${ }^{274}$ These scuole di specializzazione per le professione legali are post-graduate institutions that provide a theoretical training before a lawyer commences practical training. Initially this training was to last for a period of two years ${ }^{275}$ but after the reform of university education and the prolongation of the law degree from four to five (three plus two) years, the duration of the course at the scuole di specializzazione per le professione legali was shortened to one year. ${ }^{276}$ Similar to the CRFPA in France, entry into these specialised schools is subject to passing a competitive entry exam. ${ }^{277}$ The number of places at the specialised schools is determined by Ministerial Decree, but will not be lower than 10 per cent of the total number of law graduates. ${ }^{278}$ Attending this scuole is not obligatory.

If the prospective lawyer has chosen to follow courses at the scuole he can, after the successful completion of the year-long training there by means submitting a dissertation, ${ }^{279}$ file a request to his local Bar Association to be entered on the list of practicanti and to start the practical phase of his education to become an avvocato.

Davoni (1993), p. 196. Recently, in 1999, reforms inspired by the Bologna declaration have lead to a two-cycle law degree where the first cycle takes three years and the second cycle, which must be completed for entry into the legal profession, takes up two years. The total time for a law degree therefore is five years. See Henssler (s.d.). See also: Italian Ministry for Education, University and Research (2003). Article 17(4) reads as if a law degree from an Italian University is a necessary requirement. This is no longer the case, however. The Decreto Legislativo that implements Directive 89/48/EEC, Decreto Legislativo 27 gennaio 1992, n. 115, Attuazione della direttiva n. 89/48/CEE relative ad un sistema generale di riconoscimento dei diplomi di instruzione superiore che sanzionano formazioni professionali di durata minima di tre anni, Gazzetta Ufficiale n. 40 del 18 febbraio 1992, abolishes the requirements for having an Italian law degree and completing a stage in Italy.

273 Article 17 Avvocato law.

274 Decreto Legislativo 17 novembre 1997, n. 398, Modifica alla disciplina del concorso per uditore giudiziario e norme sulle scuole di specializzazione per le professione legali, a norma dell'articolo 17, commi 113 e 114 della legge 15 maggio 1997, n. 12, Gazzetta Ufficiale n. 269 del 18 novembre 1997.

275 Article 16 Decreto Legislativo 17 novembre 1997, n. 398.

276 Henssler (s.d). See also: <elixir.bham.ac.uk/Country\%20information/Italy/frameset.htm>, last accessed 11 November 2004. The rationale behind this shortening is that the theoretical phase of the training of an avvocato would last no longer than six years (at the minimum, as many people take more time than the five years prescribed for university education).

277 Article 16(5) Decreto Legislativo 17 novembre 1997, n. 398

278 Ibid. For example, the number of places for the specialised schools for the academic year 20042005 was fixed at 5030 places. See Ministero dell'instruzione dell'universita 'e della ricerca, Decreto 29 giugno 2004, programmazione degli accessi alle scuole di specializzazione per le professioni legali, per l'anno accademico 2004-2005, Gazzetta Ufficiale, n. 165, 16 July 2004.

279 Article 8 Decreto Ministeriale 21 dicembre 1999, n. 537, Regolamento recante norme per l'instituzione e l'organizzazione delle scuole de specializzazione per le professioni legali, Gazzetta Ufficiale, n. 24, 31 gennaio 2000, Serie Generale. 
This practical training is once again mentioned in Article 17 of the Avvocato law, ${ }^{280}$ and states that the practical training may be done in a number of guises, but it mostly takes place in the office of an avvocato. ${ }^{281}$ Traditionally this practical training took two years yet, after one year of training, a prospective lawyer could ask the Bar Association for permission to deal with certain cases on a more autonomous basis. After the introduction of the scuole specializzazione per le professione legali, the requirement for practice was reduced to one year for those who followed the scuole. ${ }^{282}$ If the prospective lawyer can produce a certificate indicating that he has fulfilled the requirements of the practical period he may sit the Bar exam. ${ }^{283}$ When the lawyer has passed this Bar exam, which consists of both written and oral parts on a number of subjects, ${ }^{284}$ he may seek to be included on the list of avvocati. ${ }^{285}$ There are two more conditions in Article 17 that need to be fulfilled in order to become an avvocato. Subsection 7 states that an avvocato must reside in Italy, while subsection 8 states that a lawyer must be a member of the fascist party. While it may be obvious that the last criterion has become obsolete, that is not so obvious for the residence criterion. Clearly, on the basis of well-established case law, ${ }^{286}$ a residence requirement as such is contrary to European Community law. This residence requirement was one of the problems ${ }^{287}$ that was dealt with in proceedings under Article 226 EC against Italy before the European Court of Justice. ${ }^{288}$ In her opinion of 3 May 2001, Advocate-General Stix-Hackl stated that, although the residence requirement was, at the time of her opinion, due to be repealed, it was contrary to European law. ${ }^{289}$ The Court agreed with her. ${ }^{290}$ The repeal of the residence requirement was foreseen in a proposal for a law. ${ }^{291}$ In Article 5 of this proposal, the residence requirement as such was transformed into a requirement of professional residence. ${ }^{292}$ It seems that at this point in time the proposal has not been transformed into a law, so the infringement of European Law remains.

\footnotetext{
280 Article 17(5) Avvocato law.

281 Decreto Presidente Repubblica 10 aprile 1990, n. 101, Regolamento relativo alla pratica forense per l'ammissione all'esame di procuratore legale, Gazzetta Ufficiale, n. 102, 4 maggio 1990, Serie Generale.

282 See < elixir.bham.ac.uk/Country\%20information/Italy/lawyers_frameset.htm>, last accessed 11 November 2004. No reference to legal instruments is present on the cited web-site. The author has not been able to retrieve a source for this reduction from any of the legal instruments at his disposal.

283 Article 22 Avvocato law. See also: Davoni (1993), p. 198.

284 Article 17(6); 20 Avvocato law.

285 Article 24-26 Avvocato law.

286 Case 107/83, Ordre des Avocats au Barreau de Paris v. Klopp [1984] ECR 2971.

287 The remainder wil be dealt with in the next paragraph.

288 Case C-145/99, Commission of the European Community v. Italian Republic, ECR[2002] I02235.

$289 \int 33$ of A-G Stix-Hackl's opinion in Case C-145/99. Italy argued that it was no longer enforced, since the Bar Association had mentioned in an advice (6/1994) that it would no longer be enforced.

$290 \int 31$ Case C-145/99.

291 Progetto di Legge N.- 5211, Nuove disposizioni sulla professione di avvocato.

292 Ibid., Article 5.
} 


\section{Spain}

The legal profession in Spain has a unique position in comparison with the legal professions examined up to this point. The representation of clients in court is not reserved for the legal profession of the abogado, but is rather reserved for the procurador. ${ }^{293}$ Spain is therefore the only country observed until now that has retained the traditional dichotomy between the profession of advocate and that of procurator. In the Netherlands, Belgium, Luxembourg, France and Italy this dichotomy has been abolished. Unlike France and Italy, where there is an abundance of laws and other governmental-level regulations regarding the legal profession, the rules governing the legal profession in Spain are quite clear. There are two main instruments that govern the legal profession. First, there is the Estatuto General de la Abogacía Española ${ }^{24}$ (hereinafter referred to as the Abogado law). Another important law for the profession of the abogado, specifically where it concerns the relationship with the profession of procurador, is the Ley Orgánica del Poder Judicial. ${ }^{295}$ As stated above, the National Bar Association (hereinafter the Consejo General) seems to have more responsibilities than its counterparts in France and Italy. Spain has a system of qualification that is fundamentally different from what is commonplace in the rest of the Member States. In the Member States already observed, a general system of qualification can be distilled, although certain differences remain. In general, qualification as a lawyer starts with an academic diploma, followed by a period of theoretical and practical training, which is concluded with a Bar Exam. Only after this period is a lawyer fully qualified. This is not the case in Spain. Qualification in Spain as an abogado is extremely simple. One only needs to have a law degree. ${ }^{296}$ When the law degree is completed, after a minimum of five years, one can request to be registered with a Colegio. Once this registration is complete, one is a qualified abogado. ${ }^{297}$ Registration with a Colegio is laid down in the Abogado law. ${ }^{298}$ Article 11 states that registration with a Colegio is obligatory, except where the law provides otherwise. The Article states further that a lawyer can register with only one Colegio, where he will exercise the majority of his activity and where he is deemed to have his professional residence. ${ }^{299}$ In order to be registered with a Colegio one needs to fulfil a number of criteria. These criteria are listed in Article 12 of the Abogado law. First a prospective abogado must have Spanish nationality or one of the nationalities of the Member States of the European Union or the European Economic Area. Secondly, a prospective abogado must be of legal age and must not be incapacitated in respect of performing legal acts. Thirdly, as already indicated, a prospective abogado must possess a Spanish degree in law, or a foreign degree that is deemed

\footnotetext{
293 See Calderón (1993), p. 280.

294 Estatuto General de la Abogacía Española, Real Decreto 658/2001 de 22 de junio, BOE no. 164 de 10 de julio de 2001.

295 Ley Orgánica 6/1985, de 1 de julio, del Poder Judicial (ultima actualización 15/01/2004) BOE, de 2 de julio de 1985.

296 See Adamson (1998), p. 25; Henssler \& Prütting (s.d.) B and Calderón (1993), p. 281. See also Article 542 Ley Orgánica del Poder Judicial.

297 Ibid.

298 Articles 11-20 Abogado law.

299 The traditional civil law unicité du cabinet. Article 11 Abogado law.
} 
equivalent to the Spanish law degree. Fourthly, one must fulfil the entry requirements of the Colegio concerned. ${ }^{300}$

As stated above, the relative ease with which one can become an abogado in Spain forces the Spanish authorities to distinguish between abogados who actually exercise the profession and those who do not. For the former, the Abogado law lists a number of additional criteria. First of all, an abogado proposing to practise must not have been the subject of a criminal conviction that disqualified him from the profession of the abogado. Secondly, there may not be any other incapacities or prohibitions that apply to the prospective abogado that prevent him from joining the profession. Thirdly, those who have gained access to the legal profession in another Member State may establish themselves if they fulfil the criteria laid down by law, as long as they do not exercise activities that fall under the public service exception. Lastly, a prospective abogado must enter into a number of social security schemes. ${ }^{301}$ The extensive prohibitions and incompatibilities with regard to the profession of lawyer are also laid down in the Abogado law. ${ }^{302}$ When the criteria for entrance to the Colegio are fulfilled, the lawyer must make an oath or a promise, after which he is a member of the Colegio and therefore an abogado. ${ }^{303}$

\section{Portugal}

The legal profession in Portugal bears some resemblance to the legal profession in Spain. Similar to most southern European systems, the Portuguese system can be characterised by a nature is rooted in civil law. Similar to Spain, the traditional dichotomy between the advocate and procurator survives in Portugal in the professions of the advogado and solicitador. The division of activities between the two professions is, however, not as clear cut as in Spain, and the professional activity of a solicitador differs somewhat from that of a Spanish procurador. The dichotomy between the two professions is not similar to the dichotomy between the profession of solicitor and barrister in the common law countries but lies more along the line of a traditional division between the continental professions of 'advocate' and 'procurator'. ${ }^{304}$ The solicitador performs acts that are similar to those of a 'procurator' (i.e., preparatory and administrative acts) ${ }^{305}$ but can also represent clients in court in cases where appeal is not possible due to the fact that there is only a very small claim, and where the law does not prescribe representation by a lawyer. Yet in the majority of cases solicitadores collaborate with advogados. ${ }^{306}$ One of the general characteristics of the legal profession in a civil law system is the fact that it is a very independent profession. This is illustrated in that lawyers traditionally work in a single-person practice and that the governing organisations are often decentralised and have a high degree of autonomy. This is not the case in Portugal. Similar to the Netherlands, there is one national Bar Association, the Ordem dos Advogados that is governed by law, the

\footnotetext{
300 Article 12(1) Abogado law.

301 Article 12(2) Abogado law.

302 Articles 14, 21-26 Abogado law.

303 Article 16 Abogado law.

304 Coelho Ribeiro \& de Lourdes Lopes Dias (1993), p. 272.

305 See Adamson (1998), p. 24; Killian (s.d.) C.

306 Coelho Ribeiro \& de Lourdes Lopes Dias (1993), p. 272.
} 
Estatuto da Ordem dos Advogados. ${ }^{307}$ The Ordem covers the entire territory of Portugal, yet it has some district administrative centres that are directly subordinate to the Ordem. ${ }^{308}$ The organisation of the profession is more centralised than in other jurisdictions.

As opposed to the case of Spain, the general way of qualifying for the legal profession of the advogado in Portugal does not differ substantially from its civil law counterparts in the rest of Europe. A person seeking to become an advogado must complete a two-tier system comprising of university education and practical training. In order to exercise the profession of the advogado the prospective lawyer must complete a traineeship, or estagio. ${ }^{309}$ In order to register for the estagio the prospective lawyer must have completed university education in law either at a Portuguese university or a foreign university. In the latter case, the diploma received must be fully recognised in Portugal. ${ }^{310}$ There are two State Universities in Portugal where a law degree can be obtained. ${ }^{311}$ For both of the two State Universities there is an entry requirement based on the results of secondary education. ${ }^{312}$ Education at the State University is essentially free. ${ }^{313}$ In addition, there are 23 private universities where a law degree can be obtained. These private universities generally have no entry requirements but do charge substantial fees. ${ }^{314}$ This division between universities also leads to a dichotomy in the labour market, where alumni of the two State Universities have a much better position than those who have obtained their degree from a private university. ${ }^{315}$ In general the estagio will last for two years, and is divided into two different phases. ${ }^{316}$ The first phase lasts for at least six months and is aimed at acquiring technical and deontological experience. This first phase takes the form of intensive theoretical education (three to four hours of lectures per day), ${ }^{317}$ which will be concluded with a test. ${ }^{318}$ When the prospective lawyer passes this test, he or she may proceed to the second phase of the estagio. ${ }^{319}$ The second phase of the estagio is aimed at gaining practical knowledge by means of taking part in the actual exercise of the profession and deepening the technical and deontological knowledge. ${ }^{320}$ Participation in the second part of the estagio is generally unpaid. ${ }^{321}$ The second phase of the estagio is concluded with an individual evaluation of the estagio and completion (and passing) of a national Bar examination. ${ }^{322}$ Both

307 Lei no. 15/2005 de 26 de Janeiro de 2005. - Aprova o Estatuto da Ordem dos Advogados e revoga o Decreto-Lei no. 84/84 de 16 de Março, com as alterações subsequentes. In diáro da República. - S.1-A n. 18 (26 Janeiro 2005) p. 612-646.

308 Coelho Ribeiro \& de Lourdes Lopes Dias (1993), p. 273.

309 Article 184 Advogado law.

310 Article 187 Advogado law.

311 Killian (s.d.) C.

312 Ibid.

313 Ibid.

314 Ibid.

315 Ibid.

316 Article 188 Advogado law.

317 Killian (s.d.) C.

318 Article 188 (2) Advogado law.

319 Article 188 (3) Advogado law.

320 Article 188 (4) Advogado law.

321 Killian (s.d.) C.

322 Article 188 (5) Advogado law. 
the contents of the estagio and the Bar exam are laid down by the General Council of the Ordem dos Advogados. ${ }^{323}$

The activities that a prospective lawyer may carry out during his estagio are also laid down in the Advogado law. Article 189 of the Advogado law states that during the estagio a prospective lawyer, under the guidance of his patrono, may exercise the activities of a solicitador by representing clients in lower courts, both in criminal and in other fields, and give legal advice. ${ }^{324}$ A prospective lawyer may also carry out other activities of an advogado as long as he is accompanied by his patrono. ${ }^{325}$ At the beginning of his estagio, a prospective lawyer will register with the Ordem dos Advogados in the district centre of his professional domicile. ${ }^{326}$ The professional domicile of a prospective lawyer is derived from the professional domicile of his patrono. ${ }^{327}$ After successful completion of the estagio, the preparatory registration with the Ordem dos Advogados will be transformed into full registration. ${ }^{328}$

Apart from the criteria mentioned above, there a number of other reasons why a person may not be able to register with the Ordem dos Advogados. These criteria are listed in Article 181 of the Advogado law and include; the lack of moral quality to exercise the profession, legal incapacity, the occurrence of incompatibilities and dismissal due to disciplinary reasons. ${ }^{329}$ When a lawyer fulfils the conditions of registration, he will be allowed to register and he will receive a document that functions as a proof of his registration. ${ }^{330}$ Whereas the route through the estagio is the most common way of becoming an advogado in Portugal, there are several exceptions to the estagio that are found in the Advogado law. ${ }^{331}$ These 'shortcuts' are available to holders of a doctorate in Legal Science who have actually taught and magistrates who have professional experience equal to or longer than the period of the estagio. ${ }^{332}$ In addition to these persons who seem to be capable of becoming fully-fledged advogados after they register, there is a more limited registration available for jurists with recognised merits, masters and other holders of other doctorates in Law. These persons may register without the estagio after the successful completion of an aptitude test. ${ }^{333}$ This aptitude test deals mainly with deontology. ${ }^{334}$ Persons registered with the Ordem dos Advogados via this method are only allowed to give legal advice and are therefore not allowed to represent clients in court. ${ }^{335}$

\footnotetext{
323 Article 188 (6) Advogado law.

324 Article 189 (1) Advogado law.

325 Article 189 (2) Advogado law.

326 Article 182 Advogado law. The article lists the requirements for registration with the Ordem. Requirements include production of birth certificate and proof of a law degree (subparagraph 2).

327 Article 179 (3) Advogado law.

328 Article 192 Advogado law.

329 Article 181 Advogado law.

330 Article 180 Advogado law.

331 Article 192/193 Advogado law.

332 Article 192 (2) Advogado law.

333 Article 193 (1) Advogado law. Only persons with more than ten years experience are eligible for this registration method (Article 193 (4)).

334 Article 193 (2) Advogado law.

335 Article 193 (5) Advogado law.
} 


\section{Professional Profile of an Avocat/Avvocato/Abogado/Advogado}

\section{France}

Characteristically for the civil law tradition, in France there are a considerable number of rules pertaining to the legal profession. As stated above, the three different professions of the avocat, avoué and conseil juridique have been merged into one modern profession of the avocat. Later on in this subparagraph it will be indicated that the origin of different avocats can still be traced back to former days. Similar to Luxembourg, as another traditional civil law profession, the legal profession in France characterises itself through extensive legal monopolies for professional activity. Although not as explicit as in Luxembourg, it becomes clear when combining a number of legal provisions that avocats have a monopoly of representing and defending clients, and with regard to giving legal advice. ${ }^{336,337}$ Also similar to Luxembourg, the legal profession in France suffers from extensive incompatibility requirements. ${ }^{338}$ For example, an avocat is not allowed to exercise any commercial activities. Unlike the situation in Luxembourg, an avocat may work in a salaried practice. ${ }^{339}$

Although the profession of the conseil juridique was merged with the profession of the avocat in the 1990s, one can still see traces of the different professions in the modern avocat. As is the case in most civil law traditions, the profession of the lawyer is mainly a solitary one. In France, however, an interesting division can be observed. On the one hand, there are avocats in the true sense of the word. These avocats will often practise on their own or in small associations. Avocats who stem from the profession of conseil juridique, on the other hand, are observed to be concentrating in a much larger association; their association is the largest law firm in France. ${ }^{340}$ There is no mention of MDPs, so it might be assumed that these are, as is the case in Luxembourg, not allowed. ${ }^{341}$ In a population of 62.5 million people ${ }^{342}$ there are 45,686 avocats $^{343}$ which leads to a ratio of one lawyer for every 1368 people. This low ratio is suprising, as in a civil law country one would expect a higher ratio. Possibly the low ratio can be explained by the fact that it is quite difficult to qualify as an avocat in France.

\section{Italy}

Similar to the other Member States which adhere to a civil law system, the rules in Italy offer a lot of protection for the profession of the avvocato, but this protection comes at a price. The Avvocato law includes a long list of professions that may not be exercised in combination with the profession of avvocato. ${ }^{344}$ With regard to the legal

336 Articles 4 and 54 of the loi du 31 décembre 1971. The latter article has been modified by reforms of the early 1990s whereby the profession of conseil juridique has been abolished and integrated in the profession of avocat.

337 This view is also supported in: Sanglade (1993), pp. 124-125.

338 Articles 111-123 of the décret du 27 novembre 1991.

339 Sanglade (1993), pp. 124-125.

340 See Adamson (1998), p. 15.

341 Although this assumption is less strong in France than it is in Luxembourg, where salaried practice is not allowed.

342 Via EUROSTAT, <europa.eu>, last accessed 28 November 2006.

$343<$ <ww.ccbe.org>, last accessed 28 November 2006.

344 Article 3 Avvocato law. 
monopolies for professional activities, a lot of uncertainty exists. ${ }^{345}$ Because of the fact that the Italian legal profession was divided between two separate professions for a number of decades, namely that of avvocato and procuratore, the legal monopoly for the modern avvocato is not entirely clear. Moreover, the Italian system distinguishes between judicial and extra-judicial activities for which different rules apply. ${ }^{346}$ No hard and fast rules are laid down in the Avvocato law and legal monopolies can only be construed based on case law of the Supreme Court of Cassation. What becomes clear from this case law is that it is unlawful for a person who is not listed on a register of avvocati to engage in activities that can be regarded as judicial activities (e.g., the representation of clients in court). ${ }^{347}$ Case law with regard to extrajudicial activities (i.e., giving legal advice) is much less explicit but several decisions of the Supreme Court seem to suggest that an exclusive right for extra-judicial activities also exists for avvocati ${ }^{348}$ Traditionally, an Italian avvocato practises on his own in a general practice. ${ }^{349}$ Avvocati are not allowed to form corporations but are allowed to form professional partnerships, limited to members of the same Bar. ${ }^{350}$ In 2001, together with the implementation of Directive 98/5/EC, rules were laid down for practice in association. ${ }^{351}$ These rules are very detailed and govern practically every aspect of practice in association. ${ }^{352}$ Associations are, for example, obliged to register with the Bar Association. By far the most important provision with regard to practice in association is laid down in Article 21 of the Decreto Legislativo, which states that all the partners in the association must hold the title of avvocato. ${ }^{353}$ From that provision, in combination with the incompatibilities laid down in Article 3 of the Avvocato law, it can be concluded that practice in Multi-Disciplinary Partnerships for lawyers is not allowed.

In 1998, there were 83,000 avvocati in Italy. ${ }^{354}$ In a population of 58 million, this represents a ratio of one lawyer for 700 persons, a ratio that is among the highest in the European Union. This is probably due to the high degree of regulation in the Italian legal profession, stemming from the profession's civil law characteristics. By 2006 the number of avvocati had increased to $121,380 .{ }^{355}$ With a population that remained stable, ${ }^{356}$ this further increased the ratio to one lawyer for every 477 people. Interestingly enough, the members of the legal profession are not equally distributed

\footnotetext{
345 See Kilian (s.d.) D, last accessed 18 November 2004.

346 Davoni (1993), pp. 201-202.

347 Ibid., p. 202.

348 Ibid.

349 Adamson (1998), p. 21

$350 \quad$ Davoni (1993), p. 201.

351 Decreto Legislativo 2 febbraio 2001, n. 96, Attuazione della direttiva 98/5/CE volta a facilitare l'esercizio permanente della professione di avvocato in una Stato membro diverso da quallo in cui e' stata acquisita la qualifica professionale. (via <www.ccbe.org>, last accessed 22 November 2004). Articles 16-33.

352 It could easily be assumed that an association of lawyers is treated as a separate form of legal form of a company.

353 Article 21 Decreto Legislativo 2 febbraio 2001.

354 Adamson (1998), p. 21.

355 See <www.ccbe.org >, last accessed 29 November 2006.

356 See CIA World Factbook, via <www.cia.gov>, last accessed 8 November 2004.
} 
across Italy. In 1992, four regions in Italy accounted for almost half of the then 53,000 avvocati. $^{357}$

\section{Spain}

As stated above, the legal profession in Spain can be characterised as a civil law profession. In general, this characterisation means that, on the one hand, the legal profession is protected by an elaborate legal monopoly, and on the other hand, there are a large number of incompatibilities. Both elements are found in Spain albeit on a moderate scale. Although a very broad legal monopoly exists, ${ }^{358}$ there are a number of professions that exert pressure on this legal monopoly. Firstly, there is the profession of the procurador. According to the Ley Organica del Poder Judicial, a procurador is exclusively responsible for the relationship between the client and the courts. ${ }^{359} \mathrm{~A}$ client (and his abogado) must therefore solicit a procurador in order to pursue legal proceedings. In addition to the profession of procurador there a number of quasi-legal professions that strain the legal monopoly laid down for abogados. ${ }^{360}$ The professions concerned are the professions of graduados sociales, asesores fiscales and gestores administrativos. ${ }^{361}$ These professions, which are basically specialists advising in their specific fields, mainly infringe on the legal monopoly of the abogados with regard to legal advice. While advising the public on their specific fields, the above-named professions often give a form of legal advice, an activity reserved for abogados. ${ }^{362}$ On the other hand, there are a number of incompatibilities in the Abogado law. ${ }^{363}$ For example, an abogado cannot be a procurador, graduado social, agente de negocios or gesto administrativo at the same time. ${ }^{364}$ An abogado also cannot be employed as a State official. ${ }^{365}$ These and other incapacities resemble those in force in other civil law jurisdictions but do not seem to be as strict. It seems that salaried practice, ${ }^{366}$ practice in association ${ }^{367}$ and multi-disciplinary partnerships, ${ }^{368}$ albeit more or less limited, are allowed in Spain.

In 2006 there were 151,542 abogados registered in Spain. ${ }^{369}$ Of these, 37,399 were registered as abogado but did not exercise professional activities, ${ }^{370}$ leaving the remaining 114,143 as practising abogados. In a population of little over 40.3 million, ${ }^{371}$ this

357 See Davoni (1993), p. 194.

358 Article 542 of the Ley Organica del Poder Judicial. This article basically refers to all activities regarding promotion and representation of the interest of parties in all forms of litigation, or in legal advice and counselling. Furthermore Articles 1, 6 and 8-9 of the Abogado law further confirm this monopoly. Legal representation is obligatory for almost all legal proceedings, except for a small number of exceptions. See Calderón (1993), p. 283.

359 Article 543 Ley Organica del Poder Judicial.

360 See <www.iel.bham.ac.uk>, last accessed 4 January 2005.

361 Ibid.

362 Ibid.

363 Articles 21-26 Abogado law.

364 Article 22(2b) Abogado law.

365 Article 22(1b) Abogado law.

366 Article 27 Abogado law.

367 Article 28 Abogado law.

368 Article 29 Abogado law. MDPs may not include professions that are incompatible with the exercise of the profession of abogado.

369 Via <www.cgae.es>, last accessed 29 November 2006.

$370 \quad$ Ibid.

371 See CIA World Fact Book, <www.cia.gov>, last accessed 29 November 2006. 
leads to one lawyer for every 350 persons, which again is an extremely high ratio. Adamson $^{372}$ tries to explain this enormous number of lawyers by stating the relative ease with which one can become an abogado in Spain. ${ }^{373}$ Yet, the figure used for this ratio omits the abogados who are merely registered and do not exercise professional activity. Lawyers who register as an abogado because it is no more than a formality and never really exercise the profession do not count in the ratio. I am therefore of the opinion that the 'ease' explanation does not really explain the high ratio of abogados. Perhaps a better explanation can be found in the legal monopoly of abogados.

\section{Portugal}

The rules pertaining to professional activities in Portugal are somewhat scattered. Title I of the Advogado law deals with the exercise of the profession of the advogado, but refers to a more specific law in that title. ${ }^{374}$ That specific law is the Lei dos actos próprios dos Advogados. ${ }^{375}$ Moreover, the Advogado law states that practice of the legal profession in association shall be governed by a separate law. ${ }^{376}$ This has been effectuated in the Novo Regime Juridico das Sociedades de Advogados. ${ }^{377}$ Generally, it can be said that advogados enjoy a large legal monopoly with regard to all activities concerning representation of clients in court and the provision of legal advice. ${ }^{378}$ Based on the Lei dos actos próprios dos Advogados ${ }^{379}$ it seems that advogados must share this legal monopoly with the profession of solicitador. ${ }^{380}$ The sharing of activities is however largely limited for solicitadores since subsection 11 of Article 1 of the Lei dos actos próprios dos Advogados states that the representation of clients in court and the provision of legal advice by solicitadores is limited by the procedural laws and the governing statute of the profession of solicitadore. ${ }^{381}$ As stated above, with regard to qualification, the right of provision of legal advice can also be granted to other categories of people, namely lawyers with recognised merit and academic staff in Law faculties. ${ }^{382}$

It goes beyond the ambit of this paragraph to give a detailed overview of all the incompatibilities and impediments laid down in the Advogado law. It suffices to say at this point that the governing principles of the profession of advogado are autonomy, independence and responsibility. ${ }^{383} \mathrm{~A}$ long list of incompatibilities and impediments is included to elaborate on these general principles. ${ }^{384}$ Practice in association

372 See Calderón (1993), p. 280 and Adamson (1998), p. 25.

373 See $\int 1.2$ above.

374 Articles 62 and 63 Advogado law.

375 Lei no. 49/2004, de 24 de Agosto - Define o sentido e o alcance dos actos próprios dos advogados e dos solicitadores e tipifica o crime de procuradoria ilícita, Diáro de República no. 199 Série I-A, de 24 de Agosto de 2004, pp. 5656-5657.

376 Article 203 Advogado law.

377 Decreto-Lei no. 229/2004 de 10 de Dezembro.

378 Coelho Ribeiro \& de Lourdes Lopes Dias (1993), p. 275. Strangely enough Killian states that there is no legal monopoly on legal advice: Killian (1999) C.

379 Lei no. 49/2004, de 24 de Agosto - Define o sentido e o alcance dos actos próprios dos advogados e dos solicitadores e tipifica o crime de procuradoria ilícita, Diáro de República no. 199 Série I-A, de 24 de Agosto de 2004. pp. 5656-5657.

380 Article 1 Lei no. 49/2004, de 24 de Agosto.

381 Article 1(11) Lei no. 49/2004, de 24 de Agosto.

382 Article 1(2)(3) Lei no. 49/2004, de 24 de Agosto.

383 Article 76(1) Advogado law.

384 Article 77 and 78 Advogado law. 
is governed by a separate piece of legislation, namely Decreto-Lei 229/2004 de 10 de Dezembro. This does not mean, however, that the Advogado law says nothing about practice in association. On the contrary, the general principles regarding practice in association are laid down in the Advogado law, ${ }^{385}$ which states that advogados are allowed to practise in association with each other, either as associates or as partners. ${ }^{386}$ While practising in association, advogados are bound to the deontological rules and the rules laid down in Decreto-Lei 229/2004 de 10 de Dezembro. ${ }^{387}$ Yet most important for the purpose of this study is the general principle laid down in subparagraph 3 of Article 203 of the Advogado law which states that association with other professions other than that of the advogado is prohibited. ${ }^{388}$ Therefore, multi-disciplinary practices are not allowed in Portugal. ${ }^{389}$ According to data of the CCBE there are 12,617 advogados in Portugal. ${ }^{390}$ In a population of 10.5 million, ${ }^{391}$ this represents one lawyer for every 832 persons, which, like Italy and Spain, is on the high end of the spectrum.

\section{\2.5 The Legal Professions in Germany, Austria and Greece}

The remaining jurisdictions that are to be reviewed - Germany, Austria and Greece are also characterised by a high degree of regulation. This regulation is concerned with a higher level of state control than in the 'traditional' civil law jurisdictions. The professions considered in this paragraph have traditionally been single professions, with no division between advocates and 'procurators'. It might be obvious for Germany and Austria to be dealt with in the same paragraph, but Greece might seem a more unlikely candidate. However, the legal developments in Greece have been based on a more German approach, so that a review of the Greek legal profession seems most appropriate in this paragraph.

\section{Qualification as a Rechtsanwalt/Dikigoros}

\section{Germany}

The main legal profession in Germany is the profession of the Rechtsanwalt. ${ }^{392}$ In addition to the Rechtsanwalt, there is also the profession of the Notar, which sees a number of variations throughout Germany. ${ }^{393}$ Next to these two 'classic' legal professions there are also three other professions that are characterised by a high degree of

385 Article 203 Advogado law.

386 Article 203(1) Advogado law.

387 Article 203(2) and (4) Advogado law.

388 Article 203(3) Advogado law.

389 See also: Killian (s.d.) C. Killian states that this problem is circumvented by the 'Big-Five' accountancy-firms by hiring an association of lawyers that works exclusively for them, often even established in the same building.

390 Via <www.ccbe.org>, last accessed 2 December 2006.

391 The precise figure is $10,605.870$, see CIA World Factbook via <www.cia.gov>, last accessed 2 December 2006.

392 Adamson (1998), p. 17.

393 Ibid. 
specialisation. These professions are that of the Patentanwalt (patent attorney), Steuerberater (tax adviser) and the Wirtschaftsprüfer (auditor). ${ }^{394}$

As is the case in almost all of the continental Member States, a career as a Rechtsanwalt is initiated at a university. However, unlike the other continental Member States, the assessment of what is actually learned at university is not done by the university itself which provides a culminated degree, but rather by the State. ${ }^{395}$ After three and a half years of studies at university, students have to sit the Erste Juristische Staatsprüfung (first State Examination) which can cover anything learned at university. ${ }^{396}$ After the first State Examination the prospective Rechtsanwalt, then referred to as Refendar, will have to engage in a period of preparation (called Vorbereitungsdienst or Refedariat), in which the Referendar receives training in a number of Courts and with numerous lawyers. ${ }^{397}$ The Refedariat lasts for two years, after which a Zweite Juristische Staatsprüfung (second State Examination) will take place. ${ }^{398}$ After the two State Examinations, the prospective lawyer is qualified as an Einheitsjurist (unitary jurist), a qualification which grants him access to all the regulated legal professions in Germany; therefore not only access to the profession of the Rechtsanwalt, but also to the profession of the Notary, State Prosecutor or even the Judge. ${ }^{399}$

Germany, therefore, has a system that has only one educational trail for all the regulated legal professions. It is, thus, clear that the education leading to the qualification of Einheitsjurist is not focussed on a single profession. Although the profession of the judge takes up most of the weight in the Refendariat, most of those who follow the Refendariat become Rechtsanwälte because there are not enough jobs in the other professions. ${ }^{400}$ This leads to an unwanted situation, namely the fact that a large number of people end up in a certain profession, but that the education they are obliged to follow focuses mainly on another profession, namely that of judge. It was for this reason that both in the Bundestag and the Bundesrat proposals were submitted to change the law in such a manner that the education for Rechtsanwälte would be in better accordance with their actual profession, i.e., to remove the focus in the Refendariat from the profession of judge and focus it on the profession of the Rechtsanwalt. ${ }^{401}$

Both proposals stated that education for lawyers was outdated and in need of reform. The Bundesrat recommends a schism in the first State examination. The bill proposed that all the compulsory courses at university should be assessed by means of a State examination, while the non-compulsory courses will be assessed at university

$394 \quad$ Ibid., p. 18.

395 Governed in Paragraph 5 of the Deutsches Richtergesetz (DriG) of 19 April 1972, (1972) BGB1 I, page 713. The exact content of the State examinations is governed by the laws of the respective Länder.

396 Paragraph 5d DRiG.

397 Paragraph 5b DRiG.

398 Paragraph 5d DRiG.

399 Bundesrat, Entwurf eines Gesetzes zur Änderung des Deutschen Richtergesetzes und der Bundesrechtsanwaltsordnung, Drucksache 671/01, 30 August 2001.

400 Deutscher Anwalt Verein, in a letter to the author dated 15 May 2000.

401 Deutscher Bundestag, Entwurf einer Gesetzes zur Reform der Juristenausbildung, Drucksache 14/7176, 17 October 2001; and Bundesrat, Entwurf eines Gesetzes zur Änderung des Deutschen Richtergesetzes und der Bundesrechtsanwaltsordnung, Drucksache 671/01, 30 August 2001. See Riedel (2001). 
level. ${ }^{402}$ With regard to the Refendariat, the Bundesrat argued that the first period (of one year) should remain unchanged, namely divided into four compulsory traineeships. ${ }^{403}$ With regard to the year-long second period, the Bundesrat proposed to have it filled in at Länder-level, so that every Land can determine the contents of the second year. In addition, the Bundesrat proposed that a prospective Rechtsanwalt should be educated with a registered Rechtsanwalt for at least a twelve-month period.

The bill of the Bundestag confirmed the proposals concerning the first State examination, namely the fact that universities should assess the voluntary subjects taught at university and that that assessment should make up half of the result of the first State Examination. The bill of the Bundestag is more rigorous to that extent, as it lays down that the traineeship at a Rechtsanwalt's office should last twelve months. So, under the bill of the Bundestag, every Referendar will have to spend twelve months in a Rechtsanwalt's office, while under the bill of the Bundesrat only Referendare who want to become Rechtsanwälte have to fulfil this requirement (i.e., via a combination of the compulsory and voluntary traineeships). In addition, the Bundestag proposal also states that Einheitsjuristen can only become judges if they have worked in a different profession for at least two years, since only then do they have the experience that is necessary to become a judge. Clearly these bills modernise German legal education and the education for regulated professions, however, the German structure of the two State examinations and the unitary education will be retained. In 2002, the fate of both proposals was decided. The bill of the Bundesrat was rejected, ${ }^{404}$ while the bill of the Bundestag entered into force on 1 July $2003 .{ }^{405}$

\section{Austria}

In Austria the legal profession also uses the title of Rechtsanwalt. The rules that govern access to the profession of the Rechtsanwalt are laid down in the Rechtsanwaltsordnung (hereinafter $R A O$ ), more specifically in paragraph $1{ }^{406}$ First, the paragraph ${ }^{407}$ states that those who seek access to the profession of the Rechtsanwalt must have Austrian nationality. Section 3 of paragraph 1 states that nationals of Member States of the European Union will be regarded as Austrian nationals. In addition to the nationality requirement, the paragraph states that Rechtsanwälte must be entitled to practise. This entitlement flows from a number of additional requirements, also listed in the paragraph.

The first of those additional requirements is that the prospective Rechtsanwalt has gained either a doctorate in law or the title of magister in law. ${ }^{408}$ This university education takes between four and six years. ${ }^{409}$ After the university education, the prospective Rechstanwalt (now called Rechtsanwaltanwärter) must complete a period

402 Bundesrat, Entwurf eines Gesetzes zur Änderung des Deutschen Richtergesetzes und der Bundesrechtsanwaltsordnung, Drucksache 671/01, 30 August 2001.

403 Paragraph 5b DRiG.

404 Stand der Gesetzgebung des Bundes (GESTA) 14. Wahlperiode, no. C171, via <www.bundes tag.de $>$, last accessed 7 November 2006.

405 Bundesgesetzblatt Jahrgang 2002 Teil 1, no. 48, 17 July 2002, pp. 2592ff., via <www. bundes tag.de>, last accessed 7 November 2006.

406 Rechtsanwaltsordnung, RGBL 96/1868, most recent change BGB I 71/1999.

$407 \$ 1(2) \mathrm{RAO}$.

408 \ $1(2 \mathrm{c}) \mathrm{RAO}$.

409 Lonbay (s.d.) A. 
of training with a Court and another Rechtsanwalt. ${ }^{410}$ This training period lasts for five years. ${ }^{411}$ During the training period, the Rechtsanwaltanwärter is obliged to follow education for at least 36 half days at the Anwaltsakademie. ${ }^{412}$ Then, the Rechtsanwaltanwärter is obliged to sit the Rechtsanwaltsprïfung, an examination that allows access to the profession of the Rechtsanwalt. ${ }^{413}$ After all this has been completed and after the Rechtsanwalt has taken out professional indemnity insurance, he can finally establish himself as a Rechtsanwalt. Overall, it takes about nine to eleven years before a person can qualify as an Austrian Rechtsanwalt. I think that it is mainly this very long educational trail, combined with financial hardship in at least the starting years ${ }^{414}$ of the profession, ${ }^{415}$ that leads to the low numbers of Rechtsanwälte in Austria.

\section{Greece}

In many ways Greece holds a unique position when compared with the other Member States considered in this book. In the first place, in respect of the fourteen other Member States before the enlargement round of 1 May 2004, Greece is geographically isolated. At least until the accession of Bulgaria, the country did not share any land borders with other Member States. The closest Member State is Italy which is found across the Adreatic Sea. Also with regard to its legal system, Greece holds a special place as it fills an intermediate position between the German and the civil law systems. ${ }^{416}$ The Greek legal profession of $\left.\Delta \mathrm{t}\right\rceil \gamma$ ópos (hereinafter Dikigoros) has as a noteworthy feature that officially a Dikigoros is an unpaid civil servant who is employed by the government. This designation has been made redundant by a ruling of the Greek Council of State, declaring that the profession of the Dikigoros is mainly a free profession but still has public features since it is associated with the system of justice. ${ }^{417}$

A single law, the Kodex Dikigoron, governs the legal profession in Greece. ${ }^{418}$ The Kodex governs qualifications as a Dikigoros as well as the rules governing the legal profession, although these are worked out in separate deontological codes issued by the regional Bars. ${ }^{419}$ Qualification as a Dikigoros starts with a law degree. A law degree can be obtained from one of the three Law Faculties (Athens, Thessaloniki and Komotini, in order of prestige and standard of entrance requirements). ${ }^{420}$ Entering a Law Faculty is rather difficult in Greece, as many students wish to follow a legal education. Everyone who finishes secondary education may take the entrance examination for the Greek universities. Entrance exams differ with regard to subject (Law

\footnotetext{
$410 \int 1(2 \mathrm{~d}) \mathrm{RAO}$.

$411 \int 2(2) \mathrm{RAO}$.

$412 \int 1(2 \mathrm{f}) \mathrm{RAO}$.

$413 \int 1(2 \mathrm{e}) \mathrm{RAO}$.

414 Maybe also due to the strict rules on advertising, as laid down in $\ 45$ of the Richtlinien furr die Ausübung des Rechtsanwaltsberufes, für die Überwachung der Pflichten des Rechtsanwaltes und für die Ausbildung der Rechtsanwaltsanwärter (RL-BA 1977).

415 This grim picture is painted by Gruner (s.d).

416 Stamatoudi (1997).

417 Kommatas (1993), p. 154.

418 Legislative Decree No. 3026/1954, of 6/8.10.1954 as modified and supplemented by later legislative decrees.

419 Kerameos (2001), pp. 349-353.

$420 \quad$ Ibid.; Stamatoudi (1997).
} 
is in the same group as Archaeology, History, Greek, Languages etc.). The highest possible mark for the entrance exam is 20, and the three Law Faculties require a minimal mark of 18 or 19 in order to be eligible for admittance. ${ }^{421}$ This demonstrates that it is extremely difficult to enter one of the Law Faculties. The same has been observed with regard to Portugal, where private universities cater to the students who do not make it into one of the State Faculties. However, that option is not available in Greece, since private universities are forbidden. Many Greek students therefore seek legal education abroad. ${ }^{422}$ The studies in a Law Faculty last for a minimum of four years and are concluded with an examination that is supervised by the Law Faculties without State involvement. ${ }^{423}$ After concluding the law degree, the prospective lawyer has six months to register for vocational training. In order to register, the candidate must have a law degree and a declaration of a Dikigoros who is willing to train him. ${ }^{424}$ The vocational training lasts for a period of eighteen months and consists of practical training under the supervision of a Dikigoros and of a more theoretical part in the form of training courses and seminars that are organised by the Bar where the lawyer is registered. ${ }^{425}$ During the training course, a prospective lawyer may represent clients before a court. In criminal matters and petty civil cases he may practise on his own, in all other cases he has to work in cooperation with the Dikigoros who supervises his training. A trainee lawyer must at least represent clients in a minimum of 30 cases during the eighteen-month training period. ${ }^{426}$ Although subject to the same professional and deontological rules as a Dikigoros, a trainee lawyer will receive only small compensation for his work, paid by the Dikigoros who supervises his training. ${ }^{427}$

The vocational training is concluded by a Bar examination that is organised by the Court of Appeal in the district of the Bar where the trainee lawyer is registered. The exam consists of both oral and written examinations in the field of civil law (including procedural law), criminal law (including procedural law), commercial law and rules concerning the profession. ${ }^{428}$ After the prospective lawyer has successfully completed the Bar examination (which he may re-sit twice) he is admitted to the Bar where he is registered as a trainee lawyer. ${ }^{429}$ In the first four years as a newly established Dikigoros he may practise before lower courts, then before the Court of Appeal, and after another five years he may also practise before the Supreme Court.

A remark must be made with regard to nationality. In an article Kommatas states that a person who seeks to establish himself as a Dikigoros must have Greek

\footnotetext{
421 Stamatoudi (1997).

422 Ibid.

423 Ibid.

424 Kommatas (1993), p. 157. Such a Dikigoros who provides training must have at least have five years experience and must be allowed to practice before a Court of First Instance or Court of Appeal, except for the Bars of Athens and Piraeus where a Dikigoros who wants to train lawyers must be able to practise for the Court of Appeal or Supreme Court.

425 Kerameos (2001), pp. 349-353.

426 Ibid.

427 Ibid.

428 Ibid.

429 Ibid.
} 
nationality. ${ }^{430}$ Although he already envisaged at the time of writing (which was in 1993) that this requirement would become redundant after the implementation of the Diploma Directive, it may be clear that such a nationality requirement was no longer sustainable after the Reyners judgment. This also applies to Greece, where the lawyer is officially an unpaid civil servant, since the Supreme Court decided already in the 1970s and 1980s that a Dikigoros exercised a liberal profession. The public service exception that was invoked in the Reyners case cannot, therefore, be applied for the Greek situation, except for special situations that will be addressed later on in this chapter. The other remarkable requirement in the process of becoming a lawyer in Greece is concerned with the maximum age, which can become problematic if applied to lawyers who seek to integrate based on the Diploma Directive or on the basis of the establishment Directive. Possible problems in this respect will be dealt with later in this chapter.

\section{Professional Profile of a Rechtsanwalt/Dikigoros}

\section{Germany}

The Rechtsanwalt in Germany enjoys an extensive legal monopoly. ${ }^{431}$ This monopoly includes representing clients in court and giving legal advice. This monopoly can be distilled from the legal provisions in both the $B R A O$ which provides for the reservation of all legal activities for Rechtsanwälte ${ }^{432}$ and the Rechtsberatungsgesetz which explicitly reserves the giving of legal advice to Rechtsanwälte (besides some exceptions mainly with regard to the other legal professions mentioned above). As of January 2008 the Rechtsberatungsgesetz is replaced by a new Rechtsdienleistungsgesetz which will maintain the same strict monopoly rules for lawyers. This means that even quasi-legal professions such as corporate lawyers (Syndikusanwälte) must qualify as Rechstanwälte before they can practise. The activities of Rechtsanwälte are regulated in the $B R A O$ on a federal level. The general rights and duties of a Rechtsanwalt are laid down in the third part of the $B R A O{ }^{433}$ In general, Rechtsanwälte are engaged in private practice from their office which must be located in the jurisdiction of the court with which they are registered. ${ }^{434}$ In addition to that, Rechtsanwälte can work in an occupation ${ }^{435}$ and in public service. ${ }^{436}$ To a certain extent, lawyers are allowed to advertise their qualities. ${ }^{437}$ The $B R A O$ also deals with the problem of multidisciplinary practices. The relevant paragraph of the $B R A O$ states that a Rechtsanwalt may practise jointly with another Rechtsanwalt (including lawyers from other Member States established under their home title), a Patentanwalt (patent attorney), a Steuerberater (tax advisor), a Steuerbevollmächtige, a Wirtschaftsprüfer (auditor) and a vereidigter

\footnotetext{
430 Kommatas (1993), pp. 158-159. Kommatas even states that where a foreigner has obtained Greek nationality he may only become a lawyer after five years. It is hard to reconcile such a rule with general non-discrimination rules.

431 Manz \& Padman-Reich (1993), p. 131.

432 Ibid.

433 BRAO: Dritter Teil: Die Rechten und Pflichten des Rechtsanwalt und die berufliche Zusammenarbeit der Rechtsanwälte (\$ 43- $\$ 59 \mathrm{~m})$.

434 Such an office is called a Kanzlei, $\$ 27$ BRAO

435 \46 BRAO.

436 \47 BRAO.

$437 \ 43 \mathrm{~b}$ BRAO.
} 
Buchprüfer (sworn-in language revisor). ${ }^{438,439}$ In 2006 there were 138,679 lawyers in Germany. ${ }^{40}$ With a population of approximately 82 million there is one lawyer for every 590 people, which is a high ratio.

\section{Austria}

In Austria the activities of a Rechtsanwalt entail the representation of clients in the broadest sense of the word. ${ }^{441}$ That means that in Austria both the representation of clients and the giving of legal advice are reserved for the profession of the Rechtsanwalt. To that end, a Rechtsanwalt may practise alone, in a joint practice with other lawyers, ${ }^{442}$ with other persons as long as they are not public officers (with the exception of teachers), notaries, or other professions that are not compatible with the subject of the profession of Rechtsanwalt. ${ }^{443}$ There are about 4850 Rechtsanwälte in Austria, and there are about 1900 Rechtsanwaltsanwärter (prospective lawyers). ${ }^{444} \mathrm{With}$ a population of 8.2 million $^{445}$ there is one lawyer for every 1690 people, which is a low ratio.

\section{Greece}

As stated above, the characteristics of the legal profession in Greece bear some resemblance to the legal professions in Germany and France. With regard to the combination between the legal monopoly and the incompatibilities, however, the Greek system resembles more the classical civil law system as applied in France than the German system. A Greek Dikigoros has in general a complete legal monopoly with regard to legal advice and the representation of clients in court. There are, however, situations where representation by a lawyer is not obligatory. In addition to the legal monopoly with regard to advice and representation, the Dikigoros also has the right to be present at the conclusion of formal documents. ${ }^{446}$

As opposed to this large legal monopoly, traditionally, there are a large number of incompatibilities. The incompatibilities in Greece are numerous and not all that clear in their application. General rules will often have a large number of exceptions. It goes beyond the purpose of this chapter to describe all these rules in a detailed fashion. A Dikigoros can generally not be employed in a public service, but there are a few exceptions to this rule. ${ }^{447}$ Furthermore, a lawyer may not work in a profession

\section{8 \59a BRAO.}

439 A new law will also influence these rules in the future: This new law is called the Rechtsdienstleistungsgesetz. It entered into force on 1 January 2008. See <www.bmj.bund.de $>$, last accessed 7 November 2006. See also: Bundesrat, Enturuf eines Gesetzes zur Neuregelung des Rechtberatungsrecht, Drucksache 623/06; Stand der Gesetzgebung des Bundes GESTA 16. Wahlperiode No. C077, via <www.bundestag.de>, last accessed 7 November 2006.

$440<$ www.ccbe.org $>$, last accessed 11 June 2007.

441 \8(1) RAO.

$442 \quad \int 1 \mathrm{a}(1) \mathrm{RAO}$.

443 \20 RAO.

444 See <www.oerak.or.at>, last accessed 14 November 2006. The CCBE mentions a number 4234. See <www.ccbe.org>, last accessed 11 June 2007.

445 CIA World Factbook, <www.cia.gov>, last accessed 14 November 2006.

446 Kommatas (1993), p. 168.

447 Ibid., pp. 163-164. For example, Members of Parliament (both Greek and European), basically any other political function (from minister to mayor), professors and other lecturers in political science or law, those who are called for military service, those who work for public entities as 
that would compromise his dignity or independence. ${ }^{448}$ People who have received a prison sentence (or the death sentence), who do not have legal capacity with regard to their property, who have not completed their military service, who have been disbarred by decision of the Disciplinary Council of the relevant Bar Association, or people who are clergymen or monks, may not become a lawyer. ${ }^{449}$ Based on the rules concerning incompatibilities, salaried practice must be possible, as long as the independence and dignity of the Dikigoros is not violated. Lawyers are also allowed to practise in association among themselves, provided they are established with the same Bar Association. ${ }^{450}$ Multi-Disciplinary Partnerships are not allowed in Greece. ${ }^{451}$ According to the CCBE, there were 36,000 lawyers in Greece in $2006 .{ }^{452}$ With a population of over 10.5 million $^{453}$ that represents one lawyer for every 291 people, which is an extremely high rate of lawyers, even higher than in Spain where no additional qualification is needed after one has obtained a law degree. This high rate is possibly explained by the fact that Greece has a maximum age for qualifying as a Dikigoros, which is not absolutely fixed, but which lies somewhere around the age of $30 .{ }^{454}$ Many law graduates, who in addition to the maximum age limit, must apply for training as a Dikigoros within six months after graduating, ${ }^{45}$ qualify as a lawyer at an early stage of their professional life just to prevent exclusion from this career option later on. Similar to Italy, the qualified lawyers in Greece are not spread evenly over the territory. The Bars in Athens and Piraeus account for more than half of the lawyers in Greece. ${ }^{456}$

\section{$\$ 2.6$ Observations}

Based on the overview of the legal professions given above, a number of observations can be made. First of all, a threefold division can be formed in connection with the legal monopoly that is reserved for the legal professions in those countries. There is a group of countries, albeit small, that have no legal monopoly for their legal

legal advisors, journalists, and lawyers who work for the Bar Associations are exempted from this incompatibility.

448 Ibid., p. 164. Professions that fall under this exception are manager, managing director, or any other representative of a commercial cooperation. He can, however, be a president or a member of the board of directors of a Societé Anonyme or a limited liability company, or an economic advisor to a company.

449 Ibid., p. 161.

450 Ibid., p. 165. Again the rules with regard to practice in association have some noteworthy features. There are restrictions in size, small Bar Associations (with 61 to 100 members) have a maximum of seven lawyers who may practise in association. Large Bar Associations (over 300 members) have a minimum of five lawyers who may practise in association. Establishment of the association is subject to approval of the relevant Bar Association. Stringent rules lead to the factual situation that few associations actually exist. A Dikigoros will generally practise on his own, or as an employee in the office of another Dikigoros. See Kerameos (2001), pp. 349-353.

451 Kommatas (1993), p. 166. See also: Kerameos (2001), pp. 349-353.

452 Via <www.ccbe.org>, last accessed 4 December 2006.

453 The precise figure is 10,668,058, see CIA World Factbook, <www.cia.gov>, last visited 4 December 2006.

$454 \quad$ Kommatas (1993), p. 157.

455 Ibid.

456 Ibid., p. 155 and Kerameos (2001), pp. 349-353. 
profession at all. In these countries, Sweden and Finland, no qualification as a lawyer is necessary to exercise the legal professions. In a larger group, the legal professions have, more or less, a monopoly in representing clients in court, but the giving of legal advice is free from regulation, or at the very least is less regulated. These countries are the United Kingdom, Ireland, Belgium and the Netherlands. Denmark is a borderline case between this group and the next. The last group, by far the largest, has a legal monopoly for lawyers in both legal representation and, aside from exceptions, legal advice. These countries are Luxembourg, France, Italy, Spain, Portugal, Germany, Austria and Greece. Based on this threefold division, the following table demonstrates the link between the degree of regulation in each Member State and the ratio of lawyers when compared with the total number of inhabitants.

Table 2: Degree of regulation of legal profession and ratio of lawyers to population, by country

\begin{tabular}{|l|l|l|}
\hline Country & Degree of Regulation & $\begin{array}{l}\text { Lawyer to Population } \\
\text { Ratio }\end{array}$ \\
\hline Sweden & Low & $1: 2045$ \\
\hline Finland & Low & $1: 2971$ \\
\hline Denmark & Intermediate/High & $1: 1186$ \\
\hline United Kingdom & Intermediate & $1: 378$ \\
\hline Ireland & Intermediate & $1: 355$ \\
\hline The Netherlands & Intermediate & $1: 1158$ \\
\hline Belgium & Intermediate & $1: 705$ \\
\hline Luxembourg & High & $1: 562$ \\
\hline France & High & $1: 1368$ \\
\hline Italy & High & $1: 477$ \\
\hline Spain & High & $1: 350$ \\
\hline Portugal & High & $1: 832$ \\
\hline Germany & High & $1: 590$ \\
\hline Austria & High & $1: 1690$ \\
\hline Greece & High & $1: 291$ \\
\hline
\end{tabular}


From this table the general conclusion that can be drawn is that in countries where the degree of regulation is high there are large numbers of lawyers, and therefore a low ratio of lawyers to the population at large. The opposite is true for countries that have a low degree of regulation, not because there is less work for lawyers in these countries, but because other professions (regulated or not) exercise elements of the legal profession. There are, however, a number of exceptions to this general conclusion. The common law countries reviewed, the United Kingdom and Ireland, do not fit in the system set out above. There the number of lawyers is higher than one would expect based on the degree of regulation in both countries. This can be explained in a number of ways. First of all, the nature of the legal system in these two countries is fundamentally different from that of the rest of the countries reviewed. Tradition might lead people to seek employment in the legal sphere to qualify themselves as lawyers even where there is no legal monopoly that forces them to do so. A second, yet less likely, explanation is the fact that both jurisdictions have a dual legal profession, i.e., solicitor/barrister, a distinction that has not been included in the table above. This explanation does, however, offer less support since the number of barristers is so low that it is unlikely to fundamentally alter the outcome. A third, and even less plausible explanation, could be sought in the fact that London is an international economic centre and, as a consequence, would require a high number of lawyers. This cannot serve as an explanation for the many lawyers since this is a phenomenon also present in Ireland that does not fulfil the vital function as being an economic centre.

The importance of Brussels may be an explanation for the anomalous situation in Belgium, however, where there are also more lawyers than one would expect on the basis of the degree of regulation. Brussels is the centre of the European Union and therefore attracts a high number of lawyers. A final anomaly occurs in two countries that have a high degree of regulation and where one would therefore expect a high number of lawyers. These countries are France and Austria, which have less lawyers than one would expect based on their strict legal monopolies. In the preceding paragraphs it has been explained that the lower numbers are probably a reflection of the difficulty of qualifying as a lawyer. This is exemplified by France in the difficult CAPA stage, and by Austria in the long qualification process and financial hardship during this period.

Another observation that can be made is that a majority of the countries reviewed have a high degree of regulation, which is also reflected in the systems of secondary legislation specifically applicable to lawyers. Both the Services Directive and the Establishment Directive are only applicable to certain legal professions. This could pose problems for professionals who exercise an activity that is protected for lawyers in countries with a high degree of regulation but is open to anyone in countries with a lesser degree of regulation. This leads to the creation of a group of professionals (in those countries with less regulation, who are not members of the profession) that will remain untouched by the application of secondary legislation and therefore cannot benefit from the system this legislation creates. I will deal with this hidden group in the review of the specific modalities of free movement in the remainder of this chapter. 


\section{$\int$ 3. The Free Provision of Services}

The previous chapter set out the rules and developments in connection with the free provision of services for lawyers. It was established that at an early stage of development of the free movement of lawyers Directive 77/249/EEC was adopted, which allows the free provision of legal activities based on the principle of mutual recognition. It was also observed that the Directive generated remarkably little case law over the 30 years of its existence. At the end of the previous paragraph the position of lawyers seeking to provide services in another Member State was described, and it can be depicted graphically as follows:

Figure 2: Free provision of services

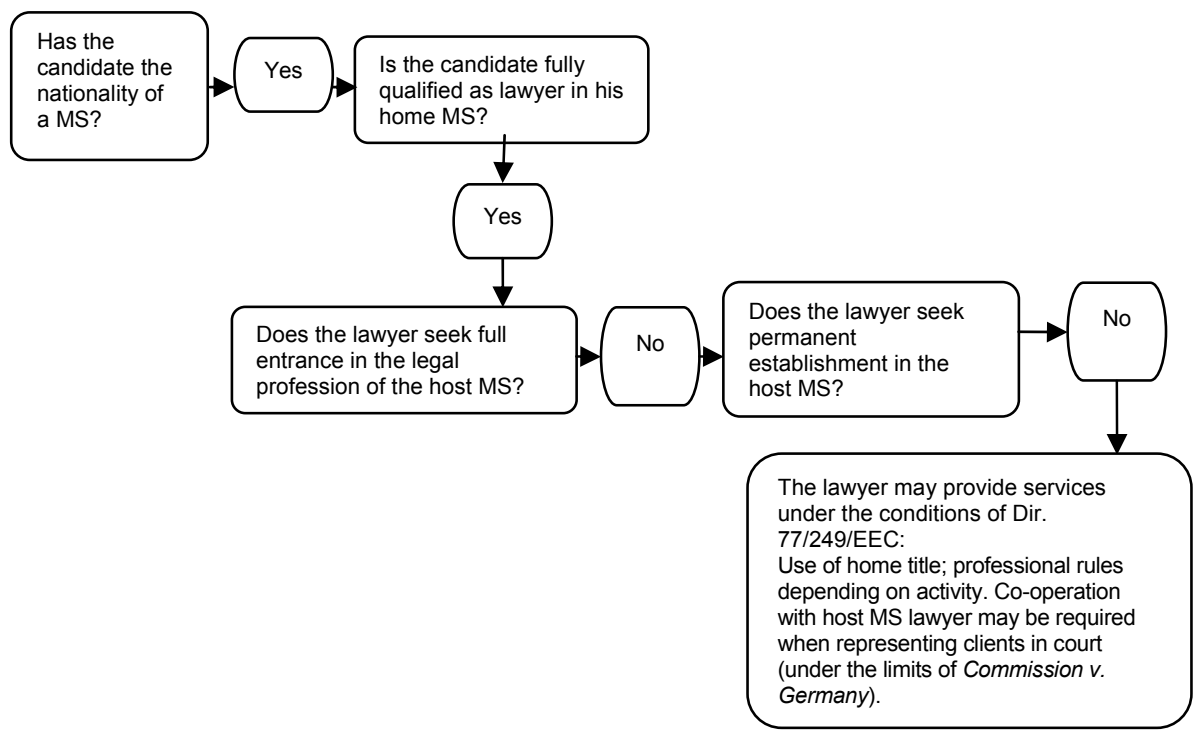

It will be the purpose of this paragraph to research how the Member States included in the review have implemented the mechanism described above. It may go without saying that the emphasis of the research will be on the possible anomalies in the different implementation mechanisms in the various Member States. For the purposes of this review the order of Member States established in the previous paragraph will be maintained.

Before embarking on the review another problem must first be tackled. In the previous paragraph it was established that, in those countries that have a low or an intermediate degree of regulation for the legal profession, there are people who exercise professional activities falling within the legal monopoly of the lawyer in those Member States that maintain a high degree of regulation. It must first be established whether, and how, this group can exercise its freedom to provide services in Member States that maintain a high degree of regulation. 


\section{$\$ 3.1$ Freedom to Provide Services for Non Lawyers in Highly Regulated Member States}

From both Figure 2 above and from Article 1(2) of Directive 77/249/EEC it becomes immediately clear that persons who wish to benefit from the provisions in the Directive must undergo a rite of initiation, namely qualification as a lawyer in the home Member State. Only then does such a person fall within the scope of application of the Directive. This means that for the group of people who exercise legal activities in countries with a low or intermediate degree of regulation, the Services Directive is rendered useless. That does not mean, however, that this group does not enjoy the freedom to provide services. In the previous chapter it was already established that Article 49 of the EC Treaty was given direct effect in the Van Binsbergen case. ${ }^{457}$ Moreover, it was also established that the general rule laid down in Gebhard ${ }^{458}$ applies, namely that any rule liable to hinder or make less attractive the exercise of any of the four freedoms is prohibited unless objectively justified. Such objective justification could be based on, for example, consumer protection arguments. Unfortunately there is no case law on this from the European Court of Justice and therefore there is no way of ascertaining how the European Court of Justice would go about applying possibilities for objective justification in these cases. Similarly, it can only be speculated how Member States with a high degree of regulation would react to a request from a non-lawyer to provide services in their territory. A Member State could invoke a justification based on the proposition that such a person is not properly qualified or insured, or any other mandatory requirement such as consumer protection. As said above, no such case law has emerged over the past 30 years and it is likely that such case law will never emerge since the problem has recently been solved in secondary legislation.

In the previous chapter it was already mentioned that the system for the recognition of diplomas was extensively revised in 2005 with Directive 2005/36/EC of the European Parliament and of the Council of 7 September 2005 on the recognition of professional qualifications. ${ }^{459}$ Recognition of professional qualification was until then only relevant in cases concerning permanent establishment in the host Member State. Therefore, Directive 2005/36/EC will be discussed extensively below, when dealing with lawyers who seek to establish themselves in the legal profession of the host Member State. There is, however, one aspect of the Directive that has to be dealt with here. Where the old system for diploma recognition only applied to establishment, the scope of Directive 2005/36/EC has been widened in such a fashion that it also covers the recognition of qualification issues in the provision of services. It therefore acts as a lex specialis compared with the system of relying directly on Article 49 EC combined with the Gebhard test described above. The rules on the provision of services are laid down in Articles 5 to 9 of Directive 2005/36/EC. Article 5 of the Directive states that without prejudice to specific provisions of Com-

\footnotetext{
457 Case 33/74, Van Binsbergen v. Bestuur van de Bedrifsvereniging voor de Metaalnijverheid, [1974] ECR 1299.

458 Case C-55/94, Reinhard Gebhard v. Consiglio dell'Ordine degli Avvocati e Procuratori di Milano, [1995] ECR 4165.

459 Directive 2005/36/EC [2005] OJ L 255/22.
} 
munity law $^{460}$ and the provision laid down in Articles 6 and 7 of the Directive, Member States shall not restrict the free provision of services in another Member State for any reason relating to professional qualifications where the potential service provider is allowed to exercise the same profession in his home Member State, or where the potential service provided has legally pursued the same activities for at least two years during the past ten years where the home Member State does not regulate this profession. ${ }^{461}$ The Article states further that the temporal and occasional nature of the service provided will be assessed on a case to case basis, ${ }^{462}$ and that the provider is subject to host Member State professional rules. ${ }^{463}$ The application of professional rules is further elaborated on in Article 6 of the Directive. In that article it is laid down that the host Member State may not impose any professional rules with regard to compulsory registration ${ }^{464}$ with a professional body (although pro forma membership may be required) nor registration with a social security body. ${ }^{465}$ Article 7 regulates the (additional) requirements that the host Member State may impose on the service provider. The Article states that the host Member State may require a declaration including the details of professional liability insurance. This declaration must be renewed every year if the service provider wants to provide services in that Member State for that year. ${ }^{466}$ In addition, when the first declaration is made or where there is a material change in circumstances the host Member State may require proof of nationality, an attestation that the holder is legally established in the home Member State, proof of professional qualifications, proof that where the profession is not regulated in the home Member State the person concerned has exercised the profession for at least two years during the last ten years. ${ }^{467}$ The service shall be provided under home country professional title, or where such title is lacking, with a mention of the formal qualification in the language of the home Member State. ${ }^{468}$ In addition to these rules, the Directive also imposes rules with regard to administrative cooperation between the competent authorities ${ }^{469}$ and information that must be provided to the recipients of the service. ${ }^{470}$

The rules laid down in Directive 2005/36/EC are clearly an improvement on the protection of those professionals who provide legal services without being fully qualified lawyers in those Member States that allow such activities due to a lesser degree of regulation. Before the adoption of Directive 2005/36/EC only the 'capstone' rules could be applied to persons in this situation. This meant that any hindrance to the free movement of services was in principle prohibited unless such a prohibition could be objectively justified. In the new atmosphere the Directive expressly forbids

460 From which it may be concluded that Directive 2005/36/EC does not apply to lawyers who are caught under the system of Directive 77/249/EEC, which is corroborated by Recital 42 of Directive 2005/36/EC.

461 Article 5(1) Directive 2005/36/EC.

462 Article 5(2) Directive 2005/36/EC.

463 Article 5(3) Directive 2005/36/EC.

464 Article 6(1) Directive 2005/36/EC

465 Article 6(2) Directive 2005/36/EC.

466 Article 7(1) Directive 2005/36/EC.

467 Article 7(2) Directive 2005/36/EC.

468 Article 7(3) Directive 2005/36/EC.

469 Article 8 Directive 2005/36/EC.

470 Article 9 Directive 2005/36/EC. 
the restriction of the free provision of services on grounds of qualification. The Directive offers no possibility for exemptions. Whereas, under Article 49 and the Gebhard system, an objective justification for such a restriction was possible at least in theory, no exemptions to the rule are allowed under the Directive, at least not with regard to restrictions on professional qualifications. The transposition period of Directive 2005/36/EC ended on 20 October 2007. Thus, at this moment in time Member States should have adapted their national rules to Directive 2005/36/EC.

The question remains how other restrictions, other than those related to professional qualifications, must be treated. As the general body of case law on the four freedoms shows, Member States can be inventive when it comes to possible restrictions. In relation to services provided by professionals who operate outside the legal monopoly of a lawyer in certain Member States in other Member States where such activity belongs to the legal monopoly of a lawyer, possible justifications in the light of insurance, or consumer protection can easily be imagined. Directive 2005/36/ $\mathrm{EC}$ is of no help in these situations since it only covers restrictions on professional qualifications. At this point in time it means that other restrictions on the provision of legal services by non-lawyers must be addressed under the general system of Article 49 EC Treaty and the objective justification test laid down in Gebhard. In the near future this is about to change. In late 2006 the Institutions of the European Union finally adopted the watered-down 'Bolkesteijn Directive' on services in the internal market as Directive 2006/123/EC. ${ }^{471}$ The CCBE did its best to keep legal services entirely out of this Directive ${ }^{472}$ and the services caught under Directive 77/249/EEC are indeed exempted from the Directive. ${ }^{473}$ It seems, however, that legal services that are not caught by Directive $77 / 249 / \mathrm{EC}$ (like the ones discussed in this paragraph) fall under Directive 2006/123/EC. This book is not the place to give an extensive review of Directive 2006/123/EC, not least because the transposition period only ends in December 2009. ${ }^{474}$ In this book, and at this point in time, a short review of the substantive improvements to the service providers dealt with in this paragraph will suffice.

The main consequence of legal services provided by non-lawyers not being caught by the exemptions laid down in Article 17 of Directive 2006/123/EC, is that the rules on the free provision of services laid down in Article 16 of Directive 2006/ 123/EC apply. The rules in Article 16 of Directive 2006/123/EC state that Member States must honour the right of service providers to provide services in other Member States. ${ }^{475}$ The Member State will guarantee access and free exercise of the provision of services. ${ }^{476}$ Member States shall not make the provision of services dependent on requirements that do not fulfil the conditions of non-discrimination, necessity and suitability. ${ }^{477}$ In addition to this general rule, which is nothing more than a codification

471 Directive 2006/123/EC of the European Parliament and the Council of 12 December 2006 on services in the internal market, [2006] OJ L 376/36.

472 See CCBE position on the Proposal for a Directive on Services in the Internal Market, via <www.ccbe.org>, last accessed 2 November 2007.

473 Article 17(4) Directive 2006/123/EC Moreover, 2006/123/EC does also not apply to restrictions to services caught under Directive 2005/36/EC. See article 17(6) Directive 2006/123/EC.

474 Article 44 Directive 2006/123/EC.

475 Article 16(1) Directive 2006/123/EC.

476 Ibid.

477 Ibid. 
of the objective justification test laid down in Gebhard, paragraph 2 of Article 16 lays down a number of specific prohibitions. ${ }^{478}$

In conclusion it can be said that recent developments in secondary legislation have considerably elaborated the rights of non-lawyers who exercise legal activities in Member States with an intermediate or low degree of regulation to provide services in Member States that have a high degree of regulation. Whereas previously such rights could only be exercised by relying on the general rules for the free provision of services, such professionals can now rely on more detailed provisions in secondary legislation. Graphically, the rules with regard to the free provision of services could be depicted as follows:

Figure 3: Free provision of services including non lawyers

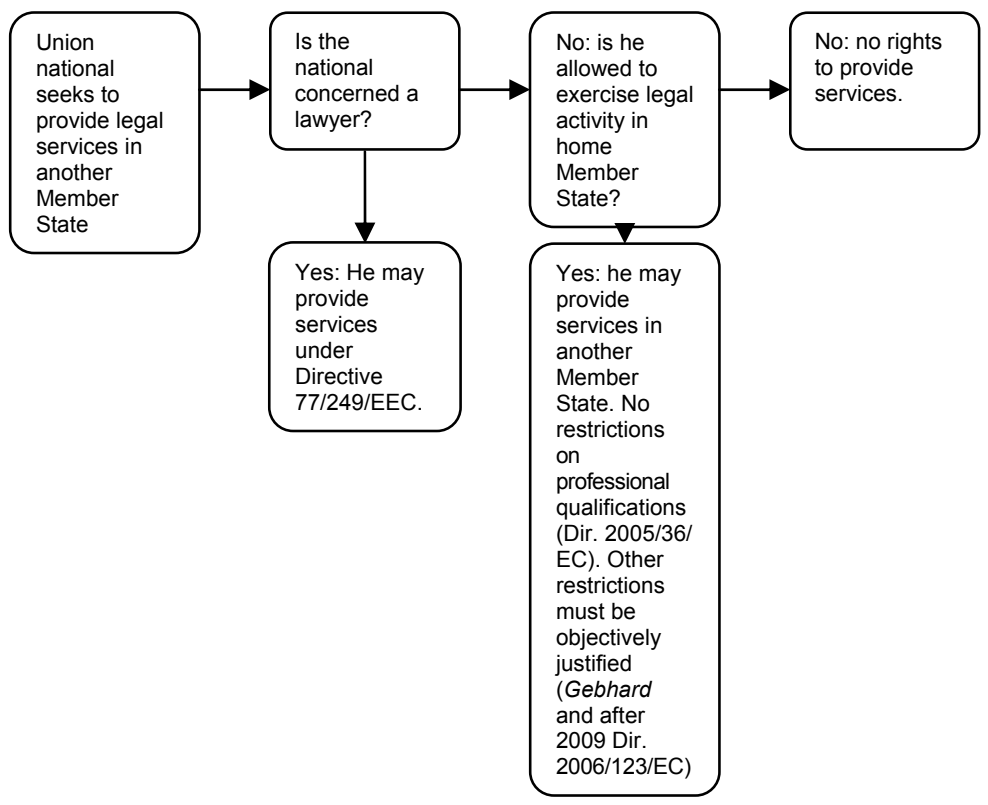

$478 \ 2$ of Article 16 of Directive 2006/123/EC forbids: (a) an obligation on the provider to have an establishment in their territory; (b) an obligation on the provider to obtain an authorisation from their competent authorities including entry in a register or registration with a professional body or association in their territory, except where provided for in this Directive or other instruments of Community law; (c) a ban on the provider setting up a certain form or type of infrastructure in their territory, including an office or chambers, which the provider needs in order to supply the services in question; (d) the application of specific contractual arrangements between the provider and the recipient which prevent or restrict service provision by the selfemployed; (e) an obligation on the provider to possess an identity document issued by its competent authorities specific to the exercise of a service activity; (f) requirements, except for those necessary for health and safety at work, which affect the use of equipment and material which are an integral part of the service provided; $(\mathrm{g})$ restrictions on the freedom to provide the services referred to in Article 19 (which relates to recipients of services). 
After this short excursion into the rights of non-lawyers to provide legal services in Member States that reserve such activities for lawyers, it is now time to turn to a review of the free provision of services by lawyers in the Member States considered. This review will focus mainly on those situations that are contrary to the Services Directive.

\section{3.2 The Free Provision of Services by Lawyers in the Member States}

\section{Sweden}

As was observed in the previous paragraph, Sweden represents a jurisdiction within which there is a complete lack of a legal monopoly for lawyers. None of the activities that lawyers normally perform, including the representation of clients in court, are legally protected. That means that anyone can exercise these activities, including lawyers from other Member States. Furthermore, in theory, at least, implementation of the Services Directive would have been very easy in Sweden, or even superfluous. Although the Directive was implemented in Sweden according to EUR-LEX, ${ }^{479}$ this adaptation of the Rättegaingsbalken (Code of Judicial Procedure) seems to be dissolved by later adaptations to the Rättegangsbalken, most notably the implementation of Directive 98/5/EC, which will be dealt with below. The Rättegangssbalken that is in force today and the Charter of the Swedish Bar Association (Stadgar för Sveriges Advokatsamfund $)^{480}$ make no mention of the freedom to provide services. Based on the absence of a legal monopoly in Sweden it must be assumed that lawyers from other Member States are free to provide services in Sweden and co-operation with a lawyer from a host Member State, in this case an advokat, will not be enforced.

\section{Finland}

Similar observations can be made for Finland. In EUR-LEX there is no specific reference to an implementation instrument of the Services Directive in the Finnish legal system. Moreover, neither the Advocates Act nor the By-laws of the Finnish Bar Association ${ }^{481}$ specifically address the freedom to provide services by lawyers of other EU Member States. There is however one article in the Advocates Act that may apply to lawyers providing services in Finland, however, its application is problematic in the light of the Services Directive. In Section 5a of the Advocates Act it is stated that when a lawyer from another Member State pursues a mandate in Finland he must act under his home country professional title. Moreover, he will be subject to Finnish professional rules when representing a client in court and while exercising other activities. This latter part is problematic in the light of the Services Directive that states that in relation to activities other than the representation of clients in court the home Member State's rules apply unless application of host Member State rules is objectively justified in the light of Article 4 of Directive 77/249/EEC.

\footnotetext{
479 Lag om ändring i rättegångsbalken, Svensk författningssamling (SFS) 1992:1511.

$480 \quad$ Via $<$ www.advokatsamfundet.se $>$, last accessed 6 November 2007.

481 Via <www.advonet.fi>, last accessed 6 November 2007.
} 


\section{Denmark}

In Denmark the free provision of services is covered by a regulation on the Government level. ${ }^{482}$ The Bekendtgørelse states that Articles 3 and 4 of Directive 77/249/EEC will be directly applicable in Denmark. In addition, the Bekendtgørelse states that a lawyer must co-operate with an advokat while representing clients in court, and that the competent authority may require proof of professional qualification and permission to practise in the home Member State. All these rules are in full accordance with the Directive.

\section{United Kingdom}

In the United Kingdom Directive 77/249/EEC was implemented by means of a statutory instrument, a sub-law level of regulation. ${ }^{483}$ This order from 1978 applies to both barristers and solicitors in all jurisdictions of the United Kingdom. The order states that persons who are qualified as lawyers in other Member States of the European Union may provide services in the United Kingdom. When providing services that entail the representation of a client in court the lawyer is obliged to cooperate with a barrister/advocate or a solicitor who has audience rights in that specific court. ${ }^{484}$ This requirement is in accordance with the Services Directive.

\section{Ireland}

The free provision of services for lawyers from other jurisdictions of the European Union in Ireland is regulated by statute. ${ }^{485}$ The division of the legal profession in Ireland between the professions of a solicitor and a barrister could be problematic, but it seems from the statutory instrument that a visiting lawyer has the freedom to exercise activities in both professions in Ireland. The implementation is in conformity with the Services Directive, excluding some specific activities for lawyers from other Member States, and requiring lawyers to cooperate with an Irish lawyer who has audience rights for a court.

\section{The Netherlands}

In the Netherlands the free provision of services is implemented in the Advocatenwet. ${ }^{486}$ Articles 16a-16f of the Advocatenwet cover the services provided by lawyers from other Member States. Like the Member States observed earlier in this paragraph, the Netherlands also imposes obligatory co-operation with a Dutch advocaat in those cases where Dutch law requires compulsory representation by an advocaat. ${ }^{487}$

482 Bekendtgørelse om EU-advokaters tjenesteydelser her i landet, 14 September 2001, via <www. advokatsamfundet.de>, last accessed 6 November 2007.

483 European Communities (Services of Lawyers) Order 1978 (S.I. 1978/1910) Most recently amended by European Communities (Services of Lawyers) (Amendment) Order 2004 (S.I. 2004/1117).

484 Yaqub (1993), p. 314.

485 S.I. 58/1979 European Communities (Freedom to provide services) (Lawyers) Regulations, 1979, as amended by S.I. 179/1981 and S.I. 226/1986, via <www.irishstatutebook.ie>, last accessed 25 August 2005.

486 By means of the Wet van 15 october 1980, Stb. 1980, 588

487 Article 16e Advocatenwet. 
The Netherlands has also correctly implemented the rules with regard to professional rules and use of professional title. ${ }^{488}$

\section{Belgium}

In Belgium the free provision of services by lawyers from Member States of the European Union is governed by Title Ibis of the Gerechtelijk Wetboek. The first three articles of Title Ibis of the Gerechtelijk Wetboek (Articles 477bis-477quater) deal with the free provision of services. Article $477 \mathrm{bis}$ states that persons who are allowed to practise as a lawyer in their home Member State may also use their home country professional title when pursuing activities in Belgium. ${ }^{489}$ Indeed, such a lawyer must use his home country professional title in the language of his home Member State. He must also indicate to which professional organisation he belongs in his home Member State and the courts he may plead before in his home State. ${ }^{490}$ According to Article 477ter a lawyer providing services in Belgium on the basis of Article $477 \mathrm{bis}$ may exercise the same professional activities as a lawyer who is a member of a Belgian Bar. ${ }^{491}$ The second sentence of that paragraph immediately states that for activities with regard to representing a client in court a lawyer providing services in Belgium must cooperate with a lawyer who is a member of a Belgian Bar. Paragraph 2 of the same article states that for a lawyer providing services in Belgium, in addition to the professional rules of his home Member State, he is also subject to the rules of professional conduct that have been laid down in Belgian legislation. ${ }^{492}$

It is worth mentioning that the Belgian professional rules are not imposed ipso facto. First of all, it is explicitly mentioned that all rules with regards to nationality and residence find no application to lawyers providing services in Belgium. However, other rules of professional conduct do not find automatic application. First of all, it must be established that the professional rule in question can be applied to a lawyer not established in Belgium. Secondly, and more importantly, it must be established that the application of the rule of professional conduct must be objectively justified as a safeguard for the correct exercise of the activity of a lawyer, for the dignity of the profession of lawyer, taking into account the rules of incompatibility. ${ }^{493}$ Paragraph 3 of the Article states that the exercise of the profession of the lawyer in Belgium by a lawyer who is established in another Member State is incompatible with every form of salaried occupation, whether public or private, unless it affects neither the independence of the lawyer nor the dignity of the Bar. ${ }^{494}$

The final article regarding free provision of services is Article 477quater which deals with disciplinary proceedings. The Article first of all lays down the fact that the Belgian rules regarding disciplinary proceedings and professional rules are applicable to all lawyers providing services in Belgium. The Article further states that the rules

488 Articles $16 \mathrm{~d}, 16 \mathrm{f}$ and $16 \mathrm{~b}$ respectively.

489 Article 477bis $\$ 1$ Gerechtelijk Wetboek.

490 Article 477bis $\$ 2$ Gerechtelijk Wetboek.

491 Article 477ter $\$ 1$ Gerechtelijk Wetboek.

492 Article 477ter $\$ 2$ Gerechtelijk Wetboek.

493 Belgium is so far the only State that has implemented the Kumulatzionsprinzip in such a detailed manner, which leads to the application for a 'rule of reason' test every time a Belgian rule of professional conduct is applied to a lawyer from another Member State, providing services in Belgium.

494 Article $477 \operatorname{ter} \$ 3$. 
regarding the profession and disciplinary proceedings from the lawyer's home Member State shall also stay in force during the lawyer's stay in Belgium. When lawyers do not adhere to the professional conduct rules they can be prevented from providing services in Belgium for a period of three years at most. ${ }^{495}$ Appeal is possible against the decision to bar a lawyer from practising in Belgium. For offences that would lead to removal from the tableau for Belgian lawyers, the sanction against lawyers providing services is a prohibition on practise in Belgium. A lawyer can ask for revision until ten years after the sentence has been imposed. ${ }^{496}$ The second paragraph of the Article states that the relevant authority shall be the council of the relevant Bar Association. ${ }^{497}$

\section{Luxembourg}

The free movement of services in the Grand-Duchy of Luxembourg is also regulated by law. ${ }^{498}$ The law pertaining to services is found in Luxembourg's implementation of Directive $77 / 249 / \mathrm{EEC}$ into its legal system. The law states that lawyers from other EU Member States may exercise the same activities as Luxembourg avocats, however the rules differ with regards to residence and enlisting with a Luxembourg Bar. ${ }^{499}$ For the representation of clients in court the lawyer providing services is obliged to cooperate with a Luxembourg avocat and he also needs to be introduced by the batônnier to the leading magistrate in the relevant jurisdiction. The Luxembourg professional rules apply fully with regard to activities for the representation of clients but there is a rule of reason for the application of rules of professional conduct for other activities. ${ }^{500}$ There are no abnormalities in the services law when compared to Directive 77/249/EEC.

\section{France}

In France the free provision of services by lawyers is regulated in the décret $d u 27$ novembre $1991 .^{501}$ Title 5 of this décret lays down the rules for this matter. ${ }^{502}$ Article 200 of the décret states that lawyers who are allowed to practise under the professional titles listed in Article 201 of the décret ${ }^{503}$ are allowed to exercise the profession of lawyer in France to the same extent as avocats on a temporary basis. ${ }^{504}$ While exercising professional activities in France the lawyers from other Member States are

495 Article 477 quater $\ 1$ Gerechtelijk Wetboek.

496 Ibid.

497 Article 477 quater $\ 2$ Gerechtelijk Wetboek.

498 Loi du 29 avril 1980 réglant l'activité en prestations de service, au Grand-Duché de Luxembourg, des avocats habilités à exercer leurs activités dans un autre Etat membre des Communautés Européenes, Memorial Journal Officiel du Grand-Duché de Luxembourg, Recueil de Legislation, A-No. 32, 14 mai 1980, page 747, hereinafter referred to as the Services law.

499 Article 2 Services law.

500 Articles 3 and 4 Services law. This is completely in accordance with Article 4 of Directive 77/249/EEC.

501 Décret no 91-1197 du 27 novembre 1991 modifié organisant la profession d'avocat, JO de la République Française, 28 novembre 1991, 15502.

502 Originally Directive 77/249/EEC was implemented in Décret no. 79-233 du 22 mars 1979, JO de la République Française 23 mars 1979, 695, but this was included in the new décret in 1991.

503 Which are all the professional titles for the profession of lawyer for all the Member States.

504 Article 200/201 of the décret du 27 novembre 1991. 
subject to French professional rules when representing clients in court and to their home Member State rules while exercising other activities. In the latter case French rules may only be applied where this is objectively justified. ${ }^{505}$ With respect to the representation of clients in court, it is interesting to note that the rule that requires compulsory cooperation with a French avocat $t^{506}$ is only applied to civil litigation. In administrative and penal litigation, a lawyer can represent clients on his own. ${ }^{507}$ Rules for disciplinary proceedings are also laid down in conformity with Directive 77/249/EEC. ${ }^{508}$

\section{Italy}

In Italy a separate law implements the free provision of services as guaranteed by Directive 77/249/EEC. ${ }^{509}$ Lawyers may provide services under their home country professional title, ${ }^{510}$ representation of clients in court must be conducted in cooperation with an Italian lawyer ${ }^{511}$ and the lawyer providing services must adhere to Italian professional rules. ${ }^{512}$ These provisions are in principle in accordance with the Directive. The only possible problem is that there is no reference to the objective justification test for the application of the host Member State's professional rules regarding activities that do not entail the representation of clients in court. Moreover, there is another provision in the law implementing Directive $77 / 249 / \mathrm{EEC}$ in Italy that is not in accordance with European law. Article 1 of the Legge 9 febbraio 1982 states that services may only be provided if the lawyer concerned does not have any infrastructure in the form of an office in Italy. ${ }^{513}$ This requirement was one of the complaints the European Commission brought before the European Court of Justice in case C-145/99, which dealt with Italian inconsistencies in connection to the free movement of lawyers. The Court wasted little time and words in arriving to the conclusion that the requirement of having no infrastructure in the host Member State is contrary to European law. The Court stated that it had decided in the Gebhard case $^{514}$ that it was in accordance with the free provision of services for lawyers that a lawyer could have a certain infrastructure at his disposal in the host Member State, and that the infrastructure as such was not the determining factor between establishment and provision of services. ${ }^{515}$ Moreover, the reasoning as to why Italy has included this provision in the Legge 9 febbraio has become redundant after the

\footnotetext{
505 Article 202/203 of the décret du 27 novembre 1991.

506 The term of avoué is still used in the text of the décret, but, as described above, these professions have merged in recent history.

507 Article 202 of the décret du 27 novembre 1991.

508 Article 204 of the décret du 27 novembre 1991.

509 Legge 9 febbraio 1982, n. 31 Libera prestazione di servizi da parti degli avvocati cittidani degli stati membri delle comunità europee, Gazzetta Ufficiale n.42, 12-02-1982.

$510 \quad$ Article 3 Legge 9 febbraio 1982.

511 Article 6 Legge 9 febbraio 1982.

512 Article 11 Legge 9 febbraio 1982.

513 Article 2 Legge 9 febbraio 1982.

514 Case C-55/94, Reinhard Gebhard v. Consiglio dell'Ordine degli Avvocatie e Procuratori di Milano, [1995] ECR 4165.

$515 \int 22$ case C-145/99. This is the same proposal as mentioned earlier. Progetto di Legge N.5211, Nuove disposizioni sulla professione di avvocato. No evidence is present that this proposal has been transformed into a law at this point in time.
} 
coming into force of Directive 98/5/EC. Italy included this provision in order to prevent illegal establishment under home title, since that form of establishment was not allowed in Italy. ${ }^{516}$ As this form of establishment is expressly allowed by Directive $98 / 5 / \mathrm{EC}$ there is no longer any reason to adhere to this prohibition. In case C-145/99, Italy claimed that in order to remove possible infringement of Article 59 EC the Italian government proposed a bill to the Italian Parliament repealing the contested part of Article 2 of the Legge 9 febbraio 1982. ${ }^{517}$

\section{Spain}

In Spain lawyers from other Member States can provide services on the basis of Directive 77/249/EEC. This Directive is implemented in Spain by means of a Real Decreto. ${ }^{518}$ The Real Decreto is a straightforward implementation of Directive 77/249/ EEC. Lawyers providing services including the representation of clients before a court are compelled to cooperate with an abogado (presumably in addition to working with a procurador $)^{519}$ and as forprofession rules, the kumulatzionsprinzip applies. ${ }^{520}$ In the original implementation, Article 9(2) prescribed a maximum number of cases that a lawyer providing services in Spain could deal with in a year. This subsection was abolished after the Commission v. Germany case. ${ }^{521}$

$516 \int 21$ case C-145/99.

517 Ibid.

518 Real Decreto 607/1986, de 21 de marzo, de desarollo de la Directiva de Consejo de las Comunidades Europeas de 22 de marzo de 1977, encaminada a facilitar el ejercicio efectivo de la Libre Prestación de Servicios de los Abogados, BOE 78/1986 de 01-04-1986, p. 11479. Articles 6 and 9 of the Real decreto were changed by means of Real Decreto 1062/1988, de 16 de septiembre, por el que se modifica el Real Decreto 697/1986, de 21 de marzo, de desarollo de la Directiva del Consejo de las Comunidades Europeas de 22 de marzo de 1977, encaminada a facilitar el ejercicio efectivo de la Ley 36/1988, de 5 de diciembre, de Arbitraje, BOE 227/1988 de 21-09-1988, p. 27737, after the judgment of the ECJ in Case 427/85, Commission v. Germany, [1988] ECR 1123.

519 Article 6 Real Decreto 607/1986, de 21 de marzo, de desarollo de la Directiva de Consejo de las Comunidades Europeas de 22 de marzo de 1977, encaminada a facilitar el ejercicio efectivo de la Libre Prestación de Servicios de los Abogados. This article, which required collaboration with an Abogado even in situations where representation by an Abogado was not prescribed by Spanish law, was changed after the Commission v. Germany case by Article 1 of the Real Decreto 1062/1988, de 16 de septiembre, por el que se modifica el Real Decreto 697/1986, de 21 de marzo, de desarollo de la Directiva del Consejo de las Comunidades Europeas de 22 de marzo de 1977, encaminada a facilitar el ejercicio efectivo de la Ley 36/1988, de 5 de diciembre, de Arbitraje, BOE 227/1988 de 21-09-1988, p. 27737

520 Article 7 Real Decreto 607/1986, de 21 de marzo, de desarollo de la Directiva de Consejo de las Comunidades Europeas de 22 de marzo de 1977, encaminada a facilitar el ejercicio efectivo de la Libre Prestación de Servicios de los Abogados.

521 See Merino-Blanco (1996), p. 111. Article 9(2) Real Decreto 607/1986, de 21 de marzo, de desarollo de la Directiva de Consejo de las Comunidades Europeas de 22 de marzo de 1977, encaminada a facilitar el ejercicio efectivo de la Libre Prestación de Servicios de los Abogados. This article was abolished by Article 2 of Real Decreto 1062/1988, de 16 de septiembre, por el que se modifica el Real Decreto 697/1986, de 21 de marzo, de desarollo de la Directiva del Consejo de las Comunidades Europeas de 22 de marzo de 1977, encaminada a facilitar el ejercicio efectivo de la Ley 36/1988, de 5 de diciembre, de Arbitraje, BOE 227/1988 de 21-09-1988, p. 27737. 


\section{Portugal}

Although Directive $77 / 249$ /EEC was originally implemented in Portugal in the $1980 \mathrm{~s},{ }^{522}$ it was also included in the implementation of Directive 98/5/EC (which will be addressed at a later stage) by means of a separate law, the Lei 80/2001 de 20 de Julho. ${ }^{523}$ This law creates a separate title in the Advogado law $^{524}$ to cover the free movement of lawyers. The Advogado law states that a lawyer who is established in an EU Member State may provide services ${ }^{525}$ in Portugal under his home country professional title. ${ }^{526}$ Lawyers exercising their professional activity under their home title are obliged to cooperate with an advogado if the exercise of their professional activities entails the representation of clients in Portuguese courts. ${ }^{527}$ With regard to applicable professional rules, the Advogado law states that, without prejudice to the professional rules applicable to the lawyer in his home Member State, activities of a lawyer in the host Member State will be subject to the professional rules of the host State. ${ }^{528}$ Clearly this formulation is not in accordance with Article 4 of Directive $77 / 249$ /EEC because it requires a distinction to be made between services related to representing a client in court to which host country professional rules apply, and other activities. As for other activities, in principle, home State professional rules apply, except in cases of incompatibility, where the application of host Member State rules is objectively justified. Therefore it might be concluded that the 're-implementation' of the Services Directive in Portugal is not in accordance with the Directive.

\section{Germany}

In Germany a similar operation was undertaken to that of Portugal. Even though the Services Directive had already been implemented in Germany ${ }^{529}$ it was included in a major overhaul in the process of implementation of Directive 98/5/EC. This led to the adoption of a single legal instrument that covered the free movement of lawyers in all three modalities in Germany, the Gesetz zur Umsetzung von Richtlinien der Euro-

522 Decreto-Lei n. 119/86 de 28/05/1986. Harmoniza o direito interno ao preceitado na Directiva do Conselho 77/249/CEE, de 22 de Março de 1977, relativa à livre prestação de serviços em Portugal por advogados de outros Estados membros das Comunidades Europeias. Diário da Republica I Série de 28/05/1986 Página 1281

523 See <www.dgci.min-financas.pt/NR/rdonlyres/6EBCF62A-1E11-421A-BFE2-95CF8E9BB985 /0/lei_80-2001_de_20_de_julho_i_serie_a.pdf $>$, last accessed 06 November 2007.

524 Estatuto da Ordem dos Advogados. Lei n. 15/2005, de 26 de Janeiro de 2005. - Aprova o Estatuto da Ordem dos Advogados e revoga o Decreto-Lei n. 84/84, de 16 de Março, com as alterações subsequentes. In diário da República. - S.1-A n.18 (26 Janeiro 2005), pp. 612-646.

Article 198 (1) Advogado law.

Article 197 (1) Advogado law.

Article 197 (2) Advogado law.

Article 199 (1) Advogado law.

Gesetz zur Durchfuihrung der Richtlinie des Rates der Europäischen Gemeinschaften vom 22.

März 1977 zur Erleichterung der tatsächlichen Ausübung des freien Dienstleistungsverkehrs der Rechtsanwälte vom 16/08/1980, Bundesgesetzblatt Teil I vom 22/08/1980 Seite 1453; Erstes Gesetz zur Änderung des Gesetzes zur Durchführung der Richtlinie des Rates der Europäischen Gemeinschaften vom 22/03/1977 zur Erleichterung der tatsächlichen Ausübung des freien Dienstleistungsverkehrs der Rechtsanwälte vom 14/03/1990, Bundesgesetzblatt Teil I vom 21/03/1990 Seite 479. 
päischen Gemeinschaft auf dem Gebiet des Berufrechts der Rechtsanwälte (EuRAG). ${ }^{530}$ The fifth part of the EuRAG ( $\$ S 25$ to 35 ) governs the provision of services for lawyers in Germany as established by Directive 77/249/EEC. The EuRAG states that a lawyer may provide services ${ }^{531}$ under his or her home country professional title. ${ }^{532}$ Lawyers may exercise all legal services ${ }^{533}$ but when representing clients in court they must be accompanied by a German lawyer. ${ }^{534}$ In the previous chapter it was shown that this provision (or rather, its counterpart in the previous implementation mechanism) led to case law of the European Court of Justice on the application of the cooperation rule. ${ }^{535}$ Under the new mechanism this rule is implemented correctly. Also the rules with regard to applicable professional rules ${ }^{536}$ are implemented correctly.

\section{Austria}

In Austria a similar operation took place to that in Portugal and Germany. Even though the Directive had been implemented earlier ${ }^{537}$ it was re-implemented at the time Austria implemented the Establishment Directive in the Bundesgesetz über den freien Dienstleistungsverkehr und Niederlassung von europäischen Rechtsanwälten in Österreich (hereinafter EuRAG). ${ }^{538}$ The first and second part of the EuRAG (paragraphs 1 to 8) deal with the free provision of services by lawyers from other Member States in Austria. Paragraph 1 states that that part of the law applies to every lawyer who is entitled to practise as a lawyer in one of the Member States of the European Union or the European Economic Area (provided that the person has the nationality of one of the Member States of those organisations). These lawyers are referred to as europäische Rechtsanwälte (European lawyers) ${ }^{539}$ In principle a European lawyer practising under his home title, ${ }^{540}$ while being subject to the same rules of professional conduct as an Austrian Rechtsanwalt, ${ }^{541}$ is entitled to exercise any activity that an Austrian Rechtsanwalt may do albeit with the restrictions laid down in that part of the law. ${ }^{542}$ These restrictions mainly consist of the fact that when representing a client in court

530 Gesetz zur Umsetzung von Richtlinien der Europäischen Gemeinschaft auf dem Gebiet des Berufrechts der Rechtsanwälte, 9 March 2000, BGBl, 2000 I, page 182. What is notable about this law is that it not only transfers Directive 98/5/EC but also Directives 89/48/EEC and 77/249/EEC.

$531 \int 25$ EuRAG.

$532 \int 26$ EuRAG.

$533 \int 27$ EuRAG.

534 SS 28-30 EuRAG.

535 Case 427/85, Commission v. Germany, [1988] ECR 1123.

536 SS 27-28 EuRAG.

537 Bundesgesetz über die Ausübung des freien Dienstleistungsverkehrs und die Niederlassung von Rechtsanwälten aus dem Europäischen Wirtschaftsraum (EWR-Rechtsanwaltsgesetz 1992 AG 1992) sowie Änderungen der Rechtsanwaltsordnung, des Rechtsanwaltsprufungsgesetzes und des Berufsprüfungs-Anrechnungsgesetzes. Bundesgesetzblatt für die Republik Osterreich, Nr. 21/1993, ausgegeben am 14/01/1993.

538 Bundesgesetz über den freien Dienstleistungsverkehr und die Niederlassung von europäischen Rechtsanwälten in Österreich (EuRAG) sowie Änderungen der Rechtsanwaltsordnung, 23 May 2000, BGBl I 27/2000.

$539 \int 1$ EuRAG.

540 \3(1) EuRAG.

$541 \int 4(1)$ EuRAG.

$542 \int 2$ EuRAG. 
a European lawyer must be accompanied by a registered Austrian Rechtsanwalt. ${ }^{53}$ Lawyers who provide services are only allowed to have an office in Austria in so far it is necessary to provide the services. ${ }^{54}$ This last requirement is clearly dubious after the Court's ruling in Gebhard, where it was held that having an infrastructure was deemed irrelevant for the distinction between services and establishment.

\section{Greece}

The rules implementing Directive 77/249/EEC in Greece also have a number of peculiar features which must be mentioned in this chapter. When a lawyer seeks to exercise his right to freely provide services in Greece he must notify the authorities of the fact that he seeks to come to Greece to provide services at least two days before he does so. He must provide identification and he must inform the authorities of the nature and the length of the activities which he wants to exercise as a lawyer in Greece. ${ }^{545}$ After the lawyer has been approved, he will be included in a register of European lawyers that is kept especially for this purpose by the respective Bars. When representing a client in court the lawyer providing services in Greece must cooperate with a Dikigoros and he must provide the President of the court with a document from the Greek Bar stating that he has fulfilled his duties in connection with the free provision of services. As a result of earlier case law from the European Court of Justice an earlier rule that required lawyers providing services in Greece to cooperate with a Dikigoros at all times was abolished. ${ }^{546}$ Kommatas discussed another interesting rule, namely the fact that a lawyer who provides services in Greece may not set up an office in Greece in order to facilitate that provision of those services. ${ }^{547}$ It must be noted, however, that Kommatas' piece predates the judgment of the European Court of Justice in Gebhard after which it was made more than clear that the freedom to provide services also included the right to set up an office in the host Member State in order to facilitate the free provision of services. Although Kerameos makes no mention of the rule in her article, ${ }^{548}$ which dates from 2001, it still is clear from all the formalities surrounding the exercise of the freedom to provide services that the legal profession is not very accessible in Greece. Greece is the only country reviewed that imposes the requirement of prior notification, at least in the implementation device itself. In light of the developments that have been described with respect to Directives 2005/36/EC and 2006/123/EC, it will be highly unlikely for the Court to quash this requirement. The prohibition on infrastructure is, of course, in violation of the Directive.

\section{$\llbracket 3.3$ Observations with regard to Services}

It has been observed that the new Diploma Recognition Directive, Directive 2005/36/EC, has largely improved the situation of those professionals who seek to

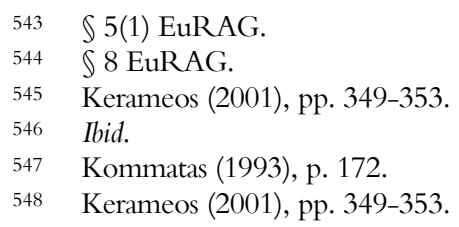


provide legal services in another Member State but who are not fully qualified lawyers. Where previously the situation of these professionals was uncertain and was only covered by the capstone rules in Gebhard, the rules found under Directive 2005/ 36/EC lay down a solid foundation for the possibility to provide legal services in those Member States where such activities belongs to the profession of the lawyer. In 2009 , this protection will be offered even more thoroughly by the implementation of the rules laid down in Directive 2006/123/EC. In this respect a silent revolution has occurred, since there seems to be no professional or academic debate (apart from the CCBE position on services) that reflects a full understanding of the potential impact of these possibilities.

These new Directives do not touch on the position of fully qualified lawyers in their ability to provide services. The provision of services by fully qualified lawyers is, after 30 years, still covered by Directive 77/249/EEC, which has been duly implemented and even in some instances re-implemented in the Member States observed above. In these 30 years the Services Directive has only generated a little case law, which was dealt with in the previous chapter. That does not mean that the Member States have an unblemished track-record for implementation. Two modalities of problematic implementation have been observed. First of all, a number of Member States have had difficulties in applying the rather complicated rules of applicable professional rules. In some cases the division between activities relating to the representation of clients in court and other activities, and the application of sets of professional rules leads to difficulties or over-simplification. Member States just lay down the obligation to adhere to host Member State professional rules. Such a view, or implementation for that matter, is incompatible with the Directive. Secondly, there are additional requirements in the different implementing instruments that have, as such, no basis in the Directive. Examples are rules on infrastructure (offices) or notification procedures. From the previous chapter it follows that two different regimes can be applied to such a situation. First, the ECJ, in a hypothetical case, may come to the conclusion that a certain rule (e.g. the rules on infrastructure) is contrary to the spirit of the Directive and therefore violates European law, as had been the case in $A M O K$. Where this is not the case, the Gebhard capstone rules apply, implying that the additional rule must be objectively justified by the Member State since it is liable to hinder or make less attractive the exercise of the free provision of services.

With regard to the anomalies observed, I believe that the rules on infrastructure, as they have been, observed can no longer be upheld after Gebhard, where it was expressly stated that the exercise of the freedom to provide services was not defined by having a certain infrastructure. Therefore, such rules need to be objectively justified, or where it can be established that they go against the spirit of the Directive, be held to be a direct violation of the Directive. The rules on prior notification that are applied by Greece, on the other hand, seem to be in accordance with what is laid down in the new Directives, and may therefore be deemed to be in accordance with the Services Directive and hence objectively justified.

Based on this review of implementation procedures, the situation of fully qualified lawyers who provide services can be refined and represented as follows: 
Figure 4: Free provision of services for qualified lawyers

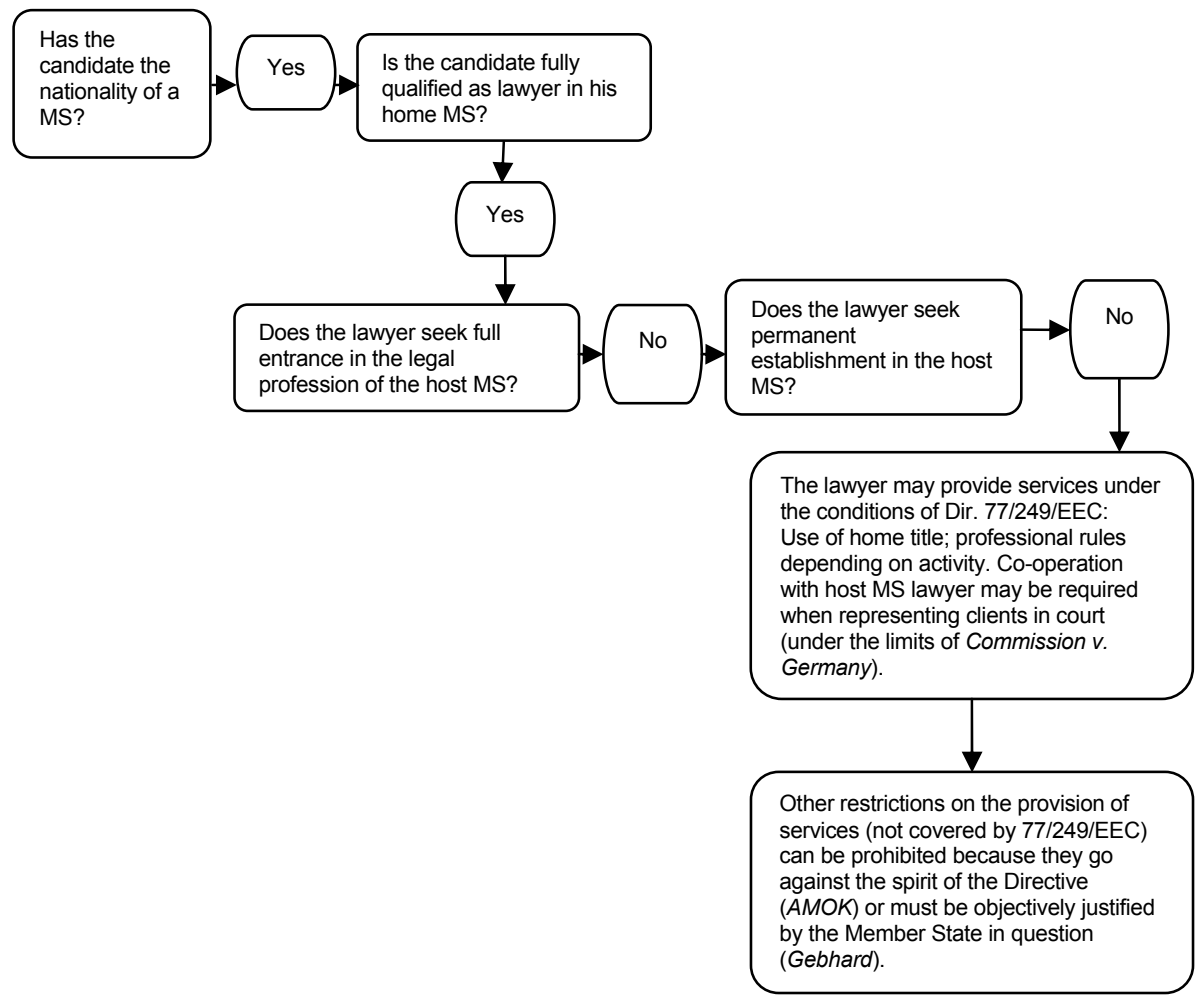

\section{$\$ 4$. Establishment of Lawyers under their Home Country Professional Title}

The second modality of the free movement of lawyers, viewed from the degree of integration in the host Member State's profession, is the establishment of lawyers under their home country professional title. This modality is laid down in Directive 98/5/EC and was, from a chronological point of view, the last modality to be regulated by the legislative institutions. This paragraph will focus on the exercise of this modality.

To that end, this paragraph will follow largely the same structure as the previous one. First, some attention will be devoted to those professionals who exercise activities in Member States with a lesser level of regulation who belong to the legal monopoly of lawyers in other Member States with a higher degree of regulation. This will then be followed with a review of the implementation of Directive 98/5/EC. This review is more detailed than the review given to the Directives in the other two modalities, since Directive $98 / 5 / \mathrm{EC}$ is the newest instrument specifically dedicated to lawyers, and a detailed review of its implementation has, until now, never been given. In order to place the review of implementation into context it will be preceded by a more 
theoretical exercise, exploring the exact impact that Directive 98/5/EC has on national regulation of the free movement of lawyers. The establishment under home title can be represented as follows:

Figure 5: Establishment under home country title

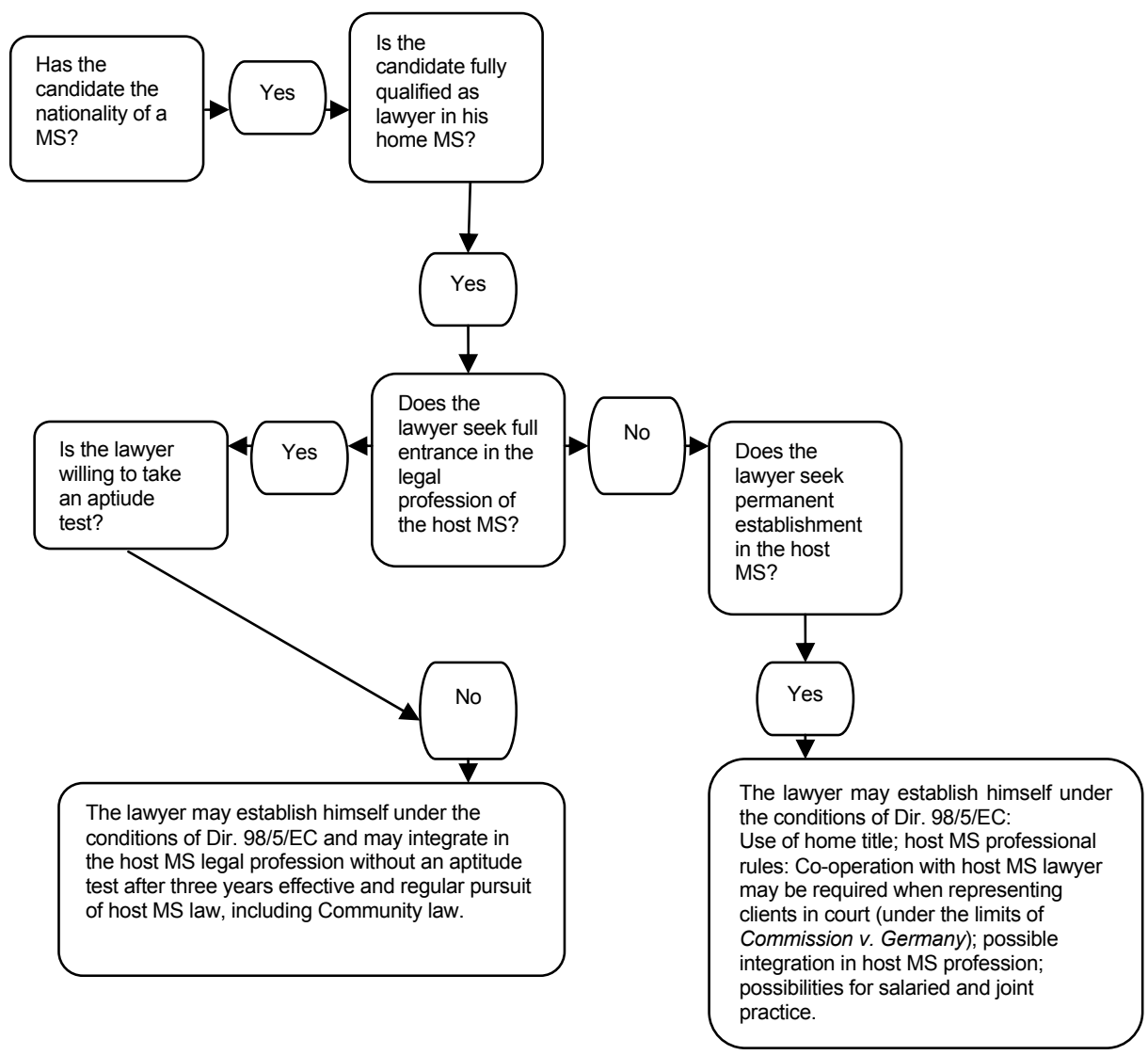

\section{\4.1 Establishment for Non-Lawyers in Highly Regulated Member States}

In the previous chapter it had been established that the origins of the Establishment Directive can be traced back to the 1970s and that the structure of the Establishment Directive closely mimics that of the Services Directive. This is certainly the case for the personal scope of application of the Establishment Directive. Similar to the Services Directive, the benefits of the Establishment Directive are only available to those professionals who are Union nationals and who are fully qualified in one of the professions mentioned in Article 1(2) of Directive 98/5/EC. Aside from implications for those who are still training to become lawyers (as dealt within the previous chapter and later below) this also has large implications for professionals 
exercising legal activities in Member States with a lesser degree of regulation who seek establishment in Member States that have a high degree of regulation, i.e., where these activities are reserved for the lawyer covered by Directive 98/5/EC.

Clearly these professionals do not enjoy any rights under Directive 98/5/EC. It can also be easily imagined that Member States with a high degree of regulation will not allow these professionals to become established in their Member State under their home country title. It must be indicated, though, that these individuals do have the right to establish themselves as part of the host country's profession. The details of this exercise will be dealt with in the next paragraph. At this point it suffices to state that in this case these professionals will also be subject to stringent compensatory measures in the form of an aptitude test, before full establishment is allowed.

In the previous paragraph it had been established that the new Diploma Directive (Directive 2005/36/EC) and the Directive on Services (Directive 2006/123/EC) include rules that apply to professionals exercising legal services in Member States with a high degree of regulation. This is not the case for incidences of establishment under home title. Neither Directive 2005/36/EC nor Directive 2006/123/EC contain specific provisions on establishment under home title. This means that a professional who seeks establishment under home title, in order to exercise legal activity as a non-lawyer in a Member State that has a high degree of regulation, can only rely on the capstone rules of Gebhard (and perhaps Vlassopoulou where the imposed restriction relates to diploma requirements). The possibilities for these professionals would look like this:

Figure 6: Establishment under home title including non lawyers

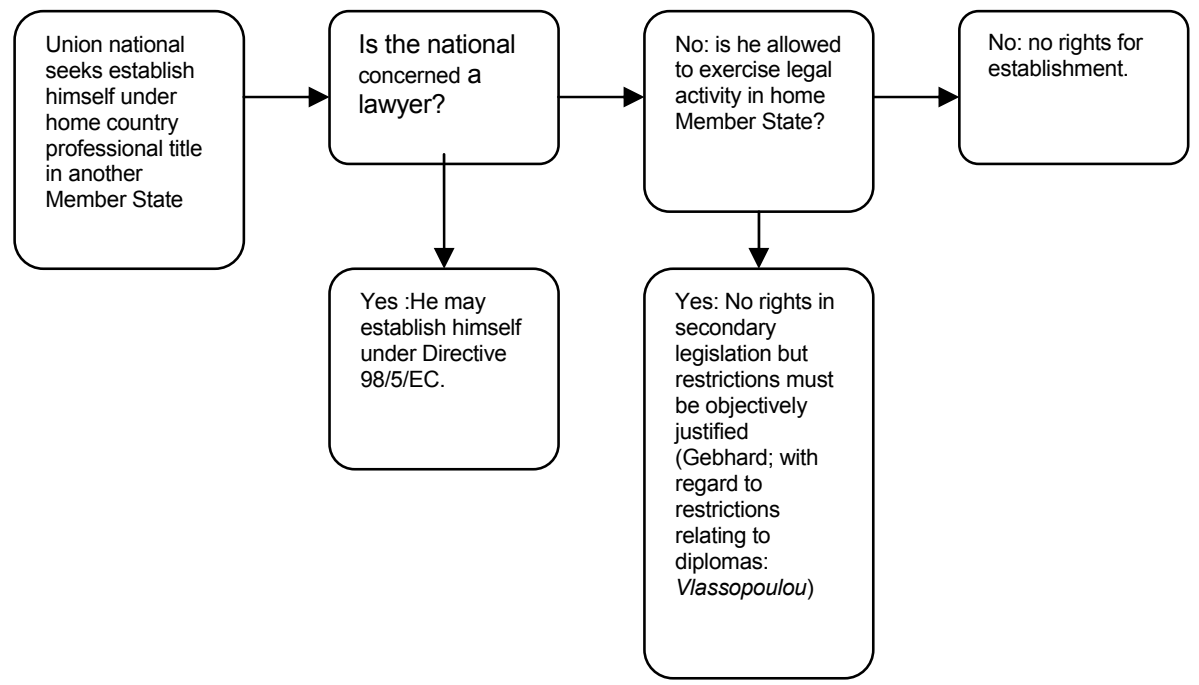

It can be observed that this situation looks a lot like the situation for lawyers before the adoption of the Establishment Directive. At that time lawyers who sought de facto establishment were forced to stretch the application of the Services Directive, 
the so-called installation limitée. It can also be observed in this respect that a similar development may take place for those professionals who are not lawyers and belongs to the legal monopoly of lawyers in Member States with a high degree of regulation but wish to exercise professional activities in less-regulated Member States. A difference in relation to the installation limitee is that, in this context, the European Court of Justice has given a clear ruling on the differences and mutual boundaries between establishment and services in the Gebhard case. On the one hand this may be beneficial for this category of persons since the Court has clearly stated that having an infrastructure (an office etc.) is not decisive for classifying an activity as one of services or establishment. The time factor is the only decisive element. Additionally, Directive 2005/36/EC states, in Article 5(2), that the temporary nature of the services shall be decided on a case by case basis. This means that the Member States cannot impose fixed time limits or limit recurrences of certain activities. On the other hand, it is now clear that the provision of services is limited in time and an 'endless' installation limitée is no longer reconcilable with the law as it stands today. At the time of writing no information is available that indicates whether, and to what extent, this modality of free movement occurs.

\section{$\S 4.2$ Impact of the Establishment Directive}

Before a detailed overview of the implementation of the Establishment Directive can be given, the impact of the Establishment Directive must be investigated. The main purpose of this investigation is to find out whether, and how much, residual legislative competence remains for the Member States after the implementation of the Establishment Directive. In general, this problem is influenced by two separate issues.

First, there is the extent of the competence of the European Community. ${ }^{549}$ If it could be established that the Community has exclusive competence the problem of residual legislative competence for Member State would be easily solved. This is because in areas of exclusive competence for the EU the Member States have no residual legislative competence. Although there is no exhaustive list of exclusive competences $^{550}$ it is generally accepted that the field of the internal market, to which Article 47 (the legal basis of the Establishment Directive) belongs, is not an exclusive competence but rather a shared competence. ${ }^{551}$ With regard to shared competences it is accepted that Member States retain legislative competence until the Community has acted. With regard to the Establishment Directive the extent of Community action must therefore first of all be established. Secondly, if it is decided that residual legislative competence exists, then which rules apply must be investigated.

Assessing the impact of a Directive in European law is not an easy task. Article 249 of the Treaty only provides a very limited amount of clarity as to the legal impact of a Directive in the national legal system. It establishes that the Member State must attain the result that is prescribed in the Directive. In a general sense, it can be said that the use of a Directive leads to 'harmonisation' of the legal provisions of the Member

\footnotetext{
549 See, for example: Craig \& de Burca (2007), pp. 101-102 and Arnull (2006), pp. 91-97.

550 Which will be included in Article 3 of the Treaty on the Functioning of the European Union which is envisaged to enter into force in 2009.

551 Arnull (2006), pp. 92-93.
} 
States. ${ }^{552}$ A Directive is generally addressed to all Member States (although it does not have to be), and since it prescribes a result that must be achieved, it is generally expected that the result will be equal in all Member States after the Directive is implemented.

The term 'harmonisation' as such leads to interpretational difficulties, and it seems that it has enjoyed some different meanings throughout the history of the European Community. ${ }^{553}$ Much of the literature uses the example of harmonisation in the field of health and safety requirements based on the free movement of goods. ${ }^{554}$ Deciding whether a directive leads to full or exhaustive harmonisation is ultimately ${ }^{555}$ of the competence of the European Court of Justice. ${ }^{556}$ Since full harmonisation leaves the Member States without any legislative competence in the relevant field whatsoever, great care is taken in the legislative process and instruments leading to full harmonisation are often the product of years of preparation and negotiation. ${ }^{557}$ It was the loss of time in the mid 1980s that led to the ultimate abandonment of the full harmonisation strategy (or at least the abandonment of full harmonisation as the only way to create harmonisation). ${ }^{558}$ The 'new' approach leads to a much less extensive harmonisation of laws of the Member States and is based on the principle of mutual recognition laid down in Cassis de Dijon. ${ }^{59}$ The process focuses on the creation of general rather than detailed rules in order to speed up and simplify the legislative process that must lead to the harmonisation measure. The essence of the new approach lies in the fact that a harmonisation measure only prescribes that free movement is ensured by means of mutual recognition, i.e., that Member States recognise each others' rules for the free movement of goods and/or persons. Taken in its purest form, harmonisation on the basis of mutual recognition does not need a legislative instrument as such. The ECJ underlined in the Cassis de Dijon judgment (and confirmed in the Gebhard case for all the four freedoms) that free movement was more or less defined by the principle of mutual recognition, i.e., the principle of mutual recognition ensured the working of free movement. Therefore, a legislative measure reconfirming that principle is not completely necessary. In practice, mutual recog-

552 Craig \& de Burca (2003), pp. 1189ff.

553 Ibid.

554 Barnard (2007), p. 589 ff.; Craig \& de Burca (2003), p. 1189 ff.; Weatherill (2006), p. 617 ff. Authors mainly focus on Article 95 as it provides the European Community with a somewhat general legal basis for harmonisation. Free movement of persons, however, does not fall under Article 95, and therefore more specific general bases need to be used. It will be demonstrated, however, that basic principles underlying harmonisation efforts are equal.

555 The European Commission, the European Parliament and the Council also have a say, of course, in this since the form in which a piece of secondary law is drafted will heavily influence the answer of the Court in deciding to which form of harmonisation a certain piece of legislation leads.

556 Barnard (2007), pp. 591-592, who uses the case C-323/93 Société Civile Agricole du Centre d'Insémination de la Crespelle v. Coopérative d'Elevage et d'Insemination Artificielle du Département de la Mayenne, [1994] ECR I-5077, as an example where the Court had to decide the extent of harmonisation in the unlikely subject of trade in deep-frozen bovine semen. For less unlikely examples, see Van der Burg (2003), p. 87.

557 Barnard (2007), pp. 591-592.

558 Craig \& de Burca (2003), p. $1189 \mathrm{ff}$.

559 Ibid.; Case 120/78, Rewe Zentrale AGv. Bundesmonopolverwaltungt für Branntwein [1979] ECR 649. 
nition did not turn out as the miracle solution it could potentially be. ${ }^{560}$ The Court itself already accepted in the Cassis de Dijon case that the principle of mutual recognition could be curtailed by Member States relying on mandatory requirements. ${ }^{561}$ In addition, Member States are often wary about readily accepting standards prescribed in other Member States. ${ }^{562}$ It is because of these limitations on the principle of mutual recognition that measures are generally created but only to a level that is necessary to ensure the full working of the principle of mutual recognition. ${ }^{563}$ This new approach, however, is still referred to as harmonisation.

This leads to a confusing situation, since the term harmonisation is used for more than one legislative process, the question arises as to what competences are left for a Member State after a legislative measure containing harmonisation has been passed by the institutions of the European Community. Both literature and case law do not provide a clear and definite answer to this question. What is clear, however, is that a number of different forms of harmonisation are distinguished. Terms like 'total', 'exhaustive', 'full', 'partial', 'optional' and 'minimum' harmonisation are observed in both literature and case law. ${ }^{564}$ Exact definitions and clear and precise delimitations between the different forms of harmonisation cannot be given. The text containing the legal basis for the Establishment Directive, Article 47 EC, mentions that Directives will be adopted in order to provide for the coordination of national measures. The terms of the legal basis therefore do not solve the problems of the extent of the harmonisation. The solution must thus be sought in Directive 98/5/EC itself.

The preamble and the text of Directive $98 / 5 /$ EC do not state specifically what level of harmonisation is required, but there are some hints in the preamble of the Directive that may shed some light on the issue. First, the preamble states that there is a strong link between Directive 98/5/EC and Directive 89/48/EEC. The latter is based on the principle of mutual recognition and was a direct result from the change of approach proposed at the summit of Fontainebleu in 1984. In addition to that it is also indicated in the preamble (and later on repeated in the articles of the Directive itself) that in some fields the Member States retain some discretionary power. For example, Member States can reserve access to their highest courts for a special category of lawyers and they may also require a lawyer established under his home country title to work in conjunction with a lawyer who is entitled to use the professional title of the host Member State (Article 5(3)). Another example can be found in Article 6(2) of the Directive which states that lawyers established under their home country title must be represented adequately in the representative bodies of the profession, and that the adequate representation shall involve at least the right to vote in the elections of the governing bodies of the profession. The two examples illustrate that there is at least some form of residual legislative competence for the Member States. The two examples given also illustrate that this residual competence differs from article to article in the Directive. The examples from Article 5 of the Directive

\footnotetext{
$560 \quad$ Barnard (2007), pp. 591-592.

561 The famous rule of reason.

562 Barnard (2007), p. 590. Once again Barnard makes this remark in the context of free movement of goods, but the remark is equally true for the free movement of lawyers in the European Community.

563 Eijsbouts (2004), p. 125.

564 Ibid., p. 120.
} 
show that a Member State can limit the professional activities of lawyers. Since the Member State has the choice of whether to implement this possibility or not, it can be said that the article leaves legislative discretion to the State. This residual competence is, however, very limited. Member States can choose either to apply the possibility or not to apply the possibility. The residual competence (apart from the practical implementation) is therefore confined to the choice of either to apply or not. ${ }^{565}$ The example of Article 6 of the Directive works in a somewhat different manner. Article 6 lays down a minimum requirement. Although it is nowhere stated explicitly, it is clear that Member States are welcome to lay down rules that give lawyers established under their home title more rights than active election rights in order to be adequately represented in the profession's governing bodies. Therefore, in this case the residual legislative competence for the Member State is larger than in the previous example. The Directive lays down a minimum standard, but from the wording of that standard it becomes clear that Member States are welcome to implement a regime that is more lenient than prescribed by the Directive. In comparison with the regime of harmonisation occurring in the free movement of goods under Article 95 EC Treaty (referred to as minimal harmonisation), this figure could be described as 'reversed minimal harmonisation'. ${ }^{566}$ Apart from these possibilities that can be deduced from the text of the articles there are no further indications as to the extent of harmonisation.

As was described above, the European Court of Justice has the last word with respect to the extent of the harmonisation that is achieved by a piece of secondary legislation. In the recent cases of Commission v. Luxembourg ${ }^{567}$ and Wilson ${ }^{568}$ the European Court of Justice took the opportunity to rule on the extent of harmonisation of a number of articles in the Directive. In these cases described extensively above, the Court rules that Article 3 (registration under home country professional title) and Article 5 (exercise of professional activity) lead to full harmonisation of the subject matter and no further exceptions to the rules, other than those included in the Article, may be imposed. That means that on the basis of these rulings Member States have no residual legislative competence in the matters dealt with in Articles 3 and 5 of the Directive. Next, it must be assessed whether that is also the case for other articles in the Directive, like Article 10, for instance, which governs the integration in the host Member State's profession. It must be clear from the outset that no definitive answers can be given before the Court has ruled on the extent of harmonisation in these remaining articles. However, if one compares the style and wording of Articles 3 and 5 with the other articles, such as Article 10, it can be concluded that there are no apparent differences between Articles 3 and 5 and the rest of the Directive. Therefore, I take the position that the rest of the Directive must be read

565 This could be called an 'optional clause' or 'optional harmonisation'. In the free movement of goods there is what is called optional harmonisation but this works in a different manner, so in order to avoid confusion I will leave the above-mentioned method nameless.

566 The normal 'minimal harmonisation' method in the field of the free movement of goods allows Member States to lay down stricter rules. Since this method, as observed above, allows for more lenient rules it is the opposite of normal minimal harmonisation, hence reversed harmonisation.

567 Case C-193/05, Commission of the European Communities v. Grand-Duchy of Luxembourg, [2006] ECR I-08673.

568 Case C-506/04, Graham J. Wilson v. Ordre des avocats du barreau de Luxembourg, [2006] ECR, I08613. 
in the light of the Court's judgments in Wilson and Commission v. Luxembourg. It can therefore be concluded (at least until more specific case law emerges) that no residual legislative competence remains for the Member States regarding matters that are dealt with in the Directive.

The question remains as to whether the Directive also affects the legislative competence of the Member States in areas that are not (specifically) covered by the Establishment Directive, and what rules, if any, should be applied to the legislative competence of the Member States that is not affected by the Directive. In answering the first question, guidance may be found in the $A M O K$ case. ${ }^{569}$ This case, described above, dealt with the Services Directive. In short, the Court ruled that restrictions that precluded the full working of the Directive are prohibited, even when the specific subject matter of the restriction was not covered by the Directive as such. Since it was already established that the Service Directive and the Establishment Directive are very closely linked, an analogous interpretation of the $A M O K$ case can be applied in the context of the Establishment Directive. That would mean that where a Member State imposes restrictions on the free movement of lawyers for the establishment under home country professional title that precludes the full working of the Directive, such a restriction would be prohibited (without an apparent right to objectively justify such a restriction, at least not one that can be deduced from the $A M O K$ case). At least in one instance such a restriction will be identified below in the review of implementation of the Establishment Directive.

With regard to restrictions that are not covered by the Directive and which do not preclude the full working of the Directive, the applicable rules are also clear. In the case law it has been decided that those restrictions do fall under European rules, and do not remain in the exclusive competence of the Member States. From the case law described above, it becomes clear that the normal rules applicable to restrictions as laid down in the Gebhard case apply, where applicable preceded by specific rules, such as the Vlassopoulou rules for the recognition of diplomas. In general this means that any restriction that is liable to hinder, or make less attractive, the exercise of one of the freedoms (in this case the free movement of lawyers) is prohibited unless objectively justified.

In conclusion, it can be said that the legislative competence of Member States is curbed on three distinct levels. There is no residual legislative competence with regard to matters covered by the Establishment Directive other than those choices specifically mentioned in the Directive. Secondly, restrictions outside the scope of the Directive that preclude its full working are prohibited and all other restrictions are prohibited unless objectively justified. This division can be represented as follows: 
Restrictions imposed on articles of the Directive that preclude residual legislative power of the Member States are prohibited per se.

Based on Wilson and Commission v. Luxembourg it has been assumed that this is the case for Directive 98/5/EC.

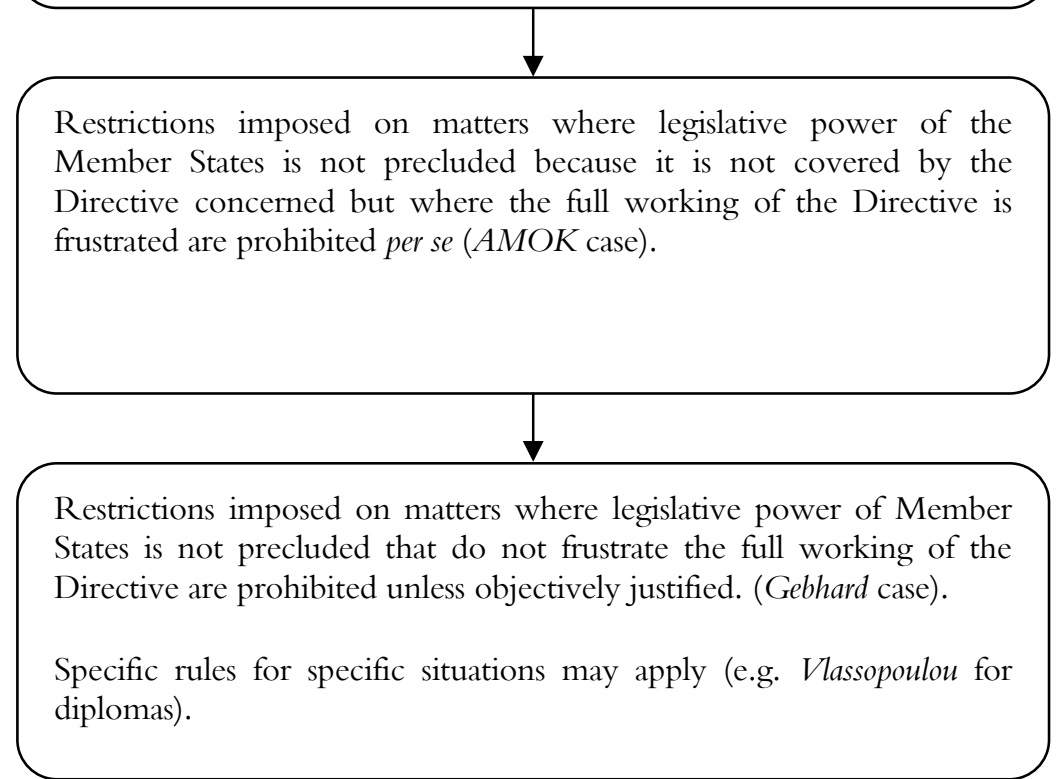

This threefold division can now be applied to the implementation of the Directive in the Member States.

\section{$\sqrt{ } 4.3$ Implementation of the Establishment Directive in the Member States}

The following paragraph provides a review of the implementation of the Establishment Directive in the fifteen selected Member States. Since this is the first time the implementation of the Establishment Directive has been described on such a scale, the level of detail is greater than within the review for the Services Directive in the previous paragraph and the review of the Diploma Directive in the next paragraph. However, in order to avoid presenting a repetitive account of the implementation in all Member States, emphasis will be given to the problems arising from the implementation in those specific States. Anomalies in implementation will be classed in the threefold division of possible restrictions as presented above. After the review of the implementation, observations and conclusions regarding the implementation of the Establishment Directive will be presented. 


\section{$\$$ 4.3.1 Implementation in the Scandinavian and Nordic Member States}

\section{Sweden}

The Swedish government implemented Directive 98/5/EC by means of an adaptation to Chapter 8 of the Rättegaingsbalken which came into force on 1 January $2000 .{ }^{570}$ Since the adaptation, paragraph 2 of Chapter 8 of the Rättegangsbalken states that henceforth the Chapter shall be applicable to lawyers coming from other Member States of the European Union, whereas before it referred only to the Member States of the European Economic Area and Denmark and Finland. ${ }^{571}$

Paragraph 2a of Chapter 8 of the Rättegangsbalken states that all persons who are entitled to practise as a lawyer in one of the Member States of the European Union are allowed to establish themselves on a permanent basis under their home country title in Sweden, once they have registered with the Swedish Bar Association. ${ }^{572}$ The remarkable feature is that the Swedish Bar Association has to ascertain that the lawyer who seeks establishment under his home title in Sweden fulfils the criterion laid down in section 6 of paragraph 2, namely that the lawyer concerned must be suitable to practise as an advocate. ${ }^{573}$ This is significant since Directive 98/5/EC allows no additional criteria to register a lawyer who seeks establishment under his home title, other than those regarding written proof of his registration in his home Member State. It can therefore be said that the additional requirement in the Rättegangsbalken is a violation of the principle of mutual recognition that underlies the Directive, and therewith of the Directive itself. ${ }^{574}$ Based on the threefold division above, this must be classed as a restriction in the field where residual legislative power is precluded. Therefore this requirement must be classed as a direct violation of the Directive. As of 2006, fifteen lawyers were registered under their home country professional title. ${ }^{575}$ All applications regarding establishment under home title are to be examined by the Swedish Bar Association. ${ }^{576}$

Paragraph 9 of Chapter 8 of the Rättegangsbalken lays down the rules in connection with professional activities and the use of the professional title by the lawyer who is established under his home country professional title. The paragraph states that all

570 Regeringens proposition 1998/99:108, Advokaters etableringsrätt. Mention must be made of the fact that the adaptation to the Rättegångsbalken will be dealt with on the basis of a French translation, which is accessible via the website of the CCBE, <www.ccbe.org>, last accessed 12 November 2002.

571 Chapter $8 \rrbracket 2$ Rättegångsbalken.

572 Chapter 8 \2a Rättegångsbalken. $\$ 3$ of the Stadgar för Sveriges Advokatsamfund is also altered in such a way to incorporate lawyers who are established under their home title.

573 Chapter $8 \llbracket 2 a$ Rättegångsbalken.

574 As it has been established in cases C-193/05, Commission of the European Communities v. GrandDuchy of Luxembourg, [2006] ECR I-08673 and C-506/04, Graham J. Wilson v. Ordre des avocats du barreau de Luxembourg, [2006] ECR, I-08613, that Article 3 of Directive 98/5EC leads to full harmonisation, it must be concluded that the Swedish requirement is a violation of the Directive.

$575<$ www.ccbe.org>, last accessed 11 June 2007.

576 Chapter $8 \int 3$ Rättegångsbalken. This supervision is further elaborated upon in $\mathbb{4} 4 \mathrm{a}$ of the Stadgar for Sveriges Advokatsamfund which, among other things states the documents necessary for admission and the fact that all decisions of the Advokatsamfund must be reasoned. 
the Swedish legislation regarding lawyers shall be equally applicable to lawyers who are established under their home country title in Sweden. ${ }^{577}$ Since there is no legal monopoly on legal activities in Sweden it is not surprising that the Rättegangsbalken says nothing about activities that may or may not be exercised by a lawyer who is established under his home title, or about the way in which certain activities should be exercised.

Paragraph 9 does lay down rules regarding the use of the professional title. The paragraph states that lawyers who seek permanent establishment in Sweden must do so under their home country professional title. In addition to that, the lawyer is obliged to give information regarding the institution that has granted him his licence to practise in his home Member State, and he can be obliged to mention the competent authority with which he is entitled to practise in his home Member State. ${ }^{578}$ Paragraph 10 states that anybody who passes himself off as a lawyer when he does not hold the qualification to do so will be subject to a penalty. ${ }^{579}$

Disciplinary proceedings for lawyers who are established under their home title are laid down in paragraph 7 of Chapter 8 of the Rättegangsbalken. ${ }^{50}$ The first section of the paragraph states that if a lawyer intentionally commits a wrong or acts dishonestly in any other way shall be expelled from the Bar. Where it concerns a lawyer who is established under his home title in Sweden, his licence to practise in Sweden shall be revoked. The section states further that the Advokatsamfundet may decide to issue a warning instead of an expulsion or revocation. ${ }^{581}$ The second section of the paragraph deals with other situations within which a lawyer has neglected to fulfil his duties. In these cases, the Advokatsamfundet shall issue a warning or a reprimand. However, if the situation is particularly grave the Advokatsamfundet can choose either to expel the lawyer (if he is an advokat) or to revoke his licence (where it is a lawyer who is established under his home title). ${ }^{582}$ In cases where a lawyer has been issued with a warning, the Advokatsamfundet can impose a fine. ${ }^{583}$ On the other hand, the disciplinary committee of the Advokatsamfundet may also decide to issue a mere declaration that the concerned lawyer's action was wrong or inappropriate. ${ }^{584}$ If a lawyer comes to a situation where he is no longer able to fulfil the criteria of paragraph 2 of Chapter 8 of the Rättegangsbalken he must resign from the Advokatsamfundet immediately. Where he fails to do so, the Advokatsamfundet may order his expulsion. If a lawyer who is established under his home title in Sweden loses his competence to practise in his home Member State, his licence to practise in Sweden will also be revoked immediately. ${ }^{585}$ There remains a possibility of appeal to the Swedish Supreme

577 Chapter 8 \$ 9 Rättegångsbalken.

578 Chapter 8 \ 9 Rättegångsbalken.

579 Chapter 8 \& 10 Rättegångsbalken.

580 With regard to notification of disciplinary proceedings and the result thereof to the relevant authorities in Sweden and to the competent authorities in the host Member State $\$ \int 44-44 \mathrm{a}$ and 45 of the Stadgar for Sveriges Advokatsamfundet apply.

581 Chapter 8 \$ 7 Rättegångsbalken.

582 Chapter 8 \7 Rättegångsbalken.

583 Chapter 8 \ 7 Rättegångsbalken.

584 Chapter 8 \ 7 Rättegångsbalken.

585 Chapter 8 \ 7 Rättegångsbalken. 
Court against any decision regarding admission to, or expulsion from, the Advokatsamfundet. $^{586}$

The means of integrating into the Swedish legal profession are laid down in paragraph 2 of Chapter 8 of the Rättegangsbalken. The paragraph states that anyone who has obtained a diploma in another Member State can take an examination in order to test whether he has enough knowledge of the Swedish legal system in order to become an advokat. When he passes this exam, he will be deemed to have fulfilled the education requirements laid down in paragraph 2 of the Chapter, which are discussed above. ${ }^{587}$ This exam is clearly an aptitude test under the system of Directive 89/48/EEC, which will be discussed in the next paragraph. Accession into the profession of the advokat without having to take an aptitude test is also possible. The paragraph states that a lawyer who is established under his home title in Sweden can accede to the profession of the advokat without taking an aptitude test if he has regularly and effectively exercised the activities as a lawyer in Sweden for a period of at least three years, and where those activities consisted of working with Swedish law. ${ }^{588}$ It is strange that although Directive 98/5/EC indicates experience in the field of European law is also relevant for the accession to the profession of the host Member State without having to take an aptitude test, the Rättegångsbalken does not mention this at all. This is even stranger since the government has mentioned the relevant experience in European law in its proposal to change the Rättegangsbalken, ${ }^{589}$ but in the final version its reference was absent. It will therefore be paramount to monitor how the Advokatsamfundet will deal with situations where a lawyer has gained three years of experience in European law and not in Swedish law.

A second method which can be used to accede to the profession of the advokat without having to take an aptitude test is relevant for lawyers who are established under their home title in Sweden and where they have gained at least three years of experience, but they have not been active in Swedish law for those three years. In that case, the lawyer concerned can prove in another way that he has enough knowledge and experience to be admitted to the Advokatsamfundet. ${ }^{590}$ In this case, i.e., without explicit reference to experience gained in European law, it looks like the Swedish authorities do not wish to grant automatic accession to lawyers who have gained three years of experience in (among other things) European law, since they would fall in the second category. This would be a direct violation of Article 10 of Directive 98/5/EC, which states that lawyers who have gained experience in European law have an automatic right of accession to the profession of the host Member State. The practice of the Advokatsamfundet needs to be monitored closely. ${ }^{591}$ As of 2006, no lawyers had sought integration into the Swedish legal profession. ${ }^{52}$

586 Chapter $8 \int 8$ Rättegångsbalken. Which is in accordance with the requirements for a 'remedy' mentioned by the ECJ in the Wilson case.

587 Chapter 8 \$2 Rättegångsbalken.

588 Chapter 8 \& 2 Rättegångsbalken.

589 Regeringens proposition 1998/99:108 Advokaters etableringsrätt, prop.1998/99:108.

590 Chapter $8 \$ 2$ Rättegångsbalken.

591 Acoording to the latest statistics of the CCBE (<www.ccbe.org>, last accessed 20 November 2006) no lawyers have gained access to the profession of advokat via Article 10 of Directive 98/5/EC.

592 <www.ccbe.org>, last accessed 11 June 2007. 
No alterations have been made to the Rättegangsbalken with regard to joint practice of lawyers who have been established under their home title in Sweden. This leads to the conclusion that the rules regarding joint practice for advokats which are laid down in paragraph 4 of Chapter 8 of the Rättegangsbalken are also valid for lawyers who are established under their home title, on the basis of paragraph 9 of Chapter 8 of the Rättegangsbalken. ${ }^{593}$ According to the government, paragraph 4 did not need any alterations before becoming applicable for lawyers who are established under their home title. ${ }^{594}$ Paragraph 4 states that lawyers may only work in joint practice with people who are advokats. This may lead to two conclusions. Either, lawyers who are established under their home title may only practise jointly with Swedish advokats, or it may mean that lawyers who are established under their home title may practise jointly with those persons who are allowed to practise as a lawyer in any Member State of the European Union and the European Economic Area. On the basis of the government's motivation with regard to alteration of the Rättegangsbalken the conclusion must be that the Swedish government had the last option in mind, since it states that the prohibition for Swedish lawyers to work together with lawyers from other EU Member States must be revoked. ${ }^{595}$

\section{Finland}

By means of a law that entered into force on 1 January 2000, the Finnish government has adapted the Advocates Act in order to bring it into conformity with Directive 98/5/EC. ${ }^{596}$ Section 5 b of the Advocates Act regulates the right to establishment for lawyers who have gained their professional qualification in another Member State. The section states that any person who is admitted to the legal profession of another Member State of the European Union is entitled to be entered into a register. ${ }^{597}$ The Finnish Bar Association shall keep this register and it shall encompass lawyers who are entitled to practise in another Member State and who operate in Finland under their home country professional title. ${ }^{598}$ Further formalities with regard to this registration are laid down in the by-laws of the Finnish Bar Association. Section 6a of the by-laws states that in order to be registered with the Finnish Bar Association the lawyer must submit a written application accompanied by a certificate which certifies he is allowed to practise as a lawyer in his home Member State. No more than three months should have elapsed since the certificate was issued. The Finnish Bar Association shall inform the competent authority of the host Member State that the lawyer concerned has sought entrance to the register of EU lawyers of the Finnish Bar Association. ${ }^{599}$ Section 8 of the by-laws of the Finnish Bar Association states further that the Board of the Finnish Bar Association shall give reasons for any decision made not to register a lawyer. ${ }^{600}$ Decisions which decline the registration of a lawyer in the EU register are eligible for appeal before the Court of

\footnotetext{
593 Chapter 8 SS 4 and 9 Rättegångsbalken.

594 Regeringens proposition 1998/99:108 Advokaters etableringsrätt, prop.1998/99:108.

595 Regeringens proposition 1998/99:108 Advokaters etableringsrätt, prop.1998/99:108, p. 20.

596 Law number 1249/1999.

597 Section 5 b Advocates Act.

598 Section 5 b Advocates Act.

599 Section 6a by-laws of the Finnish Bar Association.

600 Section 8 by-laws of the Finnish Bar Association.
} 
Appeal of Helsinki. ${ }^{601}$ As of 2006, three lawyers were registered under their home country professional title in Finland. ${ }^{602}$

Because there is no legal monopoly for the legal profession in Finland, there are few rules with regard to professional activity. As seen above, there are rules pertaining to professional ethics for Finnish advokats or asianajajas, which are laid down in the rules of conduct. ${ }^{603}$ Section $5 \mathrm{~b}$ states the rules of professional activity which must be adhered to by lawyers from other Member States of the European Union and are established under their home title in Finland. ${ }^{604}$ The section states that all the provisions in the law with regard to advokats or asianajajas and the by-laws of the Finnish Bar Association shall also apply, where appropriate, to lawyers who are registered in the EU register of the Finnish Bar Association. In addition to that, a lawyer who is registered in that same register shall arrange his activities in a manner consistent with the rules governing the activities of advokats or asianajaja's. ${ }^{605}$ The bylaws of the Finnish Bar Association say very little on professional activity for lawyers who are part of the EU register. Section 6a of the by-laws state that the rules laid down in the by-laws shall apply to lawyers who are registered in the EU register, where applicable. ${ }^{606}$ With regard to the use of professional title, Section $5 b$ of the Advocates Act only states that the EU register shall encompass all lawyers who are allowed to practise in another Member State as a lawyer, and are established under their home title in Finland. ${ }^{607}$ The actual obligations for a European lawyer to practise under his home country title are not laid down in the Advocates Act, but it are rather encompassed in the by-laws of the Finnish Bar Association. Section 6a states that a lawyer who is enrolled in the register of EU lawyers shall use the professional title of his home Member State in the language of that State, and with reference to the professional organisation to which he belongs. ${ }^{608}$ Unauthorised use of the relevant professional title is not allowed, and is punishable by a fine. ${ }^{609}$

The rules regarding disciplinary proceedings for lawyers who are enrolled in the EU register are closely intertwined with the rules for disciplinary proceedings for advokats and asianajajas. Section 7 of the Advocates Act states that any lawyer who deliberately commits an injustice through his practice, or otherwise acts in a dishonest manner as an advocate must be disbarred. ${ }^{610}$ Instead of disbarment, the Bar Associa-

601 Section 10(1) Advocates Act.

$602<$ www.ccbe.org>, last accessed 11 June 2007.

603 Rules of proper professional conduct for advocates (9.6.1972), <www.advonet.fi >, last accessed 10 December 2002. See also sections 38-41 of the by-laws of the Finnish Bar Association.

604 Section $5 \mathrm{~b}(2)$ Advocates Act.

605 Section $5 \mathrm{~b}(2)$ Advocates Act.

606 Section 6a by-laws of the Finnish Bar Association. It is uncertain what the exact extent of this provision amounts to. Does it mean that in general all the provisions of the by-laws apply to European lawyers, or does it mean that only those rules that specifically refer to European lawyers, either in the by-laws or the Advocates Act itself. Section 29 of the by-laws, for example, refers to the right of lawyers in the EU register, to vote in meetings of the local Chapter of the Bar Association.

607 Section 5b(1) Advocates Act. See Also Section 5a Advocates Act.

608 Section 6a by-laws of the Finnish Bar Association.

609 Section 11 Advocates Act.

610 Section 7(1) Advocates Act. For procedural rules regarding disciplinary proceedings and appeals see sections 45-51 of the by-laws of the Finnish Bar Association. 
tion can also opt for a caution when there are mitigating circumstances. ${ }^{611}$ In cases where an advocate has neglected to fulfil his duties and thus his coduct does not amount to the standard laid down in Section 7(1) of the Advocates Act, the sanctions are reversed, which means as a general rule a caution is given, which, in aggravating circumstances, can be transformed into a disbarment. ${ }^{612}$ Section 7(5) states that these rules shall also apply to lawyers who are entered in the EU register. ${ }^{613}$ Any lawyer, either a member of the Finnish regulated profession or any lawyer who is entered in the EU register, has the right to appeal against any of the decisions of the Disciplinary Board of the Finnish Bar Association in the Court of Appeal of Helsinki. ${ }^{614}$ Any lawyer who has suffered disbarment or removal from the EU register as a result of disciplinary matters may apply for readmission after three years. ${ }^{615}$ With regard to disciplinary proceedings commenced against a lawyer who is entered in the EU register, it must be stated that the Finnish Bar Association must inform the competent authority of the home Member State before the disciplinary proceedings start. The proceedings are then conducted in cooperation between the Disciplinary Board of the Finnish Bar Association and the competent authority of the home Member State. In this cooperation, however, none of the powers of the Disciplinary Board of the Finnish Bar Association shall be compromised. ${ }^{616}$ Lastly, when a lawyer who is entered in the EU register loses his right to practise in his home Member State, either as a result of disciplinary proceedings in his home Member State, or as a consequence of some other action, he shall be removed from the EU register. ${ }^{617}$

Section 3 of the Advocates Act lays down the means by which a lawyer who is entered in the EU register may integrate into the regulated legal profession in Finland. As stated earlier, anyone who is allowed to practise as a lawyer in another Member State of the European Union or the European Economic Area may at any time apply for an aptitude test in order to be admitted to the regulated profession in Finland. ${ }^{618}$ Section 3(3) of the Advocates Act lays down the other ways in which integration into the regulated profession can take place, namely by gaining professional experience while being established under one's home title. ${ }^{619}$ The subsection states that a person who holds the professional qualifications of a lawyer in another Member State of the European Union $^{620}$ may be accepted as an advokat or asianajaja. In order to acquire

611 Section 7(1) Advocates Act.

612 Section 7(2) Advocates Act.

613 Section 7(5) Advocates Act.

614 Section 10(1) Advocates Act.

615 Section 8 Advocates Act. This is a matter not covered by the Establishment Directive. That means that this is a restriction that falls within the residual legislative competence of the Member States. At first sight this is a requirement that is not unreasonable and might therefore be objectively justified, assuming that it is applied in a non-discriminatory manner.

616 Section $5 \mathrm{~b}(3)$ Advocates Act.

617 Section 9(3) Advocates Act. According to Section 9(2) of the Advocates Act, it is the Finnish Minister of Justice who deals with appeals regarding these decisions.

618 Section 3(2) Advocates Act.

619 Section 3(3) Advocates Act.

620 It is peculiar that the Finnish Advocates Act refers to the European Economic Area in all the other sections with regard to European lawyers, except in this section. This is even more peculiar since Directive 98/5/EC is a text with EEA relevance, and is therefore also valid in those countries. It must be said that all other sections that refer to European lawyers and that deal with scope of application, and therefore refer to EEA Member States, date from a time when Finland itself 
acceptance a lawyer must have been listed in the EU register for at least three years and must show that he has acted regularly as a lawyer in Finland for at least that same period. ${ }^{621}$ The subsection states further that the activities that must be undertaken in order to fulfil the second part of the criterion mentioned above shall be elaborated upon in the by-laws of the Finnish Bar Association. ${ }^{622}$ The only part of the by-laws of the Finnish Bar Association that refers to the manner of integration is found in Section 5 of the by-laws. ${ }^{623}$ The only addition this section makes to the material already laid down in the Advocates Act is that the applicant shall provide the Board of the Finnish Bar Association with documentation or other information regarding the matters dealt with and the activities employed. ${ }^{624}$ In addition, it must be mentioned that experience gained before the entry into force of the adaptation to the Advocates Act and the by-laws of the Finnish Bar Association is also taken into account. ${ }^{625}$ Similar to Sweden, there is no reference whatsoever with regard to experience gained in European Law. So also in the Finnish situation it remains to be seen whether or not the Board of the Finnish Bar Association will take into account experience gained in European Law when deciding on applications for accession to the profession of the advokat or asianajaja. ${ }^{626}$ As of 2006, two lawyers had sought integration into the Finnish legal profession. ${ }^{627}$

Just as in Sweden, there are no specific rules for lawyers entered in the EU register working in joint practice. It must therefore be assumed that the rules for advokats and asianajajas apply similarly to the situation of lawyers coming from other Member States. ${ }^{628}$ This is no more than an assumption, however, since in those rules no explicit reference is made to lawyers coming from other EU Member States. At first sight it appears that Finnish advokats or asianajajas are not allowed to practise with lawyers who are entered in the EU register, since the rules governing the advokats or asianajajas and lawyers entered in the EU register are not clear on this issue. When they are applied to the letter, lawyers entered in the EU register are not allowed to practise jointly with advokats or asianajajas. ${ }^{629}$ When glancing at the EU

was not yet a member of the EU but solely of the EEA. It must be assumed, however, that lawyers from EEA countries may also benefit from entrance into the regulated legal profession by this means.

621 Section 3(3) Advocates Act.

622 Section 3(3) Advocates Act.

623 Section 5(5) of the by-laws of the Finnish Bar Association.

624 Section 5(5) of the by-laws of the Finnish Bar Association.

625 Amendment 2000 of the by-laws of the Finnish Bar Association and Section 14 of the Advocates Act.

626 As of November 2006, two lawyers were admitted into the profession. See <www.ccbe.org>, last accessed 20 November 2006.

$627<$ www.ccbe.org>, last accessed 11 June 2007.

628 Section 5 Advocates Act; Section 38 of the by-laws of the Finnish Bar Association.

629 This is the case since Section 4 of the by-laws of the Finnish Bar Association states that lawyers who are entered in the EU register are not members of the Finnish Bar Association. Section 1 of the Advocates Act states that an 'advocate' is anyone who is registered in the Roll of Advocates as a member of the Finnish Bar Association. Section 5(2) of the Advocates Act and Section 38 of the by-laws of the Finnish Bar Association state that Finnish advokats and asianajajas are only allowed to practise jointly with other 'advocates', it must therefore be assumed that they are not allowed to practice jointly with lawyers who are entered in the EU register, since they are not regarded as 'advocates' in the sense of Section 1 of the Advocates Act. On the other hand, Section $5 b(2)$ of the Advocates Act and Section $6 a$ of the by-laws of the Finnish Bar Asso- 
register, ${ }^{630}$ however, it appears that the Finnish Bar Association does not apply these rules to the letter since all the lawyers entered in this register work for bigger law firms, and are therefore practising jointly with advokats or asianajajas. ${ }^{631}$ As a result it must be concluded that lawyers entered in the EU register are at least allowed to practise jointly with advokats or asianajajas, and with other lawyers entered in the EU register. ${ }^{632}$ Similar to the rules laid down for advokats and asianajajas, lawyers who are entered in the EU register are not allowed to work in multi-disciplinary practices. ${ }^{633}$

Section 26 of the by-laws of the Finnish Bar Association states that both the advokats and asianajajas and the lawyer entered in the EU register shall have to adhere to the Chapter of the Finnish Bar Association that mainly covers the area concerning where they practise. ${ }^{634}$ Section 29 of the by-laws of the Finnish Bar Association lays down the right for lawyers entered in the EU register to vote for the representative of the Chapter to the Delegation of the Finnish Bar Association. ${ }^{635}$ There is no right for lawyers entered in the EU register to be voted in as a Delegate, since Section 16 of the by-laws states that the Delegates of the Chapters shall be advocates. ${ }^{636}$ Although the Finnish Bar Association complies with the letter of Article 6(2) of Directive 98/5/EC, which states that appropriate representation shall at least include the right to vote in the election of the professions governing bodies. Section 30 of the by-laws of the Finnish Bar Association states that lawyers who are entered in the EU register must pay an annual fee which shall not exceed the annual membership fee that advokats or asianajajas must pay to the Finnish Bar Association. ${ }^{637}$ The Establishment Directive is silent on the point of membership fees. In the light of the threefold division above, this restriction must be classed as a restriction that needs objective justification. Based on the fact that every Bar Association will ask for a (substantial) membership fee it must be assumed that objective justification is not hard to acquire. Related to this subject is a potential hindrance that flows from the structure of the Establishment Directive itself, namely the fact that double registration fees (both in the home and the host Member State) will have to be paid. This matter will be addressed further at the end of this paragraph.

ciation state that the rules for 'advocates' shall apply in principle equally to lawyers entered in the EU register. In my opinion this means no more than the fact that lawyers who are entered in the EU-register are allowed to practise jointly with other lawyers who are entered in the same register, on the basis of the rules that allow Finnish 'advocates' to practise jointly, but it does not say anything with regard to the possibility of a lawyer entered in the EU register practicing jointly with a Finnish 'advocate' since these belong to two different categories.

630 As published at <www.advonet.fi>, last accessed 19 December 2002.

631 As of December 2002, there were five lawyers entered in the EU register. These are three German Rechstanwälte, one Danish advokat and an English solicitor, working with three different law-firms in Helsinki (Asianajotoimisto Bergmann Oy, Asianajotoimisto Castrén \& Snellman Oy and Roschier Holmberg Asianajotoimisto Oy).

632 Which may be concluded from the fact that the five lawyers entered in the EU register only work in three different law-firms.

633 Section 5 Advocates Act and Section 38 by-laws of the Finnish Bar Association, read in conjunction with Section $5 b(2)$ Advocates Act and Section 6a by-laws of the Finnish Bar Association.

634 Section 26 by-laws of the Finnish Bar Association.

635 Section 28 by-laws of the Finnish Bar Association.

636 Section 16 by-laws of the Finnish Bar Association.

637 Section 30 by-laws of the Finnish Bar Association. 


\section{Denmark}

Just like their Swedish and Finnish counterparts, the Danish authorities have opted for an adaptation of the Retsplejenloven ${ }^{638}$ combined with a ministerial decree that lays down more specific rules. ${ }^{639}$ The law adapting the Retsplejenloven is characteristic of a legal system that makes use of decentralised rule-makers. Instead of laying down the rules in the law, the law merely creates the framework in which the actual rulemaking can take place on a lower level. The law consists of only one article that states that a number of articles in the Retsplejenloven will be amended. The most significant adaptation to the Retsplejenloven is that paragraph 130 is changed in such a manner that it now states that the Justice Minister is allowed to lay down rules regarding the establishment of lawyers coming from other EU Member States. ${ }^{640}$ The provision in the law even allows the Minister to take up rules regarding offences and punishment. ${ }^{641}$ The Minister of Justice has taken up this opportunity and laid down additional rules regarding the free movement of lawyers in a ministerial decree. ${ }^{642}$ This decree is called Bekendtgørelse om EU-advokaters etablering her $i$ landet (hereinafter the Bekendtgørelse). The essence of the Bekendtgørelse is laid down in the first paragraph. It states that lawyers, who have obtained a licence to practise in one of the Member States of the European Union, can exercise the activities of an advokat, either in establishment or in salaried practice, under their home professional title. ${ }^{643}$ The second section of the paragraph states the relevant professional titles of the Member States of the European Union, a list that is identical to Article 1(2a) of Directive 98/5/EC.

The second paragraph of the Bekendtgørelse assigns the procedure to be followed by a lawyer who seeks to establish himself under his home title in Denmark. The paragraph first states that a lawyer who wants to establish himself in Denmark must register himself as a member with the Det Danske Advokatsamfundet. ${ }^{644}$ For registration, it is necessary to produce a certificate from the competent authority of the home Member State certifying that the applicant is allowed to practise as a lawyer in that Member State. No more than three months shall have elapsed since the certificate was issued. ${ }^{645}$ In addition to this certificate, the lawyer concerned must also inform the Advokatsamfundet of his membership of any partnership, and where applicable, must provide to the Advokatsamfundet information concerning this partnership. ${ }^{646}$ Paragraph 7 of the Bekendtgørelse states that the lawyer who is established under his home title shall, in addition to the use of his home title, indicate to which professional organisation he belongs, or which competent authority has given him the authority to practise in his home Member State. ${ }^{647}$ A lawyer who is part of a joint practice in his home Member State shall indicate the legal form of that joint practice and he shall also provide the names of other persons who are members of that

\footnotetext{
638 Lov om aendring af retsplejenloven (EU-advokaters etablering her i landet m.v.) Nr. 231, 4 April 2000.

639 Bekendtgørelse om EU-advokaters etablering her I landet m.v., 14 April 2000.

$640 \int 130$ (1) Retsplejenloven.

$641 \int 130(2)$ Retsplejenloven.

642 Bekendtgørelse om EU-advokaters etablering her I landet m.v., 14 April 2000.

$643 \int 1$ (1) Bekendtgørelse.

$644 \int 2$ (1) Bekendtgørelse.

$645 \int 2$ (2) Bekendtgørelse.

$646 \int 2$ (3) Bekendtgørelse.

$647 \int 7$ (1) Bekendtgørelse.
} 
joint practice and who are established under their home title in Denmark. ${ }^{648}$ The third paragraph of the Bekendtgørelse lays down the fact that the Advokatsamfundet, as competent authority with regard to the registration of lawyers who seek establishment under their home title, shall inform the Minister of Justice and the competent authority of the relevant home Member State of any registration carried out under paragraph 2 of the Bekendtgørelse. In 2006, 22 lawyers were registered under their home country professional title. ${ }^{649}$

The activities that can be carried out by a lawyer who is established under his home Member State in Denmark are enlisted in paragraph 4 of the Bekendtgorelse. That paragraph states that a lawyer who is established under his home title in Denmark may carry out any activity in conformity with Articles 4(1), 5(1), 6(1) and 7 (1) of Directive 98/5/EC. In essence this means that a lawyer who is established under his home title in Denmark may carry out any professional activities that an advokat may, albeit under his home title and with respect for both the professional rules of the host and home Member State. In addition to that, both the competent authorities of the host and home Member State shall be involved in disciplinary proceedings. ${ }^{650}$ The second section of the fourth paragraph states that lawyers established under their home title may represent clients under the same rules that are applicable to advokats, and which are described above. The third paragraph states that a Danish lawyer shall accompany a lawyer established under his home title when representing a client in court. ${ }^{651,652}$ It must be mentioned that all these limitations are well within the limits laid down by Directive 98/5/EC.

Paragraph 6 of the Bekendtgørelse states that the lawyer who seeks establishment under his home title in Denmark must hold insurance for professional liability, according to the rules of the Advokatamfundet. A lawyer seeking establishment under his home title does not have to fulfil this criterion if he is able to show that he has already procured professional indemnity insurance in his home Member State that is comparable to the required Danish insurance, i.e., that it fulfils the criteria laid down by the Advokatamfundet. ${ }^{653}$ In addition to that the Advokatamfundet can demand the lawyer to take insurance on those terrains that are not covered by the home Member State insurance. ${ }^{654}$

From paragraph 8 of the Bekendtgørelse it becomes clear that the proceedings regarding the cessation of the right to exercise the professional activities of a lawyer are similar to those laid down for Danish lawyers in Chapter 14 of the Retsplejenloven. ${ }^{655}$ This is the case since the paragraph states that the Chapter 14 shall also be used for lawyers established under their home title. Paragraph 9 states that when Chapter 14 of the Retsplejenloven is applied to a lawyer who is established under his home title, the Advokatsamfundet shall revoke his registration. ${ }^{656}$ That registration shall

\footnotetext{
$648 \int 7$ (2) Bekendtgørelse.

649 <www.ccbe.org>, last accessed 11 June 2007.

$650 \int 4$ (1) Bekendtgørelse.

$651 \int 4(2,3)$ Bekendtgørelse.

$652 \int 5$ of the bekendtgørelse states that the Advokatradet (a supervisory organ of the Advokatsamfundet) shall monitor the lawyers established under their home title.

$653 \int 6(1)$ Bekendtgørelse.

$654 \int 6(2)$ Bekendtgørelse.

$655 \int 8$ Bekendtgørelse.

$656 \int 9$ (1) Bekendtgørelse.
} 
also be revoked if the Advokatsamfundet receives information from the competent authority of the home Member State that the right to practise of the lawyer concerned has been revoked in the home Member State. ${ }^{657}$ According to paragraph 10 of the Bekendtgørelse, the Advokatsamfundet shall inform the competent authority of the home Member State of any disciplinary proceedings against a lawyer established under his home title in Denmark, brought before the Advokatnoevnet (Board of Discipline) ${ }^{658}$ In addition the second section of the paragraph states that the Advokatsamfundet shall inform the competent authority of the host Member State of any disciplinary proceedings in the case where such proceedings are brought against a Danish lawyer who is established under his home title in another Member State. ${ }^{659}$

Paragraph 11 of the Bekendtgørelse regulates the way in which a lawyer established under his home title in Denmark can accede to the profession of the advokat. The paragraph states that any lawyer who has occupied himself for at least three years on an effective and regular basis with Danish law, including European Union law, and who can prove such occupation to the Minister of Justice, will be exempted from the provisions laid down in Directive 89/48/EEC. ${ }^{660}$ The twelfth paragraph deals with the situation where the lawyer established under his home title has been active for at least three years, but where his experience in Danish law has been shorter than three years. In that case, the Minister of Justice can appoint such a candidate as advokat. ${ }^{661}$ The second section of the paragraph states that when assessing the effective and regular nature of the activities of the lawyer who seeks entry into the profession of the advokat, the Minister of Justice shall take into account all experiences gained by the lawyer in connection to the Danish legal system, and also any knowledge gathered from courses and seminars about the Danish legal system. ${ }^{662}$ The third section of the paragraph states that any assessment of activities shall be conducted in communication with the Minister of Justice. ${ }^{663}$ As of 2006, two lawyers had requested integration into the Danish legal profession. ${ }^{664}$

Paragraph 13 of the Bekendtgørelse states that lawyers who are established under their home title in Denmark may exercise their activities in joint practice with lawyers originating from the same Member States, lawyers originating from other Member States or lawyers originating from Denmark (or any combination thereof). ${ }^{665}$ Moreover the paragraph states that the relevant paragraphs of the Retsplejenloven (\$S 124-127) are also valid for these joint practices. ${ }^{666}$ In paragraph 14 it is laid down that if one or more established lawyers come from one joint practice in another Member State, they are allowed to exercise their activity in the form of a branch-office of that same joint practice. ${ }^{667}$ The second section of that same paragraph states that where the basic principles underlying the rules regarding joint practices

\begin{tabular}{ll}
\hline 657 & $\int 9(2)$ Bekendtgørelse. \\
658 & $\int 10(1)$ Bekendtgørelse. \\
659 & $\int 10(2)$ Bekendtgørelse. \\
660 & $\int 11$ Bekendtgørelse. \\
661 & $\int 12(1)$ Bekendtgørelse. \\
662 & $\int 12(2)$ Bekendtgørelse. \\
663 & $\int 12(3)$ Bekendtgørelse. \\
664 & $<$ www.ccbe.org>, last accessed 11 June 2007. \\
665 & $\int 13(1)$ Bekendtgørelse. \\
666 & $\int 13(2)$ Bekendtgørelse. \\
667 & $\int 14(1)$ Bekendtgørelse.
\end{tabular}


of the home Member State are incompatible with the rules of the host Member State, the latter shall prevail insofar as compliance therewith is justified by the public interest and the protection of clients and third parties. ${ }^{668}$ Multidisciplinary practices are however not allowed. ${ }^{669}$

Paragraph 16 of the Bekendtgørelse states that persons who are not considered as lawyers in the sense of paragraph 1 of the same Bekendtgørelse, are not allowed to use any of the titles mentioned in that paragraph. The same applies to persons whose right to practise as a lawyer has been withdrawn. ${ }^{670}$ The second section states that any use of such a title without permission will be regarded as a criminal offence. ${ }^{671}$

\section{\$ 4.3.2 Implementation in the United Kingdom and Ireland}

\section{England, Wales and Northern Ireland}

This paragraph shall be concerned with the implementation of Directive 98/5/EC in the different jurisdictions of the United Kingdom. Although the United Kingdom consists of three different jurisdictions, the implementation of the Directive is governed by Regulations covering England, Wales and Northern Ireland, and by a separate instrument covering Scotland. The instrument used within the Scottish legal system will be dealt with in the next paragraph. The implementation of the Directive in England, Wales and Northern Ireland is covered by the European Communities (Lawyer's Practice) Regulations 2000. ${ }^{672}$ The Regulations are issued by the Lord Chancellor's Department.

Regulation 2 lays down a number of definitions, in respect of which it is interesting to note that a distinction is made between foreign lawyers and Irish solicitors and barristers, ${ }^{673}$ and that the notion of a 'European lawyer' is introduced. ${ }^{674}$ According to the Regulation, a European lawyer is a national of the United Kingdom, or of any of the Member States of the European Union, who is not a solicitor, a barrister or an advocate, but who is allowed to practise under one of the professional titles of the different Member States. If a European lawyer who is established with more than one competent authority within the United Kingdom gains access to one of those professions, he shall be deemed to be a European lawyer for the remaining jurisdictions. ${ }^{675}$

The third part of the Regulations deals with the registration of the European lawyer. Regulation 15 states that all professional bodies shall maintain a register of 'European lawyers'. Regulation 16 states that in order to be registered as a European lawyer, which is necessary in order to exercise professional activities under his home country title, ${ }^{676}$ the lawyer must produce a certificate which states that he is allowed to practise in his home Member State. No more than three months shall

\footnotetext{
$668 \int 14(2)$ Bekendtgørelse.

$669 \int 15(1,2)$ Bekendtgørelse.

670 \ $16(1)$ Bekendtgørelse.

$671 \int 16(2)$ Bekendtgørelse.

672 The European Communities (Lawyer's Practice) Regulations 2000, S.I. 2000/1119, amended by the European Communities (Lawyer's Practice) (Amendment) Regulations 2001, S.I. 2001/644.

673 Ibid. Regulation 2(1).

674 Ibid. Regulation 2(2) and 2(3).

675 Ibid. Regulation 2(3).

676 Ibid. Regulation 16(1).
} 
have elapsed since the certificate was issued. ${ }^{677}$ The applicant must also pay an appropriate fee. ${ }^{678}$ Subject to Regulation 18, a lawyer may register himself with more than one professional body. ${ }^{679}$ Regulation 17 lays down an obligation for the professional body to register any lawyer who fulfils the criteria of Regulation $16,{ }^{680}$ and an obligation to inform the competent authority of the home Member State of that fact. ${ }^{681}$ Regulation 18 states the limitations to the registration of a European lawyer. Generally, it can be said that these limitations do not flow from anxiety in the United Kingdom about allowing European lawyers to practise freely, but from the division of the legal profession in the United Kingdom. Firstly, Regulation 18 states that a European lawyer cannot register with one of the professional bodies of a solicitor and one of the professional bodies of a barrister. ${ }^{682}$ This flows from the fact that one can be either a solicitor or a barrister but one cannot be both, hence one cannot register with both a solicitors' body and with a barristers' body. Secondly, the Regulation prohibits Irish solicitors from registering with a barristers' professional body and Irish barristers from registering with a solicitors' body. ${ }^{683}$ Lastly, the Regulation prohibits European lawyers, registered with the Law Society of Scotland, from registering with one of the barristers' professional bodies, and those lawyers registered at the Faculty of Advocates from registering with any of the solicitors' professional bodies. ${ }^{684}$ As of 2006, 230 'European lawyers' had been registered with the Law Society of England and Wales. ${ }^{685}$ Regulations 19 and 20 respectively deal with the time limit for the professional bodies to take a decision on registration and the possibility of appeal for a European lawyer against such a decision. Regulation 19 states that the professional bodies have a term of four months in which to decide on an application. ${ }^{686}$ If after the four months no decision has been taken, the application will be deemed to be rejected. ${ }^{687}$ If the professional body has taken a decision, the European lawyer has three months, or longer (with the approval of the appellate body ${ }^{688}$ ) to appeal against such a decision. ${ }^{69}$ The appellate body has the right to reverse the decision of the professional body, to refuse the appeal or to remit the matter to the professional body with such directions as the appellate body sees fit. ${ }^{600}$ All these decisions shall be reasoned. ${ }^{691}$ Regulation 21 deals with those lawyers who

677 Ibid. Regulation 16(2) and 16(3).

678 Ibid. Regulation 16(4). See the remarks made with regard to Finland.

679 Ibid. Regulation 16(5).

680 Ibid. Regulation 17(1).

681 Ibid. Regulation 17(2).

682 Ibid. Regulation 18(1).

683 Ibid. Regulation 18(2) and 18(3).

684 Ibid. Regulation 18(4) and 18(5).

685 Via <www.ccbe.org>, last accessed 11 June 2007.

686 The European Communities (Lawyer's Practice) Regulations 2000, Regulation 19(1).

687 Ibid. Regulation 19(2).

688 These appeal bodies are laid down in Schedule 1 attached to the Regulations, they are; the Master of the Rolls for the profession of solicitor in England and Wales, the Lord Chief Justice of Northern Ireland for the profession of solicitor in Northern Ireland, the Visitors to the Inns of Court for the profession of barrister in England and Wales, and the Executive Council of the Inn of Court of Northern Ireland for the profession of barrister in Northern Ireland.

689 The European Communities (Lawyer's Practice) Regulations 2000, Regulation 20(1).

690 Ibid. Regulation 20(2).

691 Ibid. Regulation 20(3). 
pretend to be a European lawyer but who are not registered as such. The Regulation states that carrying out professional activities as a lawyer without being registered shall be deemed an offence, punishable by a fine. ${ }^{62}$ This rule is not applicable to those lawyers providing services in the United Kingdom. ${ }^{693}$ Eventually, the ruling that the European Court of Justice gave in the Gebhard case ${ }^{694}$ might become important in criminal proceedings in the United Kingdom in order to find out whether a lawyer is established and unregistered, and thus is guilty of an offence, or that he is completely within the boundaries of the law, providing services under the European Communities (Services of Lawyers) Order 1978. ${ }^{695}$ Regulation 24 states that where the professional body publishes a list of its members it shall also publish a list of European lawyers registered with that professional body. Regulation 7 states that a European lawyer shall use the professional title of his home Member State in a manner that avoids confusion with the titles of a solicitor, barrister and advocate. In addition to that, he will also state the professional organisation by which he is authorised to practise, or the court of law before which he is entitled to practise in that State. He is also obliged to indicate the professional body with which he is registered in the United Kingdom. ${ }^{696}$

Regulation 6 lays down the professional activities that a European lawyer may pursue. In essence, the Regulation states that the lawyer may carry out, under his home country professional title, all the activities that may lawfully be carried out by a member of the professional body with which the European lawyer is registered. ${ }^{697}$ The same holds true for employed lawyers. ${ }^{698}$ It must be noted, however, that the rule of Regulation 6 is subject to other limitations laid down in the Regulations. In this context, it is paramount to take into account Regulations 12 and 13, which will be dealt with below. Regulation 11 deals with the representation of clients in legal proceedings. It states that a European lawyer will not be barred from representing clients in court only for the reason that he is not a solicitor or a barrister. ${ }^{699}$ If a European lawyer wants to represent a client in legal proceedings in circumstances which are reserved for a solicitor, barrister or another qualified person, ${ }^{700}$ then the European lawyer will act in these proceedings in conjunction with such a solicitor, barrister or other qualified person. ${ }^{701}$ The latter will be answerable, if necessary, to the court, tribunal or public authority concerned. Regulations 12 and 13 refer back to Regulation 6(1) which states that European lawyers may exercise any professional activity of a solicitor or a barrister, except for limitations laid down in the Regulations. Regulations 12 and 13 lay down these limitations. Regulation 12 states that a registered European lawyer is not entitled to prepare for remuneration any

692 Ibid. Regulation 21(1).

693 Ibid. Regulation 21(2).

694 Case C55/94, Reinhard Gebhard v. Consiglio dell'Ordine degli Avvocati e Procuratori di Milano, [1995] ECR 4165.

695 The implementing instrument in the United Kingdom of Directive 77/249/EEC.

696 The European Communities (Lawyer's Practice) Regulations 2000, Regulation 7(2).

697 Ibid. Regulation 6(1).

698 Ibid. Regulation 6(2).

699 Ibid. Regulation 11(1).

700 It is clear that with regard to this last category such a rule can only be upheld if it falls in the margins defined by the ECJ in Case 427/85, Commission v. Germany, [1988] ECR 1123

701 The European Communities (Lawyer's Practice) Regulations 2000, Regulation 11(2). 
instrument creating or transferring an interest in land unless he has a home professional title which was obtained in Denmark, the Republic of Ireland, Finland or Sweden. Regulation 13 states that a European lawyer is not entitled to prepare, in a similar manner, any instrument for obtaining title to administer the estate of a deceased person unless, again, he has a home professional title from Denmark, Germany, the Republic of Ireland, Austria, Finland or Sweden. The United Kingdom is perfectly entitled to limit these activities since Article 5(2) of Directive 98/5/EC specifically allows these limitations.

Regulation 8 deals with joint practice. It states that a European lawyer may carry out professional activities in a joint practice with a member of the professional body with which he is registered, a European lawyer who is registered with the same professional body or any other person permitted by the professional body with which he is registered, to the same extent as members of the professional organisation with which the European lawyer is registered. In addition, a European lawyer may also practise jointly with another European lawyer who is practising on a permanent basis under his home country title in the first European lawyer's home Member State. This rather cryptic description leads to the conclusion that, in principle a European lawyer can work in joint practice with either his peers who are registered with the same professional body, or with a European lawyer from another Member State other than his home Member State, but who is established in his home State. With regard to the first category it must be stated, that in effect, this comes down to solicitors, since it is forbidden per se, for barristers, to practise in any other way other than privately. Regulations 9 and 10 are concerned with the name and the notification of the joint practice. In connection to these rules, the Regulations do not deviate much from the Directive. Regulation 9 states that a European lawyer is allowed to use the same name for his joint practice as he does in his home Member State, except for those names that are already being used in any part of the United Kingdom by people who are not European lawyers or solicitors. He may also not use that name if the rules of the professional body prohibit him from using it. Regulation 10 states that a European lawyer who is part of a joint practice in his home Member State shall notify this fact to the professional body with which he wants to register.

Regulations 25 to 29 deal with the rules of professional conduct that are applicable to European lawyers and with the disciplinary proceedings that may be brought against him. Regulation 25 is completely in conformity with Article 6 of Directive $98 / 5 / \mathrm{EC}$, and states that a registered European lawyer is subject to the same professional rules as the members of the professional body with which he is registered. If he is registered with more than one professional body he is therefore subject to the rules of all those bodies. Regulation 26 deals with the applicable disciplinary proceedings. The Regulation states that a European lawyer shall be subject to the same disciplinary proceedings as a member of the professional body with which he is registered. Again, this is completely in conformity with Article 7 of Directive 98/5/ EC. ${ }^{702}$ Sanctions imposed in disciplinary proceedings, which must be reasoned, ${ }^{703}$ may involve the suspension or withdrawal of the registration. ${ }^{704}$ Regulation 27

\footnotetext{
702 Ibid. Regulation 26(1).

703 Ibid. Regulation 26(3).

704 Ibid. Regulation 26(2).
} 
regulates the actual disciplinary proceedings brought against a European lawyer. It lays down the obligation for the professional body to cooperate with the professional body of the home Member State of the European lawyer concerned. ${ }^{705}$ The Regulation states further that when the professional body in the European lawyer's home Member State decides to withdraw the practice licence of the European lawyer that would automatically lead to the revocation of the registration in the United Kingdom. This will not be the case if the European lawyer was allowed to practise under more than one home title, and would in such circumstances mean that his licence is taken away only in one of his home Member States. ${ }^{706}$ If there is the possibility for an appeal procedure, the professional body of the home Member State shall be allowed to make representation in such a procedure. ${ }^{707}$ Regulation 28 covers the situations where disciplinary proceedings are started against a solicitor or barrister who is established under his home title in another Member State. The Regulation states that a foreign professional body shall inform the competent authority in the United Kingdom of the intention to begin such proceedings, and of the decision reached, including any appeal proceedings.

The last part of the Regulations, namely Regulations 29 to 36, deals with the integration of the European lawyer into one of the legal professions of the United Kingdom. Regulation 29 states that in principle a European lawyer will have to sit an aptitude test ${ }^{708}$ unless he can prove that he falls within the exemptions laid down in paragraphs 2 and 3 of the Regulation. ${ }^{709}$ A European lawyer can be exempted from the applicable aptitude test if he has been registered with the professional body for at least three years. In addition he must have effectively and regularly pursued for the same period of time, in England, Wales or Northern Ireland, professional activities under his home professional title in the law of England and Wales or Northern Ireland..$^{710}$ The other way to obtain exemption is to be registered for at least three years with a professional body, and to have effectively and regularly pursued professional activities under home title for at least three years, but for a lesser period with the law of the England and Wales or Northern Ireland. With regard to these exemptions, it is at least remarkable to notice that, in contrast with the language of Article 10 of Directive 98/5/EC, the Regulation makes no mention of European Community law as part of the professional activity that could lead to integration without an aptitude test. Again, there is no mentioning of European Community law in this respect. The difference in the two possible exemptions is the size of the discretionary power that is exercised by the professional bodies of the host Member State. The actual size of the discretion is regulated by Regulations 31 and 32. Regulation 30 states that the professional body concerned will grant an exemption if the conditions under either paragraph 29(2) or 29(3) are met. ${ }^{711}$ According to the Regulation, a lawyer ceases to be a European lawyer at the moment he

\footnotetext{
705 Ibid. Regulation 27(1).

706 Ibid. Regulation 27(2) and 27(3).

707 Ibid. Regulation 27(4).

708 In case of solicitors, the Qualified Lawyers Transfer Test, in case of barristers the Bar Aptitude Test.

709 The European Communities (Lawyer's Practice) Regulations 2000, Regulation 29(1).

$710 \quad$ Ibid. Regulation 29(2).

711 Ibid. Regulation 30(1).
} 
is integrated into the legal profession concerned. ${ }^{712}$ By far the most interesting part of this Regulation is laid down in the third paragraph, which states that the professional body may refuse to grant exemption if it considers that the European lawyer would be unfit to practise as a solicitor or barrister. ${ }^{713}$ This is probably the codification of Article 10(4) of Directive 98/5/EC, which states that the professional body may reject a lawyer based on reasons of public order, mainly with regard to previous disciplinary proceedings. It seems to me that this has been transferred into what seems to be a too broad discretion for the professional bodies. In my opinion, this Regulation must be applied in the light of what is laid down in Article 10(4) of the Directive. It is my opinion, nonetheless, that an application of Regulation 30(3) as such, i.e., without a reference to the situations laid down in Article 10(4) of the Directive and without an objective justification, must be classified as a violation of European Community law. Regulation 31 states that where a European lawyer wishes to be exempted under paragraph 2 of Regulation 29, he will provide the professional body with any relevant information and documents it may reasonably require. ${ }^{714}$ In addition, the professional body, in order to verify the regular and effective nature of the professional activity pursued, may request the European lawyer to provide, orally or in writing, clarification of, or further details on, the information and documents already provided. ${ }^{715}$

Regulation 32 lays down what evidence is necessary in order to acquire an exemption under paragraph 3 of Regulation 29. This Regulation also states that the lawyer concerned shall provide the professional body with all the relevant information and documents it may reasonably require. ${ }^{716}$ When deciding upon an application, the professional body shall take into account all the professional activities the registered European lawyer has pursued during his registration, and any knowledge and professional experience he has gained, and any of the training he has received in the law of any part of the United Kingdom and the rules of the professional conduct of the profession concerned. ${ }^{717}$ In principle, the information will be assessed and verified during an interview, unless the professional body deems this unnecessary. ${ }^{718}$ It is at least interesting to note that for the second exemption possibility for the aptitude test, professional activity throughout the United Kingdom is taken into account, and not only from England and Wales or Northern Ireland. This is the case, since the professional body has more discretion under this paragraph, which is completely in accordance with Article 10 of Directive 98/5/EC. Regulation 34 lays down the time limits for the professional bodies, within which they have to take a decision based on Regulation 29. The time period is four months, just as it is the case in deciding upon registration as a European lawyer. If the professional body does not answer within four months then the application is deemed to have been rejected. Regulation 35 lays down the right for a European lawyer to appeal against a decision taken under Regulation 35 within three months of the decision, or later

\footnotetext{
712 Ibid. Regulation 30(2).

713 Ibid .Regulation 30(3).

714 The European Communities (Lawyer's Practice) Regulations 2000, Regulation 31(1).

715 Ibid. Regulation 31(2).

716 Ibid. Regulation 32(1).

717 Ibid. Regulation 32(2).

718 Ibid. Regulation 32(3) and 32(4).
} 
if approval from the appellate body is granted. On the basis of the appeal, the appellate body may take the same decisions as they would in an appeal against a decision concerning the registration of a European lawyer. The appellate body may reverse the decision of the professional body, refuse the appeal or remit the matter to the professional body with any such directions as the appeal body sees fit. As of 2006, 71 European lawyers entered the profession of the solicitor by means of the exemption laid down in Article 10 of the Directive. ${ }^{719}$

\section{Scotland}

As already stated above, Scotland forms a different jurisdiction within the United Kingdom, and therefore Directive 98/5/EC needed to be implemented separately in Scotland. This was also done by means of Regulations that were drawn up by the Scottish Ministers and approved by the Scottish Parliament. ${ }^{720}$ It might not be surprising to notice that the Scottish Regulations are very similar to those in England, Wales and Northern Ireland. I will therefore focus on the differences between the two statutory instruments.

The first notable difference between the two sets of Regulations is to be found in Regulation 8 which deals with joint practice. As I have already stated above, the English Regulations provide that a European lawyer may practise jointly with another European lawyer who was established under his home title in the home Member State of the first European lawyer. The Scottish executive has wisely chosen to leave this unclear passage out of its Regulations. ${ }^{721}$

Regulation 11 deals with matters concerning the representation of clients in legal proceedings. However, there is an additional section (section 4) in the Scottish Regulations which removes the right of audience from registered European lawyers in the Supreme Court unless they have completed a training course in evidence, pleading and practice before the Supreme Court. ${ }^{722}$ This seems to be in accordance with the Directive because Article 5(3) allows for the restriction of access to higher courts. However, some insecurity remains since the Directive does not mention the following of a course (the use of specialised lawyers is allowed however) and the Regulation remains unclear on whether the European lawyer is allowed to act on his own after the completion of the course, or whether he is still obliged to work in conjunction with a Scottish lawyer.

Section 6 of the Scottish Regulation 16 states that there is no obligation for European lawyers to register with the professional bodies in Scotland if they are already registered with one of the professional bodies in England and Wales or Northern Ireland. ${ }^{723}$ The ratio behind this section lies in the fact that English, Welsh, or Northern Irish solicitors and barristers are also not obliged to register in Scotland. ${ }^{724}$ This section caused an enormous stir in the process of creating these Regulations, ${ }^{725}$ and it is my opinion that it causes more complications than it solves. Both Regulations

\footnotetext{
719 Via <www.ccbe.org>, last accessed 11 June 2007.

720 The European Communities (Lawyer's Practice) (Scotland) Regulations 2000, S.I. 2000/121.

721 The European Communities (Lawyer's Practice) (Scotland) Regulations 2000, Regulation 8.

722 Ibid. Regulation 11(4).

723 Ibid. Regulation 16(6).

724 Subordinate Legislation Committee, 19th Report 2000, Subordinate Legislation, SL/00/R19.

725 Ibid.
} 
are based on the fact that England, Wales and Northern Ireland and Scotland are separate jurisdictions, and should be treated as such. In my opinion, it would have been better to continue with this point of view even at this level. This choice also leads to differences in Regulations 21 and 22 which exempt the unregistered European lawyer in Scotland (who is registered in England and Wales or Northern Ireland) from the offence (listed in Regulation 21) and the sanctions placed thereon (listed in Regulation 21 and 22).

With regard to Regulation 29, it is interesting to note that the Scottish Executive has not failed to take into account professional activities pursued in Community law when deciding upon entrance into the profession without an aptitude test. ${ }^{726}$

\section{Ireland}

Ireland was one of the last Member States to implement Directive 98/5/EC in national legislation. Only late in 2003, on 29 December to be precise, did the national implementation of Directive 98/5/EC enter into force. ${ }^{727}$ Not only did it take a judgment of the European Court of Justice ${ }^{728}$ to press Ireland to implement the Directive, but also a formal notice from the Commission calling upon Ireland to comply with that judgement. ${ }^{729}$ Ireland chose to implement Directive 98/5/EC by means of a separate statutory instrument, the European Communities (Lawyer's Establishment) Regulations 2003 (hereinafter, the Regulations). ${ }^{730}$

Lawyers who seek to register and practise under their home country professional title in Ireland must make a choice between performing the tasks of a barrister or those of a solicitor. The fact that a migrating lawyer is confronted with this choice is in conformity with Article 3(3) of Directive 98/5/EC. It might be obvious when taking into account the fact that solicitors have a general right of audience in Ireland that the majority of lawyers who migrate there choose to register with the competent authority for the profession of the solicitor. Lawyers from the United Kingdom, both solicitors and barristers, do not have a choice between the two professions, but are obliged to register with the competent authority of the corresponding profession in Ireland, i.e., solicitors with the Law Society of Ireland and barristers and advocates with the Bar Council. Moreover, for solicitors from England, Wales and Northern Ireland this is a purely academic situation since they are allowed to

726 The European Communities (Lawyer's Practice) (Scotland) Regulations 2000, Regulation 29(2).

727 Law Society of Ireland, EU (Lawyer's Establishment Regulation), via <www.lawsociety.ie>, last accessed 29 August 2005.

728 Case C-362/01 Commission v. Ireland [2002] ECR-I 11433.

729 Press Release IP/03/1043, via <europa.eu.int>, last accessed 29 August 2005.

730 S.I. No. 732/2003 European Communities (Lawyer's Establishment) Regulations 2003, via $<$ www.irishstatutebook.ie>, last accessed 29 August 2005. Regulation 3 regulates the relationship between the Solicitors Act 1954 (and all its subsequent amendments) and the European Communities (Lawyer's establishment) Regulations 2003. From this regulation it becomes clear that although they are separate regulations the Lawyer's establishment regulations still affects the Solicitors Act. This is of course also the case with other separate implementations observed in other Member States, but it is the only case where this relationship is part of the implementation itself. The Irish implementation can therefore be regarded as an intermediate position between the two forms of implementation observed up until this point, i.e. integration of the implementation in existing legislation, and the creation of a new legislative instrument that implements the Directive. 
integrate in the profession of the Irish solicitor without further formalities. In response to this situation with regard to the dichotomy of the legal profession in Ireland, Regulation 4 states that there shall be two competent authorities which monitor lawyers who seek establishment under their home country professional title' The Law Society for those who seek establishment to exercise the professional activity of a solicitor and the Bar Council for those who seek to exercise the professional activities of barristers. $^{731}$

The procedure for registering lawyers who seek establishment under home title in Ireland is laid down in Regulation 6 of the Regulations. First of all, the regulation states that a lawyer who wants to exercise the activities belonging to the profession of either a solicitor or a barrister must register himself with the competent authority of that respective profession. ${ }^{732}$ The request for registration must be accompanied by several documents. The lawyer who seeks registration under his home title must produce a certificate proving his right to practise as a lawyer in his home Member State. No more than three months have elapsed since the certificate was issued. ${ }^{733}$ In addition to this the lawyer may be required to produce written evidence that he has professional indemnity insurance in accordance with the rules in his home Member State, which also covers the exercise of professional activities in Ireland, or that he is otherwise covered for indemnities. ${ }^{734}$ The coverage of the home insurance must be comparable to the Irish insurance, otherwise the lawyer may be obliged to take additional insurance in order to cover the missing parts in his existing insurance. ${ }^{735}$ Any of the abovementioned documents may be required to be accompanied by a translation in English or Irish, where the competent authority so requires. ${ }^{736}$ In addition, the lawyer who seeks registration under his home title must pay the appropriate fees to the competent authority. ${ }^{737}$ Directive $98 / 5 /$ EC does not mention anything about fees, so it must be assessed whether this is a possible breach of the directive. This assessment will be made at the end of this chapter. The remainder of Regulation 6 deals with the decision of the competent authority with respect to the application of the lawyer concerned to be registered under his home title in Ireland. The competent authority shall take a decision on the request of the lawyer as soon as is practical. ${ }^{738}$ If the conditions of Regulation 6(2) are fulfilled, the lawyer will be entered in the register of lawyers who are established under their home title within a period of four months. ${ }^{739}$ If the application is rejected or is subject to conditions, the competent authority shall inform the lawyer concerned within four months of the reasons for the rejection or the imposition of its conditions. ${ }^{740}$ If no decision is communicated within the period of four months, the application is deemed

\footnotetext{
731 Regulation 4 S.I. No. 732/2003 European Communities (Lawyer's Establishment) Regulations 2003, via <www.irishstatutebook.ie>, last accessed 29 August 2005.

Ibid. Regulation 6(1).

Ibid. Regulation 6(2)(a).

Ibid. Regulation 6(2)(b)(iI)(iII) and (ii).

Ibid. Regulation 6(2)(b)(iil) and (iiII).

Ibid. Regulation 6(2)(c).

Ibid. Regulation 6(2)(d).

Ibid. Regulation 6(3)(a).

Ibid. Regulation 6(3)(b.

Ibid. Regulation 6(3)(c).
} 
to have been rejected. ${ }^{741}$ The certificate shall contain any condition that may be imposed. ${ }^{742}$ Subsection 5 of Regulation 6 states that a lawyer may not be registered with both the Law Society and the Bar Council at the same time, but that lawyers (except for solicitors and barristers from the United Kingdom) are allowed to switch between the competent authority and professional activity. ${ }^{73}$ Any decision taken by the competent authority is eligible for appeal to the High Court, which may overturn the decision of the competent authority. ${ }^{744}$ The information that needs to be included in the register is laid down in Regulation $7 .{ }^{745}$ This Regulation also states that the competent authority shall inform the competent authority of the lawyer's home Member State of that lawyer's registration and any changes, suspension, or cancellation that may occur during the registration. ${ }^{746}$ If the lawyer fulfils the criteria laid down in Regulation 6 and is entered in the register of the competent authority, the lawyer will receive a 'qualifying certificate', which allows him to exercise professional activities under his home country professional title. ${ }^{747}$ If the registration is subject to conditions, these conditions will be mentioned on the certificate. ${ }^{748}$ A 'qualifying certificate' may be refused or suspended by the Law Society if the lawyer concerned has been prohibited, temporarily or permanently, from exercising the activities of a solicitor, if he has applied for registration with the Bar Council or if the Law Society deems that the cover for indemnity is not sufficient. $^{749} \mathrm{~A}$ 'qualifying certificate' shall expire at the moment the lawyer accedes to the profession of either the solicitor or barrister. ${ }^{750}$ Regulation 9 establishes the consequences of a revocation of the lawyer's right to practise in his home Member State. If a lawyer's right to practise is temporarily revoked in his home Member State he will no longer be allowed to exercise professional activities in Ireland, and where he has chosen to register himself with the Law Society his "qualifying certificate' shall stand as suspended. ${ }^{71}$ Where the revocation of the right to practise is permanent, the lawyer concerned shall be removed from the register in Ireland. ${ }^{752}$ The lawyer shall be notified of any such decision as soon as possible. ${ }^{753}$ The revocation of the right to practise in the home Member States shall have no effect in Ireland if the lawyer concerned is fully qualified in more than one home Member State, and where the revocation only concerns one of the qualifications. The only effect such a revocation shall have is that the lawyer concerned is no longer allowed to use the home title of the jurisdiction in which his right to practise was

\footnotetext{
741 Ibid. Regulation 6(3)(d).

742 Ibid. Regulation 6(4).

743 Ibid. Regulation 6(5).

744 Ibid. Regulation 6(8) and (9).

745 Ibid. Regulation 7.

746 Ibid. Regulation 7(3).

747 Ibid. Regulation 8(1).

748 Ibid. Regulation 8(2).

749 Ibid. Regulation 8(3).

750 Ibid. Regulation 8(4).

751 Ibid. Regulation 9(1).

752 Ibid.

753 Ibid. Regulation 9(2).
} 
revoked. ${ }^{754}$ As of 2006, 33 lawyers were registered under their home country professional title in Ireland. ${ }^{755}$

Regulation 10 covers the exercise of professional activity by lawyers established under their home title in Ireland. In general, the Regulation states that lawyers who are registered under their home title in Ireland, may exercise professional activities under their registered home title, as if they were solicitors or barristers, depending on the competent authority with which the lawyer chose to register. ${ }^{756}$ More specifically, lawyers registered under their home title may give advice on the law of their home Member State, European Community law and Irish law. ${ }^{757}$ In addition the registered lawyer shall have the same rights of audience in court as a solicitor and barrister. ${ }^{758}$ However, if representation in court is reserved for a person who is registered as a solicitor or barrister the registered lawyer is obliged to work in conjunction with such a solicitor or barrister. ${ }^{759}$ While exercising professional activities in Ireland a registered lawyer is obliged to practise under his home country professional title, he must indicate the competent authority by whose virtue he is allowed to practise in his home Member State. In addition, he must use his professional title in one of the languages of his home Member State, where he is obliged to avoid any confusion with the professional title as it is used in Ireland. ${ }^{760}$ Activities that are specially reserved for solicitors in Ireland, may be exercised by lawyers established under their home title (no matter whether they exercise the professional activity of a solicitor or a barrister) provided that these activities are not reserved for a profession other than that of a lawyer in their home Member State (which will be the case for many continental jurisdictions where these activities fall under the responsibility of the notary). ${ }^{761}$ Regulation 12 is a safety-net provision to make any Statute or Regulation that applies to solicitors or barristers also applicable to lawyers who are registered under their home title. ${ }^{762}$

Regulation 11 states that the Irish rules of professional conduct that are in force for any of the legal professions in Ireland shall be applicable to registered lawyers who have sought to exercise that legal profession. ${ }^{763}$ When the need for disciplinary action arises, the competent authority involved shall notify the competent authority of the home Member State of the complaint received against the registered lawyer and it shall inform that authority of any outcome of its deliberations. ${ }^{764}$ Where a complaint is received from another source other than the competent authority, the Disciplinary Tribunal is responsible for communicating the complaint to the com-

\footnotetext{
754 Ibid. Regulation 9(3).

755 <www.ccbe.org>, last accessed 11 June 2007.

756 Regulation 10(1) S.I. No. 732/2003 European Communities (Lawyer's Establishment) Regulations 2003, via <www.irishstatutebook.ie>, last accessed 29 August 2005.

Ibid.

Ibid. Regulation 10(1)(b).

Ibid. Regulation 10(2).

760 Ibid. Regulation 10(3). Violation of these rules leads to a fine of a maximum of $€ 3000$ where the registered lawyer pursued the professional activities of a solicitor.

761 Ibid. Regulation 10(4).

762 Ibid. Regulation 12.

763 Ibid. Regulation 11(1) and (2).

764 Ibid. Regulation 11(3) and (7).
} 
petent authority of the home State. ${ }^{765}$ The regulation elaborates further that the competent authority of the registered lawyer's home Member State may make submissions in any appeal against a disciplinary decision of the competent authorities in Ireland. ${ }^{766}$ In case of a disciplinary proceeding, the competent authority shall impose the measures provided for in the rules governing the relevant profession. ${ }^{767}$

According to Regulation 13, a lawyer who is established under his home country professional title and who is a member of a grouping in his home Member State must inform the competent authority of the relevant profession in Ireland of that fact. ${ }^{768}$ Where allowed under the rules of the profession concerned, such a lawyer may exercise his professional activity as a member of that group or he may open a branch or agency of that group. ${ }^{769}$ Although it is not specifically mentioned, clearly that this is only applicable for solicitors because the profession of the barrister can only be exercised in a solitary fashion. The Regulation states that in any circumstances a grouping consisting of registered lawyers and a combination of solicitors and registered lawyers will be allowed. ${ }^{770}$ At first sight this seems to be in order, yet the Irish implementation lacks the required justification ${ }^{771}$ as to why the rules governing the association (or rather the non-association) of barristers should prevail over the rules in force in the registered lawyer's home Member State. A registered lawyer, who is apparently allowed to practise as a member of a grouping, may use the name of the grouping to which he belongs in his home Member State. ${ }^{772}$ When a registered lawyer uses the name of the grouping while exercising professional activities in Ireland he must mention the legal form of that grouping and the members of the grouping who also exercise professional activities in Ireland. ${ }^{773}$ Section 4 of Regulation 13 states the situations in which a grouping shall be deemed to consist of persons who are not members of the legal profession. This shall be the case where the capital of the grouping is held entirely or partially by, the name of the grouping is used by, or the decision making power lies de iure or de facto with persons who are not solicitors, barristers or lawyers. ${ }^{774}$ It is remarkable that the Regulation does not go further into the consequences of a grouping that contains members who are not lawyers. In the first paragraph, it was established that barristers are not allowed to work in groupings per se, and that solicitors are not allowed to work in multi-disciplinary partnerships. It may therefore be concluded that lawyers who are established under their home country professional title in Ireland are not allowed to exercise professional activities in a multi-disciplinary partnership.

\footnotetext{
765 Ibid. Regulation 11(4).

766 Ibid. Regulation 11(5).

767 Ibid. Regulation 11(8).

768 Ibid. Regulation 13(1a).

769 Ibid. Regulation 13(1b).

$770 \quad$ Ibid. Regulation 13(2).

771 Ibid. Article 11(1) Directive 98/5/EC.

772 Regulation 13(3) S.I. No. 732/2003 European Communities (Lawyer's Establishment) Regulations 2003, via <www.irishstatutebook.ie>, last accessed 29 August 2005.

773 Ibid.

$774 \quad$ Ibid. Regulation 13(4).
} 
Regulation $16^{775}$ lays down the rules governing the integration of a lawyer who is established under his home country professional title in one of the legal professions in Ireland, i.e., solicitor or barrister. This integration is made possible by amending the statutory instrument which governs the recognition of diplomas. ${ }^{776}$ Regulation 16 states that a new Regulation 5a is included in the S.I. 1/1991. That Regulation states that Regulation 5 of S.I. 1/1991 (which prescribes an aptitude test) shall not apply to circumstances in which a lawyer has effectively and regularly pursued professional activities in Irish law, including Community law. for a period of at least three years and where this lawyer has applied for integration in the solicitor's profession and the barrister's profession. ${ }^{777}$ Effective and regular pursuit is construed as pursuing activities without interruptions other than those resulting from everyday life, and not following the course of 'services' as under Directive $77 / 249 / \mathrm{EEC}$, or its implemention counterpart in Ireland. ${ }^{778}$ In order to be integrated into the legal profession of his choice the lawyer concerned must provide the competent authority with the necessary proof which it requires. Ordinarily this proof will be provided by means of any relevant document or information, especially with regard to the number, and nature, of any cases dealt with. In addition, for the purposes of validating the effective and regular pursuit of the activities, any other information or documentation that the competent authority requests. ${ }^{779}$ Where a lawyer seeks integration after pursuing activities in Ireland in a regular and effective manner for a period of at least three years, but where he has been active in the Irish law for a period shorter than that, the competent authority may decide to integrate the lawyer in the profession without an aptitude test. ${ }^{780}$ When making this decision the competent authority will take into account the activity in Irish law that is pursued, and consider any knowledge and professional experience in Irish law, and any attendance of the lawyer at lectures and seminars on Irish law, including the rules of professional conduct and practice. ${ }^{781}$ To this end, the lawyer will provide the competent authority with any information and documentation relating to the cases with which he has dealt. The assessment and verification of the lawyer's effective and regular pursuit of the professional activities and his ability to continue that pursuit will take place in the form of an interview with the competent authority, unless the competent authority deems such an interview unnecessary. ${ }^{782}$ A lawyer who is allowed integration in the solicitor's profession or the profession of the barrister will still be able to use his home country professional title alongside the title of the solicitor or barrister, provided that he remains authorised to practise in his home Member State. ${ }^{783}$ Integration in the profession in the host Member State leads to the revocation of

775 Ibid. Regulations 14 and 15 contain provisions for a compensation scheme and transitional rules respectively.

776 S.I. No. 1/1991 European Communities (General System for the Recognition of Higher Education Diplomas) Regulations 1991.

777 Regulation 16 S.I. No. 732/2003 European Communities (Lawyer's Establishment) Regulations 2003, via <www.irishstatutebook.ie>, last accessed 29 August 2005.

778 Ibid.

779 Ibid.

780 Ibid.

781 Ibid.

782 Ibid.

783 Ibid. 
the practising or qualifying certificates that were issued under home title. ${ }^{784} \mathrm{~A}$ request to be integrated in one of the Irish legal professions based on Regulation 16 may be refused, with a reasoned statement, by the relevant competent authority, in circumstances where the lawyer concerned fails to provide the necessary evidence required under the Regulation or where the admission of the lawyer to one of the legal professions in Ireland would be contrary to public policy in particular because of disciplinary proceedings, complaints, or incidents of any kind. ${ }^{785}$ Any information provided by the lawyer in the process of integrating into one of the legal professions in Ireland shall be dealt with confidentially. ${ }^{786}$

\section{\4.3.3 Implementation in the Benelux}

\section{The Netherlands}

The process of implementing Directive 98/5/EC in the Netherlands was a lengthy one. Although the Nederlandse Orde van Advocaten was already dealing with the possible consequences of the Directive in May $1998,{ }^{787,788}$ an official proposal for a law implementing the Directive did not emerge until 20 January 2001, and the proposal did not become law until 13 July 2002. ${ }^{789}$ The reasons for this delay have always been unclear, although anecdotal information seems to suggest that the Dutch Ministry of Justice was of the opinion that the Directive did not have any real added value and that all situations could be solved with the existing rules. ${ }^{790}$ Similar to the Scandinavian countries and unlike the United Kingdom, the Dutch authorities have opted for an elaborate amendment of the Advocatenwet instead of creating a new law to govern all the nuances of the free movement of lawyers in the European Union. The law which adapts the Advocatenwet ${ }^{791}$ consists of six articles, of which Article 1 is the most important since it includes the significant changes to the Advocatenwet (the other articles change other laws but are of minor importance to this review). The adaptation of the Advocatenwet consists of a number of elaborations in

\footnotetext{
784 Ibid.

785 Ibid.

786 Ibid.

787 The Directive was published in early March 1998.

788 Notitie of the General Council of the Nederlandse Orde van Advocaten, 15 May 1998, number $5.6 .4 / 2$.
}

789 The Commission had to provide some incentive, by starting an Article 226 procedure because of late implementation (the implementation date was 14 March 2000). On 25 January 2001 the Commission sent its reasoned opinion to a number of Member States, among which was the Netherlands. See < europa.eu.int/comm/internal_market/en/update/infr/infr01.htm\#4>, last accessed 27 June 2003. In the end only the cases of France, Spain and Luxembourg were referred to the Court of Justice. See < europa.eu.int/comm/internal_market/en/update/infr/ 01-1042.htm>, last accessed 27 June 2003.

790 Phone conversation between civil servant of the Ministry of Justice and the author. As has been shown above, there are some significant lacunae in the pre-98/5/EC Dutch system, so the informal remarks are evidently untrue.

791 Wet van 13 juli 2002 to aanpassing van de Advocatenwet aan richtlijn 98/5/EG van het Europees Parlement en de Raad van de Europese Unie van 16 februari 1998 ter vergemakkelijking van de permanente uitoefening van het beroep van advocaat in een andere lidstaat dan die waar de beroepskwalificatie is verworven (Implementatie vestigingsrichtlijn advocatenwet), Staastsblad 2002, no. 440. 
order to make the rules of the Advocatenwet also applicable to those lawyers who seek permanent establishment under their home title in the Netherlands.

The establishment under home title for lawyers is laid down in a new paragraph in the Advocatenwet that is introduced after the paragraph which deals with lawyers from other Member States who provide services in the Netherlands. ${ }^{792}$ Article $16 \mathrm{~h}$ of the new Advocatenwet states that a lawyer who is qualified to practise as a lawyer in a Member State of the European Union, or in a Member State of the European Economic Area, may also exercise the same activities as a Dutch lawyer. He may exercise these activities after he is entered in the registers of the Raad van Toezicht ${ }^{793}$ of the constituency where he intends to practise. ${ }^{794}$ Section 2 of Article $16 \mathrm{~h}$ states that the Raad van Toezicht shall enrol any lawyer who can produce a certificate from the competent authority of his home Member State stating that he is allowed to practise as a lawyer in his home Member State. ${ }^{795}$ No more than three months shall have elapsed since the certificate was issued. ${ }^{796}$ The Raad van Toezicht shall notify the competent authority of the host Member State of the lawyer's enrolment in the Netherlands. ${ }^{797}$ When the Raad van Toezicht publishes a list of lawyers that are enrolled in that constituency it shall not only list the lawyers who are enrolled on the basis of Article 1 of the Advocatenwet. but it shall also include the lawyers who are enrolled by virtue of Article 16h Advocatenwet. ${ }^{798}$ As of 2006, 41 lawyers were registered under their home country professional title. ${ }^{799}$ According to Article 16i of the new Advocatenwet, lawyers from other Member States who are enrolled in the Netherlands are obliged to use their home country professional title in the language of their home Member State, or in such a way that it does not lead to confusion with the Dutch professional title of the advocaat. ${ }^{800}$ In addition to that, a lawyer established on the basis of Article $16 \mathrm{~h}$ of the Advocatenwet is also obliged to mention the professional organisation under which he is allowed to practise in his home Member State, and the fact that he is enrolled by the Raad van Toezicht. ${ }^{801}$

Article $16 \mathrm{~h}$ of the Advocatenwet states that a lawyer who is established on the basis of that article may exercise the same activities as a lawyer who is established by way of Article 1 of the Advocatenwet. ${ }^{802}$ In addition to the rule mentioned in Article $16 \mathrm{~h}$ Advocatenwet, Article $16 \mathrm{j}$ states that with respect to activities which involve representing clients in legal proceedings, a lawyer established on the basis of Article $16 \mathrm{~h}$ must seek cooperation with a lawyer ${ }^{803}$ who is established on the basis of Article

792 Article 16g-16k Advocatenwet.

793 The Raad van Toezicht is the controlling body of the Nederlandse Orde van Advocaten in the different legal constituencies. Since there are nineteen constituencies in the Netherlands there are also nineteen Raden van Toezicht. See Article 22 Advocatenwet.

Article $16 \mathrm{~h}$ Advocatenwet.

795 Article $16 \mathrm{~h}(2)$ Advocatenwet.

796 Ibid.

797 Article 16h(3) Advocatenwet.

798 Article 16h(4) Advocatenwet.

799 <www.ccbe.org>, last accessed 11 June 2007.

$800 \quad$ Article 16i(1) Advocatenwet.

801 Article 16i(2) Advocatenwet.

802 Article 16h Advocatenwet.

803 The rules with regard to cooperation between a lawyer from another Member State who provides services in the Netherlands and a Dutch lawyer, which are laid down in Article 16d 
1 of the Advocatenwet. This obligation is only enforced if Dutch law prescribes that a person must be represented by a lawyer (i.e., where the legal monopoly with regard to representing clients in court is effective). ${ }^{804}$

Article $16 \mathrm{k}$ of the Advocatenwet states that a lawyer who is established under Article $16 \mathrm{~h}$ of the Advocatenwet is subject to the same professional rules as a lawyer enrolled under the regime of Article 1 of the Advocatenwet. ${ }^{805}$ According to this Article, the professional rules laid down in both the Advocatenwet ${ }^{806}$ and the Verordeningen ${ }^{807}$ shall be applicable to lawyers who establish themselves in the Netherlands under the regime of Article $16 \mathrm{~h}$ of the Advocatenwet. ${ }^{808}$ The amendments to the Advocatenwet in connection with disciplinary proceedings are not laid down in the new paragraph that is introduced in the new Advocatenwet but instead find their place in the articles that were written for the lawyers established under the regime of Article 1 Advocatenwet. Article 46fa of the new Advocatenwet states that when the Raad van Toezicht of a legal constituency is of the opinion that disciplinary proceedings should be commenced against a lawyer who is established under the regime of Article $16 \mathrm{~h}$ of the Advocatenwet, the Raad shall first inform the competent authority of the host Member State. In addition, it shall provide that competent authority with all the necessary information. ${ }^{809}$ The newly introduced Article $60 \mathrm{~b}$ of the Advocatenwet lays down the procedure for disciplinary proceedings involving lawyers who are established under Article $16 \mathrm{~h}$ of the Advocatenwet. In essence, the Article states that the procedure for lawyers who are established under the regime of Article 1 of the Advocatenwet shall be followed when disciplinary proceedings are initiated against a lawyer who is established on the basis of Article $16 \mathrm{~h}$ Advocatenwet. ${ }^{810}$ In addition to that basic rule, this Article lays down a number of exceptions, i.e., circumstances where the disciplinary proceedings against lawyers who are established under their home title differ from the proceedings used when dealing with lawyers who use the host country title. The first deviation from the traditional procedure is the possible outcome of a disciplinary proceeding. ${ }^{811}$ Article $16 \mathrm{~h}$ states that in deviation of Article 48 of the Advocatenwet the possible measures that may be taken after a disciplinary proceeding are a simple warning, a reprimand, a prohibition on exercising the activities authorised under Article $16 \mathrm{~h}$ of the Advocatenwet for a maximum of

and 16e of the Advocatenwet are also applicable to the situation where a lawyer established on the basis of Article 16h Advocatenwet is obliged to co-operate with a Dutch lawyer.

804 Article 16j Advocatenwet.

805 Article 16k Advocatenwet.

806 Article 10,11,12, 13, 14 and 16 are named explicitly in the Article. The first five are genuine professional rules (clothing in court etc.), while the latter resembles more the articles covering disciplinary proceedings, since it regulates that a lawyer's licence to practise shall be revoked when he is declared bankrupt, or when he is physically or mentally incapable of exercising his profession.

807 Such as the Samenwerkingsverordening (cooperation regulation) as mentioned above.

808 Although not explicitly mentioned in the amended Advocatenwet a lawyer established under his home title, according to Article 6 of Directive 98/5/EC, is also bound by the rules of professional conduct of his home Member State.

809 Article 46fa Advocatenwet.

810 Article 60b(1) Advocatenwet. It falls outside the scope of this work to deal with the Dutch disciplinary proceedings extensively. It suffices to remark that the same procedure shall be followed for lawyers who are established under their home title.

811 Article 60b(2)-60b(7) Advocatenwet. 
one year, or a complete revocation of the enrolment in the registers of the Raad van Toezicht. ${ }^{812}$ The third section of the new Article $60 \mathrm{~b}$ of the Advocatenwet states that the rules concerning the publication of the verdict of the Raad van Toezicht as they apply to lawyers who are established under Article 1 of the Advocatenwet, shall also apply to lawyers who are established under Article $16 \mathrm{~h}$ of the Advocatenwet. ${ }^{813}$ In the event of a disciplinary proceeding being commenced in the Netherlands against a lawyer who is established under the regime of Article $16 \mathrm{~h}$ of the Advocatenwet, the competent authority of the home Member State shall be informed and shall be asked for its opinion. The fact that the competent authority of the host Member State is informed of the disciplinary proceeding shall be communicated to the lawyer involved. During the disciplinary proceeding, the Raad van Toezicht shall co-operate with the competent authority of the host Member State. ${ }^{814}$ If the competent authority of the host Member State revokes the right of a lawyer who is established under the regime of Article $16 \mathrm{~h}$ of the Advocatenwet, to practise in his home Member State (either temporarily or permanently) the lawyer is automatically precluded from practising law in the Netherlands. The Raad van Toezicht shall revoke the registration of the lawyer, either temporarily or permanently. ${ }^{815}$ The Raad van Toezicht shall inform the competent authority of the host Member State of this decision. ${ }^{816}$

Two modifications to the existing articles in the Advocatenwet ensure the rules laid down in Article 6(2) of Directive 98/5/EC regarding representation in professional bodies, are implemented correctly. The modified Articles 24 and 40 of the Advocatenwet state that lawyers who are established under the regime of Article $16 \mathrm{~h}$ of the Advocatenwet are allowed to elect and be elected in the elections of the profession's bodies. ${ }^{817}$

The integration of lawyers established under their home title in another Member State into the profession of the host Member State, as guaranteed by Article 10 of Directive 98/5/EC, is covered by the newly introduced Articles $2 \mathrm{a}, 2 \mathrm{~b}$ and $2 \mathrm{c}$ of the Advocatenwet. As of 2006, eight lawyers were integrated into the legal profession of the Netherlands. ${ }^{818}$ Article 2a of the Advocatenwet states that in addition to the situation described in Article 2 of the Advocatenwet, ${ }^{819}$ lawyers who gained their professional education in another Member State of the European Union or the European Economic Area may establish themselves as an advocaat, i.e., under the professional title of the host Member State (the Netherlands). This is subject to their producing a document which proves that over a period of at least three years the lawyer has been pursuing effectively and regularly professional activities that

812 Article $60 \mathrm{~b}(2)$ Advocatenwet. Article 48 is essentially the same apart from the fact that it speaks about different registers, since it only applies to lawyers established under Article 1 of the Advocatenwet.

813 Article $60 \mathrm{~b}(3)$ Advocatenwet.

814 Article 60b(4), (6) and (7) Advocatenwet.

815 Article $60 \mathrm{~b}(5)$ Advocatenwet. Article 9aa of the Advocatenwet mirrors this article since it deals with Dutch lawyers whose registration as a lawyer in another Member State is revoked by the competent authority of the host Member State.

816 Ibid.

817 Articles 24 and 40 Advocatenwet.

$818<$ www.ccbe.org>, last accessed 11 June 2007.

819 This article lists the requirements that a prospective lawyer has to fulfil in order to be established under the regime of Article 1 of the Advocatenwet. 
involve Dutch law, including European Community law. ${ }^{820}$ The lawyer who seeks integration in the legal profession of the host Member State must file an application for such integration with the Raad van Toezicht of the legal constituency where he has exercised his professional activities under his home country professional title. ${ }^{821}$ The application must be accompanied by documents that provide information on the number and sorts of cases dealt with over the three-year period. ${ }^{822}$ The Raad van Toezicht can verify this information by asking the lawyer concerned for further information if this is regarded as necessary. ${ }^{823}$ In addition to this information, the lawyer will also have to provide a document regarding his conduct (as is required for Dutch lawyers on the basis of Article 2 of the Advocatenwet) issued by a Dutch judge, or an equivalent document originating from his home Member State. ${ }^{824}$ As with most implementations reviewed in this section of the book, the newly created articles for the Advocatenwet do not mention anything about the amount of Dutch law that a foreign lawyer must have dealt with in order to integrate into the legal profession of the host Member State. The Dutch Minister of Justice has addressed this subject a number of times in the preparatory stages of the new Advocatenwet. On three occasions, his clarification of the bill itself, ${ }^{825}$ his reaction to the Raad van State, ${ }^{826}$ and in his answers to the questions posed by Parliament, ${ }^{827}$ the Minister of Justice stated that if the experience gained was only in European Community law then this was not sufficient to integrate into the profession of the Netherlands. This is potentially in violation of the Establishment Directive. What is far more disturbing in the Dutch implementation is that the Dutch authorities have made use of an old distinction of functions that are exercised by an advocaat in order to deprive Article 10 , and the Dutch implementation thereof, of much of its effect. ${ }^{828}$ In the Netherlands the separate function of the procureur also exists. ${ }^{829}$ This function is that of the representative in a trial. An advocaat pleads the case of the client, a procureur deals with the relationship between the client and his advocaat on the one side and the court on the other side. ${ }^{830}$ Since all district courts have different rules with regard to filing documents etc., a procureur can only practise within the legal constituency where he is established. ${ }^{831}$ If a lawyer wants to represent a client in another district, he needs to work with a procureur from that district. ${ }^{832}$ Where an advocaat deals with a case in his 'own' constituency, he fulfils the task of both advocaat and procureur.

\footnotetext{
820 Article 2a(1) Advocatenwet.

821 Article 2a(2) Advocatenwet.

822 Article 2a(3) Advocatenwet.

823 Article 2a(4) Advocatenwet.

824 Article 2a(5) Advocatenwet.

825 TK 2000-2001, 27 587, nr. 3.

826 TK 2000-2001, 27 587, nr. A.

827 TK 2001-2002, 27 587, nr. 5.

828 See Claessens (2003) B, p. 881.

829 In other systems avoué or procurador etc. See Adamson (1998), pp. 22-23.

830 Van Boneval Faure (1893), p. 193, who cites Von Feuerbach, Ueber die Gerichtsverfassung Frankreichs, Giessen 1825, page 163: 'Die Verrichtung der avoués wird mehr als mechanischer Handwerkdienst betrachtet, das Geschäft der Advocaten, welke als Rechtsgelehrte mit den Waffen der Wissenschaft und durch die Macht der Beredsamkeit die Rechte der Partheijen durchzufechten berufen sind, als ein edle freie Kunst.'

831 Hoegen Dijkhoef (1993), p. 226.

832 Ibid.
} 
Historically the functions of the advocaat and procureur were meant to be exercised by different persons. ${ }^{833}$ Until the 1879 , it was prohibited to be both an advocaat and a procureur. ${ }^{834}$ After this prohibition was revoked, it became more commonplace for advocaten to fulfil the task of procureur in their own constituency. Nowadays it is common usage to follow this route, and new advocaten are automatically sworn in as procureurs, and the profession of the procureur is no longer viewed as a separate function, it is merely a guise that advocaten uses in some procedures. ${ }^{835}$ In the current discussion regarding legal reform in the Netherlands, there has also been debate on whether to abolish the difference between the functions of the advocaat and procureur. Recently a bill was proposed by the government to abolish the distinction. ${ }^{836}$ The reason why this distinction is of importance lies in the problem of the legal monopoly of advocaten/procureurs in civil proceedings. ${ }^{837}$ As was mentioned above, the previously separate functions of the procureur and advocaat are now embodied in the modern advocaat. However, unlike criminal cases, where the legal monopoly rests with the advocaat, the legal monopoly to represent clients in civil cases lies with the procureur and not with the advocaat. ${ }^{838}$ So in order to benefit from the legal monopoly in civil cases, the advocaat must also be entitled to use the title of procureur. As seen above, Dutch advocaten are automatically sworn in as procureurs at the same time as they are sworn in as advocaten. ${ }^{839}$ According to Article 62 of the Advocatenwet which regulates the functions of the procureur, a lawyer from another Member State can also become a procureur if he obtains an EC declaration. As seen above, in the case of advocaten such a declaration can be obtained by taking an aptitude test that is constructed by the Nederlandse Orde van Advocaten. According to the Orde the aptitude test for an advocaat and the test for a procureur are identical. ${ }^{840}$ In fact, there is only one test, and if a lawyer from another Member State passes that test he is sworn in as an advocaat and a procureur, just like his Dutch counterparts.

The problem lies in the fact that the law implementing Directive 98/5/EC in the Netherlands does not amend Article 62 of the Advocatenwet. This leads to the conclusion that a lawyer who integrates under the regime of Article $2 \mathrm{a}$ of the Advcoatenwet, i.e., the implementation of Article 10 of Directive 98/5/EC, will only gain access to the profession of the advocaat and not to that of the procureur. This leads to the conclusion that advocaten who have integrated on the basis of Article 2 of the Advocatenwet are not allowed to represent clients in civil proceedings,

833 Van Boneval Faure (1893), p. 201.

$834 \quad$ Ibid. p. 202.

835 See NOVA (1965), p.15; Hoegen Dijkhoef (1993), p. 223 and Adamson (1998), p. 23.

836 Wetsvoorstel 30815, via <www.overheid.nl>, last accessed 21 November 2006. The Ministry of Justice wanted to abolish the profession of procureur by 1 March 2008. See <www.advocaten orde.nl/newsarchive/06-04-07_Brief_avp.pdf>, last accessed 11 June 2007. This was postponed until 1 September 2008. See <www.advocatenorde.nl/algemeen/afschaffing _procuraat.asp>, last accessed 24 April 2008.

837 Besides the defence of clients in criminal proceedings (where the procureur does not exist) and certain tax cases, this is the only area where advocaten have a legal monopoly. See Hoegen Dijkhoef (1993), p. 226.

838 Hoegen Dijkhoef (1993), p. 226. See also: Van Boneval Faure (1893), R. p. 195.

839 Article 62 Advocatenwet lists the same educational requirements as Article 2 of that same law in the case of advocaten.

$840<$ www.advocatenorde.nl>, last accessed 28 April 2008. 
since that legal monopoly lies with the procureurs and not with the advocaten. An advocaat who is integrated in the Netherlands on the basis of Article 2a of the $A d$ vocatenwet is therefore not allowed to represent clients in court in civil proceedings, but he will be obliged to work together with a procureur (either a Dutch procureur, or a procureur who has taken an aptitude test). One can therefore conclude that the Dutch implementation does not lead to full integration in the Dutch legal profession, and it is therefore in breach of Article 10 of Directive 98/5/EC. ${ }^{841}$ Since the exact extent of harmonisation of Article 10 was not assessed by the Court in the Commission v. Luxembourg and the Wilson cases, it is not completely clear into which of the three categories of restrictions identified above such a breach would have to be put. However, it might be clear that, were it were to be considered to fall in the legislative competence of the Member State, it is a restriction that frustrates the full working of the Directive and is therefore prohibited per se. The official explanation given for this irregularity is at best ambiguous. Both the Ministry of Justice ${ }^{842}$ (who was responsible for the implementation) and the Nederlandse Orde van Advocaten ${ }^{843}$ state that it is an unwelcome situation that a lawyer from another Member State is able to integrate fully in the legal profession of the Netherlands without having their knowledge of procedural law tested by an independent institution, in this case the Orde. This cannot save this anomaly from being illegal. However, the problem might solve itself, with the abolition of the profession of the procureur, and with it the abolition of this irregularity, which is envisaged for 1 September $2008 .^{844}$ Article $2 \mathrm{~b}$ of the Advocatenwet states that lawyers who have been working for at least three years on an effective and regular basis, but who have been dealing with Dutch law for a shorter time, are also eligible for integration. This integration may take place if the Raad van Toezicht is of the opinion that the lawyer concerned is sufficiently able to exercise the profession of the advocaat in the Netherlands. ${ }^{845}$ When ascertaining this ability, the Raad will take into account; the period of time the lawyer has worked in the Netherlands, his knowledge of, and experience in, Dutch law, together with his participation in courses and seminars regarding Dutch law, and his knowledge, experience and participation in courses and seminars with regard to Dutch professional rules. In order to verify the lawyer's knowledge and professional experience, the Raad van Toezicht will conduct an interview with the lawyer. ${ }^{846}$ Although not specifically mentioned (as was also the case with integration on the basis of Article 2a of the Advocatenwet) it can be assumed that integration via this route leads to the same irregularity as is the case with integration on the basis of Article 2a; namely that the lawyer concerned will integrate into the profession of the advocaat without gaining access to the functions that are performed by an advocaat in

841 This situation is acknowledged by both the Ministry of Justice and the Orde (phone conversation with author 23 July 2003).

842 Which is even more strange, since the Minister has always upheld the appearance that integration on the basis of Article 2a Advocatenwet would lead to a full integration in the profession of lawyer, without ever hinting at the fact that a substantial difference between integration on the basis of Directive 98/5/EC and integration on the basis of Directive 89/48/EEC would occur. See Kamerstukken II 2000-2001, 27587 no. 3; no. A and no. 5.

843 Van der Pijl (2003), p. 955.

844 See Blokland (2008) and Heemskerk \& Bijlsma (2008).

845 Article 2b(1) Advocatenwet.

846 Article 2b(2) Advocatenwet. 
his guise of a procureur. Similar to integration on the basis of Article 2a of the Advocatenwet it can be safely concluded that this result is contrary to the results that Directive 98/5/EC seeks to establish. Article 2c of the Advocatenwet states the result of integration on the basis of Article $2 \mathrm{a}$ or $2 \mathrm{~b}$ of the Advocatenwet, namely the fact that such a lawyer is, as of then, entitled to use the title of the advocaat in combination with the title he is entitled to use in his home Member State. ${ }^{847}$ The second section of Article 2c states that if disciplinary proceedings are brought against an integrated lawyer in his home Member State, which lead to the conclusion that the lawyer concerned is no longer entitled to exercise his profession in his home country title, that automatically means that the lawyer is also no longer entitled to work under his home country professional title in the Netherlands. ${ }^{848}$

Not all the rules laid down in Directive 98/5/EC are implemented by means of an adaptation to the Advocatenwet. Provisions in the Directive referring to legal remedies or access to court are not implemented in the Advocatenwet since they are covered by the Algemene Wet Bestuurstecht. ${ }^{849}$ There are, however, some other rules laid down in the Directive, namely those rules laid down in Articles 6, 8 and 11 of the Directive that are not implemented in the Advocatenwet. These rules are implemented in the Dutch legal system via verordeningen (regulations) of the Nederlandse Orde van Advocaten. Article 6(3) of Directive 98/5/EC states that the host Member State may require a lawyer who seeks to establish himself in that State under the regime of the Directive to acquire professional indemnity insurance. In the Netherlands, this provision is not implemented in the Advocatenwet but in a verordening of the Nederlandse Orde van Advocaten. ${ }^{850}$ The verordening states that advocaten are obliged to have professional indemnity insurance, the requirements of which are listed in Article 3 of the verordening. One of the criteria worth mentioning is that the insurance must at least cover events that occur within the entire European Community. ${ }^{851}$ It must be stated, however, that apart from the applicability rule laid down in Article 1 of the verordening, there is no reference whatsoever to lawyers established under their home country professional title. So in order to conclude that the verordening is a correct implementation of Article 6(3) of Directive 98/5/EC, one must assume also that insurance acquired in other Member States (provided it fulfils the criteria of Article 3 of the verordening) is recognised as insurance prescribed in Article 2 of the verordening. If the insurance acquired in another Member State is not up to the standards of Article 3 of the verordening, additional insurance must be acquired in the Netherlands in order to bring the insurance up to that standard. It can be concluded that the adaptations made to the verordening constitute the minimal implementation of Article 6(3) 98/5/EC which could have been possible without violating the Article.

The rules pertaining to salaried practice in the Netherlands are laid down in a verordening of the Nederlandse Orde van Advocaten. ${ }^{852}$ Without going too far into the rules covering the salaried practice of an advocaat in the Netherlands, it can be said

\footnotetext{
847 Article 2c(1) Advocatenwet.

848 Article 2c(2) Advocatenwet.

849 General Administrative law.

850 Verordening op de beroepsaansprakelijkheid 1991, Staatscourant 2002, 169.

851 Article 3(d) Verordening op de beroepsaansprakelijkheid 1991.

852 Verordening op de praktijkuitoefening in dienstbetrekking, Staatscourant 2002, 169.
} 
that the rules are semi-liberal. That means that lawyers are allowed to work in the employ of certain other professions, among which are other lawyers. As Article 8 of Directive 98/5/EC provides for no more than equal treatment with lawyers established under the host Member State professional title, implementation of the article can be guaranteed by declaring the verordening equally applicable to lawyers established under their home country title. That is exactly what the Orde did in Article 1 of the verordening, which states that where the verordening uses the term advocaat, this includes lawyers who are established under their home country professional title. ${ }^{853}$

The rules for joint practice for advocaten are laid down in a verordening of the Nederlandse Orde van Advocaten. ${ }^{854}$ This verordening allows joint practice with advocaten who are established in the Netherlands, some lawyers who are not established in the Netherlands, and some other professions (such as tax-advisors). Article 1 of this verordening states that those lawyers who are established under their home country title under the regime of Article $16 \mathrm{~h}$ of the Advocatenwet also fall under the notion of the advocaat as used in the verordening. ${ }^{855}$ That means that, for the purpose of the verordening, lawyers who are established under their home title are completely equal to advocaten who are established under the regime of Article 2 Advocatenwet. With that adaptation to the verordening, the implementation of the majority of the rules of Article 11 of Directive 98/5/EC is guaranteed. One problem remains, however. Section 1 of Article 11 states that where the host Member State allows joint practice, which is the case in the Netherlands, the host Member State must also permit one or more lawyers who belong to a joint practice in their home Member State to form a branch or an agency of that joint practice in the host Member State. It can be assumed that those lawyers would remain members of that joint practice which is based in their home Member State. Translated to the Dutch situation, that would lead to the following. A lawyer established under the professional title of his home Member State is viewed as an advocaat for the purposes of the verordening. A lawyer who is part of a joint practice in his home Member State who comes to the Netherlands to set up an agency or a branch of that joint practice would then be viewed as an advocaat who practises jointly with lawyers who are not registered in the Netherlands. That situation is only allowed if the lawyers who are not registered in the Netherlands are members of a Bar Association that is recognised by the Nederlandse Orde van Advocaten. ${ }^{856}$ The Orde has only recognised a number of selected Bar Associations. ${ }^{857}$ Remarkably, a number of European Bar Associations are not mentioned on

\footnotetext{
853 Article 1(a) Verordening op de praktijkuitoefening in dienstbetrekking.

854 Samenwerkingsverordening 1993, Staatsblad 2002, 169.

855 Article 1(a) Samenwerkingsverordening 1993.

856 Article 4(b) and 5 Samenwerkingsverordening 1993.

857 Annotation 7 Samenwerkingsverordening 1993:

'7) De Algemene Raad heeft de volgende organisaties erkend als organisaties waarvan de leden een samenwerkingsovereenkomst kunnen aangaan in de zin van de Samenwerkingsverordening:

- de State Bars of California, Delaware, Illinois, New York, Michigan, District of Columbia en the Bar of the Commonwealth of Massachusetts

- de 29 Orden van Advocaten in België (waaronder zowel de Nederlandse als de Franse balie in Brussel)

- de 23 Rechtsanwaltkämmer in Duitsland

- de Law Society of England and Wales (beslissing AR 12.8.74)

- de 179 Ordres des Advocats des Barreaux de France
} 
the list of the Orde. That would mean that if a Danish lawyer who practises jointly in Denmark establishes himself in the Netherlands in order to form a branch or an agency of that Danish joint practice, he would not be allowed to do so since the Orde has not recognised the Danish Bar Association. If that situation should occur, it would constitute a breach of the guarantees laid down by Article 11(1) of Directive $98 / 5 / \mathrm{EC}^{858}$ In addition to this possible breach of Article 11(1), there is absolutely no mention of the situation mentioned in Article 11(1) where fundamental rules governing joint practice in the home and host Member State collide. The rules with regard to the name of the joint practice, which are allowed by Article 12 of Directive 98/5/EC, are laid down in Article 8 of the verordening. ${ }^{859}$ These rules are in accordance with Article 12 of the Directive.

\section{Belgium}

Belgium implemented Directive $98 / 5$ /EC by means of introducing a new law that provides for an adaptation of the Gerechtelijk Wetboek. ${ }^{860}$ The Law of 22 November 2001 provides for a number of general adaptations to the Articles in the Gerechtelijk Wetboek. The most important part of the Adaptation Law is Article 18, which deals with the adaptation of Title Ibis of the Gerechtelijk Wetboek, which is concerned with the exercise of the legal profession in Belgium by persons who are citizens of a Member State of the European Union. Chapter II of Title Ibis is devoted to lawyers from other Member States who are established in Belgium, without being completely integrated into the Belgian legal profession.

Article 477quinquies of the Gerechtelijk Wetboek lays down the rules with respect to establishment of lawyers under home title. The Article states that everyone who has the right to bear the title of a lawyer in any one of the Member States may establish himself on a permanent basis in Belgium. The Article further states that

- Ordem dos Advocados Portugueses

- de Law Society of Scotland

- de 82 afzonderlijke Spaanse Collegiós de Abogados

- Sveriges Advokatsamfund

- Czech Chamber of Advocacy

- Consiglio dell'Órdine degli Avvocati di Milano (beslissing AR 4.12.95)

- de State Bar of Alabama (beslissing AR 14.1.02)

- de Law Society of Hong Kong (beslissing AR 27.5.02)

- Consiglio dell'Órdine degli Avvocati di Roma (beslissing AR 6.11.02)

- Consiglio dell'Órdine degli Avvocati di Venezia (beslissing AR 6.11.02).'

858 The violation can easily be avoided since Article 5 of the verordening gives authority to the Orde to recognise Bar Associations on an ad hoc basis. Probably the list of the previous footnote resembles, due to the scattered nature of that list, actual requests of recognition filed with the Orde, but it could make establishment for a foreign lawyer who belongs to a joint practice in his home Member State less attractive if that lawyer first has to go through the hassle of having his Bar Association recognised by the Orde. It is also unclear why the Orde does not recognise the Bar Associations that are part of the CCBE as such, and whether or not the Orde is allowed to use its own criteria, as listed in Article 5 of the verordening, to decide whether or not it recognises a Bar Association.

859 Article 8 Samenwerkingsverordening 1993.

860 Wet ter vergemakkelijking van de uitoefening van het beroep van advocaat en van de vestiging in België van advocaten die onderdaan zijn van een andere lidstaat van de Europese Unie, 22 November 2001. Via <www.juridat.be> , last accessed 26 April 2004. Hereinafter referred to as Adaptation Law. 
these persons must register themselves with the relevant Belgian Bar Association and that they must prove to the relevant Bar Association that they are allowed to practise the profession of lawyer in their home Member State. In addition to this, the lawyer must also use his home country professional title while being established in Belgium. The Belgian Bar Association shall inform the relevant Bar Association of the lawyers' establishment in Belgium. ${ }^{861}$ While engaging in professional activities in Belgium the lawyer from the other Member State is always obliged to mention in his correspondence the Bar at which is registered, ${ }^{862}$ the professional authority by virtue of which he is allowed to practise as a lawyer in his home Member State and his home country professional title. The professional title must be used in the language of the home Member State and in at least one of the official Belgian languages (Dutch, French or German), depending on the Bar where the lawyer is registered. ${ }^{863}$ As of 2006, 406 lawyers were established under their home country professional title. ${ }^{864}$

The rules regarding the professional activities that may be pursued by a lawyer established in Belgium under his home country professional title are laid down in Article 477sexies. The Article states that a lawyer who is established in Belgium under his home country professional title may exercise all the professional activities that a Belgian avocat may pursue. ${ }^{865}$ The only limitation with regard to the pursuit of professional activities lies in the fact that a lawyer who is established under his home country professional title is obliged to cooperate with a Belgian avocat who is listed on the tableau when he deals with situations that involve defending a client before a court. Before the court session commentces, the Belgian avocat will introduce the lawyer established under his home country title to the President of the relevant court. ${ }^{866}$ It is clear that these rules are in accordance with the possible limitations laid down in Article 5 of Directive 98/5/EC.

The second paragraph states which professional rules apply to the lawyer established under his home member state. It is stated in the paragraph that a lawyer who is established under his home country professional title must not only adhere to the professional rules of his home Member State, but also to the professional rules, regardless of their origin, that are in force at any given point in time in Belgium. It is clear that the rules laid down in paragraph 2 of Article 477 sexies are well within the limits set by Directive 98/5/EC.

The third paragraph of Article 477 sexies states that the Council of the relevant Bar Association can oblige a lawyer established in Belgium under his home country professional title to obtain professional indemnity insurance. If the lawyer already has insurance in his home Member State that is comparable to the Belgian insurance then he will be exempted from the abovementioned obligation. In the event that the insurance in the home Member State is only partly comparable, then the Belgian authorities can oblige the lawyer established under his home country title to acquire

\footnotetext{
861 Article 477quinquies $\$ 2$ Gerechtelijk Wetboek.

862 Presumably the Belgian Bar where he is registered.

863 Article 477quinquies $\$ 3$ Gerechtelijk Wetboek.

$864 \quad<$ www.ccbe.org>, last accessed 11 June 2007.

865 Article 477 sexies $\$ 1$ Gerechtelijk Wetboek.

866 Ibid.
} 
additional insurance. ${ }^{867}$ Again, these rules are in complete conformity with Directive 98/5/EC.

The last paragraph of Article 477sexies, paragraph 4, states that in conformity with the rules that are applied for Belgian avocats, lawyers who are established under their home country professional title are not allowed to exercise their profession in a salaried capacity unless the position does not jeopardise the independence of the lawyer nor the dignity of the Bar Association. ${ }^{868}$ This rule is the correct implementation of Article 8 of Directive 98/5/EC.

The rules for disciplinary proceedings against a lawyer established in Belgium under his home country professional title are listed in Article 477septies of the Gerechtelijk Wetboek. The Article begins by stating that the disciplinary proceedings that are applied for Belgian avocats shall also be applied to lawyers who are established under their home title in Belgium. ${ }^{869}$ Before the Belgian authorities start disciplinary proceedings against a lawyer, the battonnier of the relevant Bar Association shall inform the competent authority in the home Member State of all circumstances relevant to the procedure. The batonnier shall inform the competent authority in writing of any further decision taken. ${ }^{870}$ In the event of the lawyer's right to practise being revoked in his home Member State on either a temporary or a permanent basis, this would automatically lead to the revocation of the right to practise under home country professional title in Belgium for the duration of the revocation in the home Member State. ${ }^{871}$ This Article is the correct implementation of Article 7 of Directive 98/5/EC.

Article 11 of Directive 98/5/EC lays down rules for the exercise of the profession under home country professional title in another Member State in the so-called Multi-Disciplinary Practices, i.e., practices where lawyers work alongside non-lawyers. The Article also contains provisions regarding lawyers practising in association. These rules have been implemented in a rather detailed manner by the Belgian authorities in Article 477octies of the Gerechtelijk Wetboek. The first paragraph of Article 477 octies states that one or more lawyers who are established under their home country professional title in Belgium and who practise in association in their (shared) Member State of origin may exercise their profession in association in Belgium as a branch-office of their association. ${ }^{872}$ When the basic rules governing associations of lawyers in the Member State of origin are incompatible with the Belgian rules then the latter will prevail because of the fact that these rules protect clients and other people. ${ }^{873,874}$ The second paragraph regulates a somewhat different situation. The paragraph states that two or more lawyers who are established under their home country professional title from one group or one Member State may exercise their profession in Belgium as a group subject to the rules that are applicable for Belgian

\footnotetext{
867 Article 477 sexies $\$ 3$ Gerechtelijk Wetboek.

868 Article 477 sexies $\$ 4$ Gerechtelijk Wetboek.

869 Article 477septies Gerechtelijk Wetboek.

870 Ibid.

871 Ibid.

872 I.e., two English solicitors from the law firm Linklaters establishing an office of Linklaters in Belgium.

873 The 'rule of reason' that is introduced here is a literal translation of Article $11 \int 1$ Directive 98/5/EC.

874 Article 477 octies $\ 1$ Gerechtelijk Wetboek.
} 
avocats with regard to practising in groups. ${ }^{875}$ What seems to be the distinguishing factor between the first and the second paragraph is that in the first paragraph the lawyers exercise their profession in the form of a branch or agency of a grouping, while this is not the case with the second paragraph. Paragraph 3 states that paragraphs 1 and 2 are also applicable to groupings of lawyers from different Member States and groupings including lawyers from different Member States and Belgian avocats. ${ }^{876}$ A lawyer who is established under his home country professional title and is part of a grouping in his home Member State has a duty to inform the Belgian authorities of that fact and of the characteristics of the grouping (laid down in paragraph 4 of Article 477 octies). ${ }^{877}$ Paragraph 5 of Article 477 octies deals with the situation where non-lawyers form part of the grouping. The paragraph states that the Belgian authorities can deny a lawyer from another Member State the right to practise in a grouping if that grouping also contains persons from outside the profession of the lawyer. The group shall be considered a grouping containing persons who do not belong to the profession of the lawyer if any of the following criteria are fulfilled: The capital of the grouping is controlled in whole or in part by persons who are not lawyers, the name of the grouping is used for persons who are not lawyers, or the decision making power in the grouping is exercised, either de iure or de facto, by persons who are not lawyers. In addition to this, the Council of the relevant Bar Association in Belgium can prevent the opening of a branch office or agency from any grouping from another Member State if the aforementioned grouping is considered to be a grouping containing persons who are not lawyers. ${ }^{878}$ Persons who are allowed to practise in a group in Belgium are also allowed to use the name of the grouping in all their professional correspondence. In addition to the name of the grouping the lawyers involved will also indicate the legal form of the grouping in the home Member State, and the names of the lawyers belonging to the grouping who exercise their profession (either under their home title or under the professional title of Belgium) in Belgium. ${ }^{879}$ It is clear that Article 477octies of the Gerechtelijk Wetboek is a thorough implementation, little short of a literal translation, of Article 11 of Directive 98/5/EC. As was mentioned above the rules with regard to MDPs for Belgian avocats were adapted to bring them into conformity with the rules found in Directive 98/5/EC, since previously MDPs were prohibited for Belgian avocats because of the civil law tradition of the Belgian legal system.

Article 10 of Directive 98/5/EC is implemented in Belgium by means of Article 477nonies Gerechtelijk Wetboek. The first paragraph states that in addition to what is found in Article 428bis (dealt with earlier on in this chapter), persons who are established under the professional title of their home Member State can also integrate into the legal profession of Belgium. They can do so if they are able to prove that they have practised on an effective and regular basis under their home country professional title for at least three years. During these three years, they have to have dealt with Belgian law, including European Community law. Once they have proved that they have dealt with Belgian law for at least three years, they may use the title

\footnotetext{
875 Article 477octies $\$ 2$ Gerechtelijk Wetboek.

876 Article 477octies $\$ 3$ Gerechtelijk Wetboek.

877 Article 477octies $\$ 4$ Gerechtelijk Wetboek.

878 Article 477 octies $\$ 5$ Gerechtelijk Wetboek.

879 Article 477octies $\$ 6$ Gerechtelijk Wetboek.
} 
of avocat, take the oath and be included on the tableau of the relevant Bar Association. In order to apply for integration they must provide the Council of the relevant Bar Association with all the correspondence and information necessary for the Council to make a decision. This information is ordinarily concerned with the number and the nature of the cases dealt with.

Similar to Article 10 of Directive 98/5/EC, the second paragraph of Article 477 nonies deals with lawyers who have been actively and regularly pursuing activities in Belgium for at least three years, but for a shorter amount of time in connection with Belgian law. These persons can also integrate into the legal profession of Belgium, albeit with slightly lesser ease. In order to integrate into the legal profession, the prospective avocat who practises under his home title must provide the Council of the relevant Bar Association with all the documents and information pertaining to the number and nature of the cases with which he has dealt. The Council will take into account all the activity pursued, all the knowledge and experience of Belgian law the prospective avocat has, and all the seminars and lectures on the topics of Belgian law the prospective avocat has attended. The battonnier of the relevant Bar Association will then have a conversation with the prospective avocat in which the battonnier will assess all the activities pursued and the capacity of the prospective avocat to continue to exercise these activities as a member of the Belgian legal profession. The bâtonnier will report to the Council of the Bar Association, who, in turn, will make a decision. The applications under paragraphs 1 and 2 of Article 477nonies have to be made in the official language of the relevant Bar Association, or when they are not in the official language, they must be accompanied by a certified translation into the official language of the relevant Bar Association. ${ }^{880}$ Applications made under paragraphs 1 and 2 of Article 477nonies may only be denied if the set criteria are not proven or if granting a request forms a breach of public policy, especially in cases of disciplinary proceedings, accidents or incidents of any other kind. ${ }^{881}$ If a lawyer established under his home country title is allowed to integrate into the legal profession of Belgium, then he is still allowed to use his home country professional title in conjunction with the title of avocat on the condition that the lawyer remains enlisted with his home country professional body. ${ }^{882}$ As of 2006, there were five lawyers integrated into the Belgian legal profession. ${ }^{883}$

\section{Luxembourg}

Two and a half years after the deadline for implementation had passed, Luxembourg implemented Directive 98/5/EC into its legal system. This delay was most probably caused by the nullity appeal of Luxembourg against Directive 98/5/EC before the European Court of Justice. ${ }^{884}$ Luxembourg chose to implement Directive 98/5/EC

880 Article 477nonies $₫ 3$ Gerechtelijk Wetboek.

881 Article 477nonies $\$ 4$ Gerechtelijk Wetboek.

882 Article 477nonies $\$ 5$ Gerechtelijk Wetboek.

$883<$ www.ccbe.org>, last accessed 11 June 2007.

884 Case C-168/98, Grand-Duchy of Luxembourg v. European Parliament and Council of the European Union, [2000] ECR I-09131. See Chambre de Deputés, No 4790 Projet de Loi, 9-5-2001; Chambre des Deputés, No 4790, Projet de Loi (avis du Conseil d'État) 6-12-2001; Chambre des Deputés, No 4790, Projet de Loi (amendement adoptes par la commission juridique) 263-2002; Chambre des Deputés, No 4790, Projet de Loi (avis complementaire du Conseil d'État) 25-4-2002; Chambre des Deputés, No 4790, Projet de Loi (observations de l'ordre des 
by means of a separate law. ${ }^{885}$ This law complements, and has an effect on, the Avocat law but is not an integral part of it. Article 1 of the establishment law lays down the general criteria for application. It states that all nationals of Member States who are allowed to exercise the legal profession in their home Member State may benefit from the establishment law. For this purpose, the Article provides the list found in Article 1 of Directive 98/5/EC which lists the different legal professions for the different Member States. Interestingly, Article 1 of the establishment law introduces the concept of avocat européen. This designation is used for every lawyer who establishes himself under the provisions of the establishment law. The concept is, however, not a professional title, and lawyers established under the provisions of the establishment law may not use the designation avocat européen in the exercise of their professional activities. The designation is merely used to indicate that a lawyer falls under the scope of Article 1 of the establishment law. The Article states further that the Avocat law applies to lawyers established under their home title unless the establishment law prescribes otherwise. ${ }^{886}$

Every avocat européen has the right to exercise the same activities, in an independent or in a salaried manner, ${ }^{87}$ as a regular avocat may under the provisions of the Avocat law. This right may be influenced by provisions laid down in the establishment law. ${ }^{888}$ In order to exercise this right, an avocat européen needs to obtain an inscription on the tableaux on one of the two Bar Associations in Luxembourg. In order to obtain such an inscription, a prospective avocat européen must send a complete application, in French, to the batônnier of the Bar Association in the jurisdiction in which he wants to establish himself. Aside from the documents indicated hereafter a prospective avocat européen must indicate whether or not he is part of a group in his home Member State. ${ }^{889}$ Article 3 states further that in order to become inscribed on one of the tableaux the prospective avocat européen must have a meeting with the relevant Bar Association in order to verify the language capacities of the prospective avocat européen. Inscription on 'Liste IV' will follow if this meeting with the Bar Association is successful, and if the prospective avocat européen is able to produce a certificate from his home Member State's competent authority stating that the lawyer is entitled to exercise the legal profession in his home Member State. No more than three months shall have elapsed since the certificate was issued, and

avocats du Barreau de Luxembourg relatives a l'avis du Conseil d'État) 27-6-2002; Chambre de Deputés, No 4790 Projet de Loi (Rapport de la Commission Juridique) 9-7-2002. See also: $<$ eu-anwaelte.org>, last accessed 19 July 2004.

885 Loi du 13 novembre 2002 portant transposition en droit luxembourgeois de la Directive 98/5/CE du Parlement Européen et du Conseil du 16 février 1998 visant à faciliter l'exercice permanent de la profession d'avocat dans un Etat member autre que celui où la qualification $\mathrm{a}$ été acquise et portant:

1: modification de la loi modifiée du 10 août 1991 sur la profession d'avocat.

2: modification de la loi du 31 mai 1999 régissant la domiciliation des sociétés, Memorial Journal Officiel du Grand-Duché de Luxembourg, Recueil de Legislation, A-No 140, 17 décembre 2002, page 3202, hereinafter Establishment law.

886 Article 1 Establishment law.

887 Working in a salaried position is in principle prohibited for avocats in Luxembourg, and therefore also for lawyers who are established under their home title. There is however one small exception, which will be dealt with later on in this chapter.

888 Article 2 Establishment law.

889 Article 3(1) Establishment law. 
such a certificate must be produced again every first month of the year after registration (again with the three-months rule). Failing to produce these certificates may lead to the revocation of the registration. ${ }^{890}$

When compared with Article 3 of Directive 98/5/EC which deals with registration, two problems with the Luxembourg implementation immediately surface. First, the interview in which the lawyer's language capabilities are assessed finds no basis in Directive 98/5/EC. The second problem arises in connection to the demand to produce a certificate each year certifying that an avocat européen is allowed to practise in his home Member State. Due to all the hassle and costs involved in obtaining such a certificate this can be seen as an indirect discrimination. Moreover, the articles of that Directive make the Luxembourg rule completely redundant since the competent authority of the home Member State is obliged under Article 7 of the Directive to inform the competent authority in the host Member State of any proceedings started against a lawyer in the host Member State. A revocation of the permission to practise in the home Member State shall automatically lead to the revocation of that permission in the host Member State, according to the Directive. The Luxembourg rule which requires the lawyers to reproduce the named certificate therefore serves no purpose at all. The Luxembourg authorities may not impose such a requirement. The European Court of Justice also followed this line of reasoning in Commission v. Luxembourg and Wilson v. Ordre des Avocats, in which it concluded that with regard to Article 3 of Directive 98/5/EC the Luxembourg requirements were contrary to the Directive. ${ }^{891}$

Article 4 of the establishment law lays down the rules for the use of professional title. It states that the avocat européen is obliged to use his home country professional title when engaging in activities in Luxembourg. When doing so, an avocat européen is always obliged to avoid confusion. Lawyers who have the title avocat in their home Member State are therefore obliged to mention the professional authority that allows them to practise, or the jurisdiction in which they are allowed to practise in their home Member State, given in the language of the home Member State. ${ }^{892}$

The rules with respect to professional activities that may be pursued by an avocat européen in Luxembourg are laid down in Article 5 of the establishment law. The Article first states that an avocat européen may exercise the same professional activities as a Luxembourg avocat. ${ }^{893}$ Furthermore, the Article lists a couple of activities that are excluded or regulated for avocats européens. An avocat européen may not exercise the professional activities that are reserved for other legal professions, such as the profession of the notaire, and an avocat européen must cooperate with an avocat when representing clients in court. ${ }^{894}$ These limitations on the professional activity are perfectly in accordance with the principles laid down in Article 5 of Directive 98/5/EC. There are however two limitations on professional activity that prove to be more problematic. First of all, there is a limitation in Article 5 of the establish-

\footnotetext{
890 Article 3(2) Establishment law.

891 Cases C-193/05, Commission of the European Communities v. Grand-Duchy of Luxembourg, [2006] ECR, I-08673 and C-506/04, Graham J. Wilson v. Ordre des avocats du barreau de Luxembourg, [2006] ECR, I-08613.

892 Article 4 Establishment law.

893 Article 5(1) Establishment law.

894 Article 5(2) and (4) Establishment law respectively.
} 
ment law that cannot pass the test of Directive 98/5/EC. Article 5 of the establishment law states that an avocat européen may not exercise the same activities as lawyers who provide services in Luxembourg. ${ }^{895}$ Such a limitation is not sanctioned by Directive $98 / 5 / \mathrm{EC}$ and is therefore contrary to that Directive. On a more detailed note, it is also incomprehensible why the Luxembourg authorities have introduced this provision since the ECJ made it more than clear in the Gebhard case ${ }^{896}$ that it is not the activities which distinguish between establishment and services but the manner in which these activities are exercised, i.e., on a temporary or permanent basis. Excluding the activities of a lawyer who provides services would therefore inherently mean excluding an avocat européen from all his activities, since the activities deployed will, in essence, be the same, and only the manner in which they are exercised would be different. This limitation can therefore be regarded as no more than a violation of Directive 98/5/EC. ${ }^{897}$ Another limitation can be found in Article 15 of the establishment law. That specific article refers to a specific law which regulates the domicile for firms. ${ }^{898}$ According to this law, only certain regulated professions can provide this domicile. Among the professions listed in that law, the profession of the avocat is also mentioned. ${ }^{899}$ Article 15 of the establishment law revises this article in such a manner that only avocats inscribed on 'Liste I' may exercise this activity, therewith excluding the avocat européen who is inscribed on 'Liste IV' of the relevant tableau. This is also a violation of Article 5 of Directive 98/5/EC. Subsection 2 of that article does allow certain limitations on the exercise of professional activities, but the aforementioned matter is not among those exceptions. Moreover the wording of Article 5(2) of Directive 98/5/EC makes it clear that these exceptions were specifically introduced to honour the fundamental differences between the legal professions in civil and common law systems. The exceptions are therefore very specific and can in no way be interpreted as a general exception. The exception on professional activity with regard to the domicile of firms is, therefore, also a violation of Directive 98/5/EC. ${ }^{900}$

Article 6 states that an avocat européen is subject to the same professional rules as the avocats established in Luxembourg. In addition to that, he also remains subject to the professional rules of his home Member State. ${ }^{901}$ Subsection 2 of Article 6 states that an avocat européen has the right to vote in the elections of the General Council

\footnotetext{
895 Article 5(3) Establishment law.

896 Case C-55/94, Reinhard Gebhard v. Consiglio dell'Ordine degli Avvocati e Procuratori di Milano, [1995] ECR 4165.

897 This problem was not addressed in cases C-193/05, Commission of the European Communities $v$. Grand-Duchy of Luxembourg, [2006] ECR, I-08673 and C-506/04, Graham J. Wilson v. Ordre des avocats du barreau de Luxembourg, [2006] ECR, I- 08613. From the nature of the ruling however, it may be concluded that this would be contrary to the Directive.

898 Loi du 31 mai 1999 régissant la domiciliation des sociétés, Memorial Journal Officiel du GrandDuché de Luxembourg, Recueil de Legislation, A-No. 77, 21 juin 1999, p. 1681.

899 Article 1(2) Loi du 31 mai 1999 régissant la domiciliation des sociétés, Memorial Journal Officiel du Grand-Duché de Luxembourg, Recueil de Legislation, A-No. 77, 21 juin 1999, p. 1681.

900 Which was confirmed by the ECJ in cases cases C-193/05, Commission of the European Communities v. Grand-Duchy of Luxembourg, [2006] ECR, I-08673 and C-506/04, Graham J. Wilson v. Ordre des avocats du barreau de Luxembourg, [2006] ECR, I- 08613.

901 Article 6(1) Establishment law.
} 
of their relevant Bar Association. ${ }^{902}$ Finally Article 6 lays down the obligation to pay a membership fee to the Bar Association ${ }^{903}$ and that the avocat européen must have professional indemnity insurance either in Luxembourg or in his home Member State. ${ }^{904}$

Article 7 of the establishment law lays down the rules for disciplinary proceedings initiated against an avocat européen. Firstly, the Article states that in case of a disciplinary procedure the Luxembourg rules shall apply. ${ }^{905}$ To that effect, the relevant Bar Association shall inform the competent authority of the host Member State immediately if a disciplinary proceeding is initiated by the Luxembourg Bar Association. ${ }^{906}$ The Luxembourg Bar Association shall maintain this cooperation throughout the entire procedure, and it shall inform the competent authority of the home Member State of its decision. ${ }^{907}$ This co-operation (with the possibility for the competent authority of the home Member State to issue its views) will also be maintained in appeal. ${ }^{908}$ In return, the Luxembourg Bar shall also be informed of any disciplinary proceedings against an avocat européen in his home Member State, and the temporary or permanent revocation of an avocat européen from the legal profession of his home Member State shall also be automatically imposed in Luxembourg. ${ }^{909}$

Similar to avocats established in Luxembourg, avocats européen are also not allowed to work in a salaried occupation, except with other lawyers. Therefore an avocat européen is allowed to work in salaried practise with a lawyer enlisted with one of the Bar Associations in Luxembourg (either an avocat or an avocat européen). ${ }^{910}$

Article 9 of the establishment law regulates the entry into the profession of the avocat by an avocateuropéen. An avocat européen has the right to enter into the profession of the avocat if he has effectively and regularly dealt with the Luxembourg law, including Community law, for a period of at least three years, without having to take the aptitude test specified in the recognition law. In order to be inscribed as an avocat on 'Liste I' an avocat européen must issue a request at the Bar Association and he must prove that he fulfils the above-named criteria. In any case an avocat européen must provide all the relevant information and documents, most notably on the number and the nature of cases with which he has dealt. In cases where the documents which are provided are unclear, the Bar Association is allowed to invite the avocat européen to clarify. A decision not to inscribe an avocat européen as an avocat on 'Liste I' will be made by the Bar Association and the avocat européen will be offered a legal remedy by way of challenging the decision. ${ }^{911}$ An avocat européen who has been established in Luxembourg for at least three years but has been active for less than three years in Luxembourg law may also request to be inscribed as an avocat on

902 Article 6(2) Establishment law

903 A matter not explicitly sanctioned by the Directive, but in my view not problematic as long as it is not discriminatory.

904 Article 6(3) Establishment law.

905 Article 7(1) Establishment law.

906 Article 7(2) Establishment law.

907 Article 7(3) Establishment law.

908 Article 7(4) Establishment law.

909 Article 7(5) Establishment law.

910 Article 8 Establishment law.

911 Article 9(1) Establishment law. It must be mentioned that the remedy offered fell short of what was required in Article 9 of Directive 98/5/EC, as was established in the Wilson case. 
'Liste I' of the relevant tableau without having to take the aptitude test that is specified in the recognition law. In this situation, the Bar Association when dealing with the request shall take into account any relevant experience that the avocat européen has gained in fields of Luxembourg law, including any seminars or courses followed on Luxembourg law. The avocat européen must again produce all the relevant proof. This proof shall be the subject of a meeting between officials of the Bar Association and the avocat européen, on the basis of which the Bar Association shall take a decision on the inscription as an avocat on 'Liste I' of the avocat européen involved. If a decision is taken not to inscribe the avocat européen then it shall be reasoned and the avocat européen shall be offered a legal remedy. ${ }^{912}$ When an avocat européen has been inscribed on 'Liste I' of a Bar in Luxembourg, he may freely transfer to 'Liste I' of the other Bar Association in Luxembourg. ${ }^{913}$

Aside from the possibility to integrate into the legal profession of Luxembourg without having to take an aptitude test, an avocat européen also has the right to take an aptitude test at any time in order to integrate into the profession of the avocat. ${ }^{914}$ The Bar Association shall deal with all the information acquired in a confidential manner. ${ }^{915}$ Aside from the reasons mentioned above, inscribing an avocat européen as an avocat on 'Liste I' of the tableau can also be refused if the inscription would be against public policy, in particular because of disciplinary proceedings, complaints or incidents of any such kind. A decision by the Bar Association on these grounds must be reasoned and a legal remedy shall be offered to the avocat européen involved. ${ }^{916}$ As of 2006, one lawyer had managed to integrate into the Luxembourg legal profession. ${ }^{917}$

Article 11 of the establishment law states that practice in association is in principle not allowed except for the circumstances described under Article 34 of the Avocat law. ${ }^{918}$ In addition Article 11 states that exercise of the legal profession in a group that is composed of persons who do not belong to the legal profession is prohibited. An avocat européen who is a member of such a group in his home country is not allowed to exercise his profession in Luxembourg as a member of that group. In order to determine whether the group also consists of persons who are not members of the legal profession, the criteria of Article 11 of Directive 98/5/EC are used. ${ }^{919}$ An avocat européen who is a member of such a grouping in his home Member State is not allowed to open a branch or an agency of that grouping in Luxembourg. Article 12 of the establishment law lists some additional requirements with regard to use of professional title. An avocat européen who is inscribed as an avocat on 'Liste

\footnotetext{
912 Article 9(2) Establishment law.

913 Article 9(3) Establishment law.

914 Article 9(4) Establishment law.

915 Article 9(5) Establishment law.

916 Article 10 Establishment law.

$917<$ www.ccbe.org>, last accessed 11 June 2007.

918 Article 11 Establishment law. Article 34 of the Avocat law only allows practice in association between lawyers.

919 Article 11 Establishment law. A grouping is a grouping containing persons who are not a member of the legal profession when the capital of the grouping is held entirely or partly, or the name under which the grouping practises is used, or the decision making power in that grouping is de iure or de facto exercised by, persons who are not avocats in the sense of the Avocat law.
} 
I' of one of the tableaux may make use of both the title of avocat and the professional title of his home Member State. ${ }^{920}$ If an avocat européen operates legally in Luxembourg as a member of a group established in his home Member State, he is allowed to mention his membership of that grouping in his professional communication. ${ }^{921}$ The Bar Association where he is enlisted may also demand from the avocat européen to indicate the legal form of the grouping and/or the names of the members of the group who also exercise their profession in Luxembourg. ${ }^{922}$

Article 13 lists a general duty of cooperation between the relevant Luxembourg Bar Association and the Bar Association of the home Member State. ${ }^{923}$ Article 14 lists a number of textual changes to the Avocat law. The most notable of these has been discussed above, namely the fact that an avocat européen must undergo a language test in order to be inscribed as avocat européen. ${ }^{924}$ Article 15 introduces the notorious limitation on professional activity that has also been discussed above. ${ }^{925}$

\subsubsection{Implementation in France, Italy, Spain and Portugal}

\section{France}

France also exceeded the deadline for the implementation of Directive 98/5/EC. In France, the European Court of Justice was also involved in the implementation process. However, where the delay in Luxembourg could be explained by Luxembourg's appeal against the Directive and the time that request took for nullity before the ECJ reached a decision, the story in France is different. Here, the ECJ's involvement was a reaction to the delay and not the cause of it. On 26 September 2002, France was convicted by the ECJ on the basis of Article 226 EC Treaty for failing to implement Directive 98/5/EC. ${ }^{926}$ In a very short judgment, only three pages long, the ECJ stated that France failed to meet the requirements for implementation, and was therefore convicted. ${ }^{927}$ After its conviction in 2002, it would take France more than a year to finally implement Directive 98/5/EC into French legislation. In French legislative tradition this implementation was realised by adapting existing legislation, most notably the loi of 31 December $1971 .{ }^{928}$ Article 1 of the Loi du 11 février 2004 states that the law will create a new section in the Loi du 31 décembre 1971 that will deal with the establishment of lawyers from other Member States under their home title in France. ${ }^{929}$ The Loi du 11 février 2004 creates a new Article 83 in the Loi du 31 décembre 1971 that states that every resident of one of

920 Article 12(1) Establishment law.

921 Article 12(2) Establishment law.

922 Ibid.

923 Article 13 Establishment law.

924 Article 14 Establishment law.

925 Article 15 Establishment law.

926 Case C-351/01 Commission v. France [2002] ECR I-08101.

927 France did not contest the allegation of the Commission that it had violated its obligations under the EC Treaty, but it did not provide any information to the Commission or the Court as to why this delay in implementation occured.

928 Loi no. 2004-130 du 11 février 2004 réformant le statut de certaines professions judiciaires ou juridiques, des experts judiciaires, des conseils en proprieté industrielle et des experts en ventes aux enchères publiques, JO de la République Française, 12 février 2004, p. 2847.

Article 1 of the Loi du 11 février 2004. 
the Member States of the European Union may exercise the profession of the avocat in France using their home country professional title, if this professional title occurs on a list fixed by decree. ${ }^{930}$

Article 4 of the Loi du 11 février 2004 creates a new Article 84 in the Loi $d u 31$ décembre 1971 to regulate the establishment under home title. The new article states that every lawyer who is established under his home country title in France shall be inscribed on a special list of the tableau of the Bar of his choice. Inscription on this list is possible when the lawyer concerned is able to produce a certificate from the competent authority of the home Member State stating that the lawyer concerned is indeed a lawyer in his home Member State and that his title is recognised by that authority. ${ }^{931}$ The second section states that the lawyers who are established under their home title will become a part of the Bar of their choice under the same conditions as their French counterparts. When they have become part of the Bar they are also allowed to participate in the elections of the National Bar Association. ${ }^{932}$ The last section of the newly introduced Article 84 states that a revocation, either temporarily or definitively, in the home Member State will automatically lead to a similar revocation of the right to practise in France. The Council of the relevant Bar is authorised to take decisions in these matters. ${ }^{933}$ As of 2006, 128 lawyers were established under their home country professional title. ${ }^{934}$

Article 5 of the Loi du 11 février 2004 creates a new Article 85 in the Loi du 31 décembre 1971 that regulates the use of the professional title by a lawyer who is established under his home country title in France. The Article states that a lawyer who is established under his home country professional title must use the professional title in one of the official languages of his home Member State. In addition to that, the lawyer who is established under his home country professional title must also mention the professional organisation by whose virtue he is allowed to practise in his home Member State, the jurisdiction where he practises in his home Member State, and the Bar to which he belongs in France. ${ }^{935}$

In the $6^{\text {th }}$ Article of the Loi du 11 février 2004 a new Article 86 is created in the Loi du 31 décembre 1971. This new Article 86 lays down the rules pertaining to necessary professional indemnity insurance which must be acquired by the lawyer who is established under his home title. The text of the newly introduced Article 86 closely mimics the text of Article 6(3) of Directive 98/5/EC. The Article states that a lawyer who is established under his home title must obtain professional indemnity insurance that fulfils the criteria laid down for his French counterpart, which is found in Article 17 of the Loi du 31 décembre 1971. A lawyer who is established under his home title may be exempted from the obligation to obtain professional indemnity insurance in France if he can convince the competent authority in France that he already has compatible insurance in his home Member State. If complete equivalence

930 Article 2 of the Loi du 11 février 2004. It may be assumed that this decree, which to my knowledge does not exist at this point in time, uses the list mentioned in Article 1(2) of Directive 98/5/EC.

931 Article 4 of the Loi du 11 février 2004.

932 Article 4 of the Loi du 11 février 2004.

933 Article 4 of the Loi du 11 février 2004.

934 <www.ccbe.org>, last accessed 11 June 2007.

935 Article 5 of the Loi du 11 février 2004. 
cannot be guaranteed, the lawyer established under his home country professional title may be required to obtain complementary insurance in order to guarantee equivalence. ${ }^{936}$

Article 7 of the Loi du 11 février 2004 lays down the rules with regard to professional activities, and the pursuit of legal activity in Multi-Disciplinary Partnerships by lawyers who are established under their home country professional title in France. Article 7 creates a new Article 87 in the Loi du 31 décembre 1971. The first section of the new Article 87 states that a lawyer who is established under his home country title in France may exercise his profession under the preconditions laid down for French avocats in Articles 7 and 8 of the Loi du 31 décembre 1971. ${ }^{937}$ In deviation from these preconditions, and therefore explicitly laid down for lawyers established under their home title, under certain conditions they may work in groupings that contain members who are not of the legal professions. Lawyers are allowed to exercise professional activities as members of a grouping if this grouping fulfils certain criteria. ${ }^{938}$ This construction therefore allows for more liberal rules for lawyers who are established under their home country professional title for practising in MDPs, than for avocats who are, by virtue of Article 8 of the Loi du 31 décembre 1971 only allowed to practise in association with fellow avocats. ${ }^{939}$ When the criteria listed in the newly created Article 87 are not fulfilled, the Article states that the lawyer established under his home title may exercise his profession in France, but not as part of the grouping. He is allowed, on the other hand, to mention his membership of the contested MDP in his home Member State. ${ }^{940}$

With regard to professional activity it is impossible not to notice the absence of the rule of cooperation when representing a client in court. As is well established, Article 5 of Directive 98/5/EC allows Member States to limit the exercise of professional activities when it concerns representing clients in court to the extent that

936 Article 6 of the Loi du 11 février 2004.

937 Article 7 of the Loi du 11 février 2004. Articles 7 and 8 of the Loi du 31 décembre 1971 lay down rules with regard to independence of avocats and rules with regard to practising in groups, which is allowed for avocats among themselves.

938 These criteria are mentioned in the newly constructed Article 87 and mirror to a certain extent the criteria laid down in Article 11 of Directive 98/5/EC. Exercising activity as part of a grouping is allowed for a lawyer established under his home title if the majority of the capital or the decision making power is in the hands of people who are lawyers or exercise one of the other legal professions which are protected by a title (e.g., notaries); when the lawyers exercise activity in the name of the grouping, and the usage of the name is reserved for people belonging to the professions named above.

939 The rules with regard to MDPs for avocats have become very vague due to the merger between the profession of avocat and conseil juridique whereas the rules for practising in MDPs for the latter were more lenient than those of the profession of avocat, and some MDPs seem to exist de facto. See Adamson (1998), p. 156. It can, however, be concluded from the fact that the French legislature deemed it necessary to create separate rules with regard to MDPs for lawyers established under their home title, that the official view with regard to avocats practising in MDPs still is restrictive.

940 Article 7 Loi du 11 février 2004. The newly constructed Article 87 contains another provision which is of minor importance to this thesis and deals with the legal form of the MDP concerned: 'L'avocat inscrit sous son titre professionel d'origine peut, dans des conditions fixées par décret en Conseil d'État, exercer en France, au sein ou au nom d'une société régie par le droit de l'État membre où le titre a été acquis et ayant pour objet l'excercice en commun de plusieurs professions libérales soumises à un statut législatif ou règlementaire ou dont le titre est protégé.' 
Member States can oblige lawyers established under their home title to cooperate with a domestic lawyer, similar to the provisions found in Directive 77/249/EEC. This absence is remarkable since all Member States, at least those who maintain a legal monopoly for lawyers to represent clients in court, have made use of this restriction. It is even more remarkable since France does invoke this restriction with regard to the application of Directive $77 / 249 / E E C .{ }^{941}$ Reasons for this omission are not readily apparent, but it must be concluded that a lawyer who is established in France under his home country professional title is allowed to exercise all the activities of an avocat without the restriction of compulsory cooperation with an avocat when representing clients in court. This is perhaps a reflection of the very liberal stance of the French CCBE delegation that pleaded for an automatic mutual recognition of the legal professions in Europe.

In order to streamline the difficult issue of disciplinary proceedings against a lawyer who is established in France under his home country professional title, either in France or in his home country, Article 8 of the Loi du 11 février 2004 created a new Article 88 in the Loi du 31 décembre 1971 to regulate the modus operandi for disciplinary proceedings. Article 88 states that before disciplinary proceedings are started against a lawyer established in France under his home country professional title, the batônnier of the relevant Bar will inform the competent authority of the home Member State, which is then allowed to utter its views on the matter. ${ }^{942}$ The Article states that the normal procedure for disciplinary proceedings is followed. ${ }^{943}$

Articles 9 to 11 of the Loi du 11 février 2004 deal with the integration of lawyers who are established under their home title in France into the profession of the avocat via the route described in Article 10 of Directive 98/5/EC. Article 9 of the Loi du 11 février 2004 does nothing more than create a new chapter in the Loi $d u 31$ décembre 1971 called: 'Dispositions relatives à l'accès des ressortissants communautaires à la profession d'avocat'. ${ }^{944}$ The main body of rules regarding entrance to the profession of the avocat is laid down in Articles 10 and 11 of the Loi du 11 février 2004. Article 10 of the Loi du 11 février 2004 creates a new Article 89 in the Loi du 31 décembre 1971 which states that lawyers who exercise their profession under their home country professional title in France may integrate into the French legal profession without having to deal with the legal provisions that implement Directive 89/48/EEC in France.

A lawyer can integrate into the profession of the avocat in this manner when he has regularly and effectively pursued professional activities in French law for a period of at least three years. ${ }^{945}$ Although this requirement closely mirrors what is laid down in Article 10 of Directive 98/5/EC, the reference to European Community law that is included in Article 10 of the Directive is absent in the French implementation. It could well be the case that the French competent authorities regard Community law as an integral part of French law, but it could also be that they do not think so, which could potentially lead to an infringement of the Directive.

941 To such an extent that it was even condemned by the ECJ: Case C-351/01 Commission v. France, [2002] ECR I-08101.

942 Article 8 of the Loi du 11 février 2004.

943 Ibid.

944 Article 9 of the Loi du 11 février 2004.

945 Article 10 of the Loi du 11 février 2004. 
Although the Commission is of the opinion that experience in Community law alone is not enough to integrate in the legal profession of the host Member State, that is a long way off the view that experience in national law (in this case French law) alone, can lead to an integration in the legal profession of the host Member State. The French implementation is formulated in such a way that makes it possible for this contravening view to be upheld on the basis of the French implementation. That is a (potential) breach of Directive 98/5/EC. The newly constructed Article 89 of the Loi du 31 décembre 1971 further regulates cases in which a lawyer who is established under his home country professional title fulfils the criteria discussed above, so he may continue to exercise his professional activity under the professional title of France, i.e., the title of avocat. ${ }^{946}$

The second part of the new Article 89 regulates the eventuality where a lawyer, who is established under his home title, seeks to establish himself after he has been active in France for a period of at least three years, but had not been active in the field of French law for that same amount of time. If that is the case, the conseil of the Bar involved will appreciate the effective and regular nature of the activities exercised, and the capacity of the lawyer involved and allow him to continue the named professional activity. ${ }^{947}$ This section is intended as an implementation of Section 3 of Article 10 of Directive 98/5/EC but it lacks the detailed procedure laid down in Section 3 of Article 10 of Directive 98/5/EC in order to ascertain whether the named criteria are fulfilled. It can only be a matter for speculation whether or not France will follow this procedure. Article 11 of the Loi du 11 février 2004 creates a new Article 90 in the Loi du 31 décembre 1971 which lays down a number of more procedural requirements for accessing the profession of the avocat by lawyers who are established under their home country professional title. The first section of the newly introduced Article 90 states that the conseil of the Bar involved will maintain secrecy with regard to applications made for integration into the profession of the avocat. ${ }^{948}$ The second section of the new Article 90 states that the conseil of the Bar may not refuse an application of a lawyer who is established under his home title in France to integrate into the profession of the avocat if the said lawyer fulfils the criteria named in newly constructed Article 89 of the Loi du 31 décembre 1971. The only possibility to refuse such an application is, according to Article 90, on the basis of Articles 11(4), (5) and (6) of the Loi du 31 décembre $1971^{949}$ is in cases of incompatibility and if problems arise in connection with public policy. When the lawyer is allowed to integrate into the profession of the avocat he will be inscribed on the tableau after he has taken the oath. ${ }^{950}$ A lawyer who is allowed to integrate into the profession of the avocat will still be allowed to use his home country professional title (besides the title of avocat) while exercising professional activities in France. ${ }^{951}$

\footnotetext{
946 Ibid.

947 Ibid.

948 Article 11 of the Loi du 11 février 2004.

949 These sections of Article 11 regulate the instances that may lead (on the basis of Article 10(4) of Directive 98/5/EC) to a refusal to allow a lawyer established under his home title to integrate in the legal profession of the host Member States.

950 Article 11 of the Loi du 11 février 2004.

951 Ibid.
} 


\section{Italy}

Directive 98/5/EC was implemented in Italy by means of two legal instruments. The first legal instrument is one of these typical Italian laws that are used to implement Directives. ${ }^{952}$ These laws are created periodically in order to transpose large amounts of European law into the Italian legal system. Article 19 of the law concerned deals with the implementation of Directive 98/5/EC and is basically no more than a detailed delegation of the implementation to the Government. ${ }^{953}$ The Government laid down this implementation in a Decreto Legislativo. ${ }^{954}$ The Decreto Legislativo is a special form of legislation, where the legislative power is delegated to the Government by the Parliament, but where the result leads to a form of regulation that is equal in status to an Act of Parliament (Legge) ${ }^{955}$

The first three articles of the Decreto Legislativo deal with the scope of its application and define the terms that are used throughout the text. Article 1 states that the scope embraces all lawyers from the EU and the EEA who seek to establish themselves permanently in Italy. Lawyers who provide services may not rely on this Decreto Legislativo. ${ }^{956}$ Those persons who are regarded as lawyers coincide with the professional titles mentioned in Article 1(2) of Directive 98/5/EC. ${ }^{957}$

The Decreto Legislativo states that a lawyer who has established himself under the provisions of the Decreto Legislativo may exercise his profession under the rules that are valid for avvocati, and under the conditions of the Decreto Legislativo, under his home country professional title. This general provision is accompanied by a number of more specific provisions. Article 5 states specifically that the rules with regard to activities that are incompatible with the profession of avvocato are also applied to lawyers established under their home country title. Exemption rules for these incompatibilities are also applied to lawyers established under their home title. ${ }^{958}$ The same applies to rules regarding professional indemnity insurance. ${ }^{959}$ The fourth paragraph lists a requirement that was not explicitly named in the implementation devices of the foregoing Member States. The paragraph lists the requirement that a lawyer who is established under his home country professional title is obliged to attend the permanent training courses that are mandatory for avvocati, even when the lawyer established under his home country professional title is obliged to follow these courses in his home country. ${ }^{960}$ The fact that a lawyer established under his home country professional title can be obliged to follow permanent training courses where they are also mandatory for avvocati can probably be justified under Article 7

952 Legge 21 dicembre 1999, n. 526, 'Disposizioni per l'adempimento di obblighi derivanti dall' apertenenza dell'Italia alle Cominutà europee - legge comunitaria 1999', Gazzetta Ufficiale n. 13, 18 gennaio 2000 - Supplemento Ordinario n. 15.

953 Article 19 Legge 21 dicembre 1999.

954 Decreto Legislativo 2 febbraio 2001, n. 96, Attuazione della direttiva 98/5/CE volta a facilitare l'esercizio permanente della professione di avvocato in una Stato membro diverso da quallo in cui e' stata acquisita la qualifica professionale. (via <www.ccbe.org>, last accessed 22 November 2004).

955 Prakke \& Kortmann (1993), pp. 394-395.

956 Article 1(1), (2) and (3). Decreto Legislativo 21 febbraio 2001.

957 Article 2 Decreto Legislativo 21 febbraio 2001.

958 Article 5 (2) Decreto Legislativo 21 febbraio 2001.

959 Article 5 (3) Decreto Legislativo 21 febbraio 2001.

960 Article 5 (4) Decreto Legislativo 21 febbraio 2001. 
of Directive 98/5/EC. ${ }^{961}$ It seems more doubtful for the rule that this is mandatory irrespective of rules regarding permanent education in the home Member State, since this would violate the principle of mutual recognition that underlies the Directive as a whole.

The actual establishment of a lawyer under his country professional title is laid down in Article 6 of the Decreto Legislativo. It lays down a number of detailed provisions that need to be fulfilled before a lawyer can actually establish himself under his home country professional title. First, a lawyer may only practise under his home country professional title when he is enrolled in a special register of the district where the lawyer has his permanent residence or professional domicile. ${ }^{962}$ Secondly, a lawyer needs to be fully qualified to practise as a lawyer in his home Member State. ${ }^{963}$ The application to be listed in the special section of the register must be accompanied by a certificate of citizenship in one of the Member States, a certificate of residence or substitute document such as a certificate of professional domicile, ${ }^{964}$ and a certificate of registration with the competent authority of the home Member State issued within three months of the date of the application. ${ }^{965}$ Furthermore, if the lawyer who seeks establishment under his home title in Italy belongs to a partnership or a firm in his home Member State the lawyer must indicate the name and the legal status of the partnership/firm and the names of its members who operate in Italy. ${ }^{966}$ The application, and all the enclosed documents, must be produced in Italian, or must be accompanied by an authenticated translation. ${ }^{967}$ When the lawyer who seeks establishment has filed for registration and he has fulfilled the criteria mentioned above, the Council of the Bar Association shall register the lawyer within 30 days. ${ }^{968}$ A rejection of an application shall not take place without the applicant having been heard. A rejection shall state reasons, and a copy will be sent to the lawyer who had filed for registration and the public prosecutor in conformity with the Avvocato law. ${ }^{969}$ When the Council of the relevant Bar Association has not reached a decision within 30 days, the lawyer concerned can go the National Bar Association 10 days after the said 30 days have expired in order to obtain a decision. ${ }^{970}$ After the lawyer is registered as a lawyer established under his home country professional title he shall acquire active voting rights but no passive voting rights. ${ }^{971}$ Although not specified further, it must be assumed that this subsection seeks to

961 Albeit with some effort, since Article 7 seems to refer only to professional, i.e. deontological, rules. It is doubtful whether a requirement of permanent education must be seen as a deontological rule or a rule regarding qualification.

962 Article 6(1) Decreto Legislativo 21 febbraio 2001. It is interesting to note that again a reference is made to a requirement of residence, while it has been clearly established in case C-145/99 that a residence requirement is not allowed. The question is whether it is enough to state 'or professional domicile' in order to counter the illegality of the residence requirement. Article 6(2) Decreto Legislativo 21 febbraio 2001.

964 See note $944 .$.

965 Article 6(3) Decreto Legislativo 21 febbraio 2001.

966 Article 6(4) Decreto Legislativo 21 febbraio 2001.

967 Article 6(5) Decreto Legislativo 21 febbraio 2001.

968 Article 6(6) Decreto Legislativo 21 febbraio 2001.

969 Article 6(7) Decreto Legislativo 21 febbraio 2001; Article 31 of the Royal Decree Law no. 1587 of 1933.

$970 \quad$ Article 6(8) Decreto Legislativo 21 febbraio 2001.

971 Article 6(9) Decreto Legislativo 21 febbraio 2001. 
implement, albeit in a minimalist manner, Article 6(2) of Directive 98/5/EC which guarantees lawyers established under their home title adequate representation in the governing bodies of the profession. The Directive states that lawyers established under their home title shall at least have voting rights in the elections of the governing bodies. Lastly, the lawyer established under his home title is required to present on an annual basis a certificate of registration issued within the last three months. ${ }^{972}$ This odd, overly cumbersome, and useless ${ }^{973}$ criterion was also observed in Luxembourg's implementation, where it was observed that he ECJ held that such a requirement was contrary to Directive 98/5/EC. ${ }^{974}$

When a lawyer is established under his home country professional title, he is required to use that title in its entirety and in the language of the home country professional title, in a comprehensible manner, and in such a way as to avoid confusion with the title of avvocato. ${ }^{975}$ In addition, a lawyer must indicate the professional organisation by virtue of which he is allowed to practise in his home Member State. ${ }^{976}$ Where a lawyer is a member of a firm or partnership in his home Member State he must add the name of that firm or partnership to his professional title as well as the legal form of the firm or partnership and the names of the members of that firm or partnership who operate in Italy. ${ }^{977}$

Article 8 of the Decreto Legislativo states that where a lawyer established under his home country professional title exercises professional activities that involve representing a client before a court, in civil, criminal and administrative procedures, as well as disciplinary proceedings, he shall do so in cooperation with an avvocato. ${ }^{978}$ The avvocato shall uphold relations with the competent authorities and will be responsible for fulfilling the requirements that the regulations lay down for a lawyer exercising professional activities as stated above. ${ }^{979}$ The relationship between the lawyer established under his home title and the avvocato concerned shall be laid down in a certified private deed or a declaration made by the lawyers involved and be given to the judge or another competent authority before the said activity is carried out. ${ }^{980}$ Activity before certain superior courts is reserved for lawyers who are listed on special registers. ${ }^{981}$ Lawyers established under their home title are only allowed to carry out activity before these courts if they are listed on these special registers. ${ }^{982}$ A lawyer established under his home country professional title can apply to the National Bar

972 Article 6(10) Decreto Legislativo 21 febbraio 2001.

973 Any changes in the lawyers' status in the home Member State must be communicated to the competent authority in the host Member State under the provisions of Article 7 of Directive 98/ 5/EC. Such a requirement would therefore have no added value apart from extra hassle and costs for the lawyer established under his home country title.

974 Cases C-193/05, Commission of the European Communities v. Grand-Duchy of Luxembourg, [2006] ECR I-08673, and C-506/04, Graham J. Wilson v. Ordre des avocats du barreau de Luxembourg, [2006] ECR I-08613.

975 Article 7(1) Decreto Legislativo 21 febbraio 2001.

976 Article 7(2) Decreto Legislativo 21 febbraio 2001.

977 Article 7(3) Decreto Legislativo 21 febbraio 2001.

978 Article 8(1) Decreto Legislativo 21 febbraio 2001.

979 Article 8(1) Decreto Legislativo 21 febbraio 2001.

980 Article 8(2) Decreto Legislativo 21 febbraio 2001.

981 Article 33 Avvocato law.

982 Article 9 (1) Decreto Legislativo 21 febbraio 2001. Directive 98/5/EC allows for exemptions with regard to superior courts in Article 5(3) 
Association to be included in these registers when he has exercised the profession of lawyer in his home Member State for at least twelve years, taking into account also any professional activity carried out in Italy. ${ }^{983}$ The requirements for cooperation as discussed above remain in force for lawyers exercising activities before superior courts. So a lawyer established under his home country professional title who is enrolled in a special register is still obliged to cooperate with an avvocato. ${ }^{984}$ The requirements of Article 8 do not apply to professional activities that are regarded as 'extra-judicial activities', where the existence of a legal monopoly is much less certain, and Directive 98/5/EC does not allow forced co-operation with a host Member State lawyer. ${ }^{985}$

While exercising professional activities in Italy, the lawyer established under his home country professional title is subject to the disciplinary rules in force in Italy and the disciplinary power of the Council of the Bar Association where he is registered. ${ }^{986}$ Before starting a disciplinary procedure against a lawyer established under his home title in Italy, the Council of the Bar Association shall first inform the competent authority of the home Member State. The information shall be treated as confidential. ${ }^{987}$ In order to set up a preliminary investigation, the Council of the Bar Association concerned may request necessary information from the competent authority of the home Member State. ${ }^{988}$ Members of the competent authority of the home Member States are allowed to participate in the procedure at first instance and in an appeal procedure, where applicable, before the National Bar Association. ${ }^{989}$ Any decision by the Council of the Bar Association or the National Bar Association shall be communicated immediately to the competent authority of the home Member State. ${ }^{990}$ Any measure from the competent authority of the home Member State to revoke the right to practise, temporarily or permanently, shall have the same effect on the right to practise under home title in Italy. Measures taken by the home State's competent authority, which may have a different effect, shall be considered by the Council of the Bar Association which will then adopt appropriate measures on the basis of the Legislative Decree concerned and the forensic rules in force in Italy. ${ }^{991}$ The last section states that the Italian competent authorities shall also furnish all necessary information in connection with the disciplinary proceedings started against avvocati established under their home title in other Member States. ${ }^{992}$

Articles 12 and 13 of the Decreto Legislativo deal with the integration of a lawyer established under his home title in Italy in the profession of the avvocato. A lawyer established in Italy under his home country professional title shall be exempted from the aptitude test when it is established that he has actually and regularly pursued the profession for at least three years in Italy. ${ }^{993}$ The actual and regular pursuance

Article 9(2) Decreto Legislativo 21 febbraio 2001.

984 Article 9(1) Decreto Legislativo 21 febbraio 2001.

985 Article 10 Decreto Legislativo 21 febbraio 2001.

986 Article 11(1) Decreto Legislativo 21 febbraio 2001.

987 Article 11(2) Decreto Legislativo 21 febbraio 2001.

988 Article 11(3) Decreto Legislativo 21 febbraio 2001.

989 Article 11(4) Decreto Legislativo 21 febbraio 2001.

990 Article 11(5) Decreto Legislativo 21 febbraio 2001.

991 Article 11(6) Decreto Legislativo 21 febbraio 2001.

992 Article 11(7) Decreto Legislativo 21 febbraio 2001.

993 Article 12(1) and 12(3) Decreto Legislativo 21 febbraio 2001. 
means an uninterrupted exercise of the profession, but not taking into account interruptions arising from everyday life. Interruptions other than those arising from everyday life, which are not detrimental to the actual and regular character of the activity pursued, will not be taken into account when establishing the time period of three years. ${ }^{94}$ The lawyer concerned must apply for an exemption with the Council of the Bar Association. ${ }^{995}$ The lawyer concerned shall accompany his request with documentation regarding the number and the nature of cases handled as well as proof that he has exercised the profession on national law, including European Community law, on an actual and regular basis for at least three years. The lawyer is also obliged to inform the Council of any criminal or disciplinary procedures against him in his home State and any other useful information. ${ }^{996}$ The Council of the Bar Association shall verify regularity and actual exercise of the profession. Where necessary it may request information from other persons, or request the lawyer concerned to provide explanation and clarification on the information given. ${ }^{997}$ The Council of the Bar Association shall give its reasoned decision within three months of the application. Within fifteen days after that, the Council shall communicate its decision to the applicant and the public prosecutor. The Public prosecutor shall have ten days to give a reasoned opinion, which will then be sent to the Attorney General of the Court of Appeal concerned. The Attorney General and the applicant will have the right to appeal to the National Bar Association within 20 days. The appeal of the Attorney General (which will most likely only occur in the situation where the Bar has exempted the lawyer, but the public prosecutor has advised against it) shall have a suspending effect. The decision of the Bar Association shall also be communicated to the Ministry of Justice for the exercising of supervisory functions. ${ }^{998}$ This integration procedure based on Article 10 of Directive $98 / 5 / \mathrm{EC}$ is rather complicated. In particular, the role of the public prosecutor, his advice and the Attorney General are rather opaque. The essence of the competent authority's task in the implementation of Article 10 is to ascertain whether the lawyer fulfils the criteria laid down in the article. These criteria are of an objective nature, thus no subjective judgement of the competent authority is required. The criteria are either fulfilled and the lawyer can then integrate into the legal profession or they are not fulfilled, in which case a secondary procedure is followed or the application for integration is declined. Since this is purely an objective exercise, it is unclear what the advice of the public prosecutor to the Attorney General should entail, and how this could affect the decision of the Bar Association. The possibility of a breach of the rights conferred by Directive $98 / 5 / \mathrm{EC}$ can only be judged on the application of this procedure in practice. The Council of the Bar Association may refuse an application even before verifying the criteria laid down in this article in the event of any disciplinary proceedings against the lawyer who applies for integration, or in the case of any other issues arsing which relate to public security. ${ }^{999}$ This exception is in line with Section 4 of Article 10 of Directive 98/5/EC. If the

\footnotetext{
994 Article 12(2) Decreto Legislativo 21 febbraio 2001.

995 Article 13(1) Decreto Legislativo 21 febbraio 2001.

996 Article 13(2) Decreto Legislativo 21 febbraio 2001.

997 Article 13(3) Decreto Legislativo 21 febbraio 2001.

998 Article 13(4) Decreto Legislativo 21 febbraio 2001.

999 Article 13(5) Decreto Legislativo 21 febbraio 2001.
} 
Council of the Bar Association fails to react to an application within the said 30 days, both the applicant and the public prosecutor may appeal to the National Bar Association who in turn will decide on the exemption. ${ }^{1000}$ All information dealt with in connection with this procedure shall be treated confidentially. ${ }^{1001}$

Integration into the profession of the avvocato after having less than three years' experience in national law is governed by Article 14 of the Decreto Legislativo. This Article states that a lawyer can also be exempted from the aptitude test when he has been established under his home country title for at least three years in Italy but has been active in Italian law for a lesser period of time, when he is deemed to be able to continue this activity. ${ }^{1002}$ This ability to continue the activity shall be verified through an interview. Besides the activity carried out, note will also be taken of all the professional knowledge and experience acquired in Italian law as well as participation in courses or seminars on Italian law, including forensic and deontological rules. ${ }^{1003}$ The interview shall be carried out by the Council of the Bar Association and integration into the profession of avvocato shall be subject to the procedure of Article 13, as described above. ${ }^{1004}$ A lawyer who is successfully integrated into the profession of the avvocato has the right to use both the title of avvocato and his home country professional title. ${ }^{1005}$

The final part of the Decreto Legislativo, the part following the general rules on practice in association, deals with practice in association of lawyers who are established under their home country professional title. The Decreto Legislativo begins by stating that lawyers established under their home country professional title are also allowed to practise in association when they come from different Member States, under the designation studio associate, followed by the names and surnames of the associates and their professional titles. ${ }^{1006}$ The association as such cannot take on assignments; each associate must take on his own assignments. ${ }^{1007}$ Associations cannot be registered into the registers of the Bar Association. ${ }^{1008}$ This is a peculiar prerequisite since associations of avvocati are required to enrol in the registers. ${ }^{1009}$ Although Article 11 of Directive 98/5/EC does not guarantee equal treatment as such, it is clear from its wording that it was drafted with equal treatment in mind. The reason for difference in treatment is also not readily apparent. Due to the rather vague wording of Article 11 (a form of joint practice shall be made available) it cannot be said that Italy is in breach of the Directive, but the difference in treatment is remarkable nonetheless.

1000 Article 13(6) Decreto Legislativo 21 febbraio 2001.

1001 Article 13(7) Decreto Legislativo 21 febbraio 2001.

1002 Article 14(1) Decreto Legislativo 21 febbraio 2001.

1003 Article 14(2) Decreto Legislativo 21 febbraio 2001.

1004 Article 14(3) and (4) Decreto Legislativo 21 febbraio 2001.

1005 Article 15 Decreto Legislativo 21 febbraio 2001. The final article of the Decreto Legislativo, Article 38, states that any experience gathered between 14 March 1998 (coming into force of Directive 98/5/EC) and 21 February 2001 (coming into force of the Decreto Legislativo) shall be taken into account in granting an exemption. Applications on the basis of experience gathered in the named period must be made within one year after the date of coming into force of the Decreto Legislativo.

1006 Article 34(1) and (2) Decreto Legislativo 21 febbraio 2001.

1007 Article 34(3) Decreto Legislativo 21 febbraio 2001.

1008 Article 34(4) Decreto Legislativo 21 febbraio 2001.

1009 Article 27 Decreto Legislativo 21 febbraio 2001. 
Subsection 5 of Article 43 of the Decreto Legislativo states that the rules of Article 7 , as described above, apply when the lawyer established under his home country title is a member of an association in his home Member State. ${ }^{1010}$ Lawyers who are established under their home country title are also allowed to practise in an association with avvocati as long as one of the partners is an avvocato. ${ }^{1011}$ Article 8 applies when a lawyer established under his home title, practising in association, seeks to represent a client in court. ${ }^{1012}$ Partnership between avvocati and lawyers who are established under home title falls under the rules of Section II of the Decreto Legislativo which declares that the rules applicable to associations of avvocati also apply to these mixed associations. ${ }^{1013}$ Partnerships established (also other than those consisting of lawyers alone) in Member States other than Italy may exercise professional activities in Italy by means of a branch office with permanent representation, provided that all partners are lawyers. ${ }^{1014}$ It is clear that the Italian government has some policy regarding the section of Article 11 of Directive 98/5/EC that deals with MultiDisciplinary Partnerships. ${ }^{1015}$ However, it is not readily apparent what the exact result of this implementation entails. Subsection 2 of Article 36 of the Decreto Legislativo leads to the conclusion that lawyers who are members of an association, which also includes persons who are not lawyers, can also establish themselves in Italy as a branch office of the partnership they belong to in their home Member State, as long as the criteria of subsection 2 are fulfilled. The occurrence of MDPs that fulfil the criteria of subsection 2 will be rare to non-existent, since non-lawyers in such a partnership are very likely to use the name of that partnership. ${ }^{1016}$ In such cases the subsection will not apply, and the lawyer concerned would not be allowed to establish himself in a branch office of the partnership to which he belongs in his home Member State. There are also additional criteria. The partnership that opens a branch office in Italy is obliged to ensure, by means of specific provisions in the Articles of the Association, the personal nature of the service provided by the lawyer, the right of the client to choose his own counsel, the full independence of the lawyers within the partnership with regard to professional activities, and personal liability of the lawyer, the liability of the partnership and the deontological rules. ${ }^{1017}$ If the professional activity entails defending clients in court, Article 8 of the Decreto Legislativo, as described above, shall apply. Branch offices in Italy of partnerships originating from other Member States are obliged to enrol in the register of the relevant Bar Association. ${ }^{1018}$ Provisions of Sections I and II of the Decreto Legislativo

\footnotetext{
1010 Article 34(5) Decreto Legislativo 21 febbraio 2001.

1011 Article 35(1) Decreto Legislativo 21 febbraio 2001.

1012 Article 35(2) Decreto Legislativo 21 febbraio 2001.

1013 Article 35(3) Decreto Legislativo 21 febbraio 2001.

1014 Article 36(1) Decreto Legislativo 21 febbraio 2001. Partnerships shall be deemed not to consist of lawyers when the registered capital is held, wholly or in part; or the partnership name is used, or the decision making power is held (also de facto) by persons who are not considered a lawyer on the basis of Article 2 of the Decreto Legislativo or an avvocato.

1015 Article 11(5) Directive 98/5/EC.

1016 But there is at least a theoretical gap between the requirement in Articles 21, 34 and 35 that all members should be lawyers and the negative criteria laid down in Article 36 (as an implementation of Art 11(5)).

1017 Article 36(3) Decreto Legislativo 21 febbraio 2001.

1018 Article 37(1) Decreto Legislativo 21 febbraio 2001.
} 
shall apply to lawyers established under their home title in Italy as a branch office of a partnership established in another Member State. The rules shall also apply to the branch office itself. ${ }^{1019}$

The Italian implementation of Article 11 of Directive 98/5/EC is a complete mess. It creates a completely non-transparent body of regulations. In essence it comes down to this: Italian avvocati who practise in association fall under Section II of the Decreto Legislativo (very detailed rules regarding partnerships, enrolment in Registers); Lawyers established under their home title in Italy who seek to practise in association fall under Section III (no registration of partnership). Lawyers established under their home title who belong to a partnership in their home Member State and who seek to set up a branch office also fall under Section II (detailed rules and enrolment). The reason for this complicated structure is not readily apparent, and could, in my opinion, be more condensed. It seems that the Italian authorities have struggled with the complicated structure of Article 11 of Directive 98/5/EC and the hierarchy between the host and home Member State rules found in that article. Article 11 of Directive 98/5/EC states that, in case of incompatibility between home and host Member State rules, the latter shall prevail insofar as compliance therewith is justified by the public interest. Subsection 5 allows Member States altogether to refuse groupings that partly consist of non-lawyers. Italy has only made use of this possibility to the extent that it does not allow groupings that contain members who are not lawyers. What Italy has done, and which is contrary to Article 11 of the Directive, is to apply its own rules on partnerships to branch offices of lawyers ${ }^{1020}$ without judging whether the rules in the respective Member States are incompatible with those in Italy or whether the application of the Italian rules on groupings is justified in the light of the public interest to protect clients and third parties. With regard to joint practice outside a branch office, different rules apply to associated lawyers from other Member States on the one hand, and associated avvocati and associated avvocati and lawyers from other Member States on the other. Although sanctioned by the Directive, Article 11(2) and (3) state that joint practice is regulated by the rules of the host Member State. However this seems overly complicated, and, perhaps, discriminatory.

\section{Spain}

On 3 August 2001, over a year after the deadline had passed for the implementation of Directive 98/5/EC, the Spanish Government issued a Real Decreto that had the purpose of implementing Directive 98/5/EC in Spain. ${ }^{1021}$ The implementation stands alone, i.e., it does not directly change the established legislation in the field (such as the Abogado law). The first article of the Real Decreto regulates the scope of its application. The Article states that the Real Decreto shall apply to all citizens of Member States of the European Union and citizens of Member States of the EEA who are entitled to exercise professional activities under one of the professional titles

1019 Article 37(2) Decreto Legislativo 21 febbraio 2001.

1020 Article 37(2) Decreto Legislativo 21 febbraio 2001.

1021 Real Decreto 936/2001, de 3 de agosto, por el que se regula el ejercicio permanente en España de la profesión de abogado con titulo profesional obtenido en otro estado miembro de la Unión Europea, BOE 186/2001, 04-08-2001. 
listed in Article 2 of the Real Decreto. ${ }^{1022}$ The Article states further that the present Real Decreto does not affect the legal provisions mentioned above with regard to the recognition of foreign qualifications (Directive 89/48/EEC) and the free provision of services by lawyers in Spain (Directive 77/249/EEC).

Article 3 of the Real Decreto gives any lawyer from any Member State of the European Union or the European Economic Area the right to exercise his professional activity in Spain under the conditions given in the Real Decreto. ${ }^{1023}$ The first condition under which a lawyer from another Member State is allowed to exercise professional activities in Spain is listed in Article 4 of the Real Decreto. This Article states that a lawyer must be inscribed with the professional authority of the district where the lawyer concerned has his professional domicile or where he exercises the majority of his activities in Spain. ${ }^{1024}$ The formalities of the inscription are listed in Article 5 of the Real Decreto. ${ }^{1025}$ The Real Decreto requires proof of name and nationality, identification of the country where the professional title was obtained, details of the competent authority of the home Member State, professional domicile, and (where applicable) the name and legal form of the grouping to which the lawyer belongs in his home Member State. ${ }^{1026}$ In addition, the Real Decreto requires (an authentic copy and/or translation) ${ }^{1027}$ of the lawyer's passport, certification of inscription with the competent authority of the home Member State, issued within three months of the application, which is to be accompanied with any information regarding disciplinary proceedings, and any other document the relevant Colegio may require, provided that it also requires these additional documents from Spanish lawyers at their inscription. ${ }^{1028}$

It seems that, with this last requirement, the Spanish authorities have attempted to remove any sense of discrimination between Spanish lawyers and lawyers from other Member States seeking registration in Spain. This attempt seems in vain, as Article 3 of Directive 98/5/EC lays down the criteria for registration. Article 3 only requires a certificate of inscription with the competent authority of the home Member State. This line of reasoning was acknowledged by the European Court of Justice when it ruled that Article 3 of the Directive leads to full harmonisation. ${ }^{1029}$ It seems that, although the Government sought to formulate the provision to exclude discrimination, a breach of Directive $98 / 5 / \mathrm{EC}$ is nonetheless present.

The same may hold true for Article 6 of the Real Decreto. This article allows Colegios to ask for an inscription fee if certain criteria are fulfilled. These criteria are twofold. Firstly inscription fees may not exceed those required from those who enter

1022 Articles 1 and 2 Real Decreto 936/2001. The list mentioned in Article 2 coincides with the list of Article 1(2) of Directive 98/5/EC with the addition of the professional titles in Norway (avokat), Liechtenstein (rechtsanwalt) and Iceland (lögmaður).

1023 Article 3 Real Decreto 936/2001.

1024 Article 4 Real Decreto 936/2001.

1025 Article 5 Real Decreto 936/2001.

1026 Article 5(1) Real Decreto 936/2001.

1027 Article 5(3) Real Decreto 936/2001.

1028 Article 5(2) Real Decreto 936/2001.

1029 Cases C-193/05, Commission of the European Communities v. Grand-Duchy of Luxembourg, [2006] ECR, I-08673 and C-506/04, Graham J. Wilson v. Ordre des avocats du barreau de Luxembourg, [2006] ECR, I-08613. 
in the Spanish legal profession, they must be adequate and proportional to the service provided. ${ }^{1030}$

The procedure of inscription is laid down in Article 7 of the Real Decreto. The Article states that the Governing Council of the Colegio concerned will have two months to decide upon the request of a lawyer who seeks establishment under his home title in Spain. If the Governing Council does not decide within two months of the request, it will be assumed that the Council has made a positive decision. ${ }^{1031}$ The general rules for appeal on administrative decisions will apply to decisions taken by the Governing Council of the Colegio concerned. ${ }^{1032}$ According to Article 8 of the Real Decreto, the Colegio concerned shall keep a separate register of those lawyers who are established under their home country professional title. All information known at the time of inscription shall be laid down in the register. ${ }^{1033}$ Where the lawyer concerned seeks establishment, the Colegio shall communicate the inscription of that lawyer within a period of fifteen days to the General Council of Spanish Abogados also indicating the competent authority governing the legal profession in the lawyer's home Member State. The General Council shall than have fifteen days to inform the competent authority of the home Member State and the Minister of Justice of the lawyer's inscription. ${ }^{1034}$ The final section of Article 8 of the Real Decreto states that where a Colegio publicises the names of its members, this must also be done for those lawyers who are established under their home title, accompanied with the professional title under which they are allowed to practise. ${ }^{1035}$

Article 9 of the Real Decreto lays down a number of general criteria a lawyer established under his home title needs to comply with when being established in Spain. The first principle laid down in Article 9 of the Real Decreto concerns applicable professional rules. It is stated in the Article that aside from the rules of professional conduct and deontology the lawyer is subject to in his home Member State, the Spanish rules of professional conduct and deontology will be applicable to the lawyer established under his home country professional title when he exercises any professional activity on Spanish territory. ${ }^{1036}$ This is clearly a very straightforward implementation of Article 6(1) of Directive 98/5/EC. Moreover, a lawyer established under his home country professional title is subject to the same rights, duties, prohibitions, and incompatibilities that are applicable to Abogados, with no discrimination or exceptions other than those provided for in the Real Decreto. It is unclear what this extra sentence in Article 9 of the Real Decreto adds to the general rule already given in the first section of the Article. ${ }^{1037}$ The final section of Article 9 of the Real Decreto states that a temporary or definitive revocation of the right to exercise the legal profession in his home Member State shall have a similar effect on

\footnotetext{
1030 Article 6 Real Decreto 936/2001.

1031 Article 7(1) Real Decreto 936/2001.

1032 Article 7(2) Real Decreto 936/2001.

1033 Article 8(1) Real Decreto 936/2001.

1034 Article 8(2) Real Decreto 936/2001.

1035 Article 8(3) Real Decreto 936/2001.

1036 Article 9(1) Real Decreto 936/2001.

1037 Article 9(2) Real Decreto 936/2001.
} 
the lawyer who is established under his home country professional title in Spain, i.e., he will no longer be allowed to exercise his profession in Spain. ${ }^{1038}$

Article 10 of the Real Decreto regulates the use of professional title for those lawyers who are established under their home country title in Spain. First of all, the Article lays down the obligation for a lawyer from another Member State to always use his professional title as mentioned in Article 2 of the Real Decreto (corresponding with Article 1(2) Directive 98/5/EC and the three professional titles of the EEA countries). A lawyer established under his home title is prohibited from using the designation of Abogado as such, or in any of the official languages in Spain. ${ }^{1039}$ Moreover, where a professional title is the same in a number of Member States, the lawyer concerned is also obliged to mention his Member State of origin. ${ }^{1040}$ Where there are special limitations or privileges conferred on a legal profession in one of the Member State, a lawyer coming from such a Member State must indicate the professional authority by whose virtue he is allowed to practise and the judicial organs before which he is allowed to appear. ${ }^{1041}$

The rules with respect to the professional activities that a lawyer established under his home country professional title in Spain may exercise are laid down in Article 11 of the Real Decreto. The first section states that a lawyer established under his home country professional title may exercise the same professional activities as a Spanish Abogado, in particular, he is allowed to give legal advice concerning the law of his home Member State, European Community law, international law and the Spanish law. ${ }^{1042}$ Where professional activities include defending a client, either before a court or a tribunal (where representation by an Abogado is required), or regarding assisting, communicating with or visiting detainees or prisoners, cooperation with an Abogado is obligatory. ${ }^{1043}$ This also applied to circumstances in which representation by an Abogado is not obligatory, but where a party cannot intervene as such before a judicial body, since only intervention by an Abogado is possible. ${ }^{1044}$ Internal procedural rules will always be followed, and the Abogado who cooperates with the lawyer established under his home title will assume responsibility for the procedure with respect to the judicial body and the public organs. ${ }^{1045}$ Lawyers established under their home title are not allowed to be included in the list of the Colegio that lists the Abogados available for defending clients. ${ }^{1046}$ Clearly this requirement is a direct violation of Directive $98 / 5 / \mathrm{EC}$ as it would make it very difficult for lawyers to establish their own clientele. Furthermore, a lawyer established under his home country professional title may not exercise professional activities that are reserved for other professions in Spain, even where such lawyers are allowed to exercise this professional activity in their home Member State. ${ }^{1047}$ Finally, the Article states that lawyers are allowed to exercise their professional activities in their own capacity or

\footnotetext{
1038 Article 9(3) Real Decreto 936/2001.

1039 Article 10(1) Real Decreto 936/2001.

1040 Article 10(2) Real Decreto 936/2001.

1041 Article 10(3) Real Decreto 936/2001.

1042 Article 11(1) Real Decreto 936/2001.

1043 Article 11(2) first sentence Real Decreto 936/2001.

1044 Article 11(2) second sentence Real Decreto 936/2001.

1045 Article 11(2) third sentence Real Decreto 936/2001.

1046 Article 11(3) Real Decreto 936/2001.

1047 Article 11(3) Real Decreto 936/2001.
} 
in salaried practice insofar as this is permitted for those exercising professional activity under the title of Abogado. ${ }^{1048}$

Article 12 of the Real Decreto briefly, but firmly, states that lawyers established under their home country professional title shall have the right to vote in the elections of the Governing Council of the Colegio where the lawyer is established under the same conditions as Abogados. ${ }^{1049}$

Article 13 of the Real Decreto seeks to implement Article 6(3) of Directive 98/5/EC. The Article states that a lawyer who is established under his home country professional title in Spain must have professional indemnity insurance, either in Spain or in his home Member State. Where a lawyer is insured in his home Member State but the insurance is only partly compatible with the necessary insurance in Spain, he is obliged to purchase additional insurance. ${ }^{1050}$

Article 14 of the Real Decreto lays down the process which is applied when disciplinary proceedings are initiated against a lawyer established under his home title in Spain. Firstly, the Colegio concerned shall inform the competent authority of the home Member State as soon as possible of the intention to start disciplinary proceedings against the lawyer. The Colegio shall give the competent authority of the home Member State all necessary information. ${ }^{1051}$ Secondly, the Article lays down obligatory cooperation between the Colegio and the competent authority of the home Member State throughout the disciplinary proceedings. It is explicitly stated that the obligation of cooperation shall not influence the decision making power of the Colegio with regard to sanctions. The competent authority of the home Member State shall be invited to utter its views in the procedure before the competent authorities in Spain. ${ }^{1052}$ Thirdly, the Article reiterates what was already laid down in Article 9 of the Real Decreto, namely that, where a lawyer's right to practise is revoked, either permanently or temporarily, in his home Member State, the same will hold true automatically for his right to exercise professional activities under his home country professional title in Spain. ${ }^{1053}$ Fourthly, the Article states that the Colegio shall communicate its final decision to the competent authority of the host Member State. The decision of the Colegio can be appealed against under the rules governing such procedures for Abogados. ${ }^{1054}$ In order to inform all the Colegios and in order to ensure that an imposed sanction is given full effect, the cooperation between the Colegio and the competent authority of the host Member State shall be realised through the General Council of Spanish Abogados. ${ }^{1055}$ In conclusion, it can be mentioned that the Spanish authorities have successfully implemented Article 7 of Directive 98/5/EC.

Alternatively, something which does not particularly adhere to the order of Directive 98/5/EC is Article 15 of the Real Decreto, which regulates the possibilities for lawyers established under their home country professional title in Spain to practise

\footnotetext{
1048 Article 11(4) Real Decreto 936/2001.

1049 Article 12 Real Decreto 936/2001.

1050 Article 13 Real Decreto 936/2001.

1051 Article 14(1a) Real Decreto 936/2001.

1052 Article 14(1b) Real Decreto 936/2001.

1053 Article 14(1c) Real Decreto 936/2001.

1054 Article 14(1d) Real Decreto 936/2001.

1055 Article 14(2) Real Decreto 936/2001.
} 
in association or in a multi-disciplinary partnership. The first section of Article 15 lays down a general rule (which is then further elaborated on in subsections (a) to (d)). Firstly, the Article states that lawyers established under their home country professional title may practise in association under the same rules, modalities, prohibitions and limitations as their Spanish counterparts. ${ }^{1056}$ This main rule is then elaborated on with four more specific rules pertaining to practise in association and multi-disciplinary partnerships. First of all, Article 15 of the Real Decreto states that lawyers established under their home title who are part of a grouping in their home Member State may exercise their professional activity in Spain as a branch office or agency of their grouping. Where the rules governing such a grouping in the home Member State are fundamentally incompatible with rules governing such groupings in Spain, the latter shall apply. ${ }^{1057}$ Strangely, and in breach of Directive $98 / 5 / E C$, the justification procedure mentioned in subsection 1 of Article 11 Directive 98/5/EC is completely ignored. Secondly, two or more lawyers who are established under their home title in Spain, and who belong to the same grouping in their home Member State, may exercise their professional activity in association under the rules governing such practice in association in Spain. ${ }^{1058}$ Thirdly, the Article allows lawyers established under their home country title but who come from different Member States to practise in association with each other or with lawyers practising under the Spanish professional title under the rules in force for Spanish lawyers practising in association. ${ }^{1059}$ The fourth subsection of Section 1 of Article 15 of the Real Decreto states that lawyers who are established under their home country professional title are not allowed to establish themselves as part of a grouping when this grouping contains persons with whom Spanish lawyers are not allowed to cooperate. The Article states further that a grouping shall be deemed to contain people who are nonlawyers when the conditions of Article 11(5) of Directive 98/5/EC are fulfilled. ${ }^{1060}$ Furthermore, the subsection states that Spain may oppose the opening of an agency or branch office of a grouping that falls under the definition laid down in this subsection when the fundamental rules governing such a grouping in the home Member State are incompatible with the rules governing such groupings in Spain. ${ }^{1061}$ Similar to Italy, albeit to a lesser extent, the Spanish government seems to struggle with the implementation of Article 11 of Directive 98/5/EC. There remain questions about the use of the second and third sentences of subsection 1(d) of Article 15 of the Real Decreto. Article 11 subsection 5 clearly states that it only applies in circumstances when the host Member State prohibits multi-disciplinary partnerships for its own lawyers. This is not the case in Spain, since it allows MDPs to a certain extent, therefore subsection 5 of Article 11 does not apply to the Spanish situation. ${ }^{1062}$

\footnotetext{
1056 Article 15(1) Real Decreto 936/2001.

1057 Article 15(1a) Real Decreto 936/2001.

1058 Article 15(1b) Real Decreto 936/2001.

1059 Article 15(1c) Real Decreto 936/2001.

1060 Article 15(1d) Real Decreto 936/2001. The conditions named in Article 11 of Directive 98/5/EC are: when the capital of the grouping is held entirely or partly, or the name under which it practises is used, or the decision-making power is exercised, de facto or de iure, by persons who are not a lawyer within the meaning of Article 1(2) of Directive 98/5/EC.

1061 Article 15(1d) Real Decreto 936/2001.

1062 I believe that in the end it does not make much difference, since Spain would probably be able to enforce its rules regarding MDPs on the basis of more general rules laid down in this article.
} 
The other important feature of Directive 98/5/EC, namely the possibility to integrate in the legal profession of the host Member State without having to take the aptitude test provided for in Directive 89/48/EEC, is implemented in Articles 17 to 22 of the Real Decreto. Article 17 of the Real Decreto states that a lawyer established under his home country professional title in Spain has the right to integrate into the profession of Abogado without having to take the aptitude test, as prescribed by the Real Decreto 1665/1991 which implements Directive 89/48/EEC in Spain. Such integration can take place after the lawyer has been established under his home country professional title for a period of three years in which he has effectively and regularly pursued professional activity in Spain. ${ }^{1063}$ The procedure for integration into the profession of Abogado is laid down in Article 18 of the Real Decreto. The Article firstly states that the period of three years mentioned in the previous article commences at the moment the lawyer registers as a lawyer established under his home country professional title. ${ }^{1064}$ When a lawyer sends his request to be integrated into the profession of the Abogado to the Colegio he must accompany his request with all the relevant documents, especially those regarding the number and nature of the cases with which he has dealt in the three-year period. ${ }^{1065}$ On receiving the request and the relevant information, the Colegio will analyse and assess the request and the accompanying information. ${ }^{1066}$ Where necessary, the Colegio will ask the requesting lawyer to clarify, add to or elaborate on (either orally or in writing) the information accompanying the request. ${ }^{1067}$ Before the Colegio will reach its final decision, it will ask for a report from the General Council of Spanish Abogados. ${ }^{1068}$ Article 19 of the Real Decreto lays down the possible decisions the Colegio may take. First of all, the Article states that the Colegio shall have three months after the request has been filed to come to a decision. ${ }^{1069}$ There are several options for the Colegio. Firstly, the Colegio may refuse the request of the lawyer established under his home title. ${ }^{1070}$ This refusal can either be based on the fact that the lawyer concerned has not been active, regularly and effectively, for the period prescribed in Article 17 of the Real Decreto, or on the fact that there are concerns in connection with public policy, in particular as a result of disciplinary proceedings, complaints or incidents of any kind being faced by the requesting lawyer. ${ }^{1071}$ Secondly, the Colegio can decide to integrate the lawyer established under his home country professional title into the profession of the Abogado without the lawyer having to take the aptitude test. This integration will be justified on the fact that the lawyer concerned has been regularly and effectively active for a period of at least three years in Spanish law, including European Community law. ${ }^{1072}$ Thirdly and lastly, the Colegio can require

1063 Article 17(1) Real Decreto 936/2001.

1064 Article 18(1) Real Decreto 936/2001.

1065 Article 18(1) Real Decreto 936/2001.

1066 Article 18(2) Real Decreto 936/2001.

1067 Article 18(3) Real Decreto 936/2001.

1068 Article 18(4) Real Decreto 936/2001.

1069 Article 19(1) Real Decreto 936/2001.

1070 Article 19(1a) Real Decreto 936/2001.

1071 Article 19(1a) Real Decreto 936/2001.

1072 Article 19(1b) Real Decreto 936/2001. It is at least notable to state that it is only here, and not in Article 17, that mention is made of the nature of the activity that needs to be deployed in order to integrate in the profession of Abogado. 
the lawyer to come for an interview. This interview can be imposed if the lawyer has been active on a regular and effective basis for a period of three years under his home title in Spain, but for a shorter period in connection with actitivities in Spanish law. The interview shall have the object of verifying the effective and regular nature of the activities undertaken. After the interview, all the relevant information, i.e., the dossiers treated by the relevant lawyer, and his knowledge and experience with Spanish law (including participation in courses and seminars) will be examined. After that, the Colegio will make its final decision either to allow or to refuse the integration of the lawyer concerned. ${ }^{1073}$ In any case, the Colegio will give reasons for the decision taken, and the legal remedies available for Abogados finding themselves in similar circumstances will also apply to lawyers established under their home title in Spain applying for integration into the Spanish legal profession. ${ }^{1074}$ The effects of the decision taken by the Colegio are laid down in Article 20 of the Real Decreto. In the case of a refusal to integrate the lawyer established under his home title into the profession of the Abogado the lawyer may still continue the pursuit of establishing his professional activities in Spain under his home country professional title. He may also attempt to integrate into the profession of Abogado by means of an aptitude test. ${ }^{1075}$ Where the Colegio decides to permit the lawyer concerned to integrate into the profession of Abogado, the lawyer may proceed to take the necessary steps in order to finalise his inscription with the Colegio. To this end the Colegio will stipulate conditions in accordance with Articles 5 and 6 (which may include inscription fees) of the Real Decreto in order to finalise the inscription of the new Abogado. ${ }^{1076}$ After he has been inscribed the lawyer concerned will be a fully-fledged Abogado, but he may continue to use his home country professional title alongside the title of Abogado. ${ }^{1077}$ Any decision taken by the Colegio will be communicated within a period of fifteen days to the competent authority of the home Member State, the General Council of Spanish Abogados and the Ministry of Justice. ${ }^{1078}$ The same holds true for finalised inscriptions of those lawyers who are allowed to integrate into the profession of lawyer without having to take the aptitude test. ${ }^{1079}$ All the organs taking part in the procedures set forth in the Real Decreto shall assure the confidentiality of all the information concerned. ${ }^{1080}$ The applicant lawyer may ask for the return of any documents he has provided to the Colegio at any point in time. ${ }^{1081}$

\section{Portugal}

The implementation of Directive 98/5/EC in Portugal was introduced by Lei $80 /$ 2001 de 20 de Julho, which brought a change to the Advogado law. Article 196 of the Advogado law lays down the scope of application of Chapter $\mathrm{V}$ of the same law,

\footnotetext{
1073 Article 19(1c) Real Decreto 936/2001.

1074 Article 19(2) Real Decreto 936/2001.

1075 Article 20(1) Real Decreto 936/2001.

1076 Clearly this may be problematic in the event that the Colegio decides to impose measures that can be classed as restrictions that might fall in either of the three categories identified above.

1077 Article 20(2) Real Decreto 936/2001.

1078 Article 21(1) Real Decreto 936/2001.

1079 Article 21(2) Real Decreto 936/2001.

1080 Article 22(1) Real Decreto 936/2001.

1081 Article 22(2) Real Decreto 936/2001.
} 
which is of concern to lawyers from other Member States of the European Union. The Article enumerates the legal professions of the 25 Member States and states that members of these legal professions will be allowed to exercise the professional activities of an advogado under the terms laid down in the remainder of the chapter. ${ }^{1082}$

There are three ways for lawyers from other Member States to exercise professional activities. First of all, a lawyer from another Member State of the European Union may exercise professional activities under his home country professional title. This title must be used in the language of the home Member State and must be accompanied by an indication of the professional authority by whose virtue the lawyer is allowed to practise in his home Member State. ${ }^{1083}$ It is clear that this is the establishment under home title laid down in Article 2 of Directive 98/5/EC. Lawyers exercising their professional activity under their home title are obliged to cooperate with an advogado if the exercise of their professional activities entails the representation of clients in Portuguese courts. ${ }^{1084}$ This provision is an implementation of both Article 5(3) of Directive 98/5/EC and Article 5 of Directive 77/249/EEC. Finally, Article 197 states that lawyers from other Member States of the European Union may exercise professional activities under the professional title of advogado when they have been admitted to the Ordem dos Advogados. ${ }^{1085}$ Admission to the Ordem will be enlarged upon later on in this paragraph.

Article 198 of the Advogado law elaborates on the exercise of professional activities under home country professional title. The Article states that lawyers from other Member States of the European Union are free to provide legal services in Portugal. ${ }^{1086}$ There is one requirement which does not, however, influence the right to provide services, and that is that the Ordem dos Advogados shall be informed of any services which are to be provided. The second paragraph of Article 198 of the Advogado law deals with permanent establishment under home title in Portugal. The paragraph requires lawyers who seek to exercise professional activities in Portugal to register with the Ordem dos Advogados before they are allowed to exercise any such activity. ${ }^{1087}$ According to paragraph 3, registration can be obtained on the basis of the Regulamento de Registo e Inscrição des Advogados de Outros Estados Membros de União Europeia. ${ }^{1088}$ More specifically a lawyer seeking establishment must produce proof of the fact that he is allowed to practise as a lawyer in his home Member State, and he must prove that his licence to practise has not been revoked due to any convictions in criminal or disciplinary matters. ${ }^{1089}$ These documents may also be

1082 Article 196 Advogado law.

1083 Article 197 (1) Advogado law.

1084 Article 197 (2) Advogado law.

1085 Article 197 (3) Advogado law.

1086 Article 198 (1) Advogado law.

1087 Article 198 (2) Advogado law.

1088 Regulamento de Registo e Inscrição dos Advogados Provenientes de Outros Estados Membros da União Europeia, 07-05-2002 via <www.oa.pt>, last accessed 25 April 2005. It is interesting to note that Article 3(d) of the Regulamento requires a permanent establishment in Portugal. It is unclear whether this also entails a residence requirement, which is prohibited under European law, see Case C-145/99.

1089 Article 198 (3) Advogado law. 
required from a lawyer who provides services on an occasional basis. ${ }^{1090}$ As of 2006 , 82 lawyers were established under their home country professional title. ${ }^{1091}$

Article 199 of the Advogado law governs the professional rules applicable to lawyers from other Member States of the European Union who provide legal services in Portugal. The choice of wording in Article 199 is not very helpful, since it implies that the Article would only apply to the free movement of services. The text of the Article, however, mimics the text of Article 6 of Directive 98/5/EC. Moreover, it can be safely argued, based on the character of Chapter $\mathrm{V}$ of the Advogado law, that the article with regard to applicable professional rules applies to both the provision of services in Portugal and the establishment under home title. It states that, without prejudice to the professional rules applicable to the lawyer in his home Member State, activities of a lawyer in the host Member State will be subject to the professional rules of the host Member State. ${ }^{1092}$ The second paragraph deals with voting rights. According to this paragraph, lawyers from other Member States of the European Union established in Portugal may choose, among themselves, a representative for the representative body of advogados, the Congresso dos Advogados Portugueses. ${ }^{1093}$ This provision is a somewhat unusual implementation of Article 6(2) of Directive 98/5/ EC. Article 6(2) guarantees that lawyers established under their home title shall be adequately represented in the governing bodies of the profession. It also states that this shall entail, at least, the right to vote on the governing bodies of the profession. Most of the Member States observed have limited their implementation of this article to this minimum, the right to vote. The Portuguese implementation seems to be more elaborate on the one hand, since a passive voting right is also included, i.e., one of the lawyers established in Portugal may be elected as a representative, yet on the other hand, it also seems to be below the standard set by Article 6(2) Directive $98 / 5 / \mathrm{EC}$. This may be the case since the article implies, through its wording, that active voting is limited to the candidate(s) who seek to become the representative for the lawyers established under their home country title in Portugal.

Article 200 of the Advogado law deals with the registration of lawyers from other Member States of the European Union with the Ordem dos Advogados, who therewith gain the right to exercise their profession under the title of advogado, with the same rights and duties as Portuguese lawyers. ${ }^{1094}$ When a lawyer from another Member State registers with the Ordem and therewith gains the right to practise as an advogado, this does not preclude him from exercising his professional activities under his home country professional title. ${ }^{1095}$

Paragraph 4 of Article 200 of the Advogado law states that a lawyer established under his home title in Portugal may register with the Ordem dos Advogados without taking an aptitude test if he can prove that he has been active in a regular and effective manner for a minimum period of three years in the field of domestic Portuguese

\footnotetext{
1090 Article 198 (4) Advogado law.

1091 <www.ccbe.org>, last accessed 11 June 2007.

1092 Article 199 (1) Advogado law.

1093 Article 199 (2) Advogado law. The Congresso is established by Article $26 \mathrm{ff}$. of the Advogado law.

1094 Article 200 (1) Advogado law.

1095 Article 200 (2) Advogado law.
} 
law or European Community law. ${ }^{1096}$ The last part of this paragraph is remarkable, to say the least, since this is the only Member State observed up to this point that seems willing to allow the integration of lawyers who only have experience with European Community law. All the other Member States have sought justification in the wording of Article 10(1) Directive 98/5/EC ('...at least three years activity an activity in the host Member State in the law of that State including Community law...') to provide that experience in European Community law alone was not enough to integrate into the legal profession of the host Member State without having to take an aptitude test. Based on the wording of Article 200(4) of the Advogado law it may be concluded that Portugal allows integration into the profession of advogado without an aptitude test based on experience with European Community law alone. The final paragraph of Article 200 of the Advogado law deals with exemption from the aptitude test without the minimum of three years' experience as described above. The paragraph states that a lawyer established under his home title may integrate without an aptitude test and without a minimum of three years' experience in Portuguese or European Community law. Integration in by this method can take place if it has been established that the lawyer has enough knowledge and professional experience to exercise the profession of the advogado with the dignity and ability required from a Portuguese advogado. ${ }^{1097}$ Nothing is said about the manner in which a lawyer is required to demonstrate such ability, in contrast with Article 10 of Directive 98/5/EC which states that this takes place via an interview. As of 2006, two lawyers had sought integration in the profession of the abogado in Portugal. ${ }^{1098}$

The rules in connection with disciplinary proceedings for lawyers established under their home country professional title in Portugal are laid down in Article 201 of the Advogado law. The first paragraph states that lawyers established under their home country professional title in Portugal shall be subject to the same sanctions as Portuguese advogados. In addition, the paragraph mentions that the competent authority of the home Member State will be informed that a disciplinary proceeding will be started against their lawyer, and the authority will likewise be informed of the sanction applied to the lawyer established under his home country professional title. ${ }^{1099}$ The second paragraph states that a lawyer established under his home country title has a separate disciplinary responsibility towards the Ordem dos Advogados and the competent authority in his home Member State. A communication of the latter concerning a disciplinary proceeding against a lawyer who also exercises professional activities in Portugal shall, however, be taken into account. ${ }^{1100}$ Lawyers who have been suspended or struck from the Bar in their home Member State will, automatically, no longer be allowed to exercise professional activities in Portugal unless the right to practise in the home Member State is reinstituted. ${ }^{1101}$

The final article of Chapter V of the Advogado law deals with the practice in association of lawyers from other Member States of the European Union who are established in Portugal under their home country professional title. The first para-

\footnotetext{
1096 Article 200 (4) Advogado law.

1097 Article 200 (5) Advogado law.

1098 <www.ccbe.org>, last accessed 11 June 2007.

1099 Article 201 (1) Advogado law.

1100 Article 201 (2) Advogado law.

1101 Article 201 (3) Advogado law.
} 
graph states that lawyers who are members of a professional association in their home Member State may exercise professional activities under their home country professional title in Portugal as a branch office or agency of this professional association. ${ }^{1102}$ This can be done under the condition that prior notification of that fact is given to the Ordem dos Advogados and the professional association. ${ }^{1103}$ Registration of professional associations established in conformity with the internal law of other Member States of the European Union will be subject to verification of compatibility with the rules of the Advogado law and the Decreto-Lei 229/2004 de 10 de Dezembro, which govern the practice in association of lawyers in Portugal. In this verification process, specific attention will be paid to the laws protecting the interest of clients and third parties. ${ }^{1104}$ It is at least doubtful whether this formulation is in conformity with Article 11(1) of Directive 98/5/EC. The Portuguese rule implies that the professional associations of lawyers should always be in conformity with the Portuguese professional rules (with special attention paid to the protection of clients and third parties). This is not in accordance with Article 11(1) of the Directive, since that Article implies that a test must be taken in order to find out whether the rules governing associations in the host and home Member State are incompatible with one another, and such a test is completely absent from the Advogado law. In addition, application of the host State rules can only be justified on the basis of protecting clients and third parties, and not on the basis of professional rules as such, with extra emphasis on the protection of clients and third parties, as is prescribed by Article 202(2) Advogado law. The third paragraph of Article 202 governs the right of lawyers to form associations among themselves. The paragraph states that lawyers from other Member States of the European Union who are established under their home country professional title and who are not part of a professional association in their home Member State, may form a professional association with other lawyers from their home Member State, with lawyers of other Member States or with Portuguese lawyers in accordance with Portuguese law. ${ }^{1105}$ Albeit minimal, this paragraph is an adequate implementation of Article 11(2) and (3) of Directive 98/5/EC.

The final paragraph of Article 202 governs multi-disciplinary partnerships. As described above, MDPs are generally not allowed in Portugal. This principle is reiterated by the final paragraph of Article 202. The paragraph states that lawyers from other Member States of the European Union established under their home country professional title in Portugal are not allowed to exercise professional activities as members of a professional association that also includes members that are not lawyers. ${ }^{1106}$ This rule is clearly in accordance with Article 11(5) of Directive 98/5/EC. There is a problem, however. Article 202(4) of the Advogado law also states that practice in an association that for any other reason (other than for an MDP) violates the Decreto-Lei 229/2004 de 10 de Dezembro and is prohibited. That is a rule that finds no justification under Article 11 of Directive 98/5/EC. It may be concluded that the Portuguese implementation of Article 11 of Directive 98/5/EC fails on a number of crucial points.

\footnotetext{
1102 Article 202 (1) Advogado law.

1103 Ibid.

1104 Article 202 (2) Advogado law.

1105 Article 202 (3) Advogado law.

1106 Article 202 (4) Advogado law.
} 


\section{\4.3.5 Implementation in Germany, Austria and Greece}

\section{Germany}

Similar to the United Kingdom, the German authorities have chosen to implement Directive 98/5/EC by means of a separate legislative instrument, namely the Gesetz zur Umsetzung von Richtlinien der Europäischen Gemeinschaft auf dem Gebiet des Berufrechts der Rechtsanwälte (EuRAG). ${ }^{1107}$ Paragraph 1 of the EuRAG limits the personal scope of the law. The paragraph states that any national of a Member State of the European Union or the European Economic Area (i.e., Iceland, Liechtenstein and Norway) who is entitled to work, on his own, as a lawyer in the respective Member States, will be designated as a europäische Rechtsanwalt (European lawyer) in terms of the application of the law. The part of the paragraph that refers to lawyers working on their own could lead to the belief that the law excludes those lawyers working in a salaried capacity or those working in joint practice, but according to the reasons behind the law, this is not the case. ${ }^{1108}$ According to thereasons behind the law, the phrase, 'practising on one's own' refers to the fact that some Member States allow prospective lawyers to work in association with a patron. These lawyers are exempt from the law. It does not matter whether one works in a salaried capacity or in joint practice, as long as one is allowed to practise on one's own. ${ }^{1109}$

In the second paragraph of the EuRAG it is laid down that a European lawyer may exercise all the activities that a German Rechtsanwalt may do. ${ }^{1110,1111}$ The article once more stresses that the person concerned must be qualified as a lawyer in one of the Member States. ${ }^{1112}$ According to the motivation of the law, Paragraph 2 distinguishes the EuRAG from the old Paragraph 206 of the BRAO which allowed establishment under home title, but did not allow those lawyers to be involved in German law. ${ }^{1113}$ The European lawyer established under the EuRAG may involve himself with German law since Paragraph 2 of the EuRAG states that European lawyers may exercise the same activities as German lawyers. ${ }^{114}$

The means by which a European lawyer is registered is found in Paragraph 3 of the EuRAG. The paragraph firstly states that the decision to register somebody as a European lawyer lies with the Ministry of Justice of each of the Länder. ${ }^{115}$ Furthermore, in order to be registered, the lawyer in question is required to prove that he

1107 Gesetz zur Umsetzung von Richtlinien der Europäischen Gemeinschaft auf dem Gebiet des Berufrechts der Rechtsanwälte, 9 March 2000, BGBl, 2000 I, p. 182. What is notable about this law is that it not only transposes Directive 98/5/EC but also Directives 89/48/EEC and 77/249/EEC.

1108 Deutscher Bundestag, Entwurf eines Gesetzes zur Umsetzung von Richtlinien der Europäischen Gemeinschaft auf dem Gebiet des Berufrechts der Rechtsanwälte, 1 December 1999, Drucksache 14/2269, p. 22.

1109 Ibid.

1110 \2(1) EuRAG.

1111 See Klein (2002), pp. 23-25.

1112 \2(2) EuRAG.

1113 The new $\$ 206$ BRAO covers Member States of the WTO, that are not EU Member States.

1114 Deutscher Bundestag, Entwurf eines Gesetzes zur Umsetzung von Richtlinien der Europäischen Gemeinschaft auf dem Gebiet des Berufrechts der Rechtsanwälte, 1 December 1999, Drucksache 14/2269, p. 23.

$1115 \int 3(1)$ EuRAG. 
is a national of a Member State of the European Union or the European Economic Area. In addition, he needs to produce a certificate which states that he is a fully qualified lawyer in one of the Member States of the aforementioned organisations. ${ }^{1116}$ The authorities may require that this certificate shall have been issued no more than three months previously. The last part of the paragraph states that all the information should be given in German, or where this is not possible, be accompanied with a German translation. ${ }^{117}$ Paragraph 4 states that for the admission procedure, the relevant paragraphs of the $B R A O$ are applicable. ${ }^{1118}$ With the declaration that these paragraphs are applicable, the $E u R A G$ is in accordance with Article 9 of Directive 98/5/EC which lays down the obligation for Member States to give European lawyers a right to appeal to a court on the basis of decisions taken by the competent authorities. ${ }^{119}$ What is strange, however, is not that neither the EuRAG nor the $B R A O$ impose any time limit on the competent authorities to decide upon the applications of the European lawyers. In theory, this could mean that a European lawyer could de facto be denied registration just because of the fact that the competent authorities may take as long as they like to make a decision. Paragraph 4 states further that, in addition to the reasons laid down in the $B R A O$, a European lawyer can also be denied registration, or his existing registration can be revoked, when his capacity to practise in his home Member State ceases because his licence had been revoked, either temporarily or permanently. ${ }^{1120}$ Lastly, the paragraph states that the German competent authorities shall inform the competent authorities of the home Member State of all the decisions taken by them. ${ }^{1121}$

The fifth paragraph states that the European lawyer must use the professional title of the Member State in which he gained his professional qualifications. If the title in that Member State is Rechtsanwalt, ${ }^{1122}$ then the lawyer is obliged to mention the professional organisation of the home Member State that allowed the lawyer to practise in order to avoid confusion. ${ }^{1123}$ In addition to his home title, a European lawyer may also use the designation Mitglied des Rechtsanwaltskammer (member of the Rechtsanwalt, the chamber), but he may not use the designation europäischer Rechtsanwalt (European lawyer). ${ }^{1124}$ When the registration of a European lawyer is revoked under the previous paragraph, the lawyer is no longer entitled to use his home title. ${ }^{125}$

\footnotetext{
$1116 \int 3(2)$ EuRAG.

1117 S3(3) EuRAG. It may be clear that this language requirement falls under the definition of a measure with equivalent effect given by the European Court of Justice in the Dassonville case and therefore, when applied, it must be objectively justified in the light of the Gebhard case.

$1118 \int 4(1)$ EuRAG. The relevant paragraphs of the BRAO are paragraphs 4 to 17, without the exceptions mentioned in paragraph 4(1) EuRAG.

1119 Deutscher Bundestag, Entwurf eines Gesetzes zur Umsetzung von Richtlinien der Europäischen Gemeinschaft auf dem Gebiet des Berufrechts der Rechtsanwälte, 1 December 1999, Drucksache 14/2269, p. 25.

1120 \ $4(2)$ EuRAG.

$1121 \int 4(3)$ EuRAG.

1122 As is the case in Austria, Belgium, Italy and Liechtenstein.

$1123 \int 5(1)$ EuRAG.

$1124 \int 5(2)$ EuRAG.

$1125 \int 5(3)$ EuRAG. A European lawyer who is refused registration or whose registration is revoked thus may not profit from $\$ 206 \mathrm{BRAO}$. That leads one to believe that $\$ 206 \mathrm{BRAO}$ only applies to the Member States of the WTO that are not simultaneously Member States of the European Union, although this is not mentioned explicitly in the paragraph.
} 
Paragraph 6 of the EuRAG declares that when a European lawyer is registered with the Rechtsanwaltskammer the third, fourth, sixth, seventh, ninth, tenth, eleventh, and thirteenth part of the $B R A O$ apply to the European lawyer. ${ }^{1126}$ According to the motivation, the EuRAG herewith implements Sections 1 and 2 of Article 6 of Directive 98/5/EC (dealing with the applicable professional rules and the representation in the professional bodies), Article 7 (dealing with disciplinary proceedings), Article 8 (dealing with salaried lawyers), Article 9 (dealing with the right of appeal for a lawyer against decisions taken) and parts of Article 11 (dealing with joint practice). ${ }^{1127}$ Without going into too much detail, the effect of this paragraph is that everywhere the Directive so requires, European lawyers are treated in the same manner as national lawyers and thus the relevant parts of the $B R A O$ are applicable. In Paragraph 2 of the EuRAG it was stated that a European lawyer may exercise any activity a German lawyer is entitled to do. In this paragraph, it becomes clear that this is not entirely true, since the eighth part of the $B R A O$ is not applicable. That part of the $B R A O$ deals with a special category of Rechtsanwälte, namely those entitled to practise before the Bundesgerichtshof (the German Supreme Court). That effectively means that European lawyers are not entitled to practise before the Bundesgerichtshof. ${ }^{1128}$ Furthermore, Paragraph 6 states that, on an annual basis, a European lawyer must provide the German competent authority with a certificate that certifies that he is still allowed to practise in his home Member State. ${ }^{1129}$ An identical requirement was held as violating the Directive by the ECJ in two cases which involved Luxembourg's implementation. ${ }^{1130}$ As a consequence, it might be concluded that this requirement violates the Directive. The paragraph states further that any decisions with regard to professional conduct and any violations thereof, and convictions flowing therefrom, shall be effectuated on a federal level. ${ }^{1131}$ Following such a conviction, the European lawyer will lose his membership of the Rechtsanwaltskammer. ${ }^{1132}$ Lastly, Paragraph 6 once more states that a European lawyer must cease his activities in Germany when his licence in his home Member State is revoked, temporarily or permanently. ${ }^{1133}$

Paragraph 7 deals with obligatory professional indemnity insurance. In Germany, every Rechtsanwalt must have such insurance under Paragraph 51 of the BRAO. European lawyers are exempt from this obligation if they can prove that they have a similar insurance in their home Member State (the evidentiary documentation must be in German, or accompanied by a translation). Discrepancies that might occur

\footnotetext{
$1126 \int 6(1)$ EuRAG.

1127 Deutscher Bundestag, Entwurf eines Gesetzes zur Umsetzung von Richtlinien der Europäischen Gemeinschaft auf dem Gebiet des Berufrechts der Rechtsanwälte, 1 December 1999, Drucksache 14/2269, p. 26. Ibid., pp. 26-27. Although contradictory in the EuRAG, this is not a disaster since the Directive allows exceptions for Supreme Courts in Article 5(3) of Directive 98/5/EC.

$1129 \int 6(2)$ EuRAG.

1130 Cases C-193/05, Commission of the European Communities v. Grand-Duchy of Luxembourg, [2006] ECR, I-08673 and C-506/04, Graham J. Wilson v. Ordre des avocats du barreau de Luxembourg, [2006] ECR, I-08613

$1131 \int 6(3)$ EuRAG.

1132 Ibid.

$1133 \int 6(4)$ EuRAG.
} 
are solved with clauses providing for additional insurance. ${ }^{1134}$ The paragraph also states that the European lawyer must supply proof of insurance once a year. Nonfulfilment of this requirement will lead to revocation of the European lawyer's registration. ${ }^{1135}$

The problems faced by a lawyer who is engaged in joint practice in his home Member State are addressed in Paragraph $8 .{ }^{1136}$ Firstly, the paragraph states that if a European lawyer is part of a joint practice in his home Member State, he must make this known to the German competent authority. He must also provide information regarding the legal form and the composition of the joint practice. ${ }^{1137}$ Furthermore, the paragraph states that the fact that the European lawyer is part of a joint practice in his home Member State only limits his professional indemnity to such an extent as is allowed by the relevant paragraph of the $B R A O .^{1138}$ Lastly, Paragraph 8 allows the European lawyer to mention his membership of the joint practice in his professional life, as long as he also mentions the legal form in which this joint practice is conducted. ${ }^{1139}$

Paragraph 9 deals with disciplinary proceedings. Firstly, the paragraph states that the Staatsanwalt (public prosecutor) shall inform the competent authority of the home Member State if he intends to prosecute a European lawyer. ${ }^{1140}$ Secondly, the paragraph lays down the obligation for the competent authorities of the home and the host Member State to communicate between them and with the court that deals with the proceedings. ${ }^{1141}$ The paragraph also lays down rules for the protection of information that is of a sensitive and private nature. ${ }^{1142}$ Lastly, the paragraph states that the competent authority of the home Member State has standing before the court that deals with the proceedings, and that it will be possible for the competent authority of the home Member State to give its opinion on the matter. ${ }^{1143}$ Paragraph 10 deals with procedural rules which must be followed when notifying the European lawyer of any disciplinary proceedings brought against him. ${ }^{1144}$

The third part of the EuRAG (SS 11 to 15) deals with the European lawyer's access to the profession of the Rechtsanwalt. Paragraph 11 states that where a European lawyer has been effectively and regularly engaged for a period of at least three years in the law of Germany, including Community law, he will be given access to the profession of the Rechtsanwalt. In addition, the paragraph states that 'effectively and regularly' means the exercise of the profession with no other disruptions other than those stemming from everyday life. ${ }^{1145}$ This last element is elaborated on further

\footnotetext{
$1134 \int 7(1)$ EuRAG.

$1135 \int 7(2)$ EuRAG. For this paragraph the comments I made earlier are also valid. The paragraph seems overly bureaucratic and is potentially violating Community law.

1136 For practising jointly in Germany the relevant paragraphs of the BRAO that were described above are applicable.

$1137 \int 8(1)$ EuRAG.

$1138 \int 8(2)$ EuRAG. The relevant paragraph is $\int 59 \mathrm{j}$ BRAO.

$1139 \int 8(3)$ EuRAG.

1140 \ 9(1) EuRAG.

1141 \ $9(2)$ EuRAG.

1142 \9(3) EuRAG.

$1143 \int 9(4)$ EuRAG.

$1144 \int 10$ EuRAG.

$1145 \int 11(1)$ EuRAG.
} 
in the second section of the paragraph, which states that interruptions arising from everyday life can generally be no longer than three weeks. If interruptions exceed three weeks, then the competent authority will take its decision based on the particular facts of the case. ${ }^{1146}$ If the competent authority decides that the interruption falls outside those present in everyday life, then the period before the interruption will be taken into account as long as this does not conflict with the effective and regular pursuit of the profession. ${ }^{147}$ Paragraph 12 lays down the means by which the European lawyer must prove that he falls into the situation described by Paragraph 11. Firstly, the Paragraph states that a European lawyer must provide the competent authority with the number and nature of cases he has dealt with that have been connected to German law, together with proof of the duration of his activities. The competent authority can ask for oral clarification of these materials. ${ }^{1148}$ In addition to this, the second section states that with respect to the cases dealing with German law, the European lawyer needs to supply lists of cases he or she has dealt with, with details regarding the case number, the subject matter, the time elapsed when dealing with the case, nature and size of the activities of the lawyer, and the outcome of the case. Moreover, the competent authority may require samples of the lawyer's work, which should be made anonymous with regard to the protection of the parties involved. ${ }^{1149}$ What is remarkable in this paragraph is that no further reference is made to activities pursued in European law. It was mentioned in Paragraph 11, but merely as a direct translation of the relevant part of Article 10 of Directive 98/5/EC. It seems to me that the German authorities have implemented Article 10 to its minimum, but in terms of any further action, they would like to discourage European law, since no further mention is made of that possibility. It is also remarkable that, again, no reference is made to a set time limit within which the competent authority must take its decision. This could lead to the de facto exclusion of persons through default in making a decision, which would be a violation of Community law. Paragraph 13 states that a European lawyer, who has been active in the field of German law for a period shorter than three years, may be admitted to the profession of the Rechtsanwalt if he can convince the competent authority that he is competent to be a part of that profession. ${ }^{1150}$ When deciding on this, the competent authority will take into account all the activities pursued by the lawyer as well as his knowledge of German law, and his attendance at courses and lectures of which the subject matter was German law. ${ }^{1151}$ Paragraph 14 states that the European lawyer concerned must deliver the same proof as a lawyer who seeks entrance to the profession under Paragraph 11. ${ }^{1152}$ In Paragraph 15, it is laid down that the competent authority of Germany will establish in an interview whether the European lawyer has been pursuing activities in German law in a regular and effective manner,

\footnotetext{
$1146 \int 11(2)$ EuRAG.

$1147 \int 11(3)$ EuRAG. According to the motivation, Article 10 of Directive 98/5/EC nowhere states that the period of three years should be without interruptions. See Deutscher Bundestag, Entwurf eines Gesetzes zur Umsetzung von Richtlinien der Europäischen Gemeinschaft auf dem Gebiet des Berufrechts der Rechtsanwälte, 1 December 1999, Drucksache 14/2269, p. 30.

$1148 \int 12(1)$ EuRAG.

$1149 \int 12(2)$ EuRAG.

$1150 \int 13(1)$ EuRAG

$1151 \int 13(2)$ EuRAG.

1152 \ 14 EuRAG.
} 
and whether or not he is capable of further pursuing these activities. The contents of the interview will consist of the lawyer's experiences with German law. ${ }^{1153}$

\section{Austria}

Similar to Germany, the Austrian authorities have chosen to take all the Directives regarding lawyers together and combine it into one separate law. This law is called Bundesgesetz über den freien Dienstleistungsverkehr und Niederlassung von europäischen Rechtsanwälten in Österreich (hereinafter EuRAG). ${ }^{1154}$ Although the acronym for the law is the same as that for the German law, the laws have little further in common besides the fact that they both implement, among other things, Directive 98/5/EC. The first chapter of the third part of the EuRAG (Paragraphs 9 to 17) deals with the establishment of lawyers under their home title. Paragraph 9 of the EuRAG states that European lawyers are allowed to establish themselves under their home title in Austria, albeit under the requirement that the European lawyer is registered with the competent authorities of Austria. Once he is registered, he is allowed to exercise all the activities that may be exercised by an Austrian Rechtsanwalt, except for those activities explicitly prohibited by the EuRAG. ${ }^{1155}$ As of 2006, 70 lawyers were established under their home title in Austria. ${ }^{1156}$

The manner in which a European lawyer can become registered in Austria is laid down in Paragraph 10 of the EuRAG. That paragraph states that a lawyer wishing to establish himself in Austria must send his application to the relevant Austrian Rechtsanwaltskammer (similar to Germany, Austria is a federation consisting of different Länder). ${ }^{1157}$ In the application, the prospective European lawyer must supply proof that he or she is a national of a Member State of the European Union or a national of a Member State of the European Economic Area. In addition, he must present a certificate stating that he is allowed to practise in his home Member State, issued within a period of three months prior to the application to the Rechtsanwaltskammer. Finally, he must supply proof that he is insured in the manner prescribed by the EuRAG. ${ }^{1158}$ Similar to the German rules, all documentation must be produced in the German language, or where this is not possible, accompanied with a certified German translation. ${ }^{1159}$ Paragraph 11 states that if the European lawyer fulfils the above criteria he must be registered as a European lawyer in Austria. The paragraph states also that European lawyers will not be tested on their trustworthiness, an element that forms part of the rules of access to the legal profession for Austrians laid down in Paragraph 5 of the Rechtsanwaltsordnung. ${ }^{1160}$ If the competent authorities refuse to enter the prospective lawyer into the registers as a European lawyer, Paragraph 11 states that the same remedies are available to him as are available to Austrian

\footnotetext{
$1153 \int 14$ EuRAG.

1154 Bundesgesetz über den freien Dienstleistungsverkehr und die Niederlassung von europäischen Rechtsanwälten in Österreich (EuRAG) sowie Änderungen der Rechtsanwaltsordnung, 23 May 2000, BGBl I 27/2000.

$1155 \int 9$ EuRAG.

1156 <www.ccbe.org>, last accessed 11 June 2007.

1157 \& $10(1)$ EuRAG.

1158 \10(2) EuRAG.

$1159 \int 10(3)$ EuRAG.

$1160 \int 11(1)$ EuRAG.
} 
lawyers under Paragraph 5a of the Rechtsanwaltsordnung. ${ }^{1161}$ The competent authority of Austria will inform the competent authority of the home Member State of any decision regarding registration as a European lawyer, ${ }^{1162}$ while the registration of the European lawyer must also be made known in conformity with the rules of Paragraph 5(5) of the Rechtsanwaltsordnung. ${ }^{1163}$

European lawyers must use their home title when practising in Austria. This is laid down in Paragraph 12. Lawyers who are entitled to use the title of Rechtsanwalt in their home Member State are obliged to mention the professional authority of the home Member State that allows them to practise under that title. ${ }^{1164}$

Paragraph 13 lays down the professional activities a European lawyer may pursue. The paragraph states that a European lawyer may, in principle, pursue any activities that an Austrian lawyer is allowed to pursue, except for three fields of activity that are not open to European lawyers. ${ }^{1165}$ First of all, European lawyers are not allowed to be chosen as members of representative bodies of the profession. Secondly, European lawyers are not allowed to educate prospective Austrian lawyers in their Rechtsanwaltsanwärter period. Thirdly, they may not act as a lawyer in legal aid schemes, and they are not eligible for the compensation that Austrian lawyers receive when they work in a legal aid scheme. ${ }^{1166}$ With regard to the first limitation, it can be argued that this is in conformity with Directive 98/5/EC, since the Directive states that lawyers established under their home title must at least have the opportunity to vote in the elections of the competent authorities' governing bodies. ${ }^{1167}$ On the other hand, however, it seems doubtful whether the strict prohibition on standing as candidates in the elections of those bodies, as mentioned in the $E u R A G$, is enough to guarantee the appropriate representation that the Directive requires. Similar, and even stronger, observations hold true for the second and third limitations. The limitations regarding the activities a European lawyer may pursue are mentioned exclusively in Article 5 of Directive 98/5/EC. ${ }^{1168}$ The Article, however, makes no mention of a prohibition on educating prospective lawyers and activities within legal aid schemes because of the lack of knowledge with respect to Austrian law, ${ }^{1169}$ the second and third limitation under the EuRAG. This leads to the belief that these limitations are contrary to the Directive, and therewith contrary to Community law. This is corroborated by the rulings of the European Court of Justice which dealt with Luxembourg's implementation of Directive 98/5/EC, where it was stated

\footnotetext{
$1161 \int 11(1)$ EuRAG.

$1162 \int 11(2)$ EuRAG.

$1163 \int 11(3)$ EuRAG.

$1164 \int 12$ EuRAG.

$1165 \int 13$ EuRAG.

$1166 \int 13$ EuRAG.

1167 Article 6(2) Directive 98/5/EC.
}

1168 The view that the limitations listed in Article 5 are exclusive, and the fact that the Directive leads to full harmomisation in this respect, is also corroborated by the rulings of the ECJ in Cases C193/05, Commission of the European Communities v. Grand-Duchy of Luxembourg, [2006] ECR, I08673 and C-506/04, Graham J. Wilson v. Ordre des avocats du barreau de Luxembourg, [2006] ECR, I-08613.

1169 See Erlauterungen to $\$ 13$ EuRAG, 59der Beilagen zu den Stenografischen Protokollen des Nationalrates XXI.GP, 20 April 2000. 
that the limitations in connection with professional activity, listed in Article 5 of the Directive, are exhaustive. ${ }^{1170}$

Paragraph 14 lays down a further limitation on the activities of European lawyers, but this time a limitation sanctioned by Directive $98 / 5 /$ EC, namely the fact that in proceedings before a national court a European lawyer is obliged to be accompanied by an Austrian lawyer. ${ }^{1171}$ This limitation is a direct translation of Article 5(3) of Directive 98/5/EC.

In Paragraph 15 it is laid down that European lawyers in principle are obliged to have Austrian professional indemnity insurance unless they can prove to the Austrian competent authorities that they have professional indemnity insurance in their home Member State that is equal to the Austrian insurance, which also covers their activities in Austria. ${ }^{1172}$ In addition to that, European lawyers who keep their insurance in their home Member State must instruct their insurer to inform the Austrian competent authority of their insurance. ${ }^{1173}$

In Paragraph 16, the EuRAG deals with the situation of lawyers who are part of a joint practice in their home Member State. European lawyers who are part of a joint practice in their home Member State must inform the Rechtsanwaltskammer of that fact, and they must inform the Rechtsanwaltskammer of the name and legal form of that joint practice and any other information that the Rechtsanwaltskammer might require. ${ }^{1174}$ When European lawyers want to exercise their professional activities within the context of the joint practice, they are allowed to do so as long as they mention the name of the practice and the legal form of that practice in the exercise of their professional activities. ${ }^{1175}$ Notice that this article only deals with the membership of a foreign joint practice. Membership and rules of Austrian joint practices are dealt with in the Rechtsanwaltsordnung. ${ }^{1176}$ This leads to the belief that Austria has not implemented the objective justification test with regard to applicable professional rules that is included in Article 11(1) of the Directive, which constitutes yet another potential breach of that Directive.

Paragraph 17 states that European lawyers are subject to the same disciplinary controls as Austrian lawyers. ${ }^{1177}$ The Austrian competent authorities may only issue disciplinary measures within the Austrian jurisdiction, i.e., the Austrian competent authorities cannot issue measures that have effect outside of Austria. ${ }^{1178}$ In case of the commencement of proceedings against a European lawyer in Austria, the competent authorities shall inform the competent authorities of the home Member State. In this case, the latter has the possibility to intervene in the procedure. ${ }^{1179}$ When a

\footnotetext{
1170 Cases C-193/05, Commission of the European Communities v. Grand-Duchy of Luxembourg, [2006] ECR, I-08673 and C-506/04, Graham J. Wilson v. Ordre des avocats du barreau de Luxembourg, [2006] ECR, I-08613

1171 \& 14 EuRAG.

$1172 \int 15(1)$ EuRAG.

$1173 \int 15(2)$ EuRAG.

1174 \16(1) EuRAG.

$1175 \int 16(2)$ EuRAG.

1176 \& $21 \mathrm{c}$ RAO.

$1177 \int 17(1)$ EuRAG.

$1178 \int 17(2)$ EuRAG.

$1179 \int 17(3)$ EuRAG.
} 
European lawyer is withdrawn from the register in his home Member State this automatically means that he is no longer allowed to practise in Austria. ${ }^{1180}$

The second chapter of the third part of the EuRAG deals with the integration of a European lawyer into the profession of the Rechtsanwalt. It must be mentioned that the integration dealt with in this chapter is the integration meant by Article 10 of Directive 98/5/EC. The integration of a lawyer into the profession of the Rechtsanwalt as meant by Directive $89 / 48 / \mathrm{EEC}$ is dealt with in the third chapter of the third part of the EuRAG. Paragraph 18 states that where a lawyer has pursued activities in Austria as a European lawyer in the field of Austrian law, including European Community law, for at least three years in an effective and regular manner, ${ }^{181}$ he will be registered as an Austrian Rechtsanwalt. ${ }^{1182}$ In addition to that, the paragraph states further that the Rechtsanwaltskammer involved will assess any lacunae in professional activity and they will decide as they fit in the particular circumstances of the case. ${ }^{1183}$ The way in which a European lawyer must prove that he has been pursuing activities involving Austrian law effectively and regularly is laid down in Paragraph 19 of the EuRAG. The paragraph states that a European lawyer who wants to integrate into the Austrian profession of the Rechtsanwalt must provide the relevant Rechtsanwaltskammer with the number, subject and result of all the cases he has dealt with in Austrian law, and he must prove the duration of his professional activities. The Rechtsanwaltskammer can require the European lawyer to elaborate, either orally or in writing, on the evidence produced. ${ }^{1184}$ The paragraph states further that the evidence in connection to the cases which the lawyer has dealt with must be produced in the form of a list of cases accompanied with case numbers, subject matter of the case, duration, etc. Moreover, the Rechtsanwaltskammer may require examples of the lawyer's work, such as pleadings which have been made anonymous in order to protect the lawyer's clients. ${ }^{1185}$ Furthermore, the paragraph states that all the evidence should be produced in the German language or be accompanied with a German translation. ${ }^{1186}$

Since the Austrian implementation of this part of the Directive 98/5/EC is very similar to its German counterpart, the same can be said for the Austrian implementation. The reference to European Community law in the paragraph of the $E u R A G$ is very basic and in the further text of the paragraph no further reference is made to experience gained in this field of law. In the reasoning of this paragraph, the Austrian Government stated that the experience gained should replace the professional education Austrian candidates receive and could therefore never consist purely of experience gained in European law. ${ }^{1187}$ Although that argument seems reasonable, it is in no way supported by the Directive, so this is another element of the EuRAG that seems contradictory to the Directive. Questions remain on how the Rechtsanwaltskammers are to assess the experience which has been gained in that

\footnotetext{
1180 \17 (4) EuRAG.

1181 'effektive und regelmäßige Tätigkeit'.

$1182 \int 18(1)$ EuRAG.

$1183 \int 18(3)$ EuRAG.

$1184 \int 19(1)$ EuRAG.

$1185 \int 19(2)$ EuRAG.

$1186 \int 19(3)$ EuRAG.

1187 Erl. Zur $₫ 18$ EuRAG.
} 
field. Furthermore, the paragraph makes no reference at all to the time limit within which a decision on a request must be made. To this date, no requests have been made for integration. ${ }^{1188}$ Paragraph 20 deals with the situation where the European lawyer has been regularly and effectively pursuing activities in Austria for at least three years, but for a shorter period of time in Austrian law. Lawyers in this situation are eligible for integration into the profession of the Rechtsanwalt without taking an aptitude test under the system of Directive 89/48/EEC, if they can prove that they are able to exercise this profession successfully. ${ }^{1189}$ In addition to the documentary evidence that must be supplied with an application for integration into the profession of the Rechtsanwalt under the previous paragraph, the Rechtsanwaltskammer will interview the candidate in order to ascertain whether he or she has been active in Austrian law and whether he or she is therefore able to continue this activity in a proper manner. The contents of the interview will concentrate on the practical experience the candidate has with Austrian law. ${ }^{1190}$ In its final decision, the Rechtsanwaltskammer must take into account all experiences in Austrian law that the candidate has gained, including his or her attendance at courses and seminars on Austrian law or disciplinary rules for lawyers. ${ }^{1191}$

In addition to the two systems of integration for lawyers into the profession of the Rechtsanwalt, Paragraph 21 states that, in accordance with Directive 98/5/EC, a European lawyer can at any time request to take an aptitude test under the system of Directive 89/48/EEC. Upon successful completion of this test, a lawyer will be integrated into the profession of the Rechtsanwalt. ${ }^{1192}$ Paragraph 22 states that with regard to the protection of the lawyer requesting to be integrated, all the rules with regard to appeals, etc., laid down in Paragraph 5a of the Rechtsanwaltsordnung are applicable to requests to be integrated into the profession of the Rechstanwalt. ${ }^{193}$ Lastly, Paragraph 23 states that when a lawyer is integrated into the profession of the Rechtsanwalt he is entitled to use that title in addition to his home title which he also may continue to use. ${ }^{1194}$

\section{Greece}

The Directive was implemented in Greece by means of a Presidential Decree. ${ }^{1195}$ The Presidential Decree stands on its own and does not affect the Kodex Dikigoros. The Presidential Decree has as its object the facilitation of the exercise of professional activities by lawyers who have gained their professional qualifications in other Member States of the European Union, either in an independent or salaried fashion. ${ }^{1196}$ All the persons who bear the professional titles mentioned in Article 2 of the Presidential Decree, which coincide with the titles laid down in Article 1(2) of Directive 98/5/EC, have the right to establish themselves under their home country profes-

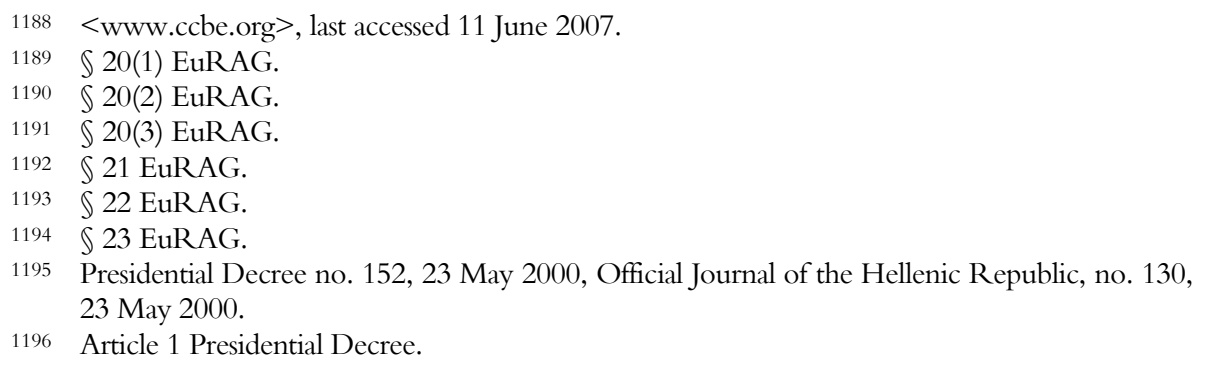


sional title. ${ }^{1197}$ The Presidential Decree does not apply to lawyers who seek to perform services in Greece. There are also specific rules for lawyers who are in salaried practice. These rules will be dealt with later on in this paragraph. ${ }^{198}$

In order to become established under home title, a lawyer from another Member State of the European Union first needs to register with the Greek authorities. He must register with the Bar Association of the district in which he exercises his professional activity and where he has an office. ${ }^{1199}$ In order to obtain that registration, a lawyer must provide the Bar Association with a document stating that he is has the nationality ${ }^{1200}$ of one of the Member States of the European Union, an extract from his criminal record, ${ }^{1201}$ a certificate of registration with the competent authority of the home Member State which must at least include an indication of the purpose for which the certificate is issued and, where appropriate, must make mention of any disciplinary proceedings against the lawyer, the nature of the disciplinary proceedings and the sanctions imposed by the competent authority of the home Member State. The certificate must have been issued within three months of the date it is presented to the Greek Bar Association where registration is sought. ${ }^{1202}$

Whenever a registration is refused, or where an existing registration is removed, the lawyer concerned shall have legal recourse before the Council of State in Greece. ${ }^{1203}$ The competent authority in Greece shall inform the competent authority of the home Member State of any decision taken either to register or not, the lawyer who seeks to establish himself under home title in Greece. ${ }^{1204}$ Every Bar Association in Greece must keep a separate register of those lawyers who are established under their home country professional title in Greece. ${ }^{1205}$ As of 2006, 79 lawyers are established under their home country professional title in Greece. ${ }^{1206}$ Article 4 of the Presidential Decree states that a lawyer who is established under his home title may, on a permanent basis, exercise the professional activities that are specified in Article 7 of the Presidential Decree, and which will be dealt with later on in that chapter. ${ }^{1207}$ Article 6 of the Presidential Decree governs the use of professional title by lawyers who are established under their home country professional title. Any lawyer who is established within the frame of the Presidential Decree must use their home country professional title in its official language, or one of the official languages of the home Member State. ${ }^{1208}$ Additionally, every individual Bar Association in Greece may require a lawyer established under his home country profes-

1197 Article 2 Presidential Decree.

1198 Article 3 Presidential Decree.

1199 Article 5(1) Presidential Decree. This rule seems to reflect a sort of unicité du cabinet which also seems logical given the highly decentralised organisation of the legal profession in Greece. See also: Kommatas (1993), p. 168.

1200 The unofficial translation of the Presidential Decree uses the term 'ressortissant'.

1201 Which seems odd, since normally there is no data from persons who have not been criminally convicted.

1202 Article 5(2) Presidential Decree.

1203 Article 5(3) Presidential Decree.

1204 Article 5(4) Presidential Decree.

1205 Article 5(5) Presidential Decree.

1206 <www.ccbe.org>, last accessed 11 June 2007.

1207 Article 4 Presidential Decree.

1208 Article 6(1) Presidential Decree. 
sional title to indicate the name of the professional organisation by virtue of which the lawyer is allowed to practise in his home Member State. He must also make mention of his registration with the Greek Bar Association. ${ }^{1209}$

Article 7 lays down the rules in connection with the professional activities a lawyer who is established under his home country professional title may pursue in Greece. The general rule is laid down in subsection 1 and states that lawyers established under their home State professional titles may employ the same activities as Dikigoros. More specifically, the lawyer may give legal advice on relevant questions of Greek law, Community law, International law and the law of his home Member State. He may also carry out acts and operations sanctioned by the rules in force in Greece. ${ }^{1210}$ With regard to the representation of clients in court, the second subparagraph requires lawyers who are established under their home country professional title to cooperate with a Dikigoros who is allowed to practise in the district where the lawyer is established. ${ }^{1211}$ The third subsection states that any activity employed by a lawyer established under his home country professional title shall be subject to the professional rules in force in Greece. ${ }^{1212}$

Finally, Article 7 of the Presidential Decree provides that a lawyer who is established under his home country professional title, unless he has Greek nationality, may not exercise activities that entail the exercise of public authority in Greece. Subsection 4 gives a number of examples of activities that may not be exercised by lawyers established under their home country professional title. Examples include; being a member of a supervisory commission during elections, functioning as a liquidator or an administrator in cases of succession or bankruptcy, preparing certified documents, or partaking in a court. ${ }^{1213}$ This subsection provides some interesting material. Although not sanctioned by the Directive itself, apart from Article 5(2) of Directive $98 / 5 / \mathrm{EC}$, I am of the opinion that the Greek implementation is not necessarily in breach of the Directive. The general public service exception, laid down in Article 45 of the EC Treaty, prevails over secondary legislation. Aspects of the legal profession that are unreconcilable with the fact that they can be exercised by people who do not have Greek nationality, can, therefore, still be brought under the public service exception of Article 45 of the EC Treaty. Whether or not the exception of subsection 4 applies depends on the nationality of the lawyer. A lawyer who is established under his home country title, but who has Greek nationality, is allowed to exercise the activities mentioned in subparagraph 4. This makes it clear that it is not the fact that the person is not a Dikigoros but the fact that a person does not have Greek nationality that makes the exception of subsection 4 apply. The provision, therefore, does not undermine the underlying principle of mutual recognition of lawyers, and is therefore acceptable, as long as the criteria laid down in case law for the application of the public service exception are respected. ${ }^{1214}$ On the other hand,

\footnotetext{
1209 Article 6(2) Presidential Decree.

1210 Article 7(1) Presidential Decree.

1211 Article 7(2) Presidential Decree.

1212 Article 7(3) Presidential Decree.

1213 Article 7(4) Presidential Decree.

1214 In these cases, Article 45 of the EC Treaty provides for the possibility that Member States exclude the free movement for professions that are connected with the exercise of state sovereignty. This provision extends the public-service exception of Article 39(4) to the freedom of
} 
this entails that persons without Greek nationality who integrate into the profession of the Dikigoros also may not carry out these activities. Evidence of this in Greece has not been found while researching this chapter. If a non-Greek Dikigoros is allowed to exercise the activities that have been banned for lawyers working under their home country professional title, a violation of the rules laid down in the Directive may occur. Above all, the Greek authorities may not unilaterally impose this exception. If an inconsistency between two European rules is found, which might be the case in this instance, it is for the European Court of Justice to rule on the issue. A Greek court must therefore ask for a preliminary ruling in order to solve this question. Since that has not yet happened, it must be concluded that this rule is contrary to Article 5 of the Directive. Moreover, the European Court of Justice has ruled that the limitations on professional activities laid down in Article 5 of Directive 98/5/EC are exhaustive. ${ }^{1215}$

Article 8 of the Presidential Decree lays down the rules on professional conduct that are applicable to lawyers who are established under their home country professional title in Greece. Subsection 1 states that, irrespective of the rules of professional conduct which are applicable in his home Member State, a lawyer established under his home country professional title is subject to the rules of professional conduct in force in Greece in respect of all the activities he pursues within Greek territory. Moreover subsection 1 states that the lawyer shall be subject to the obligations flowing from the Kodex Dikigoron, the Code of Deontology, and the internal regulations of the Bar Association where he is established. He is also obliged to respect the rules governing the exercise of the legal profession, most notably those concerning incompatibilities, the exercise of activities that do not form part of the legal profession, professional secrecy, publicity, professional dignity and the good exercise of the profession. ${ }^{1216}$ When a lawyer is registered with a Bar Association in Greece, he will be deemed to be a member of the Bar Association, he will take part in the meetings of that Bar Association and he will have a right to vote in the administrating Council of the Bar, in conformity with the rules laid down in the Kodex Dikigoron. ${ }^{1217}$ A lawyer who is established under his home country professional title is obliged to hold professional indemnity insurance, which means that he must affiliate himself with a professional guarantee fund, in accordance with the rules laid down in Greece. A lawyer will be exempted from this rule if it is established that he takes part in insurance or a guarantee fund that is similar to that prescribed in Greece. Where the similarity is only partial, the administrative Council of the Bar Association may prescribe additional insurance or guarantee fund in order to cover

establishment (Article 55 does the same for the freedom to provide services). On the subject see Craig \& de Burca (2007), pp. 764-770. At this point, it must also be mentioned that the application of this stricter regime, i.e., excluding free movement by upholding a nationality requirement, is not static. Recently the European Commission has initiated legal proceedings on the basis of Article 226 EC against 16 Member States that apply the Article 45 EC exception to the profession of notary. See Press Release IP/06/1385, 12 October 2006, via <europa.eu.>, last accessed 1 June 2007.

1215 Cases C-193/05, Commission of the European Communities v. Grand-Duchy of Luxembourg, [2006] ECR, I-08673 and C-506/04, Graham J. Wilson v. Ordre des avocats du barreau de Luxembourg, [2006] ECR, I-08613.

1216 Article 8(1) Presidential Decree.

1217 Article 8(2) Presidential Decree. 
the elements that are not covered by the insurance or guarantee fund in the home Member State. ${ }^{1218}$ The lawyer who is established under his home country professional title in Greece must also obtain obligatory membership to the lawyer's fund, mutual assistance insurance for lawyers, and health insurance for lawyers. ${ }^{1219}$ It is interesting to note the casual way in which these obligations are entered at the end of the Article, which happens to be almost a literal translation of Article 6 of Directive 98/5/EC, without there being any basis in the Directive for any of these obligations. It might well be the case that these obligations can be construed as restrictions to the free movement of persons for certain individuals, and therefore may need to be objectively justified in such cases in order to avoid a violation of the rules regarding the free movement of persons.

The first paragraph of Article 9 states that a lawyer who does not exercise his professional activities according to the professional rules of conduct in force in Greece shall be considered to have committed a disciplinary fault. To this disciplinary fault, the rules in the Kodex Dikigoron concerning disciplinary proceedings shall be applicable. The competent authority shall be the disciplinary Council of the Bar Association with which the lawyer is registered. ${ }^{1220}$ Before disciplinary proceedings are initiated, and throughout the course of the disciplinary proceedings, the competent authority of the host Member State is required to cooperate with the competent authority of the home Member State. To that end, the Greek competent authority shall inform the competent authority of the home Member State without delay and in a confidential matter of the intention to open proceedings, and during proceedings it shall inform the competent authority of the home Member State of all the relevant details in connection to the case. ${ }^{1221}$ Where the competent authority of the home Member State, either temporarily or permanently, revokes the right of a lawyer who is established under his home country title in Greece to practise in his home Member State, then his right to practise in Greece shall also be automatically revoked. Within a month of receiving a sanction notification imposed on the lawyer in his home Member State and the relevant file on the lawyer, the president of the Bar Association concerned shall transmit the decision to the disciplinary Council of the Bar Association, which shall publish the decision and therewith impose the sanction on the lawyer established in Greece. ${ }^{1222}$

In principle, a lawyer who is established under his home country title may exercise his professional activity in a salaried manner. To that end he may be employed with a public or a private legal entity, a public or a private undertaking, or an association of lawyers (subject to the provisions regarding practice in association dealt with later on). It must be mentioned that the right to practise in a salaried capacity is not unconditional. Respect must be paid to the rules regarding incompatibilities as they are laid down in the Kodex Dikigoron. ${ }^{1223}$ Clearly this rule is in accordance with Article 8 of Directive 98/5/EC since it merely secures equal treatment between

\footnotetext{
1218 Article 8(3) Presidential Decree.

1219 Article 8(4) Presidential Decree.

1220 Article 9(1) Presidential Decree.

1221 Article 9(2) Presidential Decree.

1222 Article 9(3) Presidential Decree.

1223 Article 10 Presidential Decree.
} 
lawyers established in the host Member State and lawyers established in the host Member State under their home country professional title.

Article 11 of the Presidential Decree governs the integration of lawyers who are established under their home country professional title in Greece into the profession of the Dikigoros without having to take the aptitude test provided for in Directive 89/48/EEC. Subparagraph 1 provides that a lawyer who is established under his home country professional title may, after a regular and effective exercise of activities for a minimum of three years in Greek law, including Community law, integrate into the profession of the Dikigoros. In order to effectuate that integration the lawyer must send an application to the Bar Association where he is registered. He must accompany the application with documents establishing that he has exercised the relevant professional activity in connection with Greek law, for the required period of time. These are, for example, copies of cases dealt with, contracts, various judicial acts, official reports of the meetings of administrative authorities, and a certificate of salaries paid. ${ }^{1224}$ The Council of the Bar Association will decide upon the request based on a report concerning the request that is drawn up by one of its members. Where necessary the Council may request the lawyer concerned to give more details, orally or in writing, concerning the documents submitted. In conformity with Article 10 of the Directive, it is stated that effective and regular pursuit of activities means the pursuit without interruptions other than those arising from the events of everyday life. ${ }^{1225}$

In cases where the lawyer has been active in Greece for a minimum period of three years, but where his experience with regard to Greek law is less than three years, he may still integrate into the profession of the Dikigoros. He may affect that integration if he has successfully participated in courses or seminars about Greek law, including professional law and rules regarding deontology. Additionally, he must have detailed knowledge of and professional experience in Greek law. ${ }^{1226}$ It must be noted that this is a very loose interpretation of the rules laid down in Article 10(3) of Directive 98/5/EC. The Directive speaks about taking into account courses, seminars, knowledge and professional experience, but states at no point that courses or seminars are necessary in order to integrate into the host Member State's profession. In other words, where somebody acquires enough knowledge without taking courses or seminars, he should still be eligible to be integrated into the legal profession of the host Member State. The way in which the Greek implementation of this article is formulated, however, implies that following courses is, either way, obligatory. If the Greek authorities maintain that point of view, it will be in violation of the Directive.

In order to be integrated into the Greek legal profession without at least three years experience in Greek law, the lawyer concerned would be invited by the administrative Council of the respective Bar Association for an interview. The objective is to verify whether or not the lawyer fulfils the criteria mentioned above, and whether or not the lawyer concerned is able to continue the pursuit of the activities. ${ }^{1227}$ The decision of the administrative Council of the Bar Association can exempt the lawyer

1224 Article 11(1) Presidential Decree.

1225 Article 11(2) Presidential Decree.

1226 Article 11(3) Presidential Decree.

1227 Ibid. 
from taking the aptitude test as prescribed by the Greek implementation of Directive 89/48/EEC. ${ }^{1228}$ A lawyer who is established under his home country professional title may, at any point in time, opt for the possibility to take the aptitude test in order to integrate in the Greek legal profession. ${ }^{1229}$

Subsection 6 of Article 11 of the Presidential Decree states that a decision taken by the Bar Association not to integrate a lawyer who is established under his home Member State in the profession of the Dikigoros shall include a statement of the reasons, and judicial recourse must be made available. Such a decision can be taken if the administrative Council of the Bar Association is of the opinion that the admission of the lawyer concerned in the profession of the Dikigoros would be against public policy, in particular because of disciplinary proceedings, complaints or incidents of any kind taken again him. ${ }^{1230}$ A lawyer whose request has been refused has the right to submit a new request for integration. ${ }^{1231}$ The officials of the Bar Association who deal with an application to be integrated in the legal profession shall assure the confidential treatment of any information provided by the lawyer. ${ }^{1232}$

As mentioned above, in the paragraph concerning the profession of the Dikigoros, a Dikigoros can only qualify to practise before higher courts through seniority. This is solved, rather creatively, for lawyers established under their home country professional title, who integrate in the profession of Dikigoros. Subsection 9 of Article 11 of the Presidential Decree states that a lawyer who is integrated into the profession of the Dikigoros through the means of Article 11 of the Presidential Decree shall in principle be authorised to practise only before courts of first instance. If, however, a lawyer can prove that he or she has been professionally active for a period of more than four years, taking into account professional activity exercised in the lawyer's home Member State, the administrative Council of the Bar Association can also allow him or her to practise before the Court of Appeal. If the lawyer can prove that he has been exercising professional activities for over eight years, he can be allowed to practise before the Court of Cassation. This is an interesting development, which is a more liberal approach than what is prescribed by the Directive, even amounting to something that is similar to reverse discrimination. Lawyers from other Member States may include experience gathered even before they were integrated into the profession of the Dikigoros. Looking at the requirements indicated above, it would be most likely that a lawyer from another Member State who integrates into the profession of the Dikigoros shall at least be eligible to practise before the Court of Appeal. ${ }^{1233}$ Lastly, Article 11 of the Presidential Decree states that a lawyer who is integrated into the profession of the Dikigoros still has the right to use his original professional title alongside the title of Dikigoros, while exercising professional activities in Greece. ${ }^{1234}$ As of 2006, six lawyers had integrated into the profession of the Dikigoros. ${ }^{1235}$

\footnotetext{
1228 Article 11(4) Presidential Decree.

1229 Article 11(5) Presidential Decree.

1230 Article 11(6) Presidential Decree.

1231 Article 11(8) Presidential Decree.

1232 Article 11(7) Presidential Decree.

1233 Article 11(9) Presidential Decree.

1234 Article 11(10) Presidential Decree.

1235 <www.ccbe.org>, last accessed 11 June 2007.
} 
Articles 12 to 14 of the Presidential Decree govern the different modalities in which lawyers can practise in association in Greece. The first paragraph of Article 12 of the Presidential Decree states that one or more lawyers who are established in Greece under their home country professional title, and who belong to the same grouping in their home Member State, may exercise their professional activities as a branch or agency of that grouping. ${ }^{1236}$ To that end, the lawyers who want to exercise their profession in the form of a grouping must send a request to the Bar Association where they are established. That request must be accompanied by the statutes of the grouping, which is to be signed by all the members of the grouping who seek to establish themselves in Greece, and authorised by the competent authority of the home Member State. ${ }^{1237}$ The request must also be accompanied by a document which identifies the manager and the deputy-manager of the branch or agency of the grouping. ${ }^{1238}$ The decision to authorise the opening of a branch or agency shall be taken by the administrative Council of the Bar Association concerned, upon the proposition of one of the members of the proposed grouping. The administrative Council of the Bar Association shall verify the statutes and check their conformity with the Presidential Decree, the Kodex Dikigoron, the deontological rules and all the other rules governing the legal profession in Greece. The statutes of the grouping, and therewith apparently the request to open a branch, may be refused in situations where the grouping has been operational for less than three years, or where the capital is held entirely or partly by, where the name is used, or where the decision making power lies, either in law or in fact, with persons who are not part of one of the legal professions mentioned in Article 2 of the Presidential Decree. ${ }^{1239}$ In other words, Multi-Disciplinary Partnerships are prohibited in Greece. However, refusal on the grounds that a grouping has been operational for less than three years is in violation of the Directive. There is no authority in the Directive for excluding groupings that have been in operation for a certain period. On top of that, it is a rule that is inherently discriminatory since the rule can never be applied to Greek groupings, which are recognised from their moment of inception.

Section 5 of Article 12 states that the authorisation for lawyers established under their home country professional title to practise in a grouping is subject to the restrictions laid down in the Presidential Decree governing practice in association in Greece. ${ }^{1240}$ Here, again, the Greek authorities violate Article 11 of the Directive. The

1236 Article 12(1) Presidential Decree.

1237 Article 12(2) Presidential Decree. The statutes must contain information with regard to the name, denomination and seat of the group, the names and addresses of all the members, the conditions of accession, withdrawal and exclusion of members, contributions of the members (including fluctuations), rights and obligations of the members, forms of administration and decisionmaking in the group, the distribution of profits and loss, the duration of the functioning of the group and the reasons for dissolution of the group and the liquidation of the group following its dissolution. Lawyers established in the Bar of Athens or Piraeus send their request to the Bar Association of the region where they plan to seat their branch or agency. Although Article 11 of Directive 98/5/EC does not say anything about documentation that must be provided, some might well be necessary, and therefore implicitly allowed by the Directive, in order to ascertain whether the fundamental rules governing the grouping in the home Member State coincide with those in Greece.

1238 Article 12(3) Presidential Decree.

1239 Article 12(4) Presidential Decree.

1240 Article 12(5) Presidential Decree. 
Directive states that the fundamental rules governing a grouping in the host Member State shall only prevail when the fundamental rules of the host and the home Member State are incompatible, and where the application of the host Member State's rules is objectively justified in light of the public interest in protecting clients and third parties. Application of host Member State rules to a branch or an agency of a grouping of lawyers from another Member State is by no means an automatic process. If a decision is taken not to allow the opening of a branch or agency in Greece, it shall be reasoned and the lawyers who sought to open a branch or agency shall have judicial recourse before the Greek Council of State. They must seek this recourse within a period of 60 days. ${ }^{1241}$

Section 7 of Article 12 states that the means of publication of the authorisation to open a branch or agency, the dissolution of such a branch or agency, and the entry into force of the legal personality of that branch or agency, are regulated by the Presidential Decree governing practice in association in Greece. ${ }^{1242}$ The comments made with regard to Section 5 can also be extended to this section: Directive 98/5/EC does not sanction an automatic application of the host Member State's professional rules governing practice in association. The rules mentioned above are also applicable to situations where the statutes of the grouping are changed. ${ }^{1243} \mathrm{With}$ regard to this rule, it must be mentioned that its application is only allowed where it would fall within the situation described in Article 11 of Directive 98/5/EC, i.e., in order to ascertain whether the change in the statutes creates an incompatibility between the host and home Member State's rules. ${ }^{1244}$

Lastly, and completely in line with the previous sections, Section 9 of Article 12 states that the functioning of the branch or agency in Greece - in terms of the obligations imposed on members, the legal personality of the group, the administration, representation and policy of the group, the accession, withdrawal and exclusion of members, the decision-making process, the distribution of profits and loss, the relationship with clients, the dissolution and liquidation of the group as well as the book-keeping - shall be governed by the Presidential Decree governing practice in association in Greece. ${ }^{1245}$ Once again it must be indicated that the rules governing practice in association in Greece are not automatically applicable to branches or agencies of groupings from other Member States established in Greece. Section 9 of Article 12 therefore violates Directive 98/5/EC.

Article 13 Section 1 states that two or more lawyers from the same group or from the same Member State shall have the right to create a new grouping under the rules laid down in the Presidential Decree governing practice in association in Greece. ${ }^{1246}$ In Section 2 that rule is extended to lawyers who come from different Member States and those from Greece. ${ }^{1247} \mathrm{~A}$ lawyer who is a member of a grouping in his

\footnotetext{
1241 Article 12(6) Presidential Decree.

1242 Article 12(7) Presidential Decree.

1243 Article 12(8) Presidential Decree.

1244 This is however hardly imaginable, since the Directive mentiones fundamental rules governing groupings. It is unlikely that changes in the statutes of one grouping affect the fundamental rules in force in the home Member State. It is, however, a different story where statutes are modified due to changes in the fundamental rules in force in the home Member State.

1245 Article 12(9) Presidential Decree.

1246 Article 13(1) Presidential Decree.

1247 Article 13(2) Presidential Decree.
} 
home Member State must, at all times, both during the period of approval of the new group and during its functioning, provide the competent authorities in Greece with all the relevant information in connection with the grouping of which he is a member in his home Member State. To that end, the lawyer concerned must produce the statutes of the group he belongs to, authorised by the competent authority of the home Member State. ${ }^{1248}$ Section 4 states that approval of the constitution of an association of lawyers can be withheld, or approval already given can be revoked, if in the home Member State that group is regarded as a Multi-Disciplinary Partnership (i.e., where the capital is held entirely or partly, the name of the grouping is used, or the decision making power is (in law or in fact) exercised by, persons who are not a part of one of the legal professions mentioned in Article 2 of the Presidential Decree). ${ }^{1249}$ Lawyers who are members of a group in their home Member State shall, in any event, have the right to practise individually in Greece. ${ }^{1250}$

Article 14 states that lawyers who are established under their home country professional title in Greece, and who are members of a group in their home Member State, may use the name of that group while pursuing professional activities in Greece. In addition, the lawyer concerned may be required to mention the legal form of the group and the names of the other members of the group who pursue professional activities in Greece. The Presidential Decree governing practice in association in Greece shall govern any other eventualities with regard to the formation and the denomination of the group. ${ }^{1251}$ It is not completely clear what is meant exactly by this last sentence, but it may be a reference to the application of Greek professional rules on branches and agencies of groups from other Member States, a practice that was established as violating Directive 98/5/EC.

Article 15 of the Presidential Decree lays down a general duty of cooperation between the competent authorities of the home and host Member States. Greek Bar Associations can request any information from lawyers established under their home country professional title in Greece. On the other hand, the competent authorities of the home Member State may also request information from the Greek Bar Associations. Any decisions taken by the Greek Bar Associations shall also be communicated to the Minister of Justice. ${ }^{1252}$

\section{$\int 4.4$ Observations and Conclusions in Connection with Establishment under Home Title}

Although, chronologically, it was the last modality of the free movement of lawyers to be realised, doctrinally the establishment of lawyers under home title represents the middle phase of the three modalities of free movement of lawyers observed. It is more intensive than the free movement of services, yet less intensive than the direct integration into the host legal profession based on the Diploma Directive.

\footnotetext{
1248 Article 13(3) Presidential Decree.

1249 Article 13(4) Presidential Decree.

1250 Article 13(5) Presidential Decree.

1251 Article 14 Presidential Decree.

1252 Article 15 Presidential Decree.
} 
For persons who are not fully qualified lawyers but who nevertheless exercise legal activities in a Member State with a lesser degree of regulation than their own, it has been observed that the Establishment Directive does not cover the situation where these persons choose to establish themselves in a Member State that reserves the activities of their choice for fully qualified lawyers. The more recent Directives that were observed in light of the free movement of services do not cover this situation either. This means that these persons can only rely on the rules laid down in the case law of the European Court of Justice, notably in the Gebhard case. ${ }^{1253}$ As more extensive protection is available in the free provision of services, it might well be the case that these persons resort to a method of exercising their professional activity in a manner reminiscent of the installation limitée that was observed in circumstances where lawyers sought to establish themselves under home country professional title before the Establishment Directive was created. Such a situation is undesirable for both clients and for these professionals. It would therefore be better if it was established, either through case law or through secondary legislation, that the mutual recognition rule also applies in these circumstances.

The Establishment Directive was implemented in all fifteen Member States under review. In the part preceding the review of its implementation, a threefold division of violations was presented. Now it is time to divide the violations identified along the lines of this threefold division. After that, a more general assessment of the impact of Directive $98 / 5 / \mathrm{EC}$ will be given.

\section{Restrictions Where Residual Legislative Competence is Precluded: Violations per se}

The European Court of Justice established in Commission v. Luxembourg and in the Wilson case, that Articles 3 and 5 of Directive 98/5/EC lead to complete harmonisation, i.e., they preclude Member States from imposing further requirements than those listed in these articles. It has been asserted that this rule can be applied to the entire Directive. Therefore, it may not be surprising that the majority of infringements identified fall into this category.

The majority of violations have been identified as to pertaining to Article 3 (registration) and Article 5 (professional activity). With regard to all the registration violations that have been observed in the different Member States, the most obvious violations of this article have been in connection with the requirement to repeat the production of the certificate mentioned in Article 3, i.e., lawyers are required to produce such a certificate on an annual basis. This method is used in Luxembourg, Germany and Italy, and was dealt with in the case law described above. Luxembourg and Italy have also violated Article 3 on other grounds. Italy has imposed a residence requirement that is already deemed to be against the freedom of establishment on the basis of earlier case law, ${ }^{1254}$ whilst Luxembourg imposes a language assessment

1253 Or more special rules that may be applicable, e.g., Vlassopoulou for restrictions based on the recognition of professional qualifications.

1254 Case 107/83, Ordre des Avocats au Barreau de Paris v. Klopp [1984] ECR 2971 and Case C145/99 Commission of the European Community v. Italian Republic, ECR[2002] I-02235. 
for lawyers who seek establishment under home title, a requirement that was also assessed by the European Court of Justice in the cases against Luxembourg. ${ }^{1255}$

Other violations of Article 3 have been identified in other Member States. Sweden authorises investigations into whether the lawyer who seeks registration under his home title is 'suitable to practise' as a lawyer in Sweden. Greece requires examination of criminal records, also a violation of the principle of mutual recognition and the provision of Article 3. Spain has a more subtle approach. The Spanish implementation allows competent authorities in Spain to ask for any other document that may be deemed necessary by the competent authority in order to process the request for registration. This is also not sanctioned by Article 3 of the Directive. Lastly, both Spain and Ireland demand fees for registration in the implementation mechanism. The Directive itself does not mention anything with regard to fees so it must be assessed whether Member States are allowed to ask for fees for services provided under the Directive. This assessment will take place later on in this paragraph. For now it is sufficient to state that, where the payment of fees is a condition for registration, as this is not sanctioned on the basis of Article 3 it is therefore in violation of the Directive.

Also in connection with the rules regarding the exercise of professional activities in the host Member State, a number of violations have been identified. Austria places two illegal limitations on the professional activities of a lawyer who is established under his home country professional title in Austria. First, such a lawyer is not allowed to educate prospective Austrian lawyers (Rechtsanwaltanwärter). This limitation is not sanctioned by Directive 98/5/EC and is therefore illegal. ${ }^{1256}$ In addition, Austria denies lawyers established under their home country professional title to participate in a legal aid scheme. In addition to that, it is also mentioned that lawyers established under their home title shall not receive compensation if they

1255 Case C-193/05, Commission of the European Communities v. Grand-Duchy of Luxembourg, [2006] ECR I-08673.

1256 On the other hand, it is of course clear that such a limitation is not without reason. It seems logical that those who seek to become Austrian Rechtsanwalten are trained by a Rechtsanwalt and not by a lawyer from another Member State who is established under his home country professional title in Austria. It can also be assumed that, in the legislative process that led to the adoption of Directive 98/5/EC, the legislative Institutions did not realise that education of prospective lawyers is also an integral part of all of the legal professions covered by the Directive. All those reasons, however, do not justify the fact that this limitation is in violation of the Directive. The situation could have been made less obvious if the limitation had not been put in negative terms in the major implementation of the Directive, but rather if it was put in the rules regarding training of prospective Austrian lawyers that such training should be conducted by a Rechtsanwalt. Analogous interpretation of Article 5 would then still lead to the conclusion that a lawyer established under his home title could exercise this activity and a prohibition of the Member State concerned for him to do so would still be a violation of the Directive, but it would be less obvious. I also think it is safe to assume that Austria is not alone in its attitude towards this situation and I would be surprised if the Dutch authorities, for example, would allow a lawyer established under his home title to act as a patroon in the education of a prospective advocaat. On the other hand, Austria has brought it upon itself, since it has chosen to implement this unsanctioned limitation to Article 5 in such clear terms. However, even in the terms in which it is worded, I believe that the Commission would never initiate proceedings with regard to this violation. 
participate in a legal aid scheme. ${ }^{1257}$ These limitations are not sanctioned by the Directive and are therefore illegal.

Luxembourg also violates Article 5 of the Directive. Luxembourg disallows lawyers who are established in Luxembourg under their home country professional title from acting as professional domiciles for firms, where lawyers who are established under the Luxembourg professional title are allowed to act as professional domiciles. This exception was specifically dealt with by the European Court of Justice in the cases described above. ${ }^{1258}$ Lastly, Greece withholds some activities from lawyers who are established under their home country title in Greece if they do not have Greek nationality. In the relevant part on Greece, I indicated that there is probably some justification in Article 45 of the EC Treaty for excluding these persons from some activities, but that would mean that the Directive violates Article 45 of the Treaty. The only entity which can establish such a situation and act upon it is the European Court of Justice. Until the European Court of Justice has ruled in this field, the Greek implementation of Article 5, where it exempts certain non-nationals who are established under their home country professional title from certain activities, must be deemed as illegal.

Violations of other articles in the Directive are scarce. With regard to the participation of lawyers in elections of the representative bodies of the profession in the host Member State, as laid down in Article 6, it must be mentioned that nine out of the fifteen countries reviewed have no provisions about voting rights in their primary implementation mechanisms. ${ }^{1259}$ It might of course be the case that this matter is dealt with on a lower administrative level, or even on a level of the professional associations themselves. However, if it turns out that lawyers established under their home country professional title do not have the right to vote in the elections of the relevant associations' professional bodies, such will constitute a violation of the Directive.

Additionally, Greece violates the Directive by requiring lawyers to take out obligatory membership of the Greek lawyers' fund, the Greek mutual assistance fund for lawyers, and also Greek health insurance. In my opinion, obligatory membership of these organisations cannot be caught under the provisions of paragraph 3 of Article 6 of the Directive. If paragraph 3 of Article 6 must be read in a restrictive manner (which in my opinion it should be) then Member States can only request there to be indemnity insurance or membership of a guarantee fund. Since Greece also requires professional indemnity insurance then it cannot, in addition to that, require membership of other professional funds or insurances.

With respect to Article 9 (legal remedies), no violations have been observed while researching the implementation of Directive 98/5/EC in the Member States reviewed, although it was established in the Wilson case that the appellate system in

1257 Which is a contradiction in terms after stating that lawyers established under their home country professional title are not allowed to participate in a legal aid scheme.

1258 Case C-193/05, Commission of the European Communities v. Grand-Duchy of Luxembourg, [2006] ECR I-08673. Luxembourg failed to act after this case, which is now the subject of an Article 228 procedure. See European Commission Press Release IP/07/358, via <europa.eu>, last accessed 12 June 2007.

1259 United Kingdom; Austria; Denmark; Sweden; the Netherlands; Belgium; Italy; Portugal and Ireland. 
Luxembourg was in violation of the Directive. If that were to mean that any intraprofession appellate system is in violation of the Directive, the United Kingdom at least and potentially many more Member States are in violation of the Directive.

Although the majority of the Member States have successfully implemented Article 10 of the Directive (integration in the host Member State profession), irregularities were observed in different Member States. Both France and Portugal have failed to implement the rather detailed procedure laid down for lawyers who have been active for at least three years (but for a lesser period in the law of the host Member State, including Community law) and have replaced that detailed procedure with very general procedures that are potentially illegal if competent authorities do not apply the procedure provided for in Article 10(3). The Greek implementation of Article 10(3) is even worse since, according to the implementation, it is obligatory for lawyers in the above situations to take courses and seminars on Greek law, whereas Article 10(3) only states that experience gained through courses and seminars will be taken into account.

Spain delegated the formulation of the exact criteria for the integration of lawyers in the Spanish legal profession to the individual Colegios, a situation that could potentially lead to practices that are contrary to the Directive. In Italy, the decision of the competent authority to integrate a lawyer into the Italian legal profession must be reviewed by the public prosecutor and the respective Court of Appeal, a requirement that cannot be reconciled with the procedure laid down in Article 10 of Directive 98/5/EC.

The rather difficult drafting of Article 11 (joint practice) of the Directive has led to considerable problems in the Member States. The violation observed, in all but two of the Member States, is the need to objectively justify application of the host Member State's professional rules with regard to branch offices and agencies. Member States either completely ignore the requirement of Article 11(1) or, even worse, they explicitly state that their own professional rules shall apply. This violation contributes to the fact that Article 11 has not fulfilled its revolutionary potential, which is to be discussed below. With regard to the other articles of the Directive, no violations were found.

\section{Restrictions that Frustrate the Full Working of the Directive: Violations per se}

This category of restrictions was created through analogous interpretation of the $A M O K$ case that accepted this category of restrictions for the Services Directive. It has been argued that nothing precludes the extension of this category of restrictions in order to cover any restriction that flows from the implementation of the Establishment Directive. With regard to this category two restrictions must be mentioned.

First, the most flagrant violation that has been observed must be mentioned here. It was observed that the Netherlands only awards integration into the profession of the advocaat on the basis of Article 10 of Directive 98/5/EC, where the legal monopoly in civil cases is awarded to the profession of the procureur, an old profession that is joined with the profession of the advocaat. ${ }^{1260}$ According to the Nether-

1260 Every domestic advocaat is sworn in simultaneously as an advocaat and a procureur. Lawyers who seek integration through the diploma directive are also admitted to both professions. 
lands, integration into the profession of the procureur without objective assessment of the candidate's knowledge in civil procedural law through an aptitude test is 'undesirable'. ${ }^{1261}$ The Establishment Directive does not apply exactly to the letter to the profession of the procureur but exclusion from this profession undoubtedly leads to a frustration of the full working of the Directive, since every Dutch advocaat (and every advocaat who is integrated on the basis of the Diploma Directive for that matter) is sworn in as an advocaat and procureur. It is clear that the reason behind the exploitation of this 'hidden' division in the profession of the advocaat is none other than to frustrate the full working of the Establishment Directive. Although the Netherlands deserves to be dealt with by the European Court of Justice on this matter, this is unlikely to happen since the abolition of the profession of the procureur is envisaged for September 2008, after which the problem will resolve itself. It does, however, show the completely irrational xenophobia that the Dutch Bar Association seems to have with regard to the free establishment of lawyers, that would be expected rather from a country like Luxembourg.

The other case that must be mentioned here is much more subtle, but potentially just as devastating. Spain imposes a rule under which lawyers who are established under their home country professional title may not appear on a list of lawyers available for defending clients. If this rule could be caught under one of the articles in the Directive, most notably Article 5, then it would be illegal per se since it is a limitation not sanctioned by the Directive. This is not a clear-cut case, however, because as such the rule does not limit the activity but rather only reduces the likelihood that the lawyer will actually be exercising the professional activity. It must therefore be assumed that this rule, although not directly in violation of the Directive, does indeed frustrate its full working, and is therefore illegal.

\section{Other restrictions: Objective Justifications}

The last category of possible restrictions is the residual category caught by rules laid down in case law such as Vlassopoulou and Gebhard. The rules that apply to these restrictions assume they such restrictions are illegal unless they can be objectively justified. None of these restrictions have been observed in the reviews of implementation in the fifteen Member States concerned. Restrictions that were identified either fell within the first or second category. The only observed restriction that has not yet been (completely) classified is the matter concerning payment of fees for registration or membership to the Bar Association of the host Member State. It has been asserted that where the payment of fees is presented as a condition for registration this is in violation of Article 3 of the Directive. This is because Article 3 seeks full harmonisation, and such provisions are therefore illegal per se. The question

1261 This argument fails on two important points. First: the legal monopoly for lawyers in the Netherlands in the field of criminal law lies with the profession of advocaat. No lawyer in the Netherlands will assert that criminal procedural law is less complicated than civil procedural law. So the argument that procedural law is too complicated fails. Secondly, the Dutch Bar Association seems to assume that an aptitude test can be imposed automatically. This is not true. It must first be assessed whether a person has the knowledge necessary. From an integrated advocaat that may be expected (all the more so because the aptitude tests for both professions are identical). An integrated advocaat who wants to become a procureur can do so without an aptitude test. 
of what is to happen with fees payable which are not a condition for registration is still unresolved. One could assume that the imposition of a fee by a Member States is a restriction (since it is liable to hinder free movement or make it less attractive) that needs to be objectively justified. That approach, however, would be too superficial. It is not the fact that membership fees must be paid in the host Member State $^{1262}$ that leads to the extra burden, but the fact that these fees must be paid on top that fees that are already paid in the home Member State. That is undoubtedly likely to occur because membership of the home State's Bar is necessary for application of the Establishment Directive. It is therefore not the Member State that causes the restriction but the Directive itself.

On the basis of this reasoning it must be assumed that there is a fourth category of restrictions, namely restrictions flowing from the Directive itself and which must therefore be accepted. Aside from the membership fees, or even the continued membership of the home Bar itself, there are also rules in connection with continued education which could potentially be problematic (if continued education was imposed in both home and host Member State). This situation has however been identified by the CCBE and included in its guidelines on implementation, stating that only the host Member State's scheme of continued education will apply. ${ }^{1263}$ See page 241 for the graphical representation of the possible restrictions.

\section{Impact of Directive 98/5/EC on the Free Movement of Lawyers}

The main point of criticism in connection with the rules governing the free movement of lawyers before Directive $98 / 5 /$ EC was the fact that the system of Directive 89/48/EEC left considerable discretionary powers to the Member States. Although candidates seeking integration into the legal profession of a host Member State had (and still have) the right to have their professional qualifications and experience reviewed individually, the nature of the legal professions in the Member State (i.e., the focus on the national legal system in the qualification track for the legal professions) will almost always lead to a situation where the prospective candidate would be obliged to take an aptitude test as a compensating measure under the system of Directive 89/48/EEC. It was established in an earlier part of this book that the contents of the aptitude test are at the discretion of the Member States, and that more often than not it is very hard for lawyers to successfully complete an aptitude test. In one instance, it was established by the European Court of Justice that the Italian requirements for the aptitude test were in fact more rigorous than the requirements imposed on prospective lawyers who studied law in Italy. ${ }^{1264}$

1262 It would be hard, if not impossible, to construe this as a restriction. See, for example, C-190/98, Graf v. Filzmoser Maschinenbau [2000] ECR I-493. See also: Guidelines for the Implementation of Directive 98/5/EC via <www.ccbe.org>, last accessed 12 June 2007 which state: 'All lawyers registering under Article 3 of the Directive shall pay a registration fee or fees (which term includes either a one-off or a regular payment) to the relevant competent authority (as defined under Article 1.2(f) of the Directive), and to such other authorities as may be required under local rules. Such fee or fees may be equivalent to, but not higher than, the fee or fees charged to lawyers enrolled in the host Member State.'

1263 Guidelines for the Implementation of Directive 98/5/EC via <www.ccbe.org>, last accessed 12 June 2007.

1264 Case C-145/99 Commission of the European Community v. Italian Republic, ECR[2002] I-02235. 
Restrictions imposed on articles of the Directive that preclude residual legislative power of the Member States are prohibited per se.

Based on Wilson and Commission v. Luxembourg it has been assumed that this is the case for Directive 98/5/EC.

Restrictions imposed on matters where legislative power of the Member States is not precluded because it is not covered by the Directive concerned but where the full working of the Directive is frustrated are prohibited per se ( $A M O K$ case).

Restrictions imposed on matters where legislative power of Member States is not precluded that do not frustrate the full working of the Directive are prohibited unless objectively justified. (Gebhard case).

Specific rules for specific situations may apply (e.g. Vlassopoulou for diplomas).

Restrictions that flow from the Directive itself: these restrictions are lawful. 
In that sense Directive 98/5/EC has brought about many positive changes. First of all, the rules for practice under home title have been harmonised between Member States. Before the Directive came into force, only Member States with a lesser degree of regulation allowed lawyers to exercise professional activities under their home country professional title in that Member State. However, after the implementation of Directive 98/5/EC, every lawyer who was established in one of the Member States of the European Union was allowed to establish himself, in a permanent fashion, in another Member State of his choice under his home country professional title, without any further requirements other than registration with the designated competent authority in that Member State. This harmonisation has provided for smooth access for lawyers wishing to establish themselves in the host Member State.

A second, and more important, advantage of the system after the implementation of Directive 98/5/EC, as compared with the system before the Directive's implementation, is the fact that lawyers who are established under their home country professional title are allowed to exercise professional activities in the law of the host Member State. This was a new rule even for countries that allowed practice under home country professional title, since lawyers who were established under their home country professional title in these Member States were allowed to exercise professional activities that did not encroach upon the legal monopoly of the legal profession of the host Member State. After implementation of the Directive, members of the legal profession of the host Member State were forced to share their legal monopoly with their colleagues from other Member States. This rule has offered lawyers established under their home country professional title the chance to actually deal with the law of the host Member State in a 'hands on' fashion rather than to study the law of the host Member State in preparation for an aptitude test. In my opinion, this method of familiarising oneself with the law of the host Member States offers better preparation for integration into the legal profession of the host Member State than the much more theoretical approach that is used in preparation for an aptitude test. It must be said that the implementation of Article 5 of the Directive, which actually guarantees lawyers established under their home country professional title the right to practise in the host Member State, has been correctly implemented by the majority of the Member States, and only Austria, Greece and Luxembourg have incorrectly implemented this article. The violations in Luxembourg were severe enough for the European Commission to initiate proceedings before the European Court of Justice to have Luxembourg convicted on the basis of Article 226 of the EC Treaty. The European Court of Justice did so in Commission v. Luxembourg.

The third and final change that was brought about by the implementation of Directive 98/5/EC was the fact that registration under home title could, after a certain amount of time, be transferred into accession to the legal profession of the host Member State outside the regime of Directive 89/48/EEC. This is possibly the greatest benefit to the system of free movement of lawyers. After having been allowed to work in their home Member State, in the profession of other Member States, and after having been allowed to exercise the same professional activities as members of the legal profession of the host Member State while being established under their home country professional title, Directive 98/5/EC finally allows lawyers to integrate into the legal profession of the host Member State without having to 
take an aptitude test under the regime of Directive 89/48/EEC. Even more so, lawyers who have been established under their home country professional title in the host Member State and who fulfil the criteria laid down in Article 10 of the Directive may integrate into the legal profession of the host Member State without any test whatsoever. The only discretionary power that is left for the Member States is the power to ascertain whether the criteria of the Article are fulfilled. ${ }^{1265}$ In assessing the implementation of Directive 98/5/EC it must be concluded that this single feature of the Directive is the single most important one, since it should make the integration of lawyers into the legal profession of the host Member State much easier than it was under Directive 89/48/EEC. Combined with the two other changes described above - i.e., the right to be established under one's home country professional title in another Member State and the right to exercise professional activities that are normally reserved for the legal profession of the host Member State - the right to integrate into the legal profession of the host Member State after a given period of time provides for a fully-fledged alternative to the integration track that is provided for by Directive $89 / 48 / \mathrm{EEC}$.

When compared with one another other, it becomes clear that the integration track under Directive 98/5/EC has many more advantages than its counterpart, Directive $89 / 48 /$ EEC. First, it must be mentioned that lawyers fall within the strictest category possible within the system of Directive $89 / 48 /$ EEC. This is the case since the course of preparation for lawyers tends to focus on the legal system of the respective Member State, and therefore the competent authority may require compensatory measures. ${ }^{1266}$ In addition to that, Directive 89/48/EEC states that Member States can prescribe a form of compensatory measures when the regulated professions are concerned with national law, whilst, with regard to other professions the choice of the compensatory measure is left to the candidate. It was established above that all Member States have opted for an aptitude test in connection with the legal professions described in this book. It was also established that Member States have a broad discretion when determining the level of the aptitude test, and the level of the aptitude test should be equal to the level required from students who qualify for the legal profession in the host Member State. It was established by the European Court of Justice that an aptitude test may not require more than what is required of domestic qualifiers. In practical terms, 'taking an aptitude test' is basically comparable to completing university education in law and successfully completing the professional training that would be required for lawyers established in the host Member State. ${ }^{1267}$ Deciding to take an aptitude test is not an easy step. It involves commitment over a considerable period of time during which the lawyer is ${ }^{1268}$ not allowed (in many cases) to practise in the host Member State, or where he is allowed to

1265 That this is not as straightforward as it looks will be dealt with later on in this chapter.

1266 This will almost always be the case if the candidate has no special ties with the host Member State, i.e., where a candidate has qualified for the legal profession of the home Member State and has no further knowledge of the legal profession of the host Member State.

1267 Which is also illustrated by the fact that a considerable number of applicants fail the test, and it remains unknown how many people are actually deterred from taking the test. See Report to the European Parliament and the Council on the state of Application of the general system for the recognition of higher education diplomas, 15-02-1996, COM(96) 46 Final.

Before the entry into force of Directive 98/5/EC. 
practise in a limited capacity but not allowed to exercise the professional activities that are legally reserved for the legal profession of the host Member State.

Given that Directive 89/48/EEC was the consequence of the new strategy in the European Union towards the recognition of diplomas (which was based on the principle of mutual recognition as formulated by the European Court of Justice in the Cassis de Dijon case), it can safely be said that taking into account all the exemptions that apply to lawyers, little or nothing of that original principle of mutual recognition remains applicable for lawyers. The system of Directive 98/5/EC has much more in common with the principle of mutual recognition. The Directive is based on the pretence that lawyers who are fully qualified members of the legal profession in one of the Member States are equally competent to exercise the professional activities that are reserved for the legal profession of the host Member State. Moreover, after having exercised that professional activity for a number of years, lawyers are deemed to be competent enough to integrate into the legal profession of the host Member State without other involvement from the competent authority of the host Member State other then their requirement to verify whether the criteria listed in the Directive are fulfilled. It is obvious that this method of integration into the legal profession of the host Member State is preferable to the method provided for in Directive 89/48/EEC. It therefore seems obvious that the integration track of Directive $89 / 48 / \mathrm{EEC}$ will become less popular as time marches on, and integration via Directive $98 / 5 / \mathrm{EC}$ will become more popular until the aptitude test has become almost superfluous. ${ }^{1269}$

In my opinion, after the implementation of Directive 98/5/EC, there will be only a limited role for integration via the aptitude test in the system of free movement of lawyers. As stated above, compensatory measures, which in the case of the legal profession take the form of an aptitude test, will only be applied if it is established during an earlier assessment of the candidate's previous knowledge and experience that the application of a compensatory measure is necessary. As stated above, it seems more beneficial for lawyers who have no experience with the legal system of the host Member State to integrate into the legal profession via the track of Directive 98/5/EC rather than opting for the aptitude test provided for in Directive 89/48/ EEC. At the other end of the spectrum there are those persons who seek integration into the host Member State equipped with knowledge and experience in that Member State (through earlier experience or other ties with that Member State) and who may qualify for integration into the legal profession of the host Member State without having to take an aptitude test. Only the lawyers who seek integration into the host Member State but fall outside these two categories will be interested in taking an aptitude test. These will be lawyers who have some experience and knowledge with regard to the legal profession in the host Member State but which is unfortunately not sufficient enough to integrate him into the profession without compensatory measures, but which on the other hand, fortunately does not warrant the exercise of professional activities for a minimum period of three years under their home country professional title. This, in my opinion, will be a rather small group.

1269 Extreme criticism with regard to the phasing out (or abolition, as the author wrongly states) of the aptitude test can be found in Podell (1999), pp. 57-70. In this article Podell concludes, without any apparent foundation other than his own authority, that the aptitude test cannot be replaced with an adaptation period of only 'three' years. 
There are, of course, also points of criticism to be mentioned in connection with the system as it stands after the implementation of Directive $98 / 5 / \mathrm{EC}$. It is by no means the case that, with the implementation of Directive $98 / 5 / \mathrm{EC}$, the free movement of lawyers has created a lawyer's Utopia.

Firstly, the Directive only applies to those lawyers who are members of a profession mentioned in the Directive. It has been shown that this leads to considerable problems for professionals who are not lawyers, but who have nonetheless exercised legal activities in Member States with a lesser degree of regulation, who now seek establishment in a Member State with a higher degree of regulation. ${ }^{1270}$

Another point of criticism is that the weak, if not confusing, wording of certain articles in the Directive may lead to situations that do not benefit the free movement of lawyers. An example of this is found in Article 10 of the Directive, with regard to the integration of lawyers in the legal profession of the host Member State. As stated above, the Article mentions the fact that European Community law will be regarded as national law, i.e., that Community law should be read as being an integral part of the national law. At first sight, that would mean that theoretically a lawyer established under his home country professional title can integrate into the legal profession of the host Member State without ever dealing with national law after having regularly and effectively pursued professional activity in European Community law for a period of at least three years. ${ }^{1271}$ This extreme view is not even accepted by the European Commission. ${ }^{1272}$ Instead, it seems to be the case that a lawyer seeking integration into the host Member State's profession must have at least exercised some professional activity in the national law of the host Member State, not being European Community law. The following question is, of course, how much national law? The only thing that can be said with certainty is that a requirement to have professional experience in national law in the strict sense (i.e., without Community law) for the full three years is not in conformity with the Directive because if that were the case it would render the mention of European Community law in Article 10 of the Directive pointless. For the time being, without clear guidelines from the European Commission, and without definitive rulings by the European Court of Justice on this matter, the amount of national law required (between the two extremes mentioned above) to integrate into the legal profession of the host Member State will be determined by the competent authority of the host Member State. This gives competent authorities a considerable amount of discretion that was not actually intended by Article 10 of the Directive. The original intention was that the only function of the competent authority of the host Member State was to ascertain whether the candidate did have three years' professional experience, without giving any normative judgement on the professional experience. That situation has now changed since, in practice, the competent authority must give a normative decision on the amount of professional experience in national law in the strict sense, within the required period of professional experience in national law in the broad sense (i.e., including European Community Law). Without any further guidelines, this is a situation that could possibly be abused by a competent authority that un-

\footnotetext{
1270 See Hickman (2004).

1271 In my view this is no more than an academic possibility since even the effectuation of Community Law generally involves national courts, and therefore national law.

1272 Personal communication: E-mail to author.
} 
willing to admit foreign lawyers, or could lead to discriminatory application within one Member State or between Member States. It any sense it will lead to unwanted legal uncertainty. ${ }^{1273}$

Similar observations can be made with regard to the formulation of Article 11. The majority of the Member States have failed to implement Article 11 of Directive 98/5/ EC correctly. A possible explanation for this apparent difficulty could lie in the fact that the text of the Article (and most notably the relationship between paragraph 1 and paragraph 5 of that article) is extremely complicated. In addition it is also unclear why the system under paragraph 1 deviates from the systems in Articles 6 and 8, where the Directive provides that the rules of the host Member State shall apply to the lawyer who is established under his home country professional title. Because of the fact that many Member States have missed this subtlety in connection with the implementation of Article 11, the article has missed its potential and Member States simply impose their own rules with regard to practice in association.

Besides other, smaller problems, for example, the problems concerning fees, the legal impact of Directive $98 / 5 /$ EC seems to create a more beneficial situation for the free movement of lawyers than was the case under the old system. Directive 98/5/EC can, therefore, be classified as a significant step forward in the free movement of lawyers. Above it has been proposed that the articles of the Directive that were not subject to the rulings of the ECJ in the Wilson and Commission v. Luxembourg cases also leave little or no residual legislative competence for the Member States, so that Directive 98/5/EC in its entirety leads to full harmonisation of the rules that are covered by the Directive. If that is assumed to be the case, it is interesting to assess what sort of professions a lawyer established under the regime of Directive 98/5/EC can actually exercise. In Luxembourg $v$. European Parliament and Council it was stated by the ECJ that the profession that Article 98/5/EC lawyers exercised could be distinguished from the host Member State's profession because of the possible limitations on professional activities and the use of professional title. The profession that is exercised by a Directive 98/5/EC lawyer must also be distinguished from the home Member State profession. A Directive 98/5/EC lawyer mainly pursues the host country professional activities and is primarily subject to the host Member State's professional rules. This leads to the conclusion that if the European Court of Justice was correct in its judgment in Luxembourg v. European Parliament and Council, lawyers who are established under their home country professional title exercise a profession that is only marginally different from the host Member State's profession since it is only distinguished from that profession by its title and a very small number of limitations on professional activities that are exhaustively listed in Article 5 of the Directive. This view is corroborated by the fact that after three years of professional activity the lawyer established under his or her home country professional title may integrate into the host Member State profession without any further proficiency tests.

If this conclusion is somewhat rephrased, it may be said that Directive 98/5/EC completely harmonises the legal professions in Europe in all but name and with only very few limitations on professional activity. Full integration can be easily obtained after three years of exercising professional activity in the host Member State.

1273 See comment of the Law Society at: <www.ccbe.org/doc/En/table_number_lawyers_2004 _en.pdf $>$, last accessed 12 June 2007. 
This conclusion is corroborated by the wrong implementation of Article 11 by a majority of the Member States. Article 11 provides for an objective justification test before national professional rules can be applied but this has been reduced to a mere national treatment rule by all but two Member States, therewith bringing the 98/5/EC lawyer even closer to a domestic lawyer. Therefore, 20 years after the vertical approach was abandoned, it can be concluded that the profession of the lawyer has been completely harmonised. Moreover, this harmonisation was achieved without all the difficult negotiations and detailed legal instruments that characterised the vertical harmonisation Directives.

In order to complete the review of the application of the model, the third modality must now have its own review, although it has been established that its importance is only residual.

\section{$\int 5$. Integration into the Host Member State's Profession: Recognition of Diplomas}

Before the adoption of Directive 98/5/EC, the only way for a lawyer to become officially established in another Member State was through integration into the profession of the host Member State. This could only be avoided in those States where certain legal activities could be exercised by non-lawyers or where lawyers managed to (ab)use the provisions on the free provision of services in order to realise an installation limitée. From 1989 this modality was governed by Directive 89/48/EEC. As of 20 October 2007, Directive 89/48/EEC has been replaced by Directive $2005 / 36 / E C$. In the previous chapter it was established that this modality of the free movement of lawyers has a structure that can be represented as shown in figure 9 on the next page.

In the following paragraph a number of issues will be reviewed. Firstly, I will assess the present situation of persons who are not lawyers who exercise legal activities in Member States with a lesser degree of regulation but who seek establishment in a Member State with a higher degree of regulation. After that, a review will be given of the rules in force that relate to this modality in the fifteen Member States selected. 
Figure 9: Integration in the host Member State profession

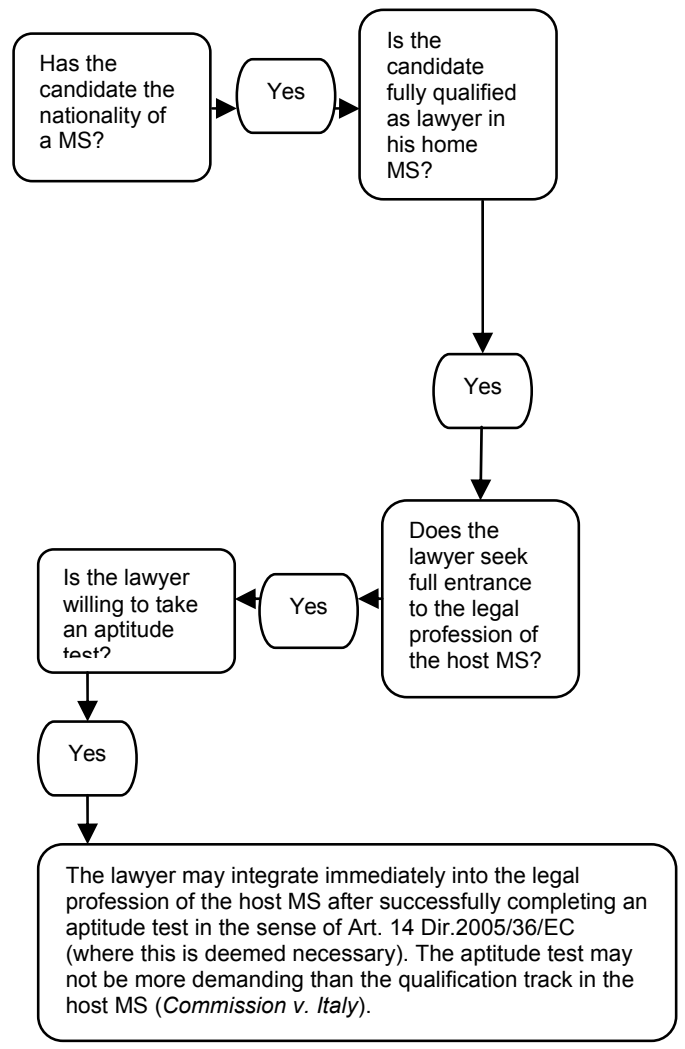

\section{5.1 Diploma Recognition for Non-Lawyers in Highly Regulated Member States}

Similar to the other two modalities, this paragraph will assess whether persons who exercise legal activities in Member States with a lesser degree of regulation may utilise this modality in order to establish themselves in a Member State where such activity is reserved for the lawyer's profession. The new Directive 2005/36/EC caters for this category in a similar manner to the old Directive $89 / 48 / \mathrm{EEC}$, and similarly to Article 5 of Directive 2005/36/EC which is applicable to the free movement of services. Article 13 of Directive 2005/36/EC states that where a candidate seeks access to a regulated profession in a Member State, and where his profession is not regulated in his home Member State, he will be allowed mutual recognition if he has exercised the profession for two years in the previous ten years in the host Member State. ${ }^{1274}$ In addition to that, the candidate must supply evidence in the form of an attestation of professional competence which is to be issued by a competent authority in the home Member State. This must establish that the candidate has a level of qualification that 
is at least equivalent to the level required in the host Member State. ${ }^{1275}$ Additionally, the attestation must prove that the candidate has been prepared for the pursuit of the profession in question. Irrespective of these rules, compensatory measures may be (and will be) imposed. ${ }^{1276}$

From this short review it becomes clear that the rules applying to the establishment of non-lawyers are not easy to fulfil. First of all, the mere right to have one's diploma recognised is qualified. Not every professional who exercises legal activities in a non-regulated manner in a Member State with a lesser degree of integration may apply for diploma recognition. Only those candidates who have a qualification level that is equal to, or one level below, the level required in the host Member State (in connection to the profession of the lawyer the level is at least one of a university education and almost always an ensuing professional education) can benefit from the rules laid down in Articles 13 and 14 of Directive 2005/36/EC. The rest cannot rely on the provisions of the Directive (although nothing precludes the application of the principles laid down in Gebhard and Vlassopoulou). Secondly, formal requirements must be fulfilled. If the non-lawyer can produce the requested attestations, integration remains by no means guaranteed. The only thing that is established at that point is the mere right to have one's qualification recognised. Nothing precludes the host Member State from imposing compensatory measures, which will be the general rule in such cases since, as was already established earlier, there are substantial differences between qualifications in the host and home Member State because of the different legal systems. Since all Member States have opted for an aptitude test it is clear that non-lawyers will be confronted with an aptitude test. This test, which will allow them to practise, will essentially be the test that is imposed on other lawyers that seek entrance into the profession of the host Member State. This might be too much for those non-lawyers who restrict their activities in their home Member State to the provision of legal advice. A non-lawyer might therefore seek a more limited entrance into the profession of the host Member State, namely limited to those activities that the non-lawyer previously exercised in his home Member State. This could be achieved by reliance upon the Caminos case ${ }^{1277}$ where the European Court of Justice accepted that the extent of integration in the host Member State's profession, and therewith the extent of the aptitude test, could be limited upon request of the candidate. In effect, application of the Caminos case would lead to the result that upon the application for integration of non-lawyers from other Member States, the host Member State would be obliged to create a sub-level of lawyers who are restricted in their activity. How this would be solved in practice (use of professional title, notification of public) is unclear. With regard to the aptitude test itself, it is clear that the rules laid down in the Commission v. Italy case ${ }^{1278}$ apply to

\footnotetext{
1275 Article 11 Directive 2005/36/EC.

1276 Article 14 Directive 2005/36/EC.

1277 Case 330/03 Colegio de Ingenieros de Caminos, Canales y Puertos, [2006] ECR I-00801. In this case the Court accepted that instead of applying compensatory measures laid down in Article 4 of the Diploma Directive, the competent authority can also allow a candidate, at the latter's own request, partial access to the profession in question, in order to provide access to at least a portion of the profession. The reason behind this ruling lies in the intimidating character and often far reaching consequences of applying compensatory measures.

1278 Case C-145/99 Commission of the European Community v. Italian Republic, [2002] ECR I02235 .
} 
this issue, i.e., that the aptitude test may not be more demanding than the qualification track designated for domestic candidates. How that rule must be applied in situations like this is also unclear. Due to the extensive burdens that integration through this route entails, very few, if any, people would use this modality. Graphically this modality would look as follows:

Figure 10: Integration in the host Member State including non lawyers

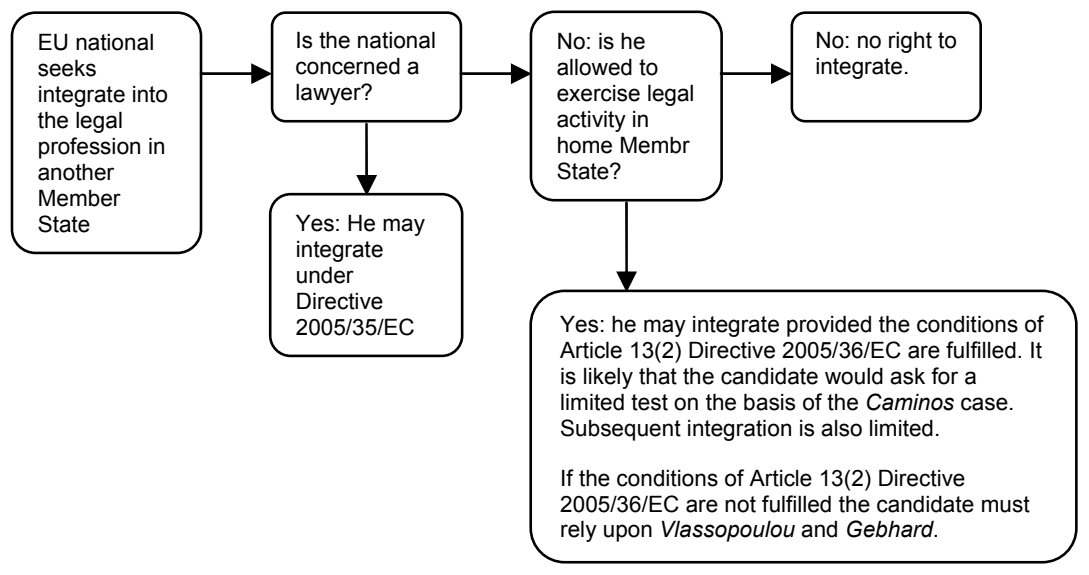

\section{$\mathbb{5}$ 5.2 Implementation of the (New) Diploma Directive in the Member States}

Although it was established that integration on the basis of the third modality, i.e., integration through application of the Diploma Directive, would only have residual importance because of the provisions of Article 10 of Directive 98/5/EC, a review of its implementation is still warranted, albeit merely for the sake of completeness. In consequence of it being established that Directive 2005/36/EC does not bring changes to the system for integration of lawyers, it is therefore unlikely that Member States will (considerably) change their implementation devices that sought to implement Directive 89/48/EEC for their legal professions. It is these mechanisms that will be reviewed in this paragraph.

\section{Sweden}

In Sweden Section 2 of Chapter 8 of the Rättegångsbalken lays down rules in connection to the recognition of diplomas of those prospective advokats who want to enter into the legal profession of Sweden. These categories are persons who are qualified as lawyers in one of the Member States of the European Union or the European Economic Area, lawyers from Denmark, Finland, Iceland or Norway, and lawyers who have been established in Sweden under their home title for at least three years. ${ }^{1279}$ This last category was already dealt with in the light of the implementation of Directive $98 / 5 /$ EC. Any person who is qualified to be a lawyer in one of the Member 
States of the European Union or in one of the Member States of the European Economic Area has to pass a test which shows he has sufficient knowledge of the Swedish legal system to enter the legal profession of the advokat. ${ }^{1280}$ If a lawyer has passed that test he shall be deemed to have fulfilled the criteria regarding the proficiency tests and the practical and theoretical training mentioned above. The lawyer still has to convince the advokatsamfund that he has the integrity to become an advokat and that there are no other circumstances that render him unfit to be an advokat. Lawyers who are trained in Denmark, Finland, Iceland and Norway are eligible to become Swedish advokats when they have worked for at least three years, in a satisfactory manner, as an assistant lawyer in a Swedish law office. When a lawyer has fulfilled those three years he will be deemed to have fulfilled the criteria for education, training, integrity and other incompatibilities. ${ }^{1281}$

\section{Finland}

Section 3 of the Advocates Act in Finland regulates the access of those prospective advokats or asianajajas who have completed the education necessary to become a lawyer in another Member State of the European Union. Subsection 2 states that any national of a Member State of the European Economic Area (Member States of the EU included) who is entitled to practise in his home Member State may gain access to the legal profession of Finland. ${ }^{1282}$ In such cases, a candidate must show that he has sufficient knowledge of Finnish legislation and of legal practice in Finland, by means of passing an examination that is organised by the Finnish Bar Association. ${ }^{1283}$ After passing this exam the lawyer will have fulfilled the second criterion of the three criteria for the profession of the lawyer as was reviewed earlier in this chapter, so the fact that he must generally be eligible for the lawyer's profession and the fact that he may not be bankrupt or in any other way legally incapacitated must still be reviewed by the Finnish Bar Association.

\section{Denmark}

Denmark has no rules with respect to an aptitude test. After implementation of Directive 98/5/EC, a working period at least three years, either as a lawyer (under home country professional title) or working for at least three years with the Department of Justice or the police, is the only way to integrate into the Danish legal profession. ${ }^{1284}$ Originally, Denmark was the only State ${ }^{1285}$ that opted for an adaptation period rather than the aptitude test that was adopted by all other Member States. ${ }^{1286}$ Apparently, the Danish authorities succumbed to the influence of other Member

\footnotetext{
1280 Ch. 8 section 2 Rättegångsbalken.

1281 Ch. 8 section 2 Rättegångsbalken.

1282 Section 3(2) Advocates Act.

1283 Section 3(2) Advocates Act. The by-laws of the Finnish Bar Association stipulate that this examination shall be organised by the Faculty of Law of the University of Helsinki according to the rules of the Decree on the Recognition of Diplomas of Citizens of States in the European Economic Area (1993/1622).

1284 See $<$ www.ciriusonline.dk/Default.aspx?ID $=6824>$, last accessed 24 April 2008. Cirius is the Danish agency that overlooks the recognition of qualifications in Denmark.

1285 Apparently because it was at that time still possible to become a Danish lawyer by vocational training alone.

1286 Torbøl \& Worsøe, (1993) p. 115.
} 
States and sought to introduce an aptitude test later, although no implementation of it has been witnessed. ${ }^{1287}$ Whatever seemed to be the case before the implementation of Directive 98/5/EC, after the implementation the Danish authorities returned to the point where an adaptation period was issued rather than an aptitude test which would henceforth lead to integration into the host Member State's profession. Denmark is thus the only Member State that has recognised that the aptitude test has become completely superfluous under the new system.

\section{United Kingdom}

The six legal professions observed in the United Kingdom regulate access of other qualified lawyers from EU Member States by means of an aptitude test. Each of the professions has its own instrument on the basis of the rules of the aptitude test laid down. In all cases, rules are laid down on a professional level, i.e. the different competent authorities have laid down their rules with regard to the test. Qualified lawyers can enter the English and Welsh profession of the solicitor by means of a Qualified Lawyers Transfer Test (QLTT) which covers property law, litigation, professional conduct, accounts and the principles of common law. ${ }^{1288}$ Access to the Bar in England and Wales is also governed by an aptitude test, but no further details are available. ${ }^{1289}$ No document could be retrieved for access to the solicitor's profession in Northern Ireland but undoubtedly the Law Society of Northern Ireland will govern access to its profession by means of a QLTT. ${ }^{1290}$ Access to the Bar in Northern Ireland for European lawyers is governed by the Honorable Society of the Inn of Court of Northern Ireland that has laid down detailed rules for application for the aptitude test, but not for the test itself. ${ }^{1291}$ The Law Society of Scotland also imposes an aptitude test for the solicitor's profession that covers the law of property, trust and sucessions and family law, the Scottish legal system, evidence, civil and criminal procedure, European Community law and Institutions, and professional conduct and account rules. ${ }^{1292}$ The Faculty of Advocates also imposes an aptitude test which covers; the Scots legal system; constitutional and administrative law; trust and succession and/or property and conveyancing and/or bankruptcy and diligence (two out of three must be chosen), criminal law and one out of delict and quasi-delict or contract and quasi-contract. Additionally, the candidate must pass the Faculty examination covering evidence, pleading, practice and professional conduct. ${ }^{1293}$

1287 See Schneider (1995), p. 320.

1288 The Law Society: Qualified Lawyers Transfer Regulations 1990 via. <www.lawsociety.org>, last accessed 27 November 2007.

1289 The Bar Council: Registration as a European Lawyer. Via <www.barcouncil.org>, last accessed 27 November 2007.

1290 See also: Schneider (1995), p. 348.

1291 Rules of the Honourable Society of the Inn of Court of Northern Ireland with regard to the Admission of Students into the Society and to the degree of Barrister at Law with regard to the admission of practising Members of the Bar of England and Wales and of the Bar of Ireland to the Degree of Barrister at Law and with regard to the Call to the Bar of Northern Ireland by virtue of EC Directive 89/48/EEC and with regard to Cessation and Resumption of Practice, via <www.barlibrary.com>, last accessed 27 November 2007.

1292 Aptitude test for EU Qualified lawyers, via <www.lawscot.org>, last accessed 27 November 2007.

1293 Faculty of Advocates, Regulations as to Intrants, December 2006. 


\section{Ireland}

Recognition of foreign qualifications in Ireland is similar to the recognition of foreign qualifications as they are observed in the United Kingdom. Each of the two professions governs its own scheme for the admittance of lawyers who gained their professional qualifications in another Member State of the European Union or even in a non-Member State. The Qualified Lawyers Transfer Test (QLTT) regulates access for lawyers who gained their professional qualifications outside Ireland. ${ }^{1294}$ The QLTT must be taken by all lawyers qualified in any Member State of the European Union (alongside a number of other jurisdictions) where the Law Society decides that their professional qualifications are not equivalent to the Irish qualifications. There is an exception for solicitors qualified in England and Wales or Northern Ireland who may gain admittance to the profession of the solicitor in Ireland without any further restrictions. ${ }^{1295}$ The QLTT takes place twice a year at the headquarters of the Law Society in Dublin. ${ }^{1296}$ The test encompasses constitutional and company law or constitutional law and criminal law, contract and tort, land law and conveyancing, professional conduct, probate and tax, solicitor's accounts and European Union law. No mention is made of the language in which the QLTT is taken, but everything seems to indicate that the QLTT is taken in English, and not in Irish (Gaelic).

The barrister's profession has its own aptitude test in order to facilitate the entrance to the profession by lawyers who have gained professional qualifications in other Member States of the European Union. A lawyer who seeks admittance to the profession of the barrister in Ireland must apply to the Council of the King's Inn. ${ }^{1297}$ The Council will then assess the professional qualifications of the lawyer concerned. Based on that assessment the Council may take a number of different decisions. The Council can deny the application, ${ }^{1298}$ approve the application, or make the approval of the application subject to the passing of all or part of the aptitude test. ${ }^{1299}$ The aptitude test consists of a written section dedicated to the Irish legal system and constitutional law, the law of tort and contract and a choice between property law or criminal law. In addition, there is an oral part that focuses on legal practice and procedure, advocacy and the Code of Conduct for the Bar of Ireland. ${ }^{1300}$ Everything seems to indicate that the aptitude test takes place in the English language.

\section{The Netherlands}

The method by which integration takes place into the profession of the advocaat in the Netherlands is through obtaining one's diploma in another Member State, and having it recognised as equivalent to the Dutch diploma on the basis of Directive

\footnotetext{
1294 See Hartnett (1993), pp 183-184 and Schneider (1995), pp. 329-330.

1295 The Law Society of Ireland (s.d.) B. Barristers from those jurisdictions must sit the QLTT.

1296 Ibid.

1297 Hartnett (1993), p. 184.

1298 It seems unclear how an application can be refused if the applicant lawyer fulfils the criteria for the legal profession in his home Member State. The Vlassopoulou judgment gives EU citizens the right to have their professional qualifications recognised. A denial can, in my view, only then take place if a person who applies turns out not to be qualified as a lawyer in his home Member State.

1299 Ibid.

1300 Ibid.
} 
89/48/EEC, ${ }^{1301}$ and therewith integrating into the Dutch legal profession. According to Article 2 of the Advocatenwet, in addition to this route, persons who have received an EC declaration on the basis of the laws implementing the Diploma Directive and its counterparts ${ }^{1302}$ can be eligible for registration as an advocaat. ${ }^{1303}$ The rules in connection with acquiring an EC declaration are laid down in a number of hierarchically sorted rulings (i.e., an Act of Parliament, a Ministerial Ruling, and two rulings of the Orde). Article 11 of the Algemene Wet erkenning EG-hoger-onderwijsdiploma's, ${ }^{1304}$ was specifically created in order to implement Directive 89/48/ EEC in the Netherlands, and it provides that the relevant Minister shall issue rules with regard to either the adaptation period or the aptitude test which gives access to that specific profession. ${ }^{1305}$ With respect to the profession of the lawyer, these rules have been laid down in the Regeling EG-verklaring advocaten ${ }^{1306}$ (hereinafter Regeling), issued by the Minister of Justice, who is the relevant Minister in respect of lawyers. Article 2 of the Regeling specifies the documents a prospective advocaat is expected to provide with his application for an EC declaration. It also states that such an application shall be directed towards the Algemene Raad of the Orde. ${ }^{1307}$ Article 3 of the Regeling lays down more of the procedure. If the Orde is of the opinion that the applicant's diploma, which has been awarded in his home Member State, is comparable, both in length and in content, then the applicant will be granted the EC declaration. ${ }^{1308}$ If the Orde is of the opinion that discrepancies exist in respect of duration and content of the diploma awarded in the home Member State, which is more often the case than not, then the Orde will issue a probationary EC declaration. After that, the Orde will set additional educational requirements that need to be fulfilled in order for a definitive EC declaration to be issued. ${ }^{1309}$ The additional educational requirements set by the probationary EC declaration must be fulfilled by means of following additional courses and finishing them by passing an examination. ${ }^{1310}$ This examination will be conducted in Dutch, and the language proficiency of the candidate will be taken into account in the grading of the examination. ${ }^{1311}$ If a candidate passes the examination, the Orde will issue a definitive EC declaration. The Orde has also laid down rules for this examination: a Verordening, ${ }^{1312}$ and a Reglement. ${ }^{1313}$ In the Verordening, it is stated that the Algemene Raad of the Orde shall issue a

\footnotetext{
1301 [1989] OJ L 19/16.

1302 Directive 91/52/EEC [1992] OJ L 209/25 and Directive 99/42/EC [1999] OJ L 201/77.

1303 Article 2(1) Advocatenwet.

1304 Algemene wet erkenning EG-hoger-onderwijsdiploma's, 19-01-1994, Stb. 1994, 29 (General law for the recognition of EC higher education diplomas).

1305 Article 11 Algemene wet erkenning EG-hoger-onderwijsdiploma's.

1306 Regeling EG-verklaring advocaten, 31-10-1994, Stcrt. 1994, 215 (Regulation EC-declaration lawyers).

1307 Article 2 Regeling.

1308 Article 3(2a) Regeling.

1309 Article 3(2b)-(3) Regeling.

1310 Article 3(4) Regeling.

1311 Article 3(6) Regeling.

1312 Verordening op de proeve van bekwaamheid als bedoeld in de algemene wet erkenning EGhoger-onderwijsdiploma's, 25 November 1994, Stcrt. 1994, 249. (Regulation with regard to the aptitude test).

1313 Reglement op de proeve van bekwaamheid als bedoeld in de algemene wet erkenning EGhoger-orderwijsdiploma's, 14 October 1996, Stcrt. 1996, 216. (Rules with regard to the aptitude test).
} 
Reglement in which it states how the aptitude test shall be arranged. ${ }^{1314}$ In this Reglement, it is stated that nine professional fields can be the subject of an examination (this is of course dependent upon the discrepancies between the diploma awarded in the home Member State, and the diploma in the Netherlands). These subjects are civil law, criminal law, administrative law, divorce law, labour law, bankruptcy law, company law, tax law and rules of deontology. ${ }^{1315}$ After a candidate has passed both the written ${ }^{1316}$ and oral ${ }^{1317}$ part of the examination, then the EC declaration will be awarded to him after he pays a fee of $€ 159 .^{1318}$

\section{Belgium}

The Gerechtelijk Wetboek in Belgium specifies a number of alternative routes to qualification as an avocat by the method described at the beginning of this chapter. Article 428bis of the Gerechtelijk Wetboek states that lawyers who gained their qualifications in another Member State of the European Union may consequently enter the profession of the avocat. The Article states that lawyers who have obtained a qualification to work as a lawyer in another Member State can integrate into the profession of the avocat on the condition that the candidate fulfils a number of conditions. These conditions are; the prospective avocat must be able to prove that he is entitled to exercise the lawyer's profession in another Member State of the European Union. ${ }^{1319}$ In addition to that requirement, he must also prove his decent behaviour, the fact that he has never gone bankrupt, and the fact that no incidents have ever occurred that could lead to the situation where the prospective avocat is no longer able to exercise the profession of the avocat (either temporarily or permanently). Incidents that are meant in this case are serious faults regarding the exercise of the lawyer's profession, or felonies committed by the prospective avocat. In addition to the things mentioned above, a prospective avocat must also produce a list of subjects that he has dealt with in order to obtain a degree in another Member State. ${ }^{1320}$ When the lawyer has fulfilled the above named criteria he must take an aptitude test, if the subject matter of the lawyer's own degree differs substantively from the Belgian licenciaat (Belgian law degree). ${ }^{1321}$ Clearly this criterion applies to the majority of lawyers who seek integration in the Belgian legal profession. After all these criteria have been fulfilled, the prospective avocat may take the oath. Article 428bis regulates on which list the integrating lawyer is to be placed. The Article states that if a lawyer has followed a stage in his home Member State in order to qualify as a lawyer, or where such a stage is not prescribed in order to enter the legal profession of the

\footnotetext{
1314 Article 2 Verordening.

1315 Article 2 Reglement.

1316 Article 5 Reglement.

1317 Article 6 Reglement.

1318 Article 8 Reglement.

1319 Article 428bis sub 1 Gerechtelijk Wetboek.

1320 Article 428bis sub 2 Gerechtelijk Wetboek.

1321 Art.428bis sub 3 Gerechtelijk Wetboek. What is remarkable in this case is that the Gerechtelijk Wetboek refers to the Belgian licenciaat, i.e., the law degree, and not to the total amount of education that an avocat receives before he is considered a produit fini, namely the licenciaat, the experience gathered in the stage, and the CAPA (the Bar exam). The Diploma Directive focuses on these produits fini whereas the Belgian authorities focus more on the licenciaat alone.
} 
lawyer's home Member State, ${ }^{1322}$ he is exempted from the obligation to follow a stage in Belgium and can be entered on the Tableau immediately. The Article states that in all other cases the prospective avocat who has taken the oath will be listed on the list of stagiaires. ${ }^{1323}$

Remarkably, the Belgian Gerechtelijk Wetboek contains a number of detailed provisions with regard to the aptitude test. In the other jurisdictions reviewed these detailed provisions are often reserved for legislation on a lower level, or even for regulation by professional bodies. This can be characterised as a form of regulation that is akin to self-regulation, as is the case in the Netherlands. The reason why this level of detail is created at a federal level is possibly explained by the fact that the Belgian legal profession is very decentralised, and that the local Bars have much autonomy in the exercise of the legal profession in the jurisdiction of their Bar. Article 428ter Gerechtelijk Wetboek states that the Flemish and the Walloon Bar Associations shall be the competent authorities to deal with requests for the aptitude test to integrate prospective lawyers into the Belgian legal profession. The second paragraph states further that the documents which the prospective avocat must produce, which were dealt with above, must be delivered either in Dutch, French or German, or, according to the third paragraph, they must be accompanied by a certified translation in one of these languages. The fourth paragraph states that there is a certain fee, prescribed by the Minister of Justice, which may be requested but will not exceed the average costs of such a request. The fifth paragraph provides more clarity on the processing of the request for integration. The Bar Association that is the competent authority (depending on the Bar where access is sought, the Flemish or the Walloon Bar Association) examines the dossier as it is provided by the candidate, and within four months the Bar Association will inform the candidate whether or not an aptitude test must be taken. When the Bar Association decides that an aptitude test must be taken, it will inform the candidate of the subjects in which he is required to take a test. ${ }^{1324}$ The remainder of Article 428 ter is devoted to the possibility

1322 As is the case in Spain.

1323 The latter part of this article is not clear. At first sight it implies that those who are still in the process of qualifying as a lawyer in another Member State can also benefit from these integration procedures. That primary observation is supported by the fact that the question of whether a lawyer must taken an aptitude test is answered by comparison with the licenciaat alone. This observation, i.e., that a person who is still in the process of qualifying as a lawyer in his home Member State (because there are the other situations: Member States where a stage is prescribed, but where the prospective lawyer has not fulfilled this obligation) can take an aptitude test in Belgium, take the oath, and complete his stage in Belgium, is, however, not true. The first subparagraph of Article 428bis states clearly that only those who are qualified as lawyers in another Member State are eligible to benefit from this provision. It remains thus unclear who are the persons envisioned by the Belgian lawmaker when this part of Article 428bis was drafted.

1324 Curiously enough a sub-sentence of paragraph 5 states that if no decision from the Bar Association is received by the candidate, that automatically means that he must take an aptitude test. If this eventuality occurs the candidate himself decides in which subjects he should take the aptitude test. He will inform the Bar Association of the result of that test. I fail to see the rationale of this extra sentence in so far as I can understand that the sentence might have been included as a safeguard against administrative laziness, but I see no other practical use for this sentence. 
of, and the procedure for, appeal against a decision of the Bar Association regarding integration into the Belgian legal profession. ${ }^{1325}$

The matter of the aptitude test itself is regulated by Article 428quater Gerechtelijk Wetboek. Paragraph 1 of the Article states that the aptitude test will only deal with the knowledge of the prospective avocat in order to ascertain whether or not the candidate has enough knowledge to integrate into the Belgian legal profession. The paragraph further states that the aptitude test will consist of a written and an oral part, and that the test is passed when a total of 60 per cent or more of the points are awarded. Candidates can re-sit any subjects they have failed three times. Paragraph 2 of the Article contains the actual substance of the aptitude test. The paragraph states that the written part of the aptitude test shall consist of a part regarding civil law (including civil procedure), a part on penal law (including procedural law) and a choice between public law, administrative law, fiscal law, company law and social law. The oral part will consist of deontology and any subject failed in the written part. Although it is not explicitly stated anywhere, it is at least implied that the aptitude test will take place in one of the official Belgian languages (Dutch, French or German). ${ }^{1326}$ The remainder of Article 428 quater $^{1327}$ is devoted to the examination committees supervising the aptitude test and is of little concern to this study. The remainder of the section in the Gerechtelijk Wetboek regarding the aptitude test $^{1328}$ deals with the appeal against a decision of either the Bar Association or the exam committee and is also of little importance to this study. Apart from some ambiguous wordings in the relevant articles of the Gerechtelijk Wetboek no apparent inconsistencies appear to exist with regard to the aptitude test.

Long before the Diploma Recognition Directive came into force, and even before anyone envisioned the establishment Directive that is the focal point of this book, the Brussels Bar devised a mechanism that provided for limited establishment for foreign lawyers. This is the so-called Liste $\mathrm{B}^{1329}$ that was created by the Brussels Bar in 1984. ${ }^{1330}$ The 'Liste B' provides for the possibility for foreign to lawyers exercise, to a certain extent, the profession of the lawyer within the jurisdiction of Brussels. Lawyers who are on the 'Liste B' may work in conjunction with avocats who are a member of the Brussels Bar. When a lawyer has been on the 'Liste B' for a period of at least three years, he may engage in a partnership with Brussels avocats. ${ }^{1331}$ The 'Liste B' is not really a means of integration into the legal profession of Belgium, but it provides for a form of controlled establishment under home title. The list is no longer used for European lawyers since the implementation of the Establishment Directive.

1325 \6-\$10 Article 428ter Gerechtelijk Wetboek.

1326 \4 of 428 quater states that the German aptitude test will be supervised by the French examination committee. That sentence at least implies that there are three different aptitude tests: Dutch, French and German.

1327 SS 3-5 428quater.

1328 Articles 428quinquies-428decies Gerechtelijk Wetboek.

1329 Article 273 of the Statutes of the Brussels Bar.

1330 See Philippe \& Roberts (1993), pp. 73-74.

1331 Ibid. 


\section{Luxembourg}

Luxembourg has a separate system for the recognition of diplomas on the basis of Directive 89/48/EEC. This system is laid down in a separate law. ${ }^{1332}$ Article 1 of the recognition law states that any lawyer from a Member State of the European Union who is allowed to practise in that Member State may integrate into Luxembourg's legal profession by means of an aptitude test, the details of which are laid down in that respective law. ${ }^{1333}$ The aptitude test shall consist of a written and an oral part. ${ }^{1334}$ The written part shall comprise of questions regarding civil law (including procedural law), penal law (including procedural law) and at the choice of the candidate either administrative or commercial law. The oral part shall consist of questions regarding deontology and re-sits of the written exam, where applicable. ${ }^{1335}$ After the lawyer has completed both parts of the aptitude test he will be awarded a certificate $^{1336}$ that allows him to request entry into Luxembourg's legal profession. That access will be granted after it has been affirmed that the candidate has the honour and morality required for a lawyer, that he has never been declared bankrupt nor committed any grave professional mistakes. ${ }^{1337}$ After the lawyer has taken the oath in front of the Cour de Cassation he will be included in 'Liste I' of the relevant tableau. ${ }^{1338}$ Because of the fact that Article 5 of the Avocat law precludes any non-avocats from exercising professional activities that have been reserved for avocats, a solution with regard to establishment under home title as was observed in connection to the 'Liste B' in Belgium, does not occur in Luxembourg.

\section{France}

Aside from the numerous derogations that are possible in the general route to becoming an avocat in France (as was described earlier in this chapter), an important derogation that must be given special attention is the recognition of foreign diplomas. This recognition is laid down in Article 99 of the décret du 27 novembre 1991. The Article states that anyone who is allowed to practise as a lawyer in other Member States of the European Union (or the EEA) may accede to the profession of the avocat without having to fulfil the conditions described in the previous sub-paragraph. ${ }^{1339}$ The Conseil national des barreaux will deal with applications for entry to the profession of the avocat under the regime of Article 99, and will prescribe an aptitude test when the education necessary for becoming a lawyer in the other Member State concerned differs substantially from the education in France. ${ }^{1340}$ The aptitude test (the subjects are indicated by the Conseil national) shall consist of a written and an oral part, and will be taken before a jury of the CRFPA of the can-

1332 Loi du 10 août 1991, determinant, pour la profession d'avocat le système général de reconnaissance des diplômes d'enseignement supérieur qui sanctionnent des formations professionelles d'une durée minimale de trois ans, Memorial Journal Officiel Grand-Duché de Luxembourg, Recueil de Legislation, A-No 58, 27 août 1991. Hereinafter referred to as the Recognition law.

1333 Article 1 Recognition law.

1334 Article 7 Recognition law.

1335 Article 8 Recognition law.

1336 Article 11-12 Recognition law.

1337 Article 13 Recognition law.

1338 Article 14-15 Recognition law.

1339 Article 99 of the décret du 27 novembre 1991.

1340 This will of course be the case in the majority of applications. 
didate's choice (which depends, of course, on the Bar chosen by the candidate). ${ }^{1341}$ The aptitude test cannot be taken more than three times. ${ }^{1342}$

\section{Italy}

In Italy, a lawyer who is qualified in a Member State of the European Union can have his diploma recognised under the Italian implementation of Directive 89/48/EEC. ${ }^{1343}$ Articles 8 to 12 of the Decreto Legislativo regulate the aptitude test that needs to be taken by lawyers from other Member States of the European Union in order to integrate into the Italian legal profession. The manner in which the Italian aptitude test is conducted was also a subject of the Article $226 \mathrm{EC}$ case against Italy. ${ }^{1344}$ The Commission argued that the aptitude test was discriminatory since it is more elaborate, and therefore more difficult than the Italian Bar Exam. ${ }^{1345}$ Although the Advocate General disagreed with the Commission's view, ${ }^{1346}$ the Court ruled that the provisions in the Decreto Legislativo were too general to be viewed as a correct implementation of Directive 89/48/EEC since there are no specific rules for the aptitude test that needs to be taken by lawyers who seek entry to the Italian legal profession. The Court therefore ruled that the Italian implementation of Directive $89 / 48 /$ EEC was in violation of the Directive. ${ }^{1347}$ In reaction to this judgment, the relevant Italian ministers created a Decreto which laid down more detailed rules for the aptitude test for the profession of the avvocato, therewith complying with the recommendations of the Court in case C-145/99. ${ }^{1348}$

\section{Spain}

The first method by which a lawyer from a different Member State can become a member of the Spanish legal profession is via the implementation of Directive 89/ 48/EEC. This Directive is implemented in Spain by means of a Real Decreto (Royal Decree $)^{1349}$ and a number of lower-level regulations. The Real Decreto lays down the general rules for the implementation of Directive 89/48/EEC. This Real Decreto is rather non-specific and offers no detailed information on the legal professions, apart from the fact that there are no less than ten legal and economist regulated

1341 Article 4 of the arrêté du 7 janvier 1993 portant application de l'article 99 du décret du 27 novembre 1991.

1342 Article 99 of the décret du 27 novembre 1991. It is doubtfull whether this rule can be maintained under EU law.

1343 Decreto Legislativo 27 gennaio 1992, n. 115, Attuazione della direttiva n. 89/48/CEE relative ad un sistema generale di riconoscimento dei diplomi di instruzione superiore che sanzionano formazioni professionali di durata minima di tre anni, Gazzetta Ufficiale n. 40 del 18 febbraio 1992.

1344 Case C-145/99.

1345 S 57 of A-G Stix-Hackl's opinion in case C-145/99.

1346 \ 79 of A-G Stix-Hackl's opinion in case C-145/99.

$1347 \int 57$ Case C-145/99.

1348 Decreto 28 maggio 2003, Regolamento di cui all'articolo 9 del decreto legislativo 27 gennaio 1992, n. 115, in materia di prova attitudinale per l'esercizio della professione di avvocato, Gazzetta Ufficiale 25 luglio 2003, n. 171.

1349 Real Decreto 1665/1991, de 25 de octubre, por el que se regula el Sistema General de Reconocimiento de los títulos de Enseñanza Superior de los Estados miembros de la Comunidad Económica Europea que exigen una formación mínima de tres años de duración, BOE 280/1991 de 22-11-1991, p. 37916. 
professions, among them the professions of the abogado and procurador. ${ }^{1350}$ More detailed information in connection with these latter professions is laid down in lower level regulation, in an Orden (ministerial level regulation). ${ }^{1351}$ This Orden deals exclusively with the profession of the abogado and procurador. For both professions the Orden prescribes an aptitude test. ${ }^{1352}$ Without going into too much detail on the aptitude test, it must be observed that the test for the profession of the procurador is less elaborate than the aptitude test for the abogado. ${ }^{1353}$ Additionally, it must be noted that one must be a member of the corresponding profession in another Member State in order to benefit from the recognition system as it is laid down in the Orden. The corresponding professions are listed in an annex to the Orden and it is noteworthy to state that the profession of lawyer as it is listed in Article 1(2) of Directive 98/5/EC does not give access to the procurador profession. ${ }^{1354}$ In the annex it is stated that only the professions of the avoué in France, the procureur in the Netherlands and the solicitador in Portugal have access to the profession of the procurador. Since the profession of the avoué in France has been abolished, it must be assumed that only the Dutch and the Portuguese professions have access to the profession of the procurador by means of an aptitude test. ${ }^{1355}$ Another important aspect to the recognition of foreign qualifications receives more attention in Spain than in the other Member States, namely the recognition of foreign university qualifications. It may be evident as to why this recognition is so important in Spain, since a completed university education alone gives access to the profession of the abogado. Rules with regard to the recognition of university qualifications are laid down in a number of regulations. ${ }^{1356}$ Without elaborating too much on them at this point, it must be stated that the recognition of university diplomas also takes place via a test, the so

1350 Anexo I. Relación de profesiones reguladas en España. Real Decreto 1665/1991, de 25 de octubre, por el que se regula el Sistema General de Reconocimiento de los títulos de Enseñanza Superior de los Estados miembros de la Comunidad Económica Europea que exigen una formación mínima de tres años de duración, BOE 280/1991 de 22-11-1991, p. 37916.

1351 Orden de 30 abril de 1996, por la que se desarrolla el Real Decreto 1665/1991, de 25 de octubre, en lo que afecta a las Profesiones de Abogado y Procurador, BOE 112/1996 de 0805-1996, p. 15939.

1352 Articles unidecimo-decimonoveno Orden de 30 abril de 1996, por la que se desarrolla el Real Decreto 1665/1991, de 25 de octubre, en lo que afecta a las Profesiones de Abogado y Procurador.

1353 Article decimocuarto and decimotercero Orden de 30 abril de 1996, por la que se desarrolla el Real Decreto 1665/1991, de 25 de octubre, en lo que afecta a las Profesiones de Abogado y Procurador, respectively.

1354 Anexo 1. Orden de 30 abril de 1996, por la que se desarrolla el Real Decreto 1665/1991, de 25 de octubre, en lo que afecta a las Profesiones de Abogado y Procurador.

1355 Ibid.

1356 Real Decreto 86/1987, de 16 de enero, por el que se regulan las Condiciones de homologación de títulos extranjeros de Educación Superior, BOE 20/1987 de 23-01-1987, p. 1987; Orden de 21 de julio de 1995, por la que se establecen los Criterios generales para la realización de Pruebas de conjunto previas al la homologación de títulos extranjeros de educación superior, BOE 178/1995 de 27-07-1995, p. 22912; Orden ECD/272/2002, de 11 de febrero, para la aplicación de lo dispuesto en el Real Decreto 86/1987, de 16 de enero, por el que se regulan las condiciones de homologación de títulos extranjeros de educación superior, BOE 40/2002 de 15-02-2002, p. 6084. 
called prueba de conjunto. ${ }^{1357}$ This test must be taken if the diploma in the home Member State and the host Member State are not equivalent. ${ }^{1358}$

\section{Portugal}

Based on the Advogado law it seems that Portugal is not too unfriendly to foreigners seeking entrance into the profession of the advogado. The Advogado law states that any foreigner who has obtained a diploma in law from a Portuguese university may register with the Ordem dos Advogados ${ }^{1359}$ as long as Portuguese nationals enjoy the same right in the home Member State of the foreigner concerned. ${ }^{1360}$ Due to the prohibition against discrimination on grounds of nationality, as laid down in Article 12 of the EC Treaty, this requirement of reciprocity will at least be fulfilled in all of the other Member States of the European Union. Moreover, Brazilian advogados who have a law degree from a Brazilian or Portugese university may be registered as advogados with the Ordem dos Advogados in Portugal based on the principle of reciprocity (i.e., that Portuguese advogados enjoy the same rights in Brazil). ${ }^{1361}$

The old Advogado law ${ }^{1362}$ provided for a separate chapter on the provision of services in Portugal by lawyers from other Member States. ${ }^{1363}$ In this chapter, a separate article was devoted to integration into the legal profession of the advogado. ${ }^{1364}$ This article is also incorporated in the new Advogado law. ${ }^{1365}$ Since Chapter V of the Advogado law, Capitulo V. Advogados de outros Estados membros de União Europeia, incorporates all three modalities of the free movement of lawyers, it is sufficient to say at this point that lawyers who seek integration into the legal profession of the advogado can do so via an aptitude test. ${ }^{1366}$ Rules with regard to this aptitude test are laid down in a Regulation of the Ordem dos Advogados. ${ }^{1367}$ The aptitude test consists of an oral and a written part, both in Portuguese, ${ }^{1368}$ and the oral test is to be taken when the written test has been passed on the subjects of civil law and procedural law, penal law and procedural law, organisation of the judiciary, a choice between commercial law or administrative law, and deontology. ${ }^{1369}$

1357 Article 2 Real Decreto 86/1987, de 16 de enero, por el que se regulan las Condiciones de homologación de títulos extranjeros de Educación Superior, BOE 20/1987 de 23-01-1987, p. 1987.

1358 Ibid.

1359 Although not mentioned specifically in the article concerned, it is self evident that foreign lawyers who are allowed registration via this route must also fulfil the criteria with regard to the Estagio.

1360 Article 194(1) Advogado law.

1361 Article 194(2) Advogado law. Contrary to subsection (1) which mentions 'estrangeiros' (foreigners), subsection (2) speaks about 'advogados brasileiros'. That presumes that subsection (2) governs produits fini from Brazil and registration of these people will be full, i.e. these advogados do not have to fulfil the criteria of the estagio in Portugal.

1362 Decreto-Lei 84/84 de 16 de Março.

1363 Article 173A-173G Decreto-Lei 84/84 de 16 de Março.

1364 Article 173G Decreto-Lei 84/84 de 16 de Março.

1365 Article 200 Advogado law.

1366 Ibid.

1367 Regulamento de Registo e Inscrição dos Advogados Provenientes de Outros Estados Membros da União Europeia, 07-05-2002 via <www.oa.pt>, last accessed 25 April 2005.

1368 Article 3(2) Regulamento de Registo e Inscrição dos Advogados Provenientes de Outros Estados Membros da União Europeia, 07-05-2002 via <www.oa.pt>, last accessed 25 April 2005.

1369 Article 7 Regulamento de Registo e Inscrição dos Advogados Provenientes de Outros Estados Membros da União Europeia, 07-05-2002 via <www.oa.pt>, last accessed 25 April 2005. 


\section{Germany}

The implementation of Directive 89/48/EEC in Germany is found in the EuRAG, more notably in $\int S 16-24$. This Directive was implemented in an earlier law ${ }^{1370}$ but the German authorities found it preferable to have all the rules in connection with lawyers in one law, so the contents of the previous law was transferred to this one and the previous law was thus revoked. ${ }^{1371}$ Paragraph 16 states that anyone who is established as a European lawyer in Germany can at any moment in time apply for an aptitude test. ${ }^{1372}$ This part further states that the aptitude test is meant to assess the candidate's capacity to practise as a Rechtsanwalt. ${ }^{1373}$ The test will consist of a combination of compulsory and facultative subjects, ${ }^{1374}$ and will be conducted in both written and oral form in the German language. ${ }^{1375}$ The candidate can appeal against any decision taken by the authority that undertakes the aptitude test. ${ }^{1376}$

\section{Austria}

Part III Chapter 3 of the EuRAG of Austria deals with integration of lawyers into the profession of the Rechtsanwalt under the system of Directive 89/48/EEC. Paragraph 24 states that any national of a Member State of the European Union, or a national of the European Economic Area, who has a diploma as understood under Directive 89/48/EEC is eligible to take an aptitude test in order to become integrated into the profession of the Rechtsanwalt in Austria. ${ }^{1377}$ The goal of that aptitude test is to find out whether a person, who is entitled to exercise the profession of the lawyer in either a Member State of the European Union or a Member State of the European Economic Area, is able to exercise the profession of the Rechtsanwalt in Austria. ${ }^{1378}$ A commission that is attached to an Oberlandesgericht will carry out the aptitude test. The commission chosen to take the lawyer's test will depend on the country from which the lawyer originates. ${ }^{1379}$ Within four months of the application, the President of the Commission will decide whether or not to allow a candidate to take the aptitude test. ${ }^{1380}$ With his application for a test, a lawyer will additionally need to send his diploma, proof that he is allowed to practise in his home Member State, proof of nationality of the home Member State, his choice of subjects for the test and the fee for the test. Similar to all documentary evidence required under the $E u R A G$, all the above-mentioned documents must be produced in German. ${ }^{1381}$ The President of the Commission can decide to exempt the candi-

1370 Gesetz über die Eignungsprüfung für die Zulassung zur Rechtsanwaltschaft, 6 July 1990, BGB1 I, p. 1349. See extensively: Schneider (1995), pp. 295-304.

1371 Deutscher Bundestag, Entwurf eines Gesetzes zur Umsetzung von Richtlinien der Europäischen Gemeinschaft auf dem Gebiet des Berufrechts der Rechtsanwälte., 01 December 1999, Drucksache 14/2269, p.1.

1372 \16 EuRAG.

$1373 \int 17$ EuRAG.

$1374 \ 20$ EuRAG.

$1375 \ 21$ EuRAG.

$1376 \rrbracket 23$ EuRAG.

$1377 \$ 24$ EuRAG.

1378 \25 EuRAG.

1379 \26 EuRAG.

$1380 \rrbracket 27$ EuRAG.

$1381 \int 28$ EuRAG. 
date from one or more subjects because they have been dealt with in his previous education. ${ }^{1382}$ The aptitude test itself will have an oral and a written part. ${ }^{1383} \mathrm{~A}$ prospective lawyer may retake the aptitude test twice. ${ }^{1384}$ Aside from the applicable paragraphs in the EuRAG, the Rechtsanwaltspriffungsgesetz is also applicable. ${ }^{1385}$ After the lawyer has successfully completed the aptitude test, he can apply to be registered as a Rechtsanwalt in Austria. A lawyer who enters the profession in this manner must prove that he is of a trustworthy character. ${ }^{1386}$ Lastly, Paragraph 37 states that the Rechtsanwaltskammern have to cooperate with the competent authorities of the home Member State, ${ }^{1387}$ while Paragraph 38 states that European lawyers may not use the designation 'europaïsher Rechtsanwalt' when practising as a lawyer in Austria. ${ }^{1388}$

\section{Greece}

The rules in Greece in connection to the integration of nationals of other Member States into the Greek legal profession (whether these persons are already qualified as lawyers in their home Member State or not) are rather strict. The general rule for integration into the Greek legal profession by persons who are fully qualified as lawyers in their home Member State is by means of an aptitude test. ${ }^{1389}$ Kerameos states in her article that every (my italics, S.C.) lawyer who seeks to integrate into the Greek legal profession may do so after successfully completing the aptitude test. It may be clear that under the system of Directive 89/48/EEC that the aptitude test is a means of last resort. The Vlassopoulou principle that was included in Directive 89/48/EEC guarantees that every individual who seeks integration can have his qualifications and experience scrutinised, and where necessary, an aptitude test will be used in order to fill the gap of knowledge that has been established. The apparently automatic way in which an aptitude test is prescribed in Greece seems to indicate that such individual scrutiny does not take place in Greece. Schneider has also voiced criticism about this in her dissertation regarding the recognition of diplomas. ${ }^{1390}$ The aptitude test consists of both a written and an oral part which is to be undertaken in the Greek language, which covers at least civil law (and procedural law), constitutional and administrative law, commercial law and rules governing the legal profession. In addition to that, a choice must be made between criminal law (including procedural law) and labour law. The aptitude test, which takes place in Athens, can be repeated as many times as one likes. ${ }^{1391}$

\footnotetext{
$1382 \int 29$ EuRAG.

$1383 \int 30,31$ and 32 EuRAG.

1384 S33 EuRAG.

$1385 \int 34$ EuRAG.

1386 \ 35 EuRAG.

$1387 \int 37$ EuRAG. $\ 36$ is a provision about the oath that must be taken by lawyers and is not of importance to this book.

$1388 \int 38$ EuRAG.

1389 Kerameos (2001), pp. 349-353.

1390 Schneider (1995), p. 328.

1391 Kerameos (2001), pp. 349-353.
} 


\section{$\llbracket 5.3$ Observations and Conclusions}

The recognition of diplomas is the third modality of the free movement of lawyers. This modality leads to the full integration of lawyers into the legal profession of the host Member State. Recently, the rules regarding diploma recognition were consolidated and codified in a new Directive 2005/36/EC which replaces, among other instruments, Directive 89/48/EEC (which was reviewed in the previous chapter). It was established that Directive 2005/36/EC can apply to professionals who exercise legal activities in Member States with a lesser degree of regulation if they seek to integrate themselves into the legal professions of those Member States which reserve such activity for lawyers. They can rely on the Directive if they fulfil the criteria of Article 13 of Directive 2005/36EC, and if substantial differences between home and host qualifications are established, the integration will depend on the successful completion of an aptitude test. In theory such a test would cover entrance to the legal profession of the host Member State, but, according to the European Court of Justice in the Caminos case, the extent of the test (and of the integration therefore) can be limited upon request of the candidate. In theory this could lead to new professions in the host Member State, e.g. where a Dutch juridisch adviseur (which is not a regulated activity) integrates into the French profession but only for the provision of legal advice: He will enter the profession of the avocat but his activities will be limited to the provision of legal advice. In this way, the abolished profession of conseil juridique would effectively be revived.

In the previous chapter it was established that Directive 2005/36/EC did not bring about changes to the system of diploma recognition for lawyers. This also meant that it was unlikely that Member States would change their implementation mechanisms that were already in place after the implementation of Directive 89/ 48/EEC. Therefore, this review has been limited to these mechanisms. No major violations were established. In the previous paragraph it was established that the result of this modality was that integration into the legal profession of the host Member State could also be achieved through application for establishment under home country professional title. Integration into the host Member State's legal profession can be achieved without undertaking the aptitude test, and as was established in the previous part, this leaves discretionary room for the host Member State and can be a demanding hurdle for the candidate involved. ${ }^{1392}$ For these reasons, it was established that integration through this modality will be residual and will only be interesting for those candidates who can establish early integration (earlier than the three years prescribed in Directive 98/5/EC) and can evade the aptitude test (largely or completely) because they have already gained sufficient knowledge of the host Member State's profession. ${ }^{1393}$

1392 Although the ECJ in Commission v. Italy implicated that it cannot be more demanding.

1393 It is often forgotten, not least by competent authorities, that application of an aptitude test is secondary to an assessment of the candidate's knowledge. Only where substantial differences are established should compensatory measures be imposed in order to cover the lacunae established. Application of the aptitude test is therefore by no means automatic, but more a custom-made solution for individual candidates. 


\section{\6. Third-Country Nationals}

The last category of lawyers included in the model presented at the end of the previous chapter, are the third-country national lawyers who seek to exercise their free movement rights. Graphically their situation can be represented as follows:

Figure 11: Third Country Nationals

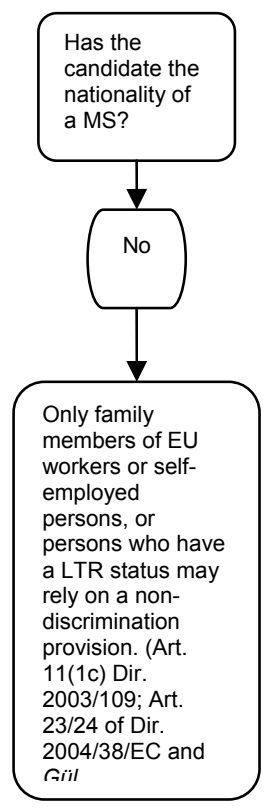

It was established that these individuals have only a very weak position, which nonetheless deserves closer scrutiny in this chapter. Additionally, there are a set of rules on the international plane that might be beneficial for this category of lawyers, namely the rules laid down in GATS. Although an extensive review of the GATS rules would fall outside the scope of this book, some space must be devoted to a short characterisation of these rules and to the questions of 'if' and 'how' these rules interconnect with the European rules forming the central issue of this book. In addition, it must be mentioned that individual Member States have their own rules in connection with third-country nationals and their access to the legal profession, and recognition of their qualifications, in the sphere of legal professions. Due to their very detailed nature, and their lack of coherence, these rules warrant a book of their own. Therefore, these rules will not be reviewed here, apart from one system which will be used as an example. 


\section{\6.1 European Rules Applicable to Third-Country Nationals}

The European rules protecting the exercise of free movement rights of third-country nationals were meagre at best. Before 2003, only family members of EU citizens who exercised their free movement rights could, through the application of Article 11 of Regulation 1612/68 (nowadays replaced by article 23 and 24 of Directive $2004 / 38 / E C)$, rely on equal treatment in the application of the rules regarding the free movement of lawyers, or at least diploma recognition. ${ }^{1394}$ Since 2003 , this equal treatment provision has been extended to all third-country nationals who gain the status of Long Term Resident (LTR) on the basis of Directive 2003/109/EC. ${ }^{1395}$ Article 11(1c) of that Directive states that third-country nationals who gained LTR status (on the basis of Article 7 of Directive 2003/109/EC) have the right to equal treatment in terms of recognition of professional qualifications according to the national rules of the Member State in question. In order to apply European rules to this case one must assume that the national rules incorporate the implementation of the Directives.

In the previous part it was established that a view which assumed that equal treatment would lead to direct application of the Directives was too short-sighted. It was established that for the Diploma Directive to apply, both nationality and a European qualification were needed. With regard to the Services and Establishment Directives, both nationality and full qualification in one of the professions listed in the Directives was necessary for application. It may be clear that the equal treatment provision of Article 11(1c) of Directive 2003/109/EC only removes discrimination in connection to nationality. Application of the Diploma Directive can, therefore, only occur when the third-country national with LTR status has a professional qualification that was obtained in a Member State of the European Union. From the wording of Article 11(1c) of Directive 2003/109/EC it is by no means certain that the provision extends to the Services Directive and the Establishment Directive, but even if it would, the Directives would only apply where the third-country national is fully qualified in one of the professions mentioned in the Directives. In addition to this, the third-country national with LTR status must establish a cross-border element, and the Member State where he obtains LTR status is regarded as his home Member State. This means that problems of diploma recognition in the Member State where the third-country national has obtained his LTR status must be established as a wholly internal situation, which falls outside the scope of European free movement rules altogether.

This leads to the conclusion that protection awarded to third-country nationals under European law, even in cases where they have gained the LTR status, is close to non-existent. Where third-country nationals with LTR status fall within the scope of the free movement protection, they are most likely to do so in a situation that was observed for EU nationals with third-country qualifications. This situation, as such, does not fall under the Directives but is awarded some protection under the case

1394 Case 131/85, Emir Gül v. Regierungspräsident Düsseldorf, [1986] ECR 1573.

1395 Council Directive 2003/109/EC of 25 November 2003 concerning the status of third-country nationals who are long-term residents, [2003] OJ L 016. 
law of the European Court of Justice. Graphically this situation can be represented as follows:

Figure 12: Third-country diplomas

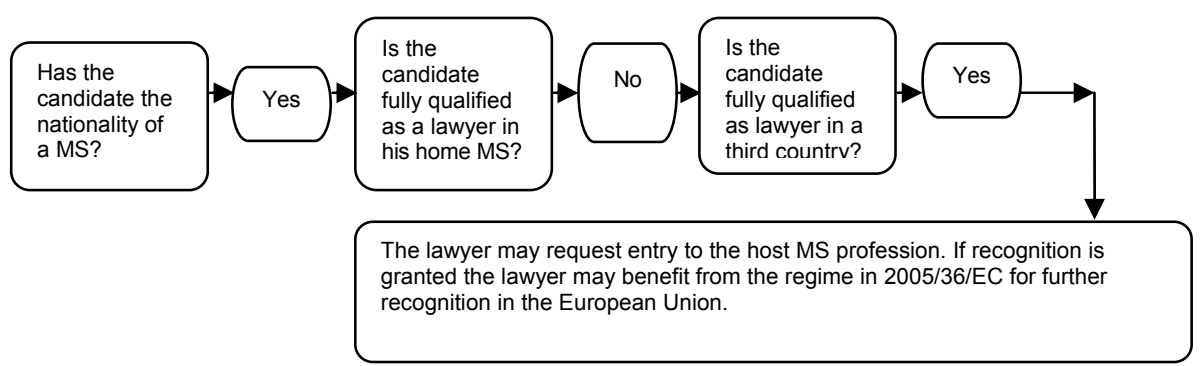

Application of this model to third-country nationals with LTR status leads to the conclusion that the third-country national has at least been awarded the right to have his qualifications reviewed, which may later lead to a decision to apply compensatory measures with regard to full integration into the legal profession of another Member State other than the one in which the third-country national has obtained his LTR status. By no means does this system award the third-country national, with LTR status or not, rights to provide legal services or establish himself under home country professional title. Whether this would be possible in the event that a thirdcountry national with LTR status, who is fully qualified as a lawyer in one of the Member States of the European Union, would seek to provide services or establish himself in another Member State is also questionable, since both the Lawyers Services Directive and the Lawyers Establishment Directive also require nationality and Article 11 of the LTR Directive does not cover these situations.

Compared with the elaborate system devised for EU nationals it can be concluded that the protection of third-country nationals under European rules is next to non-existent. Therefore, it must be assessed whether the rules under the GATS offer more protection to this category of lawyers.

\section{$\$$ 6.2 The General Agreement on Trade in Services (GATS)}

In 1995 a new international organisation was founded, the World Trade Organisation (WTO). ${ }^{1396}$ This new international organisation was founded on the General Agreement on Tariffs and Trade (GATT 1947) which was meant to be one of the substantive legal instruments to be used by the International Trade Organisation (ITO). ${ }^{1397}$ The establishment of the WTO as an international organisation also saw the introduction of new substantive agreements, i.e., agreements containing substantive rules on international trade annexed to the WTO Agreement, among them

1396 The Marrakesh Agreement Establishing the World Trade Organisation. The European Community, as an International Organisation, is a member of the WTO, and the WTO Agreement (and its annexes) therefore form an integral part of primary EC law.

1397 Van den Bossche (2005), pp. 78-85. 
the General Agreement on Trade in Services (GATS). ${ }^{1398}$ The General Agreement on Trade in Services is a unique mechanism for establishing liberalisation of the trade in services between the Members of the WTO. It allows States, largely on a voluntary basis, to negotiate on further liberalisation of services. ${ }^{1399}$ In order to achieve this liberalisation, three different mechanisms can be distinguished. First of all, there are generally applicable rules for all WTO Members with regard to measures affecting trade in services, with possible exceptions ${ }^{1400}$ laid down in Part II of the GATS. Secondly, there are the specific commitments to which a State is bound when that State has made such commitments and with them has laid down no limitations, conditions or qualifications (laid down in Part III of the GATS). Thirdly, there is the built-in agenda for further negotiations in order to secure a continuous development of liberalisation (laid down in Part IV of the GATS). ${ }^{1401}$

Article I GATS states that it will apply to State measures affecting services. Although the term 'services' is not defined as such, Article I.2 GATS lays down the different modes in which 'services' can be supplied. ${ }^{1402}$ The first mode is the crossborder mode, in which there is no movement of natural or legal persons, only the service itself crosses the border (e.g., telecommunications or internet service provision). ${ }^{1403}$ The second mode of supply provided for in Article I.2 GATS is the socalled 'consumption abroad'. In this mode, it is the consumer who travels from one Member to another in order to receive a service. ${ }^{1404}$ The third mode, 'commercial presence', is very broad and focuses on the presence of legal persons of one Member in the territory of another Member. Any type of business or professional establishment in the territory of another Member may de deemed to constitute commercial presence. ${ }^{1405}$ The fourth mode of supply is the presence of natural persons in the territory of other Members. This was deemed so potentially problematic that it also became the subject of a separate annex to the GATS. ${ }^{1406}$ From the GATS (including the annex), it becomes clear that it does not cover (among other things) 'measures regarding citizenship, residence, or employment on a permanent basis'. ${ }^{1407}$ The fourth mode, therefore, relates to services supplied on a temporary basis. Measures are State measures including regulatory powers exercised by non-State entities. ${ }^{1408}$ Article I:3(a)(ii) GATS states that non-governmental bodies can also exercise activities that can be classified as 'measures' when they exercise powers that have been delegated by a central, regional or local government. The definition of Article I GATS also requires the measure to 'affect' trade in services. In case law of the Appellate Body, ${ }^{1409}$ this requirement was given a broad meaning, so that the rules in GATS have a

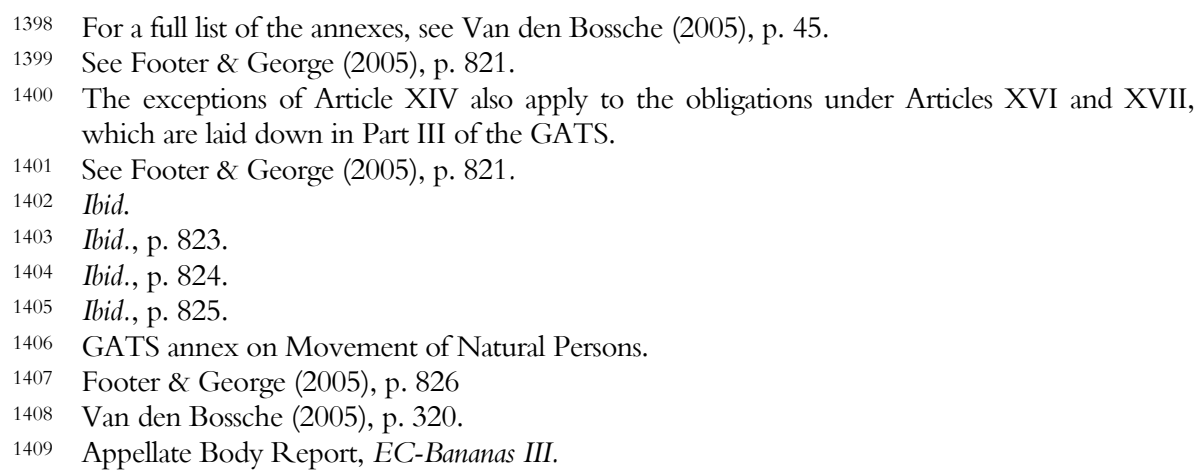


broad scope ${ }^{1410}$ Legal services, as such, are included in a list which enumerates the different services falling under the scope of the GATS, the so-called W/120 list. ${ }^{1411}$ This list uses a system of classification that is based on the United Nations system of the classification of services. ${ }^{1412}$ Although no further mention is made of this fact on the W/120 list, the United Nations classification system provides for a subdivision of legal services, which, as will be seen below, are used by members wholly or in part, including by States in the European Community. ${ }^{1413}$ This classification and sub-classification has not been without criticism. The Secretariat ${ }^{1414}$ has issued a background note on legal services in which it states that the reality of trade in legal services, and the perception of that trade by Members, is not reflected by the classification system used in the W/120 list. ${ }^{1415}$

The most important general obligation in the GATS is the Most Favoured Nation (MFN) rule laid down in Article II GATS. ${ }^{1416}$ In essence, the MFN rule comes down to a non-discrimination provision that has both internal and external effect, i.e., a member cannot treat a non-member more beneficially than members, and a member cannot treat a member more beneficially than other members. The MFN rule extends to both direct and indirect discrimination. ${ }^{1417}$ Article II:2 GATS provides the possibility for Members, before the GATS entered into force, to list exemptions to the MFN treatment principle. None of the countries reviewed in this book have made MFN exemptions in connection to legal services, so it is not necessary to explore these exemptions any further. ${ }^{1418}$ An important exemption to the MFN rule is laid down in Article V GATS. It allows countries that are involved in economic integration efforts which promote intensive liberalisation of trade in services to be exempt from the MFN treatment rule and other GATS obligations. Clearly the European Community does constitute such an economic integration effort. ${ }^{1419}$ This

\footnotetext{
1410 Van den Bossche (2005), p.323.

1411 MTN.GNS/W/120, 10 July 1991. Legal services are number 861.

1412 Terry (2002), p. 6.

1413 Sub-divisions are:
}

- Legal advisory and representation services concerning criminal law (86111).

- Legal advisory and representation services in judicial procedures concerning other fields of law (86119).

- Legal advisory and representation services in statutory procedures of quasi-judicial tribunals, boards, etc. (86120)

- Legal documentation and certification services (86130)

- Other legal information and advisory information (8619)

- Arbitration and conciliation services.

See Terry (2002), p.6. For a detailed overview of the sub-divisions see WTO (1998).

1414 For a review of institutional arrangements in GATS, see Footer \& George, pp. 865-873.

1415 WTO (1998), p. 5. See also: Terry (2002), p. 7.

1416 'With respect to any measure covered by this Agreement, each Member shall accord immediately and unconditionally to services and service suppliers of any member treatment no less favourable than that it accords to like services and service suppliers of any other country.'

1417 Both the Panel (Panel Report on EC-Bananas III $\$$ 7.286) and the Appellate Body (Appellate Body Report EC-Bananas III $\$ 220$ ) reached this conclusion, albeit on different grounds. See also: Van den Bossche (2005), p. 319.

1418 Terry (2002), p. 14. The IBA handbook is based on: Terry (2001-2002), pp. $1387 \mathrm{ff}$.

1419 The EC Treaty and subsequent enlargements were notified to the Council for Trade in Services as an economic integration effort in the light of Article V GATS. See; European Commission, EC Regional Trade Agreements, via <ec.europa.eu/trade>, last accessed 22 January 2007. 
means that through the application of Article V GATS, the internal rules on the free movement of lawyers in the EU do not fall under GATS obligations.

With regard to other general obligations, mention must be made of Article VI GATS. Although an extensive review of Article VI GATS goes beyond the scope of this book, it suffices to state at this point that its general aim is to overcome unnecessarily burdensome requirements (in domestic regulation) that create barriers to trade in services. ${ }^{1420}$ To that end it facilitates the creation of 'disciplines', which in essence means that Article VI(4) GATS asks Members to come up with common standards for future domestic regulation of a certain service. The application of that common standard, or discipline, would then lead to domestic regulation that is 'friendly' for the international trade in services. ${ }^{1421}$ In order to achieve this objective, in 1995 the Ministerial Conference created the Working Party on Professional Services (WPPS). Although disciplines in the accountancy sector may, at first sight, not be relevant for legal services, they are in fact of great relevance because the WTO has sought to apply these disciplines in a broader sense. ${ }^{1422}$ In 1999 the Working Party on Domestic Regulation (WPDR) was created in order to replace the WPPS. The WPDR has a much broader goal and seeks to achieve disciplines that are horizontally applicable, ${ }^{1423}$ i.e. on all services covered by the GATS. ${ }^{1424}$ In its work up until now, the WPDR has focussed on four major issues; necessity, transparency, equivalence and international standards. ${ }^{1425}$ These four major issues of interest to the WPDR do not simply come from nowhere. They are also the central issues of the Disciplines for Domestic Regulation for the Accountancy Sector. The Accountancy Disciplines are an example of very general and straightforward disciplines. ${ }^{1426}$ The Disciplines require Members to undertake a necessity test with regard to new domestic regulation. ${ }^{1427}$ This necessity test prescribes that domestic regulation may not pose a barrier to international trade in a way that is more than what is necessary in the pursuit of a legitimate objective. ${ }^{1428}$ To a lawyer trained in European law this must sound familiar. The necessity test in the Accountancy Disciplines bears a striking resemblance to the objective justification test as it was laid down by the European Court of Justice in the Cassis de Dijon case ${ }^{1429}$ for the free movement

1420 Footer \& George, p. 836.

1421 It must be kept in mind that the disciplines do only apply to domestic regulation, and they, therefore, do not influence the Schedule of Specific Commitments. See Terry (2002), p. 34.

1422 Or as Footer and George put it: 'It is important to note that[...] the Accountancy Disciplines are very general in scope and almost certainly could be applied, at least in part, across a wider range of other services'. See Footer \& George (2005), p. 942.

1423 This action might be comparable with the change witnessed in diploma recognition in European law in the 1980s where the European Commission changed from a vertical, professionspecific approach to a horizontal approach that ultimately resulted in Directive 89/48/EEC.

1424 Footer \& George (2005), p. 943.

1425 Ibid. p. 945. See also: See Terry (2002), pp. 37-38.

1426 Footer \& George (2005), p. 943.

$1427 \int 2$ of the Accountancy Disciplines.

1428 Footer \& George (2005), p. 943. Legitimate objectives are; protection of consumers, the quality of the service, professional competence and the integrity of the profession.

1429 Case 120/78, Rewe-Zentrale AGv. Bundesmonopolverwaltung für Branntwein, [1979] ECR 649. 
of goods, and after a number of $\operatorname{cases}^{1430}$ laid down in the Gebhard case ${ }^{1431}$ for all the four freedoms.

In addition to the necessity test, there is also one other element that bears resemblance to the European system. The Accountancy Disciplines prescribe that, in the matter of qualification requirements, account shall be taken of qualifications earned abroad based on equivalence. ${ }^{1432}$ Although the resemblance is not as striking as in the case of the necessity requirement, this part of the Disciplines shares the same atmosphere that can also be found in cases like Vlassopoulou ${ }^{1433}$ and Morgenbesser ${ }^{1434}$ and in secondary legislation such as Directive 2005/36/EC $\mathrm{EC}^{1435}$ and its predecessor Directive 89/48/EEC. ${ }^{1436}$ Further elements of the Disciplines contain rules on the transparency of domestic regulations, and rules to simplify licensing procedures and to lessen licensing requirements. ${ }^{1437}$ It is the idea that the Accountancy Disciplines become binding upon Members. The Accountancy Disciplines and other ensuing disciplines (of which there are none presently) will be incorporated into the new version of the GATS that is to emerge from the Doha Rounds. At this moment, members are under a standstill provision which requires them not to engage in domestic regulation in the accountancy sector that would violate the Disciplines. ${ }^{1438}$

As was indicated above, one of the main objectives of the WPDR is to investigate whether the Accountancy Disciplines can be applied horizontally, i.e., for all services caught under the GATS. In the world of lawyers the question of whether the Accountancy Disciplines should be applied to the legal profession, or, better put, domestic regulation influencing the trade in legal services, has been the subject of heated debate. ${ }^{1439}$ In general, it was the belief of many Bar Associations that the WPPS would soon come to apply to lawyers after they had finished work on the Accountancy Disciplines. Official WTO documents at the time corroborated that belief. ${ }^{1440}$ However, as indicated above, a culture change occurred, the WPPS was disbanded and the new WPDR created the belief that there should be one horizontal discipline for all services caught under the GATS. It is not the intention of this paragraph to give a detailed review of the standpoint of all the members,

1430 Case 33/74, Van Binsbergen v. Bestuur van de Bedrijfsvereniging voor de Metaalnijverheid, [1974] ECR 1299; Case 279/80, Criminal Proceedings against Webb [1981] ECR 3305. For similar (preceding) cases see Joined Cases 110-111/78, Ministère public and Chambre syndicale des agents artistiques et impresarii de Belgique ASBL v. Willy van Wesemael and others, [1979] ECR 32; Case C-76/90, Manfred Säger v. Dennemeyer \& Co. Ltd, [1991] ECR I-4421; See also: Case C-275/92, Her Majesty's Customs and Excise v. Gerhart Schindler and Jörg Schindler, [1994] ECR I-1039.

1431 Case C55/94, Reinhard v. Consiglio dell'Ordine degli Avvocatie e Procuratori di Milano, [1995] ECR 4165.

1432 Footer \& George (2005), p. 943.

1433 Case 340/89, Vlassopoulou v. Ministerium für Justiz, Bundes- und Europaangelegenheiten BadenWürttemberg, [1991] ECR 2357.

1434 Case C-313/01, Christine Morgenbesser v. Consiglio dell'Ordine degli avvocati di Genova, [2003] ECR I-13467.

1435 Directive 2005/36/EC of the European Parliament and the Council of 7 September 2005 on the recognition of professional qualifications, OJ L 255/022-142.

1436 Directive 89/48/EEC, [1989] OJ L 19/16.

1437 Footer \& George (2005), p. 943.

1438 Ibid. p. 944 and Terry (2002), p. 34.

1439 Terry (2002), pp. 35, 38-43. See also: Terry (2004), pp. 695ff and Hopkins (2004), pp. $427 \mathrm{ff}$.

1440 Terry (2002), p. 35. 
and/or Bar Associations involved. At this point it suffices to say that, in general, Bar Associations are at least wary about applying the Accountancy Disciplines to the legal profession. ${ }^{1441}$ Predicting how this discussion will end is anybody's guess.

The third part of the GATS accounts for its largely voluntary nature, as was signalled above. This is reflected in the fact that a Member is not bound to the rules laid down in Part III of the GATS unless that State has, for market access (Article XVI GATS) and national treatment (Article XVII GATS), for mode of supply and for specific service sectors, committed itself to upholding these rules in the Member's Schedule of Specific Commitments (Schedule). ${ }^{1442}$ The general application is that none of the Members are bound to the rules laid down in that part of the GATS. Members can then choose to list a specific service sector ${ }^{1443}$ on its Schedule. If a Member merely lists the service sector in its schedule this means that the Member then commits itself to upholding all the rules in Part III of the GATS without further reservations. A Member may also choose to specify its commitment with regard to market access and national treatment along the lines of the abovementioned four different modes of supply, and choose a commitment for a specific mode, for a specific rule. Commitments can range from 'NONE' which means that the market access or national treatment obligations apply without reservation, to 'UNBOUND' which indicates that a Member does not commit itself to any market access or national treatment. This system has been referred to as hybrid, combining a 'bottom up' and a 'top down' approach. ${ }^{1444}$

The first rule that Members can specifically commit themselves to is found in Article XVI GATS, and is commonly referred to as the Market Access rule. ${ }^{145}$ From this Article it becomes clear that where a Member chooses to enter into market access obligations it must, with regard to that market access, give other Members treatment that is no less favourable than the treatment it gives to its national service suppliers. As is the case with so many terms in the GATS, the term 'market access' is not specifically defined, and the meaning of market access must therefore be distilled from a list of measures that are prohibited when a Member commits ${ }^{1446}$ itself to Article XVI GATS for a given service sector. These measures are listed in

1441 Ibid. pp. 38-43. Generally, the Bar Association's criticism comes down to the conclusion that the legal profession is unique, has its own issues that are distinguishable from the accountancy profession and therefore 'deserves' separate Disciplines. It will be no surprise that similar beliefs are held by members of other professions. A good example of this view is the position of the CCBE, the Council of European Bar Associations, which states: 'The paper recommends that lawyers should not be subject to the Accountancy Disciplines with a few phrases added on for lawyers, but that the changes require an entirely separate set of disciplines for lawyers (albeit that there will be substantial overlap in content with the Accountancy Disciplines)'; CCBE (2003), p. 2.

1442 Ibid.

1443 Service sectors are specified in the so-called W/120 list: MTN.GNS/W/120, 10 July 1991, see Footer \& George (2005), pp. $913 \mathrm{ff}$.

1444 That means that a Member actually starts with a clean slate. The approach is 'top down' in the sense that where a Member does schedule a service sector, it must completely liberalise this sector unless it has scheduled specific limitations. See Footer \& George (2005), p. 821.

1445 Article XVI (1) reads as follows: 'With respect to market access through the modes of supply identified in Article I, each Member shall accord services and service suppliers of any other Member treatment no less favourable than that provided for under the terms, limitations and conditions agreed and specified in its Schedule.'

1446 Given that no further reservations have been made by that Member State in its Schedule. 
paragraph 2 of Article XVI GATS. ${ }^{1447}$ The second rule contained in Part III of the GATS is the so-called 'national treatment' rule, laid down in Article XVII GATS. ${ }^{1448}$ Unlike Article XVI, on market access, the national treatment rule of Article XVII GATS does not contain a list of measures that would constitute a violation of this rule. ${ }^{1449}$ In essence the national treatment rule, just like the MFN treatment rule, is a non-discrimination rule.

With regard to the Schedule it must be mentioned that there is only one Schedule of Specific Commitments for all the Member States of the European Community. ${ }^{1450}$ What has become problematic is that more States have joined the European Union since the Schedule of Specific Commitment entered into force. Within the scope of this book, that holds true for Austria, Finland and Sweden. They are now an integral part of the European Union yet differences in drafting of the Schedule result in a situation were they are more often mentioned than other Member States in the remainder of this paragraph. In general, a Schedule consists of two different parts. ${ }^{1451}$ First, there is the horizontal part which lists exceptions that are applicable to all services contained in the Schedule. Secondly, there are the sector-specific commitments which list the legal regime for that specific sector. With regard to the European Union it is worth mentioning that all fifteen Member States reviewed in this book have scheduled legal services on their Schedule, and all Member States to a greater or lesser extent have therefore entered into legal obligations with regard to international trade in legal services.

As was indicated earlier, the GATS does not contain any definition whatsoever for 'legal services'. It is therefore paramount to determine the scope Member States have given to the legal services they have scheduled. From the Schedule of the European Community, it immediately becomes clear that only a very limited scope has been given to the legal services scheduled. The European Community commits itself to services consisting of legal advice on home country law and public inter-

1447 Footer \& George (2005), p. 846. Prohibited measures are laid down in paragraph 2 of Article XVI GATS and read as follows:

- Limitations on number of suppliers.

- Limitations on total value of service transactions or assets.

- Limitations on operations or total quantity of service output.

- Limitations on value of transaction

- Measures which restrict the type of legal entity through which services may be supplied.

- Limitation on the participation of foreign capital or investment.

1448 Article XVII (1) GATS states: 'In the sectors inscribed in its Schedule, and subject to any conditions and qualifications set out therein, each Member shall accord to services and service suppliers of any other Member, in respect of all measures affecting the supply of services, treatment no less favourable than that it accords to its own like services and service suppliers'.

1449 Although limitations of the national treatment rule often contain the following aspects:

- Nationality or residence requirements for executives.

- Requirements to invest a certain amount of assets in local currency.

- Restrictions on the purchase of land by foreign service suppliers.

- Special subsidy or tax privileges granted to domestic suppliers.

- Differential capital requirements and special operational limits applying only to operations of foreign suppliers.

See Van den Bossche (2005), p. 365.

1450 Adamson (1998), p. 184.

1451 See very extensively on Scheduling: Footer \& George (2005), pp. 845-865. 
national law (excluding EC law). ${ }^{1452}$ There are a few elements that need further elaboration. ${ }^{1453}$ First of all, the commitments scheduled only relate to legal advice, not (as a most striking difference) to the representation of a client in legal proceedings or before a court, nor the drafting of certain documents. Since legal advice is only part of the lawyers' professional monopoly in some Member States, this commitment seems to be rather insignificant. With regard to all other activities normally part of the professional activities of a lawyer, no legal commitments under Part III of the GATS exist, since they are not scheduled. Secondly, although not specifically mentioned, it must be assumed that 'home country law' refers to the 'home country' of the service provider who enters the territory of one of the Member States of the European Union. ${ }^{1454}$ It must now be examined, to what extent this already very limited commitment is further limited by specific commitments made in the remainder of the Schedule.

With regard to market access some specific commitments have been made by the European Community and its Member States. With regard to the first mode of supply, i.e., the cross-border provision of services (where neither the provider nor the recipient of the service crosses a border) the European Community has made no specific reservations, except for France and Portugal which remain unbound for the drafting of legal documents. ${ }^{1455}$ Austria, Finland and Sweden also make no further exemptions, except for Sweden which states that lawyers providing services in Sweden may not use the Swedish professional title. With regard to the second mode of supply, none of the Member States concerned have entered specific exemptions to their Schedule, so they all remain fully bound to allow the consumption of legal services abroad. With regard to the third mode of supply, ${ }^{1456}$ i.e., the commercial presence of legal entities from other Members (not being EU Member States) on the territory of the Member States of the European Union there are some specific exemptions. Both France and Germany only allow commercial presence in specific legal forms, which are indicated on the Schedule. Moreover, Germany requires membership of a Bar Association under the requirements laid down in the Federal

1452 EC Schedule. Austria and Sweden have committed themselves to a similar commitment although they have not specified 'international law' (i.e., private or public) and Sweden has not excluded EC law from 'international law'. Finland has not specified 'legal advice' but merely states 'international and home country law'. It must be assumed however, that bringing other activities than legal advice into the realm of 'international and home country law' is a merely academic exercise.

1453 The Horizontal Part mentions that a 'glossary' is attached to the Schedule. From that 'glossary' it becomes clear that Italy has not included legal services in the definition of 'services' as such. See Adamson (1998), p. 185. I am of the opinion that such an action does not exonerate Italy from commitments in this sector, since any exemption should appear on the Schedule itself. Italy will therefore be treated similar to the other Member States.

1454 Here the Damocles' Sword regarding 'likeness' comes into play. To what extent can legal advice on two different legal systems be seen as 'like' services in the sense of Article II and XVII GATS?

1455 In my opinion it is doubtful whether drafting of legal documents even forms part of legal advice, but the two Member States concerned seem to create some extra certainty and explicitly exempt it from their commitment.

1456 There are very detailed provisions in the horizontal section of the Schedules which go beyond the scope of this chapter to review in detail, but which considerably limit possibilities under this mode of supply. 
Lawyers Act. Austria remains completely unbound to this commitment. Finland requires citizenship and residence when services are provided by a individual as a member of the General Bar Association. Sweden once again reserves its professional title for those persons who are members of the Swedish Bar Organisation. ${ }^{1457}$ With regard to the fourth mode of supply, the presence of natural persons in the territory of the European Union, the Member States remain generally unbound except for what is set out in the horizontal part of the Schedule. The horizontal part of the Schedule commits to very little, and at first sight it does not commit to allowing natural persons who come to provide legal services (except perhaps combined with the third mode of supply). In addition to that general commitment, there are also additional exemptions for specific Member States. Greece adds conditions of nationality to the conditions set out in the horizontal part of the Schedule, Luxembourg remains completely unbound to the fourth mode of supply, and France excludes the activities scheduled for persons who are not members of the French legal profession. Austria only allows service providers in its territory at the request of a consumer in order to supply a specific service. Finland and Sweden remain unbound to the fourth mode of supply except for what is indicated in the horizontal part of their Schedule, which are largely identical to the horizontal parts of the Schedule of the European Community.

With regard to the National Treatment rule, there are some specific limitations laid down in the Schedule of Specific Commitments. All Member States commit themselves to adhere to the National Treatment rule with respect to the first mode of supply, except for France, Portugal and Denmark. France and Portugal have listed a similar exemption to National Treatment as they had with regard to Market Access: they remain unbound for the drafting of legal documents. With regard to Denmark, the exemption is more significant. Denmark lists in the National Treatment column in connection to mode one, that the marketing of legal advice activities is restricted to lawyers with a Danish licence to practise and to law firms registered in Denmark. This exemption seems to put any 'foreign' (not including lawyers from EU Member States) lawyer at a great competitive disadvantage. Austria states that foreign legal advisors must be a member of their national Bar Association ${ }^{1458}$ and they may use their professional title only in combination with a reference to the place of registration in their home country. ${ }^{1459}$ Finland has made no exemptions to the first mode of supply, while Sweden states that in order to use the Swedish professional title the person concerned needs to be a member of the Swedish Bar Association. ${ }^{1460}$ Similarly, to the Market Access provision, no further exemptions were made with regard to the second mode of supply, which indicates that members are fully committed to awarding national treatment to consumption of legal services abroad. Since this

\footnotetext{
1457 Finland and Germany and Sweden seem to misunderstand the third mode of supply since it does not cover natural persons. To the best of the author's knowledge, law-firms cannot be members of a Bar Association.

1458 Which might be problematic for countries that have not regulated the provision of legal advice, like the Netherlands, or countries that make it possible to practice as a lawyer without being a member of the Bar, like in Finland.

1459 Which is comparable to the rules under Directive 98/5/EC.

1460 Which requires education, passing examinations, citizenship and residence.
} 
seems to have no impact on the free movement of lawyers as such, Member States seem to have little or no problems awarding national treatment.

The Member States of the European Union that were included in the EC Schedule also make no exemptions with regard to the third mode of supply, ${ }^{1461}$ apart from Denmark which reiterates that marketing of legal advice activities is restricted to law firms registered in Denmark. Denmark then states that only lawyers with a Danish licence to practise may own shares in a Danish law firm. Only lawyers with a Danish licence to practise may sit on the Board, or be part of the management, of a Danish law firm. Austria remains unbound to the third mode of supply with respect to National Treatment. Finland has made no exceptions, whereas Sweden has entered the same exception in order to protect the national professional title.

With regard to the fourth mode of supply, presence of natural persons, the European Union remains unbound except for what is listed in the horizontal section of the Schedule. The horizontal section of the Schedule states, among other things, that the European Union remains unbound to the fourth mode of supply except for the categories of persons mentioned under mode four with regard to Market Access. ${ }^{1462}$ In addition to that, the Schedule mentions further that European rules on diploma recognition do not apply to lawyers originating from other countries, except where Community law provides otherwise. In addition to the horizontal exemptions, Denmark has once more reiterated that marketing of legal advice activities is restricted to lawyers with a Danish licence to practise. In addition, it is mentioned that taking a Danish legal examination is necessary in order to obtain such a licence. Austria remains unbound to this mode of supply, except for the temporary presence of natural persons at the request of a consumer in order to provide a specific service. Such a natural person must also be a member of the national Bar Association and he must use his home country professional title as well as a reference to the place of registration in the home country. Finland has made no exceptions to the fourth mode of supply, but it must be assumed that National Treatment is only available to those who are allowed to enter under the Market Access provisions, where Finland remains largely unbound. ${ }^{1463}$ Sweden remains unbound except to the provisions listed in the horizontal section of the Schedule, which states that Sweden remains unbound, except for those natural persons who are allowed to enter the market on the basis of the Market Access provision. In addition to that, Sweden has again included a provision that is intended to protect the Swedish professional title. In conclusion, it is important to mention once again that with regard to National Treatment, and comparably to Market Access, an already very limited commitment is limited even further by extensive exemptions made by Member States. ${ }^{1464}$

1461 Similarly to the Market Access provision, there are some very detailed and far reaching exemptions in the horizontal section of the Schedules that significantly limit possibilities under this mode of supply.

1462 Where doubts were already raised whether or not a lawyer would fit this description.

1463 Although not specifically mentioned in the National Treatment column for legal services, Finland states in its horizontal commitments that National Treatment provisions are only available to those who are allowed access under Market Access provisions.

1464 Two members have scheduled additional commitments. Both France and Luxembourg have scheduled that host country law and international law (including European law) is available to lawyers who are entitled to practice as a member of the legal profession of France and Luxem- 
After taking a detailed look at the Schedule of Specific Commitment of the European Union, it becomes clear that the commitments made by the Union can in no way be compared with the system of the free movement of lawyers which has been developed within the framework of the European Union. Compared with the European system, the commitments made under the GATS are not even comparable to what is laid down in the Lawyers Services Directive (Directive 77/249/EEC) alone, which allows the provision of legal services on a temporary basis in another Member State of the European Union.

The last part of the GATS (Article XIX GATS) requires Members to enter into in successive rounds of negotiations no later than five years after the coming into force of the WTO agreement in order to achieve even more liberalisation in the field of international trade in services. ${ }^{1465}$ This built-in agenda is referred to as GATS $2000 .{ }^{1466}$ These negotiations began in 2000 and were continued as part of the Doha Development Round negotiations. The Doha Development Round was supposed to be concluded by 1 January 2005 but was subsequently extended. Since July 2006, the Round has been indefinitely suspended. It is important to understand that the Doha Rounds covers GATS in its entirety and attempts to extend it beyond legal services. It might even be concluded that legal services receive only limited attention in the Doha Rounds. ${ }^{1467}$ Some nine countries have submitted negotiation proposals that either directly or indirectly address the situation regarding trade in legal services. ${ }^{1468}$ It was already established above that the classification system used in the GATS, the so-called W/120 list based on the UN Classification System, was unsatisfactory for legal services, since a clear definition of legal services could not be given. Many of the proposals given for GATS 2000 therefore address the absence of a definition and various different classification systems have been proposed. ${ }^{1469}$ It seems that none of these have been successful up until now, since the conditional revised offer of the European Union ${ }^{1470}$ still uses the classification system based on the W/120 list.

After having established that the scope of the GATS rules falls far below that what is achieved under the freedom of movement of lawyers in Europe, it must now be questioned whether third-country nationals can invoke these meagre rights when seeking to exercise legal activities in a Member State of the European Union.

bourg respectively. It is unclear to the author why France and Luxembourg have found it necessary to schedule these commitments, since they actually fall outside the scope of the general commitment, which only commits to advice on home country law and international law excluding European Community law. For the purposes of the Schedule, France and Luxembourg, and all the other Member States for that matter, are free to impose rules on all other services falling outside the commitment.

1465 Footer \& George (2005), p. 854.

1466 Terry (2002), p. 45.

1467 See also: Cone III (2003), pp. 29-47.

1468 Terry (2002), p.46.

1469 Terry (2002), pp.46-47. See also: Cone III (2003), pp. 29-47.

1470 Via <europa.eu.>, last accessed 1 May 2006. 


\section{$\$$ 6.3 Applicability of GATS Rules for Third-Country Nationals}

At the beginning of this paragraph it was established that third-country nationals could only in certain restrictive circumstances rely on the European rules for the free movement of lawyers. In the previous subparagraph, it was established that the GATS offers (albeit severely limited) rights for lawyers from WTO Members, not being EU Member States, to exercise their profession within the territory of the European Union. The question remains whether third-country nationals can actually rely on these rights before a national court at times when a Member State of the EU denies them the enjoyment of these rights. That is where an insurmountable hindrance occurs. In the case law of the European Court of Justice it is a well established principle that the WTO agreement and other additional agreements (GATT; GATS, TRIPS and DSU) have no direct effect and therefore cannot be relied on directly by individuals. ${ }^{1471,} 1472$ That means that the rules laid down in GATS remain on the international plane and only affect the Members of the WTO rather than their citizens. This is reinforced by the fact that the dispute settlement system under the WTO is only accessible for Members. Individuals have no standing in the dispute settlement system of the WTO itself, and although de facto possible, it would be highly unlikely that two Members of the WTO would initiate proceedings under the DSU against each other based on the sole fact that an individual lawyer could not exercise the rights guaranteed to him by the GATS.

The harsh conclusion of the GATS is that it is useless for third-country nationals who seek to exercise legal activity in a Member State of the European Union. In a review of the rules in force in Member States it is shown that there is at least the possibility for a considerable softening of this conclusion.

\section{\6.4 Establishment Rights for Third-Country Nationals: The German Example}

It would go far beyond the scope of this book to give a full overview of the position of third- country national lawyers in all the Member States reviewed. The

1471 Cases C-149/96, Portugal v. Council [1999] ECR I-8395; C-307/99, OGT Fruchthandelsgesellschaft mbH v. Hauptzollamt Hamburg-St. Annen [2001] ECR I-3159; C-27/00 and C-122/00, The Queen v. Secretary of State for the Environment, Transport and the Regions, ex parte Omega Air Ltd (C-27/00) and Omega Air Ltd, Aero Engines Ireland Ltd and Omega Aviation Services Ltd v. Irish Aviation Authority (C-122/00) [2002] ECR I-2569; C-76/00, Petrotub SA and Republica $S A$ v. Council of the European Union [2003] ECR I-79; C-93/02 Biret International SA v. Council of the European Union [2003] ECR I-10497 and C-377/02 Léon Van Parys NV v. Belgisch Interventie- en Restitutiebureau (BIRB) [2005] ECR I-1465. In earlier case law, which seems to have been overturned by the cases mentioned above, the ECJ had accepted a very limited direct effect for the GATT 1947. See cases: Case 70/87, Fediol v. European Commission, [1989] ECR 1781; Case C-69/89, Nakajima v. Council, [1991] ECR I-02069. See also: Hartley (2004), pp. 243-251.

1472 So even a lawyer who is a third-country national (e.g., a US national) and who suffers from a GATS violation by the EU or one of its Member States cannot rely on the rules of GATS in a procedure before a national court or the ECJ. 
treatment of third-country national lawyers lacks coherence and warrants a complete study on its own. In the review of the different Directives it has been observed, for example, that Member States offer more extensive rights in the form of easier integration to lawyers from former colonies. One practice created specifically for thirdcountry nationals must not be ignored. This is the case since the approach is not country specific in the sense that it does not depend on historical ties between certain countries and is complete in its coverage. Therefore, it could serve as a 'best practice' example in dealing with third-country national lawyers. This example is that of Germany. Germany allows lawyers from all other WTO Members (and even non-Members in certain circumstances) to establish themselves under their home country professional title. When established they may employ activities in the law of their home State and with regard to international law. Although this is not as far reaching as the establishment under home title for European lawyers, it does however go far beyond the rights for lawyers that can be established under the GATS, as WTO lawyers may not occupy themselves with German law, European law or the representation of clients in court.

The 'best practice' in this sense is that Germany sends out a strong signal of mutual recognition, even to lawyers from outside the European Union, and allows for their establishment (rather than services) on a permanent basis in Germany, albeit with considerable restriction on the professional activities they may exercise. This provides third-country nationals with even greater rights than those which can be guaranteed on the basis of European rules applicable to third-country nationals. Limited integration into the host country can lead to situations where the lawyers over this period of time actually gain certain knowledge of the legal system of the host Member State (where he lives and works) and thus prepares for a review of his professional qualifications under the Haim and Hocsman cases (observed above). In this sense, Germany could serve as an example for other States and, perhaps for a future European regime (in the Area of Freedom, Security and Justice) in the field of free movement of third-country lawyers.

\section{$\$ 6.5$ Observations and Conclusions}

It has been observed that the protection offered to third-country nationals under the regime of the free movement of lawyers falls considerably short of the protection of awarded to European lawyers. Only in two distinct situations, as family members of European citizens who exercise their free movement rights, or as the holder of LTR status on the basis of Directive 2003/109/EC, can third- country nationals establish a right to non-discrimination with regard to the recognition of professional qualifications. This does not mean, however, that the Directives are directly applicable. Only in cases where the third-country national lawyer is a fully qualified lawyer in the sense of the Services or the Establishment Directive, or if the third-country national has qualifications that allow him to exercise a regulated profession in a Member State can he rely on the Directives. Otherwise he will be dealt with according to the rules laid down for European Union citizens with third-country qualifications.

That the GATS lays down rules on the trade in legal services is, unfortunately, of no avail for third-country national lawyers. It has been established that the rules laid down in GATS fall short even of the acquis of the Services Directive, the least 
intensive mode of free movement of lawyers in Europe. In addition, and more importantly, the European Court of Justice denies direct effect to WTO rules, which leaves those rules firmly on the international inter-State plane, and therefore without use for individuals seeking to rely on these rules.

This does not mean that third-country national lawyers are without rights in the different Member States. There are rules in force, however patchy and incoherent they may be. A number of States, for example, offer extensive rights to lawyers coming from ex-colonies. Germany has another, more coherent system in which it gives limited establishment rights to lawyers from other WTO Members (and even nonMembers). This system has been put forward as a 'best practice' and can serve as a base for other states or for a European mechanism awarding more substantial rights to third- country national lawyers.

\section{\$ 7. Observations and Conclusion}

This chapter has attempted to give an overview of the actual implementation of the model that was established in the previous chapter. It was established that only in that way could an answer be provided on how the system actually works, rather than remaining on a level of assessing how the system ought to work. To this end, the fifteen Member States have implemented the three main modalities; the freedom to provide services, the establishment under home title, and the full integration into the profession of the host State, on the basis of the Diploma Directive. Unlike the previous chapter, in which these modalities were presented in chronological order, here they were dealt with according to the degree of integration offered into the host Member State.

Application of two of the three modalities was seen to be dependent on the beneficiary being fully qualified as a lawyer in one of the Member States. This requirement called for a closer look at the different professions of the lawyer in the different Member States. It was established that the different professions differ considerably, and a broad threefold division was established on the basis of professional activities that are legally reserved for lawyers in that specific Member State. A number of northern Member States, namely Sweden and Finland have no legal monopoly for lawyers. That means that activities in connection to the representation of clients and the giving of legal advice can be exercised by non-lawyers freely. A second group, consisting of the United Kingdom, Ireland, the Netherlands and Belgium, with Denmark as a borderline case, reserve the representation of clients in court for lawyers but do not restrict activities in connection with legal advice. The largest group (Denmark, Luxembourg, France, Italy, Spain, Portugal, Germany, Austria and Greece) reserves both activities for lawyers. This threefold division was shown to indicate something very intresting, namely that in the countries with a low or intermediate level of regulation there is a 'hidden' group of professionals who legitimately exercise legal activities in their home Member State but who are 'invisible' on a European level, because they cannot benefit from direct application of the Directives. Recent developments have, however, improved their situation.

With regard to the freedom to provide services and the recognition of professional qualifications, it has been observed that the new Diploma Directive 2005/36/EC 
covers the situation of those legal professionals who exercise activities in Member States with a low or intermediate degree of regulation, but who are not lawyers. According to the Directive, Member States (with a high degree of regulation) may not impose restrictions on professional qualifications on these people if they can prove that they have exercised their profession for at least two years in the previous ten years in the home Member State. Other restrictions fall under the scheme of case law where restrictions have to be objectively justified. After 2009, other restrictions will fall under the Directive on Services in the Internal Market, Directive 2006/123/ EC. Persons previously exercising legal activities in countries with low or intermediate degrees of regulation can integrate into the profession of Member States with a high degree of regulation if certain criteria are fulfilled. Member States may in this case impose an aptitude test which would principally cover the entire legal profession of the host Member State. Based on recent case law, however, these professionals can request a limited entry, and therefore a limited aptitude test, in the profession of the host Member State. With regard to the establishment under home country professional title, it was observed that there are no rules in secondary legislation which cover the establishment of non-lawyers under their home country professional title in other Member States. The only rules that are available to them are the general rules laid down in case law such as Vlassopoulou and Gebhard. It has been observed that this situation is akin to the situation lawyers like Gebhard found themselves in before adoption of the Establishment Directive, and in the future a new version of the installation limitée might well emerge for this category of non-lawyers.

With respect to fully qualified lawyers it must be observed that the adoption and implementation of the Establishment Directive, Directive 98/5/EC, has fundamentally changed the face of the system of the free movement of lawyers. Not only has the Establishment Directive taken its place in the system of the free movement of lawyers, it has also taken over functions that were previously covered by the other two Directives reviewed. With regard to the Services Directive it must be observed that the Establishment Directive has taken over the function of the Services Directive that was dubbed as installation limitée. This is not surprising since installation limitée was an extension of the scope of the Services Directive over the material scope of application of what would later become the Establishment Directive. Installation limtée has become superfluous after the implementation of the Establishment Directive (at least with regard to fully qualified lawyers). The effect the Establishment Directive had on the other side of the spectrum, i.e., the full integration into the profession of the host Member State, is more substantial. It was observed that the Establishment Directive offers a method of integration into the host Member State's profession, essentially through the mere passage of time whereby the dreaded aptitude test that was maintained in the new Diploma Directive 2005/36/EC can be avoided. This leads to a situation in which the Diploma Directive has only residual importance for the free movement of lawyers, and the integration into the host Member State function is thus primarily covered by the Establishment Directive. The integration into the profession of the host Member State on the basis of the Diploma Directive is only relevant for those lawyers who have enough previous knowledge of the legal system of the host Member State to circumvent the aptitude test or to successfully finish the aptitude test (including preparation) in a period shorter 
than three years (the time it takes to integrate into the legal profession of the host Member State through the Establishment Directive).

With regard to the implementation of the Establishment Directive, it was established that the Directive has been implemented in the fifteen Member States without any major defects. Only in the Netherlands was it observed that integration into the Dutch legal profession through the Establishment Directive does not lead to full integration and thus the Establishment Directive is denied effet utile. This situation will be solved automatically by the abolition of the profession of the procureur in 2008. Minor defects in implementations were observed, mainly with regard to registration and the exercise of professional activities. One defect was prevalent in almost all Member States - the qualified application of host Member State professional rules with regard to joint practice (only when objectively justified) which has been reduced consistently to a national treatment clause, i.e. application of host Member State rules per se. In the previous part it was established that the rules with regard to joint practice that finally ended up in the Establishment Directive were already considerably weaker than the 'evangelistic' rules proposed by the CCBE in its draft (where lawyers could bring their home Member State rules with regard to joint practice, and could therefore lead the spreading of relaxed rules with regard to joint practice throughout Europe). The actual implementation of the rules on joint practice has led to an even weaker system whereby the lawyer who establishes himself falls prey to the professional rules of the host Member State on joint practice.

This observation, taken together with the observation that a lawyer who is established under his home country professional title basically exercises the professional activity of the host Member State under the professional rules of the host Member State, forces one to consider which profession a 98/5/EC lawyer is actually exercising. In the nullity case brought before it by Luxembourg, the European Court of Justice ruled that 98/5/EC lawyers were not a part of the host Member State's profession, and the fact that they used a different professional title and the fact that they could not independently represent clients in court distinguished their profession from the host Member State's legal profession. On the other hand, a 98/5/EC lawyer is also not exercising his home Member State profession (as his professional title might suggest) since he is exercising host Member State activities under host country professional rules. Actually, the use of professional title and the limitation on representing clients in court without the assistance of a domestic lawyer are the only things that distinguish a 98/5/EC lawyer from a host Member State lawyer. This leads to the conclusion that there is full mutual recognition of legal professions in Europe in all but name and with very limited restrictions on professional activity. Moreover, these last hurdles are taken away after little more than the passage of three years (even more so, since no integration requests on the basis of Article 10 Directive 98/5/EC have been denied $\left.{ }^{1473}\right) .{ }^{1474}$ It must therefore be concluded that the current system for the free movement of lawyers, but mainly the provisions under the Establishment Directive, leads to an almost full mutual recognition of the lawyer's

1473 Personal communication: email from CCBE to the author dated 25 September 2006.

1474 Accepting this conclusion also means that the ECJ should have ruled that the host Member State profession was affected by 98/5/EC and should subsequently have annulled the Directive on the basis of violation of an essential procedural requirement (i.e., wrong voting procedure in the Council). 
profession in Europe. It must also be concluded that this feat has been achieved without the difficult discussions that characterised the vertical system directives.

An important defect in the system lies in the treatment of third-country nationals. It has been observed that the system of European rules offers only very limited possibilities in limited circumstances, i.e., only where the third-country national is a family member of an EU citizen exercising his right of freedeom of movement or where the third-country national has gained LTR status. In those circumstances application of the model described above is still an exception, since the Services Directive and the Establishment Directive only apply to those who are fully qualified as lawyers in one of the EU Member States and the Diploma Directive only applies to qualifications obtained in the European Union. Third-country nationals are therefore likely to end up in a situation that is merely covered by case law. The international rules on the trade in legal services, laid down in the GATS, are of no avail to third-country nationals because the substantive rights of the GATS fall short of even the least intrusive modality in European law, the free movement of services. More importantly, individuals cannot rely on the GATS rules since they have been consistently denied direct effect. Individual Member States have systems in place to deal with third-country national lawyers. In this respect the German rules have been put forward as 'best practice' since they allow third-country nationals beyond the GATS and also beyond the European rules on establishment under home title in order to deal with their home country rules and international law, thus providing such lawyers with a possibility to prepare themselves for recognition and integration at a later stage (on the basis of European rules).

In conclusion it must be observed that with regard to fully qualified lawyers, a system of rules has been put into place that covers in entirety all the modalities of the free movement of these lawyers, and this has been done to such an extent that it warrants the observation that a true mutual recognition of the legal professions in Europe has been put in place. To a lesser extent that is also true for professionals who exercise legal professional activities in Member States with a lower degree of regulation and who seek to exercise that activity in a Member State with a higher degree of regulation. The position of third-country nationals is still (too) weak, and this category could benefit from an extension of the German approach towards their situation. An overall observation that must be made is that the system applies to fully qualified lawyers. It is easy to forget that it takes years to qualify as a lawyer in a Member State and it takes additional years to re-qualify as a lawyer in another Member State, so that it might take well over a decade from the point that a prospective lawyer starts his university education in a Member State to the point he can integrate into the profession of another Member State (either through an aptitude test or through integration after establishment under home country professional title). It might therefore be interesting to research whether an even more effective free movement of lawyers can be realised through the creation of free movement rights before a lawyer is fully qualified, i.e. during the qualification process. These, relatively uncharted, possibilities will be researched in the next chapter. 



\section{Chapter 4}

\section{Free Movement of Persons Seeking to Qualify as a Lawyer}

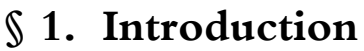

As was concluded in the previous chapter, the system of free movement that now prevails in Europe depends on qualification as a lawyer in one of the Member States. The Services Directive and the Establishment Directive apply exclusively to those persons who are fully qualified as lawyers in at least one of the Member States of the European Union. The secondary legislation on the model of free movement of lawyers, as described above, does not cover the preparatory stages of entrance into one of the professions. ${ }^{1}$ In the previous chapters it was observed that certain case law in the model does apply to those who are in the process of becoming a lawyer. The intention of this chapter is, firstly, to assess, more or less separately from the model described above, the rules applicable to those who are in the process of qualifying for the legal profession, and how their position relates to the case law that was described earlier. On the basis of that assessment recommendations will be made for an extension of the above model to include the qualification process.

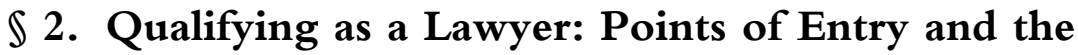 Problem of National Law}

As was established in the previous chapter, the qualification processes in the Member States reviewed are quite similar to one another. Apart from Spain, every Member State reviewed has a two-tier qualification process. The first phase of the qualification process is fulfilled by obtaining a university degree in law (except in the UK, where this is not compulsory, and the candidate can compensate for the absence by other means). The second phase (except in Spain, although de facto many lawyers follow the same route) is the following of a professional education, commonly consisting of a theoretical part, organised by the relevant competent authority (Bar Associations), and an in-house practical training under the supervision of a qualified lawyer. The theoretical part is concluded by a Bar exam. The theoretical part and the practical part may be separated (as was the case in France) or they may coincide (as is the case in the Netherlands).

This twofold division of the qualification track also provides for two distinct entry points for European Union nationals who seek to embark on the qualification process (and therewith seek to enter the legal profession) of another Member State. The first point of entry is after a candidate has finished secondary education and is

That is even true for the Diploma Directive 2005/36/EC as was illustrated in Case C-313/01, Christine Morgenbesser v. Consiglio dell'Ordine degli avvocati di Genova, [2003] ECR I-13467. 
due to commence university education. In this case, a prospective candidate can move to another Member State and start his or her university education in that State in order to obtain a law degree there. Students who are European Union nationals have a (conditional) right to free movement on the basis of Directive 2004/38/EC 2 so that they are entitled to enter and reside in other Member States in order to undertake their studies there. In addition, students will need to have their secondary education qualifications recognised. There are no European Union rules on the recognition of secondary education qualifications for the benefit of access to university education, so from a European Union point of view this competence remains with the Member States. The Member States, at least the fifteen Member States reviewed, committed themselves at a very early stage to facilitate entry of each other's nationals into their universities. In 1953 a Council of Europe Convention was concluded which stated in a very concise manner that members shall recognise the equivalence of qualifications that give access to university education. ${ }^{3}$ This has come to be known as the Paris Equivalence Convention, and has now been largely replaced by the Lisbon Recognition Convention (discussed below), but the latter has not been ratified by a number of the Member States reviewed. As a result, the Paris Equivalence Convention is still relevant for those Member States who have not ratified the Lisbon Recognition Convention (also in relation to States that have ratified the Lisbon Recognition Convention themselves). Recognition on the basis of the Paris Equivalence Convention is unconditional and does not provide for exceptions on difference in content. The only negative factor concerning entrance at this point is the fact that prospective candidates are mostly still quite young. It is doubtful that many candidates, who are just on the verge of adulthood, would be ready to make the decision to move away from home to another Member State in order to start a legal career there.

How the assessment of equivalence takes place is up to the Member States, and it falls outside the scope of this book to review all the mechanisms in place. It suffices to state at this point that the Dutch agency Nuffic has gained a reputation in Europe for, among other things, the assessment of equivalence of secondary education qualifications. On its website is a database which contains a wealth of information on this subject. $^{4}$

The second point of entry for prospective lawyers is after the completion of university education. Candidates may ask for entry into the qualification track based upon the university education they completed in their home Member State. Once again, there is no European Union legislation that directly covers the situation of (prospective) lawyers in this respect. As will be assessed below, the Lisbon Recognition Convention covers this matter, but integration at this point will be far more difficult

2 Directive 2004/38/EC of the European Parliament and the Council of 9 April 2004 on the right of citizens of the European Union and their family members to move and reside freely within the territory of the Member States [2004] OJ L 158/77. For students specifically, see Article 7(1c) Directive 2004/38/EC.

3 European Convention on the Equivalence of Diplomas leading to Admission to Universities, Paris 11-12-1953, CETS no. 015. The same subject matter is also covered by the Lisbon Recognition Convention (CETS no. 165) which will be addressed below, but which is not ratified by a number of Member States.

4 <www.nuffic.net/diplomawaardering/extranet/kenmerken.html>, last accessed 28 April 2008. 
than at the first stage. Generally, as was indicated above, the competent authorities require a law degree from a domestic university. Sometimes requirements are even laid down by law, as is the case in countries such as Germany and the Netherlands. Access at this level is difficult because the national law degrees concentrate primarily on national law. While substantial differences existing at secondary school level do not cause great concern (explaining the more or less automatic recognition under the Paris Equivalence Convention), it becomes more difficult to disregard these differences for prospective lawyers after their university studies. It is for this reason that the Lisbon Recognition Convention also takes into account the possibility that there may be substantial differences between the degrees in cases where recognition is requested. On the other hand, candidates are older at this point, and are more able to make a conscious decision as to where they want to exercise their profession.

In the introduction of this book it was stated that the main problem in connection with the free movement of lawyers is the fact that Member States have different legal systems and that lawyers are predominantly educated in the legal system of their home Member State. This problem first becomes apparent during university studies because law degree programmes are almost exclusively directed towards the study of the national law. Free movement before this problem arises (i.e., before a candidate starts his or her university studies) is not a realistic option due to the age of the persons involved. So the origin of the problem with respect to the free movement of lawyers lies in the qualification track, more specifically during university studies, where students, through qualifying themselves as experts of the national law, more or less disqualify themselves from free movement.

\section{\3. European Union Rules Affecting the Qualification Track for Lawyers}

As stated above, there are no legislative measures for the integration or recognition of the qualification track for lawyers; there are no measures of secondary legislation that cover this matter. The main reason for this absence is a result of Article 149 of the EC Treaty. This Article was introduced by the Treaty of Maastricht, and governs the precarious relationship between the Member States and the European Community with respect to matters concerning education. Although the Article recognises that the Community and the Member States have a shared competence in the area of education, the Article very clearly prohibits harmonisation in the field of higher education. ${ }^{5}$ This means that any initiative on the part of the Union is limited and falls short of actual harmonisation measures. According to Article 149 of the Treaty, the European Union's actions are limited to supporting and supplementing the actions of the Member States, with full respect for the responsibility of the Member States to manage their own education systems. In Section 4 of the Article, it is explicitly mentioned that harmonisation measures are excluded from the possible actions the European Union is to adopt in this context.

5 Lenaerts (1994), pp. 7-41. See also: Lenaerts \& Van Nuffel (2005), pp. 306-308; Shaw (1992); Verbruggen (2003) and De Witte (1989). 
This harsh conclusion does not mean, however, that there has been no activity in the field of education, but rather that that activity has been limited to the free movement of students in a technical sense. This free movement has seen a considerable development throughout the process of European integration. ${ }^{6}$ Initially, rights in connection with education were only available for workers (albeit in a limited manner) and those who additionally benefited from workers' rights. No separate free movement of students was available within the framework of the European Community. That right of free movement, as was and is the case with so many developments in the European Union, was initially recognised and developed by the European Court of Justice in cases like Forcheri, ${ }^{7}$ Gravier, ${ }^{8}$ and Raulin. ${ }^{9}$ It was not until the 1990s that a separate right of free movement of students was recognised in secondary legislation. ${ }^{10}$ In Directive $93 / 96^{11}$ a right of residence was granted to students from other Member States who could prove that they were enrolled in a recognised educational establishment in the host Member State, ${ }^{12}$ that they had enough financial resources to avoid becoming a burden on the social security system of the host Member State and were fully covered by medical insurance. ${ }^{13}$ It is striking to see that the Directive required complete financial independence from students, and that it was even explicitly stated that the Member States are in no way obliged to financially support students who reside in their territory on the basis of the Directive. ${ }^{14,15}$ As of 1 May 2006, the free movement of students is governed by Directive 2004/38/EC. ${ }^{16}$ The rules in connection with the free movement of students are now laid down in Article 7(1c) of Directive 2004/38 but do not differ from the regime that was laid down in Directive 93/96. Subsequently Directives were adopted to regulate the free movement of students who are third-country

6 For a detailed overview of the development of the free movement of students, together with extensive references, see Van der Mei (2001), pp. 393-472 and Craig \& de Burca (2007), pp. 862-866.

$7 \quad$ Case 152/83, [1983] ECR I-02323.

$8 \quad$ Case 293/83, [1985] ECR I-00593.

9 Case C-375/89, [1992] ECR I-01027.

10 First in Directive 90/366, and after that directive was nullified by the European Court of Justice because of an incorrect legal basis, in Directive 93/96, which was a duplicate of the earlier Directive. Nowadays the right to free movement of students is laid down in Directive 2004/38/EC.

11 Council Directive of 29 October 1993 on the right of residence for students (93/96/EEC), OJ 1993, L 317/59.

12 The Directive did not, however, contain provisions on how such a student would become enrolled in such an institution.

13 Article 1 Directive 93/96/EEC.

14 Article 3 Directive 93/96/EEC.

15 The European Court of Justice, however, decided in the Grzelczyk case (Case C-184/99, Rudy Grzelczyk v. Centre Public d'Aide Sociale d'Ottignes-Louvain-la-Neuve CPAS, [2001] ECR I-6193) that under certain circumstances a person residing in a Member State under the regime of Directive 93/96/EEC may rely on social assistance benefits based on the non-discrimination provision derived from European citizenship. See, in this respect also, the Bidar case (Case C209/03, The Queen ex parte Danny Bidar v. London Borough of Ealing, Secretary of State for Education and Skills, [2005] ECR I-02119), where the European Court of Justice relies on European citizenship in order to create a right for a foreign student to a maintenance grant.

16 Directive 2004/38/EC of the European Parliament and of the Council of 29 April 2004 on the right of citizens of the European Union and their family members to move and reside freely within the territory of the Member States, OJ 2004, L 158/77. 
nationals ${ }^{17}$ and to liberalise the mobility of third-country national researchers. ${ }^{18}$ From a technical perspective, these measures only apply to students, so that candidates seeking to move in order to make use of the second point of entry are not even covered by the rules on the free movement of students, and it could even be doubted whether these people have a right to free movement to begin with. Luckily, this potential bomb was defused by the European Court of Justice in the Kranemann case, ${ }^{19}$ when it ruled that a trainee lawyer could benefit from the free movement of workers.

Even though there is such limited jurisdiction for the Institutions of the European Union, the subject of education became of major importance to the Union when the European Council set a strategic goal to become the most competitive knowledge-based economy in the world. ${ }^{20}$ This so-called Lisbon Strategy has generated a considerable amount of policy papers and other 'soft law' that is intended, in the wording of Article 149 of the EC Treaty, to supplement and support national policies in this field. ${ }^{21}$ This complemented policies already in place to promote mobility of students through programmes such as Socrates and the Leonardo da Vinci subsidy programmes. ${ }^{22}$ It is by no means the intention of this paragraph to give an extensive overview of the actions of the European Union in the field of education. The soft law will not be reviewed. ${ }^{23}$

None of these developments actually addresses the mutual recognition of university diplomas and diplomas giving access to university since this is deemed to reside under the Member States sovereignty under Article 149 of the EC Treaty. ${ }^{24}$ As was shown in Chapter 2 of this book, it is clear that the European Court of Justice does not necessarily keep to this strict division of power. Chapter 2 indicated that the European Court of Justice encroached upon the rules of academic recognition in force in the recent cases of Morgenbesser, Commission v. Austria and Commission v. Belgium.

17 Council Directive 2004/114/EC of 13 December 2004 on the conditions of admission of third-country nationals for the purposes of study, pupil exchange, unremunerated training or voluntary services, OJ (2004) L 375/12.

18 Council Directive 2005/71/EC of 12 October 2005 on a specific procedure for admitting third-country nationals for the purposes of scientific research, OJ (2005) L 289/15.

19 Case C-109/04, Karl Robert Kranemann v. Land Nordrhein-Westfalen, [2005] ECR I-02421.

20 Presidency Conclusions, Lisbon European Council 23/24 March 2000, \$5. <ue.eu.int/ue Docs/cms_Data/docs/pressData/en/ec/00100-r1.en0.htm>, last accessed 23 February 2006.

21 For example: Report from the Education Council to the European Council adopted by the Education Council on 12 February 2001; Working Programme Education and Training 2001, [2002] OJ C 142; 'Mobilising the Brainpower of Europe: enabling universities to make their full contribution to the Lisbon Strategy', COM (2005) 152 final; 'The role of universities in the Europe of knowledge', COM (2003) 58 final; and 'Working together for growth and jobs: a new start for the Lisbon Strategy', COM (2005) 24.

22 See Van der Mei (2001), pp. 408-409.

23 As was already indicated in Schneider \& Claessens (2005), p. 164, the European Union lacks a holistic approach in these cases. The clear link between professional recognition and academic recognition is ignored completely in the policy documents regarding education, whereas in the context of free movement the European Court of Justice really encroaches on this matter. A detailed review of the soft law concerning education therefore falls outside the scope of this book.

24 Although encouraging the mutual recognition of academic diplomas is mentioned as a goal of Community action in $\$ 149(2)$, close reading of $\$ 149(1)$ leads to the conclusion that Member States' sovereignty is not affected. 
In order to clearly assess the impact of these cases on the rules of recognition in force, it must first be established which of the rules are applicable in this situation. In recent years, the Member States have decided to standardise these rules in a process that takes place outside the realm of the European Union, the so-called 'Bologna Process'.

\section{$\$ 4$. Creating an Area for Higher Education in Europe: The 'Bologna Process'}

The most remarkable development with respect to higher education in Europe has taken place over the last few years completely outside the framework of the European Union. This development is often referred to as the 'Bologna Process' ${ }^{25}$ It will not be the purpose of this paragraph to ponder over, or to criticise this process, but rather to assess its impact on the free movement of lawyers, whether it be positive or negative. ${ }^{26}$

As said above, competence in the area of educational systems remains firmly in the hands of Member States, and the European Union has no power as such to create secondary legislation for these subjects. It is therefore even more remarkable that those same Member States, who have always defended, and continue to defend, their own interests in educational systems in what has been described as a jealous manner, ${ }^{27}$ have decided to actively create a European Area of Higher Education which completely reforms the structure of higher education in Europe. ${ }^{28}$

The process of reforming higher education in Europe through the 'Bologna Process' was initiated in France in 1998 with the so-called 'Sorbonne Joint Declaration'. ${ }^{29}$ In that declaration, the Education Ministers of France, Germany, Italy and the United Kingdom stated their intention to create a uniform system of two cycles (an undergraduate and a graduate cycle) in order to make it easier for students to study abroad and to switch within, or between, cycles offered in different countries. ${ }^{30}$ This initiative was taken over by many more countries in the so-called 'Bologna Declaration'. ${ }^{31}$ In that declaration the then 29 signatory states agreed that they would reform their higher education systems in such a way that would facilitate the achievement of six goals that were defined in the Bologna Declaration. These goals were the following: adopt a system of easily understandable and comparable degrees; adopt a system of two main cycles (undergraduate/graduate); establish a system of

25 On the Bologna Process in general see extensively: Terry (2008).

26 For a healthy dose of scepticism see Schneider \& Claessens (2005), pp. 123-166 and Garben (2008).

$27 \quad$ Ibid.

28 For an extensive review see Terry (2008); Verbruggen (2003) and Witte (2006). For more specific issues, see Bell (s.d.); Breilat (2005); Lonbay (2001) B; Posch (2005) B; Terry (2006) and Terry (2007).

29 Sorbonne Joint Declaration, Paris 25 May 1998, via <www.bologna-bergen2005.no>, last accessed 21 March 2006.

30 There are other, less invasive, innovations, such as the introduction of the European Credit Transfer System (ECTS) credit system, which will not be discussed.

31 The Bologna Declaration of 19 June 1999, Joint Declaration of the European Ministers of Education, via <www.bologna-bergen2005.no>, last accessed 21 March 2006. 
credits (such as ECTS); promote mobility by overcoming obstacles; promote European cooperation in quality assurance; and promote the European dimensions in higher education. ${ }^{32}$ These six objectives were a considerable broadening and refinement of the goals compared with the Sorbonne Joint Declaration that had the reform of the European Higher Education systems into two-cycle systems as its focal point. ${ }^{33}$

Although the Bologna Declaration remains the most important document in the process of (re)forming the European Higher Education Area, some other documents require review in this context. In the Bologna Declaration, the signatories recognised the importance of ongoing supervision and support for the implementation of the system as it was proposed in the Declaration, and in consequence they decided to meet two years after the signing of the Declaration. ${ }^{34}$

The follow-up meeting took place in Prague in 2001, and resulted in a communique that was titled: 'Towards the European Higher Education Area' ${ }^{35}$ In that document the then 32 signatories of the Bologna Declaration reaffirmed their intention to reach the goals laid down in the Bologna Declaration. In addition to welcoming the active support of the European University Association, the National Unions of Students in Europe and the European Commission, the Ministers also furthered the six objectives of the Bologna Declaration with three more important elements, therewith enlarging the 'Bologna Process' from six to nine goals. The three new objectives were: emphasis on life-long learning, which was recognised as an essential element of the European Higher Education Area, ${ }^{36}$ emphasis on the involvement of students, and (perhaps more importantly) other higher education institutions other than universities; ${ }^{37}$ and lastly, emphasis on the promotion of the attractiveness and competitiveness of the European Higher Education Area to students from Europe and from other parts of the world. ${ }^{38}$ Again, the decision was taken to organise a follow-up meeting which was to take place two years after the Prague meeting, and in Berlin in 2003. ${ }^{39}$

The ministerial meeting in Berlin in 2003 resulted in yet another communiqué, this time titled: 'Realising the European Higher Education Area' ${ }^{40}$ In this communiqué, the now 33 signatories follow the same structure as they had done in the Prague communiqué, i.e., to report on the existing goals and to create new objectives for the European Higher Education Area. In addition to this process, the Berlin

32 See Basic Information (January 2004) The 'Bologna Process' - Towards the European Higher Education Area, <www.bologna-bergen2005.no/EN/Basic/Pros-descr.htm>, last accessed 7 April 2006.

33 Ibid.

$34 \quad$ Ibid.

35 'Towards the European Higher Education Area', Communique of the meeting of European Ministers in charge of Higher Education in Prague on 19 May 2001, <www.bologna-bergen 2005.no>, last accessed 7 April 2006.

$36 \quad$ Ibid.

$37 \quad$ Ibid.

38 Ibid.

39 See Basic Information (January 2004) The 'Bologna Process' - Towards the European Higher Education Area', <www.bologna-bergen2005.no/EN/Basic/Pros-descr.htm>, last accessed 7 April 2006.

40 'Realising the European Higher Education Area', Communique of the Conference of Ministers responsible for Higher Education in Berlin on 19 September 2003. <www.bologna-bergen 2005.no>, last accessed 7 April 2006. 
communiqué also features two new elements. In the 'preamble' of the communiqué, the Ministers reaffirm the importance of the social aspect of the European Higher Education Area, i.e., to strengthen social cohesion and reduce social and gender inequalities both at national and European level. The Ministers state explicitly that the social dimension of the European Higher Education Area must not be overshadowed by the need to increase competitiveness. ${ }^{41} \mathrm{~A}$ second new feature in the Berlin communique is the fact that for the first time in the process of creating the European Higher Education Area there is an urge among the participating Ministers to prioritise. The communiqué states explicitly that in the coming years the emphasis of the participating countries should lie with quality assurance, implementation of the two-cycle system and the recognition of degrees and periods of study. ${ }^{42}$ It might not be a surprise that these three points of emphasis also coincide with the original goals of the Sorbonne Joint Declaration. It is also the first time that the signatories commit themselves to concrete goals, stating that they will initiate actual implementation in the three areas identified in the Berlin communiqué. ${ }^{43}$

As stated above, the Berlin communiqué also added a new, tenth, initiative to the already existing initiatives from Prague and Bologna. In the communiqué, the Ministers of the signatory states refer to the adding of a third cycle to the already existing initiative of creating a two-cycle system. In the communiqué, the Ministers state that in order to strengthen the ties between the European Higher Education Area and the European Research Area, the doctoral level of studies must be included as a third cycle in the 'Bologna Process' ${ }^{44}$ It is noteworthy to mention that the doctoral level was also included in the two-cycle system that was proposed by the Sorbonne Joint Declaration. For that matter, the inclusion of the doctoral level in the Berlin communiqué was not a complete novelty but more of a reappraisal of the Sorbonne Declaration, which was also the case with the abovementioned prioritising in the existing focal points of the Bologna Declaration. With regard to follow up, the Ministers accepted a number of new signatories to the 'Bologna Process' which brought the number of signatories up to $40 .{ }^{45}$ It was also decided in the communique that the next ministerial conference would take place in Bergen in Norway in 2005. Together with the ministerial conference in Bergen it was also decided that a mid-term stocktaking should take place. This stocktaking exercise would then be presented at the meeting of the Ministers of the signatory states.

As was the case with the two previous summits, the summit in Bergen in 2005 did not result in a new Declaration, but again in a communiqué, this time titled 'The

41 Ibid. The Ministers even provide for a rule of thumb: in international academic cooperation and exchanges academic values should prevail.

42 See Basic Information (January 2004) The 'Bologna Process' - Towards the European Higher Education Area, <www.bologna-bergen2005.no/EN/Basic/Pros-descr.htm>, last accessed 7 April 2006.

43 'Realising the European Higher Education Area', Communiqué of the Conference of Ministers responsible for Higher Education in Berlin on 19 September 2003. <www.bologna-bergen 2005.no>, last accessed 7 April 2006.

$44 \quad$ Ibid.

45 Ibid. 
European Higher Education Area - Achieving the Goals' ${ }^{46}$ The Bergen communiqué was almost completely concerned with the stocktaking report that was prepared by the so-called Follow-up Group for the summit in Bergen. It was also the first communiqué that did not add new initiatives to the 'Bologna Process' but only looked at how the existing initiatives could be implemented. Because of the fact that the communique relied heavily on the stocktaking report, this report will be looked at first. After that, how the results of the stocktaking report were implemented in the Bergen communiqué will be assessed.

The stocktaking report was prepared by a working group that was appointed by the Bologna Process Follow-up Group in order to take stock of the progress made on the three initiatives prioritised by the Berlin communiqué. ${ }^{47}$ The report looks into the three areas prioritised by the Berlin communiqué, i.e., quality assurance, two-cycle degree systems and recognition of degrees and study periods. The working group developed a score card on the basis of which it can assess whether or not a signatory state lives up to the standards required in the 'Bologna Process'. Information is gathered from the signatory states by means of a national report which they prepare on the basis of a template provided by the working group. The national reports were not checked. ${ }^{48}$ The stocktaking report is rather optimistic with regard to the progress made in the 'Bologna Process':

'This report concludes that there is good news for the countries involved in the 'Bologna Process': the collective and voluntary inter-governmental process is a success. Common goals are being pursued and targets are being met by the great majority of countries. There is also good news for the higher education institutions, who are working hard to implement the Bologna actions, and who can now see their achievements being made visible. Finally, there is good news for students, because the 'Bologna Process' is creating a better and more open world of learning, with enhanced mobility, transparency, transfer and recognition of qualifications. ${ }^{49}$

This optimistic tone is maintained throughout the report, and it is therefore no great surprise that the report does not entail revolutionary recommendations, other than perhaps the recommendation to utilise in full the Lisbon Recognition Convention ${ }^{50}$ when it comes to recognition of degrees and study time.

As stated above, the Bergen communiqué relies heavily on the stocktaking report, and the recommendations in the communique therefore largely coincide with the recommendations in the stocktaking report, with its most eye-catching element being the referral to the Lisbon Recognition Convention for the initiative regarding the recognition of degrees and study time. In addition, the Ministers also seek to implement an overarching framework for qualifications that must ensure smooth access to

46 'The European Higher Education Area - Achieving the Goals', Communiqué of the Conference of European Ministers Responsible for Higher Education, Bergen 19-20 May 2005, <www.bologna-bergen2005.no>, last accessed 7 April 2006.

47 'Bologna Process' Stocktaking, Report from a Working Group appointed by the Bologna Follow-up Group to the Conference of European Ministers Responsible for Higher Education, Bergen 19-20 May 2005, <www.bologna-bergen2005.no>, last accessed 7 April 2006.

$48 \quad$ Ibid. p. 11.

$49 \quad$ Ibid. p. 5.

$50 \quad$ CETS no. 165. 
the three-cycle degree system and also provide for a smooth transition between two cycles. The Bergen communiqué concludes with the adoption of new signatory states, which brings the total of participating countries to 45 , and the notification that the next ministerial conference will be held in London in 2007.

The London communiqué, 'Towards the European Higher Education Area: Responding to challenges in a globalised world', issued on 18 May 2007 brings little new to light. ${ }^{51}$ The focus remains on the development of the three-cycle system with emphasis on the third, i.e. doctoral, cycle. In that sense the Ministers call for a curriculum reform in order to further facilitate the streamlining of the three-cycle system. The call for reform is not accompanied by any concrete measures to facilitate or stimulate such reform. The Ministers further call for ratification of the Lisbon Recognition Convention, which will be dealt with below. Further emphasis is placed on mobility, the social dimension, data collection and employability. In addition, one of the targets for 2009 is the focus on the rest of the world, i.e., applying the principles of the Bologna system to diplomas from the rest of the world. The next conference, as at the time of writing, will take place in Louvain in 2009. In addition to the communiqué, the London conference also led to the adoption of a second stocktaking report. ${ }^{52}$ The second stocktaking report built on the previous report and focused on quality assurance, degree systems and recognition. The report offered no surprising new developments, which is reflected by its conclusions. ${ }^{53}$ More specifically, with regard to the degree system and recognition, which are of primary interest for this study, the report stated that most countries have implemented a twocycle degree system and that many countries are introducing a third cycle to the system. With regard to recognition, there is only need to mention the development in the ECTS system. In its outlook for 2010, the writers of the stocktaking report put their finger on the sore spot when they stated that one of the challenges for 2010 is that, by then, 'learners'[sic] may expect that: 'higher education qualifications that are awarded in all participating countries are recognised in all other countries for access to employment, education and research opportunities'. ${ }^{54}$ The reason why this is considered a sore point will be explained below.

At first glance, and viewed from the perspective of its creators, as was the case above, the 'Bologna Process' might appear to be an enormous achievement. More than 40 states have apparently been successful in achieving, in under ten years, a complete reformation of their higher education systems in order to safeguard the mobility of students, by providing for similar degree cycles so that students can easily change between taking one cycle in one state and another cycle in the other, and, lastly, these states have successfully created a system that provides for recognition of

51 <www.dfes.gov.uk/bologna/uploads/documents/LondonCommuniquefinalwithLondon logo.pdf $>$, last accessed 12 June 2007.

52 <www.dfes.gov.uk/bologna/uploads/documents/6909-BolognaProcessST.pdf>, last accessed 12 June 2007.

53 'There are three main conclusions that can be drawn from the 2007 stocktaking.

1. There has been good progress in the 'Bologna Process' since Bergen.

2. The outlook for achieving the goals of the 'Bologna Process' by 2010 is good, but there are still some challenges to be faced.

3. Stocktaking works well as an integral part of the 'Bologna Process' strategy.'

54 <www.dfes.gov.uk/bologna/uploads/documents/6909-BolognaProcessST.pdf>, last accessed 12 June 2007. 
degrees and study periods, so that problems of having one's years of hard labour recognised in another country are a thing of the past. Moreover, all this has been achieved in an intergovernmental fashion, without the need for cumbersome supranational mechanisms. ${ }^{55}$ When assessing the 'Bologna Process' in a more objective manner, a few, very important characteristics of this process must be borne in mind.

First, there is of course the legal status of the 'Bologna Process'. As is indicated in the main conclusion of the stocktaking report, the 'Bologna Process' is founded on nothing more than the good will of the participating states. The Bologna Declaration, or the Sorbonne Joint Declaration, or any of the communiqués described above for that matter, have no legally binding nature whatsoever, and can only be classified as 'soft law'. There is no legal obligation resulting from any International Organisation to take part in the 'Bologna Process', nor is there any legal obligation to adhere to the principles laid down in the Bologna Declaration or any of the subsequent documents described above. If pursued further, the only part of the 'Bologna Process' that could be deemed legally binding is the part on degree recognition. That is the case only because the signatory states (at least those that have ratified the Convention) seem to incorporate the system of degree recognition as laid down in the Lisbon Recognition Convention. The legally binding nature of that part of the 'Bologna Process' must be sought therefore, in the binding nature of the Lisbon Recognition Convention (that derives its binding nature from general international law in connection to treaties) rather than in any binding nature of the 'Bologna Process' itself. The binding force of the 'Bologna Process' must therefore be sought in the political sphere, with all the uncertainties that are normal in that field. ${ }^{56}$

An additional problem of this so-called 'soft-law' nature of the 'Bologna Process' lies in its conception. The ministers responsible for the 'Bologna Process' are capable of creating this process on their own, without any national (or supranational for that matter) parliament being involved in their decisions. Their conduct is not controlled by an independent court, national or international. From my perspective, this is undesirable. In important issues like these, i.e., the reform of higher education policy, it seems paramount that such far-reaching processes are subjected to democratic legitimisation. ${ }^{57}$ None of this is true for the 'Bologna Process'.

It is also very important to look at the actual results of the process. The stocktaking report cries victory and states, in so many words, that it has become much easier for students to study in other jurisdictions. Is this really the case? If judged on its merits, the 'Bologna Process', and I will focus on the two-cycle (or three-cycle) system here for a moment, is nothing more than a procedural process. It only prescribes that higher education in the signatory states should consist of two (or three)

55 The main conclusion of the stocktaking report is illustrative. It seems to the author that the referral to the intergovernmental nature of the 'Bologna Process' was included for apparent reasons.

56 For it even to be politically binding might be problematic for some of the signatory states, since some of the ministers who signed the Bologna Declaration did not have any power in that field. See Schneider \& Claessens (2005), p. 161.

57 It must be considered, of course, that any implementation of the 'Bologna Process' in the signatory states may be expected to be carried out under the normal safeguards of the rule of law. It might however occur that a minister presents the 'Bologna Process' to parliament as a fait accompli and the implementation of the 'Bologna Process' therefore becomes a self-fulfilling prophecy. 
separate cycles. ${ }^{58}$ Nowhere in the entire 'Bologna Process', at least not until the 2007 London Summit, is the content or duration of an actual cycle deemed to be of any importance. There was not a single mention of the need to talk about curricula and to create similar curricula for similar studies. ${ }^{59}$ Viewed from the perspective of this book, for the lawyers, this is vital. A system of bachelor's and master's degrees will be useless for lawyers if the options for master's degrees (apart from those focusing on international topics) require the knowledge gained in corresponding bachelor's degrees from that state (which is more often than not the case in master's degrees focusing on the national law of that specific state) ${ }^{60}$ In that respect, the 'Bologna Process' is not helpful in promoting the free movement of lawyers.

Moreover, the 'Bologna Process' in no way guarantees the free movement of students. Students from European Union Member States rely on European law for their rights of free movement, whilst nationals from other signatories to the 'Bologna Process' could be subject to extremely severe conditions for entering and remaining in the territory of that state. This can be seen in countries like the Netherlands.

Thus, if the 'Bologna Process' is looked at in a more objective manner, it seems that, first and foremost, this is a technical exercise that provides for the same terminology in the signatory states (with regard to degree cycles, quality assurance and crediting systems) but that it provides little or no concrete added value. The only part of the 'Bologna Process' that could lead to concrete results is the system of degree recognition, which is only the case because the majority of the signatory states also committed themselves to a convention that had the same matter as its subject. I therefore would be hesitant to use the same jubilant language as the stocktaking report, because it might give too much credit to an operation that leads merely to the use of the same terminology. Behind the terminology is where the real problems lie, and if everybody is using the same terms, it might be even harder to identify and tackle these problems.

At this point it might be beneficial to have a closer look at the only part of the 'Bologna Process' that has a legally binding effect. This legally binding effect is not by virtue of the process itself, since it has been explained that the 'Bologna Process' is completely devoid of any legally binding force, but by virtue of the fact that the part of the 'Bologna Process' that concentrates on diploma recognition is covered by the Lisbon Recognition Convention, a Treaty conceived in the framework of the Council of Europe.

58 For example, in The Netherlands the 'old' four-year course of study in law that led to the degree of 'meester in de rechten' has been replaced by a three-year bachelor's and a one-year master's degree. See also: Bruinsma (2000), pp. 1371-1374.

59 Outside the Bologna Process such discussions were ongoing. See Reich (2002).

60 And that is for the states that adopt the two-cycle system for legal studies. Germany, as a large player in the 'Bologna Process', still exempts a number of studies, among them law, from the two-cycle system. 'Bologna Process' Stocktaking, Report from a working group appointed by the Bologna Follow-up Group to the Conference of European Ministers Responsible for Higher Education, Bergen 19-20 May 2005, <www.bologna-bergen2005.no>, last accessed 7 April 2006, p. 34. 


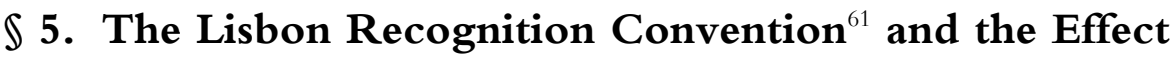 of Recent Case Law of the European Court of Justice}

As described at the beginning of this chapter, the European Community does not have any legislative power when it comes to education. Recognition of academic qualifications was, as described above, also outside the jurisdiction of the legislative institutions of the European Community, and therefore, also largely outside of the hands of the European Court of Justice. It was not until five years ago that the European Court of Justice has ruled a case, the above-cited case of Morgenbesser, in which it encroached upon the subject of the recognition of academic qualifications. The future must determine how this line of case law will develop further. The fact that the subject of recognition of academic qualifications did not fall within the competences of the European Community did not mean that there were no other international, intergovernmental organisations that dealt with this matter. Both the Council of Europe and UNESCO were, throughout recent history, rather active in this field. ${ }^{62}$ This activity, which for the Council of Europe mainly took place in the 1950s and 1960s, and for UNESCO in the 1970s, culminated in a joint Convention on the recognition of qualifications concerning higher education in the European region. ${ }^{63}$

The Convention covers both the recognition of qualifications giving access to higher education and the recognition of qualifications that are awarded after a period of higher education. The purpose of this paragraph will be to give a general overview of the workings of the Convention, with the main emphasis being placed on the second part of the Convention, i.e., the recognition of qualifications that are awarded after a period of study. The Lisbon Recognition Convention does this by declaring that everybody is entitled to an assessment of an application for recognition of qualifications solely on the basis of the knowledge and skills achieved. ${ }^{64}$ In a very general fashion, it can be said that the signatories to the Lisbon Recognition Convention commit themselves to recognising higher education diplomas from other Member States. ${ }^{65}$ This recognition may be withheld if there are substantial differences between the qualifications where recognition is sought and the qualification obtained. Apparently, although this does not become clear from the Convention itself, it is the national recognition authority that decides whether substantial differences exist. ${ }^{66}$ Alternatively, states that do not have recognition mechanisms in place also fulfil the obligations of the Lisbon Recognition Convention if they provide for an assessment of the recognition concerned. ${ }^{67}$

\footnotetext{
61 CETS no. 165.

62 Convention on the Recognition of Qualifications concerning Higher Education in the European Region, CETS no. 165, explanatory report, <conventions.coe.int/Treaty/en/reports/html/ 165.htm>, last accessed 11 April 2006.

63 CETS no. 165.

64 Article III.1(2) Lisbon Recognition Convention, CETS no. 165.

65 Article VI.1 Lisbon Recognition Convention, CETS no. 165.

66 Convention on the Recognition of Qualifications concerning Higher Education in the European Region, CETS no. 165, explanatory report, <conventions.coe.int/Treaty/en/ reports/html/ 165.htm>, last accessed 11 April 2006.

67 Article VI.2 Lisbon Recognition Convention, CETS no. 165.
} 
At first sight, the essential elements of the Lisbon Recognition Convention entail nothing more than a very broad rule to recognise higher education qualifications accompanied by the possibility to exempt, which is nearly as broad. Given the fact that this is an intergovernmental Convention this should come as no surprise. States are not willing to concede decision-making power to a supranational organisation, or to have their ability to take decisions limited by detailed treaty obligations, which is also apparent from their reluctance to cooperate on education in the framework of the European Community, or even the European Union. ${ }^{68}$

Although it is by no means my intention to deliver a judgment with regard to the Lisbon Recognition Convention for all matters concerned, because that would go far beyond the scope of this book, I do want to devote some space to an assessment of the use of the Lisbon Recognition Convention for those who aspire to become lawyers. It is likely that the Lisbon Recognition Convention is of little use to those who seek to become a lawyer in another Member State of the European Union after they finish their higher education. As stated above, it is possible under the Lisbon Recognition Convention to withhold recognition if there are substantial differences between the qualifications of the person seeking recognition and the qualifications awarded in the Member State. It has been established in the previous part of this book that, generally speaking, the first step to becoming a lawyer in a Member State of the European Union is to study law at a university of that State. It can also be said that the curricula of Law Faculties focus strongly on the national law of the respective State. It can therefore also be concluded that where a prospective lawyer seeks to have his or her law degree recognised under the Lisbon Recognition Convention, he or she will almost always encounter the problem of substantial differences, and is therefore in no way assured of recognition. Moreover, to add to the misery, the explanatory report to the Lisbon Recognition Convention states that in cases of regulated professions, which the profession of lawyer is in all Member States reviewed, the competent bodies governing those professions may ask for additional requirements. ${ }^{69}$

Lastly, and as a coup de grâce, the European Court of Justice decided in the Commission v. Austria case ${ }^{70}$ that, in the event of conflict, European Community law prevails over other international agreements such as the Lisbon Recognition Convention. In intra-Community situations, therefore, the application of the Lisbon Recognition Convention shall always be subject to European law. Moreover, the Court decided in the same case that recognition of academic diplomas falls under access to higher education, which is subject to EC law.

It seems, therefore, that the Lisbon Recognition Convention is of no help for a prospective lawyer. A prospective lawyer in fact finds more protection in the case law of the European Court of Justice. As stated above, in Morgenbesser, ${ }^{71}$ the Euro-

68 Schneider \& Claessens (2005), pp. 161-162.

69 Convention on the Recognition of Qualifications concerning Higher Education in the European Region, CETS no. 165, explanatory report, <conventions.coe.int/Treaty/en/reports/html/ 165.htm>, last accessed 11 April 2006.

70 Case C-147/03, [2005] ECR I 5969.

71 Case C-313/01, Christine Morgenbesser v. Consiglio dell'Ordine degli avvocati di Genova, [2003] ECR I-13467. 
pean Court of Justice has extrapolated its ruling in Vlassopoulou, ${ }^{72}$ so that it also applies to candidates from a regulated profession who cannot yet be considered as a produit fini, i.e., that they are fully qualified in a regulated profession in another Member State. The ruling in Vlassopoulou, and in Morgenbesser for that matter, entails that the candidate is entitled to a fair assessment of his or her qualifications, taking into account all the relevant knowledge and experience obtained by that candidate (also by means of courses and other, practical, experience). After such a comparison has been conducted, the national authority will then make a decision on what the candidate still has to do in order to obtain recognition. ${ }^{73}$

Compared with the system of the Lisbon Recognition Convention, application of the Morgenbesser ruling seems to have more effect for the prospective lawyer, since it leads, or must lead, to a decision of a national authority stating what the candidate must do in order to achieve access to the profession of the lawyer, or to one of its preparatory stages. The Lisbon Recognition Convention, on the other hand, states that recognition can be withheld in cases where substantial differences exist. This leads to the belief that a prospective lawyer can end up with a negative answer $^{74}$ without clarity on what needs to be done in order to obtain the recognition sought (as is the case with the application of the Vlassopoulou formula).

In addition, it must also be mentioned that the application of both systems, at least in the case of prospective lawyers from EU Member States, is not necessarily contradictory. It might even be construed in such a fashion that the general rule in the Lisbon Convention Recognition, i.e., the incentive to recognise each other's higher education qualifications unless substantial differences exist, can be further elaborated on by the case law of the European Court of Justice in connection with persons who are in the process of qualifying for a regulated profession, i.e., that all relevant knowledge and experience must be taken into account when making a decision on the equality of certain professional qualifications.

A last point of criticism with regard to the Lisbon Recognition Convention must be made. As stated above, the recognition of study periods and degrees is one of the ten focal points of the 'Bologna Process'. Moreover, it is one of the three points that had been given special priority in the Berlin communiqué. In essence, the actual application of this part of the 'Bologna Process' comes down to the ratification

72 Case C-340/89, Vlassopoulou v Ministerium für Justiz, Bundes- und Europaangelegenheiten Baden-Württemberg, [1991] ECR 2357.

73 It must be noted at this point that application of the Vlassopoulou formula in cases like Morgenbesser does not lead to academic recognition per se, or in the sense of the Lisbon Recognition Convention. The candidate will not receive a certificate of recognition, but the effect is similar. Ms. Morgenbesser wanted to be registered as a practicanti in Italy, but according to the rules in force in Italy one could only be admitted to that register if one had a diploma conferred (or recognised) by an Italian university. Application of the Vlassopoulou formula in her case led to the same effect as a recognition of her French law degree, namely being accepted in the register of practicanti. That is also why it must be maintained that although the European Court of Justice has encroached upon academic recognition, because the effect in the Morgenbesser case is similar, it still does not exercise academic recognition as such. Morgenbesser had applied for recognition of her maitrise but she was denied such recognition by an Italian university. The university concerned did inform her of what she needed to do in order to qualify for recognition, which basically added up to a full bachelor's degree in Italian law.

74 I.e., 'No, your diploma will not be recognised.' 
and application of a treaty, in this case the Lisbon Recognition Convention which was constructed outside the framework of the 'Bologna Process' (and existed already before the 'Bologna Process' had been initiated). Although different communiqués in the 'Bologna Process' urge all participants in the Process to ratify the Lisbon Recognition Convention, a number of states have not done so. It is even more noteworthy that a large part this concerns Member States of the European Union that are considered in this book. Belgium, Greece, Italy and Spain have not ratified the Lisbon Recognition Convention. ${ }^{75}$ Apart from the problems already mentioned in the rest of this paragraph, this leaves a significant break in the application of the Lisbon Recognition Convention in Europe.

In conclusion, it can be said that because the Lisbon Recognition Convention still leaves enormous discretionary powers for national recognition authorities, it also contains the possibility that a candidate requesting recognition is confronted with a negative decision on recognition without any further directions as to how to obtain recognition. Furthermore, a great deal of the potential benefit that has been sought throughout the 'Bologna Process' is decimated by the fact that the Lisbon Recognition Convention has not been ratified by a substantial number of Member States of the European Union. In addition, and more importantly for the scope of this book, general criticism left aside, the Lisbon Recognition Convention is not a helpful tool in furthering the free movement of lawyers in Europe since the prospective lawyers who seek to have their law degrees recognised in other (member) states will almost always encounter a negative decision from the recognition authorities because of the fact that law degrees still very much focus on the national law of a state, and therefore substantial differences between law degrees will always exist. On top of that, the Lisbon Recognition Convention also provides for additional criteria to be imposed by national authorities governing regulated professions. ${ }^{76}$

\section{\6. The Position of Those Seeking to Qualify for the Profession of Lawyer in the European Union}

The description and assessment of the EC rules and the rules ensuing from the 'Bologna Process', including the Lisbon Recognition Convention, have led to the conclusion that, when push comes to shove, it is the rules laid down by the European Court of Justice in Morgenbesser and Commission v. Austria that apply to the situation of a European Union citizen who seeks to enter the qualification process for a legal profession at one of the points of entry identified above. That statement warrants a closer look at the judgments.

75 Apart from these states, Monaco, San Marino, Canada, Tajikistan and the United States also have not ratified the Lisbon Recognition Convention. See <www.coe.int>, last accessed 16 October 2008.

76 At this point it must be mentioned that the Council of Europe has also issued a recommendation on the freedom to exercise the profession of lawyer. This Recommendation $(\operatorname{Rec}(2000) 21$, via <www.coe.int>, last accessed 11 April 2006), entails nothing that concerns the cross-border migration of lawyers but it does contain safeguards for the freedom to exercise the profession of lawyer within one Member State. Because of this fact, the recommendation is of little use to the thesis put forward in this book. 
In Commission v. Austria the European Court of Justice addressed the problem of equality of secondary education qualifications that give access to university education. Projected onto the situation of (prospective) lawyers, this would concern the first point of entry, i.e., European Union nationals moving to start university education in a law degree course in another Member State. This situation, according to the European Court of Justice, may not lead to discrimination between a national of a Member State where entrance is sought and the candidate in question. For those countries applying the Paris Equivalence Convention this poses no problems, since recognition is more or less automatic. For those countries applying the Lisbon Recognition Convention it might be more complicated, since the Lisbon Convention allows for non-recognition of secondary education in situations where a substantial difference is established. ${ }^{77}$ For Member States of the European Union this rule can no longer be applied, and should be replaced by the rule that flows from the Commission v. Austria case; namely that access to university education may not be subject to discrimination unless such discrimination can be objectively justified. As was stated above, reliance on the Lisbon Recognition Convention cannot serve as objective justification. In my opinion, entrance on the first modality for law students should not lead to major problems, and there is no evidence that Member States seek to keep other EU nationals out of their law studies (as was the case with medicine studies in Austria).

It is more interesting to assess whether the Commission v. Austria case also applies to the situation at the second point of entry, i.e. entry into the professional education part of the qualification track after having obtained a law degree in another Member State. There is nothing in the case that seems to exclude this situation from its scope, even more so because the case explicitly refers to the academic recognition of diplomas. It is, however, at this stage that the possibility of objective justification becomes more important. It can hardly be expected that Member States will automatically recognise each others law degrees, more specifically because these law degrees focus on the national law of the Member State concerned and therefore offer little added value for the Member State in which the candidate seeks to enter the qualification track. In this light it must be stated that recent case law has shown that the possibility of objective justification is a realistic option. ${ }^{78}$

Seen in the light of Morgenbesser, the extent of possible objective justification (both in cases built upon Articles 12 and 149 as Commission v. Austria and Lyyski, and in cases built on Articles 39 and 43 and secondary legislation, as was the case in Morgenbesser) seems to be that nobody may be denied access for the reason that he does not have a certain diploma (i.e., in this case, a law degree from the Member State where he seeks to enter the qualification track). ${ }^{79}$ This candidate is entitled to an individual review of his qualifications, taking into account all the knowledge that the candidate has obtained. On the basis of that assessment, the national authority may take a decision on what measures (compensation) are necessary to award equivalence to the law degree already achieved by the candidate. In Chapter 2 it was established that this protection was still too meagre, and that further jurisprudence

Article IV(1) Lisbon Recognition Convention, CETS no. 165.

Case C-40/05, Kaj Lyyski v. Umeå universitet [2007] ECR I-99. See Reich (2006).

This outer limit was established in Case 71/76, Thieffry v. Conseil de l'Ordre des Avocats à la Cour de Paris [1977] ECR 756. 
would be welcome, preferably bringing the situation of people seeking access at the second point in the qualification track within the material scope of application of the Diploma Directive. It was also established that the Morgenbesser ruling has seen little application in the Member States up to this point, however, Germany had sought to implement the ruling in the law allowing access to the qualification track for the profession of the Rechtsanwalt.

This $\$ 112 \mathrm{a}$ of the Deutschen Richtergesetz allows access to the qualification track of the profession of the Rechtsanwalt to those who can show that they have qualifications that are equivalent to the requirements for the First German State Exam. This seems to be completely consistent with the Morgenbesser ruling. However, the paragraph contains an additional requirement stating that assessment of equivalence is open to those who are eligible to enter the qualification track in their home Member State. This leads to the conclusion that the German implementation still goes beyond the limits set in the case law, since it makes the availability of the assessment of equivalence dependent on possession of a qualification. This is especially so if one considers the case of Ms. Morgenbesser, who was not qualified to enter the qualification track proper in France, since she had not passed the entrance exam to the CRFPA, but she was still allowed the enjoyment of the assessment of equivalence in Italy. If the German rule had been applied to her situation, she would not have been allowed an assessment of equivalence since she did not qualify for entrance into the qualification track proper in her home Member State. In my opinion that still goes beyond the limits set by the European Court of Justice in Morgenbesser and Thieffry.

The problem with the application of the 'Bologna Process' and the rules of the European Court of Justice is that they lack an approach on content. In the 'Bologna Process' this may be due to lack of will among its Member States. In the European Union it is clearly due to lack of competence. On the other hand, the European Court of Justice is trying to make the rules of mutual recognition so strict that Member States are more or less forced to address the content of law studies, because that is where, at least in my opinion, the answer to this problem is to be found.

\section{$\$ 7$. Furthering the Free Movement of Lawyers: the Content of Law Studies}

The preceding paragraphs were not without criticism towards the 'Bologna Process', its specific elements such as the Lisbon Recognition Convention and the applicable rules of the European Court of Justice. It has been established that the 'Bologna Process', as it stands at this moment, does not add anything to benefit further the free movement of lawyers in the European Union. Two out of the three focal points that were prioritised in the Berlin communiqué could potentially add directly to the furthering of the free movement of lawyers in the European Union. ${ }^{80}$ With regard to the two-cycle (or three-cycle) degree system, it has been observed that the conversion operation into a two- or three- cycle system has been most notably a conversion of terminology. There are no safeguards in the 'Bologna Process' itself

80 Quality Assurance, as a third point, has more of an internal effect, on the basis of which universities can be compared on an equal basis. 
that assure that cycles also have corresponding content. ${ }^{81}$ It has also been observed that this is certainly a problem for prospective lawyers, since law studies in the different Member States observed first and foremost focus on national law, therefore it might be hard for law students (from a free movement of lawyers perspective) to find master's programmes that make it easier for them to become lawyers in another Member State.

Criticism has also been uttered in connection with the system of degree recognition. Application of the Lisbon Recognition Convention has been the preferred method of fulfilling the second focal point in the 'Bologna Process'. It has been observed that this convention is, to this date, still not ratified by a substantial number of Member States of the European Union. In addition, it is of little use to prospective lawyers since recognition can be declined due to the existence of substantial differences, which are very likely to occur between law degrees from two different states. Rules with regard to recognition in force in the European Union give less leeway to Member States but still lack substantive rules on content.

The question remains as to whether anything can be done to make the best use of the 'Bologna Process', i.e., can a solution be found in which the free movement of lawyers can be furthered within the existing framework of the 'Bologna Process'? I firmly believe that the answer to this question is, and must be, yes. Although the 'Bologna Process' has a number of significant shortcomings, both in its structure (soft law) and in its application, it is undeniably a part of the policies in the participating states and, as the stocktaking report rightly assumes, many states have taken legislative action in order to implement (parts of) the 'Bologna Process'. It would therefore be naive to assume that the 'Bologna Process' should be replaced with a more effective system for assuring complementary systems of higher education in Europe. There is no real alternative. The European Community Treaty still includes the grim prohibition on harmonisation in the field of education and there is no prospect of this changing anytime in the near future. ${ }^{82}$

The key to making the best of the 'Bologna Process' as it stands today with respect to the furthering of the free movement of lawyers in Europe, lies, in my view, in the contents of the different educational programmes in the different Member States. ${ }^{83}$ Traditionally, the study of law (and the degree that follows it) focuses very much on the national law of the state in which it is taught. Room for specialisation or internationalisation often only occurs in the final part of the study, which, in many cases, is now part of the master's part of the two-cycle system. ${ }^{84}$ Generally Bar

81 This is similar to the view of the CCBE on potential 'harmonisation' of professional education, where the emphasis lies on quality rather than on content: CCBE (s.d.) A. See also: Lonbay (2001) A.

82 Van der Mei (2001), pp. 409-410.

83 This is also the view of the European Law Faculties Association (ELFA) which, immediately after the adoption of the Bologna Declaration, started discussions on the reform of legal education in Europe. See ELFA (1999); ELFA (2007) A; ELFA (2007) B; ELFA (2008); Pichonnaz \& Hirte (2006); Posch (2005) A; Reich (2002) and Steger (s.d.).

84 This is actually the system that ELFA proposes, see ELFA (1999) and Reich (2002). Remarkably ELFA proposes direct access to the professional training of the legal profession after obtaining a master's degree in another jurisdiction (where the bachelor's degree focuses on national law of the home member state and the master's degree on international (European) law) without having to resort to the 'cumbersome and lengthy' process of Directives 89/48/EEC 
Associations require a sound knowledge of the national law of the State concerned before they allow candidates into the legal profession of that State. This means that, in order to avoid aptitude tests and adaptation periods later on in life, students should obtain a bachelor's degree in the Member State where they wish to work. However, when students first commence their university studies they are often at an age and a stage in their lives when taking a decision to move abroad to study is too great a step.

It would therefore be better to offer the sound knowledge of the national law in the master's degree phase of the two-cycle degree system. ${ }^{85}$ Luxembourg has a similar system to this, since it had, until recently, no Law Faculty of its own (and it was therefore forced to accept students with foreign degrees). Questions remain with regard to what needs to be studied during the bachelor's degree phase. This is not an easy question to answer. In the past, when Roman law was studied at the different universities in Europe, lawyers who had studied Roman law taught themselves, by means of books specially issued for that purpose, the law of the jurisdiction they chose to work in. ${ }^{86}$ In that sense the reconceived Roman law was a true Ius Commune Europeum. Nowadays there is no clear Ius Commune that is the basis for all the legal systems in Europe, but there are still ties that bind legal systems close together, often closer than is assumed in those legal systems. ${ }^{87}$

There are a number of possibilities as to how more 'internationalisation' of the traditional legal education could be achieved. A number of these possibilities are already realised throughout Europe, whereas others could be regarded as more revolutionary. The first possibility with regard to achieving a larger degree of 'internationalisation' in traditional legal education is by so-called joint degrees. ${ }^{88}$ In joint degrees students are offered a degree that is valid in all the participating states. Normally this is achieved by requiring students to study for a certain period of time in the countries participating in the degree. In a joint German-French law degree, for example, the student would be required to study for two years in Germany and two years in France. One obvious positive aspect of such a degree is that the student has the guarantee that his or her degree will be recognised by the professional organisations of the participating states and has guaranteed access to the professional education of the (legal) profession in that state. The downside is that these degrees are generally focused on two Member States, which would limit the choice of candidates to studying the law of those two states. ${ }^{89}$

and 98/5/EC. In my opinion this is not a realistic option due to the value that Bar Associations give to the knowledge of national law, where this system would provide access to the legal profession without any knowledge of the national law of the host member state.

85 Dubbed by ELFA as the 'upside-down system', see ELFA (1999), and Reich (2002), where it is concluded that this system is 'premature on a general scale' mainly due to the absence of adequate teaching materials. The main advantage of this approach in my opinion is the fact that the knowledge of national law that the student obtains is in the field of the national law of the host member state in which he or she seeks to enter the legal profession.

86 Lokin \& Zwalve (2001), pp. 110-120. For a very detailed overview of the reception of Roman Law in Europe, see Mather (2001), pp. 323-362.

87 Van Gerven (2001), pp. 485-503.

88 <www.ond.vlaanderen.be/hogeronderwijs/bologna/actionlines/joint_degrees.htm> last accessed on 18 September 2008 .

89 On joint degrees, see Finocchietti \& Sticchi Damiani (2002); Guinchard (2007); Pelissier (2007) and Tauch \& Rauhvargers (2002). 
Another possibility would be that a course of study (as a single or joint degree) would focus more on the common ground among the major legal systems in Europe, while on the other hand ensuring the recognition of the professional authority in the state where the programme is located in order to guarantee unfettered access to the (legal) profession in that state. An example of this type of degree is the European Law School that was developed at the Law Faculty of Maastricht University. In 1995, the Law Faculty created a new curriculum called the European Law School. ${ }^{90}$ The purpose of this curriculum was to provide students with a sound foundation in Dutch law, good knowledge of the surrounding legal systems (i.e., France, Germany and the United Kingdom) and the law of the European Union in order to prepare students for a career in law (predominantly in law firms that operate internationally) without sacrificing the civiel effect which qualifies students with a law degree to enter the training stage of the Dutch Bar Association in order to qualify as an advocaat. This curriculum has proven to be attractive for both students and employers and is now a well established course of study offered by the Law Faculty. Compared with the joint degree, however, this degree only guarantees access to the qualification track of one legal profession (the Netherlands), and therefore it does not have the added value of having at least two countries where the degree is recognised. In the light of 'hard guarantees', the European Law School offers little more than a conventional Law degree completely focused at the national law, namely ensuring access to the professional education in that specific country. This course thus prepares for further internationalisation, but it does not really facilitate it. Additionally, with tuition in the first two years being in Dutch, the European Law School programme did not really attract any foreign students. Maastricht University has, however, taken steps to address this.

Because of its geographical location, Maastricht has close ties with the surrounding regions in Belgium and Germany. Maastricht University has a very good reputation in these countries and other faculties of the university, which prepare students for non-regulated professions, have always greatly benefited from a considerable student influx from Belgium and Germany. Although the Law Faculty has a considerable number of Belgian students, these students are always faced with the extra hurdle of having to apply for recognition of their Dutch degree in Belgium. Close cooperation between Belgian and Dutch authorities ${ }^{91}$ now ensures that this process is smooth. Differences between the Dutch and German legal systems, and educational systems for that matter, prove to be too great to overcome, however, so very few German students traditionally enrolled in the Law Faculty in Maastricht.

Recently, the Law Faculty created a course (a new version of the European Law School) which will lead to a bachelor's degree that is also appealing for students who do not seek to obtain a title that gives them the opportunity to become an advocaat in the Netherlands. ${ }^{92}$ This new curriculum includes two years of courses taught in English (focused on comparative law and international and European law) and a third year that is much more focused on national law. In this final year, students have an option to follow a track based on Dutch law or a more general track. The national track is designed to, combined with a Dutch master's degree, ensure access to the

\footnotetext{
$90 \quad$ Heringa (2002), pp. 3-15. See also: De Groot (1992).

91 See Bologna Stocktaking Report.

92 The civiel effect requires curricula to include certain compulsory subjects in Dutch law.
} 
qualification track for the legal profession in the Netherlands. It is envisaged that many of the German students in this new course will seek to follow the Dutch track to qualify for access in the Netherlands, in order to benefit from $\$ 112 \mathrm{a}$ of the Deutschen Richtergesetz, the attempted implementation of the Morgenbesser rule in Germany.

This new variant of the European Law School has some revolutionary potential. By offering the national law component at the end of the studies (and I will limit myself to the situation where a student would seek to enter professional education for the legal profession) the possibility for further differentiation is easily imaginable. It would be possible to set up networks with other universities in Belgium and Germany, for example, where students could focus in their third year on the national law of that state, thereby working towards, or even assuring, access to the legal profession in that state. For Belgium I see such a development as viable, but the problem lies with Germany. As explained above, $\mathbb{\$} 112 \mathrm{a}$ of the Deutschen Richtergesetz requires students to have access to the professional education in their home Member State before they are even eligible for taking the aptitude test provided for in $\ 112 \mathrm{a}$. That leads to the conclusion that German students who took the European Law School degree course would need Dutch civiel effect in order to ensure their access to an aptitude test in order to circumvent the First State Examination. A potential German track would therefore put German students in a worse position (since they would obtain no civiel effect in the Netherlands, and would therefore disqualify themselves from the test of $\int 112 \mathrm{a}$ ). In order for this new course to reach its full potential a lot will need to change (mainly with regard to the rules providing access to the professional training for the legal professions in the surrounding countries). But I firmly believe that the new variant European Law School at Maastricht University breathes the atmosphere of the future. By reversing the order of national law and comparative/international and European law in the approach of the curriculum, a large potential for flexibility is achieved. When rules in different Member States are adapted, it will be possible to achieve a result that resembles the free movement of lawyers in the Middle Ages as described in the introduction of this book.

Such an approach, where the emphasis of the studies does not necessarily lie with the national law of the state where the degree is obtained, could also be combined with an approach that is, for example, practised in the United Kingdom. As described above, in the United Kingdom it is not necessary to have a degree in law. NonLaw graduates can access the profession by passing a Graduate Diploma in Law, or Common Professional Examination. ${ }^{93}$ These are two-year courses that allow a person with a degree other than a Law degree to enter the professional education stage of the qualification process. These 'conversion courses', as they are commonly known, can also be used by foreigners with a foreign law degree who have to take the conversion course, or part of it, in order to qualify for access to the professional education. Such a conversion course, which is in essence the same as the so-called Luxembourg approach, could also be combined with a university degree that is more focused on the general concepts of law rather than a specific legal system. Moreover, as is the case in the United Kingdom, offering these conversion courses could be an interesting investment for universities and/or professional organisations. A system whereby all Member States have developed a one- or two-year conversion course that is 
accessible at least for any Law graduate from any other Member State and guaranteeing access to the professional education phase of the legal profession is easily imaginable. Such a system would really complete the free movement of lawyers in Europe.

The whole concept of abandoning national law as a starting point for legal education warrants some further elaboration. ${ }^{94}$ In that sense a number of other initiatives will be looked at, ${ }^{95}$ and a short excursion to the United States will be made. Although Maastricht University has been used as an example, it is not the only example of legal education that is more or less detached from the legal system of the state in which it is taught. With regard to Europe, these efforts almost all involve Dutch Universities. The University of Groningen participates with the University of Bremen and the Carl Ossietzky University in Oldenburg in the Hanse Law School. ${ }^{96}$ This law school, which offers both a bachelor's and a master's degree, focuses mainly on Dutch and German law, but also looks at the core of English common law. Strategic choice of subjects allows students to qualify for the qualification track of the legal profession in either Germany or the Netherlands. Graduates from the Hanse Law School cannot become members of the judiciary in Germany. ${ }^{97}$ The Radboud University in Nijmegen has a cooperation structure with both the University of Louvain $^{98}$ and the University of Münster in connection with master's degrees in Belgian and German law, respectively. ${ }^{99}$ Europe also has a number of cooperation initiatives between European universities and universities in the United States of America. The University of Paris I, the University of London and the University of Frankfurt all have joint degrees with Columbia University in New York that lead to double degrees, i.e., an American and respectively French, English or German degree. ${ }^{100}$ Additionally, Bucerius Law School in Hamburg, under its Dean, the leading comparative law scholar, Hein D. Kötz, has a programme that is highly internationalised. ${ }^{101}$ Lastly, there are some initiatives that are worth mentioning in North America. McGill University in Canada ${ }^{102}$ specialises in trans-systemic degrees, i.e., degrees that combine both knowledge of common law and civil law. ${ }^{103}$ By far the most ambitious effort in this field is conducted in the United States of America where New York University has created the 'Hauser Global Law School'. ${ }^{104}$ This law school envisages teaching students law in a global context by comparing the major legal systems of the world. ${ }^{105}$

\footnotetext{
94 Apart from the absence of practical matters such as teaching materials, as was indicated in ELFA (1999) and Reich (2002)

95 For a very good overview, see Gordley (2000), pp. 1003-1014.

96 <www.hanse-law-school.de>, last accessed 30 January 2007.

97 Ibid.

98 See also: Vanistendael (1999), pp. 457-466.

$99<$ www.ru.nl>, last accessed 30 January 2007.

$100<$ www.law.columbia.edu/center_program/intl_progs/Double_degrees>, last accessed 31 January 2007.

$101<$ www.law-school.de>, last accessed 31 January 2007.

102 See also: Valcke (2005), pp. 483-505.

103 <www.mcgill.ca/law-admissions/undergraduates/programs/>, last accessed 31 January 2007.

$104<$ www.nyulawglobal.org/>, last accessed 31 January 2007

105 See also: Fine (2000), pp. 567-610. See also, although not specifically on the global law school, Morris (2005), pp. 53-82 and Tarr (2004), pp. 199-206.
} 
Where a university chooses to depart from traditional legal education that is strongly based in national law and the national legal system, the question immediately arises as to how such legal education should look. In the literature on this subject $^{106}$ there seems to be a consensus that at least some form of comparison between different legal systems, preferably including the home legal system, must be offered. As Gordley explains in his piece, this comparison serves two goals. First, and most obviously, comparison leads to an awareness and the gaining of some knowledge of a legal system other than one's own. Lawyers with a basic training in legal systems other than their own are more capable of entering an international market where they are confronted with those legal systems. Secondly, comparison offers another, less obvious, but more important advantage. When a student studies law in a comparative context, i.e., studies legal problems and the different solutions to those problems in different legal systems, he learns that the solution of his own legal system is a choice rather then an empirical truth. Comparative law encourages students to think about the rationale of a certain solution, and therefore it leads to a deeper knowledge and understanding of the legal systems studied, including one's own. Comparative law therefore also leads to better national lawyers. The debate in the literature, as Gordley portrays it, centres on the question of what place the national legal system should take in this approach. There is an opinion voiced by scholars like Pound and Reimann ${ }^{107}$ that such a comparison should be made while studying the national law, in other words, the national law should form the basis of the comparison that takes place in a later phase of legal studies. ${ }^{108}$ On the other hand, Gordley presents a number of writers - Kötz, Flessner, Coing, Sacco and de Groot $^{109}$ - who state that legal studies should begin with a comparison of basic themes in law and that focus on national law should only take place at a later stage.

With the two versions of the European Law School that the University of Maastricht offers, both variants are included. The original European Law School, which commenced in 1995, begins with offering a solid foundation in Dutch law. After the first one and a half years, which is basically shared with Dutch law students (and which is taught in Dutch), the European Law School students change course and take an English-language programme that focuses on comparative law and the law of the European Union. The 'new' European Law School, which started in 2006, follows the second method since it offers a programme where the first two years (completely taught in English) focus on comparative law and the law of the European Union. In the final year of the bachelor's (and in ensuing master's degrees) students can take different tracks, which focus on the Dutch legal system or take a more general track (which does not have civiel effect or lead to entry into the qualification track for the legal profession of other countries). Maastricht therefore does not take a stand in the discussion displayed above. From the perspective of the free movement of lawyers, the choice between the two models offered by the University of Maastricht is clear. Aside from the doctrinal issue, which takes centrestage in the discussion described above, there is a practical issue which leads to the conclusion that the 'traditional' European Law School, or any other programme

106 For an excellent overview, see Gordley (2000), pp. 1003-1014.

107 Ibid., p. 1005.

108 Which is also the general view held by ELFA. See ELFA (1999) and Reich (2002).

109 See Gordley (2000). 
that is strongly based in a national legal system, is less beneficial for the furthering of the free movement of lawyers in Europe. These systems are of limited interest to foreign students, particularly as they are offered in countries whose language is not a world language, such as Dutch. Such programmes would mainly attract 'home' students. Only the second variant, which is more detached from the legal system of the country in which it is taught, is interesting for foreign students, and is capable of initiating a cross-border movement of law students.

When these general undergraduate degree systems become more prevalent, in which comparison between the major legal systems in Europe (France, Germany and the United Kingdom) and the law of the European Union serve as a true Ius Commune Europcum, ${ }^{110}$ education in national law and knowledge of national law can be reserved for master's programmes, professional education, or, as in the United States, left to the workings of the free market.

\section{\8. A Possible Result? The United States of America}

As was illustrated above, on many occasions Europe and its lawyers still suffer from a protectionist stance from the different Bar Associations, which still emphasises the importance of possessing knowledge of the national law of the system in which the lawyer practises. This general suspicion of foreign lawyers might be largely unfounded, and this can be illustrated by a short description of another jurisdiction where a large number of lawyers practise in different jurisdictions: the United States of America. When comparing Europe with the United States it must of course be borne in mind that the European Union and the USA are two completely different entities, the latter is a federal nation state whereas the former is an international organisation with considerable supranational powers. There are, however, similarities. The USA is composed of 50 states all of which have considerable autonomy in the field of law and even use different systems (Louisiana's legal system is largely based on civil law whereas the rest of the USA follows the common law system).

As was established above, qualification as a lawyer in Europe is generally the same throughout the Member States (at least the Member States observed in the context of this book): after university education in law, prospective lawyers start their professional education (which involves practical training under the direction of a qualified lawyer) concluded with a Bar Exam which leads to the right to practise as a lawyer. The only exception is Spain, since the Spanish system lacks the professional education and lawyers may obtain a practising license directly after their legal education. Qualification as a lawyer in the United States of America is substantially different from qualification in Europe, although it starts in a similar fashion.

Traditionally, lawyers in the United States would qualify by taking a Bar Exam after completing practical training delivered by another lawyer. ${ }^{111}$ This method of

110 Or as Flessner put it (translated by Gordley): 'Legal instruction which already treats the basics of law in Europe as a unified system in which national legal systems resonate like variations of a general theme'. See Gordley (2000), p. 1005; Flessner (1996). The French delegation to the CCBE was of the opinion in the 1990s that European law was integrated so much that it could serve as a Ius Commune. See Hagan (2003), pp. 149-172.

111 Costonis (1993), pp. 157-197. 
qualification was referred to as 'reading law' and it is still a manner in which one can qualify for the Bar Exam in seven states, although it is seldom used. ${ }^{112}$ In the nineteenth century, qualification through reading law gradually lost ground to a new feature, the law school, i.e., legal education that took place at universities. ${ }^{113}$ This occurred since the quality of the education in law offices varied largely in quality, and more often than not, led to the exploitation of the prospective lawyers. ${ }^{114}$ This immediately illustrates the place of the Law School in the present US system as a graduate school, whereas legal education at the European universities is normally started at undergraduate level (although it can be continued on to graduate level). This is a result of the US Law Schools replacing the professional training rather than the (preceding) university (college) education.

The qualification process in the United States takes place almost entirely at university. Prospective lawyers need to complete (or largely complete) a college education before they can go to Law School. Once they graduate from the Law School (obtaining the degree of Juris Doctor (JD) rather than Bachelor of Laws (LLB)) $)^{115}$ they subsequently take the Bar Exam in the state where they choose to practise. The form and content of the Bar Exam are decided on a state level. ${ }^{116}$ Curricula of Law Schools are basically decided by the universities themselves. University autonomy with regard to curricula does not mean that there is no quality control for Law Schools, however. The American Bar Association, ${ }^{117}$ which is a voluntary organisation, ${ }^{118}$ provides for Law School accreditation. This accreditation has become of major importance since 18 states (and three overseas territories) require candidates to have a JD from an ABA-accredited Law School before they even qualify to take the Bar Exam. ${ }^{119}$ In the remainder of the states it is possible to take the Bar Exam with a JD from a non-accredited Law School, but many states impose additional criteria so that it is easier to have a JD from an ABA-accredited Law School. ${ }^{120}$ Accreditation is dependent on a number of criteria of which the curriculum is only one. ${ }^{121}$ When one reviews the accreditation standards in connection with curricu$\mathrm{um}$, it becomes immediately apparent that there is no reference to state law. ${ }^{122}$ This is corroborated by the fact that states open their Bar Exam to graduates from any ABA-approved Law School no matter in which state the School is located. ${ }^{123}$

The next step in the qualification process is the Bar Exam. These Bar Exams fall within the prerogative of the separate states, more specifically the state Supreme Courts.

Ibid. See also: National Conference of Bar Examiners (2007).

Costonis (1993), pp. 157-197.

114 See Costonis (1993), pp. 157-197. See also: Jarvis (1995), pp. 359-412.

115 See Jarvis (1995), pp. 359-412.

116 Currier (2001), pp. 337-342.

$117<$ www.abanet.org>, last accessed 2 February 2007.

118 In a sense that it has no regulatory power as a 'federal' Bar Association.

119 National Conference of Bar Examiners (2007).

120 Ibid.

121 Currier (2001), pp. 337-342.

122 <www.abanet.org/legaled/standards/20062007StandardsWebContent/B.Chapter\%203_2 0061005150125.pdf>, last accessed 2 February 2007.

123 See Goebel (2000), pp. 413-444. Even though there is quite some criticism regarding legal education in the United States, it is never about lack of knowledge of state law. See, for example, Edwards (1992), pp. 34-78. 
Some states have laid down rules of admission in their statutes. ${ }^{124}$ There is some standardisation with regard to these Bar Exams, however. Since 1931, there has been a National Conference of Bar Examiners (NCBE) which allows bar examiners to cooperate with one another, with law schools and with the legal profession. ${ }^{125}$ On a yearly basis, the NCBE issues a guide on Bar Admission criteria, which clearly lists, for all 50 states and a number of overseas territories, the rules that lead to admission to the Bar in any given state. ${ }^{126}$ Generally, there are two distinct requirements in any given state to be admitted to the Bar. First, one must be of sufficient moral character and fitness. ${ }^{127}$ This criterion leads to the result that people who have been convicted of certain crimes or who have become bankrupt may not be admitted to the Bar of a certain state. ${ }^{128}$ Secondly, a law school graduate must pass a Bar Exam in order to be admitted to the Bar of any given state.

As was said above, the Bar Exam is the prerogative of the states, but the NCBE has done some work on standardisation of these Bar Exams. First, the NCBE has devised a number of standardised tests that can be used in more than one state. ${ }^{129}$ The most important of these is the MBE, or the Multi State Bar Exam, that is used in almost all states (except Louisiana ${ }^{130}$ and Washington). ${ }^{131}$ The MBE does not replace, but rather supplements the local Bar Exam. ${ }^{132}$ The rules of the NCBE indicate that a state should avoid questions on local law as much as possible, and that the Bar Exam should focus on fundamental principles of law. ${ }^{133}$ This seems to imply that there is very little emphasis on state law in the qualification procedure, however, a very short investigation (it is by no means intended to give a detailed review of every Bar Exam in the United States) proves that it is more the rule than the exception to test local law in the local part of the Bar Exam. ${ }^{134}$

Local law is not a subject taught in the Law Schools, which means that prospective lawyers are left to their own devices. In the early days this meant that knowledge of local law had to be gained through self-study or through lectures given by local lawyers. ${ }^{135}$ Nowadays there is a lucrative trade in selling so-called Bar Review Courses, commercial training courses to prepare lawyers for Bar Exams. ${ }^{136}$

After a short review of how individuals qualify as lawyers in the United States of America, it must be questioned how this review could be relevant for the free movement of lawyers in Europe. In the previous paragraph, the thesis was put for-

124 National Conference of Bar Examiners (2007).

125 Jarvis (1995), pp. 359-412.

126 National Conference of Bar Examiners (2007).

$127 \quad$ Ibid.

128 Ibid.

129 Ibid.

130 Louisiana has a bijural system based on both civil law and common law. See Blanc-Jouvan (2002), pp. 61-67.

131 National Conference of Bar Examiners (2007). See also: Solove (1995), pp. 1403-1406.

132 Jarvis (1995), pp. 359-412.

133 National Conference of Bar Examiners (2007).

134 See, for example, the New York Bar Exam: <www.nybarexam.org/barexam.htm>, last accessed 5 February 2007, the Indiana Bar Exam: <www.in.gov/judiciary/ble/exam/taking.html>, last accessed 5 February 2007, and the Texas Bar Exam: <www.ble.state.tx.us/Rules/NewRules/ appendixA.htm>, last accessed 5 February 2007.

135 Jarvis (1995), pp. 359-412.

136 Ibid. 
ward that the free movement of lawyers in Europe could be significantly furthered if a new form of legal education were to be created. Such legal education should focus on the main features of the legal systems in Europe and on the law of the European Union. These new legal studies would then be largely detached from the national legal system in which they are taught. This new form of legal education can be compared with the legal education in the US Law Schools which focuses on general legal concepts rather than on the legal system of the state in which the school is located. Graduation from an ABA-approved Law School qualifies the prospective lawyer to take a Bar Exam in any US state. The proposed new legal education in Europe would ideally lead to a situation where a degree from such a general education would offer access to the qualification procedure for the legal profession in any Member State of the European Union. Knowledge of national law could be obtained through a master's degree (where the 'general' degree would be a bachelor's) or via professional education (the 'Luxembourg model'). The expectation that such 'general' education, detached from the legal system in which it is taught, would work in the European Union is corroborated by the fact that the rules regarding the free movement of fully qualified lawyers in the European Union are far more advanced than the rules regarding the free movement of lawyers in the United States.

As was stated above in connection with the Bar Exam, the regulation of the legal profession in the United States of America is left exclusively to the states. ${ }^{137}$ That also means that there is no regulation of the legal profession, or the free movement of lawyers, on a federal level. ${ }^{138}$ The only protection on a federal level is a number of rulings of the Supreme Court which prohibit measures that are clearly discriminatory (residence requirements, higher fees etc.) unless they can be objectively justified. ${ }^{139}$

It is the intention of this paragraph to give a very general overview of free movement rules so that the reader can form an image of the general tendencies of the free movement of lawyers in the United States. It is by no means my intention to give a complete and detailed overview of these free movement rights. Similar to the division in the European Union, interstate legal practice can be subdivided into practice that is more or less temporary in nature (akin to the free provision of services in the European Union) and interstate practice which is more permanent (similar to establishment in the European context). The general rule regarding all legal professional activities in a certain state is that they are reserved for lawyers who have been admitted to the Bar in that state. ${ }^{140}$ Rules regarding temporary practice in the US can be sub-divided into practice involving representing clients in court and practice involving all other professional legal activities.

Lawyers from other states can obtain permission to represent a client in a court of another state. This exemption (to the general rule that professional legal activity is reserved for lawyers admitted to the Bar of that state) is granted by the court concerned only for the purposes of that case. Such an exemption is called a pro hac

137 This was held unambiguously by the US Supreme Court in Leis v. Flynt 439 U.S. 438 (1979).

See also: Goebel (2003), pp. 413-458.

138 Goebel (2003), p. 426.

139 Ibid. pp. 427-430.

$140 \quad$ Ibid. p. 433. 
vice appearance. ${ }^{141}$ This is by no means a right of the lawyer concerned but rather a favour from the court. Requests for pro hac vice are usually granted but can on occasions be denied. ${ }^{142}$ A refusal of a pro hac vice appearance led to the abovementioned ruling of the Supreme Court in Leis v. Flynt. ${ }^{143}$ This issue closely resembles a feature of the European rules on the free provision of services; namely the fact that a lawyer who is granted a pro hac vice appearance must cooperate with a lawyer who is admitted to the Bar in that state. ${ }^{144}$ Inter-state legal practice that concerns activities other than representing a client in court is even less obvious. As was stated above, every state reserves the right to engage in professional legal activity to lawyers who are admitted in that state (as a general rule, there are exceptions). This leads to the consequence that unauthorised practice of law is prohibited and can even lead to criminal proceedings. ${ }^{145}$ It falls outside the scope of this book to give even a general overview of the case law on this subject. ${ }^{146}$ Suffice to say at this point that while engaging in the practice of law in another state, a lawyer still runs the risk of engaging in conduct that is classified as an unauthorised practice of law. ${ }^{147}$ With regard to inter-state legal practice of a more permanent nature, and therefore more akin to the freedom of establishment in the European Union, the basic rule is clear and sound: A lawyer who seeks to practise permanently in a state other than that in which he passed his Bar Exam may only do so if he is admitted to the Bar where he seeks to practise. ${ }^{148}$ In about half of the states in the US, this means that the lawyer concerned must take the Bar Exam of the state where he seeks to practise. ${ }^{149}$ In the other half of the states, the requirement for taking a Bar Exam can be waived (based on reciprocity $)^{150}$ when a lawyer has a number of years of practice, sometimes accompanied by rules regarding practising full-time (or having an office) in the receiving state. ${ }^{151}$ Such admission is called an admission on motion. ${ }^{152}$

In conclusion to this very concise overview of the free movement rights in the USA, it can be deduced that they fall considerably short of the free movement rights for lawyers in the European Union. The purpose of this subparagraph was to investigate whether lessons could be learned from the system of qualification for the legal professions in the United States of America for furthering the free movement of lawyers in Europe. It has been established that the qualification of lawyers in the USA differs considerably from that in Europe. The professional education that is commonplace in Europe is replaced in the US by much more academic education in the Law Schools. It has been observed that admission to the legal profession in

\footnotetext{
141 Ibid. p. 431. See also: Jarvis (1995), pp. 359-412.

142 Ibid.

143 US Supreme Court in Leis v. Flynt 439 U.S. 438 (1979).

144 Goebel (2003), p. 431.

145 Ibid. p. 433.

$146 \quad$ Ibid. pp. 413-458 for a complete overview.

147 Ibid.

148 Goebel (2000), pp. 413-444.

149 Ibid.

150 When a lawyer comes from a state that also waives the Bar Exam for lawyers from the state where the lawyer seeks to work.

151 Goebel (2000), pp. 413- 444.

152 Ibid. See also: National Conference of Bar Examiners (2007) for a chart of states that allow admission on motion.
} 
the different states of the US is managed by the Bar Exam. Anyone who has graduated from an ABA-approved Law School may apply for a state Bar Exam. The knowledge of state law that is examined in the local part of the Bar Exam is gained through a revision course. In essence, a prospective lawyer is left to his own devices when studying the law of the state in which he chooses to practise. It has also been established that the free movement rights of US lawyers are considerably less than those of their European colleagues. From the US the lesson that might be learned is that a focus on national law in the legal education of the Member States of the European Union is not necessary anymore since in the US (which also knows different legal systems) a more restrictive system is employed without any emphasis on state law in the legal education. The method proposed in the previous paragraph, combining a more general undergraduate education with the possibilities of specialising in different 'tracks' later on (with guaranteed access to the professional education phase of the legal profession in that specific Member State) or by combining such an approach with a system of conversion courses, would encroach upon the way the qualification of lawyers is realised in the United States.

\section{S 9. Realising New Law School Education: Who Should Take Charge?}

Having established that the adoption of a new approach to law studies, based on the general characteristics of the main legal systems in Europe and European Union law as a new Ius Commune, could benefit the furtherance of the free movement of lawyers in Europe either on its own or combined with a conversion course, and after having established that such a system actually works in the United States of America, partnered with much less advanced free movement rights, I will consider who has the power to actually realise this feat. A number of candidates must be reviewed in this respect.

The first possible candidate for realising new law studies which are less focused on national law is obviously the legislative institutions of the European Community. Harmonising the content of legal education by means of a legislative instrument would provide a solid guarantee that legal studies will be reformed. However, this approach is only possible if the European Community has the power to act in this field, and that is exactly where the problem lies. At first sight, the European Community lacks such competence due to Articles 149 and 150 of the EC Treaty, which expressly prohibit harmonisation measures in the field of education. Worse still, both Articles do not even address the fact that the Community has power to busy itself with the content of education (even in measures falling short of harmonisation). These circumstances seem to warrant the powerful conclusion that the Community does not have the power to achieve such goals, even if it should have the ambition to do so. In my opinion this is not completely true. An argument could be constructed to support Article 47 of the EC Treaty, which covers the mutual recognition of diplomas, to serve as a sufficient legal base for European rules governing the actual content of curricula at law faculties throughout Europe. This case is illustrated by the efforts made in the 'Vertical Approach' of the 1970s, which were reviewed in Chapter 2 and which are nowadays laid down in Directive 2005/36/EC 
(accounting for most of its rather bulky size). ${ }^{153}$ If a clear link can be established between university education and the regulated profession to which such education should lead, it should not be an unsurpassable hurdle to justify such a piece of legislation on the basis of Article 47 of the EC Treaty. The question remains as to whether such an exercise is desirable. I strongly believe that it is not. One of the reasons for abandoning the 'Vertical Approach' in the mid 1980s was because it proved that the harmonisation of educational requirements was a very difficult, if not an impossible, task. Even when it proved possible, harmonising legal education to such an extent would lead to the awareness of the existence of potential problems and would thus provoke Member States to lay down detailed rules on this matter. A larger degree of flexibility is warranted.

The next possible candidates would be the Member States themselves, in view of the 'Bologna Process'. In this chapter, the 'Bologna Process' was reviewed and it was concluded that, to a large extent, it is a procedural exercise. Only now, almost ten years after its conception, is the subject of curriculum reform being touched upon, and I believe that the goal set for 2010 is far too optimistic. Moreover, and perhaps more importantly, the Member States keep emphasising in the Stocktaking Reports how happy they are that achievements are being made in an intergovernmental manner and that there is no central body imposing rules upon them. Additionally, and as a last example of scepticism, is the fact that an exercise leading to common standards for a legal curriculum in the context of the 'Bologna Process' would involve more than 40 Member States instead of the 27 involved in such an exercise in the context of the European Union. In my opinion it is therefore very unlikely that such an exercise would ever take place in the context of the 'Bologna Process'.

A third potential candidate to initiate the process of creating a common standard for legal curricula in Europe would be the European Court of Justice. Naturally, it is not realistic to think that the European Court of Justice would actually lay down the substantive content on such a common standard. That would never happen. The European Court of Justice can, however, manoeuvre Member States in a way that encourages them to address the only possibility that remains for them, which is actually to start addressing the substantive content that must lead to the solution for the problem. The European Court of Justice has already shown in Commission v. Austria that it is willing to go to such lengths, and that it will not be stopped even by prohibitions in the Treaty for positive integration (harmonisation) in the field of education. The problem that the European Court of Justice has left Austria with, i.e. the fact that no discrimination may take place in admitting students of different Member States, can only really be solved by talking to other countries in order to achieve a common standard for access to higher education (in this case, the study of medicine). Such a scenario, where the European Court of Justice would use a case as a 'crowbar' in order to force Member State action, is not at all unthinkable in the field of trainee lawyers. The only thing it would take is for the European Court of Justice to rule that the difference in content (with regard to national law) does not justify a rule of a Member State requiring a national diploma for entry into the qualification track of a national legal profession. It has been shown above that if Commission v. Austria, Morgenbesser and Thieffry are read together, then the case law is

153 The Directive comprises 121 pages, to be exact. 
already there. The only thing that is lacking is judicial precedent, the European Court of Justice has never ruled in such a case specifically on lawyers. If the European Court of Justice were to rule in such a case, Member States would be more or less forced to start discussing common standards. Apart from establishing this technical possibility, whether such a move is desirable or not also comes into play. In my view, it would be undesirable to base such an exercise on a ruling imposed by the European Court of Justice. Member States would attempt to find the least intrusive way out of the difficult situation imposed upon them by the European Court of Justice.

The next candidates for creating a common standard for a new legal curriculum are obviously the universities themselves. It has been shown above that universities are already (and have been for a while) busy with creating such curricula. Universities are, in some ways, the best candidates since they obviously know best in determining what is feasible with regard to the creation of such curricula, and they would also be able to find, or hire, the necessary experts to create such a curriculum. The recent creation of the English-language variant of the European Law School at the Faculty of Law at Maastricht University is but one example demonstrating that such curricula can be created. However, it also shows the potential danger of leaving the initiative to universities. This danger lies in the fact that, generally speaking, universities do not make the rules that determine which degrees are accepted as qualifications for the legal profession. These are, in the best situation, determined by respective Bar Associations, and in some Member States (as has been described in Chapter 2) they are laid down in national law. This leads to the situation where graduates of such a curriculum could find themselves in a vacuum if Bar Associations refuse, or are forced to refuse, to accept such a degree as sufficient entry to the qualification track. With regard to the new variant European Law School of Maastricht University, agreements have been made between the university and the Dutch Bar Association to give the curriculum civiel effect, i.e., that it qualifies graduates for the professional training that leads to the profession of the advocaat. As a result of the interpretation of the Morgenbesser judgment in $\$ 112$ a of the Deutschen Richtergesetz, German graduates of the Maastricht European Law School are forced to obtain Dutch civiel effect in order even to be allowed an assessment of their professional qualifications. Although universities are technically the best candidates to create these new curricula, such expertise is useless if there is no acceptance of such degrees on the level of the authorities that decide whether such a degree may lead to entrance to the qualification track of the legal profession. This means that these authorities will have to be involved.

Fortunately, European law provides the possibility for their involvement, while still guaranteeing the flexibility that was deemed necessary earlier in this paragraph. That flexibility can be found in Article 15 of Directive 2005/36/EC, which provides a new form of governance hitherto unknown in the realm of the free movement of professionals, and more specifically lawyers. The Article provides for the possibility for Member States or professional organisations to communicate common platforms to the Commission. These common platforms are defined as a set of criteria for professional qualifications suitable for compensating substantial differences (which must be identified by at least two-thirds of the Member States including all those who regulate the profession) between the professional qualifications for the regulated 
profession (or the entry to the qualification track thereto) in the different Member States. If such a common platform is then presented to the Commission, it may adopt this common platform as an implementing decision through the comitology procedure provided for in Article 58(2) of Directive 2005/36/EC. This new form of governance has considerable advantages over the harmonisation of legal education (if at all legally possible) through the classic Community Method (creating secondary legislation) described earlier in this paragraph. First of all, the prime candidate for preparing such a common platform, the CCBE, ${ }^{154}$ would be the most important player in this process rather than the mere consultant it would be in the Community Method. Secondly, the stakes would be less high compared with the traditional method, since politics would only be involved at a later stage, when preparation of the common platform is already completed. On the other hand, an approved and implemented common platform would have the same legal consequences as harmonisation of legal education in the classic sense, namely the fact that recognition would be automatic and not dependent on compensatory measures that must be fulfilled by the candidate.

It must be borne in mind that a common platform in this sense would be much broader than the legal education in the Member States alone. It would affect the legal profession as a whole and would guarantee the automatic entrance of the candidate into the legal profession of a Member State. It is unlikely that a common platform will be adopted for the legal profession at short notice, and in all honesty it is doubtful whether such a common platform would ever emerge. Developing a legal curriculum that would facilitate a candidate's move to another Member State mid-qualification under the direction of the CCBE would at least be the first step towards such a common platform.

\section{$\$ 10$. Observations and Conclusions}

At the end of the previous chapter it was concluded that the free movement of lawyers has seen a tremendous development over the last thirty years, to a point where it is now safe to conclude that there is almost full mutual recognition of the legal professions in Europe. On the other hand it has also been concluded that most of the benefits of the system of free movement for lawyers are only available to those that are fully qualified as a lawyer in at least one of the Member States. This means that a prospective lawyer must go through the entire qualification process in becoming a lawyer in one Member State before he even eligible to apply to enter the legal profession of another Member State. It has been concluded that it might take well over a decade before a candidate is fully qualified in another Member State. The purpose of this chapter was to review whether there are possibilities to further

154 The CCBE is already brainstorming about this possibility, as can be seen from the materials of its annual conference, held on 25-27 October 2007, which was completely dedicated to legal training. See <www.ccbe.org>, last accessed 8 December 2007. See more specifically the contributions made on that conference: Bühler (2007); Eisenbrükova (2007); Guinchard (2007); Kilger (2007); Lafont (2007); Latrup-Petersen (2007); Lonbay (2007); Otterlo (2007); Pelissier (2007); Petzel (2007); Slazak (2007); Steger (2007) and Thielen (2007). 
the system of free movement for lawyers so as to facilitate their transition into another Member State's legal profession with greater ease.

It was observed that, generally speaking, the qualification track leading to a legal profession in the Member States concerned consists of two distinct elements; namely a law degree and professional education. This two-fold division also provides for two distinct points of entry into the qualification track: before and after obtaining a law degree. Graphically this could be depicted as follows:

Figure 13: Entry points in the qualification track

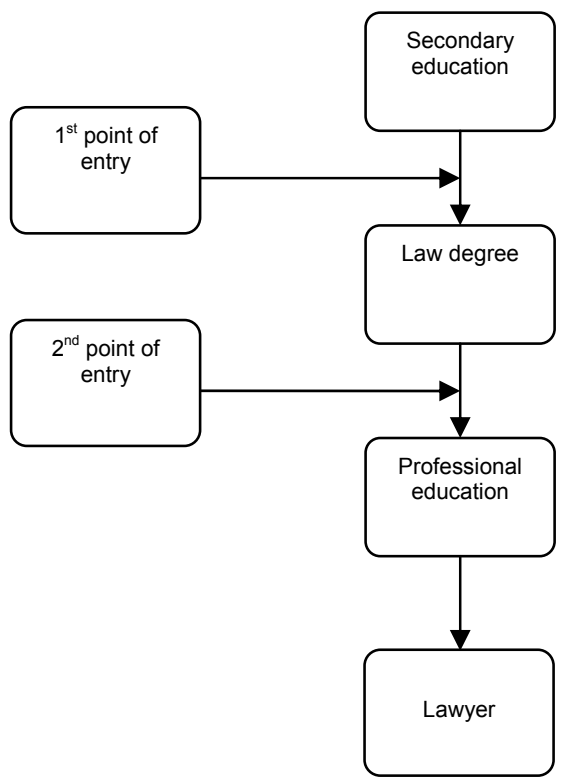

With regard to the first point of entry, it was observed that this would pose few problems since at this point in the qualification track there is as yet no need for specific knowledge of the legal system of the host Member State. The drawback to this point of entry is that usually at this stage the potential candidate is too young to make the decision to work outside the home Member State, and in which State to be based as a lawyer. At the second point of entry the problem of national law comes into play. Entry into the qualification track at this point presumes knowledge of the national law of the legal system into which the candidate seeks to enter as a lawyer, and more often than not the law degree obtained in the home Member State will have given no education about the legal system of the host Member State.

The observation has been made that there are no rules laid down in secondary European legislation that cover the possibility of entrance into any of the entry points described above. On the basis of Article 149 of the EC Treaty it is clear that the European Union has no legislative competence to issue rules that would cover, for example, mutual recognition of secondary education credentials or law degrees. It is for this reason that many Member States require a national law degree for en- 
trance into the professional education that leads to qualification as a lawyer. With the legislative competence for mutual recognition of academic diplomas firmly set within the sovereignty of the Member States, it was also observed that, outside the realm of European law, there is an ongoing (intergovernmental) process that has as its goal the creation of a European Higher Education Area, the so-called 'Bologna Process'.

On the basis of two declarations and three ministerial communiqués, which are in no way legally binding and can be fully characterised as 'soft law', 45 states throughout geographical Europe have decided to largely adapt their higher education systems in order to create a European Area of Higher Education outside the framework of the European Union. This is even more remarkable since it has been established that the Member States of the European Union are fierce defenders of their sovereignty in the field of education. Throughout the integration process the European Community has been involved in education in a supporting manner but it lacked, and still lacks, the legislative power to introduce harmonisation measures in this field. The 'Bologna Process' has been characterised as 'soft law'. Critical remarks have been made with regard to the lack of effective democratic and judicial control in the development of the 'Bologna Process'. Since it entails no legal obligations these control mechanisms are not in place. Although it has no legally binding effect, states participating in the Process have been particularly eager to implement the Bologna Declaration and its ensuing ministerial communiqués. Many, if not most, of the Member States have adapted their laws on higher education in order to facilitate or implement the 'Bologna Process'.

From a content perspective, the Bologna Declaration and the ministerial communiqués seek to establish ten different goals which were identified above. In the Berlin communiqué, three of these objectives were spear-pointed: the creation of a two- (or even three-) cycle degree system; a system for the recognition of degrees and periods spent studying; and the implementation of a system of Quality Assurance. Most attention has been given to the first two objectives. It has been observed that the creation of a two-cycle degree system has been mainly a question of terminology. Participating states have chosen to pour their existing, very diverse degrees and diplomas, into the bachelor/master mould that is prescribed by the 'Bologna Process'. Of the Member States reviewed in this book, Germany is the only country that has, to this date, excluded legal studies from the 'Bologna Process'. It has also been observed that since the 'Bologna Process' does not prescribe anything on curricula, or even the duration of the different cycles, ${ }^{155}$ the diversification in the participating states remains, and rather than solving this diversification, the introduction of common terms for degree cycles may instead camouflage or cloak such diversification, making the matter even more complex rather than simpler.

Similar critical remarks were made in connection to the issue of degree recognition. In this field participating countries in the 'Bologna Process' have chosen not to develop new criteria but to incorporate into the process an existing Council of Europe/UNESCO Convention (which was created before the 'Bologna Process') with respect to the recognition of degrees and study periods, the so-called Lisbon Recognition Convention. This Convention was assessed and it was found to be of

155 Contrary to popular belief, at least in the Netherlands. 
little or no help to further the free movement of lawyers, since it allows for the denial of recognition in cases where substantial differences exist between the degrees; which is more often than not the case for Law degrees. Moreover, the Convention allows for even stricter rules to be created for regulated professions, and a considerable number of Member States reviewed in this book have not ratified the Lisbon Recognition Convention. Lastly, the European Court of Justice decided in Commission v. Austria that the Lisbon Recognition Convention does not apply when in conflict with European Community law.

The Commission v. Austria case, read together with Morgenbesser, limits the possibilities of the Member States of the European Union even more when it comes to the recognition of academic degrees. Apparently, the European Court of Justice is not intimidated by the lack of legislative competence in the field of academic recognition, as a result of Article 149 of the EC Treaty. It has been established that, according to the case law of the European Court of Justice, Member States of the European Union may not discriminate on the basis of nationality. With regard to the second point of entry, that must be read together with the already infamous Morgenbesser judgment which allows candidates an individual review of qualifications and knowledge they have already obtained. Candidates may never be denied on the basis that they do not have the correct qualification. Therefore the diagram presented above must be qualified as follows:

Figure 14: Entry points in the qualification track revisited

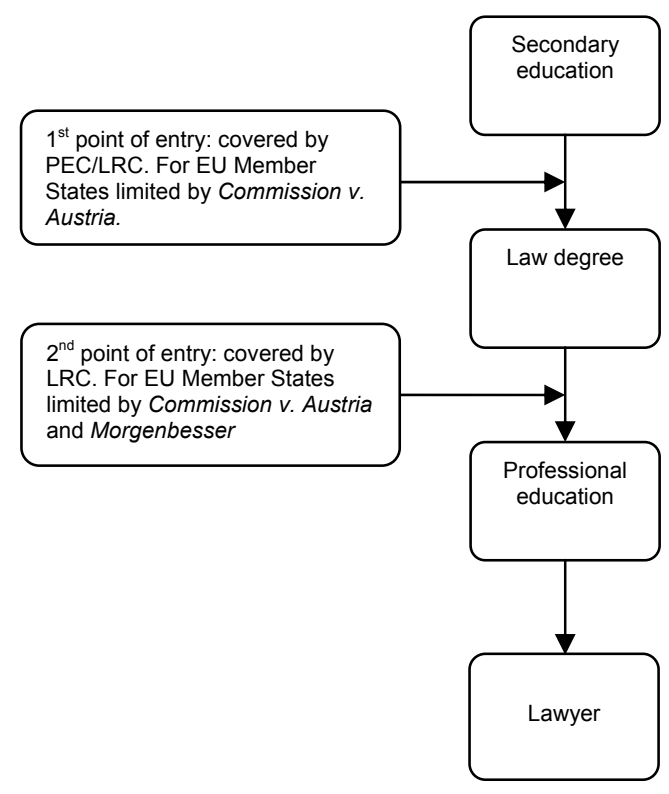

As a last, more general point of criticism, it has been observed that the 'Bologna Process' lacks certain obvious subjects. Lack of coordination of content was already identified, but the lack of coordination of access for students (although mobility of 
students is one of the ten objectives of the 'Bologna Process') is a more difficult problem. In this case, students from the European Union must rely on the rights of free movement conferred to them within the framework of the European Union, and in the future even third-country nationals may rely on Community legislation to gain access to EU Member States to study, but for the time being nationals from non-EU Member States are subject to national immigration policies.

Lastly, how the existing 'Bologna Process' could be used to further the free movement of lawyers in Europe has also been researched. It has been identified that the main course of action lies in the coordination of the content of legal education. If a major culture change can be achieved, and if legal education on a bachelor's degree level can be created that does not (or in a lesser manner) focus on national law but rather on the common ground between two or more legal systems, these broadly educated students can then choose master's programmes that focus on the national law of the Member State of their choice. This would then provide them with access to the professional training for the legal profession in that State. Maastricht University in the Netherlands has recently introduced such a non-legal-system specific bachelor's degree education. A short excursion to the system of the United States of America has taught us that a system of qualifying for the legal profession can exist without legal education that is strongly focused on gaining knowledge in national (state) law.

Establishing such a culture change is not only practically difficult, there are also legal problems to be encountered since it is not all together clear who would have the competence to initiate such an exercise. In that sense it has been concluded that after reviewing a number of potential initiators, including the Community Institutions, the Member States and the universities, the best body for coordination the development of these common standards for law degrees is the CCBE. This would take place in preparation for, or in the course of, creating a common platform (as provided in Article 15 of Directive 2005/36/EC) that would lead to automatic recognition of the legal profession in all the Member States.

It must be concluded, therefore, that the system of free movement for candidate lawyers is by no means as sophisticated as the system for the free movement of fully-qualified lawyers. The major reason for this is the lack of competence of the European Union to engage in educational matters (at least in a legally binding fashion). Any developments for the creation of such a free movement of prospective lawyers must therefore be seen in light of the 'Bologna Process'. Although there is a lot of valid criticism of the 'Bologna Process', it could serve as a useful framework in order to facilitate the free movement of (prospective) lawyers. In order to fulfil that function, attention must be given to curriculum content (which is not part of the 'Bologna Process' as such, but is in the hand of the universities, albeit in close cooperation with the competent authorities governing the legal professions in different Member States, as was established above). Moreover, as far as EU citizens are concerned, reliance on acquis communautaire for free movement rights, and with regard to the recent developments in connection with the recognition of professional qualifications for persons who are not considered to be a produit fini, is still absolutely necessary in the absence of such integration efforts with regard to curriculum content. 



\section{Chapter 5}

\section{Observations, Conclusions and Recommendations}

\section{$\mathbb{1}$. Introduction}

In the first chapter of this study I indicated that I would be posing three questions: First, I would assess whether a model for the free movement of lawyers could be distilled. Secondly, I would research how that model, distilled from the evolution of the free movement of lawyers, is implemented in the fifteen selected Member States. Lastly, I would consider how the model could be further extended in order to include a future free movement in the qualification track for the legal profession in the different Member States.

This chapter will offer a summary of the conclusions that were reached in the preceding chapters and will present them in a systematic fashion. After the overview of the conclusions, it is possible to make recommendations for a further refinement and completion of the free movement of lawyers.

\section{$\$ 2$. Observations and Conclusions with regard to Chapter 2}

Chapter 2 established that the developments within the field of the free movement of lawyers have always along two different lines, with different speeds, and, occasionally, with different results. These two tiers are represented by on the one hand, the different rulings of the European Court of Justice, while on the other hand there is a development by means of secondary legislation. These two distinct tiers make it hard to give a comprehensive overview of the rules applicable to lawyers. In Chapter 2 I presented such an overview by combining a chronological approach with a more thematic approach. In that sense, it was established that in the first generation of case law it was the European Court of Justice that revived the free movement of lawyers.

\section{First-Generation Case Law}

That first-generation case law was characterised by the creation of rights that enabled lawyers to enjoy their rights of free movement guaranteed by the EC Treaty. This development started with Reyners case, in which the European Court of Justice ruled that Member States could no longer apply the public service exception for lawyers, and that, in lieu of secondary legislation, Article 43 of the EC Treaty would have direct effect. A similar ruling with regard to Article 49 of the EC Treaty was then given in Van Binsbergen. The contested measures in both Reyners and Van Binsbergen can be classed as distinctly applicable, or directly discriminatory. 
The European Court of Justice continued to follow this line of thought and initiated the development of recognition of diplomas (a field that is strongly tied to the free movement of lawyers) and removed discriminatory barriers in this field through cases like Thieffry and Heylens. Gradually, however, more and more situations were addressed that could not be classed as discriminatory. The question was therefore whether the European Court of Justice was also willing to address non-discriminatory restrictions, i.e., restrictions that apply to both domestic and foreign lawyers. In these cases, the European Court of Justice concluded that these situations did indeed constitute a hindrance to the free movement of persons and in such cases would require objective justification. In Klopp, for example, the Court held that the French rule of unicite $d u$ cabinet could not be reconciled with the freedom of establishment. Also, in cases like Kraus and Säger indistinctly applicable rules were addressed. The case of Vlassopoulou is the seminal case in this respect. Here, the Court decided that a person who seeks entrance into a regulated profession has a right to have his qualifications and experience checked individually in order to assess whether the qualifications and experience are sufficient for access to be granted to the regulated profession in question. This case became of the utmost importance for the development of the recognition of diplomas even beyond the scope of later secondary legislation.

This case law eventually culminated in the Gebhard case in 1995. In this case, the European Court of Justice extrapolated the famous rule of reason to all the four freedoms laid down in the European Community Treaty. Originally laid down in the Cassis de Dijon case for the free movement of goods, the application of the rule of reason for the other freedoms did not come out of the blue. Cases like Kraus, Säger and even as far back as Van Binsbergen saw early applications of the rule of reason. In essence, the rule of reason states that any measure that is capable of hindering any one of the four freedoms must be objectively justified using the four-stage test laid down in the Cassis de Dijon case.

Although the situations covered in cases like Vlassopoulou and Gebhard are nowadays covered by secondary legislation, the principles laid down in these cases are still of the utmost importance in connection with situations that are not covered by secondary legislation.

\section{Secondary Legislation}

While all the above was taking place, the legislative institutions of the European Community started work on what was going to influence the second tier of the development of the free movement of lawyers. In the mid 1970s, the legislative institutions of the European Community initiated efforts to harmonise the liberal professions in Europe. This was achieved by creating two directives per profession. One directive provided minimum harmonisation for the professional education leading up to qualification for that profession, whilst the second directive guaranteed mutual recognition of those professional qualifications. These vertical, or sectoral, directives proved successful in the medical professions. Although successful, however, it proved to be a difficult and time-consuming process. Outside the medical professions, there was much less success. The profession of the architect was tackled, but with considerable difficulty and without a harmonising directive on professional 
qualifications. The institutions were unable to implement the vertical approach for the profession of the engineer, and most importantly, for lawyers. Although the sectoral approach was not applied to the profession of the lawyer, the institutions did adopt a piece of secondary legislation, the so-called Lawyers' Services Directive 77/249/EEC. This Directive allowed lawyers to provide services in another Member State, on a temporary basis. There is no limitation on the professional activities that may be pursued, however, in situations involving the representation of clients in court the lawyer providing services on a temporary basis is required to cooperate with a locally established lawyer.

At first sight, this Directive was revolutionary. It circumvented the difficult harmonisation issues that were encountered in the sectoral approach. The Directive was straightforward, concise and firmly based in the then-newly established principle of mutual recognition. It provided lawyers from other Member States with the possibility to become fully engaged in the professional activities of the legal profession of the host Member State (albeit in some instances with obligatory cooperation with a host Member State lawyer). Moreover, the rights guaranteed in Directive 77/249/EEC provided lawyers who sought a more permanent form of establishment in another Member State with a loophole in the system. The exact difference between services and establishment was for a long time shrouded in a thick fog. Lawyers who sought a more permanent form of establishment could insist that they were providing services when they were actually established under their home title. This modality was dubbed installation limitée in the literature. It was not until the judgment of the European Court of Justice in the Gebhard case that this modality was terminated through the Court's clearly-defined clarification of the differences between the two modalities. I have concluded (see below) that the phenomenon of installation limitée may become relevant again for a different category of professionals.

With regard to the Services Directive only two cases are worth mentioning. In the 1980s the Court ruled on the extent of the obligation to cooperate with a domestic lawyer laid down in Directive 77/249/EEC. This was the Commission v. Germany case, in which the Court ruled that such obligatory cooperation may only be imposed in situations where representation by a lawyer is obligatory in that specific procedure and that it may not go beyond technical cooperation. This case is also of importance for the Establishment Directive, since that Directive contains a similar possibility for Member States to impose cooperation. The second case also deals with the obligatory cooperation. In the $A M O K$ case the Court decided that rules imposed by a Member State which are not dealt with in the Directive (in this case, a rule that the costs of the cooperating lawyer could not be reimbursed) are illegal per se if they preclude the full effect of the Directive. This case is also of importance for the Establishment Directive, as will be discussed below.

The sectoral approach of the legislative institutions of the European Community came to a grinding halt after the medical professions were harmonised. The difficulties encountered in harmonising these professions proved enough for the Institutions to change course with regard to the recognition of professional qualifications and therewith to the access to regulated professions. At the European Council of Fontainebleu in 1984, it was decided that the European Commission was to investigate a horizontal approach towards the recognition of diplomas. That system was ultimately laid down in Directive 89/48/EEC, which provided for a system for 
the recognition of diplomas. The general rule laid down in the Directive is based on mutual recognition. This means that recognition of professional qualifications obtained in other Member States lies at the core of the Directive. Only when certain substantial differences between the two professional qualifications are established may the host Member State require certain compensatory measures, and only after it has also been established that there is no additional experience gained by the candidate that might compensate for the substantial differences. This is essentially the rule laid down by the European Court of Justice in the Vlassopoulou case.

These compensatory measures may take the form of an adaptation period or an aptitude test. The Directive prescribes that the choice of compensatory measure essentially lies with the candidate who seeks integration into the regulated profession of the host Member State. There is however one important exception to this principle of free choice, namely professions that require a precise knowledge of the national law of the host Member State. In that situation the host Member State may prescribe the form of compensatory measure. All the Member States reviewed have chosen an obligatory aptitude test. For the lawyer, this meant that a hurdle was created which overshadowed the principle of mutual recognition underlying the Directive. Substantial differences are, of course, almost always present between lawyers educated in different legal systems. Therefore, automatic recognition of professional qualifications will only take place in situations where the candidate has aggregated enough additional experience and knowledge in order to be exempted from the compensatory measures (the application of the Vlassopoulou ruling in its most extreme consequence). If an exemption cannot be granted, the candidate in question has to subject himself to an aptitude test (which generally consists of a written and an oral part), conducted in the language of the host Member State. It might speak for itself that this is not an easy step to take. More importantly, the Directive does not state anything about the severity of the aptitude test. Member States essentially obtain a carte blanche (within the limits of the principle of proportionality) with respect to the size and contents of the aptitude test. With regard to the Diploma Directive there has only been one case that specifically dealt with the aptitude test for lawyers. In Commission v. Italy the Court ruled that an aptitude test may not be more demanding than the qualification track for domestic lawyers, thereby minimising the worst severity of the aptitude test. Moreover, the Court ruled in Peros and Aslanidou that in cases where there has been a wrong implementation of the Diploma Directive, Member States may not rely on the system of compensatory measures laid down in the Directive. Unfortunately, these cases did not address lawyers.

Directive 89/48/EEC was a step forward for the developments of the free movement of lawyers. Now for the first time candidates from other Member States were guaranteed a possibility, albeit not an easy one, to enter into the legal profession of the host Member State. This option was open to them if they themselves were qualified to exercise the corresponding regulated profession in their home Member State. This meant that lawyers who integrated into the legal profession of another Member State became dually qualified. Normally, before the adoption of Directive 89/48/EEC, lawyers could only integrate into the legal profession of the host Member State if they followed the normal route for qualification for the legal profession in that country, via the education system. In 2005, Directive 89/48/EEC 
was replaced by Directive 2005/36/EC, the transposition period of which ended on 20 October 2007. It was also established that the new Directive did not change anything with regard to the system of diploma recognition that was observed under Directive 89/48/EEC, in spite of earlier attempts in the decision-making process to abolish the aptitude test for lawyers and replace it with the method of integration provided in Directive 98/5/EC.

The most significant development in the 30 years of the free movement of lawyers in the framework of the European Community stands at the focal point of this book as Directive 98/5/EC. This Directive was adopted to facilitate the permanent establishment and the exercise of professional activities by lawyers who had obtained their professional qualifications in a Member State other than the Member State in which they are established. The Directive can be traced back to 1975 when the European Commission asked the CCBE to consider a way to realise the free movement of lawyers. It was not until 1992 that the CCBE presented its draft to the European Commission. This early request may also explain why there was a Directive for a specific profession at a time that the European Community had changed its policy to favour a more horizontal approach. The Draft of the CCBE provided for a permanent right of establishment under home country professional title. The European Commission Draft that ensued from this proposal had a completely different character. It provided for a five-year right to practise under home title after which integration into the legal profession of the host Member State should follow. This approach was heavily criticised by other legislative institutions, Member States and scholars. Eventually the European Commission abandoned the approach of establishment under home title as preparation for the integration into the legal profession of the host Member State, and Directive 98/5/EC was adopted more along the lines of the original CCBE Draft.

The principle underlying Directive 98/5/EC, similar to Directives 77/249/ EEC and 89/48/EEC, is the principle of mutual recognition. Unlike the Diploma Directive, it is not based on the mutual recognition of professional qualifications (in order to enter the corresponding profession in the host Member State) but is rather more akin to the Services Directive, in which there is a mutual recognition of the profession itself. The Establishment Directive allows lawyers who qualify for the legal profession in one of the Member States to exercise professional activities in any other Member State under their home country professional title. While established in the host Member State, the lawyer established under his home country title may exercise all professional activities that a lawyer established under the professional title of the host Member State may exercise, except for situations which involve the representation of clients in court, where, similar to the Services Directive, obligatory cooperation with a host country lawyer may be imposed. While established in the host State, the lawyer concerned is subject to the professional conduct rules of that State. In essence, (except for representation) the lawyer established under his home country title does not therefore exercise his home country profession in another Member State, but he exercises the profession of the host country under his home country professional title.

The Directive essentially lays down the mutual recognition of the legal professions in all but name. Apart from the right to be permanently established in the host Member State, Directive 98/5/EC has two important additional features that 
have an impact on the free movement of lawyers. Firstly, this is the link with the integration in the profession of the host Member State. After a lawyer who is established under his home country title has been active in the law of the host Member State (including European Community law) he may integrate into the legal profession of the host Member State without any further testing of his capabilities. This means that a lawyer in such a situation can integrate into the legal profession of the host Member State without having to take an aptitude test. Together with the right to be established under home country title, this is the most important feature of the Directive.

Another important feature of the Directive was the effort to liberalise rules on practice in association, and, to a lesser extent, multi-disciplinary partnerships. Although some countries have a tradition of accommodating large law firms, in the majority of the Member States there is a tradition of single-lawyer practice. The articles in the Directive pertaining to practice in association do not entail a direct application of the host country rules (as is the case with disciplinary rules and salaried practice) but only provide for the application of host country rules after it has been established that home and host country rules are incompatible and application of the host country rules can be objectively justified. With regard to multi-disciplinary partnerships, the Directive provides for an elective application of host Member State rules, which is, in most cases, a blatant prohibition of multi-disciplinary partnerships. Unfortunately, this nuance has been largely disregarded in the implementations reviewed in this book, which has led to the confirmation of the status quo of rules on practice in association. In recent case law, dealt with below, the European Court of Justice decided that Articles 3 and 5 of the Directive lead to complete harmonisation in the scope of the application of those articles. It has been put forward in this book that these rulings can be extended to the entire Directive and that the Directive therefore leads to a complete mutual recognition of the legal profession in Europe in all but name.

The Establishment Directive has been involved in a variety of legal proceedings over its ten-year existence. The first case was a nullity claim by Luxembourg based on Article 230 EC. In Luxembourg v. European Parliament and Council the Court consistently dismissed Luxembourg's claims for nullity, thereby saving the Establishment Directive. This case is doctrinally important since it established the tripartite division of categories of lawyers who make use of their free movement rights; lawyers who provide services, lawyers who are established under their home country title, and lawyers who seek to integrate completely into the legal profession of the host Member State. Two other cases, also involving Luxembourg, Commission v. Luxembourg and Wilson, are very important because in them the Court ruled that Articles 3 and 5 of the Directive lead to complete harmonisation of their subject matter (registration of lawyers under their home title and professional activities respectively). This is important, because if one reads these cases together with $A M O K$ and Gebhard, they form the outlines of a system of possible restrictions that will be discussed in the next chapter. 


\section{New Generation Case Law}

After the completion of the secondary legislation in the field of lawyers, the establishment of the tripartite system that was confirmed in Luxembourg v. European Parliament and Council, and the application of that system in the case law, questions remained in connection with the relevance of the first-generation case law. The Court ruled on the relevance of this system in a number of cases. In these cases the Court has consistently ruled (in Burbaud, Aranitis and Fernandez de Bobadilla) that where situations fell (partly) outside the material scope of the application of the Directives, Union nationals could rely on the first-generation case law, more specifically on the Massopoulou ruling. The most important case for lawyers in this respect was Morgenbesser, where the Court confirmed this line of case law for trainee lawyers. This case has enormous potential for trainee lawyers because it guarantees them a right to move between qualification tracks even before they are considered a produit fini in their home Member State. This situation was addressed further in Chapter 4. Another, perhaps unintended, effect of Morgenbesser was that the Court applied the Vlassopoulou doctrine in such a way that Ms. Morgenbesser obtained more (registration as a trainee lawyer in Italy) than she had in the first place (since she did not qualify as a trainee lawyer in France). Member States have been struggling with the interpretation in the Morgenbesser case, and it was concluded that the German interpretation at least is not in line with what the Court ruled in that case. It was also concluded that more case law on this subject would be welcome.

\section{The Outside World}

With regard to the rest of the world, two distinct situations can be identified. First of all, one must consider the position of European Union nationals with thirdcountry diplomas. It was established that the system of the Diploma Directive will apply to them. In cases which touch upon professions that used to fall under the sectoral Directives, the Court ruled in Haim and Hocsman that Union nationals with third-country diplomas would benefit not from the Directives but from the Vlassopoulou ruling. There are no rulings in connection to the Services Directive and the Establishment Directive. The other problem concerns those third-country nationals who have either European Union or third-country qualifications. These thirdcountry nationals, according to the Court in Gül, could, in very specific situations, rely on the Diploma Directive. This also holds true for third-country nationals who have obtained Long-Term Resident status under the LTR Directive.

\section{Conclusion}

Thirty years of development in the realm of free movement of lawyers has led to a model which can be applied in all cases related to the free movement of lawyers. The core of the model is the tripartite system of free movement of fully-qualified lawyers who are Union citizens and who are fully qualified as lawyers in on of the Member States of the European Union. These lawyers benefit from the freedom to provide services on the basis of Directive 77/249/EEC, the right to establish themselves under their home country title on the basis of Directive 98/5/EC, and the right to fully integrate into the legal profession either by taking an aptitude on the 
basis of Directive $89 / 48 /$ EEC (2005/36/EC) or by integrating on the basis of Directive 98/5/EC. Surrounding that core there are European Union citizens with third-country diplomas, third-country nationals and trainee lawyers who cannot benefit from the Directives but who can benefit from the first-generation case law laid down by the European Court of Justice. A graphical model was presented at the end of Chapter 2.

\section{\3. Observations and Conclusions with regard to Chapter 3}

Creating a model on the basis of the rules is only the first step. The model distilled in Chapter 2 only describes how the free movement of lawyers ought to look. A deeper answer to the question of where the free movement of lawyers stands in Europe can only be given after a review of the implementation of the model in the Member States. This was the purpose of the third chapter. I selected 15 Member States in order to review their implementation of the directives concerned. The core of the implementation research was the tripartite system established in the previous chapter.

The tripartite system is based on the fact that the beneficiaries are fully qualified lawyers (expressly in Directives 77/249/EEC and 98/5/EC and implied (as a produit fini) in Directive 89/48/EEC (2005/36/EC)). This warranted a closer look at the various legal professions in the selected Member States. It was established that the legal profession does not have the same characteristics in each of the different Member States. After a review of the different legal professions in the Member States, which focused on the qualification track and the extent of professional monopolies awarded to lawyers, I established on the latter criterion that there are roughly three categories of legal professions in the 15 Member States selected. Two of the Member States have legal professions that enjoy no professional monopoly at all. A second group only gives a professional monopoly to lawyers with respect to representing clients in court, while the majority offer a professional monopoly for representation and legal advice. This threefold division leads to the conclusion that in countries with a low and intermediate level of regulation, there is a category of professionals who engage in professional legal activities but are not fully qualified lawyers. These professionals would undoubtedly run into trouble when they seek to exercise their profession in a Member State with a high degree of regulation, since this 'hidden' category of professionals falls outside the scope of the core of the model described above. This category was specifically addressed in the research regarding each specific modality.

\section{The Free Provision of Services}

A review of the implementation of the Services Directive did not bring major defects to light. With regard to the category of professionals who engage in professional legal activities in Member States that have a low or an intermediate degree of regulation, it was established that this category is covered by Directive 2005/36/EC which states that, for the provision of services, the host Member State may not impose restrictions that have to do with the professional qualifications that a service 
provider needs to have. That means that after 20 October 2007 (the end of the transposition period of Directive 2005/36/EC) this 'hidden' category of professionals can provide services in other Member States, or at least may not be refused on the grounds that they do not have certain professional qualifications. Other restrictions fall under the first-generation case law, most notably the Gebhard case, and in 2009 this will be covered by the Directive on Services in the internal market, Directive 2006/123/EC.

\section{Establishment under Home Title}

The primary part of Chapter 3 was devoted to a detailed review of the implementation of Directive 98/5/EC in the selected Member States. Two main forms of implementation were observed. A number of Member States chose a completely new legislative instrument that, more often than not, included other modalities of the free movement of lawyers, while other Member States merely chose to adapt their existing legislation. The chosen form of implementation did not seem to have influenced the result to the extent that it could be said that implementations by one method are preferable to, or better than, implementations by the other method. Apart from the situation addressed below, no major defects regarding its implementation were discovered. On the basis of case law described above, however, a fourlayer system of restrictions applicable to the Directive was established. Firstly, there had been some violations that were addressed in Commission v. Luxembourg and Wilson. In these cases it was established that Articles 3 and 5 of Directive 98/5/EC lead to complete harmonisation. I have proposed that this ruling could be applied to the majority of the articles in the Directive. The result was that if Member States created or contradicted substantial provisions laid down in these articles then this would be illegal per se, with no possible justification. Violations which were similar the ones dealt with in the cases were observed in a number of Member States. A second category of violations can be found in the application of the $A M O K$ case. In that case, the Court ruled that national rules on a subject matter that fell outside a directive, but precluded the full working of the directive, would be illegal per se without possible justification. Although decided on the basis of Directive 77/249/ EEC, it has been put forward that through analogous interpretation the case can also be applied to Directive 98/5/EC. In the case of the Netherlands, a rule stating that a $98 / 5 /$ EC lawyer could not gain access to the profession of the procureur was classed as falling into this category. The situation in the Netherlands will resolve itself since the profession of the procureur will be abolished and completely merged with the profession of the advocaat in 2008. A hypothetical third category of restrictions are those that fall outside the scope of the Directive, but that would not preclude the full working of the Directive. Based on first-generation case law, these restrictions fall under the regime of Gebhard and are prohibited unless they are objectively justified. A fourth and final category of restrictions is actually caused by the Directive itself, and must be classed as permissible. The clearest example of this fourth category is that lawyers must be registered in their home Member State before they can register in another Member State. Most likely this means that lawyers will have to pay two membership fees, a situation that must be classed as a restriction 
but that flows directly from the Directive. Rules with regard to permanent education could also be problematic in this respect.

There is one thing that needs to be addressed with respect to the implementation of Article 11 of Directive 98/5/EC. The majority of Member States have ignored the reference to objective justification in applying host Member State professional rules with regard to joint practice and have reduced this rule to a mere national treatment rule. This is something the European Commission should address in its review of the implementation of the Directive, which is due to be conducted in 2008. That observation, taken together with the other national treatment rules and the considerable ease (certainly if compared with the aptitude test under the system of the Diploma Directive) with which lawyers can integrate into the host Member State legal profession, leads to the conclusion that Directive 98/5/EC leads to full mutual recognition of the legal professions in Europe in all but name.

The situation of the 'hidden' category of professionals is much less rosy in this modality. It has been established that no secondary legislation applies to their situation and the Gebhard rule is the only safety this category can rely on when seeking establishment rights in other Member States. It has been observed that it might well be that a new installation limitée might emerge for this category of professionals since the rules on the free provision of services give more rights to this category than the rules relating to establishment. However, this would be an unwelcome situation.

\section{Recognition of Diplomas}

For the mutual recognition of lawyer's diplomas, no major defects were established. In terms of what was established for the 'hidden' category of professionals, it was found that they can request an aptitude test in order to integrate into the legal profession of the host Member State. The problem is that the profession in the host Member State is the profession of the lawyer, a profession with a much wider scope than the professional activities the individual was exercising in his home Member State. Recent case law of the European Court of Justice, more specifically the Caminos case, allowed candidates to limit their integration into a regulated profession to a certain level. This case law could prove useful for this category of professionals.

\section{Third-Country Nationals}

With regard to third-country nationals, the research in the third chapter took a different approach. It was established in Chapter 2 that only very meagre protection was available for third- country nationals in the model distilled. Therefore this study has examined whether the rules of the WTO, or more specifically of the GATS, could offer more protection for third-country nationals who seek to engage in legal professional activities in the European Union. It was concluded that this was not the case for two specific reasons. First, in a concise review of the GATS rules applicable to legal services, it was established that the guarantees offered by GATS fall short of the most limited category of the free movement of lawyers in Europe, the free provision of services. New negotiations would include guaranteeing more substantial rights to lawyers seeking free movement, but since July 2006 negotiations in the so-called Doha round have been suspended, so that there is no date in sight when these new developments can be expected. Secondly, and perhaps more im- 
portantly, it is generally assumed (and for the European level confirmed by the European Court of Justice) that WTO (GATS) rules do not have direct effect in courts. This means that individual lawyers cannot rely on these provisions in proceedings against a state or a Bar Association. Member States taking over complaints and starting inter-state proceedings in the context of the WTO dispute settlement system seems unlikely.

The paragraph on third-country nationals in this book stopped short of reviewing national rules in the Member States that govern third-country national lawyers. However, it was established that the rules in Member States are patchy and lack coherence. In a number of instances, in some Member States, lawyers from former colonies have more rights than other third-country nationals (which against the letter of the GATS rules). The rules in Germany have been put forward as a 'best practice'. Germany allows lawyers from all WTO members to establish themselves under their home country professional title (which is much more than what is required under GATS) and allows them to pursue activities in relation to their home-country law and international law. I believe that all Member States should implement this system.

\section{Conclusion}

Overseeing the implementation of the model that was distilled in Chapter 2, it must be concluded that Directive 98/5/EC is not only the latest addition to the system of free movement of lawyers from a secondary legislation perspective, but also it is the most important element of the model. This is the case for a number of specific reasons. Firstly, the Directive caters for the third category of lawyers who, until 1998, had to rely on the so-called installation limitée on the basis of Directive $77 / 249 / \mathrm{EEC}$. The Establishment Directive now gives them the right, on the basis of rules firmly based on the principle of mutual recognition, to establish themselves in another Member State and to exercise professional activities of the legal profession of that Member State under the professional rules in force there. This is more than a lawyer relying on installation limitée could ever have hoped for. But there is more. Not only does Directive 98/5/EC cater for the category of lawyers that was before its adoption orphaned, but it also enters the territory of the other two Directives. For 77/249/EEC this means that the overextended use of that Directive, known as installation limitée, has become superfluous. For the Diploma Directive the changes are more fundamental. Not only does Directive 98/5/EC allow lawyers to establish themselves under their home country professional title, it also provides for a possibility to integrate into the host country legal profession after a period of three years, without any further compensatory measures (such as an aptitude test) being imposed. In my view that must lead to the conclusion that the role of the Diploma Directive in the system of free movement of lawyers is being reduced to a residual one. Imposing an aptitude test will only be warranted in isolated situations (involving prior knowledge of the candidate, for example, but not enough prior knowledge to escape an aptitude test) but the majority of lawyers will integrate through the system of Directive 98/5/EC. This leads to the conclusion that the influence of Member States on the establishment of foreign lawyers is reduced from a carte blanche after the implementation of the Diploma Directive, to next to no influence after the Estab- 
lishment Directive. This is an evolution that cannot be underestimated, and that, it seems to me, has not sunk in with the Member States.

This last remark, read in conjunction with the national treatment rules in the Establishment Directive and the wrong implementation of Article 11 of the Establishment Directive, leads to the conclusion that, for fully-qualified lawyers who are European Union citizens, the implementation of the model distilled in Chapter 2 leads to full mutual recognition of the legal professions in Europe. In that bold statement its major weakness is also enshrined. The system only operates fully for fully-qualified lawyers. In order to benefit from the system, one must spend years qualifying as a lawyer in one Member State and then more years in another Member State integrating into its legal profession. Therefore I researched what rules applied to the system of qualification as a lawyer, and how this system could be adapted in order to further refine the free movement of lawyers in Europe.

\section{$\$ 4$. Observations and Conclusions with regard to Chapter 4}

On the basis of the review of the qualification tracks in the different Member States, it is clear that in general the qualification track used for becoming a lawyer in a Member State consists of two distinct elements; a law degree and professional education. That dichotomy also provides for two distinct entry points for people wanting to enter that qualification track: one before the law degree and one before the professional education. I have concluded that although the European Union has made rules covering the free movement of students, Article 149 of the EC Treaty precludes the legislative institutions to make rules in connection with the mutual recognition of qualifications needed to enter the qualification track on these specific points of entry. Entry to these tracks is governed by two Council of Europe Conventions which form an integral part of the 'Bologna Process'.

The Member States have started to create their own European Area of Higher Education on the basis of the so-called 'Bologna Process'. This is a soft-law process in which Ministers responsible for education of the participating states develop, on an intergovernmental and voluntary basis, close cooperation in the field of higher education. It must be kept in mind that the creation of the European Area of Higher Education is in no way especially focused on legal education or the free movement of lawyers. After a careful examination of the developments occurring within the 'Bologna Process', and mainly two of the three developments spear-pointed by the Ministers in the 'Bologna Process' (the creation of a two- or three-cycle system, and the recognition of higher education qualifications), it appears that the 'Bologna Process', as it stands today, does not add much to the free movement of lawyers in a material sense.

I have also concluded that Member States of the European Union are considerably restricted in the application of the two Council of Europe Conventions on the basis of two decisions of the European Court of Justice. It was established, on the basis of the cases of Commission v. Austria and Morgenbesser, that the Court not only showed that it was not intimidated by the prohibition laid down in Article 149 of the EC Treaty but that it would also not allow Member States to discriminate on 
the basis of an individual possessing a certain diploma. In other words, Member States may not make access to the qualification track (at either of the two entry points) dependent on possession of a national diploma. With regard to access on the level of professional education, the Morgenbesser case even requires the application of the Vlassopoulou rule.

Next, I examined how the 'Bologna Process' could be used to further develop the free movement of lawyers. I concluded that changing national legal curricula could achieve a further free movement of lawyers. Curricula should focus more on general principles rather than on the particularities of national law. In this manner, the free movement in the qualification track would become easier, since the treatment of national law would be reserved for the master's level or even for professional education. A short review of the system in the United States of America showed that such an approach is possible, even more so since there are considerably less rights of free movement for lawyers in the USA than in Europe. In Europe itself, Luxembourg could serve as an example because, until recently, it was forced to accept exclusively candidates with foreign law degrees since Luxembourg had no Law Faculty of its own. The same goes for the conversion courses used in the United Kingdom. It is clear that such an adaptation of legal curricula requires a major cultural change that will not be easily achieved. Having said this, at present there are numerous experiments in Europe that are attempting to create such a curriculum. In addition to the culture change, there are other additional legal problems. Having reviewed possible ways to achieve such a curriculum change, I concluded that it can best be achieved in the context of a new mode of governance provided in Article 15 of Directive 2005/36/EC, the so-called common platform, and that the CCBE should at least take a coordinating role in the development of such a platform.

Until this is achieved, prospective lawyers in Europe only have the European Court of Justice as the guardian of their rights, and effectuating those rights will remain a struggle which will, more often than not, involve litigation.

\section{$\int$ 5. Recommendations: The Future}

Directive 98/5/EC represented an enormous step forward in the cumulative protection of the free movement of lawyers. Before the implementation of Directive $98 / 5$ /EC, lawyers were subject to an aptitude test in order to integrate into the profession of the host Member State. They were, at best, allowed to engage in professional activities under their home country professional title where this professional activity was not part of the legal monopoly of the host Member State. After the implementation of Directive 98/5/EC, lawyers became more secure through registration under their home country professional title and were permitted access to almost all the professional activities reserved for the host country profession. Moreover, the lawyer who is established under his home country professional title may fully integrate into the legal profession of the host Member State after a period of three years without having to take an aptitude test. In my view, this leads to full mutual recognition of the legal professions in Europe.

With regard to future perspectives, the Directive itself does not provide for many interesting developments for the future. According to Article 15 of the Directive, 
the European Commission will issue a report in 2008 on possible amendments to the system. Based on the review of implementation given above, only the system of joint practice could be a potential candidate for review. This is a part of the Directive that was misunderstood by the majority of implementing countries. Based on the rest of the Directive that leads to the firm embedding of the lawyer in the professional rules of the host Member State, it might be more logical to apply the rules of the host Member State to joint practices rather than the complicated system of objective justification that is laid down in Article 11 of the Directive.

\section{Recommendation 1}

It is recommended that the system of Article 11 of Directive 98/5/EC should be changed to a national treatment clause in order to bring it into conformity with the majority of implementation mechanisms.

It was observed that the real prospects for the future of the free movement of lawyers lie outside the scope of the Directive, in the field of prospective lawyers. Until recently, the free movement of lawyers could only be enjoyed by those who had actually fully qualified as a lawyer in one of the Member States. The Services Directive (77/249/EEC), the Diploma Directive (89/48/EEC; now 2005/36/EC) and the Establishment Directive (98/5/EC) are only applicable to lawyers who are fully qualified in their home Member State. The Directives do not lay down rules for those who cannot be regarded as a produit fini. Persons who were in the process of qualifying for a legal profession were, until recently, surrendered to the mercy of the Member States. Recognition of university diplomas, or even secondary education, used to fall under the prohibition on harmonisation laid down in Article 149 of the EC Treaty. It was for the Member States alone to decide whether such diplomas should be recognised. Dependent on the regime in force in the Member State in question recognition would be subject to the rules of the Member State itself, or the rules laid down in the Lisbon Recognition Convention.

All this changed with the ruling of the European Court of Justice in the Morgenbesser case. This case opened up the possibility for prospective lawyers to hop qualification-tracks and to benefit from the guarantees laid down in the case law (more specifically Vlassopoulou) before they gained the status of produit fini. Although the ECJ did not address this specifically in the Morgenbesser case, it must be mentioned that the ruling encroaches on the recognition of academic diplomas which, according to Article 149 EC Treaty, falls under the sovereignty of the Member States. In two other recent cases, Commission v. Belgium and Commission v. Austria, the ECJ gave rulings that could also be potentially revolutionary for the system of recognition of secondary education qualifications (as the ECJ has ruled that these fall under the scope of the EC Treaty). Application of these rulings could lead to an enormous diversity of possibilities for students and prospective lawyers. If the recognition of academic and secondary education diplomas is taken from the Member States and brought under the case law that was developed for the produits fini, then it is clear that all prospective lawyers have a right to an individual assessment of their qualifications. Such a system would provide relatively easy access to education and vocational training in other Member States. On the other hand, it must be mentioned that the result from these three recent cases is far from clear. With regard to Morgenbesser, a matter of fact rendered the ECJ unable to bring the case under 
the ambit of 'regulated professional activities' which are covered by the Diploma Directive. Further development of this line of case law is strongly desired.

Application of the Diploma Directive would lead to even more legal certainty for prospective lawyers. That statement has even more importance for recognition of secondary education qualifications. The rulings in the two cases described above lead to a very crude result which seems to come down to the automatic recognition of secondary education qualifications. In light of the case law on diplomas, and the Morgenbesser case, and reminded of the fact that the recognition of academic qualifications is actually in the hands of the Member States on the basis of Article 149 EC Treaty, it seems unimaginable that no system of compensation would be developed for secondary education qualifications. In my opinion, it is self-evident that refinement of this case law is required, even more so because the European Court of Justice has ruled in the cases that the existing system for recognition of such qualifications, the Lisbon Recognition Convention, cannot serve as a justification. Therefore, it would be no more than logical to bring the recognition of secondary education qualifications also under the system of Vlassopoulou, so that one system exists for all possible stages of qualification. The legal reform in Germany in connection to the Deutschen Richtergesetz also seems to give preference to the system of Vlassopoulou over the Lisbon Recognition Convention (which has not been ratified by Germany).

Recommendation 2

It is recommended that the rules, laid down in case law, for those persons who are not fully qualified as lawyers should be refined. The Diploma Directive should be applied to those seeking entrance in professional education and the Vlassopoulou doctrine applied to the recognition of secondary education diplomas.

If this were to be realised then an enormous palette of choices would become available to the prospective lawyer. From the point of view of recognition, a full free movement would then be realised. Such a system of free movement would be of little use if the qualification tracks for lawyers were to remain focused on the national law of the Member States. Differences between the qualification tracks would then remain as substantial. These substantial differences lead Member States to require compensatory measures. So although the system of recognition of diplomas moves towards a more complete facilitation of free movement of (prospective) lawyers, such facilitation is next to useless if nothing changes in the qualification tracks themselves.

In addition to the facilitation of the previous paragraph, facilitation of streamlining higher education has also taken place through the 'Bologna Process'. The 'Bologna Process' mainly leads to facilitation in terminology, i.e., participating countries use the same terminology and credit system in order to facilitate the free movement of students between the higher education institutions. With regard to recognition of qualifications, it is noteworthy that the 'Bologna Process' has relied heavily on the Lisbon Recognition Convention. Some elaborate criticism has been voiced on this Convention. In addition, the European Court of Justice rendered the Lisbon Recognition Convention inapplicable at times when it conflicts with European law. Therefore, it must be expected that, at least for the Member States of the European Union, the recognition system of higher education diplomas and diplomas that give access to higher education will be governed by a system developed by the European Court of Justice rather than by the Lisbon Recognition Conven- 
tion that is envisioned by the 'Bologna Process'. Similar to the free movement system developed by the European Court of Justice, the 'Bologna Process' mainly facilitates the procedure. It will be up to the universities to create programmes directed to free movement which make the best use of the possibilities offered by the system laid down by the ECJ and the 'Bologna Process'. It will then be up to the competent authorities of the legal professions to create a system that accepts this curriculum, as described above.

\section{Recommendation 3}

It is recommended that special curricula should be devised by universities and accepted by professional organisations in order to further the free movement of (prospective) lawyers.

In my opinion creating the curricula is best done by creating legal education that is primarily detached from the national legal system. Universities should create curricula that are tailor-made for prospective free movement purposes (either in place of, or in addition to, 'traditional' curricula). In the Middle Ages, law students used to study the Ius Commune at a university of their choice, and would then teach themselves the law of the jurisdiction in which they chose to work, based on their knowledge of the Ius Commune. Such a construction could be repeated in the present day. Obviously, Roman law cannot serve as an Ius Commune as such anymore, but a strong common ground can be found in European Community law and comparative law. In the later stages of studies, a specialisation can be taken in national law. Specific national knowledge can further be gained in master's programmes and, as was described above, a vocational training that is directed towards national law. Luxembourg offers an example of this, since Luxembourg was devoid of a Law Faculty until recently. Focus towards a national legal system should be gradually built over the years of study.

The University of Maastricht started such a bachelor's degree programme in 2006. The European Law School (English Track) provides for an English-language curriculum that is strongly based on comparative law and European Community law. In the third year of the bachelor's degree programme a choice is offered to students to take different tracks that are either focused on Dutch law, or a more general track (which excludes the possibility of becoming a lawyer in the Netherlands). The idea behind this system is that the final year of the bachelor's degree programme would prepare students for a master's programme (and perhaps a career in a legal profession) in one of the Member States of their choice. This curriculum is still very young and only the future will tell how its alumni are received by the profession, even more so since the acceptance of these types of curricula by the professional authorities has not been assured. It is, however, my firm belief that these curricula are the way forward. This is the way to create a true European lawyer, who can move freely throughout the European Union and who is capable of acquiring knowledge of national legal systems based on the strong basis of a new Ius Commune acquired in undergraduate legal studies. 


\section{Recommendation 4}

It is recommended that these special curricula should focus in the bachelor's phase on a new Ius Commune rather than on national law. Precise knowledge of national law should be reserved for the master's phase, specially designed conversion courses or even professional education. 



\section{Epilogue}

One of the consequences of conducting $\mathrm{PhD}$ research, or writing a book in general, is that the author must, at a given point, decide where to draw the line. In the introduction of this book a justification of limitations in the research was given. However at this point, in October 2008, there are two issues that warrant at least some attention. These issues concern the 'new' Member States and a possible negative effect of the Bologna Process for law students, especially in the Netherlands.

\section{The New Member States}

In the introduction of this book it was set out that at the beginning of my research in $2001 \mathrm{I}$ had the idea to incorporate all the Member States of the European Union in this book. When the 10+2 enlargement round took effect in May 2004 (and was completed in January 2007) it became rapidly clear that this was a goal that could no longer be upheld. Not only had the research in the fifteen pre-2004 Member States led to a consistent outcome with regards to the research questions posed with regard to the implementation of Directive 98/5/EC, but language and availability problems stood in the way of including the new Member States in the review of free movement possibilities that are addressed in the book. These two issues combined have led to the decision not to include the new Member States in the research.

Now in October 2008 these considerations are still valid. The CCBE has, however, collected English translations ${ }^{1}$ of the legal instruments that implement at least Directive 98/5/EC in the new Member States. These unofficial translations cannot serve as a base for a detailed incorporation of the new Member States in the main part of the research, but they do offer the possibility to have a quick look at the implementation mechanisms in those Member States that have offered English translations to the CCBE.

Out of the twelve new Member States, nine have provided information to the CCBE. The Member States that joined the EU in 2007, Bulgaria and Romania have not provided information so they will not be included in the following overview. The same goes for Latvia that joined in 2004. Out of the other nine, Hungary and Slovakia have only provided information in their own language, so these Member States will also not be addressed. ${ }^{2}$ The remaining seven states have offered a translation of their implementation mechanism to the CCBE. In the following overview I will deal with these eight states in alphabetical order. I will only give very general comments with regard to the implementation and only anomalies (where and if they should occur) will be dealt with in greater detail.

In Cyprus Directive 98/5/EC has been implemented by the 2002 Lawyers (Amending) (No 2) that, as its title would suggests, amends the existing lawyers act

See <www.ccbe.org>, last accessed 26 September 2008.

The CCBE website mentions an English version of the Slovak implementation, but the hyperlink seems corrupted. 
in Cyprus. ${ }^{3}$ In a short amending act both Directive 77/249/EEC and Directive 98/5/EC are, on first sight, correctly implemented in the Cyprus Lawyers Act. What is noteworthy with regard to the implementation in Cyprus (in the light of the implementation research in the fifteen pre-2004 Member States) is that Cyprus states in the implementation mechanism that a fee is payable after a lawyer has registered himself under his home country professional title. With regard to integration in the legal profession of the host Member State it must be mentioned that Cyprus is among the minority of states that does explicitly include the referral to activities in Community law as counting for the three years regular practice in the law of the host Member State. In the area of joint practice the Amendment Act is completely silent on the subject of multi disciplinary partnerships (MDPs) indicating that these are not allowed in Cyprus and indicating that the Cypriot authorities have opted to treat this part of Article 11 of Directive $98 / 5 / \mathrm{EC}$ as a national treatment clause.

The Czech Republic has also opted for an amendment to the existing law on Advocacy. ${ }^{4}$ In this amendment it attempts to implement Directive 77/249/EEC; Directive 89/48/EEC (now replaced by Directive 2005/36/EC) and Directive 98/ $5 / \mathrm{EC}$. What is remarkable with regard to the Czech implementation is that, similar to Cyprus, reference is made of a fee that is payable upon registration as a lawyer under home country professional title. What is also noteworthy is that the Czech implementation has the most elaborate implementation of the requirement that a lawyer established under his home country professional title must work in conjunction with a domestic lawyer when represented in court observed until now. Although elaborate, the implementation is completely in line with the case law of the European Court of Justice on this matter. With regard to integration in the host country legal profession the implementation mechanism mentions that the lawyer concerned must have been active mainly in Czech law which is an unorthodox, and potentially infringing manner of dealing with the '...including Community Law...' phrase in Article 10 of Directive 98/5/EC. With regard to MDPs there are no specific provisions other than the prohibition in the Advocacy Act.

The Bar Association Act of Estonia also includes Estonia's implementation of Directive 77/249/EEC and Directive 98/5/EC. ${ }^{5}$ Lawyers who are established under their home country professional title are called 'Associate members of the Bar Association' whereas lawyers providing services are dubbed 'Advocates of foreign states'. Again, the implementation is rather uneventful staying very close to the wording of the Directive. What is potentially problematic is that integration into the Estonian legal profession is obtained through three years' activity in Estonian law, without mention being made of the '...including Community Law...' phrase of Article 10 of Directive 98/5/EC. This is potentially infringing the Directive it turns out that the

3 The Lawyers (Amending) (No2) Act of 2002, no. 180(1) of 2002, via <www.ccbe.org>, last accessed 26 September 2008.

4 Act No. 85/1996 Coll., on Advocacy as amended by Act No. 210/1999 Coll., 120/2001 Coll., 6/2002 Coll. And 228/2002 Coll., via <www.ccbe.org>, last accessed 26 September 2008.

5 Bar Association Act, passed 21 March 2001 (RT I 2001, 36, 201) entered into force 19 April 2001, amended by the following Acts: 18.12.2002 entered into force 23.01.2003 - RT I 2003, 4, 22; 16.06.2002 entered into force 01.08.2002 - RT I 2002, 57, 357; 19.12 .2001 entered into force 10.01.2002 - RT I 2002, 102, 676, via <www.ccbe.org>, last accessed 26 September 2008. 
Estonian authorities do not take into account any experience in European Law. MDPs are prohibited in Estonia for domestic lawyers; therefore lawyers established under their home country professional title are also not allowed to be active in an MDP.

Also Lithuania has opted for an amendment of the existing Law on the Bar in order to implement Directive 98/5/EC. ${ }^{6}$ This implementation is also uneventful and completely in line with what has been observed in the research of the fifteen Member States that are included in the book. There is only a reference to Lithuanian law in the provision governing entrance into the Lithuanian legal profession so whatever has been said with regard to the Czech Republic and Estonia is also true for Lithuania. There is one remarkable reference in the implementation mechanism that governs activities of a lawyer established under his home country professional title in Lithuania. There is a provision that reads: 'The lawyer of a EU member state shall render legal assistance in the Republic of Lithuania within the limits of the professional qualifications granted to him by a competent institution of the member state of the European Union.' If this provision where to mean that a lawyer established under his home country professional title can only give advice on his home country law and not on Lithuanian law than that is obviously in violation of the Directive.

In good common law tradition (at least compared to the common law jurisdictions that were reviewed in the book) the implementation mechanism in Malta has taken the form of a Regulation. ${ }^{7}$ The text of the Regulation stays very close to the text of the Directive and therefore this implementation can also be deemed as uneventful. In line with many of the states reviewed in this epilogue the Maltese implementation leaves out the phrase '...including Community Law...' that is included in Article 10 of Directive 98/5/EC. This could be a potential infringement of the Directive. Furthermore it is noteworthy that the Maltese implementation makes completely no mention of joint practice, therewith implying that joint practice does not occur in Malta.

Out of the Member States included in this review, Poland is the only Member State that has created a separate law that deals with the exercise of professional activities in Poland by lawyers from other Member States, and even other non-Member States. ${ }^{8}$ Because of the fact that Poland has tried to encompass every form of exercise of legal activity in Poland by lawyers from outside Poland, the structure of the Directive is less recognisable in the implementation mechanism. A quick overview of the implementation mechanism reveals no major irregularities. Poland even mentions relevant experience in Community Law in the implementation of Article 10 of Directive 98/5/EC. With regard to practice in MDPs no mention is made beyond the remark that a partnership of which a lawyer is a partner may only have as its objective the provision of legal services, therewith implying that MDPs are not allowed in Poland.

6 Law on supplementing Articles 7 and 18 of the Law on the Bar and supplementing the Law with new Chapter 10, 6 December 2001, No IX-630 (Official Gazette 1998, No. 64-1840; 1999, No. 19-508, No. 57-1830) via <www.ccbe.org>, last accessed 26 September 2008.

7 Subsidiary Legislation 12.17 Mutual Recognition of Qualifications of Legal Profession Regulations, Legal Notice 273 of 2002, via <www.ccbe.org>, last accessed 26 September 2008.

8 Act of 5 July 2002 on the provision by foreign lawyers of legal assistance in the Republic of Poland, via <www.ccbe.org>, last accessed 26 September 2008. 
The last Member State in this review is Slovenia. Unlike Poland Slovenia has opted for introducing a separate chapter to the existing Bar Act in order to regulate the free movement of European lawyers. ${ }^{9}$ What is remarkable with regard to the Slovenian implementation of Directive 98/5/EC is that irregularities with regard to the exercise of professional activity do occur. These irregularities, that lawyers established under their home country professional title are not allowed to train prospective Slovenian lawyers and are not allowed to take part in a legal aid scheme are identical to the irregularities observed in Austria. This implies that there must have been some dialog between Austrian and Slovenian authorities in the implementation process in Slovenia. With regard to assessing these irregularities the same conclusion must be reached that was reached with regard to Austria, namely the fact that these irregularities are infringements of the Directive. There is no mention of division between Slovenian and Community law with regard to the implementation of Article 10 of the Directive and MDPs are not allowed in Slovenia.

After a very general overview of seven out of the twelve new Member States it can be concluded that he conclusions reached after chapter three in the book are not altered by the implementation of the Directive in the new Member States. The new Member States offer the same picture as the fifteen pre 2004 Member States, namely implementation that lies relatively close to the text of the Directive, lack of clarity with regard to the amount of pure Community Law that might be included in the process of integrating in the host country legal profession and structural problems with the implementation of Article 11 of the Directive with regard to joint practice. That means that the recommendations based on the conclusions that were presented in Chapter 5 of the book can remain in force.

\section{Negative Impact of the Bologna Process on the Recognition of Academic Diplomas}

Chapter 4 of this book was devoted to researching whether the free movement of lawyers could be effectively furthered by creating free movement possibilities in the qualification track for lawyers, since the free movement system that was completed by Directive $98 / 5 / \mathrm{EC}$ is exclusively applicable to lawyers who are fully qualified to exercise that profession it at least one member state. It was concluded that the development of such possibilities was desirable and it was also concluded that this could be achieved trough reforming existing legal education more towards a more general (less focussed on national law) curriculum that, at later stages can be completed with knowledge in the national law of a legal system. It was also included that the existing 'Bologna Process' did not do much for the realisation of such free movement possibilities. But it might be even worse than that. Preliminary observations in the Netherlands show that professional authorities have a peculiar response to the streamlining of university education in a Bachelor-Master system: they dig their trenches even deeper. Professional authorities are becoming more and more aware of the fact that whatever lies behind one bachelor title may be completely different than what lies beyond another bachelor title. This is exactly the effect that 
was predicted in chapter 4 of the book when it was concluded that giving essentially different things the same name that leads to confusion. Professional authorities react, understandably, with caution to this uncertainty. This leads, in my view, to the unlikely observation made with regard to German students in the Maastricht ELS-ELT track that they would be worse of in Germany when they would do a hypothetical minor in German law as opposed to a minor in Dutch law because of $\$ 112 \mathrm{a}$ of the Deutschen Richtergesetz. While the extent of this effect must be researched in much more detail in the future it is all the more clear that the attention should be shifted from the names of the different curricula to the content of those curricula in order to avoid that the motto of the Bologna Process has to be 'Diversity through Unity'. 



\section{Samenvatting}

\section{Inleiding}

Bijna 35 jaar geleden wees het Europese Hof van Justitie de arresten Reyners en Van Binsbergen. Met deze arresten begon het Hof met de ontwikkeling van een hernieuwd vrij verkeer van advocaten. Van oudsher konden advocaten zich vrij door Europa bewegen maar door de ontwikkeling van de rechtssystemen in de verschillende Europese landen in de 19 e eeuw was de uitoefening van het beroep van advocaat sindsdien verbonden met het land waarin een dergelijke advocaat zijn beroepskwalificaties had verworven. Naast de eis om in die Lidstaat gekwalificeerd te zijn uitte zich dit in de meeste Lidstaten door het handhaven van een nationaliteitsvereiste voor het beroep van advocaat. In het arrest Reyners maakte het Hof een einde aan deze praktijk. In het arrest Van Binsbergen bepaalde het Hof dat ook het handhaven van een woonplaatsvereiste voor een dienstverlenende advocaat niet langer was toegestaan.

In de jaren na Reyners is er zowel van de kant van het Europese Hof van Justitie, als van de kant van de wetgevende instellingen van de Europese Unie (de Europese Commissie, de Raad van Ministers en het Europees Parlement) veel activiteit geweest op het gebied van het vrij verkeer van advocaten zodat nu, in 2008, met recht gezegd kan worden dat er een sluitend systeem is waarbinnen advocaten rechten kunnen genieten die hun vrij verkeer garanderen.

Het doel van deze studie naar het vrij verkeer van advocaten is drieledig. In de eerste plaats moet onderzocht worden hoe dat sluitende systeem van vrij verkeer van advocaten er precies uit ziet. Juist door de combinatie van aan de ene kant activiteit van de wetgevende instellingen in de vorm van richtlijnen en aan de andere kant de arresten van het Europese Hof van Justitie zijn de omvang en de precieze implicaties van dat systeem niet meteen duidelijk. Nadat de precieze omvang van het vrij verkeer van advocaten bepaald is, dringt zich meteen de vraag op of die regels ook volledig worden nageleefd in de Lidstaten. Ten slotte kan de vraag gesteld worden of, en zo ja, in hoeverre, het vrij verkeer van advocaten verder ontwikkeld en verfijnd kan worden.

\section{Ontwikkeling van een model van het vrij verkeer van advocaten}

Om tot een afdoende beantwoording van de eerste vraag te komen is het nodig om zowel de gebeurtenissen met betrekking tot de jurisprudentie van het Hof van Justitie als de activiteiten van wetgevende instellingen van de Europese Unie te verwerken in een model dat niet alleen de uitkomsten van beide trajecten weergeeft maar ook de onderlinge verhouding tussen die twee trajecten.

Het was het Europees Hof van Justitie dat in eerste instantie door zijn jurisprudentie het vrij verkeer van advocaten in de Europese Gemeenschap in principe mogelijk maakte. Deze zogenoemde eerste generatie jurisprudentie wordt gekarak- 
teriseerd door arresten waarin het Europees Hof van Justitie het Verdrag op zo een manier interpreteert dat advocaten hun rechten op vrij verkeer kunnen uitoefenen. De eerste zaken in deze lijn van jurisprudentie waren de zaken Reyners en Van Binsbergen waarin het Hof verklaarde dat artikelen 43 en 49 EG-Verdrag directe werking hebben, en dat (destijds) bij gebrek aan secundaire wetgeving advocaten een direct beroep op deze artikelen kunnen doen om hun rechten te effectueren. Het Hof zette deze lijn door in zaken als Thieffry; Klopp; Vlassopoulou. Met name deze laatste zaak, waarin het Hof bepaalde dat een persoon die toegang zoekt tot een gereguleerd beroep recht heeft op een individuele vergelijking tussen zijn kennis en ervaring en de voor het beroep noodzakelijke kwalificaties, is nog altijd van het grootste belang. Het Hof ontwikkelde zijn jurisprudentie verder in het arrest Kraus zodat ook nondiscriminatoire belemmeringen in principe verboden zijn. Die laatste ontwikkeling vond zijn sluitstuk in het Gebhard arrest waarin het Hof de befaamde formule uit Cassis de Dijon van toepassing verklaarde op alle vier de vrijheden.

Toen het Hof bezig was met de ontwikkeling van dit complex van rechten voor (onder meer) advocaten, waren de Europese wetgevende instellingen druk bezig met het ontwikkelen van een systeem van richtlijnen dat op de zogenaamde vrije beroepen (waaronder het beroep van advocaat) van toepassing is. In de jaren zeventig werd, onder aanvoering van de Europese Commissie, getracht alle vrije beroepen één voor één te harmoniseren. Deze zogenaamde sectorale aanpak voorzag in het creëren van twee richtlijnen per beroep. In de ene richtlijn werden minimumvereisten voor de opleiding tot dat beroep neergelegd, terwijl de tweede richtlijn voorzag in wederzijdse erkenning van de beroepsvereisten in de verschillende Lidstaten. Deze aanpak werkte met name in de medische sector en zodoende werden de beroepen van dokter, tandarts, dierenarts, verpleger en vroedvrouw op deze manier geharmoniseerd. Toch bleek deze sectorale aanpak te traag. De onderhandelingen over met name de minimumvereisten voor de opleidingen in de diverse medische beroepen verliepen vaak moeizaam. Buiten de medische sector was de toepassing van het sectorale systeem nog moeilijker. Voor het beroep van architect werd met moeite een erkenningsrichtlijn opgesteld, maar een richtlijn met minimumvereisten is er nooit gekomen. Voor het beroep van ingenieur bleek het überhaupt onmogelijk om tot een richtlijn te komen.

Voor het beroep van advocaat werd er niet eens een poging ondernomen om het beroep door middel van de sectorale aanpak te harmoniseren. Toch werd er voor dit beroep in 1977 een richtlijn aangenomen die het in ieder geval mogelijk maakte voor advocaten om in een andere Lidstaat diensten te verrichten. Deze richtlijn $77 / 249 /$ EEG werd gebaseerd op het principe van wederzijdse erkenning. Advocaten zijn op basis van deze richtlijn gerechtigd om de activiteiten van het beroep in de Lidstaat van ontvangst uit te oefenen met als enige restrictie dat de Lidstaat van ontvangst de samenwerking met een in die Lidstaat gekwalificeerde advocaat voor mag schrijven in het geval van vertegenwoordiging van een cliënt voor een rechter. Deze activiteit moet echter wel tijdelijk zijn (omdat het om dienstverlening en niet om vestiging ging). Blijkbaar was die concessie genoeg voor de Lidstaten om de moeizame en tijdrovende constructies zoals die in het sectorale systeem plaatsvonden niet ook bij deze richtlijn toe te passen. Zodoende blinkt de richtlijn uit in eenvoud en transparantie. Bovendien was het tot midden jaren negentig (totdat het Gebhard-arrest gewezen werd) onduidelijk wat nu de precieze afbakening tussen 
vestiging en dienstverlening was, zodat veel advocaten een erg rekkelijke opvatting van tijdelijke dienstverlening hadden en in feite in een andere Lidstaat gevestigd waren (de zogenaamde installation limitée).

$\mathrm{Na}$ de moeizame harmonisatie van de medische beroepen en de mislukkingen in de architecten- en ingenieurssector werd in 1984 in Fontainebleu voor een andere koers gekozen. Er zou een horizontaal systeem van erkenning van beroepsvereisten moeten komen dat van toepassing zou zijn op alle beroepskwalificaties waar op zijn minst een driejarige opleiding in het hoger onderwijs voor vereist was. Dit horizontale systeem zag op het einde van de jaren tachtig het levenslicht in richtlijn 89/48/EEG (de zogenaamde Diplomarichtlijn). Het systeem van de richtlijn gaat uit van wederzijdse erkenning, maar laat de mogelijkheid open voor Lidstaten om compenserende maatregelen te eisen als er substantiële verschillen zijn tussen de opleiding in de Lidstaat van herkomst en de Lidstaat van ontvangst. De compenserende maatregelen kunnen bestaan uit een aanpassingstage of een proeve van bekwaamheid. In principe heeft een kandidaat die zijn kwalificaties erkend wil zien en wil integreren in het beroep van de Lidstaat van ontvangst de keuze tussen deze maatregelen. Deze keuze wordt de kandidaat alleen ontnomen als het gaat om een beroep dat precieze kennis van het nationale recht vereist (zoals - uiteraard - bij het beroep van advocaat). In deze gevallen mag de Lidstaat een dwingende keuze opleggen. Het zal geen verbazing wekken dat alle Lidstaten gekozen hebben voor de zwaardere (althans vergeleken met de aanpassingstage) proeve van bekwaamheid.

In de praktijk doet deze opgelegde proeve van bekwaamheid het onderliggende principe van wederzijdse erkenning voor een deel teniet. De Lidstaten hebben namelijk voor een deel (binnen de grenzen van de proportionaliteitseis) de vrije hand in het bepalen van de omvang en zwaarte van de proeve. De weinige jurisprudentie (zeker vergeleken met andere beroepen) over de proeve bij het beroep van advocaat geeft als absolute grens een discriminatieverbod met de nationale opleiding. De proeve mag dus niet zwaarder zijn dan het kwalificatietraject in de Lidstaat van ontvangst, maar - blijkbaar wel (wederom binnen de grenzen van de proportionaliteitseis) - even zwaar.

Door de jaren heen werd richtlijn 89/48/EEG vergezeld van twee richtlijnen die een algemeen systeem voor erkenning creëerden voor lagere opleidingen (richtlijn 92/51/EEG en richtlijn 99/42/EG). Na een aantal wijzigingen werden deze drie richtlijnen, samen met de richtlijnen die werden aangenomen in het kader van de sectorale aanpak, opnieuw gecodificeerd in richtlijn 2005/36/EG. Deze nieuwe richtlijn verandert echter niets aan het systeem van erkenning van beroepskwalificaties van advocaten.

Met deze twee systemen, de dienstenrichtlijn en de diplomarichtlijn, waren twee modaliteiten van het vrij verkeer van advocaten gedekt, namelijk de advocaten die slechts tijdelijk diensten verlenen in een andere Lidstaat en de advocaten die volledig willen integreren in de Lidstaat van ontvangst. De derde modaliteit, advocaten die zich wel willen vestigen in een andere Lidstaat maar niet volledig willen integreren in de Lidstaat van ontvangst, en hun beroep willen uitoefenen onder eigen beroepstitel, was vooralsnog niet afgedekt (behalve door een te rekkelijke uitleg van richtlijn 77/249/EEG). Bescherming voor deze groep, en daarmee het sluitstuk voor het vrij verkeer van advocaten, kwam in de gedaante van richtlijn 98/5/EG. Deze richtlijn voorziet in het faciliteren van de vestiging van advocaten in een andere Lid- 
staat onder hun eigen beroepstitel. De oorsprong van deze richtlijn ligt in 1975 toen de Europese Commissie de Europese Organisatie van Advocatenordes (de CCBE) vroeg om na te denken over het realiseren van een vrij verkeer van advocaten. In 1992(!) bood de CCBE haar voorstel voor een richtlijn aan, aan de Europese Commissie. In dat licht kan richtlijn 98/5/EG gezien worden als een 'verlate' sectorale richtlijn.

Net zoals de richtlijnen 77/249/EEG en 2005/36/EG is richtlijn 98/5/EG gebaseerd op het beginsel van wederzijdse erkenning. Richtlijn 98/5/EG heeft grote overeenkomsten met richtlijn 77/249/EEG en leidt eigenlijk tot wederzijdse erkenning van het beroep zelf (en niet zozeer tot wederzijdse erkenning van de beroepskwalificaties zoals in richtlijn 2005/36/EG). Een advocaat die volledig gekwalificeerd is in een Lidstaat mag het beroep van advocaat, zij het onder zijn eigen beroepstitel, in alle andere Lidstaten uitoefenen. Daarbij mogen slechts marginale beperkingen worden opgelegd wat betreft de uitoefening van beroepsactiviteit. De zwaarste van deze beperkingen is een identieke samenwerkingsbepaling zoals die ook in richtlijn 77/249/EEG voorkomt in het geval van vertegenwoordiging van een cliënt voor een rechter.

Naast de erkenning van het recht om het beroep van advocaat permanent onder eigen beroepstitel uit te oefenen in een andere Lidstaat draagt richtlijn 98/5/EG nog twee belangrijke elementen in zich. In de eerste plaats is er de mogelijkheid, neergelegd in artikel 10 van de richtlijn, om volledig in het beroep van de lidstaat van ontvangst te integreren zonder dat daartoe de door richtlijn 2005/36/EG voorgeschreven proeve van bekwaamheid moet worden afgelegd. Deze mogelijkheid komt de advocaat toe als hij kan bewijzen dat hij zich gedurende tenminste drie jaar effectief en regelmatig heeft beziggehouden met het recht van de Lidstaat van ontvangst, met inbegrip van het Europees Gemeenschapsrecht. Daarnaast probeert de richtlijn de problematiek omtrent het uitoefenen van het beroep van advocaat in groepsverband, en dan met name in zogenaamde multi-disciplinaire partnerschappen te regelen. Helaas is deze poging in het wetgevingsproces grotendeels verwaterd, en de kleine nuance over de toepassing van de beroepsregels van de Lidstaat van ontvangst die overbleef, is in de implementatie door de Lidstaten structureel genegeerd.

$\mathrm{Nu}$, na de voltooiing van het systeem van secundaire wetgeving, dringt zich de vraag op of het systeem dat door het Hof van Justitie ontwikkeld werd, en vooral zijn weerslag vindt in de arresten Vlassopoulou en Gebhard, voor advocaten nog relevant is. Uit jurisprudentie over gevallen die geheel of gedeeltelijk buiten het toepassingsbereik van met name de Diplomarichtlijnen vielen is af te leiden dat het Hof in die gevallen consistent het in de jurisprudentie neergelegde model toepast en dan met name de Vlassopoulou-formule die leidt tot een direct individueel vergelijk tussen de gevraagde competenties en de competenties die de kandidaat heeft opgedaan. Een zaak moet hierbij specifiek onder de aandacht worden gebracht. In de zaak Morgenbesser heeft het Hof de Vlassopoulou formule toegepast op advocaatstagiaires, i.e. op personen die nog niet volledig gekwalificeerd zijn voor een beroep (waar dat in eerdere gevallen wel het geval was, maar het beroep zelf geheel of gedeeltelijk buiten de richtlijnen viel). Dit is een revolutionaire zaak voor de verdere ontwikkeling van het vrij verkeer van advocaten omdat het Hof nu erkent dat ook personen tijdens hun kwalificatietraject bescherming verdienen. Duitsland is vooralsnog de enige Lidstaat die heeft geprobeerd om de regel uit Morgenbesser te vertalen in nationale wetgeving ( $\$ 112 \mathrm{a}$ van het Deutschen Richtergesetz). 
In het laatste deel van Hoofdstuk 2 van het boek, waar de ontwikkeling van dit model uiteengezet is, werd kort aandacht besteed aan de positie van zogenoemde derdelanders, en werd geconcludeerd dat hun bescherming zwaar tekort schiet vergeleken met de advocaten die wel de nationaliteit van een van de Lidstaten bezitten.

\section{Toepassing van het model in de Lidstaten}

De tweede vraag die in dit onderzoek werd gesteld was hoe de regels, en dan met name de regels die zijn neergelegd in de desbetreffende richtlijnen, omtrent het vrij verkeer van advocaten daadwerkelijk in de Lidstaten zijn geïmplementeerd. Daarvoor was het allereerst noodzakelijk een overzicht te geven van het beroep van advocaat in de vijftien geselecteerde Lidstaten. Op basis van die vergelijking is duidelijk dat de verschillende gedaantes van het beroep van advocaat in de verschillende Lidstaten met name met betrekking tot de wettelijke bescherming van beroepsactiviteit nogal van elkaar verschillen.

Grofweg is er een drievoudig onderscheid te maken. Aan het ene - extreme uiteinde staan de Lidstaten waarin het beroep van advocaat geen enkel wettelijk monopolie geniet (Finland en Zweden). Alle activiteiten die een advocaat normaal uitoefent, mogen in die Lidstaten ook door niet-advocaten uitgeoefend worden. Aan de andere kant van het spectrum staan die Lidstaten waarbij zowel de vertegenwoordiging (in de breedste zin van het woord) van cliënten als het geven van juridisch advies op basis van een wettelijk monopolie aan advocaten zijn voorbehouden (Luxemburg; Frankrijk; Italië; Spanje; Portugal; Duitsland; Oostenrijk en Griekenland). Daartussen bevinden zich een aantal Lidstaten die wel de processuele vertegenwoordiging van cliënten door advocaten wettelijk beschermen, maar het geven van bijvoorbeeld juridisch advies niet (Verenigd Koninkrijk; Ierland; België; Nederland en in zekere mate Denemarken).

Deze driedeling leidt al meteen tot een complicatie met betrekking tot het toepassen van het model zoals dat eerder beschreven werd. Bij het afleiden daarvan werd vastgesteld dat de kern gevormd werd door de drie richtlijnen (77/249/EEG, 98/5/EG en 2005/36/EG) die op advocaten van toepassing zijn. De complicatie ligt in het feit dat de richtlijnen uitsluitend van toepassing zijn op gekwalificeerde advocaten, i.e. op mensen die gerechtigd zijn om in de Lidstaat van herkomst de titel 'advocaat' te voeren. Zowel in de Lidstaten die geen wettelijk monopolie hebben op de beroepsactiviteiten van advocaten, als in de Lidstaten waar een dergelijk monopolie alleen bestaat voor de processuele vertegenwoordiging van cliënten, zijn er dus beroepsuitoefenaars die beroepsactiviteit uitoefenen die in landen met een uitgebreid monopolie onder de beroepsactiviteit van advocaten valt. Deze personen hebben in hun eigen Lidstaat niet het recht de titel van advocaat te voeren. Deze beroepsuitoefenaars vallen zodoende in ieder geval buiten de toepassingssfeer van de diensten- en vestigingsrichtlijn (77/249/EEG en 98/5/EG). De problematiek van deze categorie is expliciet aan de orde gekomen tijdens het implementatieonderzoek in de verschillende Lidstaten.

Met betrekking tot de implementatie van richtlijn 77/249/EEG werden geen grote onregelmatigheden geconstateerd. De categorie van beroepsuitoefenaars uit landen met geen of weinig wettelijke bescherming voor beroepsactiviteiten die door 
advocaten worden uitgeoefend kunnen geen direct beroep doen op de bepalingen van richtlijn 77/249/EEG (of de regelgeving die het resultaat is van de implementatie daarvan). Sinds het verstrijken van de implementatietermijn van richtlijn 2005/36/EG op 20 oktober 2007 is deze categorie wel beschermd op basis van deze richtlijn. Op basis van deze richtlijn mogen Lidstaten geen restricties opleggen die te maken hebben met de beroepskwalificaties van de dienstverlener. Andere restricties vallen onder de eerste generatie jurisprudentie, en dan met name onder het Gebhard-arrest. Na 2009 vallen andere restricties onder de nieuwe dienstenrichtlijn 2006/123/EG (die 77/249/EEG onaangetast laat).

Het grootste gedeelte van Hoofdstuk 3 van het boek is gewijd aan het implementatieonderzoek van richtlijn 98/5/EG. Uit het implementatieonderzoek blijkt dat er twee varianten van implementatie voorkomen in de geselecteerde Lidstaten. Aan de ene kant zijn er Lidstaten die implementatie aangrijpen om een compleet nieuwe wet te maken die dan vaak ook nog de twee andere modaliteiten van vrij verkeer van advocaten omvat, terwijl er aan de andere kant Lidstaten zijn die 'slechts' reeds bestaande wetgeving aanpassen. Uit het onderzoek blijkt dat de manier van implementeren geen invloed heeft op het resultaat.

Met betrekking tot de implementatie van richtlijn 98/5/EG kunnen vier verschillende soorten restricties, mogelijke inbreuken van deze richtlijn, geïdentificeerd worden. In de eerste plaats zijn er restricties van de richtlijn die door het Europees Hof van Justitie (in Wilson en Commissie v. Luxemburg) werden beoordeeld en geclassificeerd worden als per se onverenigbaar met het Gemeenschapsrecht. Ook Lidstaten die in die zaken geen partij waren, maar die soortgelijke restricties opleggen, overtreden daarmee het Europese recht. Een tweede categorie van restricties wordt geconstrueerd op basis van de $A M O K$ zaak waarin het Hof besliste dat restricties die buiten het toepassingsbereik van de richtlijn vallen, maar die de volle werking van de richtlijn verhinderen ook per se niet verenigbaar zijn met het Gemeenschapsrecht. Alhoewel de $A M O K$ zaak gewezen werd met betrekking tot richtlijn 77/249/EEG werd betoogd dat deze redenering ook op richtlijn 98/5/EG van toepassing zou kunnen zijn. Een derde categorie van restricties zijn belemmeringen die buiten het toepassingsbereik van de richtlijn vallen en ook de volle werking van de richtlijn niet verhinderen. Deze restricties moeten worden beoordeeld op basis van het algemene systeem zoals neergelegd in Vlassopoulou en Gebhard en zijn dus verboden, tenzij ze objectief worden gerechtvaardigd. Een vierde en laatste categorie van restricties wordt veroorzaakt door richtlijn 98/5/EG zelf (bijvoorbeeld het handhaven van een dubbele inschrijving). Deze restricties moeten, als uitvloeisel van de richtlijn zelf, en zolang niet is vastgesteld dat de richtlijn strijdig is met het primaire Gemeenschapsrecht, als toelaatbaar worden bestempeld.

Afgezien van de situatie van procureurs in Nederland, die door de afschaffing van het procuraat opgelost is, en een massaal negeren van een bepaling in artikel 11 van de richtlijn door de Lidstaten zijn er geen grote defecten aangetroffen in de implementatie van richtlijn 98/5/EG zodat het gerechtigd is om te zeggen dat de uitoefening van het beroep van advocaat in Europa in alles behalve naam geharmoniseerd is.

De situatie van beroepsuitoefenaars uit Lidstaten waar weinig wettelijke bescherming is voor het beroep van advocaat die hun beroep zouden willen uitoefenen in een Lidstaat waar die bescherming meeromvattend is, ziet er veel minder roos- 
kleurig uit. Deze groep kan slechts een beroep doen op de regels zoals verwoord door het Hof in Gebhard. Het is zelfs denkbaar dat, omdat richtlijn 2005/36/EG meer bescherming biedt op dit punt voor dienstverlenende beroepsuitoefenaars die geen advocaat zijn, er een nieuwe installation limitée zou kunnen ontstaan. Dat zou een onwelkome situatie zijn.

Met betrekking tot de erkenning van diploma's en de volledige integratie van een kandidaat in het beroep van de Lidstaat van ontvangst werden geen onregelmatigheden vastgesteld. Met betrekking tot de niet-advocaten uit jurisdicties met weinig bescherming werd vastgesteld dat deze personen een beroep kunnen doen op richtlijn 2005/36/EG met een eventueel beroep op de Caminos zaak om de omvang van de integratie op eigen verzoek te beperken tot de omvang van hun beroep in de Lidstaat van ontvangst.

Aan het einde van Hoofdstuk 3 werd kort aandacht besteed aan de positie van derdelanders. Bekeken werd of de regels van het GATS in het kader van de WTO bescherming bieden voor een derdelander die juridische beroepsactiviteit wil uitoefenen in de Europese Unie. Na een kort overzicht van de regels van het GATS betreffende de juridische beroepen werd geconcludeerd dat de regels van het GATS geen bescherming bieden aan deze advocaten omdat deze inhoudelijk tekort schieten (vergeleken met EU regels). Bovendien zijn de GATS-regels niet direct inroepbaar voor individuen. Er werd vastgesteld dat in Duitsland advocaten uit WTO landen zich onder hun eigen beroepstitel mogen vestigen en activiteit mogen verrichten met betrekking tot het recht van hun eigen land en het internationaal recht. Dit gaat veel verder dan wat het GATS eist, maar zou door meer landen overwogen moeten worden.

\section{Verdere ontwikkeling en verfijning van het vrij verkeer van advocaten}

Wat duidelijk wordt uit hoofdstukken 2 en 3 is dat het vrij verkeer van volledig gekwalificeerde advocaten zo goed als uitgekristalliseerd is. Binnen het model liggen er alleen nog mogelijkheden voor kleine aanpassingen en aanpassingen voor personen die wel juridische beroepsactiviteiten uitoefenen maar geen volledig gekwalificeerd advocaat zijn. De meeste potentie voor een verdere verfijning van het systeem ligt echter bij de groep personen die nog bezig zijn om zich tot advocaat te kwalificeren. Uit het overzicht van de verschillende beroepen in de verschillende Lidstaten werd duidelijk dat, hoe verschillend de nationale opleidingen ook zijn, het kwalificatietraject in die Lidstaten (behalve Spanje) uit twee verschillende fases bestaat. In de eerste plaats is er de universitaire fase, die wordt afgesloten met een diploma in de rechten. Daarna begint de tweede fase die door middel van de beroepsopleiding uiteindelijk leidt tot de volledige kwalificatie als advocaat. Die tweedeling geeft ook twee duidelijke punten waar een kandidaat-advocaat zou kunnen instappen in het kwalificatietraject in een andere Lidstaat, namelijk aan het begin van de universitaire opleiding of aan het begin van de beroepsopleiding.

Het probleem met het creëren van regels over een dergelijke overstap binnen de Europese Unie, ligt in het feit dat de Europese Unie op basis van artikel 149 EG Verdrag de bevoegdheid ontbeert om op het gebied van onderwijs regelgevend te 
kunnen optreden. Er werd vastgesteld dat de toegang tot deze twee 'instappunten' werd geregeld door twee Verdragen van de Raad van Europa (het Equivalentieverdrag van Parijs en het Erkenningsverdrag van Lissabon) die een integraal deel van het 'Bologna Proces' uitmaken.

Dit 'Bologna Proces' is een intergouvernementeel 'soft law' proces dat erop gericht is om een Europese Ruimte van Hoger Onderwijs te creëren. Het moet in dezen worden opgemerkt dat het 'Bologna Proces' op geen enkele manier speciaal aandacht besteedt aan de juridische opleidingen en de juridische beroepen in de deelnemende landen. Een onderzoek van het 'Bologna Proces', en dan met name gericht op de twee speerpunten met betrekking tot het creëren van een drievoudige cyclus van diploma's (bachelor-master-doctor) en de erkenning van diploma's, wijst uit dat het 'Bologna Proces' op zich niets toevoegt aan de verdere verfijning van het vrij verkeer van advocaten in Europa. Er werd ook geconcludeerd dat de Lidstaten van de Europese Unie die participeren in het 'Bologna Proces' in grote mate worden gelimiteerd in het toepassen van de twee erkenningsverdragen van de Raad van Europa. Dit is met name het geval door wat het Hof heeft bepaald in de zaken Commissie v Oostenrijk (zaak C-147/03) en Morgenbesser. In die laatste zaak bepaalde het Hof dat de toegang tot een kwalificatietraject niet afhankelijk gemaakt mag worden van het bezit van een nationaal diploma. Met betrekking tot de toelating tot de beroepsopleiding vereist Morgenbesser zelfs de toepassing van de Vlassopoulou doctrine.

Vervolgens werd onderzocht of en in hoeverre het 'Bologna Proces' gebruikt zou kunnen worden om het vrij verkeer van kandidaat-advocaten te verfijnen. $\mathrm{Na}$ onderzoek werd geconcludeerd dat dit het geval zou kunnen zijn als Lidstaten bachelorcurricula ontwikkelen die minder specifiek ingaan op het eigen rechtssysteem maar meer op de algemene trekken van de belangrijkste systemen in Europa. Dergelijke curricula zouden het makkelijker maken voor studenten om zich vrij te bewegen door Europa, omdat de bestudering van het nationale recht gereserveerd zou blijven tot de masterfase of zelfs de beroepsopleiding. Een kort overzicht van het kwalificatietraject in de Verenigde Staten geeft aan dat dit mogelijk moet zijn omdat een dergelijk systeem daar bestaat naast veel meer gelimiteerde regels wat betreft vrij verkeer. In de Europese Unie zelf zou Luxemburg als voorbeeld kunnen dienen omdat die Lidstaat tot voor kort geen eigen rechtenfaculteit had en dus gedwongen was om personen met een buitenlands diploma te accepteren die zich dan in Luxemburg het Luxemburgse recht eigen moesten maken.

De cultuuromslag die nodig is om een dergelijk systeem op te zetten is niet te onderschatten, maar tegelijkertijd zijn er binnen de Europese Unie talloze experimenten met curricula die in deze richting wijzen. Meer en meer komen er ook curricula die tot een dubbele kwalificatie leiden. De CCBE zou betrokken moeten worden bij de ontwikkeling van dergelijke curricula om zo de acceptatie van dergelijke curricula door de verschillende beroepsorganisaties meer aannemelijk te maken. van het daadwerkelijk creëren van een dergelijk systeem zou in de handen van de CCBE moeten liggen op Een dergelijke betrokkenheid zou gebaseerd kunnen worden op de gemeenschappelijke platforms waarin is voorzien in artikel 15 richtlijn 2005/36/EG. Deze platforms voorzien in een zelfregulering van een bepaald gereguleerd beroep. 


\section{Aanbevelingen voor de toekomst}

Als laatste werden in het boek vier aanbevelingen gedaan voor de toekomst. De eerste aanbeveling betreft de implementatie van artikel 11 richtlijn 98/5/EG. Uit het implementatieonderzoek bleek dat het grootste gedeelte van de onderzochte Lidstaten de ingewikkelde procedure omtrent de toepasbaarheid van de beroepsregels van de Lidstaat van ontvangst genegeerd hebben. Dat negeren is niet geheel onterecht nu de tekst van artikel 11 het resultaat is van een aantal politieke compromissen en niet uitblinkt in helderheid en makkelijke toepasbaarheid. Daarom wordt aanbevolen de tekst van artikel 11 te veranderen zodat er een regel ontstaat die voorziet in de directe toepasbaarheid van de beroepsregels van de Lidstaat van ontvangst, om zo de richtlijn in overeenstemming te brengen met het merendeel van de implementaties.

Een tweede aanbeveling betreft de bescherming van de positie van diegenen die nog niet volledig gekwalificeerd zijn als advocaat. Het wordt aanbevolen dat op deze personen de Diplomarichtlijn van toepassing wordt en dat de Vlassopoulou doctrine wordt toegepast op diegenen die toegang zoeken tot het hoger onderwijs in een andere lidstaat. Bovendien, en dat is de derde aanbeveling, zouden er nieuwe curricula gemaakt moeten worden (door universiteiten, maar geaccepteerd door de beroepsorganisaties) die het vrij verkeer van kandidaat advocaten verder zouden moeten bevorderen.

De laatste aanbeveling betrof de inhoud van deze nieuwe curricula. Deze curricula zouden, althans in de bachelorfase niet zozeer gebaseerd moeten zijn op nationaal recht (dat zou gereserveerd moeten worden tot de masterfase) maar meer op wat de grote rechtssystemen in Europa gemeen hebben, een nieuw Ius Commune. 



\section{Bibliography}

\section{Adamson (1998)}

Adamson, H., Free Movement of Lawyers, $2^{\text {nd }}$ Edition, Current EC Legal

Development Series, Butterworths, London, 1998.

\section{Andenas \& Roth (2003)}

Andenas M., and W.H. Roth (eds.), Services and Free Movement in EU Law, Oxford University Press, Oxford, 2003.

\section{Arnull (2006)}

Arnull, A, et al, Wyatt \& Dashwood's European Union Law, $5^{\text {th }}$ Edition, Thomson, Sweet \& Maxwell, London, 2006.

\section{Arrowsmith (1998)}

Arrowsmith, S., Legal Techniques for Implementing Directives: A case study of public procurement, in: P. Craig and C. Harlow (eds.), Lawmaking in the European Union, Kluwer Law International, London, 1998, pp. 491-510.

\section{Baas (2003)}

Baas,A., Grensoverschrijdende advocaat-stagiaires, in: Advocatenblad 83 [2003] 22, p. 973.

\section{Baas (2001)}

Baas, A., Implementatie vestigingsrichtlijn advocaten, in: Advocatenblad [2001] 4, pp. 135-138.

\section{Baas (1998)}

Baas, A., Nieuwe vestigingsrichtlijn voor advocaten, in: Advocatenblad: [1998] 9, p. 496.

\section{Bailey \& Gunn (1996)}

Bailey, S.H. and Gunn, M.J., Smith and Bailey on The Modern English Legal System, $3^{\mathrm{d}}$ edition, Sweet \& Maxwell, London, 1996.

\section{Bar Council (s.d.) A}

Bar Council, Qualifying as a barrister, via <www.lawlibrary.ie>, last accessed 22 August 2005.

\section{Bar Council (s.d.) B}

Bar Council, Rules of The Honourable Society of the Inn of Court of Northern Ireland with regard to the Admission of Students into the Society and to the Degree of Barrister- atLaw with regard to the Admission of Practising Members of the Bar of England and Wales and the Bar of Ireland to the Degree of Barrister-at-Law and with regard to Call to the Bar of Northern Ireland by Virtue of EC Directive 89/48/EEC and with regard to Cessation and Resumption of Practice, Bar Council, Belfast, no date.

\section{Bar Council (1998)}

Bar Council, Steps to the Bar, 'A way of life, not just a career', Bar Council, London, 1998. 
Bar Council \& Bar Library of Northern Ireland (s.d.) A Bar Council \& Bar Library of Northern Ireland, The Barristers World, via:<www.barlibrary.com>, last accessed 19 November 2001.

\section{Bar Council \& Bar Library of Northern Ireland (s.d.) B}

The Bar Council, Code of Conduct for the Bar of Northern Ireland, via <www.barlibrary.com>, last accessed 31 October 2006.

\section{Bar Council \& Bar Library of Northern Ireland (s.d.) C}

Bar Council \& Bar Library of Northern Ireland, The Composition of the Bar, via <www.barlibrary.com/barcouncil>, last accessed 19 November 2001.

\section{Bar Council \& Bar Library of Northern Ireland (s.d.) D}

Bar Council \& Bar Library of Northern Ireland, The Legal Profession in Northern Ireland, via <www.barlibrary.com/barcouncil>, last accessed 19 November 2001.

Barnard (2007)

Barnard, C., The Substantive Law of the EU; The Four Freedoms, $2^{\text {nd }}$ Edition Oxford University Press, Oxford, 2007.

\section{Belassa (1961)}

Belassa, B. The Theory of Economic integration, Greenwood Press, 1961, as reprinted in: B.F. Nelsen and A. Stubb (eds.), The European Union: Readings on the Theory and Practice of European Integration, 3d Edition, Palgrave Macmillan, Basingstoke, 2003.

Bell (s.d.)

Bell, J., Legal Education and Bologna: A British Perspective, via <www.elfa-afde.org>, last accessed 28 April 2008.

\section{Bermann (1993)}

Bermann, G.A. et al, Cases and Materials on European Community Law, American Casebook Series, Westbook Publishing Co. (1993).

\section{Bettin (2001)}

Bettin, V., L'Europa degli avvocati: prospettive per il futuro, in: Diritto Pubblico Comparato ed Europeo, (2001) 1, pp. 196-205.

\section{Blanc-Juvan (2002)}

Blanc-Jouvan, X., Bijuralism in Legal Education: A French View, in: [2002] 52 Journal of Legal Education, pp. 61-67.

\section{Blokland (2008)}

Blokland, A., Wet afschaffing procuraat en invoering electronisch berichtenverkeer, in: Ars Aequi, (2008), pp. 652-657.

\section{Bologna Follow-up Group (2005)}

Bologna Follow-up Group, Bologna Process Stocktaking, Report from a working group appointed by the Bologna Follow-up Group to the Conference of European Ministers Responsible for Higher Education, Bergen 19-20 May 2005, via <www.bolognabergen2005.no>, last accessed 07 April 2006. 


\section{Van den Bossche (2005)}

Bossche, van den, P., The Law and Policy of the World Trade Organization, Text, Cases and Materials, Cambridge University Press, Cambridge, 2005.

\section{Breillat (2005)}

Breillat, D., The Bologna Process in France, in: Slovenian Law Review [2005] 2, pp. 197-205.

\section{Brucher (1993)}

Brucher, J., The Legal Professions in Luxembourg, in: Tyrrell QC, A., and Yaqub, Z., The Legal Professions in the New Europe, a Handbook for Practitioners, Blackwell Business, Oxford, 1993.

\section{Bruinsma (2000)}

Bruinsma, F., De ondraaglijke lichtheid van de rechtenstudie, in: Nederlands Juristenblad, (2000), 28, pp. 1371-1374.

\section{Bühler (2007)}

Bühler, R., Coping with non-nationally trained applicants, Contribution to the 2007 CCBE Conference 'Improving Legal Education \& Training in a Converging Europe' in Warsaw 25-27 September 2007, via <www.ccbe.org>, last accessed 17 October 2008.

\section{Van der Burg (2003)}

Burg, van der, F.H., Europees Gemeenschapsrecht in de Nederlandse Rechtsorde, $2^{\text {nd }}$ Edition, Kluwer, Deventer, 2003.

\section{Cabral (2002)}

Cabral, P., Case Law, in: Common Market Law Review, [2002] 39, pp. 129-150.

\section{Calderon (1993)}

Calderón, L.A., The Legal Professions in Spain, in: Tyrrell QC, A., and Yaqub, Z., The Legal Professions in the New Europe, a Handbook for Practitioners, Blackwell Business, Oxford, 1993.

\section{Calkoen (2000)}

Calkoen, W., Globalization and the Future of the International Practice of Law from a European Perspective, in: European Journal of Law Reform, [2000] 2(4), pp. 491-503.

\section{Van Camp (1989)}

Camp, van, S., Het statuut van de advocaat in het Europese Gemeenschapsrecht, Kluwer, Deventer, 1989.

\section{CCBE (s.d) A}

CCBE, CCBE Resolution on Training for Lawyers in the EU, via <www.ccbe.org>, last accessed 06 June 2006.

\section{CCBE (2003)}

CCBE, CCBE Response to the WTO Concerning the Applicability of the Accountancy Disciplines to the Legal Profession, May 2003, via <www.ccbe.org>, last accessed 1 May 2006. 


\section{CCBE (s.d.) E}

CCBE, Chronology(I), Analysis(II) and Guidance(III) to Bars and Law Societies regarding Case C-313/01 Christine Morgenbesserv Consiglio dell'Ordine degli Avvocati di Genova, 5th Chamber (13 November 2003), January 2004, via <www.ccbe.org>, last accessed 11 February 2008.

CCBE (s.d.) B

CCBE, Discussion Papers on Transnational Legal Profession, via <www.ccbe.org>, last accessed 02 June 2006.

CCBE (s.d.)C

CCBE, Forum on Transnational Practice for the Legal Profession, Joint Closing Committee, via <www.ccbe.org>, last accessed 02 June 2006.

CCBE (s.d) D

CCBE, Guidelines on the Implementation of the Establishment Directive (98/5/EC of 16th February 1998) issued by the CCBE for Bars and Law Societies in the European Union, via <www.ccbe.org>, last accessed 15 December 2005.

CCBE (2005)

CCBE, The History of the CCBE, via <www.ccbe.org>, last accessed 6 October 2008.

Chalmers (2006)

Chalmers, D. et al, European Law, Text and Materials, Cambridge University Press, Cambridge, 2006.

Claessens (2003)A

Claessens, S., Minder controle op instromende advocaten, in: Advocatenblad, [2003] 83(4), 21 February 2003, p. 148.

Claessens (2003)B

Claessens, S., Vrije Vestiging niet voor Procureurs, in: Advocatenblad, [2003] 83(20), 31 October 2003, p. 881.

Clark (1988)

Clark, G.J., An Introduction to the Legal Profession in Spain, in: Arizona Journal of International and Comparative Law, (1988), pp. 1-26.

Clarcke (1996)

Clarcke Q.C., M.G., Scots or European Lawyer - Quid Sum?, in: The Juridical Review, [1996] 6, pp. 361-373.

Coelho Ribeiro \& de Lourdes Lopes Dias (1993)

Coelho Ribeiro, J.M. \& M. de Lourdes Lopes Dias, The Legal Professions in Portugal, in: Tyrrell QC, A., and Yaqub, Z., The Legal Professions in the New Europe, a Handbook for Practitioners, Blackwell Business, Oxford, 1993.

\section{Comijs (2005)}

Comijs, D.E., Go West Young (Wo)Man: stagelopen in het buitenland met een reiskostenvergoeding, in: Nederlands Tijdschrift voor Europees Recht, [2005] 11(7/8), pp. 150-153. 


\section{Cone III (2003)}

Cone III, S.M., Legal Services in the Doha Round, in: Journal of World Trade Law, [2003], 37(1), pp. 29-47.

\section{Costonis (1993)}

Costonis, J.J., The MacCrate Report: Of Loaves, Fishes and the Future of

American Legal Education, in: Journal of Legal Education, [1993] 43, pp. 157-197.

\section{Cownie \& Bradney (1996)}

Cownie, F., and Bradney, A., English Legal System in Context, Butterworths,

London, 1996.

\section{Craig \& de Burca (1996)}

Craig, P. and G. de Burca, EC Law, Text, Cases and Materials, Oxford University Press Oxford, 1996.

\section{Craig \& de Burca (2003)}

Craig, P. and G. de Burca, EU Law, Text, Cases and Materials, 3d Edition, Oxford University Press Oxford, 2003.

\section{Craig \& de Burca (2007)}

Craig, P. and G. de Burca, EU Law, Text, Cases and Materials, 4th Edition, Oxford University Press Oxford, 2007.

\section{Craig \& Harlow (1998)}

Craig, P. and C. Harlow (eds.), Lawmaking in the European Union, Kluwer Law International, London, 1998.

\section{Currier (2001)}

Currier, B.A., Assuring Quality in Legal Education: The Accreditation Process of the American Bar Association, in: South Texas Law Review, [2001-2002] 43, pp. 337-342.

\section{Curtin (1994)}

Curtin, D. et al, Leading Cases on the Law of European Communities, 6th Edition, Kluwer Law and Taxation Publishers, 1994.

\section{Darnstädt (2001)}

Darnstädt, T., Rechtswissenschaft in der Reformmühle, in: UniSPIEGEL (2001) 4, 23 August 2001.

\section{Davoni (1993)}

Davoni, R., The Legal Professions in Italy, in: Tyrrell QC, A., and Yaqub, Z., The Legal Professions in the New Europe, a Handbook for Practitioners, Blackwell Business, Oxford, 1993.

\section{Denys (1995)}

Denys, C., Naar een vrije vestiging van advocaten, in: Nederlands tijdschrift voor Europees Recht, [1995] 6, pp. 143-151. 


\section{Denys (1996)}

Denys, C., Vrije Dienstverlening door advocaten: nieuw leven ingeblazen?, in:

Nederlands Tijdschrift voor Europees Recht, [1996] 3(3), pp. 34-37.

\section{Dove Williams (1894)}

Dove Williams, J., Irnerius, in: Juridical Review, [1894] 6, pp.304-307.

\section{Drolshammer (2000)}

Drolshammer, J., The Future Legal Structure of International Law - Is the Experience of the Big Five Structuring, Auditing and Consulting Organizations Relevant?, in: European Journal of Law Reform, [2000] 2(4), pp. 713-775.

\section{Duncan (2001)}

Duncan, G.E. The Rise of Multidisciplinary Practices in Europe and the Future of the Global Legal Profession Following Arthur Andersen v. Netherlands Bar Ass'n, in: Tulane Journal of International \& Comparative Law, [2001] 9, pp. 537-559.

\section{Edwards (1992)}

H.T. Edwards, The Growing Disjunction between Legal Education and the Legal Profession, in: Michigan Law Review [1992-1993] 91, pp. 34-78.

\section{Eijsbouts (2004)}

Eijsbouts, W. et al, Europees Recht; Algemeen Deel, Europa Law Publishing, Groningen, 2004.

\section{Eisenbrïkova (2007)}

Eisenbrükova, L., Coping with non-nationally trained applicants, Contribution to the 2007 CCBE Conference 'Improving Legal Education \& Training in a Converging Europe' in Warsaw 25-27 September 2007, via <www.ccbe.org>, last accessed 17 October 2008.

\section{ELFA (1999)}

ELFA, For a European Space of Legal Education, via <www.elfa-afde.org>, last accessed 28 April 2008.

\section{ELFA (2007) A}

ELFA, ELFA Resolution on the London Communiqué and the general development of the Bologna Process, via <www.elfa-afde.org>, last accessed 28 April 2008.

\section{ELFA (2007) B}

ELFA, Strengthening the European Dimension of Legal Education, via <www.elfaafde.org>, last accessed 28 April 2008.

\section{ELFA (2008)}

ELFA, Tuning Legal Studies in Europe: Initial Findings, via <www.elfa-afde.org>, last accessed 28 April 2008.

\section{Ewig (1996)}

Ewig, E., Niederlassungsfreiheit für Anwälte in Europa, Folgerungen aus dem Urteil des EuGH C55/94 vom 30.11.1995 - Rechtssache Gebhard, in: BRAKMitteilungen, [1996] 1, pp. 13-15. 


\section{Ewig (1999)}

Ewig, E. Verwirklichung der Niederlassungsfreiheit für Rechtsanwälte in der EU und im EWR, in: Neue juristische Wochenschrift, (1999) 4, pp. 248-253.

\section{Faculty of Advocates (s.d.)}

Faculty of Advocates, A Career at the Scottish Bar, Faculty of Advocates, Edinburgh, no date.

\section{Farthouat \& Puel (1996)}

Farthouat, J.R., and Puel, F., L'Arrêt 'Gebhard': la clarification de la distinction entre établissement et prestation de services, in: Gazette du Palais, [1996] doctrine pp. 18-22.

\section{Fasciani (1998)}

Fasciani P., Entwicklung des Anwaltsberufes in Italien und internationale Anwaltstätigkeit in Europa, in: IPRax, (1998) 1, pp. 51-53.

\section{Ferraro (2001)}

Ferraro, F., Libertà di stabilimento degli avvocati, anche alla luce di una recente sentenza della Corte di giustitzia, in: Diritto Pubblico Comparato ed Europeo, (2001) 1, pp. 205-217.

\section{Fierstra (1992)}

Fierstra, M.A., Jurisprudentie, in: Sociaal Economische Wetgeving, [1992] 40(7), pp.640-649.

\section{Fine (2000)}

Fine, T.M., The Globalization of Legal Education in the United States, in: European Journal of Law Reform, [2000] 2(4), pp. 567-610.

\section{Finocchietti \& Sticchi Damiani (2002)}

Finocchietti, C., and Sticchi Damiani, M., Joint degrees and double degrees, the Italian experience, via <www.cimea.it>, last accessed 17 October 2008.

\section{Flessner (1996)}

Flessner, A., Deutsche Juristenasbildung. Die Kleine Reform und die europäische Perspektive, Antrittsvorlesung 16-11-1995, Humboldt-Universität zu Berlin, 1996.

\section{Footer \& George (2005)}

Footer, M.E. and C. George, The General Agreement on Trade in Services, in: P.F.J. Macrory et al (eds.), The World Trade Organisation; Legal, Economic and Political Analysis, Springer, 2005.

\section{Forsyth (1875)}

Forsyth, W., The History of Lawyers ancient and modern, Estes \& Lauriat, Boston, 1875.

\section{Garben (2008)}

Garben, S., The Bologna Process From a European Law Perspective, EUI Working Papers, LAW 2008/12, via <www.eui.eu>, last accessed 17 October 2008. 


\section{Van Gerven (2001)}

Gerven van W., A Common Law for Europe: The Future Meeting the Past, in: European Review of Private Law, [2001] 4, pp. 485-503.

\section{Goebel (2000)}

Goebel, R.J., Legal Practice Rights of Domestic and Foreign Lawyers in the United States, in: International \& Comparative Law Quarterly, [2000] 49, pp. 413- 444.

\section{Goebel (2003)}

Goebel, R.J., The Liberalization of Interstate Legal Practice in the European Union: Lessons for the United States?, in: M. Andenas and W.H. Roth (eds.), Services and Free Movement in EU Law, Oxford University Press, Oxford, 2003, pp. $413-458$.

\section{Goldsmith (2004)}

Goldsmith, J., Global Legal Practice and GATS: A Bar Viewpoint, in: Penn State International Law Review, [2004] 22(4), pp. 625-634.

\section{Gordley (2000)}

Gordley, J., Comparative Law and Legal Education, Tulane Law Review, [20002001] 75, pp. 1003-1014.

\section{Gout (1995)}

Gout, M., Á propos de la proposition de Directive du Conseil de Communautés concernant le droit d'Établissement des avocats, in: Gazette du Palais, [1995] chronique, pp. 1285-1294.

\section{Gout (1998)}

Gout, M., Quality Harmonization: The Current Situations and the ways forward, Interim Report of the CCBE on harmonization of the training of lawyers in Europe, Präsidentenkonferenz, Vienna, 20 February 1998, via <www.ccbe.org>, last accessed 02 June2006.

\section{Groeben (1991)}

Groeben et al, Kommentar zum EWG-Vertrag, Artikel 1-84, 4th Edition, Nomos Vorlagsgesellschaft, (1991), pp. 986-990.

\section{De Groot (1992)}

Groot, G.R. de, European Education in the 21st Century, in: B. de Witte and C. Forder (eds.), The Common Law of Europe and the Future of Legal Education, Kluwer, Deventer, 1992.

\section{Gruner (s.d.)}

Gruner, M., Wie ist das so, als Anwalt?, in: Juridicum Online, via <www.oerak.or.at>, last accessed 18 December 2001.

\section{Guinchard (2007)}

Guinchard, A., The double degree experience: a contribution to an integrated European Legal Education, Contribution to the 2007 CCBE Conference 'Improving Legal Education \& Training in a Converging Europe' in Warsaw 25-27 September 2007, via <www.ccbe.org>, last accessed 17 October 2008. 


\section{Hagan (2003)}

Hagan, C., The Free Movement of Lawyers, in: Irish Student Law Review, [2003] 11, pp. 149-172.

\section{Hartley (2004)}

Hartley, T.C., European Union Law in a Global Context, Text Cases and Materials, Cambridge University Press, Cambridge, 2004.

\section{Hartnett (1993)}

Hartnett, B., The Legal Profession in Ireland, in: Tyrrell QC, A., and Yaqub, Z., The Legal Professions in the New Europe, a Handbook for Practitioners, Blackwell Business, Oxford, 1993.

\section{Heemskerk \& Bijlsma (2008)}

Heemskerk, W. en Bijlsma, P., Zorgen voor morgen. Afschaffing procuraat per 1 september 2008, in: Advocatenblad, [2008] 88, pp. 462-465.

\section{Henssler (s.d.)}

Henssler, M., Die Reform der Anwaltsausbildung in Italien, via <www.uni-koeln.de/ jur-fak/dzeuanwr/indexenglisch.html>, last accessed 11 November 2004.

\section{Henssler (1999)}

Henssler, M., Der lange Weg zur EU-Niederlassungsrichtlinie für die Anwaltschaft, in: Zeitschrift für europäisches Privatrecht, 1999, pp. 689-712.

\section{Henssler \& Prütting (s.d.) A}

Henssler and Prütting, Juristische Ausbildung in Dänemark, via <www.uni-koeln.de>, last accessed 07 June 2006.

\section{Henssler \& Prütting (s.d.) B}

Henssler and Prütting, Juristische Ausbildung in Spanien. via <www.uni-koeln.de /jur-fak/dzeuanwr/indexenglisch.html>, last accessed 15 December 2004.

\section{Heringa (2002)}

Heringa, A.W., Towards a European Law School! A Proposal for a Competitive, Diversified Model of Transnational Co-operation, in: M. Faure et al (eds), Towards a European Ius Commune in Legal Education and Research, METRO, Intersentia, Antwerpen, 2002, pp. 3-15.

\section{Hickman (2004)}

Hickman, L., Establishment Directive: Break for the Borders, in: Law Society Gazette, 5 february 2004.

\section{Higgins \& Svenningsen (1995)}

Higgins, I., and Svenningsen, J., Chronique des principeaux arrêts de la jurisprudence de la Cour de Justice et du Tribunal de première instance des communautés européennes au cours de la période compromise entre septembre et décembre 1995, via <http://www.eipa.eu/ files/repository/eipascope/Scop96_1_4.pdf >, last accessed 20 October 2008.

\section{Hilpold (2005)}

Hilpold, P., Hochschulzugang und Unionsbürgerschaft, in: Europäische Zeitschrift für Wirtschaftsrecht, [2005] 16(21) pp.647-652. 


\section{Hilpold (2006)}

Hilpold, P., Quotenregelungen im Gemeinschaftsrecht - Rehabilitiering eines an sich verpönten Instruments?, in: Europäische Zeitschrift für Wirtschaftsrecht, [2006] 17(11), pp. 333-336.

\section{Hirte \& Mock (2005)}

Hirte, $\mathrm{H}$ and Mock, S., Ausgestaltung der Juristenausbildung vor dem Hintergrund des Bologna - Prozesses, via <www.elfa-afde.org>, last accessed 25 April 2008.

\section{Hodgson (2005)}

Hodgson, J., Expanding your portfolio: opportunities abroad, in: New York Law Journal, 2005, 4.

\section{Hoegen Dijkhoef (1993)}

Hoegen Dijkhoef, H., The Legal Profession in The Netherlands, in: Tyrrell QC, A., and Yaqub, Z., The Legal Professions in the New Europe, a Handbook for Practitioners, Blackwell Business, Oxford, 1993.

Honourable Socities of Lincoln's Inn, Inner Temple, Middle Temple and Gray's Inn (s.d.)

Honourable Socities of Lincoln's Inn, Inner Temple, Middle Temple and Gray's Inn, The Consolidated Regulations of the Honourable Societies of Lincoln's Inn, Inner Temple, Middle Temple and Gray's Inn, (1st October 1998 to 30th September 1999).

\section{Hopkins (2004)}

Hopkins, R.W., Liberalizing the Trade in Legal Services: The GATS, The Accountancy Disciplines and the Language of Core Values, in: Indiana International and Comparative Law Review, [2004-2005] 15(3) p. 427-472.

\section{House of Commons (1996)}

House of Commons, Select Committee on European Legislation, Freedom of Establishment for Lawyers, Sessions 1996-1997, third report, via <www.parliament. the-stationary-office.co.uk/pa/cm199697/cmselect/cmeuleg/ 036iii/el0306.htm.>, last accessed 25 April 2008.

\section{House of Lords (1994)}

House of Lords, Select Committee on the European Communities, The right of establishment for lawyers, House of Lords Paper 82, Sessions 1994-1995, 14th Report.

\section{Huglo (1996)}

Huglo, J., Liberté d'établissement et libre prestation des services, in: Revue Trimestrielle de Droit Européen, [1996] 32(4), pp. 741-746.

\section{Institute of Professional Legal Studies (s.d.)}

Institute of Professional Legal Studies, Information Booklet, via <www.qub.ac. uk/ipls>, last accessed 19 November 2001.

\section{Italian Ministry for Education (2003)}

Italian Ministry for Education, University and Research, National Report on the Implementation of the Bologna Process, July 2003, via <www.bologna-berlin2003.de/ en/main_documents/index.htm>, last accessed 11 November 2004. 


\section{Jarvis M (1996)}

Jarvis, M., Freedom of establishment and freedom to provide services; Lawyers on the move?, in: European Law Review, [1996] 21, pp. 247-252.

\section{Jarvis R (1995)}

Jarvis, R.M., An Anecdotal History of the Bar Exam, in: Georgetown Journal of Legal Ethics [1995-1996] 9, pp., 359-412.

\section{Jordan (2001)}

Jordan, M., Die Umsetzung der Niederlassungsrichtlinie in Griechenland, via <www.dgjv.de/content/aufsaetze/a_jordan.html>, last accessed 17 June 2005. Also published in the BRAK-Mitteilungen I/2001.

\section{Kerameos (2001)}

Kerameos, K., Der Rechtsanwalt in Griechenland, in: Anwaltsblatt, (2001), pp. 349353, via < www.uni-koeln.de/jur-fak/dzeuanwr/indexenglisch.html>, last accessed 02 June 2005.

\section{Kilger (2007)}

Kilger, H., The view from the Bars and Law Societies: what is expected from preprofessional education, Contribution to the 2007 CCBE Conference 'Improving Legal Education \& Training in a Converging Europe' in Warsaw 25-27 September 2007, via <www.ccbe.org>, last accessed 17 October 2008.

\section{Kilian (s.d.) A}

Kilian, M., Aktuelle Entwicklungen: Der swedische Advokat, via <www.uni-koeln.de/ jur-fak/dzeuanwr/indexenglisch.html >, last accessed 15 November 2002.

\section{Kilian (s.d.) B}

Kilian, M., Aktuelle Entwicklungen: Rechtsanwaltschaft in Dänemark, via <www.unikoeln.de/jurfak/dzeuanwr/indexenglisch.html >, last accessed 08 June 2006.

\section{Kilian (s.d.) C}

Kilian, M., Rechtsanwaltschaft im Portugal, via <www.uni-koeln.de/jur-fak/ dzeuanwr/indexenglisch.html>, last accessed 15 April 2005.

\section{Kilian (1999) A}

Kilian, M., Rechtsberatungsmonopol, Rechtsschutzversicherung und Kostenerstattung im Dänemark, in: Zeitschrift für den gesamten Versicherungswissenschaft, 1999, pp. 29-30.

\section{Kilian (s.d.) D}

Kilian, M., Rechtsberatungsmonopol, Rechtsschutzversicherung, und Kostenerstattung in Italien, via <www.unikoeln.de/ jurfak/dzeuanwr/indexenglisch.html>, last accessed 18 November 2004.

\section{Kilian (1999) C}

Killian, M., Rechtsberatungsmonopol, Rechtschutzversicherung und Kostenerstattung in Portugal, in: Zeitschrift für den gesamten Versicherungswissenschaft, 1999, pp. 49-50, via <www.uni-koeln.de/jur-fak/dzeuanwr/indexenglisch.html>, last accessed 15 April 2005. 


\section{Kilian (1999) B}

Kilian, M., Rechtsberatungsmonopol, Rechtsschutzversicherung und Kostenerstattung in Schweden, in: Zeitschrift für den gesamten Versicherungswissenschaft, 1999, page 36-38.

\section{Klein (2002)}

Klein A., et al, Tätigkeit europäischer Rechtsanwälte in Deutschland. Kurz-Kompendium zum Europäischen Rechtsawaltsgesetz (EuRAG), Richard Boorber Verlag, Stuttgart, 2002.

\section{Kommatas (1993)}

Kommatas, T., The Legal Profession in Greece, in: Tyrrell QC, A., and Yaqub, Z., The Legal Professions in the New Europe, a Handbook for Practitioners, Blackwell Business, Oxford, 1993.

\section{Korhonen (2000)}

Korhonen, O., International Lawyer: Towards Conceptualization of the Changing World and Practice, in: European Journal of Law Reform, 2 [2000] 4, pp. 545-555.

\section{Lafont (2007)}

Lafont, P., Former des avocats libres et efficaces, Contribution to the 2007 CCBE Conference 'Improving Legal Education \& Training in a Converging Europe' in Warsaw 25-27 September 2007, via <www.ccbe.org>, last accessed 17 October 2008.

\section{Lasok (1986)}

Lasok, D., Q.C., The Professions and Services in the European Economic Community, Kluwer Law and Taxation Publishers, (1986) pp. 163-164.

\section{Latrup-Petersen (2007)}

Latrup-Petersen, T., Tuning Legal Studies in Europe, Preliminary Results, Contribution to the 2007 CCBE Conference 'Improving Legal Education \& Training in a Converging Europe' in Warsaw 25-27 September 2007, via $<$ www.ccbe.org>, last accessed 17 October 2008.

\section{Law Society (2005) A}

Law Society, Annual Statistical Report, 2005, Trends in the solicitors' profession, Law Society, London, 2005.

\section{Law Society (s.d.) A}

Law Society, Key facts on the solicitors' profession, via <www.lawsociety.org>, last accessed 30 October 2006.

\section{Law Society (s.d.) B}

Law Society, Law Society Proposal, via <www.lawsociety.org.uk>, last accessed 14 November 2001.

\section{Law Society (2004)}

Law Society, Statement on the Training Framework Review, London, June 2004.

\section{Law Society (2005) B}

Law Society, Statement on the Training Framework Review, London, January 2005. 


\section{Law Society (2001) A}

Law Society, The Students Guide to Qualification as a Solicitor, Issue No. 40, Law Society, London, 2001.

\section{Law Society (2001) B}

Law Society, Training Framework Review Consultation Paper July 2001,

Law Society, London, 2001.

\section{Law Society (2003)}

Law Society, Training Framework Review Consultation Paper September 2003,

Law Society, London, 2003.

\section{Law Society (2005) C}

Law Society, Training Framework Review Consultation Paper March 2005,

Law Society, London, 2005.

Law Society of Ireland (s.d.) A

Law Society of Ireland, How to become a solicitor, via <www.lawsociety.ie>, last accessed 22 August 2005.

\section{Law Society of Ireland (s.d.) B}

Law Society of Ireland, Overseas Lawyers: The Qualified Lawyers Transfer Test: an Overview, via <www.lawsociety.ie>, last accessed 24 August 2005.

\section{Law Society of Northern Ireland (s.d.)}

Law Society of Northern Ireland, The Law Society of Northern Ireland Notes for Guidance of Intending Students, The Law Society of Northern Ireland, no date.

\section{Law Society of Scotland (s.d.) A}

Law Society of Scotland, Getting the best from your solicitor, The Law Society of Scotland, no date.

\section{Law Society of Scotland (s.d.) B}

Law Society of Scotland, Guide to the New Training Regime for Scottish Solicitors, via:<www.lawscot.org.uk>, last accessed 19 November 2001.

\section{Law Society of Scotland (s.d.) C}

Law Society of Scotland, How to Become a Scottish Solicitor, via

<www.lawscot.org.uk>, last accessed 19 November 2001.

\section{De Leeuw \& Nispen (1998)}

Leeuw, de V. and van Nispen, M., Vestiging als advocaat in een andere lidstaat, in: Advocatenblad (1998) 16.

\section{Lenaerts (1994)}

Lenaerts, K., Education in European Community Law after Maastricht, in:

Common Market Law Review, [1994] 31, pp.7-41.

\section{Lenaerts \& Van Nuffel (2005)}

Lenaerts, K., and Van Nuffel, Constitutional Law of the European Union, $2^{\text {nd }}$ Edition, Thomson Sweet \& Maxwell, London, 2005. 


\section{Lokin \& Zwalve (1992)}

Lokin, J.H.A. and W.J. Zwalve, Hoofdstukken uit de Europese Codificatiegeschiedenis, 2nd Edition, Wolters-Noordhoff/Egbert Forsten, Groningen 1992.

\section{Lonbay (1996) A}

Lonbay, J., Case C-55/94 Reinhard Gebhard v. Consiglio dell'ordine degli Avvocati e Procuratori di Milano, Judgment of 30 November 1995, [1995] ECR I-4165. Full Court, in: Common Market Law Review [1996] 33, pp. 1073-1087.

Lonbay (s.d.) A

Lonbay, J., Comparative Table on Training of Lawyers in Europe, via $<$ www.ccbe.org>, last accessed 30 October 2006.

\section{Lonbay (1992)}

Lonbay, J., Differences in the Legal Education in the Member States of the European Community, in: B. de Witte and C. Forder (eds.), The Common Law of Europe and the Future of Legal Education, Kluwer, Deventer, 1992, pp. 75-93.

\section{Lonbay (1996) B}

Lonbay, J., Lawyers bounding over the borders: the Draft Directive on lawyer's establishment, in: European Law Review, [1996] 21, pp. 50-58.

\section{Lonbay (1991)}

Lonbay, J., Picking over the bones: rights of establishment reviewed, in: European Law Review, [1991] 16, pp. 507-520.

\section{Lonbay (s.d) B}

Lonbay, J., Qualification Process (Barristers), via <elixir.bham.ac.uk>, last accessed 15 November 2001.

\section{Lonbay (2001) A}

Lonbay, J., The Educational work of the CCBE and the FBE, in: European Journal of Legal Education, [2001] 0, pp. 7-25.

\section{Lonbay (2000)}

Lonbay, J., The Regulation of Legal Practice in the UK and Beyond, in: J.W. Bridge (ed.), UK Law for the Millenium, United Kingdom Comparative Law Series, Volume 19, $2^{\text {nd }}$ Edition, UKNCCL, s.1., 2000, pp. 594-633.

\section{Lonbay (2007)}

Lonbay, J., Training outcomes for European Lawyers, Contribution to the 2007 CCBE Conference 'Improving Legal Education \& Training in a Converging Europe' in Warsaw 25-27 September 2007, via <www.ccbe.org>, last accessed 17 October 2008.

\section{Lonbay (2001) B}

Lonbay, J., University Training: The Implications of the Bologna Declaration for the UK, in: European Journal of Legal Education, [2001] 0, pp. 36-51.

\section{Lord High Chancellor (1998)}

Lord High Chancellor, Modernising Justice, The Government's plans for reforming legal services and the courts, Lord Chancellor's Department, London, 1998. 


\section{Manschot (1975)}

Manschot, G.J., Vrijheid van vestiging en dienstverlening, in Advocatenblad, [1975] 3 pp 136-147.

\section{Manz \& Padman-Reich (1993)}

Manz, G., and Padman-Reich, S., The Legal Professions in Germany, in: Tyrrell QC, A., and Yaqub, Z., The Legal Professions in the New Europe, a Handbook for Practitioners, Blackwell Business, Oxford, 1993.

\section{Mather (2001)}

Mather, H., The Medieval Revival of Roman Law: Implication for Contemporary Legal Education in: Catholic Lawyer, [2001-2002] 41 (4), pp. 323-362.

\section{Mattoo (1997)}

Mattoo, A., National Treatment in the GATS: Corner-Stone or Pandora's Box?, in: Journal of World Trade Law, [1997] 31(1), $118 \mathrm{ff}$.

\section{Van der Mei (2001)}

Mei, van der, A.P., Free Movement of Persons within the European Community, Cross Border Access to Public Benefits, Doctoral Thesis, Maastricht, 2001.

\section{Merino-Blanco (1996).}

E. Merino-Blanco, The Spanish Legal System, Sweet \& Maxwell, London, 1996.

\section{Morris (2005)}

Morris, R.J., Globalizing \& De-Hermeticizing Legal Education, in: BYU Education and Law Journal, (2005), pp. 53-82.

\section{Murray \& Drolshammer (2000)}

Murray, P.L. and J. Drolshammer, The Education and Training of a New International Lawyer, in: European Journal of Law Reform, [2000] 2(4), pp. 505-543.

\section{Nachbaur (1991)}

Nachbaur, A., Art. 52 EWGV - Mehr als nur ein diskriminierungsverbot, in: Europäische Zeitschrift für Wirtschaftsrecht, [1991] 2(15), pp. 470-472.

\section{National Conference of Bar Examiners (2007)}

National Conference of Bar Examiners, Comprehensive Guide to Bar Admission Requirements 2007, via <www.ncbex.org>, last accessed 02 February 2007.

\section{Nelsen \& Stubb (2003)}

Nelsen, B.F. and A. Stubb (eds.), The European Union: Readings on the Theory and Practice of European Integration, 3d Edition, Palgrave Macmillan, Basingstoke, 2003.

\section{NOVA (1965)}

NOVA, Advocaat \& Procureur, NOVA, Den Haag, 1965.

\section{Otterlo (2007)}

Otterlo, R., Entrance to the Netherlands Bar, Contribution to the 2007 CCBE Conference 'Improving Legal Education \& Training in a Converging Europe' in Warsaw 25-27 September 2007, via <www.ccbe.org>, last accessed 17 October 2008. 


\section{Pelissier (2007)}

Pelissier, A., Double Degrees in the context of the Bologna Process, Contribution to the 2007 CCBE Conference 'Improving Legal Education \& Training in a Converging Europe' in Warsaw 25-27 September 2007, via <www.ccbe.org>, last accessed 17 October 2008.

Pertek (1992)

Pertek, J., Free Movement of Professionals and Recognition of Higher Education Diplomas, in: Yearbook on European Law [1992] 12 pp. 293-324.

Pertek (2000) A

Pertek, J., L'Avocat, L'Europe du droit et le Citoyen, in: Colloque Cedece Poitiers, 7-6-2000.

Pertek (2000) B

Pertek, J., Les Avocats en Europe, L.G.D.J., Paris 2000.

Pertek (1994)

Pertek, J., L’Europe des Diplomes et des Professions, Bruylant, Bruxelles, (1994).

Pertek (2001)

Pertek, J., L'Europe des profession d'avocat après la Directive 98/5 sur l'exercice permanent dans un autre état membre, in: Revue du Marché Commun et de L'Union Européene, no. 445 [2001], pp. 106-111.

\section{Petzel (2007)}

Petzel, J., Common standards for continuing legal learning in Europe, Contribution to the 2007 CCBE Conference 'Improving Legal Education \& Training in a Converging Europe' in Warsaw 25-27 September 2007, via <www.ccbe.org>, last accessed 17 October 2008.

\section{Philippe \& Roberts (1993)}

Philippe, D.M. and Roberts, H., The Legal Professions in Belgium, in: Tyrrell QC, A., and Yaqub, Z., The Legal Professions in the New Europe, a Handbook for Practitioners, Blackwell Business, Oxford, 1993.

\section{Pichonnaz \& Hirte (2006)}

Pichonnaz, P., and Hirte, H., Where is Law Thaught? Who Teaches Law? An Exchange of Experiencesof the Institutions in which Law is being Thaught and of the Persons who teach Law, in: European Journal of Legal Education, [2006] 3(1), pp. 79-81.

\section{Pina (2006)}

Pina, S., Fonctionnaires stagiaires et liberté de circulation, in: Revue Trimestrielle de Droit Européen, [2006] 42(2) pp. 394-402.

\section{Platteau (1997).}

Platteau, K., De toepassing van het mededingingsrecht op vrije beroepen: een achterhoedegevecht?, in: Revue de droit commercial Belge, [1997] 9 pp. 575-578. 


\section{Podell (1999)}

Podell, M.S., When Zeal for European Unity overcomes Common Sense: The Lawyers' Directive, in: Boston College International and Comparative Law Review, [1999] 23(1), pp. 57- 70.

\section{Pollard (1994)}

Pollard, D., and M. Ross, European Community Law: Text and Materials, Butterworths, London, (1994).

\section{Posch (2005) A}

Posch, W., Die Zukunft der Rechtswissenschaften and den Universitäten, via <www.elfa-afde.org>, last accessed 28 April 2008.

\section{Posch (2005) B}

Posch, W., The Austrian View of the Bologna Process in Legal Education, in: Slovenian Law Review, [2005] 2, pp. 207-211.

\section{Pound (1943) A}

Pound, R., The Legal Profession in England from the End of the Middle Ages to the Nineteenth Century, in: Notre Dame Lawyer, [1943-1944] 19, pp. 315-333.

\section{Pound (1943) B}

Pound, R., The Legal Profession in the Middle Ages, in: Notre Dame Lawyer, [1943-1944] 19, pp. 229 - 244.

\section{Pound (1943) C}

Pound, R., What is a Profession? The Rise of the Legal Profession in Antiquity, in: Notre Dame Lawyer, [1943-1944] 19, pp. 203-228.

\section{Prakke \& Kortmann (1993)}

Prakke, L., and C.A.J.M. Kortmann, Het Staatsrecht van de landen van de Europese Gemeenschappen, Kluwer, Deventer, 1993.

\section{Prinssen (2001)}

Prinssen, J.M., Zaak C-238/98, H.F. Hocsman en Minister van Werkgelegenheid en Solidariteit, in: Sociaal Economische Wetgeving, [2001] 49(5), pp.184-186.

\section{Van der Pijl (2003)}

Pijl van der, M.J., Reactie op: Vrije Vestiging niet verplicht voor procureurs, in: Advocatenblad [2003] 83(21), p. 955.

\section{Rasmussen (1989)}

Rasmussen, H., The European Community Constitution, Summaries of Leading EC Court Cases, Handelshølskolens Forlag, n.l., (1989).

\section{Reich (2006)}

Reich, N., Kurzbesprechung der Schlussanträge von Frau Generalanwalt Christine Stix-Hackl v. 14.9.2006 in der Rs. C-40/05 - Kai Lyyski gegen Universität Umea, in: Europäische Zeitschrift für Wirtschaftsrecht, [2006] 17(20), pp.612-613. 


\section{Reich (2002)}

Reich, N., Recent Trends in European Legal Education: the Place of the European Law Faculties Association, in: Penn State International Law Review, [2002-2003] 21, pp. 21-38.

\section{Reinmüller (1995)}

Reinmüller, B., Der Anwalt und die ihm anvertrauten Mandatengelder bei grenzüberschreitender anwaltlicher Tätigkeit nach dem Standesregeln der Rechtsanwalten in der Europäischen Gemeinschaft, in: DACH, Der Anwalt und die ihm anvertrauten Vermögenswerte, Österreichische Staatsdruckerei, (1995).

\section{Ricour \& Vatier (1996)}

Ricour, C., and Vatier, B., Les sort des Avocats Européens et de leurs clients dans les mains des institutions communautaires, in: Gazette du Palais, [1996] doctrine pp. 1235-1238.

\section{Riedel (2001)}

Riedel, J., The Reform of Legal Education in Germany, in: European Journal of Legal Education, [2001] 0, pp. 2-6.

\section{Rieder (2006)}

Rieder, C., Case C-147/03, Commission of the European Communities v. Republic of Austria, Judgement of the Court (Second Chamber) 7 July 2005, not yet reported, in: Common Market Law Review, [2006] 43, pp. 1711-1726.

\section{Rivkin (1998)}

Rivkin, D.H. Transnational Legal Practice, in: The International Lawyer, [1998] 32(2), pp. 423-426.

\section{Roth (1993)}

Roth, W.H., Case C-19/92, Dieter Kraus v. Land Baden-Württemberg, Judgment of 31 March 1993 (not yet reported), in: Common Market Law Review, [1993] 30, pp. 1251-1258.

\section{Sanglade (1993)}

Sanglade, P., The Legal Professions in France, in: Tyrrell QC, A., and Yaqub, Z., The Legal Professions in the New Europe, a Handbook for Practitioners, Blackwell Business, Oxford, 1993.

\section{Slapper \& Kelly (1997)}

Slapper, G., and Kelly, D., Principles of the English Legal System, Cavendish, London, 1997.

\section{Slazak (2007)}

Slazak, M., Legal Education and training in Poland, Contribution to the 2007 CCBE Conference 'Improving Legal Education \& Training in a Converging Europe' in Warsaw 25-27 September 2007, via <www.ccbe.org>, last accessed 17 October 2008. 


\section{Von Schmidt auf Altenstadt (1999)}

Schmidt auf Altenstadt von, P.J.M., Schipper mag ik overvaren?, in: Advocatenblad [1999]1, p. 3.

\section{Schneider (1995)}

Schneider, H., Die Anerkennung von Diplomen in der Europäischen Gemeinschaft, MAKLU, Antwerpen, 1995.

\section{Schneider (1989)}

Schneider, H., Een klein stapje in de richting van echte 'Europese' juristen?, in: Ars Aequi, [1989] 5 pp. 368-374.

\section{Schneider (2002)}

Schneider, H., The Free Movement of Lawyers in Europe and its Consequences for the Legal Profession and the Legal Education in the Member States, in: M. Faure et al (eds.), Towards a European Ius Commune in Legal Education and Research, Intersentia, Antwerpen, 2002, pp. 15-38.

\section{Schneider \& Claessens (2005)}

Schneider, H., and S. Claessens, The Recognition of Diplomas and the Free Movement of Professionals in the European Union, in: H. Scheider (ed.) Migration, Integration and Citizenship; A Challenge for Europe's Future, Volume I, Forum Maastricht, Maastricht, 2005.

\section{Shaw (1992)}

Shaw, J., Education and the Law in the European Community, in: Journal of Law and Education, [1992] 21, pp. 415-442.

\section{Smith (1994)}

Smith, L.J., Postgraduate degrees, vocational training and reverse discrimination: the narrow divide, in: European Law Review, [1994]19, pp. 643-662.

\section{Sobotta \& Kleinschnittger (1998)}

Sobotta, C., and C. Kleinschnittger, Frezügigkeit für Anwälte in der EU nach der Richtlinie 98/5/EG, in: Europäische Zeitschrift für Wirtschaftsrecht, (1998) 21, pp. 645-650.

\section{Solove (1995)}

D.J. Solove, The Multistate Bar Exam as a Theory of Law, in: Michigan Law Review, [2005-2006] 104, pp. 1403-1406.

\section{Stamatoudi (1997)}

Stamatoudi, I.A. Legal Education in Greece, in: Web Joural for Current Legal Issues, [1997] 3, via <webjcli.ncl.ak.uk/1997/issue3/stamat3.html>, last accessed 4 May 2005.

\section{Steger (s.d.)}

Steger, W., Die Position der Europäischen Anwaltschaft zur Studienreform nach dem Bologna Modell Punktation, via <www.elfa-afde.org>, last accessed 28 April 2008. 


\section{Steger (2007)}

Steger, W., Enhancing training for lawyers in an ever closer Europe from the perspective of the Austrian Bar Association, Contribution to the 2007 CCBE Conference 'Improving Legal Education \& Training in a Converging Europe' in Warsaw 2527 September 2007, via <www.ccbe.org>, last accessed 17 October 2008.

\section{Stein (1992)}

Stein, T., Case C-340/89, Vlassopoulou v. Ministerium für Justiz, Bundes- und Europaangelegenheiten Baden-Württemberg, Decision of the European Court of Justice of 7 May 1991, not yet reported, in: Common Market Law Review, [1992] 29, pp. 625-636.

\section{Steiner (2006)}

Steiner, J., et al, EU Law, 9th Edition, Oxford University Press, Oxford, 2006.

\section{Sveriges advokatsamfund (s.d.) A}

Sveriges advokatsamfund, Regler om obligatorisk advokatexamen för inträde I Sveriges advokatsamfund, via <www.advokatsamfund.se>, last accessed 31 October 2002.

\section{Sveriges advokatsamfund (s.d) $B$}

Sveriges advokatsamfund, 'Sveriges Advokatsamfund inför Advokatexamen', via <www.advokatsamfund.se>, last accessed 31 October 2002.

\section{Tarr (2004)}

Tarr, A.A., Legal Education in a Global Context, University of Toledo Law Review, [2004-2005] 36, pp. 199-206.

\section{Tauch \& Rauhvargers (2002)}

Tauch, C. and Rauhvargers, A., Survey on Master Degrees and Joint Degrees in Europe, via <www.eua.be>, last accessed 17 October 2008.

\section{Terry (2008)}

Terry, L.S., The Bologna Process and Its Impact in Europe: It's So Much More than Degree Changes, in: Vanderbilt Journal of Transnational Law, [2008] 41, pp. 107-228.

\section{Terry (2007)}

Terry, L.S., The Bologna Process and its Implications for U.S. Legal Education, in: Journal of Legal Education, [2007] 57(2), pp. 237-252.

\section{Terry (2002)}

Terry, L.S., GATS, A Handbook for International Bar Association Member Bars, IBA, 2002, via <www.ccbe.org>, last accessed 26 April 2006.

\section{Terry (2001-2002)}

Terry, L.S., GATS' Applicability to Transnational Lawyering and its Potential Impact on U.S. State Regulation of Lawyers, in: Vanderbilt Journal of Transnational Law, [2001] 34, pp. $989 \mathrm{ff}$. and revised in: Vanderbilt Journal of Transnational Law, [2002] 35, pp. 1387-1392. 


\section{Terry (2004)}

Terry, L.S., Lawyers, GATS, and the WTO Accountancy Disciplines: The History of WTO's Consultation, the IBA GATS Forum and the September 2003 IBA Resolutions, in: Penn State International Law Review, [2004] 22(4) p. 695-842.

\section{Terry (2006)}

Terry, L.S., Living with the Bologna Process: Recommendations to the German Legal Education Community from a U.S. Perspective, in: German Law Journal, [2006] 7(11), pp. 863-905.

\section{Thielen (2007)}

Thielen, P., La formation professionelle des avocats au Grand-Duché de Luxembourg, Contribution to the 2007 CCBE Conference 'Improving Legal Education \& Training in a Converging Europe' in Warsaw 25-27 September 2007, via $<$ www.ccbe.org>, last accessed 17 October 2008.

\section{Timm \& Kempter (2005)}

Timm, S. and Kempter, D., Diskriminierung beim Zugang zum Referendardienst in Deutschland - Schein oder Sein?, in: Neue juristische Wochenschrift, [2005] 59(39) pp. 2826-2828.

\section{Torbøl \& Worsøe (1993)}

Torbøl, A., Worsøe, A., The Legal Profession in Denmark, in: Tyrrell QC, A., and Yaqub, Z., The Legal Professions in the New Europe, a Handbook for Practitioners, Blackwell Business, Oxford, 1993.

Valcke (2005)

Valcke, C., Comparative Legal Education in Canada, in: Revue Juridique Themis, [2005] 39,pp. 483-505.

\section{Vagts (2000)}

Vagts, D.F., The Impact of Globalization on the Legal Profession, in: European Journal of Law Reform, [2000] 2(4), pp. 403-413.

\section{Van Boneval Faure (1893)}

Van Boneval Faure, R., Het Nederlandsche Burgerlijk Procesrecht, Part I, 3th edition, E.J. Brill, Leiden, 1893.

\section{Vanistendael (1999)}

Vanistendael, F.J., Blitz Survey of the Challenges for Legal Education in Europe, in: Dickinson Journal of International Law, [1999-2000] 18, pp. 457-466.

\section{Van der Vlies (2000)}

Vlies van der, M.D.M., Europese Harmonisatie en het Vrij Verkeer van Advocaten, in: Rechtskundig Weekblad, (2000-2001) 1, pp. 1-11.

\section{Verbruggen (2003)}

Verbruggen, M.L.W., De Bolognaverklaring kritisch getoetst aan het Europees onderwijsbeleid, in: Sociaal Economische Wetgeving, [2003] 51(6), pp. 199-212.

\section{Viciconte (1999)}

Viciconte, G., L'Avvocato e L'Europa, Giuffrè Editore, Milano, 1999. 


\section{Vossestein (2002)}

Vossestein, A.J., Case Law, in: Common Market Law Review, [2002] 39, pp. 841-863.

\section{De Waard (1995)}

Waard de, T., Vestigingsrichtlijn, in: Advocatenblad, (1995) 2, p. 59

\section{Wackie Eysten (1995)}

Wackie Eysten, P.A., Een Europese Balie verder dan ooit, in: Nederlands Juristen Blad, (1995) 17, pp. 631-632.

\section{Wackie Eysten (1995)}

Wackie Eysten, P.A., Het Ontwerp voor een Richtlijn Vestigingsrecht Advocaten, in: Sociaal en Economische Wetgeving, (1995) 12, pp. 743-758.

\section{Van der Wal (1985)}

Wal van der, G., De vrijheid van vestiging van advocaten in de EEG: het arrestKlopp, in: Nederlands Juristen Blad, (1985) 27, pp. 857-860.

\section{Wasmeier (1999)}

Wasmeier, M., Aktuelle Fragen in Zusammenhang mit der Anerkennung von Berufsabschlüssen, in: Europäische Zeitschrift für Wirtschaftsrecht, [1999] 10(24), pp. 746-750.

\section{Weatherill (2006)}

Weatherill, S., Cases \& Materials on EU Law, 7th Edition, OUP, Oxford, 2006.

\section{Weil (1997)}

Weil, H., Der europäische Rechtsanwalt wird Wirklichkeit, in: St. Galler Europarechtsbriefe, 11/97, pp. 530-533.

\section{Weil (1991-1992)}

Weil, H., The Proposal for a Directive on the Right of Establishment for Lawyers in the European Community, in: [1991-1992] Fordham International Law Journal, 15, pp. 699-721.

\section{Witte (2006)}

Witte, J.K., Change of Degrees and Degrees of Change, CHEPS/UT, Enschede, 2006.

\section{De Witte (1989)}

De Witte, B.(ed.), European Community Law of Education, NOMOS, Baden-Baden, 1989.

\section{Woolf (1990)}

Woolf, H., The Legal Profession in England: Overshadowed by Europe and About to be Reformed by a Scottish Lord Chancellor, in: Texas International Law Journal, [1990] 25, pp. 271-285.

\section{WTO (1998)}

WTO, Legal Services, Background Note by the Secretariat, 6 July 1998, S/C/W/43 


\section{Yaqub (1993)}

Yaqub, Z. et al, The Legal Professions in the United Kingdom, in: Tyrrell QC, A., and Yaqub, Z., The Legal Professions in the New Europe, a Handbook for Practitioners, Blackwell Business, Oxford, 1993.

\section{Ysewyn (1997)}

Ysewyn, J.L., Zaak C-55/94, R.. Gebhard en Consiglio dell'Ordine degli Avvocati e Procuratori di Milano, in: Sociaal Economische Wetgeving, [1997] 45(1), pp. 24-29.

\section{Table of Cases}

Case 26/62, Van Gend \& Loos v. Nederlandse Administratie der Belastingen [1963] ECR 1.

Case 2/74, Reyners v. Belgium [1974] ECR 631.

Case 33/74, Van Binsbergen v. Bestuur van de Bedrijfsvereniging voor de Metaalnijverheid, [1974] ECR 1299.

Case 48/75, Royer [1976] ECR 497.

Case 71/76, Thieffry v. Conseil de l'Ordre des Avocats à la Cour de Paris [1977] ECR 756.

Cases 110-111/78, Ministère public and 'Chambre syndicale des agents artistiques et impresarii de Belgique’ ASBL v. Willy van Wesemael and others [1979] ECR 32.

Case 120/78, Rewe-Zentrale AG v. Bundesmonopolverwaltung für Branntwein [1979] ECR 649.

Case 102/79, Commission v. Belgium [1980] ECR 1473.

Case 149/79, Commission v. Belgium [1980] ECR 3881.

Case 279/80, Criminal Proceedings against Webb [1981] ECR 3305.

Case 96 and 97/81 Commission v. The Netherlands ECR [1982] 1791, 1819.

Case 160/82, Commission v. The Netherlands ECR [1982] 4637.

Cases 286/82 \& 26/83, Luisi and Carbone v. Ministero del Tesoro [1984] ECR 377.

Case 107/83, Ordre des Avocats au Barreau de Paris v. Klopp [1984] ECR 2971.

Case 152/83, Sandro Forcheri and his wife Marisa Forcheri, née Marino, v Belgian State and asbl Institut Supérieur de Sciences Humaines Appliquées - Ecole Ouvrière Supérieure [1983] ECR 02323.

Case 182/83 Robert Fearon v Irish Land Commission [1984] ECR 3677.

Case 293/83, Françoise Gravier v City of Liège, [1985] ECR 00593.

Case 29/84 Commission v. Germany, ECR [1985] 1661.

Case 221/85 Commission v. Belgium (Clinical Biology Services) [1987] ECR 719.

Case 427/85, Commission v. Germany [1988] ECR 1123. 
Case 222/86, UNECTEF v. Heylens [1987] ECR 4097.

Case 292/86, Gullung v. Conseil de l'Ordre des Avocats [1988] ECR 111.

Case 70/87, Fediol v. European Commission [1989] ECR 1781.

Case C-69/89, Nakajima v. Council [1991] ECR I-02069.

Case 340/89, Vlassopoulouv Ministerium für Justiz, Bundes- und Europaangelegenheiten Baden-Württemberg [1991] ECR 2357.

Case C-375/89, V.J. M. Raulin v Minister van Onderwijs en Wetenschappen [1992] ECR I 01027.

Case C-76/90, Manfred Säger v Dennemeyer \& Co. Ltd. [1991] ECR I-4421.

Case C-19/92 Kraus v Land Baden-Württemberg [1993] ECR I-1663.

Case C-42/92, Thijssen v. Controledienst voor de Verzekeringen [1993] ECR I-4047.

Case C-275/92, Her Majesty's Customs and Excise v Gerhart Schindler and Jörg Schindler [1994] ECR I-1039.

Case C-319/92, Haim v. Kassenärtzliche Vereinigung Nordrhein [1994] ECR I-425.

Case C-55/94, Reinhard Gebhard v. Consiglio dell'Ordine degli Avvocati e Procuratori di Milano [1995] ECR 4165.

Case C-150/94, United Kingdom v. Council [1998] ECR I-7235.

Case C-164/94, Arantis v. Land Berlin [1996] ECR I-135.

Case C-149/96, Portugal v. Council [1999] ECR I-8395.

Case C-234/97, Teresa Fernández de Bobadilla v. Museo Nacional del Prado, Comité de Empresa del Museo Nacional del Prado, Ministerio Fiscal [1999] ECR I-4773.

Case C-168/98, Grand-Duchy of Luxembourg v. European Parliament and Council of the European Union [2000] ECR I-09131.

Case C-238/98, Hocsman v. Minister de l'Emploi de la Solidarité [2000] ECR I-6663.

Case C-145/99 Commission of the European Community v. Italian Republic [2002] ECR I-02235.

Case C-184/99, Rudy Grzelczyk v. Centre Public d'Aide Sociale d'Ottignes-Louvain-laNeuve CPAS [2001] ECR I-6193.

Case C-307/99 OGT Fruchthandelsgesellschaft GmbH v Hauptzollamt Hamburg-St. Annen [2001] ECR I-3159.

Case C-309/99 J.C.J. Wouters, J.W. Savelbergh, Price Waterhouse Belastingadviseurs BV v Algemene Raad van de Nederlandse Orde van Advocaten [2002] ECR I-01577.

Case C-27/00 and C-122/00 The Queen v Secretary of State for the Environment, Transport and the Regions, ex parte Omega Air Ltd (C-27/00) and Omega Air Ltd, Aero Engines Ireland Ltd and Omega Aviation Services Ltd $v$ Irish Aviation Authority (C-122/00) [2002] ECR I-2569. 
Case C-76/00 Petrotub SA and Republica SA v Council of the European Union [2003] ECR I-79.

Case C-285/01, Isabel Burbaud v. MInistère de l'Emploi et de la Solidarité [2003] ECR I-08219.

Case C-313/01, Christine Morgenbesser v. Consiglio dell'Ordine degli avvocati di Genova [2003] ECR I-13467.

Case C-351/01 Commission v. France [2002] ECR I-08101.

Case C-362/01 Commission v. Ireland [2002] ECR-I 11433.

Case C-93/02 Biret International SA v Council of the European Union [2003] ECR I-10497.

Case C-102/02, Ingeborg Beuttenmüller v. Land Baden-Württemberg, [2004], ECR I-5405.

Case C-153/02, Valentina Neri v. European School of Economics (ESE Insight World Education System Ltd.) [2003] ECR I-13555.

Case C-377/02 Léon Van Parys NVv. Belgisch Interventie- en Restitutiebureau (BIRB) [2005] ECR I-1465.

Case C-65/03 Commission v. Belgium [2003] ECR I-06427.

Case C-147/03, Commission v. Austria [2005] ECR I-05969.

Case C-209/03, The Queen ex parte Danny Bidar v. London Borough of Ealing, Secretary of State for Education and Skills [2005] ECR I-02119.

Case C-330/03 Colegio de Ingenieros de Caminos, Canales y Puertos [2006] ECR I-00801.

Case C-109/04, Karl Robert Kranemann v. Land Nordrhein-Westfalen [2005] ECR I-02421.

Case C-141/04 Michail Peros v. Techniko Epimelitirio Ellados [2005] ECR I-7163.

Case C-142/04 Maria Aslanidou v. Ypourgos Ygeias \& Pronoias [2005] ECR I-7181.

Case C-506/04, Graham J. Wilson v. Ordre des avocats du barreau de Luxembourg [2006] ECR, I-08613.

Case C-149/05, Harald Price v. Conseil des ventes volontaires de meubles aux enchères publiques [2006] ECR I-07691.

Case C-193/05, Commission of the European Communities v. Grand-Duchy of Luxembourg [2006] ECR I-08673.

Case C-40/05, Kay Lyyski v. Umeá universitet [2007] ECR I-00099.

Case C-197/06, Confederatie van Immobiliën-Beroepen van België VZW, Beroepsinstituut van Vastgoedmakelaars v. Willem Van Leuken [2008] ECR I-nyr. 



\section{Curriculum Vitae}

Sjoerd Claessens was born on 22 June 1976 in Weert, the Netherlands. After obtaining his secondary school degree in 1994 he graduated 'cum laude' from the European Law School at the Faculty of Law of Maastricht in 1998. Supported by a 'Nuffic Talent Scholarship' Sjoerd Claessens obtained his LL.M. in International Law from the University of Nottingham in the United Kingdom in 1999.

Since September 1999 Sjoerd Claessens has been working as a lecturer in European Law at the Law Faculty of Maastricht University. In that capacity Sjoerd Claessens teaches in a variety of bachelor courses in international law and European law. Additionally, he is also active in developing and executing the Law Faculty's skills training in the different curricula. 
